Judeans in Babylonia 


\section{Culture and History of the Ancient Near East}

Founding Editor

M.H.E. Weippert

Editor-in-Chief

Jonathan Stökl

\section{Editors}

Eckart Frahm

W. Randall Garr

B. Halpern

Theo P.J. van den Hout

Leslie Anne Warden

Irene J. Winter

VOLUME 109

The titles published in this series are listed at brill.com/chan 


\section{Judeans in Babylonia}

\section{A Study of Deportees in the Sixth and Fifth Centuries BCE}

by

Tero Alstola

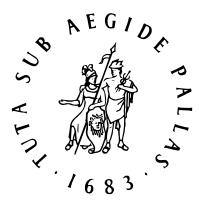

B R I L L

LEIDEN | BOSTON 

which permits any non-commercial use, distribution, and reproduction in any medium, provided the original author(s) and source are credited.

\section{Library of Congress Cataloging-in-Publication Data}

Names: Alstola, Tero, author.

Title: Judeans in Babylonia : a study of deportees in the sixth and fifth centuries BCE / Tero Alstola.

Description: Leiden ; Boston : Brill, [2020] | Series: Culture and history of the ancient Near East, 1566-2055; volume 109 | Includes bibliographical references. | Summary: "In Judeans in Babylonia, Tero Alstola presents a comprehensive investigation of deportees in the sixth and fifth centuries BCE. By using cuneiform documents as his sources, he offers the first book-length social historical study of the Babylonian Exile, commonly regarded as a pivotal period in the development of Judaism. The results are considered in the light of the wider Babylonian society and contrasted against a comparison group of Neirabian deportees. Studying texts from the cities and countryside and tracking developments over time, Alstola shows that there was notable diversity in the Judeans' socio-economic status and integration into Babylonian society"-- Provided by publisher.

Identifiers: LCCN 2019044633 (print) | LCCN 2019044634 (ebook) | ISBN 9789004365414 (hardback) | ISBN 9789004365421 (ebook)

Subjects: LCSH: Jews--History--Babylonian captivity, 598-515 B.c. | Jews--History--586 B.C.-70 A.D. | Jews--Social conditions. | Jews--Economic conditions.

Classification: LCC DS121.65 .A75 2020 (print) | LCC DS121.65 (ebook) | DDC 935/.004924009014--dc23

LC record available at https://lccn.loc.gov/2019044633

LC ebook record available at https://lccn.loc.gov/2019044634

Typeface for the Latin, Greek, and Cyrillic scripts: "Brill”. See and download: brill.com/brill-typeface.

ISSN 1566-2055

ISBN 978-90-04-36541-4 (hardback)

ISBN 978-90-04-36542-1 (e-book)

Copyright 2020 by Tero Alstola. Published by Koninklijke Brill NV, Leiden, The Netherlands. Koninklijke Brill NV incorporates the imprints Brill, Brill Hes \& De Graaf, Brill Nijhoff, Brill Rodopi, Brill Sense, Hotei Publishing, mentis Verlag, Verlag Ferdinand Schöningh and Wilhelm Fink Verlag. Koninklijke Brill NV reserves the right to protect the publication against unauthorized use and to authorize dissemination by means of offprints, legitimate photocopies, microform editions, reprints, translations, and secondary information sources, such as abstracting and indexing services including databases. Requests for commercial re-use, use of parts of the publication, and/or translations must be addressed to Koninklijke Brill NV.

This book is printed on acid-free paper and produced in a sustainable manner. 


\section{Contents}

Acknowledgements IX

List of Figures and Tables XI

Conventions and Abbreviations XII

1 Introduction 1

1.1 Aims and Relevance of This Study 1

1.2 Historical Background 2

1.2.1 Political History 2

1.2.2 Forced and Voluntary Migration in the Ancient Near East 8

1.2.3 Deportations from Judah to Babylonia 11

1.2.4 Babylonian Society 15

1.3 Babylonian Exile: Reception and Research History 24

1.3.1 Reception History 24

1.3.2 Research History 27

1.4 Sources 33

1.4.1 The Hebrew Bible 34

1.4.2 Cuneiform Sources 37

1.4.2.1 Archival Approach 38

1.4.2.2 Ethics and Unprovenanced Artefacts $\quad 39$

1.4.2.3 Text Groups 43

1.4.3 Archaeology 46

1.5 Identifying Foreigners in Babylonian Sources 47

1.5.1 Naming Practices in Babylonia $\quad 47$

1.5.2 Yahwistic Names as the Criterion for Identifying Judeans 49

2 Judean Royalty and Professionals in Babylon $\quad 58$

2.1 Introduction $\quad 5^{8}$

2.2 German Excavations at Babylon $\quad 5^{8}$

2.3 The Palace Archive of Nebuchadnezzar II 60

2.4 Foreign Royalty and Professionals in Babylon 63

2.5 Living Conditions in Babylon and Jehoiachin's Amnesty 70

2.6 Conclusion 77

3 Judean Merchants in Babylonia 79

3.1 Introduction 79

3.2 Trade and Traders in Babylonia 80 
3.3 Judean Royal Merchants in Sippar

82

3.3.1 Sources 82

3.3.2 Social Network 91

3.3.3 Identity, Integration, and Socio-Economic Status

95

3.4 Other Judean Merchants in Babylonia $\quad 98$

3.5 Conclusion: Long-Distance Trade and Judean Merchants 100

4 Texts from Yāhūdu, Našar, and Their Surroundings 102

4.1 Introduction 102

4.2 Geographical and Economic Environment 104

4.2.1 The Location of Yāhūdu and Našar 104

4.2.2 The Land-for-Service Sector: Economic Environment of the Texts $\quad 108$

4.3 Text Groups and Their Protagonists $\quad 110$

4.3.1 Three or More Groups? $\quad 110$

4.3.2 Texts Pertaining to Rìmūt/Abì-ul-ìde and Rìmūt/

Samak-Yāma 112

4.3.3 Texts Pertaining to Ahīqar, Son of Rìmūt $\quad 115$

4.3.4 Texts Pertaining to Bēl-ahhē-erïba, Son of Nūr-Šamaš $\quad 120$

4.3.5 Scribes and Royal Administration in Našar 121

4.3.6 Texts Relating to Yāhūdu 125

4.3.6.1 General Remarks $\quad 125$

4.3.6.2 Early Texts Relating to Yāhūdu 126

4.3.6.3 Texts Pertaining to Ahīqam/Rapā-Yāma and His Sons 133

4.3.6.4 Royal Administration in the Environs of Yāhūdu 142

4.3.7 Texts from Āl-šarri $\quad 146$

4.3.8 Texts Pertaining to Zababa-šar-uṣur and Bït-Abī-râm $\quad 148$

4.3.9 Loosely Connected and Isolated Texts $15^{2}$

4.3.10 Administrative Practices and the Origins of the Text

Corpus $\quad 154$

4.4 Judeans in Yāhūdu and Its Surroundings 159

5 Judeans in the Murašû Archive $\quad 164$

5.1 Introduction 164

5.1.1 The Murašûu Archive 164

5.1.2 Judeans in the Murašû Archive $\quad 167$

5.1.3 Seal Impressions $\quad 169$

5.2 Yadi-Yāma and Pili-Yāma: Entrepreneurs or

Representatives? $\quad 170$ 
5.2.1 Business Partners of the Murašûs? 171

5.2.2 Yadi-Yāma and the Village of Bìt-Gērāya $\quad 172$

5.2.3 Pili-Yāma's Transactions 174

5.2.4 Yāhû-natan, Son of Yadi-Yāma 177

5.2.5 Representatives of a Community of Farmers 178

5.3 Judean Landholders and the Land-for-Service Sector 181

5.3.1 General Features $\quad 181$

5.3.2 Hațru of the Sēpirus 186

5.3.2.1 Hațus in the Murašû Archive $\quad 186$

5.3.2.2 Hatru of the Seppirus (of the Troops) $\quad 187$

5.3.2.3 Hatrus and High-Ranking Sēpirus 189

5.3.2.4 Conclusion 194

5.3.3 Large-Scale Landholding: Rahim-il and His Family 196

5.3.4 Other Judean Landholders 200

5.3.5 Patterns of Judean Landholding 201

5.4 Judean Officials 203

5.5 Judean Witnesses 206

5.6 Socio-Economic Status 207

5.6.1 The Framework of the Archive: the Land-for-Service

Sector 207

5.6.2 Taxation and Service Obligations $\quad 209$

5.6.3 Dependency and Freedom 211

$5 \cdot 7$ Culture 213

5.7.1 Seal Use 213

5.7.2 Naming Practices 218

5.7.3 Conclusion 219

5.8 Conclusion 220

6 Judeans Outside the Main Archives 223

6.1 Officials 223

6.2 Temples 226

6.3 Royal Lands and the Land-for-Service Sector 231

6.4 Miscellaneous Texts 234

6.5 Seals of Exiles 235

6.6 Conclusion 235

7 The Neirabian Community in Babylonia 237

7.1 Neirab of Syria and Neirab of Babylonia 237

7.2 The Archive and Its Socio-Economic Context 241

7.2.1 The Protagonists of the Texts 241

7.2.2 Promissory Notes for Barley $\quad 242$ 


\subsubsection{Promissory Notes for Silver $\quad 244$ \\ 7.2.4 Diverse Documents 246 \\ $7 \cdot 3$ Conclusion 248}

8 Conclusions 251

8.1 Sources: the Perspective of Babylonian Scribes 252

8.2 Resettlement and Organisation of Deportees 254

8.3 Social and Economic Aspects of Life in Babylonia $\quad 258$

8.4 Women 263

8.5 Religion 265

8.6 Identity and Integration $\quad 272$

Research Data $\quad 277$

Bibliographical Abbreviations $\quad 278$

Bibliography $\quad 282$

General Index $\quad 341$

Terms $\quad 345$

Sources $\quad 347$ 


\section{Acknowledgements}

This book is a revised version of my doctoral dissertation submitted under a cotutelle agreement to Leiden University and the University of Helsinki in 2017. My work in Leiden was financially supported by the ERC Starting Grant project 'By the Rivers of Babylon: New Perspectives on Second Temple Judaism from Cuneiform Texts'. In Helsinki, my work has been supported by three projects funded by the Academy of Finland: the Centre of Excellence in Changes in Sacred Texts and Traditions, the Centre of Excellence in Ancient Near Eastern Empires, and the project 'Semantic Domains in Akkadian Texts'. The open access publication of this book was made possible by a generous grant from OpenAIRE. I want to express my gratitude for all this support.

A large number of people have contributed to the realisation of this book in Leiden and Helsinki. First, I wish to thank the supervisors of my dissertation, Prof. Caroline Waerzeggers in Leiden and Prof. Martti Nissinen in Helsinki. They have trusted in me, provided me with excellent feedback, and supported me through the various stages of my project. This book would not have been realised without them. I thank the examiners of my dissertation in Leiden and Helsinki and the two anonymous reviewers of this book for their careful work and feedback.

In Leiden, I want to express my gratitude to the members of the ERC Starting Grant project 'By the Rivers of Babylon', Rieneke Sonnevelt, Bastian Still, Jason Silverman, Anne-Mareike Wetter, and Jonathan Stökl. My dissertation greatly benefitted from their expertise, and their kindness made my four years in Leiden enjoyable. I would also like to express my thanks to Akiko Tsujita, Maarja Seire, Cristina Barcina, and Johan Lundberg for the relaxed and encouraging conversations over lunch and to the LIAS PhD council for many happy moments.

In Helsinki, numerous teachers and colleagues have contributed to my academic education and research projects during the last ten years. I would like to thank Kirsi Valkama for her inspiring teaching and Raija Mattila for guiding me through my studies in Assyriology. I wish to thank the whole research community working within the two Centres of Excellence, especially Katri Antin, Johannes Bach, Heidi and Tommi Jauhiainen, Tuukka Kauhanen, Katja Kujanpää, Sanna Saari, Aleksi Sahala, Tuula Tynjä, Joanna Töyräänvuori, and Hanna Vanonen.

I also wish to thank all those who made it possible to turn my dissertation into this book: Jonathan Stökl for accepting the manuscript to his series, Krister Lindén and Saana Svärd for generously allowing me to finish the 
manuscript while working as a postdoctoral researcher in Helsinki, and Katelyn Chin at Brill for helping me with the practicalities of the publishing process. I thank Dr. Albion M. Butters for revising the English language of the manuscript. All the remaining shortcomings are my own.

Many colleagues from abroad have provided me with help and support during my research project. I would like to thank Cornelia Wunsch, Laurie E. Pearce, Angelika Berlejung, Sonja Ammann, Reettakaisa Sofia Salo, and the members of the OTSEM and Neo-Babylonian networks for collaboration and feedback.

Finally, I want to express my deepest gratitude to my friends and family who have made this journey enjoyable. 


\section{Figures and Tables}

\section{Figures}

1 Documents pertaining to Ahīqar $\quad 116$

2 The family of Ahīqar 120

3 Documents pertaining to Rapā-Yāma, Ahīqam, and Ahīqam's sons 126

4 The descendants of Samak-Yāma 140

5 Administrative hierarchy in the environs of Yāhūdu $\quad 144$

6 Documents pertaining to Zababa-šar-uṣur $\quad 149$

7 Documents pertaining to Ahīqar and Ahīqam $\quad 156$

8 Main text groups of the Yāhūdu corpus $\quad 159$

9 Murašû texts pertaining to Judeans $\quad 168$

10 The descendants of Rahīm-il 197

\section{Tables}

1 Transactions with quantifiable data pertaining to Judeans $\quad 185$

2 Judean seal users in the Murašû archive 214

3 Judean naming practices in the Murašû archive $\quad 218$

4 Judean naming practices $\quad 269$ 


\section{Conventions and Abbreviations}

Dates. Babylonian dates are given as day-month-regnal year. For example, '10-XI-12 Nbk' refers to the tenth day of the eleventh month in the twelfth regnal year of King Nebuchadnezzar II. In the same vein, ' 7 Dar' refers to the seventh year of King Darius I. The abbreviations of kings' names are given below. The corresponding Julian dates are adopted from Parker and Dubberstein 1942. All Julian dates in this study are BCE unless otherwise indicated.

$\begin{array}{ll}\text { Nbk } & \text { Nebuchadnezzar II } \\ \text { AM } & \text { Amēl-Marduk } \\ \text { Ner } & \text { Neriglissar } \\ \text { Nbn } & \text { Nabonidus } \\ \text { Cyr } & \text { Cyrus } \\ \text { Camb } & \text { Cambyses } \\ \text { Bar } & \text { Bardiya } \\ \text { Nbk III } & \text { Nebuchadnezzar III } \\ \text { Nbk IV } & \text { Nebuchadnezzar IV } \\ \text { Dar } & \text { Darius I } \\ \text { Xer } & \text { Xerxes I } \\ \text { Art I } & \text { Artaxerxes I } \\ \text { Dar II } & \text { Darius II }\end{array}$

Filiation. In Neo-Babylonian legal texts, people are normally referred to by their name and patronymic. The standard formula in Babylonian cuneiform is PN a-šú šá PN2 ('PN, son of $\mathrm{PN}_{2}$ '), abbreviated in this study as $\mathrm{PN} / \mathrm{PN} 2$. For those people who bore family names, the formula is $\mathrm{PN}$ a-šú šá $\mathrm{PN}_{2}$ a $\mathrm{PN}_{3}$ ('PN, son of $\mathrm{PN}_{2}$, descendant of $\mathrm{PN}_{3}$ '), abbreviated in this study as $\mathrm{PN} / \mathrm{PN}_{2} / \mathrm{PN}_{3}$ or $\mathrm{PN} / / \mathrm{PN}_{3}$. See Section 1.5.1.

Weights and measures (see Baker 2004, ix-x; Jursa 2010a, xvii-xviii).

A kurru was the standard measure of capacity, circa 180 litres. 1 kurru $=5$ pānu $=30$ $s \bar{u} t u=180$ qû. Fractions of kurru are recorded in positional notation (e.g. 1;2.3.4 stands for 1 kurru 2 pānu 3 sūtu 4 qû).

A shekel (c. 8.3 grams) was the standard weight for measuring silver and gold. 60 shekels equal 1 mina (c. 500 grams) and 60 minas equal 1 talent (c. 30 kilograms).

The translations of biblical passages are adopted from the New Revised Standard Version. 


\section{Introduction}

\subsection{Aims and Relevance of This Study}

This book is a study of Judeans ${ }^{1}$ in Babylonia in the sixth and fifth centuries BCE. ${ }^{2}$ Most of these people arrived in Babylonia in the early sixth century, being but one of numerous ethnic groups deported and resettled after King Nebuchadnezzar II's conquest of Syria and the Levant. At the same time, voluntary and forced migration had shaped Babylonia over millennia, and continuous immigration had resulted in a multi-ethnic and multi-lingual society. These features of Babylonia in the mid-first millennium have been acknowledged for a long time and a significant amount of pertinent evidence has been made available. Naming practices among immigrant groups have been thoroughly analysed, but there has been little interest in writing a social-historical study of Judeans or other immigrants in Babylonia based on cuneiform sources. ${ }^{3}$ This book aims to fill this gap by conducting a case study of the Judean deportees and placing its results in a wider context of Babylonian society. An important point of comparison is the case of the Neirabians, who were deported from Syria to Babylonia roughly at the same time as the Judeans, lived in the village of Neirab in the Babylonian countryside, and finally returned to their ancient hometown in Syria.

A study of Judean deportees in Babylonia can provide new insights into a period commonly known as the Babylonian exile, which refers to Judean existence in Babylonia after the deportations in the early sixth century. The end of the kingdom of Judah and the destruction of the temple in Jerusalem was a catastrophe which required theological explanation. The deportations and exile started an interpretative process that contributed to the birth of Judaism and biblical literature, and, indirectly, to the emergence of Christianity and Islam. Academic studies of this period have been primarily based on the Hebrew Bible despite the publication of relevant cuneiform sources already in

1 'Judean' refers here to the inhabitants of the kingdom of Judah and their descendants. This is the standard term used in recent studies, and the terms 'Jew' and 'Judaism' are mostly used in reference to later periods. For a discussion of the terms 'Judean', 'Jew', and 'Judaism', see, for example, Mason 2007; Blenkinsopp 2009, 19-28; Beaulieu 2011, 249-250, 258-259; Kratz 2011, 421-424; Law and Halton (eds.) 2014.

2 All dates are BCE unless otherwise indicated.

3 See Section 1.3.2. 
the late nineteenth and early twentieth centuries. A study of Judeans in Babylonia is especially timely at the moment, as the recent emergence of cuneiform sources from the environs of Yāhūdu, '(the town of) Judah' in Babylonia, has more than doubled the number of sources relevant to this study.

At the same time, the present study can enhance our knowledge of Babylonian society and early migration history in the Near East. Despite their antiquity, many aspects of Babylonian society and economy are relatively well understood due to tens of thousands of extant cuneiform texts from the sixth and fifth centuries. However, the majority of available sources originate from temple archives and private archives of the urban upper class, and life in the countryside or the workings of the state apparatus are worse understood. A study of deportees and their descendants sheds new light on the margins of Babylonian society, it enhances the understanding of the economic sectors in which deportees participated, and it allows a diachronic study of state involvement in deportees' lives over two centuries. Moreover, an understanding of migration as an ancient phenomenon and appreciation of cultural diversity in the ancient Near East offer perspectives on often heated debates on migration and remind us that the movement of people is an intrinsic part of world history.

The study is structured as follows. The first chapter introduces the subject, its historical context, previous research, available sources, and methods used in this study. Chapters 2 to 7 are case studies on Judeans and Neirabians in Babylonia. They bear witness to the diversity of geographic location, socioeconomic status, and integration ${ }^{4}$ among the deportees and their descendants. Chapter 8 concludes the study by offering a synthesis of the findings made in the preceding chapters and providing an up-to-date historical reconstruction of the life of Judean communities in Babylonia. The data generated during the research project is freely available online. ${ }^{5}$

\subsubsection{Political History}

This study covers the period from 591 to 413, from the first until the last attestation of Judeans in Babylonian cuneiform sources. The early sixth century

4 'Integration' refers here to an immigrant's process of adapting oneself to the host society in social, economic, and cultural terms. The term is widely used in Europe, whereas 'assimilation' is preferred in the United States. Although the two terms refer, by and large, to the same phenomenon, there are important differences in their meaning. See Schneider and Crul 2010 and other articles in the thematic issue of Ethnic and Racial Studies 33/7.

5 For the data sets, see the section titled 'Research Data'. 
marks the zenith of the Neo-Babylonian Empire: Kings Nabopolassar and Nebuchadnezzar II had consolidated their power in most parts of the former Neo-Assyrian Empire, and the flow of resources to the core of the empire resulted in massive construction projects in Babylon and its surroundings. Judeans, Neirabians, and other deportees from the fringes of the empire were resettled in its core areas. The Persian conquest of Babylon in 539 did not radically alter anything in Babylonian society, but the rule of Darius I at the turn of the century introduced some changes. A major upheaval occurred, however, after the Babylonian revolts against Xerxes in 484. Xerxes' actions against the rebels and their supporters resulted in the loss of power of many old Babylonian families and in the end of many Babylonian cuneiform archives. ${ }^{6}$ The richly documented period from the accession of Nabopolassar in 626 until the revolts in 484 attests to economic growth and institutional continuity in Babylonia despite the Persian conquest, and, for this reason, it has been called the long sixth century in Babylonia. ${ }^{7}$ The number of available cuneiform sources from Babylonia sharply declines after 484 , but Judeans are well attested in surviving documents from the late fifth century. The year 413 marks the end of cuneiform sources pertaining to Judeans in Babylonia but certainly not the end of Judean habitation in the region.

Before the Neo-Babylonian Empire emerged under the leadership of Nabopolassar in the late seventh century вСЕ, territories from the Eastern Mediterranean to the Persian Gulf had been under Assyrian rule for a century. The Neo-Assyrian period was decisive for many later developments, as state formation in Palestine, the use of Aramaic as an administrative language, and the Babylonian practice of mass deportation were all influenced by the Assyrians. The heartland of Assyria was located on the Upper Tigris, which was the point where the state started to expand from in the late tenth century. ${ }^{8}$ The Aramean states in Syria were among the first to come into conflict with the emerging empire. ${ }^{9}$ By the late eighth century, the Aramean states were incorporated into Assyria, among them the town of Neirab, located in the vicinity of Aleppo. ${ }^{10}$ Aramaic-speaking population groups had migrated to the east and south already long before the expansion of Assyria, and Aramean and Chaldean tribes

\footnotetext{
$6 \quad$ Waerzeggers 2003/2004.

7 Jursa 2010a, 4-5.

8 On the history of the Neo-Assyrian Empire, see Kuhrt 1995, 473-546; Bedford 2009; Radner 2014a; Frahm (ed.) 2017, all with further literature.

9 See, most recently, Sader 2014; Younger 2016.

10 Neirab is mentioned in Tiglath-pileser III's list of cities subjugated by Assyria (RINAP 1, Tiglath-pileser III 43 ii:3).
} 
had reached Babylonia at the turn of the second and first millennia. ${ }^{11}$ Moreover, the voluntary and forced migration of Arameans within the empire brought the Assyrians and Arameans into close interaction with each other, and Arameans served the empire in various positions, including high offices. ${ }^{12}$ This led to the adoption of Aramaic as an important administrative language of the empire, a practice that was later adopted by the Babylonian and Persian Empires. ${ }^{13}$

Assyrian expansion continued westwards across Syria and reached the small kingdoms of Southern Palestine, including Israel and Judah, in the ninth century. Assyrian rule in the region was not permanent before the reign of Tiglath-pileser III who turned Israel and Judah into vassal states of Assyria in the second half of the eighth century. ${ }^{14}$ Although Israel and Judah were two separate kingdoms, they shared Hebrew as a common language, as well as many cultural traditions, one of them being the worship of Yahweh. After unsuccessful resistance against Assyria, Israel was turned into an Assyrian province of Samerina, its capital Samaria was destroyed, and part of its inhabitants were deported to the east..$^{15}$ The kingdom of Israel ceased to exist, but Judah retained its status as a vassal state of Assyria, received Israelite refugees, and became the main cult centre of Yahweh and keeper of some Israelite traditions. ${ }^{16}$ However, King Hezekiah of Judah also rebelled against his Assyrian overlords, and a significant number of Judeans were deported in $701 .{ }^{17}$ The deportations from Israel and Judah resulted in the emergence of Yahwistic names in Northern Mesopotamia, ${ }^{18}$ but nothing suggests that a significant number of Israelite or Judean deportees found their way to Babylonia at this time. ${ }^{19}$ Despite its unsuccessful rebellion, Judah was not reduced to a provincial status, and native kings continued to rule the vassal state.

The territorial interests of Assyria also touched Babylonia, which had, however, a very different status from Neirab and Judah. Babylonia, especially the city of Babylon, was the cultural epicentre of Mesopotamia, and the Assyrians generally respected its special status. Although Assyria intervened in the affairs of its southern neighbour, before the reign of Tiglath-pileser III the empire

\footnotetext{
11 See Section 1.2.2.

12 Nissinen 2014.

13 Beaulieu 2007; Fales 2007b; Millard 2009; Nissinen 2014, 276-282; Radner 2014b, 83-86.

14 Kuhrt 1995, 458-472; Miller and Hayes 2006, 360-391.

15 Becking 1992; Younger 1998; Knoppers 2004.

16 Finkelstein 2013, 153-158, 162-164.

17 Grabbe (ed.) 2003; Kalimi and Richardson (eds.) 2014; Matty 2016.

18 Zadok 2015b.

19 See Section 1.5.
} 
did not aim to control Babylonia directly. ${ }^{20}$ At the same time, internal chaos characterised Babylonia: Chaldeans and native Babylonians fought for the Babylonian throne, and the foreign powers Elam and Assyria interfered in this struggle. For religious and political reasons, Assyria was hesitant to use ruthless practices of conquest against Babylonia, and it tried to employ alternative strategies instead. ${ }^{21}$ However, constant Babylonian revolts and the abduction of the Assyrian prince Aššur-nādin-šumi to Elam in the 69o's drove Sennacherib to destroy Babylon, deport the ruling family, and eradicate or deport local gods to Assyria. ${ }^{22}$ Babylon did not remain in ruins for long, as Sennacherib's successor Esarhaddon started to rebuild the city; this policy was continued by his son Assurbanipal, who returned the statue of Marduk to Babylon. ${ }^{23}$

Despite Esarhaddon and Assurbanipal's restorative policy, internal chaos continued in Babylonia. Assurbanipal's older brother Šamaš-šum-ukīn, who ruled as the vassal king of Babylonia, rebelled in $652 .{ }^{24}$ The revolt was quelled and Babylonia brought under Assurbanipal's rule, but peace lasted only until the death of Assurbanipal in 627. The empire was weakened by the struggles of succession, and a man named Nabopolassar, perhaps of Chaldean origin, ${ }^{25}$ succeeded in taking the throne in Babylon. After fifteen years of ravaging war, Assyria fell to the Median and Babylonian armies, and the Assyrian capital Nineveh was captured in $612 .{ }^{26}$

After the fall of Nineveh, Nabopolassar and his crown prince Nebuchadnezzar II continued their military operations in Syria and Palestine, confronting the Egyptians who had annexed former territories of Assyria after the empire's control declined on its western periphery. After the Babylonian troops broke the Egyptian resistance at the battles of Carchemish and Hamath, Nebuchadnezzar annexed the Mediterranean coast, including Judah, under Babylonia. Judah continued its existence as a vassal state of Babylonia. However, the turbulent political situation in the Levant and Egypt's promises of support sparked Judean hopes of independence, and the small kingdom revolted against its

20 On the political history of Babylonia in the first millennium, see Brinkman 1968, 1984a; Frame 1992; Kuhrt 1995, 573-622; Jursa 2014a.

21 Porter 1993, 27-31.

22 Frame 1992, 52-63; Holloway 2002, 353-358; Vera Chamaza 2002, 89-102.

23 Porter 1993, 41-6o; Holloway 2002, 118-122, 139-141 + n. 202, 358-379; Vera Chamaza 2002, 95-99; Nissinen 2010; Nielsen 2012.

24 On Assurbanipal's accession to the throne as younger brother and the civil war between Assurbanipal and Šamaš-šum-ukīn, see Frame 1992, 92-19o; Crouch 2009, 132-155; Fales 2012, 134-136.

25 Jursa 2014b, 96.

26 Fuchs 2014. 
Babylonian overlords. The attempt was futile and Egypt's promises short-lived, and the Babylonian troops captured Jerusalem in the spring of $597 .{ }^{27}$ Part of the Judean population, including King Jehoiachin and other members of the upper class, were deported to Babylonia. Nebuchadnezzar placed Zedekiah, Jehoiachin's uncle, on the throne in Jerusalem. Jehoiachin and his sons were held hostage in Babylon to prevent Zedekiah from rebelling, but this was in vain. Zedekiah did revolt, and Jerusalem was destroyed, perhaps in 587 or $586,{ }^{28}$ and more Judeans were deported to Babylonia. Judah was reduced to a province, and the native kingship in Jerusalem came to an end.

Judeans start to appear in Babylonian cuneiform sources right after the deportations in the early sixth century. King Jehoiachin and other royal hostages in Babylon are mentioned in a text from 591, and the first attestation of Yāhūdu, '(the town) of Judah', in the Babylonian countryside is dated to $572 .{ }^{29}$ Babylonian deportations from Judah and the advent of Judeans in Babylonia are thus chronologically closely related. There is no account of the conquest of Neirab or deportations of Neirabians to Babylonia, but the existence of a twin town of Neirab in the Babylonian countryside in the reign of Neriglissar (559-556) implies that some Neirabians were also deported during the Babylonian expansion at the turn of the seventh and sixth centuries. ${ }^{30}$

Babylonia prospered in the long sixth century. ${ }^{31}$ Favourable climatic conditions and political stability in Southern Mesopotamia provided a basis for economic growth. The standard of living was relatively high, and both workers and large institutions could - and often had to - participate in the market-oriented economy. A reliable legal system, well-functioning labour market, and high degree of monetarisation supported commercial activity and economic growth. At the same time, booty from conquered regions flowed to the centre of the empire, and it was used in massive public building projects. Monumental buildings in the cities and defensive structures in the countryside reflected Babylonia's power, and irrigation projects enhanced transport, trade, and agriculture. Transition from cereal farming to date gardening intensified agriculture, especially around the cities in the north, and, at the same time, new land was brought under cultivation in less-populated regions. Deportees played a key role here: they were settled in marginal rural areas and integrated into the

27 See Section 1.2.3 for a detailed discussion.

28 On the problems of dating the second deportation, see Albertz 2003, 78-81; Müller et al. 2014, 114-116.

29 See Chapters 2 and 4, respectively.

$30 \quad$ See Chapter 7.

31 For an excellent overview, see Jursa 2014c; for painstaking analysis and representation of the available data, see Jursa $2010 a$. 
land-for-service sector of agriculture. ${ }^{32}$ Given plots of land to cultivate, they had to pay taxes and perform work and military service in return. The majority of cuneiform sources pertaining to Judeans originate from the land-for-service sector of Babylonian agriculture. The social structures of long sixth-century Babylonia are studied in section 1.2.4 below.

The Neo-Babylonian Empire only ruled over the Near East for 70 years, and the last Babylonian king Nabonidus was defeated by the Persian king Cyrus in 539. Babylonia proper did not suffer dramatically from this transition, and Cyrus did not introduce major changes in Babylonian society and the local administration. ${ }^{33}$ Babylonia was not, however, the centre of an empire anymore, and Darius I introduced new tax-related policies aimed at channelling the flow of resources from Babylonia to the heartland of the empire. ${ }^{34}$ A noticeable change occurred in 484 when unsuccessful revolts against Darius' successor Xerxes resulted in reprisals against the rebels and their supporters among the Babylonian urban upper class, people closely associated with Babylonian temples. ${ }^{35}$ From our perspective, the most dramatic effect of Xerxes' actions was the end of many temple archives and private archives of the urban elite in the Northern Babylonian cities. It is likely that Xerxes removed many priestly families from their offices, and, at this time, these people sorted temple and private archives. Useless, outdated documents were disposed of and deposited together, whereas tablets with long-lasting value were kept elsewhere. It is not entirely clear what happened to these people and their valuable deeds: although obsolete tablets have been found in great numbers, the documents which people retained have not survived to us. In any case, writing in cuneiform continued after 484 for hundreds of years, but the number of cuneiform sources dating after 484 is small in comparison to the rich evidence from the long sixth century. ${ }^{36}$

Judeans and other deportees were not involved in the organisation of the revolts against Xerxes, and they were not directly affected by his reprisals. Texts from the environs of Yāhūdu attest to the continuity of Judean habitation in the local countryside before and after 484, and a significant number of Judeans are attested in the Murašu archive from the second half of the fifth century.37 The cuneiform record on Judeans in Babylonia ends in 413, when the last Murašû tablet pertaining to Judeans was written in the Nippur countryside.

32 van Driel 2002, 226-273; see Chapters 4, 5, and 7.

33 Jursa $2007 \mathrm{~b}$.

34 Jursa 2007b, 86-89; 2011a; Waerzeggers 2010b; Kleber 2015.

35 Waerzeggers 2003/2004.

36 Geller 1997; Jursa 2005a, 1-2; Clancier 2011.

37 See Chapters 4 and 5 . 
The evidence of the Neirabian community in Babylonia ends in the reign of Darius I, and it appears that some Neirabians returned to their ancestral hometown in the early Persian period. ${ }^{38}$

\subsubsection{Forced and Voluntary Migration in the Ancient Near East}

Migration is a common phenomenon in world history, ${ }^{39}$ and it profoundly shaped the demographics of the ancient Near East as well. Although deportations from and to conquered regions were the fate of many, the impact of other types of migration was as - or even more - significant.

The arrival of Aramean and Chaldean population groups from the north and north-west at the turn of the second and first millennia had a profound effect on the subsequent political formation in Babylonia. ${ }^{40}$ The tribes did not amalgamate with the urban Babylonian population but introduced a strong counterforce to the old cities and occasionally vied for the throne in Babylon. Due to the lack of sources, the actual migration process of Arameans and Chaldeans is poorly understood, but conflicts between Assyria and the Aramean states in Syria, a lack of centralised power in Babylonia, and the fertile lands of the floodplain are among the plausible push-pull factors. In the same vein, Arabs started to find their way from the arid regions in the west to the Babylonian floodplain in the first half of the first millennium. ${ }^{41}$

Political stability and the thriving economy induced other types of migration to Babylonia during the long sixth century. Foreign traders found their way to the bustling quays of the large cities. ${ }^{42}$ Soldiers of foreign origin are attested in the Babylonian army, and it is very well possible that not all of them were deportees but some were also recruited as mercenaries. ${ }^{43}$ In general, the Near East was characterised by a high degree of connectivity in the first millennium, and people, objects, and ideas travelled from one region to another. ${ }^{44}$ Deportations were far from being the sole trigger for migrations. However, as the present study is concerned with the life of deportees and their descendants

$38 \quad$ See Chapter 7.

39 Bellwood 2013; Manning 2013.

40 On Arameans and Chaldeans in Babylonia, see Brinkman 1968, 1984a; Dietrich 1970; Cole 1996, 23-34; Lipiński 2000, 409-489; Fales 2007a, 2011; Beaulieu 2013a; Frame 2013; Zadok 2013; Streck 2014; Younger 2016, 670-740.

41 Zadok 1981; Eph ${ }^{\Upsilon} a l$ 1982; Cole 1996, 34-42; Beaulieu 2013a, 47-51.

42 See Chapter 3.

43 On foreign elite troops, see Section 2.4; on ordinary soldiers in the land-for-service sector, see Sections 4.2.2, 5.3, and 5.6.

44 Wasmuth 2016. See also Versluys 2014, 12. 
in Babylonia, it is necessary to discuss the aims and practices of deportations in closer detail.

In this study, the term 'deportation' refers to a form of forced migration ${ }^{45}$ in which the state transfers population groups from one region to another. In the ancient Near East, deportation was usually the consequence of a military conquest or a reprisal after an unsuccessful revolt, and it served political as well as economic interests of the dominant state. Most of the available information on deportation policies in the first millennium BCE stems from the Neo-Assyrian royal inscriptions, since the Neo-Babylonian state archives have mostly disappeared ${ }^{46}$ and the extant Neo-Babylonian royal inscriptions primarily focus on the kings' building projects. ${ }^{47}$ The sources from the Persian period are not abundant either: Persian sources attest to the presence of foreign workers in Susa and Persepolis, and the Greek writers occasionally refer to Persian deportations of conquered peoples. Therefore, the logical starting point for our discussion of deportation policies in the ancient Near East is the rich NeoAssyrian evidence.

Neo-Assyrian sources on deportations are abundant, but they have to be used with caution as they tend to give an exaggerated and propagandistic picture of the Assyrian kings' treatment of their enemies. ${ }^{48}$ Deportations were carried out as punishment for rebellion and to prevent future revolts. Selective deportations of the upper class aimed at stabilising the empire, as the old elite was unlikely to start a rebellion after resettlement in a foreign region. ${ }^{49} \mathrm{An}-$ other form of selective deportations involved craftsmen and soldiers, who were employed to work in state projects and serve in the Assyrian army. Moreover, population groups were deported to underdeveloped or sparsely populated regions to increase agricultural output. ${ }^{50}$ Two main trends are visible in the geographical scope of the deportations: on the one hand, deportees were settled in the core areas of the empire to increase population, but on the other hand, two-way deportations from one peripheral area to another stabilised and pacified annexed regions. ${ }^{51}$ Deportees were not generally turned into slaves, and their socio-economic status was diverse. Professionals employed by

\footnotetext{
45 On forced migrations, see Fiddian-Qasmiyeh et al. (eds.) 2014. For an application of forced migration studies on the Babylonian exile of Judeans, see Ahn 2011.

$46 \quad$ See Section 2.3.

47 Da Riva 2008.

48 The standard work on Assyrian deportations is Oded 1979. See also Zehnder 2005, 120-191; Crouch 2009, 43-46; Berlejung 2012, 45-48.

49 Oded 1979, 41-48.

$50 \quad$ Oded 1979, 48-74; Zehnder 2005, 143-165.

51 Oded 1979, 26-32; $\mathrm{Na}^{\text {?aman }}$ and Zadok 1988.
} 
the state could enjoy a high standard of living, whereas people working in building projects or farming land lived at a subsistence level. ${ }^{52}$

There are no Persian sources on actual deportations, ${ }^{53}$ but the Persepolis Fortification tablets and building inscriptions from the reign of Darius I confirm that workers from the west were present in Persepolis and Susa. ${ }^{54}$ The Babylonian chronicle on the reign of Artaxerxes III describes the deportation of Sidonians to Babylon and Susa. ${ }^{55}$ Moreover, Greek writers such as Herodotus and Diodorus Siculus provide us with some information on Persian deportation policies. Given the Greek writers' distrust of the Persians, these accounts are suspect in terms of being partial and propagandistic. However, as they find support in the Persian sources and mirror the practices of the Assyrian Empire, they are hardly pure imagination or mere propaganda. According to the Greek writers, deportations were often a consequence of rebellious behaviour, and people were deported across great distances from the Mediterranean to the eastern parts of the empire, including the Persian heartland. ${ }^{56}$ Deportations of foreign professionals are also referred to. ${ }^{57}$

The aims of Persian population transfers resemble those of the Assyrians. Both empires used deportations as a geopolitical tool to crush rebellions, maintain stability in peripheral regions, and bring labour to the core areas of the empire. As will be shown in this study, Babylonian deportation practices were not markedly different from those of Assyria and Persia. It has to be noted that both Assyria ${ }^{58}$ and Persia ${ }^{59}$ resettled people in Babylonia, and thus the population diversity in Southern Mesopotamia did not only result from voluntary migration and Babylonian deportations in the long sixth century. However, there is no clear evidence of deportations from the region of Israel and Judah to Babylonia before Nebuchadnezzar II's expulsions in the early sixth century.

$5^{2}$ Oded 1979, 75-115; Younger 1998, 219-224; Zehnder 2005, 166-191.

53 On deportations in the Persian period, see Shahbazi 1994-2011; Briant 2002, 505-507; Potts 2013; van der Spek 2014, 256-259; Silverman 2015a.

54 For the Persepolis Fortification tablets, see Henkelman and Stolper 2009 with further literature. For Darius I's $D S f$ ans $D S z$ inscriptions, see Lecoq 1997, 234-237, 243-245.

$55 \quad A B C 9$.

$5^{6}$ See, for example, Herodotus 4.200, 4. 204, 6.18-20, 6.119; Diodorus Siculus 17.110.3-5.

57 Diodorus Siculus 1.46.4.

58 Fuchs 1994, 170:380-381; Zadok and Zadok 2003.

$59 A B C$ 9. On possible deportations from Egypt to Babylonia in the Persian period, see Hackl and Jursa 2015, 159 . 


\subsubsection{Deportations from Judah to Babylonia}

Nebuchadnezzar II's deportations from Judah are undoubtedly the bestknown population transfers in the ancient Near East due to their legacy in the Hebrew Bible and later Jewish and Christian traditions. Extra-biblical sources also attest to Babylonian military operations in Judah in the early sixth century BCE and to the resulting destruction of Jerusalem, population collapse, and deportations. The primary sources for these events are the Babylonian chronicle on the early years of Nebuchadnezzar II ( $A B C 5$ ), the results of archaeological excavations and surveys in Palestine, and legal and administrative documents referring to Judeans in Babylonia. The Hebrew Bible is an important secondary source, but its use is hampered by textual problems and inconsistent information on deportations. ${ }^{60}$

Palestine was located in the border zone between Egypt and the Mesopotamian empires, and struggles for the control of this area affected Judah as well. Assyria had conquered Egypt for a short period in the early seventh century, but the tables were turned at the end of the century when Egypt invaded former Assyrian territories all the way up to Carchemish on the Euphrates. ${ }^{61} \mathrm{Ju}-$ dah also came under the dominion of Egypt (2 Kgs 23:28-35). After the fall of Nineveh, the Babylonian army started to advance on Syria and Palestine and push back the Egyptian troops. According to $A B C 5$, it took years to expel the Egyptian forces from Palestine, ${ }^{62}$ but Babylonia finally managed to annex the former provinces and vassal states of Assyria by the end of the seventh century. Judah also had to submit to Babylonian rule, and the native dynasty continued to rule as vassal kings in Jerusalem (2 Kgs 24:1).

It was in Egypt's interest to destabilise Babylonian rule in Palestine, and Nebuchadnezzar's annual military campaigns in the west suggest that Babylonia experienced difficulties in consolidating its power in the region. ${ }^{63}$ It is probable that Egypt was also involved in the events that resulted in the Babylonian conquest of Jerusalem in the spring of $597 \cdot{ }^{64} A B C 5$ (rev. 11-13) describes how

60 Person 1997, 80-113; Pakkala 2006; Müller et al. 2014, 109-125. Cf. Cogan and Tadmor 1988, 320-321; Holladay 1989, 439; Fischer 2005, 639-640.

61 On Egypt's role in Palestine in the late seventh and early sixth centuries, see $\mathrm{Na}^{2}$ aman 1991; Fantalkin 2001, 2015, 235-237; Lipschits 2005, 1-97; Kahn 2008, 2015; Schipper 2010, 2011.

62 The destruction of Ashkelon in 604 (Stager 2011) was probably a part of this process (Fantalkin 2011).

$63 \quad A B C 5$.

642 Kgs 24:7 seems to indicate that Jehoiakim, the king of Judah, was hoping for support from Egypt. Altogether, it is very unlikely that he would have rebelled against Babylonia without any promises of Egyptian aid. See Albertz 2003, 53; Lipschits 2005, 51-52. 
Nebuchadnezzar captured the king of Judah, took great booty from Jerusalem, and installed a new vassal king on the Judean throne in his seventh regnal year. ${ }^{65}$ This account corresponds to the general outlines of the events described in 2 Kings 24, according to which King Jehoiakim of Judah rebelled against Nebuchadnezzar but died before the Babylonian army besieged Jerusalem. It appears that Jehoiakim hoped for Egyptian support for his revolt, but this never happened, and his son Jehoiachin chose to surrender to the Babylonians. Jehoiachin, his retinue, Jerusalemite elite, and craftsmen were deported to Babylon, and Nebuchadnezzar appointed Jehoiachin's uncle Zedekiah as the vassal king in Jerusalem. Cuneiform documents from the city of Babylon confirm that Jehoiachin was held there six years later in $591 .{ }^{66}$ Jeremiah 52:28 refers to this deportation as well. ${ }^{67}$

The account of Nebuchadnezzar II's reign in $A B C 5$ breaks up after his eleventh year. As there are no other cuneiform sources on the history of Judah in the early sixth century, the reconstruction of the events following Jehoiachin's capture is primarily dependent on archaeology and biblical sources. Archaeological excavations and surveys in Judah attest to destruction and population collapse in the early sixth century. Jerusalem was destroyed, and the region recovered slowly in the Persian period. It was only in the Hellenistic period that the population finally started to grow rapidly. ${ }^{68}$ Despite the destruction of Jerusalem and its environs, there was a noticeable continuity of settlement in the Benjamin region to the north of Jerusalem and around Ramat Rahel to the south of Jerusalem. ${ }^{69}$

As $A B C 5$ (rev. 13) and 2 Kgs 24:17 claim that Nebuchadnezzar appointed a new vassal king in Jerusalem, it is unlikely that the archaeological record of destruction and population collapse in Jerusalem is primarily related to Nebuchadnezzar's military operations against Jerusalem in 597. Therefore, the accounts of Zedekiah's revolt in 2 Kings $24-25$ and Jeremiah $34,37,39$, and 52

65 The date of the conquest can be firmly located in the spring of 597 on the basis of the data from $A B C 5$ rev. 11-12. Jer 52:28 agrees with $A B C$, but 2 Kgs 24:12 suggests that the conquest took place a year later in Nebuchadnezzar II's eighth regnal year. The data from the Babylonian primary source is followed here. For a discussion of the dates and number of deportations from Judah, see Albertz 2003, 74-81; Valkama 2012, 50-54.

66 Weidner 1939. See Section 2.4.

67 However, 2 Chr 36:6-7 and Dan 1:1-2 claim that Nebuchadnezzar also deported Jehoiachin's father Jehoiakim and vessels from the temple of Yahweh to Babylon. This information is hardly trustworthy as the accounts are late and they contradict earlier sources. For similar judgements, see, for example, Albertz 2003, 75; Valkama 2012, 50.

68 Carter 1999; Lipschits 2005; Finkelstein 2008a, 2008b, 2010; Faust 2012; Valkama 2010, 2012.

69 Valkama 2010, 2012, 55-71, 118-123, 272-275; Lipschits 2011. But cf. Faust 2012, 209-231, 243-249. 
provide a reasonable explanation for the archaeological record. In addition to biblical sources and archaeology, the letters from the Judean fortified town of Lachish shed light on the last days of Judah before the Babylonian conquest (see Jer 34:6-7). ${ }^{70}$ It appears that Zedekiah also hoped to receive support from Egypt, but these hopes were in vain (Jer 37:1-10). The Babylonian troops destroyed Jerusalem and deported another group of Judeans to Babylonia perhaps in 587 or $586 .{ }^{71}$

In addition to the deportations in the reigns of Jehoiachin and Zedekiah, Jer 52:30 refers to a third deportation from Judah in Nebuchadnezzar's twentythird year. The passage does not indicate the reason for the deportation, but some scholars have connected it to the murder of Gedaliah, whom Nebuchadnezzar appointed as the governor of Judah after Zedekiah's defeat, according to 2 Kgs $25: 22-26$ and Jer $40-41 .^{72}$ No extra-biblical sources, however, attest to this population transfer. Although it remains a possibility, a historical reconstruction based on two deportations seems most plausible. Yāhūdu, the village of Judah in Babylonia, and its Judean inhabitants start to appear in cuneiform sources from 572 onwards, bearing witness to the deportations. ${ }^{73}$

The Hebrew Bible provides information on the size of the deportations from Judah, but this information is not consistent and its historical reliability remains doubtful. When it comes to the first deportation in 597, 2 Kgs 24:14 refers to 10,000 and verse 16 to 8 , ooo deportees. According to Jer 52:28, the number was only 3,023 people. When it comes to the second deportation, there is a strong sense of definitiveness in the accounts found in 2 Kings 25 and 2 Chronicles 36 . According to 2 Kgs 25:11, 'all the rest of the population' were deported to Babylonia, although the next verse adds that the Babylonians 'left some of the poorest people of the land to be vinedressers and tillers of the soil'. The totality of the second deportation is emphasised in $2 \mathrm{Chr} 36: 20-21$ in particular, and the land is described as being desolate during a Sabbath rest of seventy years. On the contrary, Jer 52:29-30 supplies the reader with precise numbers: the second deportation was comprised of $83^{2}$ Judeans, and the alleged third deportation of 745 people. The exact numbers in Jer 52:28-30 are often taken as more reliable than the round numbers in 2 Kings $24,{ }^{74}$ but this matter needs to be assessed in light of archaeology and cuneiform sources as well.

\footnotetext{
70 Torczyner et al. 1938; Pardee 1982, 67-114; Lemaire 2004; Ussishkin 2004.

712 Kgs 25:1-21; Jer 39:1-10; 52:29. On the date of the second deportation, see Albertz 2003, 78-81; Müller et al. 2014, 114-116.

72 Albertz 2003, 74-75; Fischer 2005, 366, 654; but cf. Lipschits 2005, 100 n. 229. See also Miller and Hayes 2006, 486.

73 See Chapter 4.

74 See, for example, Holladay 1989, 443; Fischer 2005, 653; Blenkinsopp 2009, 45.
} 
Recent archaeological studies on Judah in the sixth century do not conform to the idea of desolate land depicted in 2 Chronicles 36 , but they do not support the opposite view of strong continuity either. ${ }^{75}$ They show that there was a significant collapse in population, especially in the Jerusalem region, but also a continuity of settlement in the north and south of the capital. The population estimations in Judah before and after the Babylonian military actions vary, but they all attest to a major disruption: the population fell from about 110,000 to $15,000-40,000 .{ }^{76}$ Naturally this change did not result from deportations only, and two other factors are equally or even more important. First, people were killed in battles, they were executed, and the disruption of farming activities could result in severe famine. Second, many people left the land seeking refuge. ${ }^{77}$ Given the sharp population collapse, deportations of roughly ten thousand people do not seem exaggerated and they would be large enough to explain the relatively large number of Yahwistic names in the Babylonian cuneiform documents from the sixth and fifth centuries. The transfer of a mere several hundred people to Babylonia would not adequately explain the genesis of Judean communities in Babylonia, but given the different factors accounting for the population collapse in Judah, deportations of tens of thousands of people seem unlikely. ${ }^{78}$

Judean revolts against Babylonia led to two conquests of Jerusalem and to two deportations to Babylonia, the first one in the reign of Jehoiachin in 597 and the second one in the reign of Zedekiah, perhaps in 587 or 586 . Babylonian military operations led to a serious population collapse in Judah, but deportations were only one contributing factor. A rough estimation of 10,000 deportees appears to be plausible, given the number of Judeans attested in Babylonia

75 For somewhat polemical arguments for strong continuity in Judah, see Barstad 1996.

76 Lipschits 2005, 270: from 110,000 in the late seventh century to 40,000 in the Babylonian period; Faust 2012, 128-138, 169: the population in the sixth century was less than 20 per cent of the population in the seventh century; Valkama 2012, 221: 20,000-30,000 in the mid-sixth century (this follows the estimation of Broshi and Finkelstein 1992, 51-52 and Lipschits that the Iron Age population of Judah was about 110,00o people). Carter (1999, 114-118, 199-202, 246-247) estimates that the population in the province of Yehud - which was geographically smaller than the kingdom of Judah - was around 60,00o in the Iron Age and 13,350 at the turn of the sixth and fifth centuries.

77 Faust 2011, 2012, 140-143.

78 Estimations on the extent of the deportations from Judah vary considerably. Barstad 1996, 78-81: only the upper classes and skilled professionals were deported; Albertz 2003, 87-90: one fourth of Judeans, about 20,000, were deported; Liverani 2005, 253-254: there were no more than 20,000 deportees; Blenkinsopp 2009, 45: the number was closer to 4,600 (Jer 52:30) than 18,00o (2 Kgs 24:14-16) deportees. Faust 2011 emphasises the view that deportations were only one factor resulting in the population collapse. 
in the sixth century. Part of these people were the Jerusalemite elite and educated professionals, and the existence of the village of Yāhūdu in Babylonia already twenty-five years after the first deportation suggests that the group consisted of both men and women. The aims of the Babylonian deportations from Judah match the outlines of Assyrian and Persian deportation policies described above. The deportations aimed to punish Judah for rebellion, prevent future unrest, and, as the present study will show in detail, increase agricultural output and provide the state with taxes and a work force. ${ }^{79}$

\subsubsection{Babylonian Society}

The study of any ancient society is hampered by our inability to have a balanced view of different social groups and the interactions between them. Written sources express the perspectives of a literate minority, and the archaeological record is rarely substantial enough to fully balance this view. At the same time, finding appropriate terminology to describe an ancient society is challenging, for our modern concepts - however accurate they may be in our current societies can be misleading. The choice of terms is not a trivial question, as language necessarily guides our research questions and analysis.

These methodological concerns have to be taken seriously in NeoBabylonian studies: indeed, the surviving texts were written by a well-defined elite group in society, and archaeological remains cannot satisfactorily complement the picture. Some widely used terminology can also be misleading if not defined carefully. For example, Babylonia and the Babylonians are etic concepts which conform to modern perceptions of state and nation, but they do not find a counterpart in cuneiform sources from Southern Mesopotamia. There is growing concern among Assyriologists about methodological rigour in the field, which is characterised by immense numbers of unpublished texts and a very small number of academics studying them..$^{80}$ Quite understandably, methodological considerations have often been overshadowed by the justifiable aspiration to make as many new sources available as possible. This section is an attempt to briefly discuss the methodological issues raised above and sketch some characteristics of 'Babylonian' society in the mid-first millennium.

79 See Liverani 2005, 194-195.

8o See, for example, Van De Mieroop 1997b, 2013; von Dassow 1999a; Fleming 2014; Richardson 2014. The recently established Journal of Ancient Near Eastern History is an attempt to provide a platform for such methodological discussions (see Van De Mieroop and Garfinkle 2014). 
The cuneiform records from the mid-first millennium provide us with a rich source for a historical study, but a serious methodological pitfall has to be taken into account. Despite their huge number, the written sources originate from a small segment of society. Scribes did not represent the local population as a whole, but they belonged to an educated minority which had mastered both the technical skills of writing Akkadian cuneiform and the traditions and values connected to it. ${ }^{81}$ The texts written by these scribes undoubtedly offer an emic perspective on the social structures of the literate elite, but their perceptions of other groups in society may only reflect etic conceptions of the other. This is emphasised by the fact that two languages, Akkadian and Aramaic, played a major role in Southern Mesopotamia in the mid-first millennium, but hardly anything written in Aramaic has come down to us. ${ }^{82}$ In contrast to tens of thousands of extant clay tablets written in Akkadian cuneiform, only a small number of short Aramaic inscriptions on clay tablets and bricks have survived. Aramaic was primarily written on perishable materials such as parchment and papyrus, of which nothing is left in Southern Mesopotamia. In the same vein, texts written in other languages spoken by immigrants do not survive from Babylonia. Accordingly, the Akkadian cuneiform texts and the terminology used in them by an educated elite have come to represent the whole society. This one-sidedness must be taken into account and its effects analysed critically.

The present book claims to be a study of ancient Babylonia, but, from an emic perspective, the term 'Babylonia' is not without its problems. Babylonia is the later Greek name of Southern Mesopotamia, and it is never used in NeoAssyrian or Neo-Babylonian sources to describe the region around the cities of Babylon, Borsippa, Sippar, Nippur, and Uruk, located on the alluvial plain of the Euphrates and Tigris between present-day Baghdad in the north and the Persian Gulf in the south. ${ }^{83}$ At the same time, cuneiform sources make a distinction between the southern alluvial plain and, for example, the Assyrian heartland in the north. These sources refer to the floodplain as Akkad, Sumer and Akkad, or Karduniaš, the last term being attested in Kassite and occasionally in Assyrian sources. ${ }^{84}$ Sumer and Akkad were ancient terms which originally denoted two different regions on the alluvial plain, Sumer in the south and Akkad in the north. ${ }^{85}$ Later this distinction was no longer meaningful, and

\footnotetext{
81 Gesche 2000; Carr 2005; van der Toorn 2007; Still 2019, 213-227.

82 Beaulieu 2007, 2013 b; Jursa 2012; Hackl (forthcoming).

83 von Dassow 1999a, 241-245; Beaulieu 2007, 209-210; Kanchan and Radner 2012.

84 Seux 1967, 301-303; Brinkman 1976-1980; Frame 1992, 33; von Dassow 1999a, 242.

85 Cooper 2012, 291-293.
} 
the longer form Sumer and Akkad and the shorter form Akkad could be used interchangeably to refer to the whole alluvial plain, with the name Sumer and Akkad being predominant. ${ }^{86}$

The ancient names Akkad, Sumer and Akkad, and Karduniaš suggest that the southern alluvial plain was perceived as a distinct entity, different from the surrounding regions. The area is indeed well defined geographically, as the plain is bordered by the Arabian Desert in the west, the Persian Gulf in the south, and the Zagros Mountains in the east. In the north, the alluvial plain begins roughly where the courses of the Euphrates and Tigris are closest to one another, near the ancient city of Sippar. ${ }^{87}$ The interconnected waterways created a network of cities which shared many cultural and social traits and participated in a close-knit economic system. ${ }^{88}$ The dialect of Akkadian spoken on the alluvial plain - commonly referred to as Babylonian - was different from the dialect spoken in the north (Assyrian). ${ }^{89}$ Despite strong local identities and claims for self-governance, ${ }^{90}$ the old cities of the alluvial plain shared a number of cultural features and social structures. These included, for example, literature, ${ }^{91}$ scholarship, ${ }^{92}$ and the social organisation of the elites and temple service. ${ }^{93}$ In light of this evidence, the southern alluvial plain was not just a distinct geographical entity, as its urban literate elite shared cultural and social structures which were characteristic of the region. For the purposes of the present study, we can legitimately adopt the Greek term and call the southern alluvial plain Babylonia.

Babylonia was a distinct entity but not a state in the modern sense. The term 'Babylonia' is derived from the name of the most important city in the region, Babylon, which was also a royal seat from the late seventh to the late sixth century. The standard title of the kings from Nabopolassar to Nabonidus in royal inscriptions was 'King of (the city of) Babylon' (šar Bäbili), and the title 'King of Sumer and Akkad' (šar mät Šumeri u Akkadi) was used only occasionally. ${ }^{94}$ 'King of Babylon' was also the standard title used in the dating formula of legal

86 Beaulieu 2007, 209.

87 Adams 1981, 3 .

88 On waterways and the Babylonian economy, see Jursa 2010a, 62-140.

89 Streck 2011.

9o Barjamovic 2004.

91 Southern and Northern Mesopotamia shared a literary tradition in Akkadian, but the regions also had distinctive traditions of their own. See Foster 2007.

92 See, for example, Rochberg 2004; Ossendrijver 2008; Geller 2010; Van De Mieroop 2016.

93 Waerzeggers 2010a, 2011; Nielsen 2011; Still 2019.

94 Da Riva 2008, 93-107. 
and administrative texts. ${ }^{95}$ This was an ancient and prestigious title, which rose to prominence already in the reign of King Hammurapi in the eighteenth century when Babylon became the political and cultural centre of southern Mesopotamia. ${ }^{96}$ However, it has to be noted that there was no state of Babylonia which continuously existed on the alluvial plain since the reign of Hammurapi, but the region of Babylonia was sometimes a part of a larger state or empire, sometimes fragmented into numerous political entities. Babylonia was not a state, but rather a cultural entity and geographic region, as described above. ${ }^{97}$ Accordingly, I will use the term 'state' to refer to the political entities which governed Babylonia in the sixth and fifth centuries, that is, first the NeoBabylonian Empire and later the Persian Empire. The term 'Neo-Babylonian Empire' will be used to refer to the political entity founded by Nabopolassar in 626 and brought to an end by Cyrus in 539. Its successor, the Persian Empire, ruled over the ancient Near East from 539 until the conquests of Alexander the Great in the 330s.

In the self-identification of the rulers of the Babylonian Empire, the title 'King of Babylon' emphasised the importance of a city rather than a state. Sources from the mid-first millennium suggest that common people also identified themselves with a family, tribe, or city rather than a state. Although empires shaped the political landscape of Babylonia in the first millennium, cities still retained some autonomy and carried on the legacy of the earlier city states. ${ }^{98}$ The term bäbilāya ('Babylonian') in cuneiform sources does not refer to an inhabitant of the alluvial plain in general but to an inhabitant of the city of Babylon in particular. The same applies to people from other ancient cities of the alluvium, and migrants or visitors from another Babylonian city were occasionally labelled according to their place of origin. ${ }^{99}$

Mesopotamian sources from the first millennium do not provide us with an umbrella term to describe the inhabitants of Babylonia. Neo-Assyrian sources refer to several population groups: the Akkadians (akkadû), Arameans (aramu or aramāya), Chaldeans (kaldu or kaldāya), and Arabs (urbu or arbāya). In addition, the Sealand (mät tâmti) is mentioned as a separate entity. ${ }^{100}$ The terms 'Chaldean' and 'Aramean' are also used in Babylonian sources before 626, but

95 The title 'King of Babylon' remained in use in the Persian period as well; see Rollinger 1998, 355-361, 369-373; 1999.

96 Note that Hammurapi also used many other titles, which emphasised the geographical extent of his kingdom; see Charpin 2012, 75-77.

97 See von Dassow 1999a, 241-245.

98 Barjamovic 2004.

99 Kessler 2004; Jursa 2010a, 72, 126-127, 136-137.

100 Frame 1992, 32-51; 2013. 
the first term disappears and the second one is rarely used after the emergence of the Neo-Babylonian Empire under Nabopolassar. ${ }^{101}$ In the earlier sources, 'Chaldean' and 'Aramean' appear to be umbrella terms which cover a number of distinct entities. Five groups (Bīt-Amūkāni, Bīt-Dakkūri, Bīt-Yakīn, BītSa'alli, and Bīt-Silāni) are assigned under the rubric 'Chaldean', and although the term was no longer used in the sixth century, the names Bìt-Amūkāni, BìtDakkūri, and Bīt-Silāni continued to be employed in Babylonian sources. ${ }^{102} \mathrm{On}$ the other hand, the term 'Aramean' appears to cover about forty groups, the most prominent in our sources being Gambūlu and Puqūdu. ${ }^{103}$ However, the situation is complex, and it is often impossible to make a neat division between the Aramean and Arabian population groups. ${ }^{104}$

Social entities like Bīt-Dakkūri or Puqūdu are traditionally called tribes, but this term may be misleading as it is often associated with a semi-nomadic pastoral lifestyle. ${ }^{105}$ In particular, the Chaldeans lived in cities and cultivated land. ${ }^{106}$ Because we do not possess any sources written by the Arameans or Chaldeans, we are dependent on the cuneiform scribes' perceptions of these population groups. Accordingly, we do not know whether these people perceived themselves as members of, for instance, both Bīt-Amūkāni and a population group called the Chaldeans. However, the designations of these groups were not linguistically Akkadian but Aramaic and Arabian, and therefore they were most likely emic terms used by the members of the group themselves, not ones imposed on them by the cuneiform scribes. ${ }^{107}$ Moreover, the membership of a Chaldean group like Bìt-Dakkūri seems to have been grounded in the idea of shared kinship among its members. ${ }^{108}$ Labels like 'Chaldean' or 'Aramean' may have been given by outsiders, and we should not necessarily expect that strong feelings of solidarity existed between the members of Bīt-Amūkāni and Bìt-Dakkūri. ${ }^{109}$ However, from the etic perspective of the Assyrian cuneiform scribes the social entities Aramean and Chaldean existed, and the terminology employed by the scribes will be used in this study for the sake of convenience.

\footnotetext{
101 Beaulieu 2007, 199-200.

102 Lipiński 2000, 419-420; Beaulieu 2013a, 37; Frame 2013, 98-100.

103 Lipiński 2000, 422-489, Beaulieu 2013a, 45-47; Frame 2013, 90-97.

104 Lipiński 2000, 422-489.

105 See von Dassow 1999a, 234-241; Szuchman (ed.) 2009.

106 Frame 2013, 102-103.

107 According to Zadok 2013, these group names are primarily Aramaic, but Lipiński 2000, 416-489 favours an Arabian etymology of many names.

108 Lipiński 2000, 416.

109 On the tensions and cooperation between different Aramean and Chaldean groups in Babylonia, see Fales 2011.
} 
Groups such as Bït-Dakkūri will be called 'tribes' in this study, indicating primarily their social organisation, but this is not to claim that such organisation was a certain way or that their lifestyle was nomadic.

It is commonly thought that the Arameans and Chaldeans arrived in Babylonia at the turn of the second and first millennia and that they were Aramaicspeaking population groups from the north and north-west. ${ }^{110}$ Nevertheless, they should not be regarded as outsiders in Babylonian society, as both groups exercised significant political power in Babylonia: men of Chaldean descent led numerous rebellions against the Assyrian Empire in the eight and seventh centuries and were occasionally able to claim the throne in Babylon. ${ }^{111}$ Furthermore, it is possible that King Nabopolassar was also of Chaldean descent, and it seems probable that King Neriglissar belonged to the Puqūdu tribe and Nabonidus' mother was an Aramean from the Syrian city of Harran. ${ }^{12}$ The political power of the Aramean and Chaldean tribes is reflected on Nebuchadnezzar II's Hofkalender, which lists a number of tribal leaders among the magnates of his empire. ${ }^{113}$ Yet another testimony to the importance of Chaldean tribes in Babylonia are the Hebrew Bible and Greek sources, which use the word 'Chaldean' to refer to the inhabitants of Babylonia. ${ }^{114}$

Kinship was not only a central element of social organisation among the Arameans and Chaldeans. It appears to have been the most decisive affiliation in a person's social world among other population groups as well. This was obviously the case among cuneiform scribes, priests, and the other people in their circles, a group which Assyriologists have often called the urban elite or urban upper class. ${ }^{115}$ There is no evidence of an emic term which was used to describe this group or its members, but there is plenty of evidence to suggest that such a social group existed in antiquity and that it is not a mere modern construction. The most distinctive feature of this group is its habit of tracing family genealogies back to eponymous ancestors, resulting in such naming patterns as ' $\mathrm{PN}$ the son of $\mathrm{PN}_{2}$ the descendant of $\mathrm{PN}_{3} 3{ }^{\text {'.16 }}$ The identification of a person using his first name and his father's name was commonplace in the scribal and legal tradition of the period, but the usage of family names was confined to certain clans or lineages in each city. Many of these families were

\footnotetext{
110 See Section 1.2.2, but cf. Lipiński 2000, 416-489 on their possible affiliation with Arabian tribes.

111 Frame 2013, 97-116.

112 Jursa 2014a, 131-133.

113 Da Riva 2013, 213 vi*:19'-32'. See Da Riva 2013, 204; Jursa 2014a, 127-130.

114 Beaulieu 2007, 199.

115 See, for example, Waerzeggers 2003/2004, 158; Jursa 2010a, 4.

116 Nielsen 2011; Wunsch 2014.
} 
associated with temples and inherited prebends, whereas some engaged in large-scale entrepreneurial activities. ${ }^{117}$ These families maintained the cuneiform culture, performed the rites in Babylonian temples, and exercised significant power in the old cities. The long sixth century was the golden age of these families, but their involvement in the unsuccessful revolts against King Xerxes in 484 led to changes in the Babylonian social landscape at the expense of this old elite. ${ }^{118}$

The urban elite comprised only a small minority of the population, but, as noted above, they are usually attested as protagonists of private archives and as scribes of any given document. ${ }^{119}$ As a result, our perspective of the rest of the population is primarily their perspective, and a significant part of the Babylonian population is underrepresented in the available sources. This would include common people in the cities and countryside, including craftsmen, unskilled workers, slaves, farmers, herdsmen, fishermen, and, in particular, women and children. ${ }^{120}$ Some of these people had recently arrived in Babylonia, while other families had lived in Babylonia for centuries. Some affiliated themselves with an Aramean or Chaldean tribe while others did not. Only a minority of the urban population belonged to the upper class. Babylonia experienced a period of population growth and urbanisation in the mid-first millennium, ${ }^{121}$ and, as described above, this was accompanied by economic growth. There was a demand for hired labour and people could make their living as paid workers, for instance, in public construction projects.

At the same time, Babylonia was an agricultural society, and the number of farmers must have exceeded the more specialised population in the same way as in other non-industrialised societies. ${ }^{122}$ Agriculture in Babylonia was wholly dependent on irrigation and thus vulnerable to floods, drought, and salinization. ${ }^{123}$ The Euphrates was the main source of water and an important

117 On the social world of Babylonian priests, see Waerzeggers 2010a; Still 2019. The most famous example of entrepreneurs is the Egibi family of Babylon, on whom see Wunsch 2007. On the urban elite in Sippar, see Waerzeggers 2014a.

118 See Section 1.2.1.

119 According to Michael Jursa (personal communication, June 2015), 4-8 per cent of the population belonged to this group.

120 See Jursa 2007d, 2015a on different socio-economic groups and professions in Babylonian society.

121 Adams 1981, 178; Brinkman 1984b; Jursa 2010a, 37-42.

122 On the agricultural basis of Babylonian society, see Jursa 2010a, 2014c. For estimations of people participating in agricultural production in non-industrialised societies, see Lenski 1966, 199-200; Lenski et al. 1991, 181. For urban population in Europe in 1500-180o, see de Vries 1984, 38-39, 76 .

123 Adams 1981; Cole and Gasche 1998; Altaweel 2013. 
waterway, and shifts in its course also changed urban settlement patterns over time. ${ }^{124}$ Access to water was a prerequisite for a farmer's livelihood, and continuous work was necessary to maintain irrigation infrastructures on a local and regional scale. ${ }^{125}$ Barley and date palm were the main crops, and the annual cycle of their cultivation dictated the work and leisure of a farmer's family. ${ }^{126}$ Animal husbandry played an important role in the rural economy as well. ${ }^{127}$ Villages appear only on the fringes of our source material, however, and little is known about their social organisation and daily life. ${ }^{128}$ The texts discussed in this study can shed light on this issue, as the majority of them were written in rural settlements.

The urban elite should probably be included in the category of Akkadians mentioned in the Assyrian sources, but we lack information about the inclusion of the urban lower classes or peasants in this group. Because Assyrian sources focus on the political developments in Babylonia, it is conceivable that the categories of Akkadians, Chaldeans, and Arameans refer first and foremost to the power blocs, not to the three main population groups of the region. ${ }^{129}$ In this regard, it has to be emphasised that a person's linguistically Akkadian or Aramaic name did not necessarily correspond to his affiliation with the Akkadians or Arameans. ${ }^{130}$ There is no emic terminology that would correspond to the term 'Akkadian', and it is not to be equated with the modern usage of terms like 'Dutch' or 'Iraqi'. Nor does it correspond to the term 'Babylonian' if the latter is understood to denote the native inhabitants of Babylonia.

The term 'Babylonians' may in fact lead us to overlook the heterogeneity of the society and create imagined solidarities which did not actually exist. In this study, I aim to use more nuanced categories when possible, such as those related to socio-economic status. However, the word 'Babylonians' cannot be discarded altogether, because there is an obvious need for a general term which juxtaposes deportees with the native population of Babylonia. I use the term 'Babylonians' to refer to people who bore Akkadian or common Aramaic names and who were apparently not descendants of deportees or recent migrants to Babylonia. This group will unavoidably include deportees and other

\footnotetext{
124 Brinkman 1984b, 175-176. For the case of Nippur, see Cole 1996, $5^{-22 .}$

125 van Driel 1988; Joannès 2002.

126 van Driel 1988, 1990; Widell et al. 2013.

127 van Driel 1993, 1995.

128 On the Babylonian countryside and villages, see van Driel 2001; Richardson 2007. On the urban perceptions of the countryside, see Van De Mieroop 1997a, 42-62.

129 On the situation in the seventh and sixth centuries, see Frame 1992, 32-51; Jursa 2014a, 126-133.

130 See Section 1.5 .
} 
immigrants, because Akkadian names often disguise the foreign background of their bearers. At the same time, Aramaic was widely spoken in Babylonia, and Aramaic names are not indicative of a person's foreign origin. As Section 1.5 shows, uncommon personal names are normally the only means to identify people of foreign origin.

Despite our inability to find an emic term that would cover the population of Babylonia as opposed to the recently arrived deportees, foreignness - in the sense of originating from a different region - was presented in cuneiform sources as a distinctive feature of certain population groups. In the texts from the Palace Archive of Nebuchadnezzar II, rations were given to sailors from Tyre, carpenters from Arwad and Byblos, and to Judean courtiers, to name but a few. ${ }^{131}$ Moreover, the foreign origins of the Egyptian temple dependants (širkus) in the Ebabbar archive ${ }^{132}$ and the Carian population in Borsippa ${ }^{133}$ are made explicit. Finally, several foreign groups were deported to the countryside of Nippur and settled in communities according to their geographic origin. Consequently, places like Judah (Yāhūdu), Ashkelon, and Neirab appear in cuneiform documents from the sixth and fifth centuries. ${ }^{134}$ Yāhūdu is also called the Town of Judeans ( $\bar{a} l u$ ša Yāhüdāya) and Neirab the Town of Neirabians ( $\bar{a} l u$ ša Nerebea $y a$ ), which further corroborates the view that foreign origin was perceived as a distinctive feature of the Judean and Neirabian deportees.

I will use the following terminology to refer to people of foreign origin in Babylonia. The terms 'Judean' and 'Neirabian' will be used to refer to people who or whose ancestors had arrived in Babylonia from the kingdom of Judah or the city of Neirab. The great majority of them were deported to Babylonia at the turn of the seventh and sixth centuries. The criteria for identifying these people will be discussed in Section 1.5. Moreover, I use the terms 'deportee' and 'immigrant' to refer to people who had arrived in Babylonia after the late seventh century, excluding the population groups that had settled there earlier, such as the Chaldeans and Arameans. 'Deportee' specifically refers to people who arrived in Babylonia as a result of forced migration, whereas 'immigrant' refers to all people who had - voluntarily or involuntarily - resettled in Babylonia.

In the context of first-millennium Babylonia, it is probably most appropriate to speak of a multicultural and multilingual society in which power was

$131 \quad$ See Section 2.4 .

132 See, for example, Bongenaar and Haring 1994.

133 Waerzeggers 2006.

134 See Chapters, 4, 5.3.5, and 7, respectively. On this phenomenon in general, see $\mathrm{Eph}^{\varsigma}$ al 1978; Dandamayev 2004. 
divided between different actors. ${ }^{135}$ Chaldean and Aramean tribes exercised significant political, economic, and military power, whereas the closed circle of urban families dominated the sphere of temples, science, and cuneiform culture but were also entrepreneurs and owners of capital and real estate. A significant part of the population lived in the countryside outside the scope of the preserved sources, and among them were numerous immigrants and their descendants from different parts of the Near East. The tribes and urban elite enjoyed political and cultural hegemony, but they probably did not constitute the majority of the population in quantitative terms. There was no single social entity called the Babylonians, but rather population groups that were living in Babylonia and participated in its complex society. A key feature of the region was demographic diversity.

\subsection{Babylonian Exile: Reception and Research History}

Nebuchadnezzar II's deportations from Judah were only one of numerous population transfers in the ancient Near East, but their legacy is unparalleled. The catastrophe of Jerusalem's destruction and deportations is reflected throughout the Hebrew Bible, and Christian Europe learned to know Babylon as a place of splendour, decadence, and oppression. The term 'Babylonian exile' came to describe the period from the deportations until the alleged return migrations in the early Persian period. The terms 'exile' and 'exilic period' are also used in biblical scholarship, but this is problematic as the terms convey the idea of a period which had a clearly defined beginning and end. ${ }^{136}$ The Judean presence in Babylonia did not end in a mass return to Judah in the early Persian period. ${ }^{137}$ Moreover, the term 'exile' is loaded with images of oppression and does not do justice to the different experiences among the Judeans in Babylonia. The present section will use this traditional terminology to describe the reception and research history of the 'Babylonian exile', but the following chapters aim at discussing Babylonian sources in their own terms.

\subsubsection{Reception History}

The earliest reception history of the Babylonian exile is visible in the Hebrew Bible. It is not an exaggeration to state that most books in the Hebrew Bible

135 On this division of power, see Jursa 2014a, 126-133.

136 See Grabbe (ed.) 1998.

137 Large Judean communities are attested in Babylonia in the late fifth century. See Chapter 5 . 
react to the exile in one way or another, and that the emergence of the Hebrew Bible and Judaism were greatly influenced by the Babylonian exile. ${ }^{138}$ Above all, the exile was a catastrophe, and it is explained in Deuteronomy, the Former Prophets, and Chronicles as the consequence of sins against Yahweh. ${ }^{139}$ When the Israelites are still on their journey from Egypt to the land of Canaan, Moses warns them about violating the covenant between Yahweh and Israel. The consequence of transgressions would be exile from the Promised Land (Deut 28:47-68). This warning is repeated several times in the subsequent books (Josh 23:15-16; 1 Sam 12:24-25; 1 Kgs 8:46-53) and given as the reason for the fate of Israel and Judah (2 Kgs 17:5-23; 24:1-4). ${ }^{140}$ The Latter Prophets are busy with anticipating and explaining the exile or prophesying a return to Judah and a restoration of the temple in Jerusalem. ${ }^{141}$

The continuous historical narrative from Genesis to 2 Kings begins at the creation and ends at the onset of the exile. The exile marks a break in the story and the biblical narrative continues only when the exiles return to Judah in Ezra-Nehemiah. ${ }^{142}$ However, the exile in Babylon and Susa serves as the setting for Daniel and Esther, two literary works reflecting the Judean experience of living in diaspora. Both books feature Judean heroes who find themselves in serious danger in a foreign land but, with God's help, gain favour with foreign kings. ${ }^{143}$ These stories imply that Judeans could prosper in exile, and optimistic voices about life in exile can also be found in Jer 29:4-7.

Despite some hopeful tones in Daniel, Jeremiah, and elsewhere, the Hebrew Bible describes the exile first and foremost as a catastrophe. The powerful language of Psalm 137 has become the most well-known expression of the exilic experience: 'By the rivers of Babylon - there we sat down and there we wept when we remembered Zion. On the willows there we hung up our harps. For there our captors asked us for songs, and our tormentors asked for mirth, saying, "Sing us one of the songs of Zion!"' (verses 1-3). ${ }^{144}$ The opening words of the psalm have even become synonymous with the exile, as can be seen in the names of recent exhibitions, books, and research projects related to it. ${ }^{145}$

\footnotetext{
138 See, for example, Carr 2014, 67-140.

139 Albertz 2003, 8-15; Sweeney 2007, 1-15; Römer 2015.

140 Römer 2015, 264-269.

141 See, for example, Sweeney 2005.

142 Albertz 2003, 3-4.

143 On these stories and their relevance to the study of the exile, see Section 1.4.1.

144 On exile as suffering, see Becking 2009a. For a good overview of artistic depictions of the miserable life in exile, see Vukosavović 2015.

145 Some recent examples include the ERC Starting Grant project 'By the Rivers of Babylon: New Perspectives on Second Temple Judaism from Cuneiform Texts' at University College
} 
The motif of Babylon as a place of oppression and captivity has found its way into religious language, art, and popular culture. ${ }^{146}$ An early and important adoption of this motif can be found in the Book of Revelation (14, 16-18), in which Rome is compared to Babylon as a city of sin, decadence, and oppression. ${ }^{147}$ Later, in his treatise On the Babylonian Captivity of the Church, Martin Luther employed the motif of Babylon to criticise the Roman Catholic Church. ${ }^{148}$ In the twentieth century, the motif of Babylon has featured in reggae and pop music. For the Rastafari, Babylon symbolises the oppressive Western world and captivity there, whereas Zion represents Africa, especially Ethiopia, where the Rastafari and other Africans ought to return. ${ }^{149} \mathrm{~A}$ famous product of this tradition is Boney M.'s disco hit Rivers of Babylon, originally a Jamaican song based on Psalm 137. ${ }^{150}$

Another important stream of tradition is the biblical story of the Tower of Babel (Gen 11:1-9), which has had a huge effect on European culture. For centuries, the Tower has been a major theme in visual arts, with examples extending from medieval images to the iconic paintings of Pieter Bruegel the Elder in the sixteenth century and to Barnaby Barford's installation at the Victoria and Albert Museum in London in 2015. ${ }^{151}$ Greek writers and their accounts of the Hanging Gardens and other wonders of Babylon have also greatly contributed to the legacy of the city and the empire. ${ }^{152}$ The name Babylon and the story of its Tower also carry positive connotations in contemporary culture as the symbol of multiculturalism and multilingualism. The shopping centre, office, and apartment complex New Babylon in The Hague, several companies offering language learning services, and Art Cafe Babylon in the small Finnish town of

London and Leiden University in 2009-2015; 'By the Rivers of Babylon', the exhibition of the tablets from Yāhūdu and its surroundings at the Bible Lands Museum Jerusalem in 2015-2016; and the conference proceedings edited by Gabbay and Secunda, Encounters by the Rivers of Babylon: Scholarly Conversations between Jews, Iranians and Babylonians in Antiquity (2014). It must be noted, however, that these undertakings often challenge the picture of the exile given in Ps 137 .

146 On the reception history of Babylon and the Babylonian exile, see Finkel and Seymour (eds.) 2008, 102-212; Wullen et al. (eds.) 2008, 145-272; Becking et al. 2009.

147 Seymour 2008 b.

148 See Allard 2008, 146-149, for a discussion on the use of this motif during the Reformation.

149 Chevannes 1994, 1; Scholz 2008, 187.

150 Scholz 2008, 186-189.

151 Seymour 2008a; Brown 2015.

$15^{2}$ See the essays in Rollinger et al. (eds.) 2011; Wiesehöfer et al. (eds.) 2011; Haubold et al. (eds.) 2013. 
Kirkkonummi all make use of a positive image of a culturally diverse and exotic city.

\subsubsection{Research History}

Research on Judeans in Babylonia has been traditionally guided by biblical sources. Indeed, the Hebrew Bible and later Jewish writings were the only source for the study of the exile until the emergence of relevant cuneiform sources in the late nineteenth century. The discovery of Judean names in cuneiform material then attracted some attention, but the scholarship on Judeans in Babylonia was dictated by the biblical material during the whole twentieth century. Since the Hebrew Bible hardly ever describes life in exile, a great deal of exegetical ingenuity was needed to distil information from the bits and pieces that were available. In recent decades, archaeological work in Israel and fresh sociological approaches to the exile have nuanced the prevailing picture, but only after the emergence of the tablets from the environs of Yāhūdu have cuneiform sources on Judeans attracted major interest among students of the exilic period. The following review of research history focuses on the use of Babylonian sources in the study of the exile in the twentieth century and on the general developments in the field during the last twenty years. The reader is advised to consult Ahn 2011 for an overview of biblical scholarship on the exile in the twentieth century.153

The twentieth-century scholarship on Judeans in Babylonia did not need to be informed only by biblical texts, as the first cuneiform sources on Judeans in Babylonia were unearthed and published already at the turn of the nineteenth and twentieth centuries. The presence of Judeans in the Murašu archive is recognised already in the first volume of text editions, ${ }^{154}$ and Albert T. Clay discussed Yahwistic names in Babylonian sources and the importance of the Murašu archive for the study of Judeans in $1907 .{ }^{155}$ A very early study on Judeans in the Murašû archive was Samuel Daiches' The Jews in Babylonia in the Time of Ezra and Nehemiah according to Babylonian Inscriptions in 1910. ${ }^{156}$ Most of his conclusions would be contested today, but his attempt to use cuneiform documents as his main source was - and still is - exceptional.

Daiches had a special interest in the naming practices of Judeans, and this interest has dominated the study of the Judeans in Babylonia ever since. The studies of Léon Gry, D. Sidersky, and Gerhard Wallis focus on an analysis of the

\footnotetext{
153 Ahn 2011, 8-27.

154 Hilprecht and Clay 1898, 26-28.

155 Clay 1907, 235-250, 390-429.

156 Daiches 1910.
} 
Judean onomasticon in the Murašu archive, leaving the analysis of the texts themselves aside. ${ }^{157}$ In the 1970s, Michael D. Coogan and Ran Zadok laid a foundation for the later research on West Semitic names and especially on the Judean onomasticon in cuneiform texts. ${ }^{158}$ Zadok's highly productive work on Judean and West Semitic onomasticons in Babylonia has continued ever since, and his studies are foundational for the present study as well. ${ }^{159}$ However, apart from occasional brief excursions into Judean life in Babylonia, this line of research has shown little interest in social and economic historical questions.

The Murašû archive has had relatively little influence on biblical scholarship on the exile, but Ernst F. Weidner's publication of four administrative tablets from Babylon has had considerable impact. ${ }^{160}$ The texts are lists of oil rations which were distributed by the Babylonian royal administration to numerous recipients, many of whom were of foreign origin. King Jehoiachin of Judah and his five sons are also attested on the lists. Although the rest of this administrative archive remains unpublished, ${ }^{161}$ the four published texts have become a standard part of scholarship on the exile. In particular, they have been discussed in connection to the accounts of Jehoiachin's exile and his amnesty in 2 Kings $24-25 \cdot{ }^{162}$

The 1970 and 1980 s saw a number of studies aimed at reconstructing the history of Judeans in Babylonia based on cuneiform and biblical sources. ${ }^{163}$ The attempts of Israel Eph ${ }^{\mathrm{s}}$ al and Elias J. Bickerman to use Babylonian sources in a thorough and analytical manner led to some interesting observations: $\mathrm{Eph}^{\varsigma}$ al noticed the practice of settling deportees in the Nippur countryside and naming the communities according to the ethnic or geographical origin of the deportees. Moreover, he was the first to suggest that the cuneiform tablets excavated in Neirab, Syria actually belonged to a group of Neirabian deportees who returned from Babylonia to their ancestral hometown. ${ }^{164}$ Bickerman detected a generational difference in the naming practices among the Judeans in the Murašu archive and suggested that this was related to a religious awakening behind the missions of Ezra and Nehemiah. ${ }^{165}$ Bustenay Oded continued

\footnotetext{
157 Gry 1922, 1923; Sidersky 1929; Wallis 1980. Wallis also wrote his dissertation (1953) on Judeans in the Murašû archive, but I was not able to access it.

$15^{8}$ Coogan 1973, 1976a, 1976b; Zadok 1977, 1979a. Note also Stolper 1976.

159 Zadok 1988, 2002, 2003, 2014a, 2015a, 2015b.

160 Weidner 1939.

161 See provisionally Pedersén 2005a, 2005b, 2009; Jursa 2007c, $2010 b$.

162 See, for example, Gerhards 1998; Becking 2007, 181-182, both with further literature.

163 Bickerman 1978, 1984; Eph'al 1978, 1983.

$164 \mathrm{Eph}^{\varsigma} \mathrm{al} 1978$.

165 Bickerman 1978.
} 
this Assyriologically oriented research tradition in his two short articles on Israelite and Judean exiles. ${ }^{166}$

The current state of scholarship on the exilic period and Judeans in Babylonia is characterised by a more precise archaeological picture of sixth-century Judah, new critical discussions of and methodological approaches to the study of the exile, and the publication of new cuneiform sources. First, the study of the exilic period has greatly benefitted from a better understanding of life in Judah in the exilic period. The opinions of archaeologists such as Charles E. Carter, Avraham Faust, Israel Finkelstein, Oded Lipschits, and Kirsi Valkama are divided on certain issues, but the big picture of development in the Babylonian and Persian periods is clear. The Babylonian campaigns led to serious devastation in Judah in the early sixth century, even though there was evident continuity to the north and south of Jerusalem. There are no signs of any significant return migration in the early Persian period and the population started to grow more rapidly only in the Hellenistic period. ${ }^{167}$

Second, new methodological approaches to and critical discussions of the exile have advanced the field in the last three decades. Daniel L. SmithChristopher has been influential in introducing sociological approaches to the study of the exile, ${ }^{168}$ and his work has found followers such as John J. Ahn, Tracy M. Lemos, Dalit Rom-Shiloni, and Katherine Southwood. ${ }^{169}$ At the same time, the term 'exile', its historical framework, and its ideological dimensions have been discussed by a number of scholars, including Bob Becking, Robert P. Carroll, Lester L. Grabbe, and Jill Middlemas. ${ }^{170}$ A lot has been written about the alleged return migrations from Babylonia, on the historicity of the accounts in Ezra-Nehemiah, and the situation in the province of Yehud in the early Persian period. ${ }^{171}$ As a result of these developments, the interest in and the number of methodological approaches to the study of the exile has been constantly growing, which can been seen in recent edited volumes on the topic. ${ }^{172}$ Although the importance of cuneiform sources has been acknowledged in these studies, the historical reconstructions of Judean life in Babylonia and the exilic experience have been primarily based on biblical texts.

\footnotetext{
166 Oded 1995, 2000.

167 Carter 1999; Lipschits 2005, 2011; Finkelstein 2008a, 2008b, 2010; Faust 2012; Valkama 2012.

168 Smith-Christopher 1989, 2002.

169 Ahn 2011; Lemos 2011, 2012; Rom-Shiloni 2013; Southwood 2012, 2015.

170 Becking 1998, 2006; Carroll 1992, 1998; Grabbe 1998a, 2015; Middlemas 2005, 2012.

171 See, for example, Grabbe (ed.) 1998; Edelman 2005; Grabbe 2006; Blenkinsopp 2009; Pakkala 2010; Becking 2011a; Southwood 2012; Rom-Shiloni 2013; Silverman 2015b.

172 Becking and Human (eds.) 2009; Kelle et al. (eds.) 2011; Ahn and Middlemas (eds.) 2012; Boda et al. (eds.) 2015 .
} 
Third, concurrently with new approaches to the study of the exile, the recent publication of cuneiform sources has sparked new interest in the study of the exilic period. The most important text group consists of tablets written in the environs of Yāhūdu, the village of Judah in the Babylonian countryside. These tablets started to surface on the antiquities market in the early 1990s at the latest and the majority of them ended up in private collections around the world. Tablets from the collection of Shlomo Moussaieff have been published by Francis Joannès, André Lemaire, and Kathleen Abraham, and those from the collection of David Sofer by Laurie E. Pearce and Cornelia Wunsch. ${ }^{173}$ Moreover, Wunsch is preparing a publication of the texts in the collection of Martin Schøyen. ${ }^{174}$ A number of tablets seized by the Iraqi Antiquities Authority will be included in the forthcoming volume as well. ${ }^{175}$ The study of the documents from Yāhūdu and its surroundings is still in its infancy, but a number of important articles have already been published. Pearce has analysed Judean naming practices, social structures in the environs of Yāhūdu, and the implications of the new data for the study of Judeans in Babylonia. ${ }^{176}$ Abraham has studied marriage practices in Yāhūdu and among foreign population groups in Babylonia, ${ }^{177}$ and Wunsch has discussed slavery in the environs of Yāhūdu (together with Rachel F. Magdalene) and the social and economic context of the documents. ${ }^{178}$ Furthermore, Angelika Berlejung, Yigal Bloch, Johannes Hackl, and Caroline Waerzeggers have worked on the corpus and contributed to the study of Judean life in Babylonia, Babylonian chronology, scribal practices, and archival structures in the corpus. ${ }^{179}$

The documents from Yāhūdu and its surroundings have excited biblical scholars and the media, and Pearce's and Wunsch's publication of 103 tablets from the corpus in late 2014 was accompanied by an exhibition at the Bible Lands Museum Jerusalem. Moreover, the texts have encouraged Assyriologists to engage with the materials related to Judeans in Babylonia. Bloch published and studied a dossier pertaining to Judean royal merchants in Sippar, ${ }^{180}$ and previously published documents have received new attention in several research projects. The ERC Starting Grant project 'By the Rivers of Babylon' brought biblical scholars and Assyriologists together to study the Babylonian

\footnotetext{
173 Joannès and Lemaire 1996, 1999; Abraham 2005/2006, 2007; Pearce and Wunsch 2014.

174 Wunsch (forthcoming).

175 See Hackl 2017.

176 Pearce 2006, 2011, 2014, 2015, 2016a.

177 Abraham 2005/2006, 2015.

178 Magdalene and Wunsch 2011; Wunsch 2013.

179 Berlejung 2017a, 2017b; Bloch 2015, 2017; Hackl 2017; Waerzeggers 2015.

180 Bloch 2014. See also Alstola 2017.
} 
exile and Second Temple Judaism from interdisciplinary perspectives. ${ }^{181}$ The Стіл project has built an online database of Israelites and Judeans attested in cuneiform sources. ${ }^{182}$ This renewed interest in Babylonian sources on Judeans has resulted in a number of publications during the last five years or so, and many more are expected after the full publication of the documents from Yāhūdu and its surroundings. ${ }^{183}$ At the same time, there has been renewed interest in the study of cultural interaction in Mesopotamia and its impact on Judaism and the Hebrew Bible. ${ }^{184}$

The need for the present study arises from the lack of a comprehensive treatment of Judeans in Babylonia in light of the cuneiform sources. On the one hand, Judean names in Babylonian texts have attracted a lot of attention, and the present study builds upon the extensive prosopographical work of Ran Zadok and others. On the other hand, biblical scholars have focused on biblical texts, on their deconstruction and interpretation, and they have been reluctant to incorporate Babylonian material in their studies. Too often the existence of Babylonian material is acknowledged but discussed only briefly before a more detailed treatment of the biblical material. ${ }^{185}$ In general, the references to King Jehoiachin on the ration lists from Babylon have received the attention they deserve, whereas other Babylonian evidence has been mentioned only in passing. ${ }^{186}$ It must be emphasised that it would have been possible to conduct a detailed study of Judeans in Babylonia already before the publication of the documents from Yāhūdu and its surroundings: in 2002, Zadok listed 161 people whom he identified as Judeans in Babylonian sources. ${ }^{187}$ The majority of these people are attested in the Murašû texts. The reluctance to study the Murašû texts has been partly connected to the traditional periodisation of biblical history: the sixth century is perceived as the exilic period, and the fifth-century evidence from the Murašû archive has been regarded as too late to shed any light on the life of the exiles.

Judeans were only one of numerous immigrant groups living in Babylonia in the sixth and fifth centuries, and migrants from Egypt, the Eastern Mediterranean, Anatolia, Syria, Iran, and the Arabian Peninsula found their way to the

\footnotetext{
181 The principal investigator of the project was Caroline Waerzeggers.

182 'Cuneiform Texts Mentioning Israelites, Judeans, and Related Population Groups' (http:// oracc.museum.upenn.edu/ctij/corpus).

183 Cogan 2013; Waerzeggers 2014b; Stökl and Waerzeggers (eds.) 2015; Berlejung 2018.

184 See, for example, Ben-Dov 2008; Gabbay and Secunda (eds.) 2014; Popović 2014; Popović et al. (eds.) 2017 .

185 See, for example, Albertz 2003, 73-74, 99-104.

186 A good example is Mitchell 1991, 418-422.

187 Zadok 2002, 27-45.
} 
floodplain. Although no comprehensive social and economic history of these people has been written, there are numerous studies which deal with the subject and focus especially on the onomastic evidence. Immigrant groups which have been studied include, among others, Anatolians, ${ }^{188}$ Arabs, ${ }^{189}$ Egyptians, ${ }^{190}$ and Iranians. ${ }^{191}$ The case of the Neirabians has attracted quite a bit of attention because of its relevance to the question of return migrations from Babylonia, but it is still not very well known among biblical scholars. ${ }^{192}$ Despite the onomastic evidence gathered, only few studies have attempted to offer a bird's-eye view of the matters of integration and socio-economic status among the immigrants. In a seminal article, Israel $\mathrm{Eph}^{\varsigma}$ al focuses on immigrants attested in the Nippur countryside, ${ }^{193}$ and Muhammad A. Dandamayev explores immigrants in two articles. ${ }^{194}$ As noted above, the emergence of the texts from Yāhūdu and its surroundings has initiated a growing interest in the study of Judeans in Babylonia, which will probably be reflected in the study of other deportee and immigrant groups as well.

Any deeper understanding and proper contextualisation of the evidence of minorities in Babylonia would not be possible without the advancements in Neo-Babylonian studies since the late 1980 . The exceptionally large cuneiform record from the late seventh to the fifth centuries has been made more easily accessible, and it has been used to promote an understanding of the social and economic history of Babylonia. First, Babylonian primary sources are becoming more and more accessible, not only to Assyriologists but also for general historians. Numerous archive studies have made large text corpora available for historical inquiry, ${ }^{195}$ and Michael Jursa's overview of Babylonian archives is an indispensable tool for any student of these tens of thousands of texts scattered in museums all over the world. ${ }^{196}$ Currently, there are serious efforts to make Babylonian sources more easily available online in order to facilitate

\footnotetext{
188 Eilers 1940; Zadok 2005; Waerzeggers 2006.

189 Zadok 1981, 1990; Eph`al 1982; Beaulieu 2013a.

190 Dandamayev 1992a; Zadok 1992, 2005; Bongenaar and Haring 1994; Mattila 2004; Huber 2006; Wasmuth 2011; Hackl and Jursa 2015.

191 Dandamayev 1992b; Tavernier 2007; Zadok 2009.

192 Dhorme 1928; Fales 1973; Eph`al 1978; Oelsner 1989; Cagni 1990; Timm 1995; Cussini 2000; Tolini 2014, 2015.

193 Eph'al 1978.

194 Dandamayev 1983, 2004.

195 Some important archive studies from the last three decades include Joannès 1989; Wunsch 1993, 2000a; Jursa 1999; Abraham 2004; Baker 2004; Pearce and Wunsch 2014; Waerzeggers 2014a.

196 Jursa 2005a.
} 
their use by non-Assyriologists as well. ${ }^{197}$ Second, the social and economic history of Babylonia has been the subject of several studies. Two important works on economic history are Govert van Driel's Elusive Silver and Michael Jursa and his team's Aspects of the Economic History of Babylonia. ${ }^{198}$ In addition to these general works, different aspects of the Babylonian economy have been studied in detail. These include, but are not limited to, temple economy, ${ }^{199}$ private business, ${ }^{200}$ labour, ${ }^{201}$ and taxation. ${ }^{202}$ Social historical studies have focused on topics such as dependence and slavery, ${ }^{203}$ Babylonian urban elite, ${ }^{204}$ housing and urbanism, ${ }^{205}$ priesthood and temple personnel, ${ }^{206}$ and officialdom. ${ }^{207}$ New methodological and theoretical approaches have been tested on the historical record, including the application of social network analysis to cuneiform sources. ${ }^{208}$

\section{$1.4 \quad$ Sources}

There are rich sources for the study of immigrants in Babylonia in the mid-first millennium, but these sources have been used very sporadically in historical research. The Hebrew Bible has served as the main source for the study of Judeans, whereas cuneiform sources have been used more often for onomastic than historical studies. According to standard historical methodology, historical investigation must start with an evaluation of the available sources. Primacy must be given to sources that are contemporary with the events studied, and later accounts can be given only a secondary place as historical witnesses. Regardless of their age, the reliability of each source must be assessed

197 Three projects should be mentioned in this regard: the Achemenet Project, PI Damien Agut-Labordère (http://www.achemenet.com), the NaBuCCo project in Leuven, PI Kathleen Abraham (https://nabucco.arts.kuleuven.be), and the ERC Consolidator Grant project 'Persia and Babylonia' in Leiden, PI Caroline Waerzeggers (http://persiababylonia. org).

198 van Driel 2002; Jursa 2010a.

199 Jursa 1995; Da Riva 2002; Kleber 2008; Kozuh 2014.

200 Stolper 1985; van Driel 1989, 1999; Wunsch 2007, 2010; Jursa 2009.

201 Dandamayev 1987; Jursa 2015a.

202 Jursa and Waerzeggers 2009; Waerzeggers 2010b; Jursa $2011 \mathrm{a}$.

203 Dandamayev 1984; Baker 2001; Kleber 201; Wunsch and Magdalene 2014.

204 Nielsen 2011.

205 Baker 2007, 2015.

206 Bongenaar 1997; Waerzeggers 2010a, 2011; Still 2019.

207 Jursa 2011b, 2015b.

208 Wagner et al. 2013; Waerzeggers 2014a, 2014C; Still 2019. 
individually. The following discussion will offer an overview and evaluation of sources for the present study.

\subsubsection{The Hebrew Bible}

The Hebrew Bible is an important but also problematic source for the study of history in the sixth and fifth centuries. The historical reconstruction of the fall of Judah and the early Second Temple period is largely dependent on biblical sources. At the same time, the Babylonian exile itself constitutes a gap in the biblical narrative, even though theological reflection on the exile characterises many parts of the Hebrew Bible. Moreover, although the accounts on the fall of Judah and deportations to Babylonia undeniably refer to historical events, they are not primary sources written at the time of the events they describe. Biblical texts are secondary sources at best, and books like the Chronicles fall into the category of tertiary sources. The Hebrew Bible should not be excluded out of hand from a methodologically responsible historical study, but its information must be critically evaluated, like any other source.

When it comes to the fall of Judah and deportations to Babylonia, the Hebrew Bible is an important source for a historical reconstruction of the events. The general picture of destruction and deportation in 2 Kings $24-25$ is corroborated by archaeology and cuneiform sources. ${ }^{209}$ In the same vein, the lists of Babylonian officials in conquered Jerusalem in Jeremiah 39 appear to be based on correct information of contemporary office holders. ${ }^{210}$ At the same time, however, biblical books provide contradictory information on the number, date, and extent of the deportations to Babylonia. ${ }^{211}$ The use of this information is further complicated by the unstable textual traditions of these passages. ${ }^{212}$ Second Kings 25:27-30 can be seen as an epilogue to the fall of Judah: the Babylonian king Evil-merodach (Amēl-Marduk) releases King Jehoiachin of Judah from prison and raises him above other kings at Evil-merodach's table. Cuneiform sources confirm that Jehoiachin was indeed taken to Babylon and received food rations, along with other Judeans. The account of Jehoiachin's amnesty will be discussed together with the pertinent cuneiform sources in Section 2.5.

The Hebrew Bible provides us with a historical narrative which ends at the onset of the exile and begins again at the fall of the Babylonian Empire. Numerous biblical books resonate with the trauma of the exile, but life in exile is

\footnotetext{
209 See Section 1.2.3.

210 Jursa 2008, 2010b, 85-88; Becking 2009b.

211 2 Kgs 24-25; 2 Chr 36; Jer 39; 52:28-30; Dan 1:1-2.

212 See Section 1.2.3.
} 
not the subject of these theological reflections. The exile serves as the setting for the prophecies in the Book of Ezekiel and for the narratives in Daniel and Esther, but, as the following discussion reveals, none of these books are particularly useful as a source for historical enquiry. The same applies to Jeremiah, Psalm 137, and Ezra-Nehemiah. All these accounts may shed light on the exilic experience and perceptions of life in exile, ${ }^{213}$ but they are of little help in writing a social history of Judeans in Babylonia.

The Book of Ezekiel is situated in the context of the Babylonian exile, and the prophet is depicted as a Judean exile living in sixth-century Babylonia. The authors of the book certainly had information about Mesopotamian culture 214 and Babylonian geography, including the Kabaru canal (the river Chebar in Ezek 1:1, 3:15, etc.), ${ }^{215}$ which is also referred to in a text from the environs of Yāhūdu (J7). It may well be that the references to the elders of Judah (8:1) and Israel (14:1), ${ }^{216}$ as well as to the Judean settlement at Tel-abib (3:15), reflect historical reality, but the focal points of the book are Ezekiel's prophetic visions and oracles. Apart from mentioning the river Chebar, Tel-abib, and the elders of Judah and Israel, the Book of Ezekiel contains hardly any information about Judean exiles in Babylonia.

Another prophetic book closely related to the exile is Jeremiah. However, the focus of the book is on early sixth-century Judah, and events in Babylonia are referred to only in Chapter 29, which describes the correspondence between the prophet Jeremiah and the Babylonian exiles. The historicity of the episode is disputed, ${ }^{217}$ and even if it contained a kernel of truth, it is not very informative for our purposes. Two things can be noted: the chapter takes for granted that it was possible to send letters from Judah to Babylon and back, and, like the Book of Ezekiel, it suggests that prophets were active among the Judeans in Babylonia.

Psalm 137 has become a strong symbol, as its opening words are commonly used as a reference to the Babylonian exile of Judeans. ${ }^{218}$ The psalm is a piece

213 See, for example, Smith-Christopher 1989; Rom-Shiloni 2013.

214 Nissinen 2015 and other articles in the thematic issue of Die Welt des Orients $(45 / 1,2015)$.

215 Vanderhooft 2012. On the location of the Kabaru canal, see Waerzeggers 2010b, 790, 804; Tolini 2011 vol. 1, 491-498.

216 Eph ${ }^{\text {ala }} 1978,76-80$.

217 Holladay 1989, 131-144; McKane 1996, 742; and Lundbom 2004, 342-367 suggest that the letters in Jer 29 are not a mere literary creation, whereas Carroll 1986, 566-568; and Fischer 2005,88 doubt their historicity.

218 See, for example, the exhibition of the tablets from Yāhūdu and its surroundings at the Bible Lands Museum Jerusalem (Vukosavović 2015) and recent edited books on the Babylonian exile (Ahn and Middlemas (eds.) 2012; Gabbay and Secunda (eds.) 2014). 
of powerful poetry which delicately expresses the trauma of being uprooted and placed in a foreign country. Many deportees of today can undoubtedly share the despair reflected in its verses, but one must be careful not to claim that the psalm represents the experience of every Judean in Babylonia. ${ }^{219}$ Its message must be taken seriously, but it should not be used as a backdrop to the present study.

The Books of Daniel and Esther share several common themes, including their setting at a foreign court and the motif of Judeans who trust their God and gain favour with the king. The Book of Daniel has two main parts, the stories at the Babylonian court in Chapters 1-6 and the apocalyptic visions in Chapters 7-12. It is widely held that the latter part of the book reflects the historical situation in the 16os в $\mathrm{CE}$, when the actions of the Seleucid king Antiochus IV Epiphanes resulted in the Maccabean revolt. ${ }^{220}$ The stories in Chapters 1-6 are probably of older origin, and some of their motifs - such as the renaming of Judean youth and the presence of foreign specialists at the Babylonian court $^{221}$ - are historically accurate or plausible. ${ }^{222}$ However, accidental historical accuracy does not mean that Daniel 1-6 can be used as a source for writing a history of Judeans in Babylonia. The stories are full of miracles, fantastic scenes, and thrilling adventures, which do not lend much support to historical reliability. It is also noteworthy that the authors of Daniel $1-6$ were unaware of or did not care about the correct chronology of Babylonian and Persian kings: King Nebuchadnezzar (Dan 1-4) is succeeded by his son Belshazzar (5), and Darius the Mede seizes power after Belshazzar is killed (5:30-6:29). Finally, Cyrus the Persian ascends the throne after Darius (6:29). Given all these characteristics of literary fiction, the Book of Daniel cannot be used as a source for the present study.

The Book of Esther is not set in Babylonia but in the Persian capital of Susa. Nevertheless, the book suggests that Nebuchadnezzar's deportations from Jerusalem led to the emergence of a Judean exilic community in Susa (2:6). Unlike the separate stories in Daniel, the Book of Esther narrates one coherent story about two Judeans, Esther and Mordecai, and their success in preventing the genocide of Judeans in the Persian Empire. The story has some features which are historically accurate or plausible, the most important being the Judean presence in Susa in the early fifth century все confirmed by cuneiform

219 See Becking 2009a.

220 On the composition and dating of the Book of Daniel, see, for example, Hartman and Di Lella 1978, 3-71; Collins 1993, 25-71.

221 On the renaming of officials, see Section 1.5.1. See Section 2.4 on foreign professionals at the court of Nebuchadnezzar II.

222 On these issues, see the essays in Collins et al. (eds.) 2001. 
sources. ${ }^{223}$ However, the story is clearly a literary fiction, and it resembles the Greek accounts which ridicule the Persian court life. ${ }^{224}$ The Book of Esther is a reflection of life in diaspora, but it cannot be used as a source for a study of Judeans in Babylonia.

Finally, the Books of Ezra and Nehemiah are not concerned with the Babylonian exile, but they narrate the story of the alleged return migrations to Judah and the rebuilding of the temple in Jerusalem in the early Persian period. Although the use of these books is hampered by complex textual traditions and their historicity is debated, ${ }^{225}$ they have been widely used - due to the scarcity of other sources - to reconstruct the history of Yehud in the early Persian period and social conflicts between the returned exiles and the rest of the population in Yehud. ${ }^{226}$ Yet, as the present study is concerned with life in Babylonia, the books of Ezra and Nehemiah must be excluded from its sources.

This short overview has shown that although the Hebrew Bible is an important source for the study of the fall of Judah, very few biblical books explicitly describe the life of Judeans in Babylonia. The Books of Daniel and Esther narrate life in exile, but they are both widely regarded as literary fiction. The Book of Ezekiel does not focus on life in Babylonia but on prophecy, and EzraNehemiah, Jeremiah 29, and Psalm 137 contribute very little to the question at hand. Accordingly, the study of Judeans in Babylonia must primarily rely on Babylonian cuneiform sources.

\subsubsection{Cuneiform Sources}

As the previous discussion reveals, the Hebrew Bible is an important source for the reconstruction of the events leading to the Babylonian exile, but it offers relatively little information on Judean life in Babylonia. On the contrary, hundreds of clay tablets written in Babylonian cuneiform shed light on the everyday lives of Judean deportees, ${ }^{227}$ although only a single chronicle relates to Nebuchadnezzar II's campaigns in the Levant. ${ }^{228}$ Babylonian legal and administrative texts from private and temple archives from the sixth and fifth centuries are a treasure trove for a student of social and economic history, and tens of thousands of such tablets are preserved in museums and private collections. ${ }^{229}$ At the same time, Babylonian state archives have almost completely

\footnotetext{
223 Bloch 2014, text no. 7.

224 See, for example, Berlin 2001; Fox 2010, 131-140; Stern 2010.

225 See Becking 1998, 2011a; Grabbe 1998b, 2015; Pakkala 2004; Fried (ed.) 2011.

226 For some recent examples, see Blenkinsopp 2009; Southwood 2012; Rom-Shiloni 2013.

227 For an overview of these sources, see Pearce 2016b.

228 This is the Babylonian chronicle on the early years of Nebuchadnezzar II ( $A B C 5$ ).

229 For an overview, see Jursa 2005a.
} 
disappeared, ${ }^{230}$ and Babylonian royal inscriptions are less interested in describing political events than their Assyrian counterparts. ${ }^{231}$ Babylonian legal and administrative texts also have their limitations, the most significant being their origin. As noted above, these texts were written by members of the urban elite and they predominantly belong to temple archives and private archives of this same elite. The great majority of the population - women, peasants, children, and foreigners - are usually seen only in the margins of the text corpora. In any case, Babylonian sources are well-suited for the purposes of this study, as they are contemporary sources which originated in the course of everyday transactions and thus are not suspect of ideological colouring.

\subsubsection{Archival Approach}

The sources used in this study are only a tiny fraction of tens of thousands of extant Neo-Babylonian cuneiform documents. The great majority of these texts are not isolated documents, as a cuneiform tablet normally belongs to an ancient archive which connects a single text to a group of related documents. Scholars of the Neo-Babylonian period have invested a lot of time and effort in reconstructing ancient archives and developing the necessary methods to do so. ${ }^{232}$ As most of the cuneiform tablets from the mid-first millennium have been unearthed during badly documented or illicit excavations, interconnected texts cannot be normally identified on archaeological grounds. This has forced Assyriologists to develop methods to reconstruct ancient archives from tablets dispersed in museum and private collections around the world.

The reconstruction of an ancient archive is based on two main principles. ${ }^{233}$ First, the dispersal history of interconnected texts can be traced from excavation journals, museum catalogues, and other records documenting the journey of the tablets from their archaeological find-spot to a museum or private collection. Second, tablets can be grouped together in relation to internal criteria, especially on the basis of onomastic evidence. Private archives are normally centred around few protagonists, first and foremost the owners of the archive. A careful study of these people and their circles helps to establish the bulk of texts belonging to the archive. However, this method has obvious limitations regarding documents which do not refer to any of the protagonists. This

\footnotetext{
$230 \quad$ See Section 2.3.

231 Da Riva 2008.

232 Archive studies such as Wunsch 1993; Jursa 1999; and Baker 2004 are the most concrete outcomes of this work. See Jursa 2005a for an indispensable overview of Neo-Babylonian archives.

233 On these methods and their application, see van Driel 1992; Baker 2004, 5-13; Jursa 2005a, 57-58; Waerzeggers 2005 .
} 
applies especially to retroacta, documents which were transferred together with a property to trace its history of ownership.

The reconstruction of ancient archives has clear benefits for historical study. If studied in isolation, a cuneiform tablet cannot be placed in the right social context and its interpretation remains superficial. This applies particularly to legal and administrative texts which usually provide the reader with a small amount of rather dry information. By reading only a single promissory note or list of purchases, very little can be gleaned about the people mentioned in the document or the background of the transaction. By contrast, even a single receipt can be very informative when studied in its archival context. ${ }^{234}$ This macro view of interconnected texts sheds light on the social status of the people mentioned in the texts, their sources of livelihood, and their social networks. Moreover, different archives are often connected to each other, which allows historical research from a yet wider angle on society.

In the present study, the archival approach guides the contextualisation of all cuneiform evidence, as documents are not read in isolation but as part of archives and, even more, of interrelated archives. In particular, the texts from Yāhūdu and its surroundings are a complex corpus of related archives or archival groups. In order to fully comprehend the social setting of these texts, a careful analysis of the underlying archival structures is a necessity.

\subsubsection{Ethics and Unprovenanced Artefacts}

Before proceeding to a discussion of different text groups, an ethical and methodological problem related to ancient artefacts must be addressed. Especially after the failure of the Iraqi and Syrian states to protect their cultural heritage, a large number of looted cuneiform tablets and other ancient Mesopotamian artefacts have entered the antiquities market and found their way to private collections in the West. ${ }^{235}$ The export of antiquities from their country of origin without the permission of local authorities has been banned by the unesco Convention on the Means of Prohibiting and Preventing the Illicit Import, Export and Transfer of Ownership of Cultural Property, ${ }^{236}$ but states have not been able or willing to enforce the statutes of the convention to their full extent. As a result, growing concern about the trade of looted cultural artefacts has prompted several scholarly organisations to ban the publication of unprovenanced artefacts in their publications and conferences. These

234 On this approach, see Waerzeggers 2014b, 2014c, 208-210.

235 Emberling and Hanson (eds.) 2008; Stone 2008; Brodie 2011; Casana 2015.

236 UNESCO 1970. 
organisations include the American Schools of Oriental Research (ASOR), ${ }^{237}$ the Archaeological Institute of America (AIA), ${ }^{238}$ and the Society of Biblical Literature (SBL). ${ }^{239}$

The measures taken by the scholarly organisations are aimed at preventing the negative effects of looting and illicit trade in antiquities: ${ }^{240}$ unprovenanced artefacts lack information about their archaeological context, which is permanently lost during uncontrolled and undocumented excavations. As a result, the artefacts lose most of their value as sources for scientific enquiry. At the same time, the trade of looted artefacts is a criminal activity which has disastrous effects on archaeological sites and cultural heritage, but which greatly benefits the dealers at the top of the trafficking hierarchy. The scientific publication of unprovenanced artefacts further encourages illicit trade in antiquities as publicity and the authentication of artefacts increases their value. Moreover, the antiquities trade also creates a market for skilful forgeries, and this further complicates the professional study of history.

However, some scholars have questioned the negative impacts of publishing unprovenanced inscriptions and criticised the restrictions set by the scholarly organisations. ${ }^{241}$ The primary arguments for publishing inscriptions are that they can convey historical information even without a known archaeological context and, accordingly, that their contents must be made available to the public and academic community because of their great value for studying ancient history. When it comes to publishing unprovenanced cuneiform tablets, the Asor Policy on Professional Conduct - followed by the SBL - is indeed somewhat more permissive, ${ }^{242}$ because

a. in zones of conflict since the early-1990s, most prominently in Iraq and Syria but also elsewhere, looting of cuneiform tablets has occurred on a truly massive scale;

b. cuneiform texts may be authenticated more readily than other categories of epigraphic archaeological heritage;

c. the content of a cuneiform text can provide information independent of archaeological provenience. ${ }^{243}$

\footnotetext{
237 ASOR 2015.

238 Norman 2005; AIA 2016.

239 SBL 2016.

240 For a number of recent studies, see Brodie and Renfrew 2005; Brodie et al. (eds.) 2006; Brodie et al. 2013; Rutz and Kersel (eds.) 2014, all with further literature.

241 Cross 2005; Owen 2009; Westenholz 2010.

242 On this issue overall, see Cherry 2014; Gerstenblith 2014.

243 ASOR 2015, emphasis in original.
} 
However, the policy demands that any cuneiform tablets published in ASOR journals or conferences must be returned to their country of origin or, if this is not possible, their title must be ceded to this country or 'some other publiclyaccessible repository'. As this is not appealing to collectors and other channels exist to publish texts, the ASOR policy has effectively worked as a ban on publishing unprovenanced cuneiform tablets in ASOR journals and conferences. ${ }^{244}$

The ethical questions related to unprovenanced artefacts are highly relevant to the present study. Although the majority of text groups originate from controlled excavations (Section 1.4.2.3), the largest and most important source for the study of Judeans in Babylonia is of unprovenanced origin. At least 200 texts from the environs of Yāhūdu (Chapter 4) have found their way to private collections, including those of David Sofer, Martin Schøyen, and Shlomo Moussaieff. The contents of these tablets reveal that they were written in the Babylonian countryside, but nothing is known about their find-spot and very little about their modern ownership history. It is regrettable that Laurie E. Pearce and Cornelia Wunsch, the editors of 103 Yāhūdu texts from the collection of David Sofer, ${ }^{245}$ do not discuss the origin of the tablets or the ethical problems involved. ${ }^{246}$ They merely treat the unprovenanced origin of the tablets as a methodological problem complicating our attempts to localise the villages mentioned in the archive and to identify which texts were kept together in antiquity. 247

According to a newspaper article, David Sofer has claimed that he bought the tablets in the United States in the 1990s and that their previous owner had bought them in public auctions in the 1970s. ${ }^{248}$ However, this information is not repeated in Pearce and Wunsch 2014 or in any other source, and it is probable that the tablets are a more recent find. Given their exceptional contents, it is unlikely that the tablets have been in the hands of collectors for decades. For instance, the existence of the town of Judah in Babylonia was announced in the publication of the first tablet from the Moussaieff collection only in 1999. ${ }^{249}$ On the contrary, there is reason to suspect that the tablets appeared on the antiquities market in the early 199os. First, Joannès and Lemaire published a group of Bìt-Abì-râm tablets - a subgroup of tablets from the environs of Yāhūdu - from the Moussaieff collection in $1996 .{ }^{250}$ Second, it appears that

\footnotetext{
244 Gerstenblith 2014, 223-224.

245 Pearce and Wunsch 2014.

246 See Waerzeggers 2015, 187-188; Alstola 2016, 327.

247 Pearce and Wunsch 2014, 3-9.

248 Estrin 2015.

249 Joannès and Lemaire 1999.

250 Joannès and Lemaire 1996.
} 
Schøyen obtained (part of) his lot of tablets in the 1990s as well, because Wunsch studied them some time before 2003-2004. ${ }^{251}$ Third, Pearce announced the existence of a larger corpus of texts from the environs of Yāhüdu in a conference presentation in 2003 and in print in 2006. ${ }^{252}$ These are the tablets belonging to the Sofer collection. Most importantly, the Iraqi Antiquities Authority recently confiscated a number of tablets belonging to the corpus. ${ }^{253}$ This indicates that the tablets have been available on the antiquities market in recent years and that new tablets are perhaps still being illicitly excavated somewhere in Iraq. In conclusion, there is little reason to believe that the tablets in the private collections were exported legally from Iraq and sold in public auctions already in the 1970s. It is more probable that they originate from illicit excavations in Iraq in the early 1990 s or later. ${ }^{254}$

The dubious and possibly illicit origin of the tablets from Yāhūdu and its surroundings leaves us with ethical problems surrounding their publication and study. It must be admitted that these unique tablets are of exceptional historical importance and that they profoundly affect our understanding of Judeans in Babylonia and life in exile. One can argue that their information must be made available because of their importance and that the academic community has a responsibility to preserve this data for future generations. As the tablets have already been removed from their archaeological context and the damage cannot be undone, there is no reason to leave them unpublished.

However, their publication also has negative consequences. First, the tablets are not a group of ordinary promissory notes and sales documents from Babylonia. Their historical and monetary value derives from the fact that they feature a community of Judean deportees living in Babylonia during the exilic period. It is beyond doubt that professional authentication of the tablets, their inclusion in high-quality publications, and their exhibition at the Bible Lands Museum Jerusalem have significantly increased their monetary value. Second, one cannot deny the causality between trade on the antiquities market and the illicit digging and destruction of archaeological sites. If there were not a market for cuneiform tablets, large-scale looting and smuggling in Iraq and Syria would not take place. It can be concluded that professional involvement in the authentication, publication, and exhibition of the tablets not only benefits the academic community and public but also the financial interests of the collectors. This in turn encourages antiquities dealers to find similar artefacts for

251 Waerzeggers 2003/2004, 157 n. 38.

252 Pearce 2006; Lipschits and Oeming (eds.) 2006, ix.

253 Hackl 2017.

254 As already suggested in Jursa 2005a, 151. 
their stock. Given these circumstances, academic publication and the collectors' continued possession of the tablets do not appear to be an ethically acceptable solution. It would have been advisable to follow the Asor guidelines and publish the tablets under the condition that the objects be repatriated back into the hands of the Iraqi Antiquities Authority.

Finally, it must be asked how the tablets from Yāhūdu and its surroundings should be treated in this study. The policies of the AIA, ASOR, and SBL are concerned with the first publication of unprovenanced artefacts, and they do not take a stand on subsequent studies on the published materials. Yet the basic ethical problem remains the same: new studies open fresh insights into unprovenanced tablets and establish their place among the standard sources of an academic study of history. New studies also serve as a further authentication of the tablets as genuine ancient artefacts. At the same time, however, the present circumstances emphasise the need for critical scholarship on these tablets: they cannot simply remain on the pages of primary publications and in the exhibition halls of the Bible Lands Museum Jerusalem.

In this study, I have decided to discuss and analyse the available material from Yāhūdu and its surroundings. I am aware of the ethical problems concerned with the publication and further scholarly treatment of these tablets, but I perceive that it is necessary to study them critically, highlighting their unprovenanced origin and the problems involved. This needs to be done, especially because these issues are not highlighted in the first publications of the texts. I hope that my decision will lead to further critical discussion of these tablets and the study of unprovenanced artefacts at large by the academic community and professional societies in biblical and Near Eastern studies.

\subsubsection{Text Groups}

The sources of this study comprise 291 Babylonian cuneiform texts which were written in the sixth and fifth centuries and which pertain to Judeans, Neirabians, and other people in their immediate surroundings. The majority of the texts belong to dossiers or archives, which helps to place them into a broader historical and social context. The following text groups can be identified; it has to noted that only a part of texts in certain groups relate to Judeans or Neirabians.

The Palace Archive of Nebuchadnezzar II was unearthed in Babylon during the German excavations in the early twentieth century (Chapter 2). The tablets, excavated in three different find-spots but relating to the same administrative procedures, are the only surviving remnants of the state archives of Babylonia. The 346 tablets document the delivery of barley, dates, and other commodities to Babylon and their distribution to various recipients in the city 
during the reign of Nebuchadnezzar II in the early sixth century. A number of long ration lists document the distribution of sesame seed oil to numerous individuals and professional groups, many of which were of foreign origin. The tablets are important for the present study, as some of them mention King Jehoiachin of Judah, five Judean princes, and other Judeans as recipients of oil rations. Only four ration lists have been published by Ernst F. Weidner in 1939, but Olof Pedersén's recent work has shed more light on the archive as a whole. ${ }^{255}$ Although the references to King Jehoiachin have made these tablets famous, they are an elusive source. The texts themselves are not very informative, and the incomplete publication of the archive seriously hinders its study.

Six tablets pertaining to a Judean family of royal merchants were written in Sippar in 546-503 вСE (Chapter 3). The tablets primarily originate from Hormuzd Rassam's excavations and belong to the collections of the British Museum. ${ }^{256}$ The texts pertain to the descendants of Arih, who traded with the Ebabbar temple and were well-integrated in the local mercantile community. Four texts shed light on the economic activities of the family, whereas two marriage agreements show that a granddaughter of Arih married into a Babylonian family. As the majority of Judeans are attested in a rural context, the descendants of Arih serve as a noteworthy reminder about the socio-economic diversity of immigrants in Babylonia. The documents have been published and discussed by Martha T. Roth, Michael Jursa, and Yigal Bloch, ${ }^{257}$ but they still need to be placed in their proper socio-economic context. In addition, I discuss three more texts that relate to Judeans involved in long-distance trade.

The most important source for the study of Judeans in Babylonia is formed by texts from Yāhūdu, Našar, and their surroundings (Chapter 4). Yāhūdu, '(the town of) Judah', was a village located in the Babylonian countryside and named after the geographic origin of its inhabitants. Written in $572-477 \mathrm{BCE}$, the texts are centred around three main protagonists: Ahīqam, son of Rapā-Yāma, Ahīqar, son of Rīmūt, and Zababa-šar-ușur, son of Nabû-zēr-iddin. Both Ahīqam and Ahīqar were of Judean descent, and thus the text corpus is unique in allowing us a glimpse inside Judean communities, rather than merely describing Judeans on the fringes, as is the case with most Babylonian archives. The whole corpus consists of 250 or more texts, 113 of which have been published thus far. ${ }^{258}$ Cornelia Wunsch kindly allowed me to use 42 unpublished

255 Weidner 1939; Pedersén 2005a, 2005b, 2009.

256 See Section 3.3.1.

257 Roth 1989, 92-95; Jursa 2001, 2007a; Bloch 2014.

258 Joannès and Lemaire 1996, 1999; Abraham 2005/2006, 2007; Pearce and Wunsch 2014. For a detailed discussion, see Section 4.1. 
texts in the present study, ${ }^{259}$ making a total of 155 available texts. The tablets were bought from the antiquities market, and their provenance and the number of excavated tablets are unknown. ${ }^{260}$ These legal texts originated in the framework of the land-for-service sector of Babylonian agriculture, and they mostly document tax payments and credit operations relating to the cultivation of dates and barley. The texts have aroused significant interest among biblical scholars, Assyriologists, and the general public, especially in Israel, and a vast array of studies on them is expected in the near future.

The texts from the environs of Yāhūdu are not the first ones to document Judean life in the land-for-service sector in the Babylonian countryside. The 750 texts of the Murašû archive were unearthed in Nippur in 1893, and the bulk of them were published already in 1898-1912 (Chapter 5 ). ${ }^{261}$ After a gap of seventy years, most of the remaining tablets were finally published in 1985 and $1997 .{ }^{262}$ The archive documents the business activities of a Babylonian family, the Murašûs, in the environs of Nippur in 454-414 BCE, with a handful of related documents extending until $404 \mathrm{BCE}$. The Murašûs were agricultural entrepreneurs working in the land-for-service sector, and the promissory notes, receipts, leases, and other legal texts in the archive relate to their dealings with landholders and the state administration. The archive reveals that numerous communities of foreign origin lived in the Nippur countryside. Judeans also appear in the fringes of the archive, most often as farmers dealing with the Murašûs. Some Judean minor officials are attested as well. After the texts from Yāhūdu and its surroundings, the Murašu archive is the single most important source for an investigation of Judeans in Babylonia. However, it has generally been overlooked in previous studies.

A group of texts from Neirab resemble the two afore-mentioned archives, as they also relate to the Babylonian land-for-service sector (Chapter 7 ). The texts were found in Neirab, near Aleppo, Syria, in 1926-1927, and they were published by Édouard Dhorme in $1928 .^{263}$ Despite their find-spot in Syria, the twenty-seven tablets were obviously written in Babylonia, where a group of Neirabians was deported in the Neo-Babylonian period. The deportees were settled in the twin town of Neirab in the Babylonian countryside, but eventually some of their descendants returned to the original Neirab in Syria and took a bunch of their tablets along. The text group is relevant for the study of

259 These texts will be published in Wunsch (forthcoming).

26o See the detailed discussion in Section 1.4.2.2.

261 Hilprecht and Clay 1898; Clay 1904, 1912.

262 Stolper 1985; Donbaz and Stolper 1997.

263 Dhorme 1928. 
Judeans in two ways: first, it sheds some light on the problem of return migrations from Babylonia. Second, the texts are a significant point of comparison for documents relating to Judeans in the Babylonian countryside. The texts primarily concern the Nusku-gabbē family, whose activities can be compared with those of Ahīqam and Ahīqar in Yāhūdu and Našar.

In addition to the main groups discussed above, there are a number of single texts pertaining to Judeans (Chapter 6). ${ }^{264}$ These originate from different geographical and socio-economic locations, and they bear witness to the diversity among the Judeans in Babylonia. Although they only provide us with glimpses of the life of a given Judean, these texts can usually be contextualised by placing them in a wider archival context.

\subsubsection{Archaeology}

Apart from clay tablets, there are no other artefacts or archaeological remains that bear witness to the presence of Judeans in Babylonia. Of the four main texts groups, only the Palace Archive of Nebuchadnezzar II (the 'Palace Archive') and the Murašu archive have a documented find-spot, whereas the tablets pertaining to the descendants of Arih primarily originate from Rassam's badly documented excavations in Sippar. Most unfortunate is the fact that the tablets from the environs of Yāhūdu were acquired from the antiquities market and their provenance is thus completely unknown. Nor are the find-spots of the Palace and Murašû archives informative about Judean life in Babylonia: although the administrative office which produced the Palace Archive was probably situated in the South Palace of Babylon, this does not necessarily mean that Judeans resided on the same premises. In the same vein, texts from the Murašû archive make clear that the Murašûs themselves lived in Nippur where the archive was unearthed, but their Judean clients inhabited the surrounding countryside. The provenance of the Neirabian archive from a funerary context has important implications for the value of the tablets for their owners, but because the tablets were excavated in Syria but written in Babylonia, the find-spot does not shed any light on the nature of Neirabian life in Babylonia. ${ }^{265}$ However, all major Babylonian cities have been partially excavated and regional surveys have been carried out. Material aspects of urban life are thus known to us, ${ }^{266}$ and there are informative studies about settlement

264 These texts have been collected in various publications by Zadok (1979a, 2002, 2004, 2014a), and they are predominantly transliterated at CTIJ.

265 See Chapter 7.

266 Miglus 1999; Marzahn et al. (eds.) 2008; Baker 2014, 2015. 
patterns and ancient water courses in the region. ${ }^{267}$ Unfortunately, the scope of the data is limited due to the lack of general treatments of Neo-Babylonian material culture. ${ }^{268}$

\subsection{Identifying Foreigners in Babylonian Sources}

\subsubsection{Naming Practices in Babylonia}

Babylonian sources rarely make the ethnic or geographic origin of people explicit. There are some exceptions, like the foreign professionals in the Palace Archive of Nebuchadnezzar II or the twin towns and hatrus in the Nippur region, named after the hometowns and homelands of their residents. ${ }^{269} \mathrm{How}-$ ever, there are very few texts that describe an individual as Judean or Egyptian, and, in most cases, personal names are our primary means of identifying people of foreign origin in Babylonian sources.

In Neo-Babylonian legal texts, people are normally referred to by their name and patronymic. The standard formula in Babylonian cuneiform is PN a-šú šá $\mathrm{PN} 2$ ('PN, son of $\mathrm{PN}_{2}$ '), abbreviated in this study as $\mathrm{PN} / \mathrm{PN}_{2}$. There are two notable exceptions: cases when no patronymic is given and cases when a family name is given in addition to a name and patronymic. The first exception applies to slaves and royal officials, who usually appear without a patronymic. Their owner's name or their official title is often given instead. ${ }^{270}$ People working in or aiming for a career in the royal administration can often be identified by the so-called Beamtennamen, which include the element šarru ('king'). ${ }^{271}$ Three-tier genealogies involving a name, patronymic, and family name were borne by the members of the Babylonian urban upper class, the boundaries of which were partially defined by the use of these family names. ${ }^{272}$ This group was exclusive, and families of deportees are not found among its ranks, even though women of foreign origin were occasionally able to marry into these families. $^{273}$

267 For example, Adams 1981; Brinkman 1984b; Cole and Gasche 1998.

268 For a recent overview of the archaeology of the Neo-Babylonian period, see Baker 2012.

269 On twin towns and hațrus in the Nippur region, see Dandamayev 2004; Stolper 1985, 7279 , respectively.

270 Baker 2001, 22; Jursa 2011b, 159.

271 Stamm 1939, 118, 315-317; Bloch 2014, 135-141; Jursa 2015b.

272 PN a-šú šá PN2 a PN3 ('PN, son of $\mathrm{PN}_{2}$, descendant of $\mathrm{PN}_{3}$ '), abbreviated in this study as $\mathrm{PN} / \mathrm{PN}_{2} / \mathrm{PN}_{3}$ or $\mathrm{PN} / / \mathrm{PN}_{3}$. On family names and their bearers, see Nielsen 2011; Wunsch 2014; Still 2019.

273 See Section 3.3. On the family name Mișirāya ('Egyptian'), see Hackl and Jursa 2015, 158. 
Personal names are difficult markers of a person's origin as they do not simply express ethnicity, beliefs, or cultural background. A person may choose a new name when he migrates to a new country in order to help his integration, but the practice of renaming slaves was also well known in Babylonia. ${ }^{274}$ Moreover, Aramaic was commonly spoken in Babylonia, and Aramaic names were not indicative of a person's non-Babylonian origin. ${ }^{275}$ Consequently, people bearing Babylonian or Aramaic names and patronymics may have been native Babylonians but also immigrants of foreign origin. In some cases, there is also evidence of double-naming or fluidity in a person's name. Some royal officials were apparently renamed when they entered their office, yet they still retained their original name. ${ }^{276} \mathrm{~A}$ rather interesting case is that of Bēl-šar-ușur/Nubâ, who worked as a minor official in Yāhūdu in the mid-sixth century. He is twice named as Bēl-šar-ușur (C2, 3, 'Bēl, protect the king!') but once as Yāhû-šar-ușur (C4, 'Yahweh, protect the king!').277 Nicknames were also used in Babylonia and long personal names abbreviated. ${ }^{278}$

Despite the caveats described above, name-giving is not an arbitrary process. It is influenced by traditions, current trends, and practical considerations. Names of a certain type and language are usually favoured in a certain region, and names given in Egypt were rather different from the names given in Babylonia. The local pantheon had an effect on name-giving, and there are significant onomastic differences between Babylonian cities. ${ }^{279}$ Ancient Semitic names were often theophoric, that is to say, nominal or verbal clauses with the name of a deity as their subject. To cite an Akkadian and Hebrew example: Nabû-šum-iddin ('Nabû has given a son') and Zekaryāh( membered'). Despite the regional differences, the worship of a deity was not confined to a certain city or region, and theophoric names are often unreliable indicators of ethnic or geographic origin.

Practical considerations of a child's parents also play a central role in namegiving: a name can give its bearer an advantage or disadvantage in social life, work, or education. The attractiveness of a certain name is closely related to power relations between different population groups. The names of a politically

\footnotetext{
274 Baker 2001, 22.

275 Beaulieu 2007, 2013b; Hackl and Jursa 2015, 158; Hackl (forthcoming).

276 Jursa 2011b, 165. See also Baker 2002, 4-6.

277 For a more detailed discussion of this person and his name, see Section 4.4.

278 Names such as Rīmūt-Ninurta could be abbreviated as Rīmūt or names such as Arad-Gula as Ardia. See Tallqvist 1905, xvi-xix; Streck 2001, 110-111. In contrast to abbreviated names, real nicknames could be quite different from their bearer's official name. For some examples, see Wunsch 1993 vol. a, 15 + n. 64.

Baker 2002, 1-3.
} 
or economically stronger party are often attractive for a weaker one, whereas the stronger does not borrow names from the weaker. There is no evidence that any other population group borrowed Judean names, but foreign names of higher status, including Persian, Egyptian, and later Greek names, were attractive to other population groups as well. ${ }^{280}$

Accordingly, a Babylonian or Aramaic personal name or patronymic alone tells nothing about the ethnic origin of its bearer in Babylonia in the mid-first millennium. He or she might have been a native Babylonian or foreign deportee. Family names form an exception to this rule, for they indicate that the family in question had resided in Babylonia for a longer time. Iranian and Egyptian names are also complicated, as they are often indicative of their bearer's Iranian or Egyptian origin, but sometimes they were borne by other people as well.

\subsubsection{Yahwistic Names as the Criterion for Identifying Judeans}

Yahwistic names - that is, personal names with the divine name Yahweh - are the main criterion for identifying people of Judean origin in Babylonian sources. ${ }^{281}$ They can be rather easily discerned from other names used in Babylonia and they appear to be indicative of a person's Judean origin in Babylonia in the mid-first millennium. This section discusses the main features of Yahwistic names, their connection to the people living in ancient Israel and Judah, and their usability as a criterion for identifying Judeans in Babylonian cuneiform sources.

The cult of Yahweh originated in the area south and east of the Dead Sea, but Israel and Judah became the centres of his worship in the first millennium. ${ }^{282}$ This is reflected in Yahwistic names, which are not only found in the Hebrew Bible but are well attested in epigraphic finds from Israel ${ }^{283}$ and Judah. ${ }^{284}$ In a similar vein, Assyrian royal inscriptions refer to the kings of Israel and Judah who bore Yahwistic names. ${ }^{285}$ The Assyrian and Babylonian deportations from Israel and Judah in the eighth to sixth centuries resulted in the

\footnotetext{
$280 \quad$ Boiy 2005; Hackl and Jursa 2015, 172.

281 On Yahwistic names and the identification of Judeans in cuneiform sources, see Zadok 1979a, 2002, 2015b; Pearce and Wunsch 2014, 14-29; Pearce 2015.

282 van der Toorn 1995, 1711-1717; Sweeney 2013, 153-156.

283 'Israel' refers here to the Northern Kingdom of Israel and 'Israelite' to its inhabitants and their descendants.

284 Donner and Röllig 2002; Ahituv 2008.

285 Cogan 2008.
} 
emergence of Yahwistic names in legal and administrative texts in Mesopotamia. ${ }^{286}$ Yahwistic names are also attested at Elephantine in Southern Egypt in the fifth century; a part of the soldiers there were of Judean origin. ${ }^{287}$ This evidence indicates a strong connection between a person's Israelite or Judean origin and their use of Yahwistic names. However, there are some cases which appear to indicate that Yahweh was also worshipped by other population groups, and thus Yahwistic personal names would not necessarily indicate their bearers' Israelite or Judean origin. Before turning to these cases, it is worthwhile to investigate how the Yahwistic theophoric element is written in West Semitic and Akkadian sources.

The pronunciation of the name Yahweh is a modern scientific reconstruction, as the religious prohibition against saying the name led to eventual ignorance of its original vocalisation. Only the consonants $y h w h$ remain to us, vocalised in a deliberately wrong way in the Hebrew Bible to prevent the reader from voicing the name unintentionally. ${ }^{288}$ In personal names, abbreviated forms of the name were used. ${ }^{289}$ The form $y w$ appears to be Israelite, whereas $y h w$ and later $y h$ were predominantly used in Judah. 290 The Neo-Assyrian spelling of the Yahwistic element in initial position is usually $I a-u$ - and in final

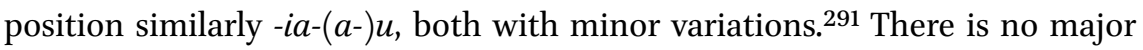
difference between the initial and final element, and the Israelite and Judean forms of the name Yahweh cannot be distinguished. The spellings are different in Babylonian cuneiform: the Yahwistic element is predominantly written as Ia-hu-ú- in initial position and as -ia-a-ma in final position, both with

286 Zadok 2002, 2015b; Pearce and Wunsch 2014.

287 On the term 'Judean' in the Elephantine papyri, see below. On the Judeans of Elephantine, see Porten 1968; Granerød 2016, the latter with an up-to-date bibliography.

288 van der Toorn 1995, 1711; Sweeney 2013, 153.

289 Fowler 1988, 32-38, 371, 380.

290 van der Toorn 1995, 1711-1712; Weippert 2007, 380-381; Sweeney 2013, 153. Weippert argues that $y h w$ is a Judean form, but van der Toorn and Sweeney point out that it was used in Israel as well.

291 Zadok 2015b, 159-16o, gives the forms Ia-u- and A+A- $u$ - in initial position and -ia/iá- $(a-)$ $u / u$, $-(\mathrm{C}) i-a-u,-(\mathrm{C}) i-\mathrm{A}+\mathrm{A}-u ́$, and $-i-u / u ́$ in final position ('C' stands here for consonant). It should be noted that the Yahwistic element is never spelled as -ia- $a$ in final position (cf. Zadok 2015b, 160). The name of the Judean king Hezekiah is always spelled with $u / u$ as the final sign, which is made clear by the recent edition of Sennacherib's inscriptions (RINAP 3/1 and 3/2). RINAP 3/2 44:21 reads ${ }^{m}$ ha-za-qi-a-a-ú; cf. Luckenbill 1924, 77:21; Zadok 2015b, 16o; PNA 2/I, 469. The name of a certain Hilqi-Yau is spelled once as mi-il-qi-ia (ND 2443 iv:4), but as other occurrences of his name on the same tablet end in $u$ (ND 2621 i:3'; ND 2443 ii:6), this abnormal spelling obviously results from a lack of space at the end of the line (ND 2443+2621 is edited in Parker 1961, 27-28; see Zadok 1979a, 99-100; Younger 2002, 213; Galil 2009; PNA 2/I, 472). 
orthographical variation. ${ }^{292}$ However, the initial element is occasionally written as $I a-(a)-m u$ - and the final element as -ia-hu-ú, both with orthographical variation. ${ }^{293}$ There are also abbreviated forms of the final element. ${ }^{294}$ The peculiar spelling ia-a-ma results from the Neo-Babylonian orthography, in which $m$ represents also $w{ }^{295}$ There is consensus that both ia-hu-ú and ia-a-ma represent the Yahwistic theophoric element, but pronunciation of the element $i a-a-m a$ and its relation to $i a-h u-u$ and to the alphabetic spellings of the divine name are disputed. ${ }^{296}$

The previous overview of orthographic practices helps one to evaluate possible attestations of Yahwistic theophoric names outside the Israelite and Judean onomasticon. It should first be noted that the ending -ia in cuneiform does not represent the Yahwistic theophoric element but is a common hypocoristic suffix in personal names. ${ }^{297}$ Accordingly, names such as Bānia and Zabdia are not Yahwistic, although it is possible that they are occasionally hypocoristics of Yahwistic names. ${ }^{298}$ The alleged attestations of the Yahwistic theophoric element in the Eblaite ${ }^{299}$ and Amorite ${ }^{300}$ onomastica and in documents from the Sealand and Nippur in the second millennium ${ }^{301}$ need to be refuted as they are not supported by a closerlinguistic analysis of the evidence. A reference to yw in the Ugaritic Baal Cycle (KTU 1.1 iv:14) does not bear evidence to the worship of Yahweh in Ugarit. ${ }^{302}$

In addition to the Israelites and Judeans, it has been suggested that Yahweh was worshipped in the first millennium by the Arameans, Philistines,

292 Pearce and Wunsch 2014, 19-20 list all the known orthographies of these two elements. The spellings of the initial element Yāhû are $I a-(a)-h u-(u / u ́)-, E-h u-u ́-, I-h u-u ́, H u-u ́-, I a-k u-$ $u^{u}$-, $I a-a-, I a^{2}-$, and $I a^{2}{ }^{2} u^{-}$. The final element Yāma has numerous different spellings; only

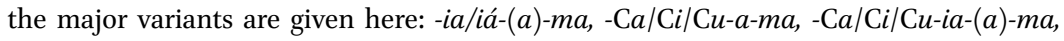
$-\mathrm{C} a / \mathrm{C} i^{-}{ }^{2}-a-m a,-(\mathrm{C} e)-e-m a,-(a)-a-m a$, and $-a-a m$.

293 I $a-(a)-m u-$ and Ia-ma-?:(BU)- for the initial element and -iá-a-hu-ú, -Ca/Ci-ia-hu-ú, -Cu$i a / i a ́-a-h u-u ́$, and -Cu-i-hu-ú for the final element (Pearce and Wunsch 2014, 19-20).

$294-\mathrm{C} a-a-a$, -Ce-e-ia- $a^{-}{ }^{2},-\mathrm{C} i-i a-a^{-}{ }^{2},-\mathrm{C} u-i a,-i a-[a]-{ }^{2}$, and -ia- $a^{-}{ }^{2}$ (Pearce and Wunsch 2014, 20).

295 GAG § 21, 31. See also Coogan 1973, 189-190; Tropper 2001, 81-82.

296 See Coogan 1973; Zadok 1979a, 7-22; Tropper 2001; Millard 2013.

297 Lipiński 2001, 229-230.

298 Cf. Ahn 2011, 52-53, who suggests that names such as Ardia and Zabdia are Yahwistic. See Pearce and Wunsch 2014, 41, 92. Hypocoristics could naturally be formed from Yahwistic names as well; see the case of Hananī and Hanan-Yāma in Section 5.7 and the (somewhat unclear) case of Bānia and Banā-Yāma in J9 and C84 (Pearce and Wunsch 2014, 43).

299 See the claims in Pettinato 1980. On their refutation, see Müller 1980; van der Toorn 1995, 1712-1713; Chavalas 2002, 40-41.

300 See the discussion of this question and an overview of earlier scholarship in Streck 1999.

301 Suggested by Dalley 2013, 182-184; Keetman 2017; refuted by Zadok 2014b, 229-232.

302 Smith 1994, 151-152; van der Toorn 1995, 1713. 
Phoenicians, Nabateans, and Syrians. According to Jeaneane D. Fowler, identification of Judeans in Babylonian sources is difficult because Arameans tended to add new gods, including Yahweh, to their pantheon. ${ }^{303}$ Fowler claims that this is suggested by the Aramaic Yahwistic names in the Murašu archive and by the usage of Yahwistic names by 'Arameans' at Elephantine. First, the fact that a name is linguistically Aramaic does not mean that its bearer was ethnically 'Aramean'. Aramaic was very widely spoken in the Near East and Babylonia in the late fifth century, ${ }^{304}$ and thus the use of Aramaic names was not confined to a certain population group. ${ }^{305}$ Judeans undoubtedly spoke Aramaic in Babylonia as well, and the distinction between Hebrew and Aramaic Yahwistic names does not reflect ethnic divisions among the population in the Murašû archive. Second, the situation at Elephantine is far more complicated than Fowler assumes. It is true that some people bearing Yahwistic names are explicitly called 'Aramean', but, surprisingly, some of them are referred to as 'Judean' on another occasion. ${ }^{306}$ This shows that the terms 'Judean' and 'Aramean' were not mutually exclusive and they did not simply demarcate the divisions between population groups. ${ }^{307}$ The worship of Yahweh and the use of Yahwistic names appear to be linked to the Judean origin of a part of the population at Elephantine. ${ }^{308}$

There is no evidence that Yahweh was worshipped by Philistines, Phoenicians, or Nabateans either. Niels Peter Lemche's suggestion that Șidqâ, the king of Ashkelon attested in Assyrian sources, ${ }^{309}$ had a Yahwistic name was effectively disproven by K. Lawson Younger, Jr. ${ }^{310}$ The spelling of the king's name (Si-id-qa-a) does not conform to the Assyrian conventions of writing the Yahwistic element, and it is actually a hypocoristic of a longer personal name. The single reference to the god Iعv' in Eusebius' Praeparatio evangelica 1.9.21 does not confirm that Yahweh was worshipped by the Phoenicians, ${ }^{311}$ and the word

\footnotetext{
303 Fowler 1988, 212, 319-333.

304 Beaulieu 2007, 2013b; Hackl (forthcoming).

305 See Hackl and Jursa 2015, 158.

306 Kratz 2011, 421-424; van der Toorn 2016a.

307 van der Toorn 2016a.

308 However, I am hesitant to follow van der Toorn (2016a) in translating the Aramaic word $y h w d y$ ' as 'Jews' rather than 'Judeans'. In this period, the designation seems to be primarily related to ethnicity and geographic origin, not so much to religious beliefs or practices. See Becking 2011b.

309 Lemche 2000, 189 n. 66.

310 Younger 2002, 207-216.

311 van der Toorn 1995, 1712.
} 
'hyw in Nabatean personal names cannot be identified as the Yahwistic theophoric element. ${ }^{312}$

Finally, one needs to consider Stephanie M. Dalley's suggestion that Yahweh was worshipped in Syria in the eighth century. ${ }^{313}$ Her thesis is based on three names, Azri-Yau, Yau-bi'di, and Joram, the first two being attested in Assyrian royal inscriptions and the latter one in the Hebrew Bible. The first of these people, Azri-Yau (Az-ri-a-ú; Az-ri-ia-a-ú), was a rebel in the area of Hamath, defeated by Tiglath-pileser III in $738 .{ }^{314}$ He should not be identified as the Judean king Azariah, ${ }^{315}$ but his name appears to be undeniably Yahwistic in light of the Assyrian spellings surveyed above. It has been suggested that this AzriYau was of Israelite origin, ${ }^{316}$ the son of an Israelite princess and a Hamathean ruler, ${ }^{317}$ or a local Syrian ruler with a Yahwistic name. ${ }^{318}$ If Azri-Yau was of Syrian origin, one would expect the Aramaic spelling ${ }^{\varsigma} d r$ of the first element instead of the Canaanite form ${ }^{s} z r$ found in the cuneiform. ${ }^{319}$ These linguistic considerations point towards Azri-Yau's Israelite or Judean origin, but it cannot be excluded either that he was a native of Northern Syria who worshipped Yahweh.

The second person with a possibly Yahwistic name was Yau-bi? di or Ilu$\mathrm{bi}^{2} \mathrm{di}$, a Hamathean rebel in the beginning of the reign of Sargon II. His name is spelled two different ways in cuneiform, ${ }^{\mathrm{d}} I a-(\hat{u})-b i^{2}-d i$ and $I-l u-(\hat{u})-b i-^{2}-d i$, both with small variations. ${ }^{320}$ The first name appears to be Yahwistic, but the second one replaces the divine name with the general word for 'god' (ilu). Dalley suggests, 'The Assyrians thought of Yahweh as El..., and give a variant of Yau-bi'di's name as El-bi' di' ${ }^{221}$ It is too far-fetched to assume that the Assyrians had such ideas about Yahweh and El, but it may be possible that the Yahwistic theophoric element was occasionally replaced with ilu in cuneiform,

\footnotetext{
312 Knauf 1984.

313 Dalley 1990.

314 RINAP 1, Tiglath-pileser III 13:2, 31:7.

$315 \mathrm{Na}^{2}$ aman 1974, 36-39.

316 van der Toorn 1992, 90; Weippert 2007, 383-387.

317 Zadok 2015b, 160 n. 3; see also Weippert 2007, 387 .

318 Naªman 1974, 39; 1978, 229-239; Dalley 1990, 26-29. See also the discussion in Lipiński 2000, 313-315.

319 Cogan and Tadmor 1988, 166; Weippert 2007, 385. Cf. Dalley 1990, 28. See also Abraham 2007, 215-216; Zadok 2015d.

320 PNA 2/I, 497, 526; Fuchs 1994, 410. Note that the Ilu-bi? di mentioned in SAA 1171 is not identical with the homonymous rebel in Sargon's inscriptions (see PNA 2/I, 526).

321 Dalley 1990, 31.
} 
and the spelling Ilu-bidi does not exclude taking Yau-bi ${ }^{2} d i$ as a Yahwistic name. ${ }^{322}$

The third person listed by Dalley is Joram, the son of the king of Hamath, who brings gifts to King David in 2 Sam 8:9-11. His name is given as Hadoram

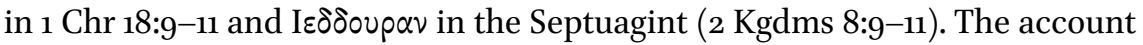
may not be based on any real historical event, ${ }^{323}$ but the idea of a Hamathean prince with a Yahwistic name is noteworthy in any case.

Apart from these three names there is no other evidence of native worship of Yahweh in Syria, and it is difficult to accept Dalley's conclusion that there were 'several cities in Syria where people worshipped Yahweh as a major god in the 8th century вс' ${ }^{324}$ In the 730 s and 720 something prompted the use of Yahwistic names among the rebel leaders in the region of Hamath, but the geographic origins of Azri-Yau and Yau-bi'di remain unclear. Azri-Yau's nonAramaic name may indicate that he was a foreigner from Israel or Judah, and Sargon's inscriptions make clear that Yau-bi'di was not the legitimate heir to the throne. ${ }^{325}$ This evidence indicates that none of the rebels belonged to the local ruling dynasties. Prince Joram of Hamath is, first and foremost, a character in the narratives surrounding the mythical kingdom of David. It cannot be excluded that the Yahwistic names of the Syrian rebels of the late eighth century are reflected in the name of this literary character as well. Accordingly, the available evidence does not support the conclusion that Yahweh was worshipped among the native population of Syria in the eighth century or later.

In light of the previous discussion, the use of Yahwistic names was generally indicative of a person's Judean or Israelite origin in the first millennium. The cult of Yahweh is well attested within the geographical boundaries of these two kingdoms, and Yahwistic names start to appear in Assyria after the deportations from Israel and Judah in the late eighth century. ${ }^{326}$ In Babylonia, Yahwistic names appear in cuneiform sources after the deportations in the early sixth century. ${ }^{327}$ Moreover, there are several instances that make the connection

322 See the doubts expressed in Lipiński 1971 (but see Lipiński 2000, 314 n. 430); van der Toorn 1992, 89-90.

323 See van der Toorn 1992, 90.

324 Dalley 1990, 32.

325 Prunkinschrift 33 (Fuchs 1994, 200-201, 345).

326 Zadok 2015b, 16o. On the possibility that Tiglath-pileser III and Sargon II had Judean wives, see Dalley 1998; but cf. Younger 2002, 216-218.

327 Zadok 2002, 27-28; Pearce and Wunsch 2014, xxxviii (see $\mathrm{C}$, the earliest document from Yāhūdu). A certain Gir-re-e-ma is mentioned in the accession year of Sîn-šum-līšir (626 вСE; СтмMA 41 = BE 8 141) - he is the single person who possibly bore a Yahwistic name in Babylonia before the early sixth century. See Da Riva 2001; Zadok 2002, 27; Section 6.2. 
between a Yahwistic name and a person's origin explicit. The correct identification of the Yahwistic element in cuneiform sources is confirmed by references to the kings of Israel and Judah in Assyrian royal inscriptions ${ }^{328}$ and by the presence of King Jehoiachin and other Judeans on the ration lists from Babylon. ${ }^{329}$ Yahwistic names are attested among a group of Samarian charioteers at $\mathrm{Kalhu},{ }^{330}$ and, finally, there is a great number of Yahwistic names in the village of Yāhūdu in the Babylonian countryside. ${ }^{331}$ The same applies to Elephantine, where people characterised as 'Judeans' bore Yahwistic names.

In Babylonia in the sixth and fifth centuries, Yahwistic names indicated a person's Judean origin. It is of course possible that some people of Israelite origin found their way to Babylonia or that some people in close contact with Judeans adopted Yahwistic names. However, these scenarios cannot involve a large number of people. Babylonian deportations from Judah and the advent of Yahwistic names in Babylonia are chronologically very closely related, and the majority of Yahwistic names can be found in rural communities where deportees were resettled. It is possible that some descendants of Israelite or Judean deportees migrated from Assyria to Babylonia after the fall of the Assyrian Empire, and that some people from the territory of the former kingdom of Israel were deported to Babylonia. ${ }^{332}$ However, the evidence remains inconclusive, and it can hardly explain the emergence of Yahwistic names in Babylonian cuneiform sources.

When it comes to the adoption of Yahwistic names, it is highly unlikely that the native population or other immigrants had any reason to do this. Immigrants can benefit from the adoption of local names, but others do not have an incentive to use the names of an unimportant minority. The situation is different when it comes to the names of a dominant minority: Iranian and perhaps Egyptian names were attractive to outsiders in Achaemenid Babylonia. ${ }^{33}$ However, Yahwistic names did not have such status. Admittedly, friendship, marriage, or business relationships may have affected the naming practices of a certain family and led to the adoption of Yahwistic names by non-Judeans, but there is no reason to assume that this was a common phenomenon. It should be also noted that the linguistic and socio-economic environment of Yahwistic names in Babylonia was peculiar: they are typically not found in the

328 Cogan 2008.

329 See Section 2.4.

330 Dalley and Postgate 198499 ii:16-23; see also Dalley 1985 .

331 See Chapter 4.

$33^{2}$ See Zadok 2015b, 175-176.

333 Hackl and Jursa 2015, 172. See Boiy 2005 on the practice of using Greek names in Hellenistic Babylonia. 
social sphere of temples or priestly families but in multicultural contexts where other West Semitic names also occur.

At the same time, we need to realise that a great number - perhaps even the majority - of Judeans cannot be identified in Babylonian sources. Only some Judeans bore Yahwistic names, and those with Babylonian and non-Yahwistic West Semitic names can only be identified as Judeans if they had relatives with Yahwistic names. Consequently, the picture is skewed in favour of those families which retained the practice of using Yahwistic names. This has important consequences for the study of identity and integration.

There are also some other names that have been regarded as being indicative of their bearer's Judean origin. Hoshea $(A-m u$-še-e or $U$-še-eh in Babylonian cuneiform), ${ }^{334}$ Nubâ (Nu-ba-a or Nu-ba-ú-a), ${ }^{335}$ and Šillimu (ك̌i-li-im, Še-li-im$m u$, etc. $)^{336}$ were indeed used predominantly, if not exclusively, by Judeans in

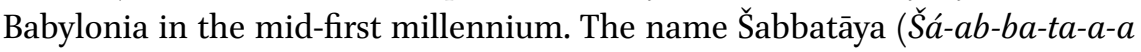
and other forms with minor differences in spelling) is not common in Mesopotamian sources ${ }^{337}$ and it was used by Judeans, but it cannot be shown that the name was exclusively Judean. ${ }^{338}$ The same applies to Haggâ (Ha-ag-ga-a, Haga-a). ${ }^{339}$ It cannot be confirmed that the name Minyamin (Mi-in-ia-a-me-en, etc.) was used by Judeans at all. ${ }^{340}$

334 Only three different individuals used the name, and two of them had blood relatives with Yahwistic names: Amušê (Nbn 1), Amušê/Arih (from a Judean family of royal merchants; see Section 3.3), and Mattan-Yāma/Amušê (EE 113; written as Ú-še-eh in PBS 2/1 60). See Zadok 1979a, 26-27; Bloch 2014, 145-146; but cf. Zadok 2014a, 112. See the Neo-Assyrian attestations of this name in PNA 1/I, 238; PNA 3/II, 1421.

335 The name is not attested in cuneiform sources apart from the documents from Yāhūdu and its surroundings. Except for Bānia/Nubâ in J9, people with this name always had blood relatives with Yahwistic names. Moreover, it is possible that the Bānia in J9 is identical with Banā-Yāma/Nubâ in C84 (see Pearce and Wunsch 2014, 42-43, 287). On the name Nubâ and its attestations in the environs of Yāhūdu, see Joannès and Lemaire 1999, 29; Pearce and Wunsch 2014, 75, 287.

336 The name is not attested in Tallqvist 1905, and it is borne only by Judeans in the documents published in Pearce and Wunsch 2014, BE 9 (except for Natunu/Šillimu whose Judean origin cannot be confirmed in BE 945 ), EE, and IMT.

337 It is not attested, for example, in Tallqvist 1905 or PNA.

338 See the attestations and discussion in Coogan 1976a, 34-35, 84; Zadok 1979a, 22-24; Pearce and Wunsch 2014, 81, 291; Pearce 2015, 21-22. The name is also attested in Elephantine, on which see Granerød 2016, 196-204. Although some people bearing this name had blood relatives with Yahwistic names, there are several cases where their Judean background is unclear or improbable. Pearce and Wunsch (2014) analyse Šabbatāya as a Hebrew name, whereas Coogan, Zadok (2014a, 112), and Granerød do not regard it as exclusively Judean. Pearce $(2015,22)$ suggests that the name 'can, in fact, identify Judeans'.

339 Coogan 1976a, 23, 73; Zadok 1979a, 23-24; Pearce and Wunsch 2014, 52-53, 271.

340 The name is attested in the Murašu archive, but not in the environs of Yāhūdu. None of the people with this name had blood relatives with Yahwistic names. The name is analysed 
In this study, people bearing Yahwistic names are identified as Judeans. Logically, their blood relatives can be identified as Judeans as well, regardless of their names. The business partners, acquaintances, debtors, or creditors of Judeans are identified as Judeans only if they or their family members had Yahwistic names. Names such as Hoshea, Nubâ, and Šabbatāya may have been exclusively Judean, but as this cannot be confirmed, these names will not be used as indicators of a person's Judean origin. Using this set of criteria, 282 people can be identified as Judeans in Babylonian documents written in 591413 BCE. This number does not include persons who are referred to only as patronymics. My corpus of texts is primarily based on the list presented in Zadok 2002, ${ }^{341}$ the documents published in Pearce and Wunsch 2014, and nos. 1-42 in Wunsch (forthcoming).

Unlike Judeans, people of Neirabian origin can be identified only in a single group of 27 texts, excavated in Neirab, near Aleppo, Syria. As explained in detail in Chapter 7 , these texts were written in the twin town of Neirab in Babylonia, and when the descendants of Neirabian deportees returned to their ancestral hometown in Syria, they took the texts along. Although a significant proportion of inhabitants in the twin town of Neirab must have been of Neirabian origin, the example of Yāhūdu shows that other people also found their way to these settlements. Therefore, personal names are again the main criterion for identifying persons of Neirabian origin in this small corpus, a remarkable feature of which is the abundance of Sîn and Nusku names. Nusku, the son of the moon god Sîn/Sahr, is rarely attested in the Neo-Babylonian onomasticon, ${ }^{342}$ but worship of the moon god, his consort, and his son was very popular in Northern Syria. ${ }^{343}$ Although Sîn or Nusku names are not reliable identifiers of Neirabians in the Babylonian text corpus in general, in this particular group of texts the families which used these theophoric elements and West Semitic names can be identified as Neirabian. ${ }^{344}$

and the pertinent evidence is surveyed in Coogan 1976a, 28-29, 77; Zadok 1979a, 24-26, but they perceive the name as more typically Judean or Hebrew than I do.

However, as my criteria for identifying Judeans are stricter than those of Zadok, several people from Zadok's list are omitted. The main difference is that Zadok includes people who used names like Šabbatāya or were co-debtors or colleagues of Judeans (see, for example, persons 106-108 and 111 in Zadok 2002, 41).

342 Tallqvist 1905, 170.

343 Lipiński 2000, 620-623.

344 Tolini 2015, 69-73. 


\section{Judean Royalty and Professionals in Babylon}

\subsection{Introduction}

According to 2 Kings 24, Nebuchadnezzar II deported King Jehoiachin, members of the Judean upper class, and craftsmen to Babylonia after the conquest of Jerusalem in his eighth regnal year. ${ }^{345}$ The selective deportation of ruling elites and professionals was a common practice in the Neo-Assyrian period, ${ }^{346}$ and a group of administrative texts from Babylon show that the Babylonian Empire exercised a similar policy. These texts, the only surviving remnants of the state archives of Babylonia, record the distribution of oil rations to people of Babylonian and foreign origin around the thirteenth year of Nebuchadnezzar. King Jehoiachin, Judean princes, and other people of Judean origin are also attested on these lists, less than ten years after the deportations from Jerusalem in 597. Before the publication of the texts from Yāhūdu and its surroundings, documents from the Palace Archive of Nebuchadnezzar II (from now on, the 'Palace Archive') were undoubtedly the best-known cuneiform source for the study of Judeans in Babylonia. The reason for their fame, especially among biblical scholars, is obvious: the texts not only corroborate Jehoiachin's exile in Babylon, but their contents can also be compared with the account of his amnesty in 2 Kgs 25:27-30.

In this chapter, I study the Palace Archive and its information on immigrants in Babylon. I begin by introducing the archive, its archaeological context, and its publication history. Second, I move on to analyse the texts, focusing on the socio-economic status of Judeans and other foreigners in Babylon. Finally, I discuss the texts in relation to the account of Jehoiachin's amnesty in 2 Kings 25 .

\subsection{German Excavations at Babylon}

A German excavation team led by Robert Koldewey conducted the first thorough archaeological excavations at Babylon in 1899-1917. ${ }^{347}$ Because of the

\footnotetext{
345 According to a Babylonian chronicle, Jerusalem fell in the twelfth month of Nebuchadnezzar's seventh year, in spring 597. See Section 1.2.3.

346 Oded 1979, 22-23, 44, 48-59.

347 The following summary of the German excavations is based on the information in Pedersén 1998, 183-191; 2005a, 1-16, 109; 2005b, 267. Pedersén 2005a is not only a painstaking
} 
high level of the water table, the excavators had difficulties in reaching beyond the Neo-Babylonian and Persian strata, which are thus studied better than the earlier periods. The excavated area was primarily located in the palace and temple districts of the ancient city, but it also included the residential area of Merkes. The results of the excavations were well documented, compared to the archaeological practices of the early twentieth century. Almost 4,00o photographs provide valuable information on the excavations and on many objects that can no longer be located in museum collections.

The careful documentation of the German excavations turned out to be valuable, because many of the findings have become inaccessible during years of political turmoil in the Middle East. When the excavations started in 1899, the ruins of ancient Babylon lay within the borders of the Ottoman Empire, and the archaeological findings were supposed to be divided between Istanbul and Berlin. However, only a small number of items were delivered to the Istanbul Archaeological Museum before the First World War dramatically changed the political landscape of the Middle East. The excavation team was evacuated in 1917 when the Allied troops approached Babylon, and the findings were left in the excavation house until 1926. The majority of the items remained safe, but some of the most precious finds were looted and sold on the antiquities market. The Vorderasiatisches Museum in Berlin and the Iraq Museum in Baghdad divided the remaining items in 1926.

The discovery of the Ishtar Gate and its reconstruction in Berlin made Koldewey's excavations famous, but the other finds are poorly studied and published. Out of circa 5,200 tablets discovered in Babylon, 2,300 are in Berlin, 130 in Istanbul, and several dozen in museums and private collections around the world. Consequently, almost 3,00o tablets should be located in the Iraq Museum, but the war in Iraq prevented Olof Pedersén from inventorying these tablets in the early twenty-first century. Approximately 2,500 tablets can be located in museums and private collections, and when the excavation photographs are taken into account, there is some information on the contents of 4,067 tablets. Only six per cent of the tablets are published so far. ${ }^{348}$ Pedersén and Joachim Marzahn intend to publish the remnants of the Palace Archive, and a major publication project of the Babylon tablets in Berlin is planned. ${ }^{349}$

inventory of the discovered tablets but also an excellent overview of the excavations with further bibliography.

348 Pedersén 2005a, 1-13, 305.

349 Pedersén 2009, 195; personal communication with Pedersén in July 2013. 
The South Palace (Südburg) was the older of two huge royal palaces which Nebuchadnezzar II built in Babylon between the Processional Way and the Euphrates. Koldewey's team excavated the South Palace thoroughly, and its architectural design around five successive courtyards is well known. The eastern part of the building housed the offices and workshops of palace personnel, whereas the central part was dominated by the main courtyard and throne room. Living quarters were located in the west end of the palace. ${ }^{350}$ The northeast corner of the administrative premises was architecturally different from the rest of the palace. It was a vaulted structure that, according to Koldewey, might have been the foundation of the Hanging Gardens of Babylon. It may indeed have supported some heavy structure, and the foundations of the vaults contain a number of chambers that could have been used as storage rooms or a prison. ${ }^{351}$ When Koldewey's team excavated the vaulted structure, they found a group of circa 300 Neo-Babylonian tablets (archival group N1 in Pedersén 2005a), predominantly located in the vicinity of a staircase leading to the vaulted structure. These administrative texts had probably fallen there from an upper floor when the building was destroyed. Pedersén has been able to identify 303 tablets belonging to this group. ${ }^{352}$

Two smaller groups of tablets with similar contents were found outside the South Palace near the Ishtar Gate (N2, 25 tablets) and on the south side of the main entrance to the palace $\left(\mathrm{N}_{3}, 18\right.$ tablets). Tablets of group $\mathrm{N}_{2}$ were found deep below the floor level of the Processional Way and the Ishtar Gate, which means that they had already been discarded before the construction works during Nebuchadnezzar's reign. Because the excavation notes do not describe the find-spot of group $\mathrm{N}_{3}$ but only locate it in the sector Kasr $25 \mathrm{v}$, it cannot be confirmed whether these tablets were found inside the palace or just outside its walls. A number of fragmentary tablets were unearthed on the north side of the main entrance, but their contents and possible connections with the other three groups remain largely unclear. Almost all tablets in the three groups were written during the reign of Nebuchadnezzar in 601-577 BCE. The tablets from the entrance of the palace are the earliest (3-13 Nbk), followed by the tablets discovered at the Ishtar Gate (8-12 Nbk). The tablets from the vaulted structure

350 Van De Mieroop 2003, 268; Miglus 2004; Pedersén 2005a, 109-111; Jursa 2010b, 69-72.

$35^{1}$ Koldewey 1969, 38-64; Pedersén 2005a, 111-112. Koldewey (1969, 48) suggests that the chambers functioned as storage rooms; Pedersén (2005a, 112) leaves the question open. According to Jursa (2010b, 72 ), the eastern, administrative wing of the palace was a probable location for a prison.

Pedersén 2005a, 112-113. 
are the latest, dated predominantly in $10-28 \mathrm{Nbk}$ with the exception of a tablet dated in the fifteenth year of Šamaš-šum-ukīn $\left(65^{2}\right.$ BCE) and another one dated in the thirty-fourth year of Nebuchadnezzar (571 ВCE). ${ }^{353}$

In addition to the text groups discussed above, no other Neo-Babylonian archives were found in the North and South Palaces of Babylon. Accordingly, the administrative tablets in the three groups comprise the only surviving part of the documentation that the Neo-Babylonian state kept in the capital of the empire. When one considers the size of the royal archives unearthed in the Assyrian capital of Nineveh, it is clear that the Babylonian royal archives must have been impressive as well. ${ }^{354}$ Even though a significant part of the archives were probably written in Aramaic on perishable materials, the surviving tablets were hardly the only ones recorded on clay. ${ }^{355}$ It remains unclear why nothing else was found during the thorough excavation of the palace area.

Out of these 346 tablets, only 80 are located in museum collections. An additional 65 or so are preserved as photographs. The excavation journal briefly describes each of the 346 tablets. No more than 13 tablets are fully or partially published or their contents discussed in research literature. ${ }^{356}$ The tablets of group $\mathrm{N}_{1}$ are administrative documents recording the delivery of commodities to be stored and processed in Babylon, as well as their eventual distribution to people of Babylonian and foreign origin. Several different officials administered this process, among them courtiers ( $\check{s} a$ rēšs šarri), scribes, measurers, and counting officials. ${ }^{357}$ The tablets of groups $\mathrm{N}_{2}$ and $\mathrm{N}_{3}$ resemble those of the main group $\mathrm{N}_{1}$ and record the same process of delivery and distribution. As the systems of record-keeping differ somewhat between the three groups, they may originally have belonged to separate archival units. ${ }^{358}$ For the sake of convenience, I refer to these three groups collectively as 'the Palace Archive'.

The majority of the texts pertain to barley and dates. ${ }^{359}$ The quantities of delivered barley and dates are so large that they could not have been consumed by the personnel of the palace, and significant amounts must have been

353 Pedersén 2005a, 113, 128, 130.

354 On the royal archives from Nineveh, see Parpola 1986; Pedersén 1998, 158-165; Reade 2000.

355 See Fales 2007b; Jursa 2014b, 97-101; Radner 2014b, 83-86 on the role of Aramaic in the Babylonian and Assyrian state administration.

356 Pedersén 2005a, 113, 128-132; Jursa 2007c. Pedersén was able to locate 71 tablets in museum collections, and he is aware of nine tablets which are published or discussed. Michael Jursa identified an additional nine texts in museum collections, four of which are published.

357 Pedersén 2005a, 113-118. See also Waerzeggers (forthcoming a).

358 Pedersén 2005a, 128, 130.

359 Pedersén 2005a, 114-116. 
delivered elsewhere ${ }^{360} \mathrm{~A}$ few texts pertain to the delivery of emmer, flour, and sesame. In general, barley was transported to storehouses, but dates were often delivered to brewers for processing. ${ }^{361}$ Some of the barley was later ground into flour by people who were dependent on the palace. ${ }^{362}$ In addition to accounts of delivery and processing, the Palace Archive records the distribution of foodstuffs to people who worked for or were otherwise dependent on the palace. ${ }^{363}$ The texts reflect a real ration system, by means of which food was distributed to cover the basic needs of the palace personnel. This is different from the temple economy, in which payments in barley or dates often functioned as cash which could be exchanged for other products. ${ }^{364}$

A number of long lists record the distribution of sesame oil as rations to people of Babylonian and foreign origin, but also for the maintenance of wooden and metallic objects. ${ }^{365}$ Some oil was even sent to graves, probably for sacrifices. ${ }^{366}$ Four of the ration lists were partially published by Ernst F. Weidner in 1939, ${ }^{367}$ and Pedersén has summarised the contents of some unpublished tablets. ${ }^{368}$ Transliterations of the texts published by Weidner are available at CTIJ. The date has been preserved only in one document, which was drafted in the thirteenth year of Nebuchadnezzar II (591 BCE). ${ }^{369}$ Some of the recipients, such as shipbuilders, probably did not live in the palace; only

\footnotetext{
36o Jursa 2010b, 76 .

361 Pedersén 2005a, 114-117.

362 Grain was delivered to a prison for grinding (Jursa 2010b, 72). The recipients of grain included, among others, women and prisoners of war, who probably ground it as well (on the recipients, see Pedersén 2005a, 116). Grinding of flour was typically the task of women and, in an institutional context, forced labour. See Bongenaar 1997, 113, 118-120; Kleber 2005, 293-294, 317-318.
}

363 Pedersén 2005a, 116-118.

364 Jursa 2010b, 76. In general, ration systems are well-attested in the ancient Near East. People of foreign origin were often among the recipients of rations in the capital cities of empires. For two examples, see the discussions on the Persepolis Fortification tablets in Aperghis 2000 and on the wine lists from Kalhu (Nimrud) in Kinnier Wilson 1972, esp. 1-6, 90-94.

365 Weidner 1939; Pedersén 2005b.

366 Weidner 1939, text A obv. 16, rev. 19; Jursa 2010b, 71.

367 Weidner 1939. Consequently, these documents are often referred to as the 'Weidner tablets'. I refer to these four tablets using the same letters as Weidner: A = Bab $28122=$ Pedersén 2005a no. 35; B = Bab 28178 + 28299a = Pedersén 2005a no. 91; C = Bab 28186 = Pedersén 2005a no. 99; $\mathrm{D}=$ Bab 28252 (erroneously given as 28232 by Weidner) = Pedersén 2005a no. 165 .

368 Pedersén 2005a, 117-127; 2005b.

369 The available information on preserved dates is somewhat contradictory. According to Pedersén 2005a, 117, the oil lists are dated to 11 and 13 Nbk, but his inventory of the tablets gives a date only for no. 91 (?-XII-13 Nbk). The date 13 Nbk is corroborated by Pedersén 
the administration was run there. ${ }^{370}$ The lists record oil rations of one or more consecutive months; the average oil ration was one $q \hat{u}$ (about one litre). Because the sum of individual oil rations is significantly smaller than the total sum at the end of the lists, Pedersén raises the possibility that the rations were given on a daily instead of a monthly basis. ${ }^{371}$ As a daily ration, however, one $q \hat{u}$ would be too generous; as a monthly ration it would be enough to cover the basic needs of an individual. In any case, the variation in the size of individual rations is large, which seems to indicate that oil was distributed according to the status of the recipients, who were perhaps responsible for its redistribution in their circles. ${ }^{372}$

A peculiar feature of the ration lists is the ethnic diversity of the recipients. The palace not only maintained people of Babylonian origin, as areas on the fringes of the empire, especially the Eastern Mediterranean coast, are well represented: oil rations were distributed to people from Tyre, Judah, Ashkelon, Egypt, Media, and Elam, to name but a few. Interestingly enough, these areas closely follow the borders of the Neo-Babylonian Empire during the reign of Nebuchadnezzar II. ${ }^{373}$ The large number of immigrants from the Levant reflects the Babylonian campaigns in the west, as described in the Babylonian chronicle on the early years of Nebuchadnezzar II. ${ }^{374}$ In the following, I first discuss the presence of foreign professionals in Babylon, and, second, the attestations of foreign royalty in the archive.

\subsection{Foreign Royalty and Professionals in Babylon}

The foreign origin of the people in the Palace Archive and the archaeological and textual evidence of the Babylonian campaigns in the Levant suggest that a large number of people arrived in Babylon as deportees in the early sixth century. The Babylonian chronicle on the early years of Nebuchadnezzar II $(A B C 5)$, the Hebrew Bible, and archaeological data from Ashkelon and Jerusalem shed light on the fate of the very same people who are later attested on the ration lists. ${ }^{375}$ Although the land-for-service sector in the Babylonian

2005b, 268 and Weidner 1939, 925 (but note that on page 927 Weidner assigns the date to text C instead of B).

See Jursa 2010b, 73; Pedersén 2005b, 270.

371 Pedersén 2005a, 117-118.

372 Weidner 1939, 927; Waerzeggers (forthcoming a).

373 Pedersén 2005b.

$374 A B C 5$.

375 Section 1.2. 
countryside absorbed large numbers of deportees, skilled professionals were also needed in the capital and employed as craftsmen, officials, and soldiers. At the same time, members of foreign royalty were held hostage at the palace to ensure the loyalty of their relatives who ruled over the vassal kingdoms of Babylonia. ${ }^{376}$

Both selective deportations of craftsmen and elite ${ }^{377}$ and the practice of holding royal hostages ${ }^{378}$ are well attested in the Neo-Assyrian sources. Royal inscriptions boast about the deportations of royal officials, craftsmen, soldiers, and agricultural workers, ${ }^{379}$ and the Nimrud Wine Lists refer to groups of foreign professionals who were maintained by the royal palace. ${ }^{380}$ Although some craftsmen or mercenaries may have migrated to Assyrian cities on a voluntary basis, deportations must have played a key role in the influx of foreign professionals. ${ }^{381}$ Hostages were taken from royal houses opposing the empire, including Egypt, the kingdoms in Syria, and the Aramean tribe of Hindāru in Babylonia. These people were held captive in the Assyrian capital to ensure the loyalty of family members who ruled in vassal kingdoms and to indoctrinate prospective rulers into the beliefs and values of the empire. ${ }^{382}$

The Palace Archive of Nebuchadnezzar II bears witness to the presence of foreign officials, soldiers, and craftsmen in Babylon. Courtiers ( ̌̌a rēš šarri) from Egypt, Ashkelon, Judah, and Elam worked in the palace, ${ }^{383}$ and numerous soldiers of foreign origin received rations from the royal storehouses. A small number of Egyptians guarded the boatyard (bit sapināti) and the administrative wing of the palace (bìt qīpūti). ${ }^{384}$ Moreover, 800 Elamites were employed as guards of the bit qüputti, and more than 200 Carian guards worked in the city as well. ${ }^{385}$ Not all of these men were necessarily prisoners of war. They also could have been hired troops, because Carian mercenaries are attested around the Eastern Mediterranean and ancient Near East. ${ }^{386}$ Likewise, messengers

\footnotetext{
376 On the living conditions of these people, see Section 2.5.

377 Oded 1979, 22-23, 41-59.

378 Zawadzki 1995; Radner 2012.

379 RINAP 3/1 22 i:31-35; RINAP 433 iii:14'-22'.

380 Kinnier Wilson 1972, 90-94.

381 On the (forced) migration of Arameans to Assyria, see Nissinen 2014, 273-276, 295-296.

382 Zawadzki 1995; Radner 2012.

383 A rev. 20; C rev. ii:22; Pedersén 2005b, 269. See also Jursa 2011b, 161.

384 Weidner 1939, 930. On bìt qīpüti, see Jursa 2010b, 71.

385 Pedersén 2005b, 270.

386 Pedersén 2005b, 271. On Carians, see Haider 1988, 153-223; Raaflaub 2004, 206-210; Zadok 2005; Waerzeggers 2006. Cf. the critical views in Fantalkin and Lytle 2016, who seem to be unaware of the Palace Archive and the Carians in Borsippa.
} 
from Ionia, Persia, Hume (Que), ${ }^{387}$ and Pirindu ${ }^{388}$ were maintained by the palace, but only visited there. ${ }^{389}$

Carpenters, sailors, and other specialists enjoyed royal maintenance as well. Carpenters (naggāru) from Arwad, Byblos, and Ionia are attested on the ration lists, and Ionian carpenters also worked at the boatyard. ${ }^{390}$ Boats and ships were operated by numerous sailors (malähu) from the Mediterranean coast and Tilmun. ${ }^{391}$ In the same vein, Sennacherib deported boatbuilders and sailors from the Eastern Mediterranean to Nineveh, ${ }^{392}$ which implies that their expertise was highly valued in Mesopotamia. Finally, foreign professionals were needed to entertain the king and his court in Babylon, as the presence of

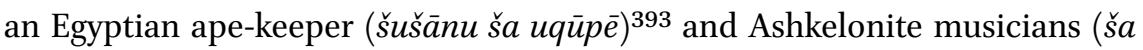
rēši nāru $)$ on the ration lists demonstrates. ${ }^{394}$

Some Judean professionals were brought to Babylon as well, which matches the information on selective deportation from Jerusalem in 2 Kings $24 .{ }^{395}$ In addition to King Jehoiachin and his sons, a number of Judean people are referred to on the ration lists. A certain Qanā-Yāma delivered oil rations to Jehoiachin's sons, ${ }^{396}$ which suggests that he was a servant or overseer of the Judean princes. ${ }^{397}$ A Judean sêpiru ${ }^{398}$ named [...]-Yāma delivered rations to a group of captives (hubtu) from Hume. ${ }^{399}$ Three other Judeans are mentioned by name: Samak-Yāma ${ }^{400}$ and Šalam-Yāma the gardener (nukaribbu ${ }^{401}$ bear Yahwistic names, and a certain Üru-Milki is explicitly described as Judean. ${ }^{402}$ Judean

387 The country of Que was located in the Cilician Plain. See Hawkins 2007.

388 Located in Cilicia. See Streck 2005.

389 A rev. 12-18; Pedersén 2005b, 270.

390 C rev. ii:13-15; D:16-18.

391 B rev. i:7-11; Pedersén 2005b, 270. The regions on the Eastern Mediterranean coast include Egypt, Ashkelon, Tyre, Mahazīnu, and Șapūnu. Mahazīnu and Șapūnu were perhaps located on the Mediterranean coast north of the Phoenician cities. See Zadok 1979b, 164-166.

392 RINAP 3/2 46:57-62.

393 A rev. 24.

394 C rev. ii:22-23; D:25-26; Weidner 1939, 928. See also Jursa 2011b, 161.

395 See Section 1.2.3.

396 C rev. ii:18; D:21.

397 Zadok 1979a, 38-39.

398 Sēpirus were not mere alphabetic scribes but officials who performed various administrative functions. See Stolper 1985, 22; Pearce 1999; Jursa 2012; Bloch 2018; and Section 5.3.2.

399 A rev. 8. On this text, see Bloch 2018, 224-230.

400 A obv. 28.

401 A obv. 31; rev. 22.

402 A obv. 11; rev. 13. The titles of Šalam-Yāma and Üru-Milki are broken on the obverse, but the same persons are probably referred to on both sides of the tablet. On the name Üru-Milki, 
courtiers (ša rēšs šarri) are attested among other royal officials of foreign origin (see above), and a group of eight Judeans are referred to several times on the ration lists. ${ }^{403}$

Royalty from three western kingdoms - Lydia, Ashkelon, and Judah - are

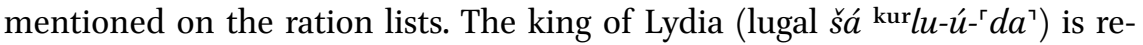
ferred to in A obv. $4 .{ }^{404}$ Weidner published the tablet on the basis of an excavation photo, and the dirt on the tablet prevented him from reading the other signs on the line; therefore, it remains unclear whether the former king of Lydia himself, his family members, or messengers resided in Babylon. The presence of the Lydian king in Babylon does not fit into the general historical picture very well, because Lydia retained its independence until the Persian conquest of Western Anatolia in the 540S BCE ${ }^{405}$ However, Babylonian military operations reached the borders of Lydia, ${ }^{406}$ and high Lydian officers or members of the royal family could have arrived in Babylon as deserters or prisoners of war. ${ }^{407}$ This argument is supported by the presence of other Lydians in Babylon, one of whom is called maqtu ('refugee, fugitive').408

Two sons of Aga? , the king of Ashkelon, are attested on the ration lists. ${ }^{409}$ The amount of oil they received, one $q \hat{u}$ for each of them, is the average ration in the Palace Archive. ${ }^{410}$ Aga ${ }^{2}$ himself is not attested on the lists, but the fate of Ashkelon in the late seventh century is well known. A Babylonian chronicle describes the events in the first year of the reign of Nebuchadnezzar II (604603 BCE): 'He (Nebuchadnezzar) went to Ashkelon(?) and captured it in the month of Kislimu. He took its king captive, plundered it, and [carried off] its booty. He turned the city into mounds and ruins and set off in the month of Šabāțu and [returned] to Baby[lon]'411 The name of the conquered city is partly

see Zadok 1988, 54; PNA 3/II, 1419-1420. Gad-il (A obv. 18) has a West Semitic name, but nothing suggests that he was of Judean origin; cf. Weidner 1939, 927; Zadok 1979a, 39. On the name, see PNA 1/II, 418 .

403 A obv. 26; rev. 28; B obv. ii:40.

404 See Weidner 1939, 934.

405 Briant 2002, 34-38. On the cuneiform evidence of this event, see Schaudig 2001, 24-25 n. 108.

406 Chronicle of Neriglissar ( $A B C$ 6:23-27); Nabonidus' 'King of Justice' inscription (Schaudig 2001 P2 v:20-21, see also pp. 579-580).

407 Compare to the case of Egyptians in Nineveh; see Radner 2012.

408 A obv. 22 (perhaps also 33); rev. 25; Weidner 1939, 934. Weidner (1939, 934) understands ba/ma-ak-tu as a title of an official (baktu), but CAD B, 35; CAD M/1, 254-255; and Wiseman 1985,83 understand it as a reference to maqtu ('refugee, fugitive').

4092 dumu.meš šá ${ }^{\mathrm{I} a} a-g a^{2}{ }^{2}$ lugal šá ${ }^{\text {kur }}$ iš-qil-lu-nu 1 sila. [àm] (B rev. i:6).

410 Pedersén 2005a, 117.

$411 \quad A B C$ 5: obv. 18-20. 
broken, but on the grounds of the remnants and clearly readable signs (-il-lu$n u$ ), the name should be restored as Ashkelon (iš-qí-il-lu-nu). ${ }^{412}$ This assumption is further supported by archaeological evidence, which shows that Ashkelon was destroyed in the late seventh century during the Babylonian campaigns in the Levant. ${ }^{413}$ It appears that the sons of the last king of Ashkelon were taken to Babylon as prisoners of war. Ashkelon lay in ruins and was rebuilt only in the Persian period, ${ }^{414}$ which suggests that there was no vassal king ruling over the city. Therefore, the well-being of the Ashkelonite princes in Babylon was not dependent on their relatives' loyalty to the Babylonian king. ${ }^{415}$

Despite the destruction of Ashkelon, some areas in the Levant were evidently turned into vassal states and ruled by local kings. The nature and extent of the Babylonian control and administration of the Levant is a debated topic, ${ }^{416}$ but the existence of vassal states finds support in the Hofkalender of Nebuchadnezzar II. The Hofkalender is a building inscription that commemorates the king's building works at the South Palace, but it also contains a list of dignitaries who contributed to the building project in one way or another. ${ }^{417} \mathrm{Be}-$ fore the list breaks at the end, kings of Tyre, Sidon, Arwad, Ashdod, Gaza, and two other kingdoms are mentioned ( col vii $\left.: 23^{\prime}-29^{\prime}\right)$. There is no reason to believe that they were held captive in Babylon, but they ruled vassal states in the Levant and participated in the building project by sending tributes to Babylon. ${ }^{418}$ This implies that these cities were not destroyed and abandoned in the late seventh century, but they still functioned as centres of royal power when the Hofkalender was written. ${ }^{419}$ As only the site of Ashdod has been excavated, it remains unclear how most of these vassal states and their capital cities were

412 For a discussion on restoring the name, see Fantalkin 2011, 87 n. 1; Stager 2011, 3 n. 2. Grayson (1975a, 100) is cautious about restoring the name as Ashkelon, but Glassner (2004, 228-229) reads 'Ashkelon' without expressing any doubts.

413 Stager 2011; Fantalkin 2011. For the full excavation reports, see Stager et al. (eds.) 2008, 2011.

414 Lipschits 2005, 41 n. 17 (but cf. 64 n. 98); Stager 2011, 11; Faust 2012, 200.

415 Cf. Weidner 1939, 928.

416 See, for example, Barstad 1996; Vanderhooft 1999, 61-114; Lipschits 2005; Faust 2012.

417 The inscription is edited in Da Riva 2013. See also Vanderhooft 1999, 92-98; Jursa 2010b, 67-68, 78-91.

418 Vanderhooft 1999, 97; Da Riva 2013, 204-205. Cf. Cogan and Tadmor 1988, 329; Katzenstein 1994, 46-47; Avishur and Heltzer 2007, 20.

419 The Hofkalender was written in the seventh year of Nebuchadnezzar (598-597 BCE) at the earliest. This year is mentioned in col. iv $: 25^{\prime}-31^{\prime}$, but it only refers to a delivery of commodities to storehouses, not to the year when the inscription was written (Da Riva 2013, 196, 227). 
affected by Egyptian and Babylonian military operations. ${ }^{420}$ Babylonian sources reveal that Tyre remained inhabited, although under the control of the Babylonian Empire. ${ }^{421}$

Although its name is not mentioned in the preserved sections of the Hofkalender, Judah was also turned into a vassal state in the late seventh century. ${ }^{422}$ After an unsuccessful revolt, the Babylonian troops conquered Jerusalem in 597 and deported King Jehoiachin to Babylon. Jehoiachin's uncle Zedekiah was set on the throne as the new vassal king in Jerusalem, but after a second unsuccessful revolt, Jerusalem was destroyed and Judah's existence as a vassal state came to an end, perhaps in 587 or 586 . The presence of King Jehoiachin and five Judean princes on a ration list from 591 shows that they were held hostage while Zedekiah was still ruling Judah as a vassal king. In addition to the list from 591, Jehoiachin is attested on three other ration lists from the Palace Archive:

A obv. 29: $[\ldots]^{\mathrm{I}} i a^{-}{ }^{2}-u$-gin lugal $[\ldots]$

B obv. ii:38: 1 bán $a-n a ~\left[{ }^{1} i a\right]^{2}$-gin lugal šá ${ }^{\mathrm{kur}} i a-[a-h u-d u]$

C obv. ii:10: 1 bán I ia-a-ú-ia(?)[...]

C rev. ii:17: 1 bán $a-n a$ I $i a-k u-u ́-k i-n u$ dumu lugal šá ia-ku-du

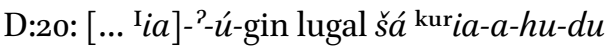

The standard formula is 'one sūtu for Jehoiachin, the king of Judah', but C rev. ii:17 is an interesting exception, 'one sütu for Jehoiachin, son of the king of Judah'.

The sons of the king of Judah are attested four times:

B obv. ii:39: $2^{1 / 2}$ sila $a-n a ~ 2[+3$ dumu.]meš lugal šá kur $i a-a-h u-d u[\ldots]$

C obv. ii:11: $2^{1 / 2}$ sila ana 5 dumu.meš [...]

C rev. ii:18: $2^{1 / 2}$ sila šá 5 dumu.meš šá lugal šá ia-ku-du ina šuII I $q a-n a-{ }^{2}-a-[m a]$

D:21: [... 5 dumu.meš šá lugal] šá kur ia-a-hu-du ina šu ${ }^{\mathrm{II}}$ I $q a-n a-a-m a$

The standard formula is ' $21 / 2$ qu for the five sons of the king of Judah from the hand of Qanā-Yāma'.

420 Aubet 2001, 60-69; Stern 2001, 412. Ashdod was certainly inhabited in the Persian period, but the situation in the seventh and sixth centuries is disputed. See Finkelstein and Singer-Avitz 2001, 2004; Ben-Shlomo 2003, 2005; Faust 2012, 31; Fantalkin 2014; Thareani 2016, 90-91.

421 Zawadzki 2015; van der Brugge and Kleber 2016.

422 For a more detailed discussion of these events and relevant sources, see Section 1.2. 
The oil rations given to Jehoiachin were large, being six times bigger than the average ration of one qu in the archive. ${ }^{423}$ As this amount would have been too much for his own personal needs, the rations were perhaps meant to be redistributed to his family members and other dependants. ${ }^{424}$ Jehoiachin's excessive rations may also imply that the Babylonians respected his royal status. ${ }^{425}$ This is corroborated by the fact that he also retained his royal title, even though he was taken to Babylon and actually it was Zedekiah who ruled the vassal state of Judah. Jehoiachin is once called 'the son of the king of Judah' on the ration lists, but this must be a scribal error. ${ }^{426}$ Weidner also raises the possibility that because the Babylonians held Zedekiah as the king of Judah, the same title was not used when referring to Jehoiachin. However, it is difficult to explain why this applies only to one instance on the ration lists.

Five sons of the king of Judah are regularly attested after Jehoiachin on the ration lists. Weidner wondered whether these people were Jehoiachin's sons or brothers. ${ }^{427}$ The first option is more plausible, ${ }^{428}$ as supported by the simple reasoning that if the king of Judah and the sons of the king of Judah are attested on two successive lines, the text naturally refers to a single king and his sons. ${ }^{429}$ Moreover, if Jehoiachin was eighteen years old when he was deported to Babylon in 597 (2 Kgs 24:8), he could easily have begot five sons by 591. This implies that some of his children were born in exile and that his living conditions in Babylon were good enough to allow him to beget and raise children.430 The Judean princes received a modest oil ration of half a qu each, only half of the rations given to the Ashkelonite princes. This is perhaps related to the young age of the Judean princes. A Judean man called Qanā-Yāma delivered the oil rations to the princes, and he was likely their servant.

423 Jehoiachin's rations were smaller than Weidner $(1939,927)$ suggests. One should read ' 1 bán' (CTIJ) instead of ' $1 / 2$ (pi)' (Weidner 1939, 925-926). This becomes clear in C rev. ii:14, according to which $7^{1 / 2} q \hat{u}$ (1 bán $1^{1 / 2}$ sila) of oil was distributed to eight people, 1 qu for each, and half a $q \hat{u}$ was still to be delivered.

424 Weidner 1939, 927; Waerzeggers (forthcoming a).

425 Albertz 2003, 99.

426 Weidner 1939, 926. Pedersén 2005b, 269, writes that 'he [Jehoiachin] is sometimes referred to as king sometimes as prince'. It remains unclear whether Jehoiachin is also titled as a prince in the unpublished tablets.

427 Weidner 1939, 926-927. Gerhards 1998, 66, argues that the five princes were not Jehoiachin's sons.

428 See, for example, Albright 1942, 52-53; Oded 1995, 210; Albertz 2003, 102-103; Becking 2007, 181-182.

429 Observed already by Albright 1942, 53 .

430 Oded 1995, 210; Albertz 2003, 103. 


\subsection{Living Conditions in Babylon and Jehoiachin's Amnesty}

It is striking that such a diverse group of people originating from the border zones of the Babylonian Empire resided in Babylon in the early sixth century. Although some of these people, such as Carian mercenaries, may have migrated to the city voluntarily, the majority arrived in Babylon as deportees. They were maintained by the royal administration, but hardly all of them resided at the palace. Boatbuilders and some guards worked at the boatyard, and more probably lived there than at the South Palace. ${ }^{431}$ Courtiers and foreign messengers certainly spent more time at the palace than boatbuilders, but it still cannot be ascertained that they actually lived on the palace premises. The ration lists were found at the South Palace and its vicinity because the recipients were dependent on the palace and royal officials managed the inflow and distribution of the commodities. Therefore, their find-spot is related to their function and origin, not necessarily to the whereabouts of the people they referred to. ${ }^{432}$

The living conditions of the foreign recipients of oil were hardly uniform. The average monthly ration of one $q \hat{u}$ or one litre of oil was not particularly generous, but if other commodities were distributed in proportion to oil, the rations satisfied the basic needs of recipients. The size of the rations differed from one recipient to another, with King Jehoiachin, for instance, receiving twelve times more oil than his sons. This could be connected to their difference in status, and it is possible that recipients of large rations had to distribute the oil among their family members and other dependants. In addition to oil, barley and date beer were distributed to the foreigners, but meat and other more expensive commodities are not referred to in the Palace Archive. ${ }^{433}$ Courtiers and other palace personnel of upper rank certainly received meat rations as well, but this was apparently documented in a separate archive. ${ }^{434}$ Accordingly, even though foreign professionals and royalty were nourished well enough to do their work and reproduce, it remains unclear if their diet differed from that of the average Babylonian craftsman or farmer.

Even if the majority of foreign people did not reside at the palace, they were certainly supervised and their freedom was limited. However, the means to exercise control over foreigners were manifold. Mercenaries and messengers

\footnotetext{
431 See Jursa 2010b, 73 .

432 Pedersén 2005b, 270; Waerzeggers (forthcoming a).

433 Distribution of barley is documented in the archive, and dates were delivered to brewers. Pedersén 2005a, 115-117.

434 Waerzeggers (forthcoming a). On rations, see also Waerzeggers 2006.
} 
from distant kingdoms were overseen, but they must have been free to leave the city when their service contract or diplomatic mission came to an end. At the other extreme, a prison (bit kiläni) is mentioned in the texts, ${ }^{435}$ but it is unlikely that foreign professionals were kept there, as incarceration was at odds with the productivity of craftsmen. Deported specialists certainly had reasons to resist their Babylonian overlords and attempt to escape, but economic dependence and administrative control were more useful bonds than incarceration. The ration lists and the administrative system related to them were effective control mechanisms as such: dependence on royal maintenance and the regular distribution of rations linked the recipients to the royal officials running the system. When scribes drafted the ration lists, they not only produced a record but also exercised control over the people listed on the tablets. ${ }^{436}$ Escape from Babylon without any travel funds was a huge risk for people who had been deported from their distant homelands in Iran or on the Mediterranean coast. Accordingly, the deportees could be supervised and their freedom severely limited even if they were not necessarily confined physically in a prison or sweatshop.

The previous discussion also outlines the parameters of the freedom and living conditions of Jehoiachin and other foreign royalty in Babylon. The incarceration of foreign royalty seems unlikely, because Jehoiachin apparently enjoyed family life in Babylon and received large rations. One should not be misguided by the fact that prison wardens are mentioned two lines below Jehoiachin and his sons on two ration lists. ${ }^{47}$ Although the more complete text $\mathrm{C}$ reads $4{ }^{\text {lúsag } u ́-s ̦ e-e r-t i-s ̌ u ́-n u ~(' f o u r ~ c o u r t i e r s, ~ t h e i r ~ p r i s o n ~ w a r d e n s '), ~ t h e ~ p o s-~}$ sessive suffix hardly refers to the Judean royalty. ${ }^{438}$ On the line between the Judean royalty and prison wardens, the texts mention wooden stools (giskit-tu$r a-n u)$ as recipients of oil rations. ${ }^{439}$ As this line clearly introduces a new topic, it is difficult to maintain that the prison wardens were responsible for guarding the Judean royalty or other people listed above.

Because Ashkelon and Lydia were probably not vassal kingdoms of the Babylonian Empire, the royalty from these kingdoms were not held in Babylon in order to ensure the loyalty of their relatives in a vassal state. They were not

\footnotetext{
435 Pedersén 2005a, 115-116; Jursa 2010b, 72.

436 See Waerzeggers 2015, 186-187.

437 C rev. ii:20; D:23.

438 Cf. Jursa 2000, 506-507. On the word usertu, see also CAD U-W, 285-286.

$439 \mathrm{C}$ rev. ii:19. Line 22 in text $\mathrm{D}$ is broken but is to be read similarly. The word should probably be read as kitturrānū ('stools', see CAD K, 476; Deller and Finkel 1984, 87-88), although CTIJ suggests reading it as gišs' $a t^{\prime}$ (КIT)-tu-ra-nu ('wagons', see CAD A/2, 510). In any case, the determinative giš leaves no doubt that the passage refers to wooden items.
} 
hostages per se, because their life and well-being was not dependent on the good behaviour of their family members back home in Ashkelon or Lydia. Their situation is reminiscent of Egyptian princes in Nineveh, who were taken captive in battle and perhaps sent back to Egypt only after Assyria conquered the region. ${ }^{440}$ Ashkelonite and possibly Lydian royalty were kept in Babylon for the same purpose, to serve the Babylonians if the political situation in their native country changed over time. The practice of sending vassal kings from Babylon to Tyre is also alluded to by Josephus, but this late account cannot be verified from any other source. ${ }^{441}$

The reason for keeping Jehoiachin and his sons in Babylon was partially the same, but, unlike the Ashkelonites, they were held hostage to ensure the loyalty of the vassal king in Jerusalem. This did not prevent Zedekiah from rebelling, but because the only datable ration list was drafted before his revolt, it remains uncertain if the hostages were killed or harmed as punishment. Jehoiachin's captivity in Babylon is also treated in 2 Kings, which ends in an optimistic account of his amnesty in the reign of Amēl-Marduk, or Evil-merodach, as the name is written in the Masoretic text: ${ }^{442}$

In the thirty-seventh year of the exile of King Jehoiachin of Judah, in the twelfth month, on the twenty-seventh day of the month, King Evilmerodach of Babylon, in the year that he began to reign, released King Jehoiachin of Judah from prison; he spoke kindly to him, and gave him a seat above the other seats of the kings who were with him in Babylon. So Jehoiachin put aside his prison clothes. Every day of his life he dined regularly in the king's presence. For his allowance, a regular allowance was given him by the king, a portion every day, as long as he lived. (2 Kgs $25: 27-30)^{443}$

The text depicts Jehoiachin's first thirty-seven years in Babylon as a hard time: he was confined in prison $\left(b y t k l^{2}\right)$, and his low status is further emphasised by a reference to his prison clothes $\left(b g d y k l^{2} w\right)$. However, his life changed drastically after the accession of Amēl-Marduk: he was released from prison and enjoyed his meals at the king's table until the end of his life. Interestingly, 2 Kings assumes that Jehoiachin was not the only foreign king held in Babylon. After

$440 \quad$ Radner 2012.

441 Josephus Ag. Ap. 1.21.

442 On the name, see Gerhards 1998, $5^{2}$ n. 2.

443 The same account is given in Jer 52:31-34. Unlike in many other parts of 2 Kgs $24-25$, there are no major textual problems in this passage (Person 1997, 90; Chan 2013, 567). 
his release, Jehoiachin was elevated to a higher status than the other kings. It is noteworthy that the text explicitly refers to Jehoiachin's regular allowance (' $r h t$ tmyd), which immediately reminds the modern reader of the ration lists in the Palace Archive.

The relationship between the biblical account of Jehoiachin's captivity and the information gleaned from the Palace Archive has been interpreted in different ways. On the one hand, some scholars have strong doubts about the historicity of Jehoiachin's amnesty, and they argue that the account primarily has an ideological and literary function. ${ }^{444}$ Even if one does not accept this view, it is obvious that the verses have a clear narrative function as the ending of the Book of Kings and the story of the kingdom of Judah. Whether or not the account intends to convey a message of hope - and if so, for what end - is a contested issue. ${ }^{445}$

On the other hand, it has been argued that the account in 2 Kgs 25:27-30 has some historical core, but the Palace Archive reflects a favourable treatment of Jehoiachin. This can lead to two different conclusions. First, the biblical account of Jehoiachin's imprisonment does not describe the situation at the time when the ration lists were written. Second, both the biblical account and the Palace Archive bear testimony to the leniency towards Jehoiachin. Rainer Albertz argues that Jehoiachin enjoyed good treatment for some time, but that he was punished for the revolt of Zedekiah or, more likely, for the murder of Gedaliah and imprisoned until the accession of Amēl-Marduk. ${ }^{446}$ According to Bustenay Oded and Bob Becking, Jehoiachin was held captive until he was released by Amēl-Marduk, although he was treated well and his living conditions were good, as reflected in the Palace Archive. ${ }^{447}$ Oded further argues that the word 'prison' should not 'be taken in the narrow sense' in this context. ${ }^{448}$ Becking suggests that the release of Jehoiachin was an act of amnesty right before the first akitu festival of Amēl-Marduk. ${ }^{449}$ Yitzhak Avishur and Michael Heltzer also understand Jehoiachin's captivity and living conditions in similar terms, speculating that his release was related to Amèl-Marduk's attempt to win the support of the well-organised community of Judean exiles. ${ }^{450} \mathrm{Jacob} \mathrm{L}$. Wright suggests that although Jehoiachin enjoyed royal maintenance already

\footnotetext{
444 See Barstad 1996, 28-29; Pakkala 2006, 451-452.

445 See the literature in Chan 2013, 567-568.

446 Albertz 2003, 102-104.

447 Oded 1995, 209-210; Becking 2007, 181-182.

448 Oded 1995, 210.

449 Becking 2007, 177-184.

$45^{\circ}$ Avishur and Heltzer 2007, esp. 21, 35-36.
} 
in the reign of Nebuchadnezzar, a late date for his release better fits the narrative 'sequence of defeat and restoration' in the last chapters of 2 Kings. ${ }^{451}$

As regards Jehoiachin's amnesty in the reign of Amēl-Marduk, Irving Finkel's article from 1999 has received surprisingly little attention. ${ }^{452} \mathrm{He}$ argues that, according to Babylonian and later Jewish traditions, Amēl-Marduk fell from grace and was imprisoned during the reign of his father Nebuchadnezzar II. Moreover, a medieval Jewish text suggests that Amēl-Marduk was imprisoned together with Jehoiachin, and once the crown prince was released and he ascended the throne, he also liberated Jehoiachin. Finkel's point of departure is an undated Late Babylonian literary text BM 40474 ('the Lament of Nabûšum-ukīn'), which records the lament of a distressed person. ${ }^{453}$ An exceptional feature of this text is that the name of the supposed author, Nabû-šum-ukinn, son of Nabû-kudurri-uṣur, is mentioned at the end of the tablet. Nabû-šumukīn laments his misfortunes in prison and prays to Marduk for help. Finkel argues that the father of this man was none other than King Nebuchadnezzar and that Nabû-šum-ukīn should be identified as crown prince Amēl-Marduk.

Finkel finds further support for his view in another Babylonian tablet and two Jewish texts. The Babylonian text in question is BM 34113, which is an undated, fragmentary literary text concerning Amēl-Marduk. ${ }^{454}$ The beginning of the obverse is partially readable, but the rest of the obverse is lost and the reverse is almost illegible. The poor condition of the tablet allows different interpretations. The beginning of the tablet undoubtedly refers to Nebuchadnezzar and Amēl-Marduk, and, according to Finkel, it describes how Amēl-Marduk is slandered and how he prays to Marduk for help. ${ }^{455}$ This interpretation is possible, but it is not more likely than Schaudig's reading, according to which the tablet gives a negative account of the reign of Amēl-Marduk and possibly depicts Nabonidus' piety in positive light. ${ }^{456}$ Furthermore, it should be noted

451 Wright 2011, 110-111 + n. 11 .

$45^{2}$ Finkel 1999. See Waerzeggers (forthcoming b).

453 The text is edited in Finkel 1999; Oshima 2011, 316-327. The tablet was found during Rassam's excavations and originates from Babylon or Borsippa. See Finkel 1999, 324; and the British Museum catalogue entry at http://www.britishmuseum.org/research/collection online/collection_object_details.aspx?objectId=327274\&partId=1\&searchText $=40474 \& p a$ ge $=1$.

454 Edited in Grayson 1975b, 87-92; Finkel 1999, 336 (only obverse); Schaudig 2001 P3. The tablet originates from the antiquities market. It may have been found in Babylon. See the British Museum catalogue entry at http://www.britishmuseum.org/research/collection online/collection_object_details.aspx?objectId=794748\&partId=1\&searchText=34113\&pa ge $=1$.

455 Finkel 1999, 337.

$45^{6}$ Schaudig 2001, 589. See also von Soden 1975, 284. 
that von Soden suggests that the fragment might join the 'King of Justice' inscription, ${ }^{457}$ in which case it would probably originate from the reign of Nabonidus. ${ }^{458}$ If this is correct, the text is hardly a reliable source for the study of historical events in the reign of Nebuchadnezzar or Amēl-Marduk.

Finally, two Jewish sources, Leviticus Rabbah (or Wayiqrah Rabbah) and the Chronicle of Jerahmeel, suggest that Nebuchadnezzar imprisoned AmēlMarduk before the latter ascended to the throne in Babylon. According to Leviticus Rabbah xviii: $2,{ }^{459}$ an early Midrash perhaps from the fifth century $\mathrm{CE},{ }^{460}$ the Babylonian elite raised Amēl-Marduk to the Babylonian throne during his father's absence of seven years. When Nebuchadnezzar returned to Babylon, he imprisoned his son because of the coup d'état. According to the Midrash itself, this account has been influenced by the tradition of Nebuchadnezzar's absence from Babylon, which can be found in Daniel 4. It is easy to see how the narrative of Amēl-Marduk's coup and imprisonment developed from the existing tradition.

The Chronicle of Jerahmeel refers to a Medieval Hebrew manuscript held at the Bodleian library. ${ }^{461}$ It is a collection of Jewish writings apparently compiled by a certain Eleazar ben Asher ha-Levi, who claims to have used the texts of Jerahmeel ben Solomon as one of his sources. Little is known about Eleazar and Jerahmeel, but the traditions used in the Chronicle appear to originate from numerous sources, including Midrashim and classical authors such as Strabo. According to the Chronicle of Jerahmeel, ${ }^{462}$ Amēl-Marduk was imprisoned because his brother slandered him. The brother ascended to the Babylonian throne and Amēl-Marduk was only released after the death of his brother. Amèl-Marduk had met Jehoiachin in prison, and when he started to reign after his brother, he also ended Jehoiachin's captivity.

Finkel's thesis is intriguing, and Leviticus Rabbah and the Chronicle of Jerahmeel seem to support his argument. However, both texts were written at least a thousand years after Amēl-Marduk's lifetime, and the narratives were obviously created on the basis of earlier literary motifs. As argued above, Leviticus Rabbah builds upon the traditions of Nebuchadnezzar's and Nabonidus' seven-year absence from Babylon. The Chronicle of Jerahmeel seems to be aware of the narrative in Leviticus Rabbah, as both of them share the motifs of

\footnotetext{
457 von Soden 1975, 284. See also Schaudig 2001, 589 .

$45^{8}$ See Schaudig 2001, 579-580, 589.

459 For an English translation, see Neusner 1986, 356.

46o Neusner 1986, xviii; Heinemann 2007.

461 Jacobson 1997, 239-250; David 2007. The Chronicle of Jerahmeel is translated in English in Gaster 1899 .

462 Gaster 1899, 206-207.
} 
Amèl-Marduk's imprisonment and his fear that his father might come back to life even after his death. ${ }^{463}$ It is suspicious that these traditions emerge only at a very late date, with both of them aimed at providing the reader with more information about the obscure character of Amēl-Marduk. ${ }^{464}$

When read in light of Leviticus Rabbah and the Chronicle of Jerahmeel, the two cuneiform texts indeed appear to speak of Amēl-Marduk's fall from grace and his pleas to Marduk. However, the texts themselves are very ambiguous in this regard. As von Soden and Schaudig show, the text fragment concerning Amèl-Marduk can be interpreted differently from Finkel's reading. The first part may well be a pejorative description of Amēl-Marduk's rule, but the latter part does not necessarily refer to Amēl-Marduk's reverence for Marduk; instead, it could refer to Nabonidus' veneration. When read without presuppositions, the text does not portray Amēl-Marduk as the victim of a slander campaign. When it comes to the Lament of Nabû-šum-ukīn, the text is an expression of grief and a prayer for deliverance. Reading it as a work of literature, I do not accept that Nabû-šum-ukīn is to be identified with Amēl-Marduk, let alone that the text would reflect a historical event. Therefore, Finkel's thesis on the Babylonian tradition of Amēl-Marduk's captivity is to be rejected ${ }^{465}$ as his reading of the Babylonian literary texts is too strongly guided by much later Jewish traditions, which appear to be narratives aimed at shedding some light on the life of Amēl-Marduk.

The ration lists from the Palace Archive remain the main source for studying Jehoiachin's life in exile. He and his sons were held hostage to ensure the loyalty of Zedekiah and to prepare a new generation of pro-Babylonian vassal kings to rule over Judah. They were maintained by the royal administration, and Jehoiachin was able to live with his family and beget sons in Babylon. The Palace Archive itself is a testimony of Jehoiachin's dependence on the Babylonian administration, and it reminds us that the freedom of the hostages must have been severely limited. They were not restrained by shackles or iron bars, but they were supervised, dependent on their overlords, and not free to leave the city.

The accounts of Jehoiachin's exile in 2 Kings 24 and his amnesty in 2 Kings 25 demonstrate that the authors of these passages were informed of Jehoiachin's deportation to Babylon and his stay there. However, 2 Kgs 25:27-30 paints a grim picture of Jehoiachin's imprisonment, contrasting it with his

463 Leviticus Rabbah xviii:2; Gaster 1899, 207.

464 See Waerzeggers (forthcoming $b$ ).

465 See Waerzeggers (forthcoming b); but cf. Foster 2005, 852; and Oshima 2011, 316-317, who are in favour of Finkel's thesis. 
release and honoured status in the reign of Amèl-Marduk. This narrative appears to describe his past as too gloomy and his future as too bright. The ration lists show that his captivity may be better described as house arrest rather than imprisonment, but it is hard to find any reason why Amēl-Marduk would have accorded him special status in the beginning of his reign. There is no basis to postulate that Jehoiachin first enjoyed royal maintenance and was only later imprisoned. ${ }^{466}$ In the same vein, Becking's theory about Amèl-Marduk's act of amnesty and Finkel's thesis about Jehoiachin's and Amēl-Marduk's common captivity fail to provide a credible historical background for Amēl-Marduk's actions. The last verses of 2 Kings are not a historical remark about Jehoiachin's fate, ${ }^{467}$ but they should be read as literature which yet again uses the motif of an exiled Judean who wins the favour of a foreign king. ${ }^{468}$ The narrative thus provides the reader with some hope after the dark days of exile. ${ }^{469}$

\subsection{Conclusion}

The Palace Archive of Nebuchadnezzar II bears unique evidence of Babylonian deportation practices and the fate of upper-class deportees. Craftsmen, soldiers, officials, and royalty from the border areas of the empire were deported to Babylon in the late seventh and early sixth centuries and maintained by the royal administration. The Palace Archive records oil rations given to people from Iran and the Eastern Mediterranean, who also received at least barley and date beer for their sustenance. It remains unclear whether meat and other more expensive commodities were handed out as well. Be that as it may, deportees were nourished well enough to perform their work, and they were allowed to live with their families and reproduce in exile. This suggests that the deportees were not imprisoned or treated harshly, which would also have damaged their ability to work productively for the state. However, the deportees were supervised and their freedom of movement was severely limited. The ration system itself was an efficient means of control.

The majority of foreigners in the Palace Archive are craftsmen and soldiers who were employed in building projects, crafts, and guarding the city. Some of them may have arrived in Babylon voluntarily, but given their countries of

\footnotetext{
466 Cf. Albertz 2003, 102-104.

467 Noth 1981, 98.

468 Compare to the stories about Daniel, Esther, and Joseph. See Barstad 1996, 28-29 n. 6; Chan 2013, 569-572, the latter with further literature.

469 See, for example, Murray 2001, 264-265; Chan 2013, 572-576; Bodner 2016, 210-212.
} 
origin, most of them were deported as a result of Nabopolassar's and Nebuchadnezzar's campaigns. Also, some members of foreign royalty were taken to Babylon. Royalty from Judah, Ashkelon, and perhaps from Lydia were held captive for two purposes. First, they could be indoctrinated into the values and beliefs of the Babylonian royal house and later sent to rule over the distant vassal states. Second, King Jehoiachin and his sons were held hostage to ensure the loyalty of the vassal king Zedekiah in Jerusalem.

The Palace Archive is famous for its few attestations of King Jehoiachin and his sons as the recipients of oil rations. Their presence in Babylon confirms the biblical account of Jehoiachin's exile at the foreign court, but the narrative of his captivity and amnesty in 2 Kgs 25:27-30 should not be taken at face value: Jehoiachin's severe imprisonment is purposefully contrasted with his release and elevated status at Amēl-Marduk's court, while the final verses of the Book of Kings were intended to offer a ray of hope for those in exile. 


\section{Judean Merchants in Babylonia}

\subsection{Introduction}

According to the Hebrew Bible, Judeans in Judah and Babylonia remained in touch with each other after the deportations. ${ }^{470}$ Jeremiah 29 describes how letters were sent from Judah to Babylonia and back, and, later in Chapter 51, Jeremiah writes prophecies against Babylon on a scroll that would be sent with a Judean royal official to Babylon. Ezekiel 33:21-22 refers to a Judean refugee who brings the news about the destruction of Jerusalem to the exiles. Whatever the historicity of these accounts, it is interesting that their ancient authors took the possibility of communicating between Judah and Babylonia for granted.

Later in the first millennium CE, the exchange of thoughts, goods, and people between the Jewish communities in Palestine and Babylonia is well documented. ${ }^{471}$ These contacts were not only driven by social and religious concerns but also by commercial ambitions, and Jewish businessmen engaged in trade along the Silk Road. ${ }^{472}$ However, long-distance trade between the Eastern Mediterranean and Babylonia flourished already a millennium earlier in the Neo-Babylonian period. Babylonia had fertile soil, but it was poor in natural resources, which had to be obtained by means of tributes, taxes, and trade. Metal, wood, and luxury items were imported from different parts of the Near East, which offered opportunities for traders of non-Babylonian descent. ${ }^{473}$

The present chapter focuses on Judean merchants in Babylonia, their social networks, and their business activities. I argue that these people were integrated into the commercial sphere of Babylonian society and that they had native Babylonian merchants as well as traders of foreign origin among their acquaintances. Furthermore, because travelling and the transportation of

470 This chapter has previously been published as a journal article in Die Welt des Orients 47 (Alstola 2017). I am grateful to the publisher for the kind permission to use the article in this book. Small revisions have been made in order to accommodate it to the present study. I wish to thank the Trustees of the British Museum for their kind permission to study and cite from tablets in their care.

471 See Oppenheimer 2005, 417-432; Hezser 2011, 311-364.

472 Utas 1993, 27-28; Dignas and Winter 2007, 208-209; Hezser 2011, 325-332.

473 On Babylonian long-distance trade, see Oppenheim 1967; Graslin-Thomé 2009; Kleber 2017, 9-29. 
goods are an integral part of commercial activity, Judean merchants provide an example of people who could have maintained connections between the communities in Judah and Babylonia. The chapter begins with an overview of Babylonian trade and traders in the first millennium BCE. This is followed by a case study of the descendants of Arih, a family of Judean royal merchants in Sippar. In order to situate them in the right socio-economic context, I study the community of traders in Sippar more generally and explore the evidence of other Judean merchants in Babylonia. Finally, I discuss the role of Judean merchants in long-distance trade.

\subsection{Trade and Traders in Babylonia}

Trade in first-millennium Babylonia was not a state-monopolised business, and a diverse group of people engaged in mercantile activities. ${ }^{474}$ On the one hand, some people were explicitly identified as tamkāru ('merchant') or tamkār $(\check{s} a)$ šarri ('royal merchant'). On the other hand, urban families played a central role in local trade in agricultural staples and some even engaged in longdistance trade, although these people are never called tamkāru or tamkār šarri in the documents. ${ }^{475}$

The title tamkāru is attested in cuneiform documentation from the Old Akkadian period onwards, ${ }^{476}$ and the term was used both in the Neo-Assyrian and Neo-Babylonian periods. In the first millennium, tamkāru probably denoted the specific status of a professional merchant, but it is unclear if tamkārus were exclusively royal officials. The close connection between tamkārus and the royal administration is evident in the Neo-Assyrian period, and many tamkārus worked for the king and his high officials. ${ }^{477}$ However, Laetitia Graslin-Thomé argues that this view is skewed by the nature of the available evidence and that not all tamkärus worked for the state, as some of them could have been independent actors. ${ }^{478}$

In the Neo-Babylonian period, some tamkārus bore titles describing the type of trade they were specialised in, ${ }^{479}$ and some played a role in long-distance

474 On trade and merchants in first-millennium Babylonia, see Oppenheim 1967; Dandamayev 1995; Joannès 1999; Heltzer 2006; Graslin-Thomé 2009, 2014; Jursa 2010a, 214-228.

475 Dandamayev 1995; Jursa 2004a, 130-131; 2010a, 224-225.

476 CAD T, 125 .

477 Elat 1987; Radner 1999.

478 Graslin-Thomé 2009, 384-390.

479 Sheep and date merchants are explicitly mentioned in the archives. See Joannès 1999, 179. 
trade. ${ }^{480}$ Many luxury products - such as gold, incense, and dyes - were of foreign origin and could be obtained only via extensive trade networks covering the whole Near East. ${ }^{481}$ Tamkärus were also involved in the temple economy: they bought staples from the temple and acquired luxury products for that institution. ${ }^{482}$ In addition to tamkārus, royal merchants, tamkār $(\check{s} a)$ šarris, are attested in Babylonian sources. Even though it is clear that royal merchants were somehow affiliated with the palace, there is not enough evidence to determine whether or not they were royal officials. ${ }^{483}$ Furthermore, the terminological difference between tamkāru and tamkär šarri is not clear and the terms may have been interchangeable. ${ }^{484}$

It is important to note that tamkārus did not monopolise Babylonian domestic or long-distance trade, and people who are never identified as tamkärus engaged in various trading activities. Prosperous entrepreneurial families, such as the Egibis of Babylon and the Murašûs of Nippur, played a central role in the transportation of staples from the countryside to cities and their retail sale to urban customers. Entrepreneurs bought crops from farmers, thus providing them with a channel to sell their products and a means to pay taxes. ${ }^{485}$ Long-distance trade was only a minor interest for these wealthy families. ${ }^{486}$ Nevertheless, some Babylonian businessmen - such as Iššar-tarïbi, son of Bunene-ibni - actively participated in long-distance trade, even though they are not referred to as tamkārus. ${ }^{487}$

The existence of people like Ǐšar-tarībi, who earned his living from trade but did not bear the title of tamkāru, illustrates the complex meanings of the designations discussed above. Tamkāru was not a blanket term referring to anybody involved in domestic or long-distance trade, but it denoted rather a certain status or affiliation. As it appears that the tamkāru of the Neo-Assyrian period and the tamkār šarri of the Neo-Babylonian period were closely connected with the royal administration, it is possible that an institutional connection underlay the Neo-Babylonian term tamkāru as well. This does not

\footnotetext{
48o Dandamayev 1995, 527; Joannès 1999, 177-178.

481 Oppenheim 1967; Joannès 1999, 184-189; Graslin-Thomé 2009, 179-338; Kleber 2017, 9-29.

482 Joannès 1999, 177-178; Jursa 2010a, 580-581.

483 See Dandamayev 1995; Joannès 1999, 178; Jursa 2004a, 129-130; Heltzer 2006; GraslinThomé 2009, 397-398, 400-402.

484 Jursa 2004a, 130; 2010a, 580. However, Dandamayev 1995; Joannès 1999, 177-179; and Graslin-Thomé 2009, 401-402 take tamkāru and tamkār šarri as two different categories.

485 Stolper 1985, 27-28; Wunsch 1993 vol a, 19-55; 2007, 238-239; Jursa 2010a, 214-220.

486 Jursa 2004a, 130-131; pace Dandamayev 1995, 528.

487 On the available evidence of long-distance trade in private archives, see Jursa 2010a, 224225. On Iššar-tarībi, see Section 3.4.
} 
necessarily mean that tamkārus were dependent on the palace or temple; such an institution could be seen more as a client or, alternatively, an employer. Be this as it may, it is safe to conclude that both tamkārus and tamkār šarris were professional merchants in the Neo-Babylonian period, with the latter group being employed by the state in one way or another. ${ }^{488}$

Many merchants who engaged in long-distance trade were evidently of foreign origin, as A. Leo Oppenheim suggested already in 1967.489 Several royal merchants from the sixth century indeed bear non-Babylonian names, ${ }^{490}$ and in Nebuchadnezzar's Hofkalender the official in charge of royal merchants ( $\mathrm{rab}$ tamkārǐ ša šarri) bears the West Semitic name Hanūnu. ${ }^{491}$ The exact duties of this official are unknown, but his title and appearance among other royal officials in the Hofkalender emphasises the close connection between tamkār šarris and the royal administration. There are no other certain attestations of rab tamkārī ša šarri in Neo-Assyrian or Neo-Babylonian documents. In contrast, persons identified as rab tamkārī ('the chief of merchants') appear in Neo-Assyrian and Neo-Babylonian texts. ${ }^{492}$ It is plausible that they worked for an institution and were responsible for the management of their employer's traders or trading operations. ${ }^{493}$

\subsection{Judean Royal Merchants in Sippar}

\subsubsection{Sources}

Six cuneiform tablets pertain to the descendants of Arih, a family of Judean royal merchants in Sippar. In 1989, Martha T. Roth published a marriage agreement (BM 65149 = BMA 26) between the Judean bride Kaššãya/Amušê and the Babylonian groom Guzānu/Kiribtu/Ararru from the fifth year of Cyrus.

488 Cf. Jursa 2010a, 580.

489 Oppenheim 1967, 253-254. He is followed by Jursa 2004a, 131. On the situation in the NeoAssyrian period, see Nissinen 2014, $288+$ n. 101.

490 See Zadok 2004, 112-113; Heltzer 2006; Bloch 2014. Add also text no. 17 from the Neirabian archive (Dhorme 1928; see Tolini 2015, $84+$ n. 83).

491 Da Riva 2013, col. vi*: 18'. On the name, see Zadok 2004, 114.

492 ND 2684: 9 (Kalhu, the reign of Sargon II?, edited in Parker 1961, 43); possibly in SAA 79 obv. ii:2o' (Nineveh, the reign of Esarhaddon or Assurbanipal); CT 55 823:2 (Sippar, 21-V-13 Nbn); Camb 384:11 (Humadēšu?, 1-IX-7 Camb; for this and the following text, see Zadok 1976, 67-74); Pinches 1892a, 134: 9 (Humadēšu?, 17-X-7 [Camb]); Cameron 1948, no. 85:3 (Babylonia?, 25-IX-2o Dar); MacGinnis 1995, no. 118:6 (Sippar, 5-I-Dar).

Nbn 464:6 (Sippar, 13-X-1o Nbn) reads l' 'ial lúdam.meš [...], but Bongenaar 1997, 138-139, 406, completes the text as lígal lúdam. 〈gàr〉.meš [šá lugal]. Dandamayev 1971, 74; and Heltzer 2006, 348, understand the text similarly, but cf. MacGinnis 1994, $205+$ n. 38 .

493 See Elat 1987, 253-254; Bongenaar 1997, 138; Radner 1999, 101 n. 3. 
Another version of the marriage agreement (BM 68921), not a duplicate, was discussed by Roth in 1989 but published in full by Michael Jursa only in 2001. ${ }^{494}$ In 2007, Jursa identified an additional three tablets relating to the bride's family. ${ }^{495}$ The present author collated these three tablets (BM 68420, 74411, and 75434) in the British Museum in July 2014. Yigal Bloch added yet another tablet (CT 4 21a) to the group in his article in 2014. ${ }^{496}$ Bloch's article presents an edition of all the six tablets and a discussion of their contents and relevance for the study of Judeans in Babylonia. Because of their recent publication, there is no need to edit any texts here, but some emendations to Bloch's readings are suggested. The numbering of the tablets follows Bloch 2014.

The earliest text of the group is no. 3, written in Sippar in the tenth year of Nabonidus (BM 75434, 18-II-10 Nbn, 546 BCE). It is a promissory note for half a mina of silver, owed by the royal merchant (tamkär šarri) Basia, son of Arih, to Marduka/Bēl-īpuš/Mušēzib. Unlike his creditor, Basia is not known from other sources, and he was not a member of the urban Babylonian social stratum bearing family names. ${ }^{497}$ Judging by his patronymic, he was instead of foreign origin. ${ }^{498}$ His creditor Marduka was a well-known tithe farmer ( ̌̌a muhhi ešr $\hat{\imath}$ ) of the Ebabbar temple in Sippar. ${ }^{499}$ Because it is unlikely that the royal merchant Basia owed tithes to Marduka, the transaction was perhaps connected to the resale of agricultural produce. It is noteworthy that the tablet was written at the time of the barley harvest and repayment was to take place a month later. Professional merchants customarily bought dates from the Ebabbar temple, ${ }^{500}$ and a purchase of barley might have been behind this promissory note.

Two more tablets pertaining to the descendants of Arih were written in the eleventh and twelfth years of Nabonidus. They are similar in their contents, both referring to house rental payments and trade in gold. The more complete tablet of the two is no. 5 (BM 74411, 30-II-12 Nbn, 544 BCE), a receipt of sale which originates from the Ebabbar temple, even though the temple or the

494 Jursa 2001.

495 Jursa 2007a.

496 Bloch 2014.

497 On family names, see Section 1.5 .

498 The meaning and etymology of Arih is not clear. See Zadok 2004, 108-110; Bloch 2014, 128-129; PNA 1/I, 131. Add OIP 122 15, a sale of slaves written in Biranatu in $24 \mathrm{Nbk}\left(5^{80}\right.$ BCE), to Zadok's list of people named Arih in Babylonia (see Jursa 2006, 453-454; 2007a, n. 4). In this text, a certain Šadiku/Arih is the buyer of the slaves. Jursa 2006, 453 suggests a possible connection between this text and the text group from Sippar, but this remains hypothetical due to the lack of any other evidence than the occurrence of the name Arih.

Bongenaar 1997, 429-433; Jursa 1998a, esp. 49-52.

500 Jursa 2010a, $580-584$. 
place of writing is not explicitly mentioned. ${ }^{501}$ The transaction did not take place between two individuals; only the name of the seller of gold, Amušê/ Arih, is referred to. The purchaser remains anonymous, and neither the scribe nor the witnesses of the document are mentioned. However, the origin of the capital required for the purchase is specified in detail. The silver component was partially taken from a storehouse, part of it originated as house rental payments, and a substantial part of the price was paid in 100 kurru of dates, the equivalent of 3 minas of silver. The value of the transaction was not negligible: Amušê sold 42 shekels of gold for 5 minas and 36 shekels of silver. ${ }^{502}$ These features point towards an institutional background of the transaction, in this case the Ebabbar temple.

Text no. 4 (BM 68420, III-11 Nbn, 545 BCE) is broken, but a comparison with no. 5 helps to understand its contents. It was written in Sippar and originated in the Ebabbar administration, as the property of Šamaš is referred to on line 4. The structure of the text follows no. 5: information on house rental payments is combined with a reference to gold received from Marduka, son of Arih. A certain Marduka is also attested on line 1, but he seems to be one of the suppliers of silver and not identical to Marduka/Arih. Judging by the similarities between texts 4 and 5 , it is reasonable to suggest that no. 4 pertains to a sale of gold to Ebabbar by Marduka, son of Arih. Two points are of interest here. First, gold was a rare metal in ancient Babylonia, used solely for luxurious or cultic purposes, and silver was used as the medium of exchange. ${ }^{503}$ Second, trade in gold was the business of professional merchants, ${ }^{504}$ which strongly supports the conclusion that both Amušê and Marduka were tamkārus, if not royal merchants (tamkār šarri).

501 See Bloch 2014, 147 n. 64, 158.

502 Line 10 concerning the amount of silver is broken, which leaves some room for different interpretations. The first readable sign must be either $1 / 2$ or $5 / 6$, followed by ma.na 6 gín kù.babbar. The amount of silver is thus x minas and ${ }_{3} 6$ or 56 shekels. Line 11 reads $[a-n] a$ $5 / 6$ ma.na 2 gín kù.gi ki-i pi-i 8.kam. Accordingly, gold was exchanged for silver at a ratio of 1 to 8 . Based on the information on line 11 , Jursa (2010a, $524 \mathrm{n}$. 2856) multiplies $5^{2}$ shekels of gold by 8 , which makes 6 minas and 56 shekels of silver. However, as it appears that the origin of the silver is described on the preceding lines, Bloch $(2014,156-158)$ arrives at a different conclusion. If the broken numeral at the beginning of line 7 is 1 , the sum of the payments is 5 minas and 36 shekels of silver. Because the cuneiform signs for $2 / 3$ and $5 / 6$ closely resemble each other, Bloch suggests that $5 / 6$ minas should be taken as a scribal error for $2 / 3$ minas on line 11 . This fits the ratio of 1 to 8 ( 42 shekels of gold for 5 minas and 36 shekels of silver). Considering the transaction as a whole, Bloch's suggestion is to be followed.

503 Jursa 2010a, $474+$ n. 2584, 508, 524 .

504 Jursa 2007a. 
A number of comments on and corrections to Bloch's edition of the texts are in order here. According to Bloch, the operative part of text no. 4 continues from the obverse to the reverse and there is no witness list before the name of the scribe. ${ }^{505}$ Only the last two or three signs of the first four lines of the reverse are visible, and according to my collation of the tablet at the British $\mathrm{Mu}$ seum, they most likely present the remnants of a witness list. The beginning of the reverse can be reconstructed as follows:

8) [' ${ }^{\mathrm{l}} m u$-gin $\mathrm{PN} \mathrm{a}$ a]-šú šá

9) [PN2 a ${ }^{\text {lísanga-s]ip-parki }}$

10) $\left[\mathrm{PN}_{3}\right.$ a-šú śá $\left.{ }^{\mathrm{I}}\right] \mathrm{su}^{-\mathrm{d}}$ amar.utu ${ }^{506}$

11) [a ${ }^{\text {lí }}$ sanga-dinanna-tin.t $]$ irki507 $^{\mathrm{k}}$

12) ["úumbisag Idag?]-mu-si.sá a-šú šá

13) [ $\left.{ }^{\mathrm{I}} \mathrm{x} ?\right]-b a ?-[\mathrm{x}]$ a ${ }^{\text {lúsanga-dinanna-tin.tirki }}$

[Witnesses: $\mathrm{PN} 1$, son] of [PN2, descendant of Šangû-S]ippar; [PN3, son of] Erība-Marduk, [descendant of Šangû-Ištar-Bāb]ili. [Scribe: Nabû?]šum-līšir, son of [Balassu?], descendant of Šangû-Ištar-Bābili.

Two sequences of names with three-tier genealogies fit the available space and the remnants of the signs perfectly. Moreover, the families of Šangû-Sippar (Šangû-Šamaš) and Šangû-Ištar-Bābili played a central role among the priesthood of Ebabbar and they are frequently attested in the documentation from the temple archive. ${ }^{508}$ The person mentioned on lines 10-11 was probably one of the sons of Erība-Marduk/Marduk-zēr-ibni/Šangû-Ištar-Bābili. ${ }^{509}$ As Bloch's copy of the tablet shows, the last three signs of the personal name on line 12 are at least partially visible. The remnants of the sign before 'si.sá' suggest reading 'mu', resulting in a personal name ending with ‘šum-lišir'. From the ŠangûIštar-Bābili family, only one such man, Nabû-šum-lī̌sir/Balassu, is known to me, but reconstructing his patronymic on line 13 causes difficulties. ${ }^{510}$

505 Bloch 2014, 154-156.

506 According to Bloch 2014, 155, 'The signs at the end of 1.10 are slightly deformed'. However, instead of 'máš-šu' (Bloch 2014, 154), the signs quite clearly present the sequence 'damar. utu'.

The reading ' $\mathrm{t}] \mathrm{irk}$ ' fits the preserved signs better than Bloch's $(2014,154)$ reading ' $e$ ' $-e h$ '.

508 Zawadzki 1990, 17-25; Bongenaar 1997, 12-15, 435-463; Waerzeggers 2014a, 28-29.

509 See Bongenaar 1997, 436 with further references.

510 One sign of the patronymic is visible on line 13 . Bloch reads it as 'i', but I only see three horizontal wedges. The sign might thus be 'ba', but there is not enough space to insert 'lat$s u$ ' in the break after the sign. On Nabû-šum-lǐšir/Balassu/Šangû-Ištar-Bābili, see Bongenaar 1997, 439-440. 
On line 2 in text no. 5, one should read '1 me gur zú.[lum.ma]' ('100 kurru of $\mathrm{da}[\mathrm{tes}]$ '), instead of ' 1 me gur ina gišr $b a ́ n$ " ('100 kurru by the sütu measure'). ${ }^{511}$ A reference to the type of produce makes the most sense in this context, and the price of 1.8 shekels of silver per 1 kurru of dates fits well with the range of date prices at Ebabbar in the twelfth year of Nabonidus. ${ }^{512}$ Jursa has convincingly shown that Ebabbar could not set the cost of dates independently, as market mechanisms determined the prices. ${ }^{513}$ Because the price paid for gold is also not exceptional, Bloch's conclusion that Ebabbar was 'able to bend the prices in its favour' appears to be mistaken. ${ }^{514}$ The last two signs on line 2 should perhaps be read as 'é gur' ('storehouse'). Moreover, ' $1 / 3$ gín' on line 6 is not a mistake, but a common way of referring to $1 / 3$ mina in Neo-Babylonian economic texts. ${ }^{515}$ In texts 4 and 5 , Bloch systematically translates ina qāt (ina šu ${ }^{\mathrm{II}}$ ) as 'under the charge of', referring to a commodity at someone's disposal. However, ina qāt should often be translated simply as 'from', pointing to the payer or supplier of the goods in question. ${ }^{516}$ This seems to be the correct translation, at least in no. 5 where part of the dates and silver for the purchase are supplied by Kīnā and Bakûa.

Basia and Marduka both had Babylonian names, ${ }^{517}$ but Amušê's name points to his non-Babylonian origin. A-mu-še-e is the Babylonian spelling of $H w s^{\varsigma}$ ('Hosea' or 'Hoshea'), a name which is attested several times in the Hebrew Bible. ${ }^{518}$ The significant differences in the spelling result from the characteristics of Babylonian, in which the West Semitic $h$ could not be accurately presented and $w$ was customarily written as $m$ or left completely out. ${ }^{519}$ As discussed in Section 1.5, the name Amušê was used predominantly, if not exclusively, by Judeans in Babylonia in the mid-first millennium.

\footnotetext{
511 See Jursa 2010a, 534 .

512 Jursa 2010a, 593 .

513 Jursa 2010a, 590-591.

514 Bloch 2014, 131. On the prices which the Eanna temple of Uruk paid for gold, see Joannès 1982a, 242-244.

515 Lorenz 2005/2006, 248-251.

516 CAD E, 404; CAD Q, 192.

517 Even though the etymology of both names is disputed, they are typical of the NeoBabylonian onomasticon. See PNA 1/II, 276; PNA 2/II, 704; Streck 2001, 116; Bloch 2014, 129, 153; Pearce and Wunsch 2014, 44, 65; Nielsen 2015, 58-59, 206, 208-209.

518 Zadok 1979a, 26-27; Jursa 2007a; Bloch 2014, 145-146. An alternative spelling of the name in Babylonian was Ú-še-eh (PBS 2/1 6o), for which see Stolper 1976, 26 n. 10; Zadok 1979a, 26. For some attestations of the name in the Hebrew Bible, see 2 Kgs 17-18 and Hos 1. Cf. the Neo-Assyrian attestations of this name in PNA 1/I, 238; PNA 3/II, 1421. GAG $§ 8,21,23,25$, 31. See also Coogan 1973, 189-19o; Bloch 2014, 122.
} 
Arih is a rare foreign name in Babylonian sources. It is thus striking that three sons of Arih are attested in the economic sphere of the Ebabbar temple within a period of three years. Furthermore, Basia is explicitly called a royal merchant, whereas Amušê and Marduka also appear in a context related to trade. This evidence alone may not be strong enough to confirm that the three men were brothers, but two marriage agreements corroborate their family relationship and Judean background. Bēl-uballit (son of Amušê), his unnamed brother, and their mother Gudadadìtu gave their sister and daughter Kaššāya in marriage in the fifth year of Cyrus (no. 2, BM 68921, ${ }^{520}$ II-[5 Cyr], 534 BCE). The groom was Guzānu, son of Kiribtu, whose family name of Ararru betrays his Babylonian descent. For an unknown reason, the marriage agreement of Kaššāya and Guzānu was drafted again a month later (no. 1, BM 65149, 11-III-5 Cyr). ${ }^{21}$ The witnesses had changed somewhat, but the contract remained almost the same. The only major difference seems to be the absence of the unidentified brother, who, together with his brother and mother, gave Kaššāya in marriage in no. 2. Two brothers of the bride, Šamaš-iddin and Nabû-ittannu, and a brother of the groom, Lâbâši, are among the witnesses of both documents. Amušê, the father of the bride, was absent on both occasions.

The patronymic of Amušê is not mentioned in the marriage agreements, but some of the numerous witnesses establish a link between the bride's family and the three sons of Arih discussed above. Both marriage agreements were witnessed by four royal merchants: Ahu-Yāma/Arih, Arad-Gula/Šamri-Yāma, Niqūdu/Mušallammu, and Šamaš-aplu-uṣur/Rapê. As in the previous three documents, people engaged in professional trade play a major role here. Moreover, they all have West Semitic names or patronymics, two of which are Yahwistic. ${ }^{522}$ The key person here is the first witness, Ahu-Yāma/Arih, who must have been a brother of Basia, Marduka, and Amušê. Arih is a rarely attested non-Babylonian name, but it appears four times as a patronymic of professional merchants in Sippar within a period of 12 years. This leaves little room for doubt. Accordingly, Kaššãya's father must be the same person as Amušê/ Arih in text no. 5. The Yahwistic name of Ahu-Yāma confirms the immigrant background of this family, which appears to consist of Judean royal merchants living in Sippar. ${ }^{523}$

\footnotetext{
520 The text has been previously edited in Jursa 2001. See also Roth 1989, 94-95.

521 The text has been previously edited as BMA 26. See also Jursa 2001, 2004b, 90-91. Bloch 2014, 132, suggests that the contract was drafted again because 'some difficulties arose with the marriage of Kaššaya'.

522 On Mušallammu, see Abraham 2005/2006, 216; on Rapê, see PNA 3/I, 1032-1033. On both names, see Bloch 2014, 133 .

523 For the family tree of the descendants of Arih, see Bloch 2014, 127.
} 
The three documents pertaining to Basia, Marduka, and Amušê originated in the administration of the Ebabbar temple and may thus belong to the temple archive. Alternatively, they were handed over to the merchants after the transactions were completed and the debts were paid back. ${ }^{524}$ The marriage agreements between Kaššāya and Guzānu are not related to the temple, and, together with the three other documents, they may be the remnants of the private archive of the descendants of Arih. The documents belong to the 82-918, AH 82-9-18A, and AH 83-1-18 collections of the British Museum, which are predominantly comprised of Ebabbar texts but also contain documents from private archives. ${ }^{525}$ It is likely that the private archives were unearthed together with the temple archive. ${ }^{526}$ Most of the private archives found in the vicinity of Ebabbar relate to people who held prebends and might have kept their private documents on the temple premises. ${ }^{527}$ At the same time, some private archives - such as the archive of the non-prebendary trader Iššar-tarībi - were deposited in the vicinity of the Ebabbar material because of their connection to the archive of Marduk-rēmanni. ${ }^{528}$ The main protagonist of this archive, Marduk-rēmanni, was an influential man both in the temple and in the trading communities of Sippar. The parties of the present marriage agreements belonged to the Sipparean trading community and knew people in Mardukrēmanni's circles, ${ }^{529}$ but nothing suggests that a connection to the archive of Marduk-rēmanni brought these texts into contact with the Ebabbar archive. However, the discovery of other - also non-prebendary - private archives at Ebabbar confirms that the documents pertaining to the descendants of Arih do not necessarily belong to the temple archive, but they may constitute the remnants of the private archive of the Judean family.

Even though the bride's family was of Judean origin, the marriage agreements comply with the standard features of such documents from sixthcentury Babylonia. ${ }^{530}$ As customary, the dowry given by the bride's family is described in detail: it included jewellery worth 20 shekels of silver, ${ }^{531}$ earrings

524 Promissory notes were usually handed over to the debtor when the debt was paid back; however, this was not always the case. See Jursa 2005a, 42.

525 Reade 1986, xxxiii-xxxiv; Leichty and Grayson 1987, 143, 233, 247; Leichty et al. 1988, 4, 34 (note that BM 75434 is catalogued as a receipt for a sheep); Waerzeggers 2014a, 145.

$5^{26}$ Waerzeggers 2014a, $16+$ n. 6 .

527 Bongenaar 2000, esp. 91-92. See also Jursa 2005a, 120-129; Waerzeggers 2014a, 15-22, 144-146.

$5^{28}$ Waerzeggers 2014a, esp. 19-22, 86-89.

529 See Section 3.3.2.

530 See Roth 1989; Abraham 2015, 45.

$5311 / 3$ gín šu-kut'-tu $u_{4}$. As in no. $5,1 / 3$ gín refers here most likely to $1 / 3$ mina (i.e. 20 shekels of silver). Wunsch 2003a, 4 n. 14; Jursa 2004b, 91. 
worth one shekel of gold, an Akkadian bed, five chairs, a table, a goblet, and a bronze platter. Kaššāya's family could afford to provide their daughter with some dowry, but it is noteworthy that no silver, real estate, or slaves were included. These items normally constituted the most valuable part of the dowry and were of primary interest to the husband's family, whereas jewellery, furniture, and household utensils were intended for the personal use of the bride and for housekeeping. ${ }^{532}$

The small size of the dowry may lead to two different conclusions: either Kaššayya's family could not afford to give anything else or they did not need to. The stipulations about divorce and adultery may indicate that the families of Kaššāya and Guzānu were not very wealthy. In the case of divorce, Guzānu was to pay six minas of silver and let his wife return to her paternal house. ${ }^{533}$ If Kaššãya was found with another man, she would die by the iron dagger. ${ }^{534}$ The 'iron dagger' clause is attested in marriage agreements with a small dowry or none at all, but which include a stipulation about a payment from the husband to his wife in case of divorce. According to Cornelia Wunsch, this implies that economic factors dictated the choice to include these stipulations in the marriage agreement. ${ }^{535}$ If the bride's family could afford to give a substantial dowry, the economic consequences of losing the dowry due to divorce were serious. Accordingly, no stipulations about compensatory payment were necessary. A wife's adultery must have been severely punished in these marriages as well, even though this is not made explicit in the agreements. In the marriage agreements of less wealthy people, however, clauses about a large compensation and death by the iron dagger emphasised the serious consequences of divorce and adultery.

Caroline Waerzeggers understands the social context of the iron dagger clause differently, and her interpretation fits better with the available evidence. ${ }^{536}$ She notes that the connection between poverty and the iron dagger clause is not consistent and that the clause was also used in some marriage agreements involving a dowry. The clause is never found in marriage agreements between parties who bore family names, but it is always attested in marriage agreements between parties who did not bear family names. In marriage agreements between parties from different social backgrounds, the status of the bride was decisive. If she bore a family name, the iron dagger clause was

532 Roth 1989/1990, esp. 1.

533 On divorce in Babylonian marriage agreements, see Roth 1989, 12-15; Oelsner et al. 2003, 935-936.

534 On the iron dagger clause, see Roth 1988, 186-206; Wunsch 2003a, 3-7; Waerzeggers 2016.

535 Wunsch 2003a, 3-7.

536 Waerzeggers 2016. 
not included. It thus appears that the usage of the iron dagger clause was related to the social background of the parties involved, not primarily to their wealth. In the case of Kaššāya and Guzānu, the non-Babylonian background of the bride, not her poverty, prompted the inclusion of the iron dagger clause in the marriage agreements.

Moreover, not only property was transferred in marriage. The families of the husband and bride also shared each other's prestige and social networks. ${ }^{537}$ Kaššāya's small dowry may indicate that her husband's family placed a high value on marriage ties to a family of royal merchants and that they were satisfied with a dowry consisting only of jewellery and household goods. A daughter of royal merchants was a highly prized bride, even if her family was of foreign origin. Accordingly, Kaššāya's small dowry is hardly indicative of the modest means of her family.

Before addressing the social status and networks of the descendants of Arih in more detail, two more documents have to be discussed. Text no. 6 (CT 4 21a, 5-I-19 Dar, 503 в СЕ) was drafted in Sippar 31 years after the marriage agreements. ${ }^{538}$ The document is a lease of 30 hașbattu vessels, which were probably used in a beer brewing and tavern business by the lessee Šamaš-uballiț/Nādin/ Bā'iru. ${ }^{539}$ The lessor was someone called Rìmūt/Šamaš-zēr-ibni, and the third witness was a certain Bēl-iddin/Amušê. The document belongs to the private archive of Bēl-ittannu/Šamaš-uballiț/Ša-nāšišu. ${ }^{540}$ As will be shown below, prosopographical evidence connects this document closely to the marriage agreements, and Bēl-iddin must have been a brother of Kaššāya.

A second document $(N b n$ 1) belongs to the Ebabbar archive and was written in the accession year of Nabonidus (18-III-o Nbn, 556 BCE). It is a partially broken list of people, kur.ra textiles, and small amounts of silver. The garments were most likely distributed to the workers of the temple, and the value of each garment in silver is given on the list. ${ }^{541}$ The recipients are listed without their patronymics, and a certain Amušê is mentioned on line 13. Even though he was a contemporary of the sons of Arih and attested in Sippar, he appears to have

537 The wealthy Egibis, for instance, were able to give their daughters in marriage with relatively small dowries. Becoming a member of the family was already profitable in a socioeconomic sense. See Roth 1991, 19-37.

538 BM 78391 . The tablet was acquired for the British Museum by E.A.W. Budge, and it belongs to the Bu 88-5-12 collection. See Walker 1988; Leichty et al. 1988, $15^{2}$.

539 On the connection between hașbattu vessels, beer, and taverns, see Joannès 1992; Tolini 2013.

540 The Ša-nāšišu B archive in Jursa 2005a, 126-127.

541 On kur.ra textiles and their distribution to temple personnel, see Bongenaar 1997, 39-40; Zawadzki 2010, esp. 412-414; Spar and Jursa 2014, 67. 
been a member of the temple personnel and thus different from the (royal) merchant Amušê. In any case, he was perhaps of Judean origin, given the rarity of the name and its connection with Yahwistic names in Babylonian sources.

\subsubsection{Social Network}

To have a better understanding of Kaššāya and her family of royal merchants, it is necessary to study the other people who appear in the documents discussed above. ${ }^{542}$ The extensive research done on Sipparean cuneiform documentation over the past 25 years allows me to locate the descendants of Arih and their acquaintances in a wider social context. ${ }^{543}$ However, before mapping out the social networks, it is helpful to focus briefly on the city of Sippar in the sixth century BCE.

The city of Sippar on the banks of the Euphrates was ideally located for trading purposes. The courses of the Euphrates and the Tigris were closest to one another near Sippar, and the trading routes to the Iranian plateau beyond the Tigris and to the Levant beyond the Euphrates met naturally in Sippar. In addition, the state strongly invested in the Sippar region in the sixth century ВСЕ, and royal projects created a boom in agriculture and trade. ${ }^{544}$ Consequently, a vibrant community of local businessmen, foreign traders, and royal merchants arose around the harbour of Sippar. On the other hand, Sippar was an important cult centre of the sun god Šamaš, whose temple Ebabbar stood in the middle of the city. The priests of Ebabbar formed their own closed community, and they rarely took part in trading activities as private persons, even though the temple itself traded regularly with outsiders. The communities of priests and traders can thus be seen as two distinct groups in Sipparean society. ${ }^{545}$ The international character of the Sipparean trading community is also reflected in the marriage agreements of Kaššāya and Guzānu. In addition to Amušê's brother Ahu-Yāma, three other royal merchants witnessed the marriage agreements, and they all bore West Semitic patronymics. This corroborates the wellestablished view that people of foreign origin played a key role in professional trade in Babylonia.

The descendants of Arih knew people from both the temple and the trading communities of Sippar. In their business transactions with the Ebabbar

\footnotetext{
542 Some aspects of this social network are studied in Waerzeggers 2014b, 140.

543 The most important studies for the present discussion are Bongenaar 1997; Waerzeggers 2014a. See the latter for further literature on Sippar.

544 Woods 2005, 37-40; Jursa 2010a, 64, 84-86, 322-359; Jursa and Baker 2011, 533-537; Waerzeggers 2014a, 2-4.

545 On the priests of Ebabbar, see Bongenaar 1997. Sipparean society is studied in Waerzeggers 2014a, 119-126.
} 
temple, Basia, Marduka, and Amušê came into contact with a well-known tithe farmer of the temple and with members of the most important priestly families in Sippar. ${ }^{546}$ These transactions are important in showing that merchants of Judean origin customarily traded with the temple and met people working for the institution and belonging to priestly families. However, these encounters were professional in nature, and they tell nothing about the friendship or family ties of the Judean family. When it comes to their private circles, it is more fruitful to study the people attested in the marriage agreements.

An evident point of departure for this discussion is the family of Kaššãya's husband Guzānu/Kiribtu/Ararru. The family name Ararru ('miller') is very rare in the Neo-Babylonian sources, and only seven certain attestations of the name are known to me. ${ }^{547}$ Two of these documents - namely, the present marriage agreements - come from Sippar, four from Babylon, and one probably from Babylon or Sippar. The earliest document from Babylon records the sale of an unbuilt plot in the city from the sixth year of Esarhaddon (20-v-6 Esarh, 675 BCE). The seller was Bēl-ēreš//Ararru and the buyer a certain Ea-qayališemme. ${ }^{548}$ The tablet was unearthed in the Ninurta temple in Babylon, where the Sîn-ili archive was found. ${ }^{549}$ As the tablet is older than the archive, they may be unrelated. It is also possible that the tablet was kept in the archive to record the ownership history of the plot, which was later bought by the Sîn-ilī family. 550

Two tablets from Babylon belong to the Egibi archive, the first one being a promissory note that concerns a house rental payment (Nbk 137, 21-IV-23 Nbk, $582 \mathrm{BCE}$ ). Bēl-iddin/Balassu/Ararru is listed as the second witness. The other document from the Egibi archive is also a promissory note ( $\mathrm{Nbn}$ 60o, 5-III-12 Nbn, 544 BCE), which records a debt of 23 kurru (4,140 litres) of dates to be paid back with 25 vats of good beer. The creditor was Itti-Marduk-balāțu/Nabûahhē-iddin/Egibi and the debtor Balāțu/Marduk-nāṣir/Ararru.

The fourth tablet from Babylon is a promissory note for 6 kurru of dates (VS 3 53, 4-III-11 Nbn, 545 вCE), written by a scribe called Arad-Marduk/Bēl-[...]/ Ararru. The names of the creditor and debtor are both peculiar, the former

$546 \quad$ See Section 3.3.1.

547 I am grateful to Cornelia Wunsch for her substantial help in gathering the evidence. See also CAD A/2, 233; Tallqvist 1905, 67; Wunsch 2014, 303; Nielsen 2015, 36. There are three other documents that may mention the family name Ararru: Dar 411:13 (but according to Abraham 2004 no. 119, the sign should be read as šitim, 'Itinnu'); OECT 10 295; RINAP 4126.

548 Jakob-Rost 1970 no. 4. Note that according to Jakob-Rost's translation of the broken passage, the seller was Ea-qayal-išemme and the buyer Bēl-ēreš. See Pedersén 2005a, 239.

549 Pedersén 2005a, 228-232, 239. On the Sîn-ilī archive, see Jursa 2005a, 69-71.

550 Pedersén 2005a, 228-231. 
being Nabû-ahhē-bulliț/Aššur-mutaqqin-dīn(?) and the latter Mil-ki-šu-mulugal-ùru/Ha-am-[ma?]-ta-a-a. Names containing the theophoric element A ššur are rare in Babylonia, ${ }^{551}$ and $m l k$ is not an Akkadian root but a common West Semitic one. ${ }^{552}$ If Hammatāya is the correct restoration, the patronymic means 'the Hamathean. ${ }^{553}$ The tablet cannot be assigned to any known archive. Yet another text concerning the Ararru family most likely originates from Babylon or, alternatively, from Sippar. The unpublished tablet BM 77945 (19 Nbk?, 586 вСE?) mentions PN/Aplā/Ararru among the witnesses of a lawsuit. 554

There is no prosopographical evidence to demonstrate that the descendants of Ararru were all members of a single family. However, several interesting conclusions can be drawn from the seven texts discussed above. First of all, nothing suggests that the Ararrus held prebends at Ebabbar or any other temple in Babylonia. Even though they bore a family name and thus belonged to the upper social stratum in Babylonian society, their profile appears more mercantile than priestly. ${ }^{555}$ Whereas the private life of prebendary families was turned towards the priestly in-group, ${ }^{556}$ Guzānu took a wife from a Judean family of merchants and the Ararrus of Babylon had contacts with people of nonBabylonian origin. The fact that they engaged in beer brewing and were connected to the wealthy business family of Egibi indicates that they were involved in business activities in Babylon. Finally, the Ararrus originated from Babylon rather than from Sippar. The marriage agreements of Kaššāya and Guzānu are the only certain attestation of the Ararrus in Sippar, whereas there are four or five separate documents from Babylon. This is noteworthy because several families moved from Babylon to Sippar in the sixth century, including the Șāhit-ginês, a branch of the Ša-nāšišus, and the Arad-Nergals. Royal investment and the booming economy made Sippar attractive for newcomers, some of whom achieved great success in their new hometown. Even though some members of these families were able to make their way into the priestly circles of Ebabbar, the community of newcomers was geared towards trading

\footnotetext{
$55^{1}$ See Tallqvist 1905, 16-17.

$55^{2}$ See PNA 2/II, 750-753.

553 Zadok 1977, 12, 20-21, 248.

554 Personal communication with Cornelia Wunsch. She suggests that the tablet probably originates from Babylon. Cf. Leichty et al. 1988, 121. According to Walker 1988, xi-xiv, the tablet was acquired from a private person and it possibly originates from Babylon or Sippar.

555 Cf. Bloch 2014, 145.

556 Still 2019.
} 
activities. ${ }^{557}$ It is much easier to fit the family of Guzānu into this mercantile community than into the old, established elite of Sippar and the priestly circles of Ebabbar.

Some of the witnesses with Babylonian names, patronymics, and family names can also be identified as members of the Sipparean mercantile community. The business profile of these people becomes apparent from the documents belonging to the archive of Marduk-rēmanni/Bēl-uballiț/Sāhit-ginê and its satellite archives. Marduk-rēmanni's family originated in Babylon but moved to Sippar in the sixth century, and Marduk-rēmanni became a member of the local trading community. At the same time, he succeeded in gaining a strong foothold in the priestly circles of Ebabbar, and his archive is an indispensable source of information on the life of these two distinct communities. ${ }^{558}$ Neither Marduk-rēmanni nor members of his family appear in the documents pertaining to the descendants of Arih, but they shared several common acquaintances. A witness of both marriage agreements, Nabû-iddin/ Bānia/Pahhāru, was related to two business agents of the Șāhit-ginê family.559 Another link to the Șāhit-ginê family was Bānia/Bēl-nāșir/Arad-Nergal. He belonged to a family which had moved from Babylon to Sippar at the same time as the Șāhit-ginês and had become part of the Sipparean trading community. ${ }^{560}$ Another interesting witness in the earlier marriage agreement is Šuzubu/ Zababa-ah-iddin/Ile'i-Marduk, who acted several times as a scribe in documents in Marduk-rēmanni's archive. ${ }^{561}$ Finally, a certain Guzānu/Kiribtu is a witness in a promissory note belonging to the archive of Marduk-rēmanni, and it is possible that this Guzānu was the groom of Kaššāya. ${ }^{562}$

Prosopographical data connects text no. 6 with the marriage agreements and the family of Kaššāya, even if Bēl-iddin/Amušê, the third witness of no. 6, is not attested in the marriage agreements. A direct link between the earlier marriage agreement no. 2 and text no. 6 is (Nabû-)Bān-zēri/Rīmūt-Bēl/Isinnāya, who witnessed both documents. Interestingly enough, he is the only witness of the marriage agreements to have held a prebend at the Ebabbar temple. ${ }^{563}$ The profiles of the lessee and surety in no. 6 indicate that the text originated in the same social setting as the five earlier documents. The lessor Rīmūt/Šamaš-zēribni cannot be definitively identified in other extant documents, but the lessee

\footnotetext{
557 On these families, see Waerzeggers 2014a, 45-49, 119-124.

$55^{8}$ Waerzeggers 2014a, esp. 15-30, 61-93, 113-125.

559 Waerzeggers 2014a, 81-82, 214; MR 8, 25.

56o Waerzeggers 2014a, 45-49.

$561 \quad$ MR 23, 24, 69, 85, 86, 171.

562 Waerzeggers 2014a, 214; MR 39.

$5^{63}$ He held a baker's prebend; see Bongenaar 1997, 173 .
} 
Šamaš-uballiț/Nādin/Bā'iru participated in a harrānu business venture with a member of the Ša-nāššsu family in BM $74469 \cdot{ }^{564}$ The Ša-nāšišu family, which had also migrated to Sippar from Babylon, was a part of the Sipparean mercantile and priestly communities. ${ }^{565}$ Another member of this family, Bēl-ittannu/ Šamaš-uballiț/Ša-nāšišu, acted as a surety in text no. 6, a document which belongs to his private archive. ${ }^{566}$ Bēl-iddin/Amušê must have been familiar with these people and their businesses. It is likely that his father Amušê was the father of Kaššãya: the descendants of Arih and the lessee and surety of text no. 6 shared an interest in entrepreneurial activities, Amušê is a rare name in Babylonian sources, and a brother of Kaššāya could still have been alive 31 years after the marriage agreements were drafted. However, it is impossible to know if Bēl-iddin was the unnamed brother in the earlier marriage agreement. ${ }^{567}$

Prosopographical research shows that the descendants of Arih were closely connected with the community of merchants in the city of Sippar. As royal merchants, they traded with the Ebabbar temple, but only one of the witnesses in the marriage agreements was a priest holding a prebend. ${ }^{568}$ The family of the groom had a mercantile rather than a priestly profile, and the witnesses of the marriage agreements were predominantly royal merchants or belonged to families which participated in trading activities. The international character of Sipparean traders is also quite apparent in the texts, and people of both West Semitic and Babylonian origin were among the acquaintances of the Judean family. In this connection, it is important to note that some members of the Sipparean trading community participated in long-distance trade from Syria and the Levant to Babylonia. ${ }^{569}$ Accordingly, the family of Arih was rooted in two distinctively international realms of Babylonian society. On the one hand, they were part of the state apparatus as royal merchants; 570 on the other hand, they were members of the multi-ethnic community of traders at the quay of Sippar.

\subsubsection{Identity, Integration, and Socio-Economic Status}

Analysis of the social network of the descendants of Arih shows that the Judean family had found a place among the community of merchants in Sippar.

\footnotetext{
$564 \quad$ Jursa 2005a, $126+$ n. 968.

565 On the Ša-nāšišus, see Waerzeggers 2014a, 46, 72-74, 124-125.

566 The Ša-nāšišu B archive in Jursa 2005a, 126-127.

567 Cf. Bloch 2014, 160-161.

568 Cf. Bloch 2014, 141.

569 Bongenaar 2000, 86; Waerzeggers 2014a, 85-89.

570 See Jursa 2015 b on the multi-lingual and multi-ethnic character of the Babylonian state administration.
} 
In the following discussion, I study how this is reflected in their identity and how deeply they were integrated into Babylonian society. These questions have been studied in detail by Bloch, ${ }^{571}$ and I thus limit my discussion to some new aspects and interpretations of the evidence.

The majority of the names of the descendants of Arih are Babylonian. ${ }^{572}$ Only two of his sons, Ahu-Yāma and Amušê, had distinctively Judean names. The names borne by the third generation are fully Babylonian, and three different gods - Bēl (Marduk), Nabû, and Šamaš - are referred to in the theophoric elements. At first sight, the naming practices of this Sipparean family are in stark contrast to the figures derived from the Judean communities in the countryside. A significantly higher number of identifiable Judeans in the Murašû archive bear Yahwistic names, and the same applies to Judeans in Yāhūdu and its surroundings. ${ }^{573}$ The descendants of Arih were certainly quite different from the Judeans in the countryside, but the available data is somewhat misleading as well. Judeans can be normally identified only on the basis of Yahwistic or other distinctly Judean names possessed by them or their relatives. This skews the overall picture in favour of those who bore traditional Judean names.

The relationship between theophoric names and religious practice is complex, and a theophoric name devoted to a certain deity does not exclude its bearer's worship of other gods. Therefore, it cannot be argued that Ahu-Yāma revered Yahweh and Bēl-iddin worshipped Marduk. However, the readiness to use Babylonian theophoric names indicates that the descendants of Arih were at home in the religious environment of Babylonia. ${ }^{574}$ This is visible also in Kaššāya's and Guzānu's marriage agreements, in which Marduk, Zarpanītu, and Nabû were customarily invoked in the curse section. This is noteworthy in light of Kathleen Abraham's argument that the stipulations of a marriage agreement were negotiated by the parties and not dictated by the scribe. ${ }^{575}$ Accordingly, the invoking of Babylonian gods could not have been an abomination to the Judean family. Judean traditions are visible in the names of AhuYâma and Amušê, but Yahweh's importance for the descendants of Arih remains unknown.

\footnotetext{
571 Bloch 2014, 127-135.

572 See Bloch 2014, 127-130.

573 Section 8.5. On the Murašû archive, see Bickerman 1978, 15; Bloch 2014, 124-125. A similar picture arises when Bickerman's method is applied to the prosopographical data from Yāhūdu and its surroundings (see the prosopographical index in Pearce and Wunsch 2014, 257-300). See also Pearce 2015, 19-22, 29.

574 See Bloch 2014, 129-130.

575 Abraham 2015, 33-57.
} 
The names of the descendants of Arih reflect the environment they were living in. As members of the Sipparean trading community, they had people of Babylonian and foreign origin in their intimate circles. Close contact with Babylonians accelerated their integration and adoption of local naming practices. Their professional life as merchants naturally played a role in this process, but a desire to advance trade relations with the Ebabbar temple was hardly the main reason for it. ${ }^{576}$ Contact with Babylonians was not a decisive factor in the adoption of Babylonian names or culture, as the example of Ahīqam, son of Rapā-Yāma, from the village of Yāhūdu shows. This Judean was in close contact with Babylonians $\left(\mathrm{C}_{14}, 17,18\right)$ and even traded in Babylon $\left(\mathrm{C}_{44}, 45\right)$, but he did not give Babylonian names to his sons. ${ }^{577}$ The nature and intensity of contact were likely important, as collegial and friendship ties are often more influential than business relationships. ${ }^{578}$

Several aspects of Kaššāya's marriage agreements exhibit a high level of integration into Babylonian society. These include her marriage into a Babylonian family, the Babylonian witnesses of the contract, and its conformity to the standard legal practices of its time. An interesting detail of the dowry is the Akkadian bed (gišná $a k-k a-d i-i-t u_{4}$ ), which stands out from the list of jewellery, furniture, and household utensils. Kaššayya is one of three brides in Neo-Babylonian sources who received such a bed as a part of their dowry. ${ }^{579}$ Another bride, Habašinnatu (Nbn 258), came from the Kāṣir family and married into the Rab-banê family; in her case, the Akkadian bed was one of four beds given as a dowry. The family names confirm that the marriage was established between native Babylonians. A third bride, Tahê-[...], not only received an Akkadian bed but also an Akkadian table, according to the marriage agreement BMA 23 (= Dar 301). Both Tahê-[...] and her husband Pațmiustû were of Egyptian origin, ${ }^{580}$ which makes this case comparable to the marriage agreement of Kaššaya. Even though the nature of an Akkadian bed is unknown, it must have been somehow different from the ordinary beds of the period. ${ }^{581}$ It is tempting to perceive the Akkadian bed as a device which these two immigrant families used to emphasise their integration into Babylonian society. ${ }^{582}$ The Akkadian

576 Cf. Bloch 2014, 132.

577 See Section 4.3.6.3 and Ahīqam's family tree in Pearce and Wunsch 2014, 8.

578 This relates to the concept of tie strength in social network analysis. See Granovetter 1973, 1360-1380.

579 See Roth 1989/1990, 21-22; CAD E, 317.

580 Abraham 2015, 40-44; Hackl and Jursa 2015, 162-163, 165 .

581 This is made clear in Nbn 258:8-9. In addition to the three dowries, an Akkadian bed is also included in a list of furniture and household utensils in Nbk 441:1.

582 Personal communication with Caroline Waerzeggers. 
bed was a product of their new homeland and thus loaded with symbolic value, not a mere piece of furniture.

The previous observations about their integration, social networks, and status as royal merchants indicate that the descendants of Arih had a relatively good social standing in Sippar. Intuitively, one would like to suggest that professional merchants like the family of Arih were wealthy, but the scanty information on their possessions does not allow easy conclusions. First, the transactions of Basia, Marduka, and Amušê are silent on the profits which the brothers made from their trade. Only the marriage agreements reveal something about the wealth of the family, but, as noted above, the picture is somewhat unclear. The bride indeed received some jewellery for personal use and furniture and kitchen utensils for running the new household, but the dowry lacked any truly valuable items such as silver, real estate, or slaves. However, a modest dowry was not always indicative of financial constraints, and it cannot be reliably used to estimate the wealth of the bride's family. Given their profession, social networks, and success in marrying their daughter to a man from the Ararru family, the descendants of Arih belonged to the better-off segment of Babylonian society. .83

\subsection{Other Judean Merchants in Babylonia}

In addition to the descendants of Arih, three other Judeans were involved in trading activities in Babylonia in the sixth century вСЕ. The documents concerning these people relate to long-distance trade, which helps to contextualise the transactions of the Judean royal merchants in Sippar. The earliest attestation of a Judean trader in Babylonia is dated in the fortieth year of Nebuchadnezzar II (21-IV-40 Nbk, 565 BCE). The document was written in Opis, an important hub of Babylonian foreign trade in the sixth century. Even though the town was located in north-east Babylonia on or near the Tigris, it also functioned as a station of Trans-Euphratian trade. ${ }^{584} \operatorname{In} N b k 361$, a certain Aia-ahâ, son of Šani-Yāma, appears as a party in a court case concerning trade goods or capital (mēreštu) worth $2^{1} \frac{1}{2}$ minas of silver. ${ }^{585}$ In Neo-Babylonian

583 See Waerzeggers 2014b, 140; Abraham 2015, 45, 48.

584 Jursa 2010a, 80-84, 120-121.

585 The document belongs to a group of judicial texts written by Nabû-ahhē-iddin/Šulā/Egibi in Opis, where he - in close contact with people in Prince Neriglissar's retinue - was pursuing a career as court scribe in the late reign of Nebuchadnezzar II. Nabû-ahhē-iddin does not seem to have had any personal interests in this court case, and, as van Driel suggests, the document must have ended up in the Egibi archive because Nabû-ahhē-iddin 
business documents, the word mēreštu refers to trade goods that were imported to Babylonia or to silver capital that was invested to acquire such goods. ${ }^{586}$ In the context of the present document, it seems likely that the dispute concerned the capital of a harrānu trading venture, which the investor Nabû-na ${ }^{\text {id }}$ had put at the disposal of his agents Aia-ahâ and Barūhi-il. ${ }^{587}$ Since the word mèreštu belongs to the terminology of long-distance trade and Opis was a starting point for such overland trading missions, it is reasonable to suggest that the venture of Aia-ahâ and Barūhi-il was directed towards an area outside Babylonia proper.

Two other documents on Judean merchants or business agents in Babylonia belong to the archive of the Sipparean trader Iššar-tarībi, son of Bunene-ibni. ${ }^{588}$ Iššar-tarībi's business profile was rather unusual, as he was a non-institutional merchant taking part in long-distance trade. This is indicated by the fact that Opis and the Iranian town of Humaděšu are mentioned in his archive, the latter in a clear trade context. ${ }^{589}$ Iššar-tarībi was a member of the trading community of Sippar ${ }^{590}$ and shared common acquaintances with the descendants of Arih. ${ }^{591}$ Another important feature of Iššar-tarībi's archive is the great number of people with non-Babylonian names, ${ }^{592}$ an element which strengthens the idea that Iššar-tarībi participated in long-distance trade, in which people of foreign origin played a central role.

The first document concerning Judeans in Iššar-tarībi's archive was written in Sippar in the seventh year of Cambyses (26-X-7 Camb, 522 BCE ). ${ }^{593}$ A certain Mannu-kī-Bānītu, son of Bēl-ab-uṣur, sold a donkey to Iššar-tarībi. The contract defines that the donkey was delivered to Mannu-kī-Bānitu by a third

kept copies of some of the documents he wrote in Opis. See van Driel $1985^{-1986,54-59 \text {; }}$ Wunsch 200ob, 98-102; 2007, 237.

586 Oppenheim 1967, 239-240; van Driel 1986, 16-17 + n. 40; Tolini 2009, 249; Jursa 2010a, 93, 505-506.

587 On harrānu partnerships, see Jursa 2009, 53-68; 2010a, 206-214.

588 The texts in the archive of Iššar-tarībi are dated to the second half of the sixth century вСE (8 Cyr-23 Dar). There is no thorough study of Iššar-tarībi and his archive. For short overviews, see Bongenaar 2000, 89-90; Jursa 2005a, 124; 2010a, 220-221, 224-225; Waerzeggers 2014a, 86-89. On his contacts with Judeans, see Waerzeggers 2014b, 140.

589 Dar 149 and Weszeli 1996 no. 2, respectively. See Jursa 2010a, 224-225.

590 Waerzeggers 2014a, 19-22, 86-89.

591 Nabû-iddin/Bānia/Pahhāru witnessed the marriage agreements of Kaššāya and Guzānu, and his nephew Nabû-iqī̌sa is a witness in a promissory note from Iššar-tarībi's archive (unpublished BM 7446o; see Waerzeggers 2014a, 21 n. 33).

592 Il-hanan in Weszeli 1996 no. 2, and Barīkia in Jursa and Weszeli 200o, 82-84, to name but a few. See Zadok 1977, 88, 122-123, respectively.

593 Weszeli 1996 no. 2. 
man called Tagabi-Yāma in Humadēšu. ${ }^{594}$ As Weszeli points out, the scribe obviously made a mistake in the section concerning the delivery of the animal: the recipient of the donkey should naturally be its buyer, Iššar-tarībi. ${ }^{595}$ Humadēšu was not in the vicinity of Sippar, but it was located in Iran, near the site where Persepolis was later built. ${ }^{596}$ There must have been a special reason for a journey to Humadēšu, and in this case, long-distance trade appears to be the most probable explanation. Iššar-taribi was a businessman, and the evidence of a businessman buying a pack animal in a foreign locality points strongly towards trading activities. ${ }^{597}$ Unfortunately, there is no way to know whether Tagabi-Yāma was a servant of the seller or buyer, or their colleague or acquaintance. However, judging from his Yahwistic name, he was a Judean and a man involved in long-distance trade outside Babylonia proper.

In addition to Tagabi-Yāma, another Judean, the son of Gamar-Yāma, is attested in the archive of Iššar-tarïbi. This man, whose name is broken, witnessed a document concerning the sale of a Bactrian female slave. Drafted in Sippar in the tenth year of Darius I (18-II-10 Dar, 512 BCE), 598 this sale contract emphasises the international nature of Iššar-taribi's social circles: none of the witnesses bore a family name, three of them had a non-Babylonian name or patronymic, ${ }^{599}$ and the Bactrian slave had alphabetic writing tattooed or burned on her neck. Tagabi-Yāma and the son of Gamar-Yāma lived in this world of traders, non-Babylonians, and speakers of Aramaic. It cannot be ascertained whether the son of Gamar-Yāma was a merchant himself, but his connection to the circles of Iššar-tarībi is suggestive of such a profile.

\subsection{Conclusion: Long-Distance Trade and Judean Merchants}

It is beyond doubt that some Judeans participated in Babylonian long-distance trade. Tagabi-Yāma's actions in Humadēšu (Iran) took place in an obvious trading context, and all aspects of Aia-ahâ's court case suggest a connection to an overland trading mission. The son of Gamar-Yāma was not perhaps a merchant himself, but he knew people who certainly participated in long-distance trade. In the case of the descendants of Arih, several features of their business activities are indicative of their participation in long-distance trade. Gold had to

594 On the name Tagabi-Yāma, see Zadok 1996, 727.

595 Weszeli 1996, 473.

596 Henkelman 2008, 338.

597 See Zadok 2002, 31; Jursa 2010a, $225+$ n. 1311.

598 Jursa and Weszeli 2000, 82-84.

599 Zadok 2002, 31-32. 
be imported to Babylonia, which means that the family had, at the very least, contacts with people who took part in the importation of the precious metal. Being stationed at Sippar, they were well positioned to either acquire gold from their local contacts or embark on trading missions along the Euphrates. As royal merchants, they belonged to the group of professional traders who undertook such missions to fulfil the needs of the palace, temples, and elite in Babylonia. Finally, people in their social circles in Sippar were involved in local and long-distance trading operations.

It is well known that people of foreign origin played a central role in Babylonian long-distance trade, and it is not surprising that Judeans participated in it as well. The commercial sphere of Babylonian society was open to immigrants, who had some advantages over their Babylonian peers when it came to longdistance trade. One important factor was their ability to reduce the transaction costs of trade: existing networks and knowledge of local languages, products, and trading practices gave immigrants easier access to the markets in their native country. ${ }^{600}$

Judeans participated in Babylonian long-distance trade, and documented evidence shows that some of them travelled as far as Iran for this purpose. There is no evidence that their trading missions reached Syria and the Levant, even though people in their surroundings participated in Trans-Euphratian trade. Judean merchants are attested in Opis and Sippar, which were important stations of trading missions to the west. The descendants of Arih were deeply integrated into the Sipparean trading community, some members of which were involved in trade from Syria and the Levant to Babylonia. Therefore, it is possible that some Judean merchants - such as the descendants of Arih and their colleagues - also travelled to the Levant, perhaps as far as Judah, for the purpose of trade. ${ }^{601}$ This would also make them good candidates for having been intermediaries between Judeans living in Judah and Babylonia. News and messages easily travel along with trade goods over long distances.

6 oo On brokers in cross-cultural trade, see Curtin 1984. On immigration and its impact on modern international trade, see Gould 1994, 302-316; Rauch and Trindade 2002, 116-130; Law et al. 2013, 582-6o6.

601 See Waerzeggers 2014b, 132. 


\section{Texts from Yāhūdu, Našar, and Their Surroundings}

\subsection{Introduction}

The texts from Yāhūdu, ${ }^{602}$ Našar, and their surroundings are the most important source for the study of Judeans in Babylonia. The uniqueness of these texts is not only related to the fact that some of them were written in the "Town of Judah', Yāhūdu, but they constitute the only large corpus of texts to feature Judeans among its main protagonists. The tablets are of unprovenanced origin and they have found their way into several private collections, including those of Shlomo Moussaieff, Martin Schøyen, and David Sofer. ${ }^{603}$ Eleven tablets from the Moussaieff collection were published in 1996-2007. In 1996, Francis Joannès and André Lemaire published seven tablets relating to a place called BìtAbī-râm and to a certain Zababa-šar-uṣur a steward ( $r a b$ biti) of the crown prince's estate somewhere in the Babylonian countryside. ${ }^{604}$ The village of Yāhūdu itself was first attested in a text published by Joannès and Lemaire in 1999, along with a text from Našar. ${ }^{605}$ A little more light was shed on Yāhūdu when Kathleen Abraham published two texts originating from the village and featuring a large number of Yahwistic personal names. ${ }^{606}$

Laurie E. Pearce and Cornelia Wunsch published the texts belonging to the Sofer collection in 2014. ${ }^{607}$ The volume includes 103 texts, which are divided into three groups: texts relating primarily to Yāhūdu (group 1), texts relating primarily to Našar (group 2), and texts relating primarily to Bīt-Abī-râm (group 3 ). Groups 1 and 2 are of roughly the same size, with the former consisting of 54 and the latter of 47 texts in the authors' classification. Only two texts belong to

602 Although the name has usually been transcribed as Âl-Yāhūdu ('town of Judah'), a more accurate transcription of uru ia-hu-du might simply be 'Yāhūdu'. The sign 'uru' probably represents the determinative for towns and is not an independent word. See Waerzeggers 2015, 179; Zadok 2015d, 142.

603 On the origin of these tablets and the ethical problems involved, see Section 1.4.2.2.

604 Joannès and Lemaire 1996. In the following, references to these texts are abbreviated as J1-7.

605 Joannès and Lemaire 1999. In the following, references to these texts are abbreviated as J8-9.

606 Abraham 2005/2006, 2007. In the following, references to these texts are abbreviated as A1 and A2, respectively.

607 Pearce and Wunsch 2014. References to these texts are abbreviated as $\mathrm{C}+$ text number. 
group 3, and they are assumed to be connected to the Bìt-Abì-râm texts published by Joannès and Lemaire.

The publication of the texts in the Schøyen collection is scheduled for the near future, ${ }^{608}$ but Cornelia Wunsch kindly granted me access to the preliminary edition of all group 1 (17 texts) and group 2 (25 texts) documents of the collection. The bulk of this forthcoming volume consists of 55 texts belonging to group 3. Not all tablets found their way into the collections of Moussaieff, Sofer, and Schøyen, however. Pearce and Wunsch refer ambiguously to 'other collections' where the tablets are kept, ${ }^{609}$ and the Iraqi Antiquities Authority has confiscated about 40 texts relating to Bìt-Abī-râm. The tablets in Iraq will be published in the Babylonische Archive series. ${ }^{610}$ Thus, the number of known texts in the corpus is circa 250 , but because the tablets most likely originate from illicit excavations and they have been and may still be circulating on the antiquities market, even more texts may surface in the future. ${ }^{611}$

In several articles, Pearce and Wunsch have discussed Judean naming practices, general characteristics of the corpus, and the relevance of the corpus for the study of the exile. ${ }^{612}$ Different aspects of the corpus - such as marriage, scribal practices, and archival structures - have been studied in a further number of articles. ${ }^{613}$ The tablets published by Pearce and Wunsch have also been collated and their readings improved. ${ }^{614}$ Yāhūdu and the texts from its surroundings have aroused great interest, especially among biblical scholars, but no comprehensive studies have yet been published. ${ }^{615}$

The current state of affairs provides opportunities and challenges for the study of the text corpus. On the one hand, very little has been written about the texts and most of the key research questions are still to be asked and answered. Moreover, access to the unpublished texts from groups 1 and 2 has allowed me to study the majority of documents relating to Judeans, because very few Yahwistic names are attested in the texts from group $3{ }^{616}$ On the other

608 Wunsch (forthcoming). References to these texts are abbreviated as B + text number.

609 Pearce and Wunsch 2014, vii.

610 Hackl 2017, 126 n. 5; personal communication with Cornelia Wunsch and Angelika Berlejung in October and November 2015.

611 See Section 1.4.2.2.

612 Pearce 2006, 2011, 2014, 2015, 2016a; Magdalene and Wunsch 2011; Wunsch 2013.

613 Abraham 2005/2006, 2015; Bloch 2015, 2017; Waerzeggers 2015; Zadok 2015c, 2015d; Berlejung 2017a, 2017b; Hackl 2017.

614 Waerzeggers 2017; Abraham et al. 2018.

615 Short overviews of this material include Granerød 2015, 364-370; Kratz 2015, 147-153.

616 This conclusion is based on the prosopographical index of Pearce and Wunsch 2014 and on the nine group 3 texts published in Joannès and Lemaire 1996 and Pearce and Wunsch 2014. 
hand, the lack of information about the origin of the tablets and the inaccessibility of a hundred or so Bìt-Abī-râm texts hinder any attempt to study the overall archival structures of the entire corpus. Accordingly, the following discussion can only focus on the texts assigned to groups 1 and 2 , and its results will inevitably be preliminary until the rest of the tablets are published. A total of 155 texts were accessible to me and are treated in this chapter. ${ }^{617}$ If not otherwise indicated, the statistics presented below are based on my own database, which contains detailed information about these 155 texts and general information about texts 43-97 in Wunsch (forthcoming) as presented in the indices of Pearce and Wunsch 2014. ${ }^{618}$

This chapter is structured as follows. First, I explore the geographical and economic environment of the texts. Second, I discuss the archival structures of the present material and evaluate Pearce and Wunsch's division of the tablets into three neat groups. This discussion is intertwined with a study of the main protagonists of the texts, namely, Ahīqar, son of Rīmūt, Ahīqam, son of RapāYāma, and people in their circles. Finally, I address the questions of the identity, integration, and socio-economic status of Judeans in these texts.

\subsection{Geographical and Economic Environment}

\subsubsection{The Location of Yāhüdu and Našar}

Texts from Yāhūdu, Našar, and their surroundings were not recovered from controlled excavations, and thus they lack any archaeological context which would help us to locate them geographically. As shown below, the texts do not belong to one ancient archive but several groups, some of which are closely connected to each other, while others exhibit only a few weak ties with the other groups. ${ }^{619}$ However, because it appears that the texts have been traded as a group on the antiquities market and some linkage exits between the groups, it is highly probable that the texts were unearthed at a single spot somewhere in Iraq. ${ }^{620}$ Accordingly, we can legitimately speak of a corpus of texts.

Despite the lack of archaeological context, the chronological span and the geographical origin of the corpus can be studied, thanks to the Babylonian

617 In the figure above, the three pairs of duplicates $\left(\mathrm{C} 16 \mathrm{AB}, \mathrm{C}_{71} \mathrm{AB}\right.$, and $\left.\mathrm{C}_{45} \| \mathrm{A} 2\right)$ are counted as one text each.

618 A data set of the chronological distribution of the documents is available at https://doi. org/10.5281/zenodo.2661373 and a prosopographical database of people attested in Yāhūdu and its surroundings at https://doi.org/10.5281/zenodo.2654300.

619 See Pearce and Wunsch 2014, 7-9; Waerzeggers 2015, 182-186.

620 Pearce and Wunsch 2014, 9 . 
practice of recording the date and place of writing on the clay tablet. The two earliest texts of the corpus were written in a place called Âlu ša Yāhūdāya $(\mathrm{C} 1$, 20-I-33 Nbk, 572 BCE) or Āl-Yāhūdāya (B1, 7-IX-38 Nbk, 567 BCE), the 'Town of the Judeans'. Already in the last years of Nebuchadnezzar $\left(\mathrm{C}_{2}\right)$, the name of the village had changed to Yāhūdu, (the town of) 'Judah', and this name was still in use in 9 Xer (477 BCE) when the last surviving document of the corpus $\left(\mathrm{C}_{53}\right)$ was written. It is beyond doubt that the village was named after the geographic origin of its inhabitants: 34 per cent of people bear Yahwistic names in the documents written in Yāhūdu and an additional 6 per cent were related to someone bearing such a name. The practice of naming new settlements according to the geographic origin of their inhabitants is well attested in rural Babylonia, where place names such as Ashkelon, Sidon, and Neirab appear. ${ }^{621}$ The state settled foreign deportees in these twin towns in order to bring new lands under cultivation. ${ }^{622}$

A place called Ālu ša Našar ('Town of Našar') or Bīt-Našar ('House of Našar') was located in the vicinity of Yāhūdu. ${ }^{623} \mathrm{~A}$ substitute of the dēkû of Yāhūdu collected a tax payment in Našar ( $\mathrm{C}_{3} 3$ ), and a promissory note written in Našar stipulates that commodities are to be delivered in Yāhūdu (C84). Moreover, two people are attested in both places. ${ }^{624}$ Unlike Yāhūdu, Našar was not a twin town. It was both a village and an administrative estate originally held or managed by a certain Našar. This is suggested by the following evidence. First, it is clear that the toponym was named after an individual called Našar: the name is usually preceded by the determinative for masculine personal names. ${ }^{625}$ Second, the practice of governing the land-for-service sector through estates or administrative centres is well attested in the Murašu archive and other texts of the present corpus. ${ }^{626}$ Bìt-Šinqāma (C18), Ālu-ša-Ṭūb-Yāma (C8), and Bìt-Bābaēreš (C80) are good examples of this phenomenon in the vicinity of Yāhūdu and Našar.

Third, the toponym itself is written in several different ways which not only exhibit differences in orthography but also differences in usage and meaning. ${ }^{627}$ The most common form of the name is uru šá In $a$-šar (Ālu ša Našar,

\footnotetext{
621 Eph`al 1978; Dandamayev 2004.

622 Jursa 2011a, 435 .

623 Pearce and Wunsch 2014, 6.

624 Bēl-upehhir/Arad-Gula is usually attested in Našar but once in Yāhūdu ( $\mathrm{C}_{32}$ ), and Ahīqam/Rapā-Yāma is normally attested in Yāhūdu but once in Našar (C13).

625 Našar is a West Semitic name meaning 'eagle' (Pearce and Wunsch 2014, 73).

626 On estates in the Murašû archive, see Sections 5.3 and 5.4.

627 The following statistics account for the instances when the place name is readable with reasonable certainty.
} 
'Town of Našar'), which is attested - with its by-forms - 38 times, 33 times written by the scribe Arad-Gula/Nabû-šum-ukīn/Amēl-Ea. With two exceptions, the name refers to the place where the tablets were written. ${ }^{628}$ The second most common form of the name is é Ina-šar (Bìt-Našar, 'House of Našar'), which is attested twelve times, exclusively on tablets written by Arad-Gula and only as the place where agricultural produce was to be delivered. ${ }^{629}$ Eight tablets exhibit a place name that combines features from the two previous forms, uru é na-šar (Āl bìt Našar, 'Town of the house of Našar') or the like. ${ }^{630}$ This form is used by five different scribes and it always refers to the place of writing the tablet. The Canal of Našar (íd šá Ina-šar-ri) is attested once in C64.

An interesting pattern emerges when we look at the place names referring to Našar. There is no change over time, but Arad-Gula made a clear distinction between the place names Ālu ša Našar and Bìt-Našar. This can be seen in the documents in which both names are used: Bìt-Našar is always the place where agricultural produce is to be delivered, while the tablets were always written in Ālu ša Našar. ${ }^{631}$ Accordingly, Bìt-Našar appears to be an estate or local administrative centre surrounded by a village that was named after it. The deliveries of agricultural produce took place at the estate, whereas the documents were written in the village. ${ }^{632}$

The presence of twin towns in the Nippur countryside suggests that Yāhūdu and Našar may also have been located in the region. ${ }^{633}$ However, there is no conclusive evidence to confirm this suggestion. None of the texts in the corpus

628 The form uru šá Ina-šar is attested 33 times, 7 Cyr - 3 Dar, always written by AradGula except for one tablet by Niqūdu/Șillâ/Aškāpu and one by Lâbâši-Marduk/ Arad-Nabû/Sîn-imitti. There are several by-forms of this place name. Uru šá na-šar (B35, written by Nabû-ittannu/Nabû-šum-ukīn) and uru na-šar (B37, written by Arad-Gula) both refer to the place where agricultural produce was to be delivered. Other three byforms refer to the place of writing. These tablets were written by Arad-Gula, Nabû-ittannu, and Šamaš-iddin/Enlil-mukīn-apli.

629 The tablets were written in o Camb - 3 Dar. C9o exhibits a small orthographical difference, é $\mathrm{I}$ na-aš-ri. Eleven texts were written by Arad-Gula. The name of the scribe is broken in $\mathrm{C}_{5}$, but it is probably Arad-Gula.

630 There are small variations in orthography but not in meaning. The tablets were written in 12 Nbn - 3 Dar by five different scribes: Arad-Gula, Niqūdu, Mukīn-apli/Zēria, Rīmūt/ Nabû-zēr-ibni, and Šamaš-zēr-ibni/Gimillu.

$631 \mathrm{~B} 38 ; \mathrm{C}_{5}, 70,74,81,89,93$. Âlu ša Našar is also the place of delivery in $\mathrm{B}_{3} 6 ; \mathrm{C} 85,87,88,90$, but the place of writing is partially or fully broken.

632 Cf. Pearce and Wunsch 2014, 202, who suggest that the variation in the place name results from its novelty. Moreover, they seem to cautiously suggest that Našar, the father of Kalbâ in $\mathrm{C} 8$, gave his name to the homonymous village. This is speculative, as the person is not attested in any other texts.

633 Cf. Pearce and Wunsch 2014, 6-7. 
were written in Nippur or refer to the city. ${ }^{634}$ Moreover, people attested in the corpus cannot be linked to external texts and their personal names do not favour deities such as Enlil or Ninurta of Nippur. Several texts were written in Babylon, but because of the city's role as an administrative and economic centre of Babylonia, this is not an indication of proximity. ${ }^{635}$ Uruk and Sippar are not referred to in the corpus, but Borsippa is attested once as a place where Zababa-šar-ușur bought a house. ${ }^{636}$ Yāhūdu, Hursagkalamma (Kiš), and Susa are mentioned together in a list of expenses $\left(\mathrm{C}_{54}\right)$, but the document bears witness to the geographical scope of someone's economic activities, not to the location of Yāhūdu. ${ }^{637}$ Našar or Bìt-Našar is referred to in external sources as well, and they seem to point towards a location in the vicinity of Borsippa. ${ }^{638}$

Pearce and Wunsch locate Yāhūdu and Našar in 'the region to the east and southeast of Babylon, beyond the city of Nippur, delimited to the east by the river Tigris and to the south by the marshlands'.639 This suggestion is supported by several geographic names attested in the corpus. The towns of Kēš and Karkara can be located with reasonable certainty somewhere between Nippur, Uruk, and the Tigris, ${ }^{640}$ and the Kabaru canal connected Babylon and Borsippa to south-east towards Nippur and Susa ${ }^{641}$ Bìt-Amūkāni was the territory of the homonymous Chaldean tribe in Southern Babylonia. ${ }^{642}$ Joannès and Lemaire propose that Bìt-Abī-râm, one of the three main sites of the corpus, is to be located in the region south-east of Babylon. ${ }^{643}$ Moreover, the Sîn canal is well attested in the Murašû archive and located in the Nippur region; a

634 Pearce and Wunsch (2014) read lines 16-17 in C82 as ú-il-tì.meš šá ina en.líl(!) ${ }^{\mathrm{ki}}$ e-țir(!)-?, translating the sentence as 'the debt notes in Nippur are paid'. However, Waerzeggers' collation (2017) shows that the signs on lines 16-17 should be read as ú-il-tì.meš šá hal-li-qa $e$-la- $a$ ' ('the lost debt notes have shown up').

635 Pearce and Wunsch 2014, 6.

636 Personal communication with Cornelia Wunsch in October 2015; Pearce and Wunsch 2014, 313-314.

637 See Section 4.3.9.

638 Zadok 1985, 98; Waerzeggers 1999/2000, 192.

639 Pearce and Wunsch 2014, 7.

640 The town of ki-e-šú is attested in C12. According to Pearce and Wunsch (2014, 7 n. 19, 114), unpublished documents from Kēš confirm that this syllabic spelling refers to Kēš instead of Kiš. Note, however, that Hursagkalamma (Kiš) is referred to in $\mathrm{C}_{54}$ (see Waerzeggers 2017). Karkara is referred to in four unpublished documents: B59, 85, 89, 97 (Pearce and Wunsch 2014, 314). For the location of these two cities, see Adams and Nissen 1972, 52-53; Powell 1980; Zadok 1985, 195; Pearce and Wunsch 2014, 6-7 n. 18-19.

641 J7. Tolini 2011 vol. 1, 491-498.

642 B3o and probably B25 and B31 as well. Zadok 1985, 80-81; Frame 1992, 39.

643 Joannès and Lemaire $1996,5^{2-53}$. 
homonymous canal is referred to in B $47{ }^{644}$ Finally, two twin towns or related hatrus, named after the cities of Gaza and Hamath, are mentioned both in the texts from the vicinity of Yāhūdu and in the Murašû archive. ${ }^{645}$

Even though there is no evidence connecting the present corpus with the cities of Nippur or Uruk, the countryside surrounding these two cities is the most probable geographical setting for our texts. A single attestation of Borsippa and several documents referring to Babylon do not imply that Yāhūdu and Našar were located in Northern Babylonia; references to Kēš, Karkara, BītAmūkāni, the Sîn canal, Hamat, and Hazatu suggest a location in Central or Southern Babylonia. Našar itself poses a problem, because the texts published by Waerzeggers indicate proximity to Borsippa rather than to Nippur or Uruk. However, it is possible that two homonymous villages existed in different parts of Babylonia. The close linkage between twin towns and the land-for-service sector of the Babylonian agriculture is apparent both in the present corpus and the Murašu archive. This does not mean that these phenomena were not found elsewhere in Babylonia, but, as regards their content, the texts from Yāhūdu and Našar fit well into the countryside of Central or Southern Babylonia.

\subsubsection{The Land-for-Service Sector: Economic Environment of the Texts}

The texts from Yāhūdu and Našar bear witness to the land-for-service sector of the Babylonian economy. ${ }^{646}$ The system existed already in the reign of Nebuchadnezzar II and its most elaborate form is known from the Murašu archive in the second half of the fifth century вСЕ. ${ }^{647}$ In short, royal land was granted to individual landholders who in exchange had to pay taxes and perform military or corvée service. ${ }^{648}$ 'Taxes' are to be understood here in the widest sense

644 Zadok 1985, 381-382.

645 Hazatu (C101: ha-za-tu $u_{4}$ BE 10 9: ha-za-tú) is to be identified as a twin town of Gaza which is written as $h a-z a-t i, h a-a z-z a-t i$, etc. in the cuneiform texts. See Falkner 1971; Zadok 1985, 158 for the references to Gaza in the Assyrian and Babylonian sources. Eph ${ }^{\varsigma}$ al $(1978,80-82$ $+\mathrm{n} .18$ ) is somewhat vague in his discussion of Hazatu in the Nippur region and its connections to the Philistine city. Ha-mat is attested in C55-56 and ha-mat-ta in B21. Hatru ša šušānê ša Büt-Hamatāya is attested, for example, in the Murašû text BE 10 16. See Eph`al 1978, 80 + n. 17; Stolper 1985, 76; Zadok 1985, 149-150; Pearce and Wunsch 2014, 190.

646 For studies of the land-for-service sector in Babylonia, see Stolper 1985, 24-27, 52-103; van Driel 1989, 2002, 226-273; Jursa 2011a, esp. 435-437. The following discussion of the general features of the land-for-service sector is based on these studies.

647 The earliest attestation of bìt qašti ('bow land') is from $35 \mathrm{Nbk}$ (Jursa 1998b) and bìt azanni ('quiver land') from the reign of Nebuchadnezzar II (C2). On the Murašû archive, see Chapter 5 .

648 'Landholder' does not denote here the owners of the land but people to whom the state granted lands encumbered with service obligations. 
of the term: they also encompassed rent-like sütu and imittu payments in kind or silver. ${ }^{649}$ The basic unit of the system was 'bow land' (bit qašt $i$ ), which was a plot cultivated by one or more landholders and their families. ${ }^{650}$ The size of bow lands varied greatly, but the term clearly referred to a certain type of landholding burdened with service obligations. ${ }^{651}$ Ideally, the holder of a bow land was obliged to submit an archer for royal service, in the same manner as holders of 'horse land' (bìt sīsê) and 'chariot land' (bìt narkabti) were obliged to provide a horseman or war chariot, respectively. ${ }^{652}$ However, the obligations also varied, depending on the size of the landholding in question.

In the Murašu archive, bow lands were grouped together in larger administrative units called hatrus. ${ }^{653} \mathrm{~A}$ hatru consisted of several bow lands and landholders, who often shared a common ethnic or geographic background or were members of the same military or professional unit. ${ }^{654}$ Each hatru had a foreman called a šaknu and his subordinates, who ensured that the unit fulfilled its joint responsibilities and produced the required tax revenue. The word hatru is not mentioned in the documents from the environs of Yāhūdu, but this is not surprising, because the term starts to appear in Babylonian sources only in the mid-fifth century все. ${ }^{655}$ However, the related term kișru is mentioned in $\mathrm{C}_{23},{ }^{656}$ and other hatru-like structures appear in the corpus. ${ }^{657}$ Two documents from the fifth year of Darius I ( $\mathrm{C}_{4} 4$ and $\mathrm{C}_{5}$ ), both written in Yāhūdu, list imittu rents which were owed by men bearing primarily Yahwistic names. Even though ten landholders are listed in $\mathrm{C}_{14}$ and twenty in $\mathrm{C}_{15}$, only one and two men are referred to as the nominal debtors, respectively. The nominal debtors seem to appear on the list of landholders as well, which suggests that the landholders were grouped in units of ten, represented by one of their peers.

Each of the farmers in $\mathrm{C}_{14}$ and $\mathrm{C}_{5}$ held a bow land or a fraction of such, and, according to the lists, the imittu payments originated from the fields of šušānus. In the Persian period, šušānus were semi-free persons who often held bow lands and, in the Murašû archive, were incorporated in hațrus. Their legal

649 A sūtu rent was fixed in advance, whereas an imittu rent was assessed only before the harvest (Stolper 1985, 38).

650 Bìt qašti has a rare by-form bìt azanni ('quiver land'). See van Driel 2002, 237-245 (add C2, for which see Section 4.3.6.2).

651 On the size of bow lands and the number of people holding them, see Section 5.3.

652 van Driel 2002, 232-245. UCP 9/3 is an important example that these designations were not arbitrary but corresponded to concrete service obligations. See Section 5.3.2.

653 See Stolper 1985, 70-103; Section 5.3.2.

654 For a list of hațrus in the Murašu archive, see Stolper 1985, 72-79.

655 Stolper 1985, 71 .

656 On kișru, see van Driel 2002, 308-310.

657 On the question of hațrus in Yāhūdu and its surroundings, see Pearce 2011, 271-274. 
status was different from slaves, but they were apparently not free to leave the lands they held. ${ }^{658}$ The term šušānu starts to appear in the texts from Yāhūdu and its surroundings in the reign of Darius I, when it becomes a common keyword in texts referring to the royal lands cultivated by Judeans. ${ }^{659}$ The expression 'fields of the Judean šušănus' clearly refers to collective lands, which were managed within an administrative unit. These lands fell under the authority of several officials, such as the rab urâti and the governor of Across-the-River (C18-19), and the rabșāb kutalli (C24-25). ${ }^{660}$

The presence of Judean šušannus and their collective fields points towards the existence of hatru-like structures in the present corpus. Moreover, dêkûs ('tax summoners') are attested in the environs of Yāhūdu. A Judean dēk̂u is mentioned in two documents (C12; J9), and the Judean dēkû of Yāhūdu in C83. ${ }^{661}$ In the Murašu archive, dēkûs collected tax payments in hațru organisations. ${ }^{662}$ Finally, the Murašû texts make clear that there was a direct connection between several hatrus and homonymous towns or villages; some of these were named after the geographic origin of their inhabitants. ${ }^{663}$ Yāhūdu would qualify as one of the villages where the settlement of deportees and the organisation of agricultural production intertwined. In sum, it is likely that Judeans in Yāhūdu were organised in one or more hațru-like administrative units supervised by several high officials and their subordinates.

\subsection{Text Groups and Their Protagonists}

\subsubsection{Three or More Groups?}

Pearce and Wunsch (2014) divide the 103 texts into three separate groups centred around different localities. The texts in group 1 originate primarily from

658 The use of the term šušannu developed in the sixth and fifth centuries. Originally, it referred to people working with horses, but already in the Neo-Babylonian period, the word started to designate social status in addition to a profession. Only in the Persian period is the connection to a subordinate social status in the land-for-service sector apparent. See CAD Š/3: 378-380; Dandamayev 1984, 626-642; Stolper 1985, 79-82; van Driel 2002, 210-211, 232 n. 28; MacGinnis 2012, 13-14; Bloch 2017. Bloch suggests that the šušānus in the environs of Yāhūdu were dependent people who had to provide horses for the Persian army. However, there is no evidence of horse breeding or training in the texts from Yāhūdu and its surroundings.

659 See, for example, $\mathrm{C}_{15}, 18-20$.

66o These administrative structures are discussed in Section 4.3.6.4.

661 The dēkû Ia-a-hu-ú-e-dir in C12 is identical with Ia-mu-i-zi-ri in C83. See Zadok 2015d.

662 Stolper 1985, 83. See also Pearce 2011, 273-274.

663 See the list of hatru names and corresponding villages in Stolper 1985, 72-79. 
Yāhūdu, group 2 primarily Našar, and group 3 primarily Bìt-Abī-râm. As far as I see, the same division is followed in Wunsch's forthcoming volume. It is undeniable that the geographical origins of the texts roughly follow this division, but the classification does not do justice to the more complicated structures of the text corpus. ${ }^{664}$ Moreover, the division in three groups draws attention only to three protagonists - Ahīqar, Ahīqam, and Zababa-šar-ușur ${ }^{665}$ - even though the roles of certain other individuals, like the scribe Arad-Gula, are central in the corpus.

Although the provenance of the tablets is unknown, it is highly likely that they all derive from the same find-spot. There are prosopographical connections between the texts written in Yāhūdu and Našar, but the texts from BītAbī-râm also show faint links to the other groups. ${ }^{666}$ Moreover, the economic framework of all the texts is the same, namely, the land-for-service sector of the Babylonian agriculture. It is also significant that texts from all three key localities have found their way into the collections of Moussaieff, Schøyen, and Sofer. In the following discussion, I use the term 'corpus' to refer to the whole lot of 250 texts and the terms 'group' and 'archive' to refer to smaller units of texts within the corpus.

In this section, I offer a redivision of the texts in group 1 and 2 and briefly discuss the published texts relating to Zababa-šar-ușur. I argue that the texts do not belong to three ancient archives which were later brought together, but the present corpus comprises several groups of texts and a number of isolated texts. ${ }^{667}$ All the texts came into being as a result of administrative practices in the land-for-service sector and they originally belonged to several independent archives, the exact number of which cannot be reconstructed. During administrative changes or after the death of archive-holding protagonists, the texts were sorted and some of them deposited in a larger administrative archive. The present corpus consists of remnants of this archive, being documents which were disposed of when they were no longer needed. 668

664 Waerzeggers 2015, 182-186.

665 Cf. Pearce and Wunsch 2014, 7-9.

666 The connections between the texts from Yāhūdu and Našar are discussed below. For the connections between Bīt-Abī-râm and the rest of the corpus, see Pearce and Wunsch 2014, 9. Note, however, that the information provided by Pearce and Wunsch appears to be partially incorrect, because the presence of Arad-Gula and Ahīqam in Karkara is not supported by the indices in Pearce and Wunsch 2014.

667 On the archival division of the tablets, see Pearce and Wunsch 2014, 7-9; Waerzeggers 2015 .

668 Cf. Pearce and Wunsch 2014, 9. 
My division of the texts into groups or dossiers does not imply that each of the groups comprises the remnants of an ancient archive. The division is based primarily on prosopographical criteria. The groups discussed under headings $4.3 .2,4.3 .3,4.3 .4,4.3 .6 .3,4.3 .7,4.3 .8$, as well as the texts pertaining to ȘidqiYāma/Šillimu and Rapā-Yāma/Samak-Yāma under heading 4.3.6.2, are centred around one or two protagonists and, in some cases, their families. By 'protagonists', I refer to persons whose activities are documented in these texts. Texts which originate from the village where a protagonist worked are not included in the group if there is no direct connection between the protagonist and the text. Accordingly, the earliest and latest documents from Yāhūdu are not included in the Ahīqam/Rapā-Yāma group, although the majority of other documents from Yāhūdu indeed pertain to Ahīqam or his family members.

\subsubsection{Texts Pertaining to Rìmūt/Abì-ul-ìde and Rìmūt/Samak-Yāma}

Texts relating to Rīmūt, son of Abì-ul-ìde, and his namesake Rīmūt, son of Samak-Yāma, constitute a well-defined, small subgroup. The twelve texts were written between $7 \mathrm{Nbn}$ ( $548 \mathrm{BCE}$ ) and $4 \mathrm{Cyr}(534 \mathrm{BCE})$ and they are assigned to group 2 by Pearce and Wunsch. This classification seems to be based on the fact that both men were connected to Ahīqar, son of Rīmūt, the main protagonist of group 2.

Rīmūt/Abì-ul-īde is first attested with his sons Ah-immê and Ahīqam in Hamat in $7 \mathrm{Nbn}\left(\mathrm{C}_{55}\right)$ and for the last time in the very same town in 4 Cyr with his son Ah-iqmê (B21). ${ }^{669}$ Five out of seven texts relating to him (B20, 22; C55, 57, 58) concern debts in silver owed by Rīmūt alone or by him and his sons to several creditors in Hamat, Bāb-ṣubbāti, Šamahunu, and Bīt-Dibušiti. The earliest of these documents ( $\left.\mathrm{C}_{55}\right)$ concerns a harrānu venture, which, together with the predominance of silver debts in this file, suggests that Rimunt was involved in the world of business. ${ }^{670}$ This view is further corroborated by the two documents featuring his son Ah-immê alone: $\mathrm{C}_{59}$ (2 Cyr) shows that Ah-immê was involved in fish trade in Himuru, 671 and $\mathrm{C} 61$ (3 Cyr) reveals that he was a partner in a harrānu venture in Babylon. The harrānu ventures of the father and son had to do with barley, and together with $\mathrm{C}_{59}$ this indicates that they were engaged in trade in staples. The size of the two ventures was not negligible, as

669 Rīmūt/Abì-ul-ìde is attested in B2o-22; $\mathrm{C}_{55}, 57,58,83$. It is possible that Ah-iqmê was the same son as Ah-immê or Ahīqam, and the spelling Ǐšeš-iq-me- ${ }^{2}$ is a scribal mistake. See Wunsch (forthcoming), 68.

670 See Pearce and Wunsch 2014, 192. Harrānu was a common type of business partnership in the Neo-Babylonian and Persian period, which, in its most basic form, involved an investor and an agent running the business. See Jursa 2009, 53-68; 2010a, 206-214.

671 Himuru is not attested elsewhere in the corpus. 
C55 pertains to 25 shekels of silver and C61 to 75 kurru of barley and 30 shekels of silver. The retail of agricultural produce in cities was an important commercial activity in Babylonia, and it has also left traces in other texts of this corpus. ${ }^{672}$ Rìmūt and Ah-immê did not work alone, and the frequent creditors, debtors, and witnesses of their documents were most likely their business partners. ${ }^{673}$

Several details in Rīmūt's and Ah-immê's documents suggest that the landfor-service sector was the economic framework of their activities. The village of Hamat (B21; $\left.\mathrm{C}_{55}, 56\right)$ was most probably a settlement of deportees from the Syrian city of Hamath, ${ }^{674}$ and Bitqa-ša-Anu-ibni $\left(\mathrm{C}_{55}\right)$ was likely an estate named after its owner or the official in charge of it. A few Judeans are another example of deportees in these documents $(\mathrm{C} 61,83)$. Moreover, people associated with the royal administration were present when documents $\mathrm{B}_{20}$ and $\mathrm{B}_{22}$ were drafted; this is suggested by the šarru names of two witnesses and a scribe.

There is a possibility that Rīmūt/Abì-ul-īde was the father of Ahīqar/Rìmūt, the main protagonist of the texts from Našar: he witnessed Ahīqar's tax payment to the agent of the tax-summoner (dêkûu of Yāhūdu in a text written in Našar in 1 Cyr (C83). Moreover, both men were active in a place called Bābșubbāti (B22-23; C6o), and Ahīqar and Rīmūt's son Ah-immê were both involved in fish trade (B23; $\left.\mathrm{C}_{59}-60\right)$. However, there are no other prosopographical connections that would corroborate the family relationship between Rīmūt/Abì-ul-ìde and Ahīqar/Rīmūt.

The suggestion that Rīmūt/Abì-ul-īde was the father of Ahīqar is seriously complicated by the presence of a certain Rīmūt/Samak-Yāma in three texts from Hamat and Bāb-ṣubbāti in 7 (?) Nbn -3 Cyr. ${ }^{675}$ Judging by the Yahwistic name of Samak-Yāma, he was of Judean descent. The first text, $\mathrm{C}_{56} 6$, pertains to the voiding of a promissory note in Hamat owed by Rīmūt/Samak-Yāma. The date of the text is broken, but it is from the reign of Nabonidus and written by a scribe named Marduk-šum-ușur/Ṭābia. This is peculiar because Rīmūt/ Abī-ul-îde is attested in Hamat in $7 \mathrm{Nbn}$ in a document written by Mardukšum-ușur/Ṭābia/Dābibì (C55), who must be identical with the scribe in $\mathrm{C}_{5} 6$. However, the texts do not have parties or witnesses in common.

\footnotetext{
672 See Section 4.3.6.3.

673 Aqria/Mannu-likīn (B22; C57, 59), Dannâ/Šalti-il (C57, 58, 61), and Bēl-īpuš/Dannia (C58, $59,61)$.

674 Waerzeggers 2015, 190. For an account of Nebuchadnezzar II's conquest of Hamath, see $A B C$ 5: obv. 6-8.

675 B19; $\mathrm{C}_{5} 6,60$.
} 
The next attestation of Rīmūt/Samak-Yāma is found in Bāb-ṣubbāti in 11 Nbn (B19). He owed a little over 3 kurru of barley to Nabû-lēêi/Nabû-ah-iddin, who is attested as the creditor of Rīmūt/Abì-ul-īde and Ah-iqmê in B21. Nabûlêp $\mathrm{i}$ is not attested in any other text of the corpus. Moreover, in B19 the barley is to be delivered to Bitqa ša Anu-ibni, which is the place where two sons of Rìmūt/Abì-ul-ìde had to deliver their barley in C55. Another connection to $\mathrm{C}_{55}$ is the name Amurru-bēl-šamê: a certain Amurru-bēl-šamê/Dūrlāya is the investor of venture capital in $\mathrm{C}_{55}$ (7 Nbn) and Bulțâ/Amurru-bēl-šamê is the first witness in $\mathrm{B} 19$ (11 Nbn). The name Amurru-bēl-šamê is not attested elsewhere in the corpus, and it is very well possible that these two people were a father and son. Finally, the toponym Bāb-ṣubbāti connects B19 to B22, with the latter text featuring Rīmūt/Abì-ul-ìde and his son Ah-immê.

The last attestation of Rīmūt/Samak-Yāma is C6o, a promissory note for $5^{2}$ or 53 shekels of silver owed by Ibni-ilu/Kīnâ and Ahīqar/Rīmūt to Rīmūt/ Samak-Yāma in 3 Cyr. The text specifies that the silver is the price of fish. ${ }^{676}$ Except for Rīmūt and Ahìqar, the other people in the text are not attested elsewhere in the corpus. This text was also written in Bāb-ṣubbāti, which emphasises the geographical proximity of the activities of Rīmūt/Samak-Yāma and Rīmūt/Abī-ul-īde.

Rīmūt/Samak-Yāma and Rīmūt/Abì-ul-ìde operated in the environs of Hamat and Bāb-ṣubbāti in the reign of Nabonidus and during the first years of Cyrus. They are never attested in the same document, but they knew the same people, including Ahìqar, son of Rīmūt. What is more, they disappeared at the same time, some years before the well-documented period of Ahīqar's business activities in $7 \mathrm{Cyr}-3$ Dar. Rīmūt/Abì-ul-īde had at least two sons, Ahimmê and Ahīqam, whereas there is no direct evidence of the sons of Rīmūt/ Samak-Yāma. Rīmūt/Abì-ul-īde and his son Ah-immê traded in staples, but the activities of Rīmūt/Samak-Yāma are more elusive. The texts pertain to debts in silver and agricultural produce and to a sale of fish. It is striking that fish trade connects Ahīqar/ Rīmūt, Rīmūt/Samak-Yāma, and Rīmūt/Abì-ul-īde's son Ahimmê, while no other texts in the corpus refer to fish.

The texts pertaining to Rīmūt/Samak-Yāma and Rīmūt/Abì-ul-īde are like a prelude to the group of texts featuring Ahīqar/Rìmūt, who is frequently attested from 7 Cyr onwards but together with the two Rīmūts already in 1 and 3 Cyr. The localities where the two namesakes worked vary significantly from the geographical environment of the Ahīqar texts, although Hamat and Bābșubbāti could not be located far away from Našar, the centre of Ahīqar's activities. Two early texts (B23; C6o) show that Ahīqar also participated in fish trade

676 See Waerzeggers 2017. 
in Bāb-ṣubbāti, but the focal point of his activites shifted quickly away from this region after $7 \mathrm{Cyr}$ and fish trade is not mentioned in the Ahīqar texts anymore. Other texts in the whole corpus do not pertain to the localities attested in this group.

Ahìqar helps to connect these texts to the rest of the corpus, and it is possible that either Rīmūt/Samak-Yāma or Rīmūt/Abī-ul-īde was his father. This question cannot be settled on the grounds of the available evidence, ${ }^{677}$ and it cannot be ruled out that the two Rìmūts were not just namesakes but one and the same individual whose father was known by two different names. This suggestion remains speculative, and it is safer to assume that we are dealing with two different men who were both working in the same region and with the same people. On the archival context of these texts, see Sections 4.3.5 and 4.3.10.

\subsubsection{Texts Pertaining to Ahìqar, Son of Rìmūt}

Ahīqar, son of Rīmūt, is attested in 54 texts of the corpus. ${ }^{678}$ He was of Judean descent, which becomes apparent in the Yahwistic name of his son Nīr-Yāma, attested in only two documents $\left(\mathrm{B}_{27}, 88\right) .{ }^{679}$ The focal point of Ahīqar's activities was the village of Našar, located in proximity to Yāhūdu. Ahīqar was attached to the Judean community of Yāhūdu, at least from an administrative perspective, as he was liable for paying taxes to the dēkû official of that village (C83). His tax payments to dèkûs (C83; J9) also suggest that he held a bow land or a similar landholding, but the bulk of the texts show him actively expanding his activities into agricultural management. This business took place outside the Judean community, and very few texts pertain to his interaction with other Judeans. ${ }^{680}$

The evidence of Ahìqar spans over twenty-three years, from the first year of Cyrus ( 538 BCE) until the seventh year of Darius I ( 515 BCE). However, the chronological distribution of the preserved documents is not even: after two stray texts in 1 and $3 \mathrm{Cyr}, 24$ texts are dated in $7 \mathrm{Cyr}-5 \mathrm{Camb}$. As is the case in the whole corpus, no texts survive from $6-7$ Camb, but a significant number of 24 texts can be assigned to o Bar -3 Dar. After a break of three years, one stray

677 Cf. Pearce and Wunsch 2014, 191, who suggest that Rīmūt/Samak-Yāma was Ahīqar's father. Judging by the name of Ahīqar's son Nīr-Yāma, Ahīqar was of Judean descent, but this does not necessarily mean that his grandfather bore a Yahwistic name.

678 The relevant texts are B23-25, 27-40; C6o, 62-63, 66-79, 81-83, 85-10o; J9.

679 Pearce and Wunsch 2014, 9, 287.

680 Other Judeans than Ahīqar's family members are certainly attested only in seven documents: B29, 34; C76-77, 83, 96; J9. If Šá- '--me-eh is a hypocoristic of Šamā-Yāma (see Pearce and Wunsch 2014, 83), we should add C62-63. 


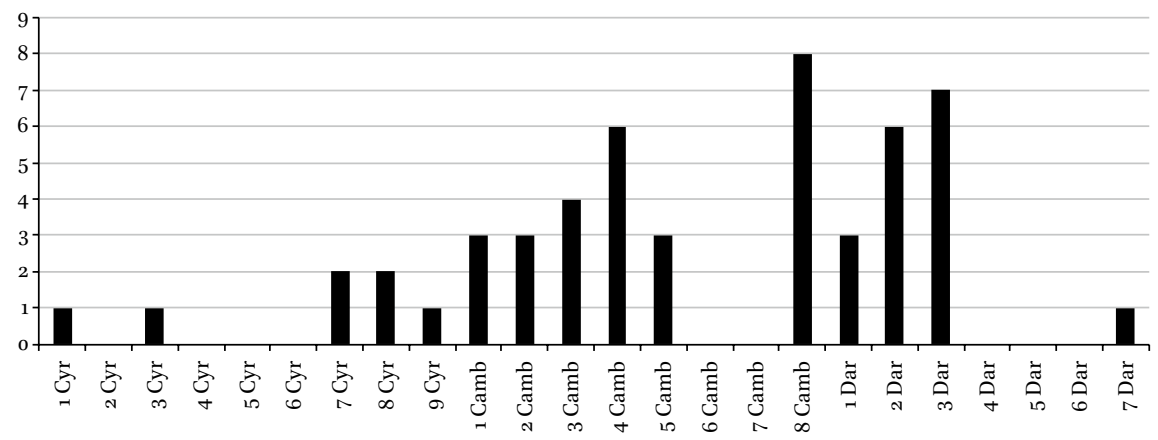

FIGURE 1 Documents pertaining to Ahīqar

text is dated in 7 Dar. The chronological distribution of these texts is shown in Figure $1 .{ }^{681}$

Ahīqar's business activities resulted in three major types of documents: promissory notes, leases of land, and contracts related to cattle and plough teams. They bear witness to the main features of his business portfolio, namely, granting credit and agricultural management. His clients were farmers in the land-for-service sector, often of non-Babylonian origin, who were in need of credit or who wanted to outsource some of their tax and service obligations. Contracts or business transactions between Ahīqar and royal officials are absent from the corpus, but this does not necessarily mean that Ahīqar ran his business without the blessing of the local authorities.

More than half of the texts pertaining to Ahīqar are promissory notes, but the origin of the debts is hardly ever made explicit. ${ }^{682}$ They are evenly distributed over time, and the debts are almost always owed to Ahìqar, who sometimes has co-creditors. The debts are mostly in barley and dates, and several times they include a silver component as well. The produce was normally obtained from the fields and gardens of the debtors, and the due date for the debts was either in the second month after the barley harvest or in the seventh month after the date harvest. Unlike the documents pertaining to Ahīqam/ Rapā-Yāma (see Section 4.3.6.3), these promissory notes cannot be directly connected to leases or subleases of royal lands. There is only one uncertain attestation of an imittu rent (C68), and in all extant four leases of land, Ahīqar

681 The figure shows 51 tablets that can be dated to a certain year. B32 is likely to be dated in the reign of Cambyses or Bardiya, $\mathrm{C}_{5}$ in ${ }^{-1} 5$ Camb, and $\mathrm{C}_{90}$ in the accession year of Darius.

682 There are 32 promissory notes owed by or to Ahīqar: B23, 30-39; C6o, 63, 66, 68, 70-74, $81-82,85^{-94}$. 
was the lessee. Therefore, it appears that the promissory notes reflect real credit granting and agricultural management instead of rent farming.

There is strong evidence that Ahīqar granted credit to landholders in order to help them pay their taxes. Three promissory notes for dates and barley from the troubled early years of Darius I explicitly refer to the underlying reason for the debt: Ahīqar had lent landowners silver for their șāb šarri tax payments, and the repayment was to be made in staples after the harvest. ${ }^{683}$ We may suppose that the circumstances behind some other promissory notes for dates and barley were similar, even though the reason for the debt is not made explicit. It is noteworthy that all the three șāb šarri payments were made during a period of political instability in $5^{22-520 ~ B C E}$, when Bardiya, Darius, and Nebuchadnezzar III and IV fought over the throne of Babylon. ${ }^{684}$ Moreover, the number of documents pertaining to Ahīqar in general peaks between 1 Bar and 3 Dar. When we analyse all the debts owed to Ahīqar, we notice that over a third of the promissory notes (14) refer to outstanding debts and six to property that was pledged to secure the repayment. ${ }^{685}$ The abundance of promissory notes in the creditor's archive indicates that they were unpaid, bad debts. ${ }^{686}$

The large number of bad debts indicates that local farmers in Našar had difficulties in managing the tax burden, especially during the accession wars after the death of Cambyses. Ahīqar was able to provide landholders with a service that was important for them for two reasons. On the one hand, Ahīqar had the necessary capital already available when the farmers were still waiting for the next harvest; on the other hand, Ahīqar had access to silver that was needed for tax payments. Even though there is no direct evidence of beer brewing or retail of produce in Ahīqar's archive, such activities were a necessity to convert the payments in staples into silver. ${ }^{687}$ In 3 Dar, Ahīqar invested 32 shekels of silver in a harrānu venture, but the nature of this business enterprise remains unknown (C97).

683 The relevant documents are C73 (o Dar), C86 (1 Nbk IV), and C91 (2 Dar). The term șāb šarri ('troops of the king') refers to a military or service obligation and its compensation in silver. See van Driel 2002, 245-246.

684 On this turbulent period, see Briant 2002, 107-128; Lorenz 2008; Beaulieu 2014; Bloch 2015.

685 Previous, unpaid debts: $\mathrm{B}_{32-33}$, 35, 38-39; $\mathrm{C} 63$, 70-74, 82, 92-93; pledged property: C66, 70-73, 92 .

686 In Babylonia, promissory notes were to be destroyed or given to the debtor after the debt was settled. Accordingly, the large number of promissory notes in the creditor's archive may indicate bad debts, even though creditors are also known to have preserved copies of settled debts (Wunsch 2002, 222; Jursa 2005a, 42). In the case of Ahīqar, nothing suggests that the promissory notes were mere copies instead of unsettled, bad debts.

687 Jursa 2010a (216-224) gives examples of this phenomenon in other contemporary archives. 
Occasionally, the strained economic situation of small farmers allowed Ahīqar to gain control of their landholdings. Plots were pledged to secure debts or they were leased to Ahīqar on terms that were disadvantageous to the landholders. Three documents pertaining to Aqria and Rīmūt, sons of Ammu, exemplify this side of Ahīqar's business. In 5-VIII-3 Camb, the scribe Arad-Gula wrote a promissory note and two leases in Našar. Promissory note C66 concerns a significant debt of 8 kurru of barley and 20 kurru of dates owed by Aqria to Ahīqar. It was supplemented by a stipulation that Aqria's share in a jointly held bow land be pledged to secure the payment. This information helps us to put the leases of bow lands (B24 and $\mathrm{C}_{7}$ ) in their proper context. Even though Ahīqar acted formally as a lessee in these documents and the produce was to be shared equally between the lessee and the lessors (Aqria in B24 and Rīmūt in C67), it is unlikely that the sons of Ammu entered into these contracts voluntarily. To pay back his outstanding debts, Aqria had to lease his bow land to Ahīqar, who probably enjoyed his half-share of the produce when the landholder himself still had to work on the field. It is likely that Rīmūt's decision to lease his landholding to Ahīqar was dictated by similar circumstances.

Pledges and leases of land formed another crucial aspect of Ahīqar's economic activities, namely, agricultural management. Tax payments and service obligations were not the sole economic challenge which landholders faced: they also had to cope with the high costs of setting up plough teams to cultivate their fields efficiently. ${ }^{688}$ This offered business opportunities for entrepreneurs who had the capital to buy oxen and equipment. Several documents in Ahīqar's archive relate to oxen and to the formation of plough teams, suggesting that this type of agricultural management played an important role in his work. ${ }^{689}$ By acquiring land through pledges and leases, Ahīqar was able to control more extensive landholdings and take full advantage of the plough teams at his disposal.

The economic framework of Ahīqar's activities is relatively clear. He profited from the opportunities offered by the land-for-service sector by granting credit to small landholders to help them pay their taxes or hire a substitute to

688 On tax burdens and credit in the land-for-service sector, see Stolper 1985, 104-107; van Driel 1999, 219-220; Jursa 2011a, 435-437. On the costs of plough teams and oxen, see Stolper 1985, 125-143; Wunsch 2013, 254-257, the latter with a discussion of some relevant Yāhūdu texts as well.

689 B25, 27-29; $\mathrm{C}_{75}-79$. See also B26, a contract for sharing two heifers, which can be connected to the rest of the corpus only via Našar, where it was written. As suggested by Wunsch (forthcoming, 80), this document may have ended up in the corpus as a result of Ahīqar's later purchase of these animals. 
perform service obligations. The landholders did not always manage to pay back the debts, which is demonstrated by the large number of promissory notes - unpaid, bad debts - in Ahīqar's file. If a landholding had been pledged to secure the bad debt, Ahīqar was able to profit from the landholder's bankruptcy and take possession of the pledged property. By pooling pledged and rented plots and forming plough teams, Ahìqar was able to efficiently cultivate large tracts of land. The activities of Ahīqar are similar to the business model of the Murašû family from fifth-century Nippur, although on a smaller scale. Landholders had to pledge their fields and gardens to secure the debts issued by the Murašuss, and if they did not manage to pay back their debts, they ended up cultivating their own plots as tenants of their creditor. ${ }^{690}$

Ahīqar did not work alone, as a number of colleagues regularly appear in his transactions. For example, Milkâ, son of Šalāmān, is attested in twelve documents, covering the whole period of Ahīqar's high activity (7 Cyr -3 Dar). ${ }^{691}$ He features as Ahīqar's co-creditor and co-lessee, surety, and witness to his transactions. Šili/Aia-abī witnessed Ahīqar's transactions five times (B27; C70, $87-88,90)$ and is once attested as his debtor (C94). Šalāmān/Bušêa formed a plough team together with Ahīqar and a third partner in $\mathrm{C}_{75}$, and only three months later he owed over 22 kurru of barley and 14 kurru of dates to Ahīqar and Milkâ $\left(\mathrm{C}_{74}\right)$. Taking these two transactions together, it seems to me that he was more likely a colleague than a client or tenant of Ahīqar. ${ }^{692}$

Ahīqar's family plays a small role in the extant documents: his wife Bunnannitu is attested only once in the seventh year of Cyrus (J9), when she paid her husband's $i l k u$ tax to a Judean tax-summoner (dēkû). Ahīqar's son NīrYāma features in two documents. A judicial document from the second year of Darius I (B27) relates to litigation over oxen. Because Nabû-bēl-ilì//Na ${ }^{3} \mathrm{id}-\mathrm{ilu}$ charged both Ahīqar and Nìr-Yāma in the lawsuit, it is obvious that the father and son had a shared interest in the oxen. Accordingly, Nīr-Yāma played a role in his father's business, but no more evidence of this collaboration survives. Nìr-Yāma is attested without his father in 25 Dar (B88); this tablet connects him to the entourage of the royal official Zababa-šar-ușur. ${ }^{693}$ In addition to Ahīqar's wife and son, his father may be attested in the corpus as well. As

\footnotetext{
690 See Chapter 5 .

691 B23, 30-31, 35; C62-63, 74, 77-78, 82, 90, 97. Wunsch (forthcoming, 90-91) suggests that Milkâ might have been a son of Šalāmān, the brother of Ahīqam/Rapā-Yāma. However, this suggestion is not corroborated by any direct evidence.

692 Cf. Pearce and Wunsch 2014, 216.

693 Pearce and Wunsch 2014, xli, 287. On Nīr-Yāma's connection to Zababa-šar-ușur, see Section 4.3.8.
} 


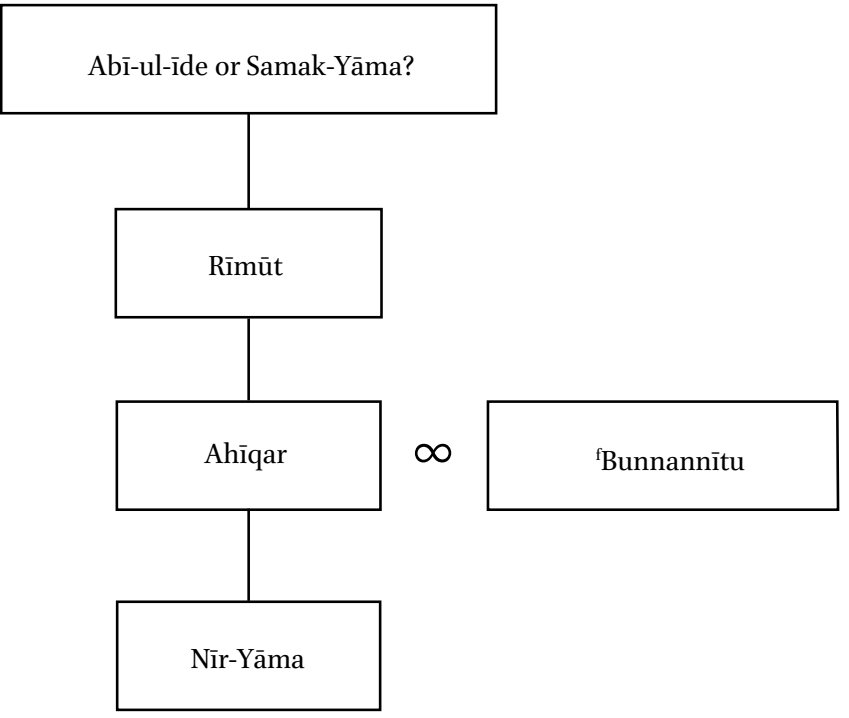

FIGURE 2 The family of Ahīqar

discussed in the previous section, Ahīqar was possibly the son of Rīmūt/Abīul-ìde or Rīmūt/Samak-Yāma.

Ahìqar's family tree (Figure 2) bears witness to the fluidity of the namegiving practices of this Judean family. Even though Ahīqar's own name was non-Yahwistic and his father and wife bore Akkadian names, he chose to give a Yahwistic name to his son. This is an important reminder that names are notoriously difficult markers of identity and, in many cases, West Semitic and Babylonian names hide the Judean background of their bearer.

\subsubsection{Texts Pertaining to Bēl-ahhē-erība, Son of Nūr-Šamaš}

All of the documents written in Našar cannot be connected to Ahīqar, and three documents $\left(\mathrm{C}_{4}-65,84\right)$ pertaining to the activities of Bēl-ahhē-erība, son of Nür-Šamaš, comprise a small, distinct dossier. ${ }^{694}$ The documents were written in Našar between 3 Cyr and 3 Camb by the scribe Arad-Gula/Nabûšum-ukīn/Amēl-Ea, and their contents resemble the Ahīqar texts. Two texts are promissory notes for small amounts of agricultural produce: one is issued by Bēl-ahhē-erība (C65) and another is issued by his brother Bēl-uṣuršu and witnessed by him (C84). Finally, in C64 Bēl-ahhē-erība leases the landholding of a certain Ahu-lèti to a third man. The lessee was supposed to work on the field and the landholder of the field to fulfil the $i l k u$ (tax or service) obligations

694 Waerzeggers 2015, 184-185. 
and maintain the dam of the field. It appears that Bèl-ahhē-eriba held the plot at his disposal and was able to lease it out under conditions that were favourable to him but disadvantageous to the landholder. Given the promissory notes issued by Bēl-ahhē-erība and his brother, it is very well possible that Bēl-ahhēeriba held the land as a pledge.

\subsubsection{Scribes and Royal Administration in Našar}

The dossiers of Bēl-ahhē-erība and Ahīqar are similar: both men worked in Našar, issued credit to landholders, and managed pledged landholdings. Like many such documents in the Ahiqqar dossier, the two promissory notes issued by Bēl-ahhē-erība and his brother may represent unpaid, bad debts. Moreover, the two men had clients in common. Šum-iddin/Șillâ, Bēl-ahhē-erība's debtor in $\mathrm{C}_{5}$, is Ahīqar's debtor in $\mathrm{C} 90$ and witness to another promissory note C89. Bēl-uṣuršu's debtor Banā-Yāma/Nubâ (C84) may be attested as a witness to Ahīqar's ilku payment in J9. ${ }^{695}$ However, Bēl-ahhē-erība and Ahīqar are never attested together and nothing suggests that they were business partners or members of the same family.

In addition to the documents pertaining to Ahīqar and Bēl-ahhē-erība, five more texts written in Našar belong to the corpus. Two of them $\left(\mathrm{B}_{42} ; \mathrm{C}_{13}\right)$ can be linked to the family of Ahīqam/Rapā-Yāma (see Section 4.3.6.3). A contract for sharing cows (B26, $4 \mathrm{Camb})$ probably entered the corpus as a retroacta - that is to say, a text that documents the ownership history of a piece of property. Because Ahīqar regularly acquired oxen to form plough teams, this document probably relates to his businesses. ${ }^{696}$ Two documents can be connected to the corpus only via the scribes who wrote them. $\mathrm{B} 41$ ( $7 \mathrm{Cyr}$ ) is a receipt of a house rental payment from the scribe Niqūdu/Șillâ/Aškāpu (see below) to a certain Ubārāia/Nabû-dalā. Although Ubārāia was Ahīqar's debtor ten years later in C86 (1 Nbk IV), it does not seem likely that the receipt belongs to the Ahĩqar dossier. B18 (12 Nbn) is a receipt for $6 \frac{1}{2}$ shekels of silver, supplied perhaps as provisions. ${ }^{697}$ The scribe Rīmūt/Nabû-zêr-ibni is probably attested in B22 (8 Nbn), a text pertaining to Rīmūt/Abì-ul-īde. ${ }^{698}$ However, the text B18 seems to be unconnected to Rīmūt/Abì-ul-īde's activities.

The most important connection between Ahīqar and Bēl-ahhē-erība is the scribe Arad-Gula/Nabû-šum-ukinn/Amēl-Ea ${ }^{699} \mathrm{He}$ wrote all the documents

695 The second witness in J9 is Bānia/Nubâ. The name is perhaps a hypocoristic of BanāYāma. See Pearce and Wunsch 2014, 43, 230; Pearce 2015, 22-23.

696 Wunsch (forthcoming), 8 o.

697 Ina šu-șú-bu-ut-ti(!)-šú. See Wunsch (forthcoming), 62.

698 Wunsch (forthcoming), 63 .

699 Waerzeggers 2015, 184-185. 
pertaining to Bēl-ahhēereiba and 38 out of $54(70 \%)$ documents pertaining to Ahīqar. Four of the Ahīqar texts were written by Niqūdu/Șillâ/Aškāpu and each of the rest of the documents by a different scribe. ${ }^{700}$ The earliest attestation of Arad-Gula is in the Bēl-ahhē-eriba text C64 (3 Cyr); after a gap of four years, he is attested again in two documents pertaining to Ahīqar (B23; J9) and in a document pertaining to Ahīqam/Rapā-Yāma, the central figure of the texts from Yāhūdu ( $\left.\mathrm{C}_{3}\right)$. From then on, Arad-Gula and Ahīqar are attested together for the whole active period of the latter's career until 3 Dar. After Arad-Gula wrote his last document for Ahīqar in 10-XI-3 Dar (C97), both men are attested only once. The last text pertaining to Ahīqar was written by Niqūdu/Șillâ/ Aškāpu, probably in Našar in 7 Dar (C94). Arad-Gula features for the last time in Babylon in 4 Dar, together with Ahīqam/Rapā-Yāma (B5).

Arad-Gula wrote almost all of his documents to three men: Ahīqar, Bēlahhē-erība, and Ahīqam. A single text pertains to Ahīqam's brother Šalāmān (C8o, Bìt-Bāba-ēreš, 2 Dar) and another text to the slave woman Nanâ-bihī, who was later acquired by Ahīqam (B42, Našar, 5 ? Camb). ${ }^{701}$ According to the available texts, Ahīqar, Ahīqam, and Bēl-ahhē-erība never dealt with each other, but Arad-Gula wrote documents for all of them. Moreover, Arad-Gula's son Bèl-upehhir was connected to all the three men. He witnessed the transactions of Ahīqar (C75-76, 92, 97), Bēl-ahhē-erība (C65, 84), Ahīqam (C13), and Ahīqam's son Nīr-Yāma $\left(\mathrm{C}_{32}\right)$.

Arad-Gula's activity was centred in Našar, where he wrote all his documents except for three texts written in Bït-Bāba-ēreš (B34, 39; C80) and one in Babylon (B5). The scribe Niqūdu also wrote his documents for Ahīqar in Našar, and only four Ahīqar documents were written in Našar by a scribe other than AradGula or Niqūdu. When Ahīqar travelled outside Našar, the documents were predominantly written by other scribes.

Before drawing any conclusions about Arad-Gula's role in Našar, it is necessary to focus on the scribe Niqūdu/Șillâ/Aškāpu. He wrote only five documents in Našar, but the chronological distribution is very different from the texts written by Arad-Gula: Niqūdu wrote both the first and the last tablet pertaining to Ahīqar in 3 Cyr and 7 Dar $\left(\mathrm{C}_{3}, 94\right)$. In between, he wrote two tablets for Ahīqar in the fifth year of Cambyses (B29; C99), as well as an additional fifth tablet (B41, 7 Cyr) which records Niqūdu's house rental payment to a certain

700 The name of the scribe is broken in $\mathrm{C}_{5} 5$ and the text is not included in the numbers above. However, it was probably written by Arad-Gula as well. See Pearce and Wunsch 2014, 231.

701 The text probably came into the disposal of Ahīqam when he later bought the slave woman. She is listed among the business assets in the inheritance division $\mathrm{C}_{45} \| \mathrm{A} 2$. See Wunsch (forthcoming), 116. 
Ubārāia/Nabû-dalā, Ahīqar's debtor in C86 (1 Nbk IV). All tablets written by Niqūdu were drafted in Našar, ${ }^{702}$ but, except for Ahīqar, no one is attested more than once in these five texts. Whereas the majority of documents written by Arad-Gula are promissory notes, Niqūdu wrote a variety of different text types. They include a promissory note (C94), two receipts of house rental payments (B41; C99), a sale of an ox (B29), and a receipt of tax payment (C83).

Arad-Gula's central role in the text group is further emphasised by the observation that the break in Ahīqar texts after 3 Dar and Arad-Gula's disappearance after 4 Dar seem to be related. The break does not result from Ahìqar's death or retirement, because he is still attested in a single text in 7 Dar as a creditor of his business partner Šìli/Aia-abī (C94). It is also unlikely that Ahīqar or his son Nīr-Yāma sorted out the archive and disposed of useless tablets after 3 Dar: some recently bought oxen were still alive and the promissory notes for unpaid debts were still valuable. The break after 3 Dar seems to be related to administrative changes in the land-for-service sector. Arad-Gula is attested for the last time in 4 Dar, together with Ahīqam/Rapā-Yāma in Babylon. Ahīqam's peak activity in the environs of Yāhūdu started immediately after this, but his dossier attests to a very different organisational landscape and administrative structures in the land-for-service sector than any previous documents of the corpus (Section 4.3.6.3). This linkage between Ahīqar, Ahīqam, Arad-Gula, and administrative changes suggests that it was not only private business activity which connected the three men. ${ }^{703}$

As I argued in Section 4.2.1, the way Arad-Gula uses the place names BitNašar and Âlu ša Našar relates to a distinction between an administrative estate and the village surrounding it. It is noteworthy that the deliveries of produce owed to Ahìqar systematically took place at the estate, often specifically at the gate of the storehouse. Even if the produce ended up in Ahìqar's hands and he was a businessman in the sense that he worked for his own profit, it appears that his transactions were supervised by the local administration. It is hard to escape the conclusion that Arad-Gula was also a part of the administrative bureau at Bìt-Našar rather than just a scribe who offered his services to local farmers and businessmen. ${ }^{704}$ This is supported by Arad-Gula's structural role in the corpus and by his strong presence in the texts pertaining to Ahīqar. Arad-Gula works as a hinge between the Ahīqar and Bēl-ahhē-erība dossiers, on the one hand, and the Ahīqar and Ahīqam dossiers on the other. During his

\footnotetext{
702 One should most probably restore 'Našar' in C94 (Pearce and Wunsch 2014, 240).

703 This discussion on the archival structures of the text corpus will be elaborated in Section 4.3.10.

704 Waerzeggers 2015, 187; but cf. Berlejung 2017a, 26-27.
} 
active career in Našar, Arad-Gula recorded and supervised Ahīqar's transactions with farmers in the land-for-service sector. Although five different scribes wrote documents relating to Ahīqar in Našar, their role was different from that of Arad-Gula: four scribes each wrote only a single document relating to Ahīqar. ${ }^{705}$ The scribe Niqūdu wrote texts in Našar before and after Arad-Gula, but the text types are different from those written by Arad-Gula. The single promissory note written by Niqūdu to Ahīqar in 7 Dar post-dates all Arad-Gula texts, and the three other documents which he wrote to Ahīqar comprise receipts for tax and house rent payments $\left(\mathrm{C}_{3}, 99\right)$ and the sale of an ox (B29). The three latter texts pertain to Ahīqar's business transactions but not to his dealings with farmers in the land-for-service sector. Although other scribes were present in Našar, Arad-Gula had a special administrative role in the village and estate.

The texts from Našar are something more complex than the remnants of the private business archive of Ahīqar. The Bēl-ahhē-erība dossier does not look like an annex to Ahìqar's archive, a number of texts which found their way into the main archive through marriage or a business partnership. Although the business profiles of the two men are similar, they are not connected by a family relationship or by common business partners but by the scribe Arad-Gula and his son Bēl-upehhir. The relationship between Rīmūt/Abì-ul-ìde and Rīmūt/ Samak-Yāma is equally complicated: there is no direct connection between the two and it is hard to imagine how the texts would comprise a single private archive. At the same time, the two men knew the same people and worked in the same villages. It is striking that the scribe Nabû-êtîr/Niqūdu, who wrote two tablets for Rīmūt/Abì-ul-ìde and his son Ah-immê in Bìt-Dibušiti in 14 Nbn $\left(\mathrm{C}_{57-58)}\right.$, travelled together with Ah-immê to Babylon in 3 Cyr (C61). It appears that scribes from rural villages were regularly present when people from the countryside travelled to Babylon.

Ahīqar's transactions highlight only one side of his activities, namely, his interaction with landholders and business partners. However, the state administration supervised and authorised his undertakings, although this is not immediately visible: official titles and explicit administrative structures are absent from the texts. In any case, Ahīqar was working in the land-for-service sector, which was primarily designed to serve the economic interests of the state. He was among the people who were needed to keep the land-for-service sector running, fields cultivated, and tax payments flowing to the coffers of the empire. It may well be that Ahīqar was working for his own profit, but within

$705 \mathrm{~B} 35,40 ; \mathrm{C} 63,86$. 
the limits of royal control. Ahīqar's clients had to deliver their produce at the estate of Našar, and it seems that Arad-Gula not only wrote documents for Ahīqar but actually supervised his and his clients' activities. This is suggested by Arad-Gula's omnipresence in Našar and his structural role as a link between several dossiers of the text corpus from Yāhūdu, Našar, and their surroundings. At the same time that Arad-Gula disappears from the corpus in 4 Dar, the recorded activity of Ahīqar ceases and the focal point of the corpus turns to Yāhūdu and to a completely different administrative landscape.

The personal history of Ahīqar's son Nīr-Yāma further emphasises the importance of the state administration in the genesis of the present text corpus. He is attested only twice, for the first time together with his father in 2 Dar (B27) and for the last time in $25 \mathrm{Dar}$ (B88). The latter document relates to the entourage of the royal official Zababa-šar-ușur, the key figure in Pearce and Wunsch's group $3 \cdot{ }^{706}$

The dossiers pertaining to Rīmūt/Abì-ul-īde, Rīmūt/Samak-Yāma, Ahīqar, and Bēl-ahhē-erība do not easily fit into a single private archive. Even if one of the two Rīmūts was Ahīqar's father, the texts pertaining to another Rīmūt and Bèl-ahhē-eriba would remain strangely unconnected to the protagonists of the archive. All these texts originate, however, in the context of the land-for-service sector. The recording of transactions was an efficient means of controlling the rural population in the land-for-service sector, and it is probable that the origins of the present corpus are to be found in the workings of the local administration. I will return to these questions in Section 4.3.10.

\subsubsection{Texts Relating to Yāhūdu}

4.3.6.1 General Remarks

The village of Yāhūdu ('Judah') is attested from the thirty-third year of Nebuchadnezzar II (572 BCE) until the ninth year of Xerxes (477 вCE). The texts written in the village can be chronologically divided into two groups. The earlier one covers the years $33 \mathrm{Nbk}-5 \mathrm{Cyr}$, whereas the main group concerns 4-15 Dar, followed by a small number of related documents. The majority of the texts pertain to the activities of three generations of a Judean family. RapāYāma/Samak-Yāma, his son Ahīqam, and his five grandsons are attested in Yāhūdu and its surroundings from the first year of Amēl-Marduk until the thirty-fourth year of Darius I (561-488 вСE). Rapā-Yāma is frequently attested in the early Yāhūdu group, whereas Ahīqam and his sons are central figures in

706 See Section 4.3.8. 


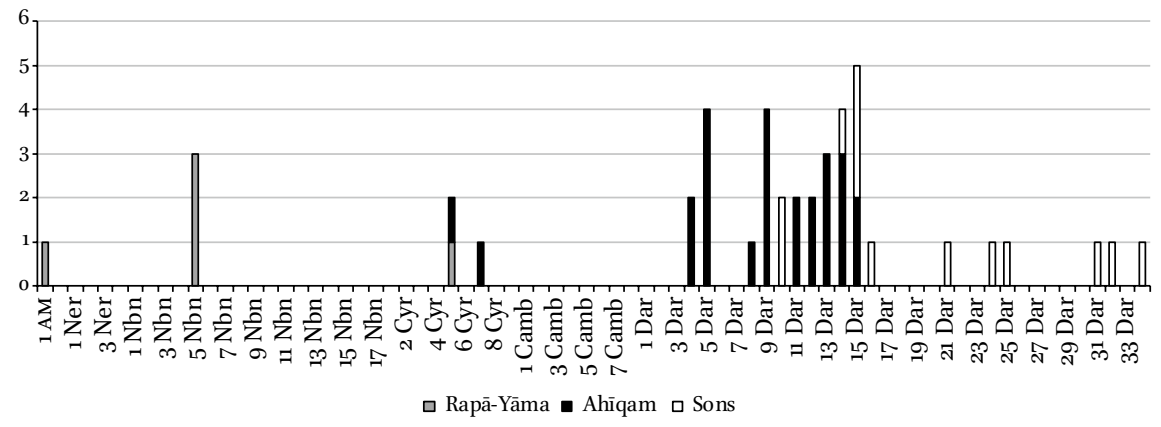

FIgURE 3 Documents pertaining to Rapā-Yāma, Ahīqam, and Ahīqam's sons

the main Yāhūdu group. Figure 3 shows the chronological distribution of the texts pertaining to Rapā-Yāma, Ahīqam, and Ahīqam's sons..$^{707}$

Despite the centrality of Ahīqam's family, the texts from Yāhūdu cannot simply be characterised as their private archive. Although part of the documents may fit this description, a number of texts from the reign of Darius I appear to belong to an administrative archive. Moreover, a number of other texts written in Yāhūdu, including the two earliest documents from the reign of Nebuchadnezzar II and the latest document from the reign of Xerxes, are difficult to connect to the family of Ahīqam.

\subsubsection{2 $\quad$ Early Texts Relating to Yāhūdu}

The earliest texts from and relating to Yāhūdu do not constitute a homogenous group. Instead, they can be classified into two categories. First, the majority of the documents pertain to two Judeans, Rapā-Yāma/Samak-Yāma and ȘidqīYāma/Šillimu, who lived and worked in Yāhūdu in the late Neo-Babylonian and early Persian periods. They were colleagues or relatives who held plots of land in the land-for-service sector, and many texts document their interactions with state officials. Second, four documents are not related to these two Judeans, but they originate from Yāhūdu. Two texts can be connected to the rest of the corpus via the scribe Nabû-na'id or Nabû-nāșir, son of Nabû-zēriqī̌sa, but the remaining two are difficult to link to any other text. Finally, two

707 The figure only includes those documents which can be dated to a certain year. Two documents are excluded: C46, in which Nīr-Yāma/Ahīqam rents a house in Yāhūdu, should be perhaps dated roughly to 25 Dar, and C39, a promissory note owed by Haggâ/Ahīqam, to 32 Dar. For the date of $\mathrm{C}_{39}$, see Pearce and Wunsch 2014, 162. There are three documents in which both Ahīqam and one or more of his sons are attested together. Of these texts, $\mathrm{C}_{25}$ and $\mathrm{C}_{29}$ are classified as Ahīqam texts and $\mathrm{C}_{30}$ as a text pertaining to his sons. 
early attestations of Ahīqam in 5 and 7 Cyr are discussed in the following section, together with other tablets pertaining to him.

The two earliest texts of the corpus, $\mathrm{C} 1$ and $\mathrm{B} 1$ ( 33 and $38 \mathrm{Nbk}, 572$ and 567 ВСE, respectively), were written in the village while it was still called $\bar{A} l-$ Yāhūdāya ('the Town of the Judeans'). The name Āl-Yāhūdāya and the wealth of Yahwistic names borne by its population testify to the origin of the village as a settlement of Judean deportees. Given the existence of the village already in $33 \mathrm{Nbk}$, it is likely that the deportees were settled in the countryside right after Nebuchadnezzar's deportations in the early sixth century. The characteristic structures of the land-for-service sector were also present from early on: $\mathrm{C}_{2}$ (the late reign of Nebuchadnezzar II) refers to the büt azanni of Șidqi-Yāma/ Šillimu. Bìt azanni ('quiver land') is a rare by-form of bït qašti ('bow land'). ${ }^{708}$

The text $\mathrm{C} 1$ pertains to the delivery of barley and perhaps some other agricultural produce in $33 \mathrm{Nbk}$. It is an administrative document rather than a private transaction, as the obliged person Šum(?)-[...]/Giddâ was a messenger of a sēpiru. ${ }^{709}$ Although the title sēpiru is commonly translated as 'alphabetic scribe', the available sources make clear that seppirus were not mere scribes but officials of various ranks. ${ }^{710}$ Despite frequent attestations of seppirus in the Murašu archive, $\mathrm{C} 1$ is the only tablet in the present corpus which refers to these officials. The recipients Nergal-iddin and Nabû-zēr-ukīn in C1 were perhaps officials as well. They bear Babylonian names and their patronymics are not mentioned, implying that they were so well known in Yāhūdu that more specific identification was not needed. The administrative nature of the document is also corroborated by its relationship to the rest of the corpus. The protagonists or witnesses are not attested in other documents, but the scribe Nabû-na'id/Nabû-zēr-iqiša also wrote the texts $\mathrm{C}_{3}, \mathrm{C}_{4}$, and $\mathrm{C}_{10}$ under the name Nabû-nāșir. He presumably changed his name upon the accession of King Nabonidus (Nabû-na'id) in order to avoid using the name of the new monarch.711

B1 is a promissory note for 10 kurru of barley, owed by Pigla(?)-Yāma/Šullumu to Nubâ/Šalam-Yāma in $38 \mathrm{Nbk}$. The document looks like a private transaction, and both parties were of Judean descent. Except for being written in Yāhūdu, B1 cannot be connected to any other text in the corpus. There is a possibility that the creditor Nubâ/Šalam-Yāma was the father of Bēl- (or Yāhû-)šar-uṣur/Nubâ,

708 van Driel 2002, 237-245.

709 Abraham et al. 2018; cf. Pearce and Wunsch 2014, 98-99.

710 Stolper 1985, 22; Pearce 1999; Jursa 2012; Bloch 2018. See also Section 5.3.2.

711 Pearce and Wunsch 2014, 99. 
who is attested as a creditor in several early texts from Yāhūdu, but this remains uncertain. ${ }^{712}$

A peculiar similarity between $\mathrm{C}_{1}$ and $\mathrm{B} 1$ is the presence of non-cuneiform signs on the edges of both tablets. In $\mathrm{C}$, they resemble the Aramaic letter $\sin$ or shin, and in $\mathrm{B} 1$ there is a short alphabetic inscription, as yet undeciphered. ${ }^{713}$ Several other tablets of the corpus bear Aramaic inscriptions, including the last tablet from the ninth year of Xerxes $\left(\mathrm{C}_{53}\right)$. Similar alphabetic inscriptions are found on other Late Babylonian cuneiform tablets, and they testify to the importance of Aramaic in Babylonia in the mid-first millennium. ${ }^{714}$

The majority of early texts from Yāhūdu pertain to Șidqī-Yāma/Šillimu and Rapā-Yāma/Samak-Yāma, who were landholders in the land-for-service sector. Șidqī-Yāma held a bìt azanni already in the reign of Nebuchadnezzar (C2), and Rapā-Yāma is once said $\left(\mathrm{C}_{7}\right)$ to owe barley belonging to the property of the king (makkūr šarri). An ilku tax payment by his son Ahīqam (C12) further supports this view. Rapā-Yāma is attested in five documents $(\mathrm{C} 6-9,11)$ from the first year of Amēl-Marduk until the fifth year of Cyrus (561-533 BCE), and Șidqī-Yāma in six documents $\left(\mathrm{C}_{2}-6,9\right)$ from the late reign of Nebuchadnezzar II until the eighth year of Nabonidus (c. 565-548 в ве).

All documents featuring Rapā-Yāma and Șidqī-Yāma pertain to their debts in barley and silver, and also once in dates. The amounts are not very large, ranging from a little over 1 kurru of barley to 15 shekels of silver. The debtor is always either Rapā-Yāma or Șidqī-Yāma, and the latter acts once as a witness (C6) and once as a surety (C9) for the former. Șidqī-Yāma also had close contact with Rapā-Yāma's two brothers: Mī-kā-Yāma witnessed promissory note C2 and Yāma-kīn is among the witnesses in $\mathrm{C}_{5}$. Nothing in the documents suggests that these Judeans played any major role in the administration of the local land-for-service sector or that they were running a substantial business. Ṣidqī-Yāma's tie to the sons of Samak-Yāma more likely resulted from friendship or a family relationship than a business partnership.

Șidqī-Yāma was the holder of a quiver land who occasionally needed credit to pay his taxes $\left(\mathrm{C}_{2}\right)$ or to acquire seed grain for sowing $\left(\mathrm{C}_{4}\right)$. The two early debts owed by him are small $\left(\mathrm{C}_{2}-3\right)$, but the two latter ones are somewhat larger: 7;2.3 and 9 kurru of barley $\left(\mathrm{C}_{4}-5\right)$. All these documents were written in Yāhūdu. C2 reveals that Șidqī-Yāma's quiver land was pledged to secure his debt, and again, in $\mathrm{C}_{5}$, he has to pledge his slave in order to secure

712 See Wunsch (forthcoming), 2.

713 Wunsch (forthcoming), 4.

714 Aramaic inscriptions on clay tablets from Babylonia in the mid-first millennium will be studied in Rieneke Sonnevelt's (Leiden) forthcoming dissertation. 
the repayment of his debt, the interest of which was paid off with the work of the slave. ${ }^{715}$ In three cases, his creditor was Bēl-šar-ușur or Yāhû-šar-ușur, son of Nubâ, who was apparently an official responsible for the lands allotted to Șidqī-Yāma. ${ }^{716}$ Thus, Șidqī-Yāma is to be seen as a landholder in the land-for-service sector, whose possible involvement in business or administrative duties is not indicated by the present texts.

The picture emerging from the texts pertaining to Rapā-Yāma is not very different from that in the Șidqī-Yāma texts. Rapā-Yāma is also attested only as a debtor, and two of his debts are small $(\mathrm{C} 9,11)$ whereas two are larger (C6: 15 shekels of silver; C8: 6;0.5 kurru of dates and 5 kurru of barley). The amount of barley is broken in $\mathrm{C}_{7}$, but the document bears witness to Rapā-Yāma's role in the land-for-service sector. The barley was property of the king (makkūršarri), being the rental income $(s \bar{t} t u)$ of a certain Enlil-šar-ușur, son of Itti-Šamašbalāțu. This property was further managed by Ninurta-ana-bītišu, son of Rihētu, but it ultimately belonged to a high Babylonian military officer: RapāYāma was obliged to deliver the barley to the estate of the rab mügi. ${ }^{717}$ Enlilšar-ușur was not necessarily the rab mügi himself but perhaps an official in charge of the rab mügi's estate and landholdings in the vicinity of Yâhüdu. The šarru element in his name corroborates his ties to the royal administration. ${ }^{718}$ As noted by Pearce and Wunsch, Rapā-Yāma's role in the transaction is not completely clear, and the barley could originate from his own field or from the lands he managed. ${ }^{719}$

Promissory note C8 sheds some light on Rapā-Yāma's social status: he owed dates and barley to a certain Țūb-Yāma, son of Mukkêa, and the document was written in Ālu-ša-Tūb-Yāma, which was evidently named after the creditor. ${ }^{720}$ This also appears to be a sort of administrative estate, like that of the rab mügi, and implies that Rapā-Yāma had obligations towards different functionaries in the region. The document also bears rare witness to the role of women in the Judean community in Babylonia. The delivery of staples was guaranteed by Rapā-Yāma's wife Yapa-Yāhû, who was thus competent to engage in economic activities in the public sphere. ${ }^{721}$ Promissory note $\mathrm{C} 9$, written in Adabilu, shows that Rapā-Yāma's activities were not confined to Yāhūdu.

715 See the discussion in Pearce and Wunsch 2014, 104-106.

716 The peculiar double name of the creditor is discussed in Section 4.4.

717 On the rab mügi, see Jursa 2010b, 85-86.

718 See Section 1.5.1.

719 Pearce and Wunsch 2014, 109. However, they favour the option that Rapā-Yāma managed royal lands because his son Ahīqam was involved in such activities.

720 Pearce and Wunsch 2014, 110.

721 Abraham et al. (2018) suggest reading 'mother' (ama) instead of 'wife' (dam). 
Did Șidqī-Yāma and Rapā-Yāma only cultivate plots of their own or did they participate in agricultural management? On the one hand, Rapā-Yāma moved around the countryside surrounding Yāhūdu and was responsible for delivering commodities to two different administrative centres in the region. If the administrative structures did not change over time or Rapā-Yāma did not hold several plots of land, he may have managed plots held by other people. ${ }^{722} \mathrm{On}$ the other hand, the transactions themselves do not corroborate the idea that he managed other plots than his own. Moreover, his son Ahĩqam almost certainly held a parcel of royal land, and these landholdings are known to have been hereditary. ${ }^{723}$ Thus, we may conclude that both Șidqī-Yāma and RapāYāma held plots of royal land in the Yāhūdu countryside, but there is no conclusive evidence of their involvement in the management of other landholdings. ${ }^{724}$

In addition to the two earliest texts from Yāhūdu, documents C1o and A1 were written in Yāhūdu during the active period of Șidqī-Yāma and Rapā-Yāma, but they do not relate to the activities of these two men. C1o is a promissory note for barley, owed by Šalam-Yāma/Nadab-Yāma to Gummulu/Bi-hamê (6 Nbn). The document was written in Yāhūdu, but the barley was to be delivered in Adabilu, where Gummulu issued a promissory note for Rapā-Yāma in 5 Nbn (C9). Although the creditor connects this text to Rapa-Yāma, it is difficult to explain why it would belong to the private archive of Șidqī-Yâma or RapāYāma. It is more likely that the text is connected to the corpus via its scribe Nabû-nāṣir/Nabû-zēr-iqī̌ša, who also wrote documents $\mathrm{C}_{1}, \mathrm{C}_{3}$, and $\mathrm{C}_{4}$. He thus links two isolated documents $\left(\mathrm{C}_{1}, 10\right)$ to two documents pertaining to ȘidqīYāma $\left(C_{3}, 4\right)$, which suggests that scribal practices shaped the early Yāhūdu group at least to some extent. C1o also bears an alphabetic inscription referring to the debtor of the document. ${ }^{725}$

The single marriage agreement from Yāhūdu (A1, 5 Cyr) pertains to people we know very little about. ${ }^{726}$ Only two witnesses of the document, ŠilimYāma/Nadab-Yāma and Șidqī-Yāma/Natīn, are perhaps attested in Cio and B3, respectively. The bride Nanâ-kanāta was given in marriage to the groom

722 Pearce and Wunsch $(2014,109)$ favour this option.

723 See Ahīqam's $i l k u$ tax payment in C12. On the hereditary nature of the landholdings in the land-for-service sector, see van Driel 2002, 226-229.

724 Cf. Berlejung 2017b, 107-110.

725 Pearce and Wunsch $(2014,112)$ analyse the inscription as being written in Paleo-Hebrew, but according to Rieneke Sonnevelt (personal communication), this is not certain at all. See Section 8.6.

726 The document has been discussed in Abraham 2005/2006, 2015; Lemos 2010, 237-244. 
Nabû-bān-ahi/Kīnâ by her mother Dibbî/Dannâ, ${ }^{727}$ and the agreement was concluded in the presence of her brother Mušallam. The groom and his father bore Akkadian names, but the bride and her brother had West Semitic names. ${ }^{728}$ None of the bride's or husband's family members had a typically Judean name, and although the majority of witnesses bore Yahwistic names and the document was drafted in Yāhūdu, one should be careful not to conclude that the bride's family was of Judean descent. ${ }^{729}$ In any case, their names point towards foreign origin. The husband's family was not necessarily Babylonian either, as their Akkadian names may disguise their foreign descent. The text hardly fits the private archive of Șidqī-Yāma or Rapā-Yāma, nor is the scribe attested in any other text of the corpus. The text remains as an isolate.

Nanâ-kanāta and Nabû-bān-ahi's marriage agreement conforms to the general outline of such documents. ${ }^{730}$ It contains stipulations about divorce and adultery, and Marduk, Zarpanītu, and Nabû are named in the curse section. However, Nanâ-kanāta's family could not obviously afford to provide their daughter with a dowry, and an uncommon stipulation states that the groom was to provide the bride's mother with a garment worth five shekels of silver. Gifts from the groom's family are rare in contemporary Babylonian marriage agreements, although such a custom is well attested in Old Babylonian and Middle Assyrian law. ${ }^{731}$ If the payment was actually an indirect dowry and not a mere gift to the bride's mother, it finds a parallel in the Aramaic marriage agreements from Elephantine. The exceptional wording of the divorce clause also echoes the Elephantine marriage agreements, which may indicate that Nanâ-kanāta's marriage agreement was influenced by non-Babylonian customs and legal tradition..$^{732}$

An important point of comparison is a contemporary marriage agreement from Ālu-ša-banê (Yos 6 188, 27-IX-14 Nbn), which pertains to a bride and groom of foreign origin. ${ }^{733}$ The place name Ālu-ša-banê is not attested elsewhere, ${ }^{734}$ and the most probable geographical context of the marriage is a

727 A certain Dannâ/Šalti-il is attested in three texts $\left(\mathrm{C}_{57}-58,61\right)$ belonging to the Rīmūt/Abīul-îde group, but he was hardly identical with the Dannâ mentioned in the marriage agreement.

728 Abraham 2005/2006, 216.

729 Cf. Abraham 2015, 36.

730 Roth 1989, 1-28; Abraham 2005/2006, 202-206.

731 Roth 1989, 11-12; Waerzeggers 2001; Abraham 2015, 50-52.

732 Abraham 2015, 52-56.

733 The document is edited as no. 17 in Roth 1989, 69-71. See also Abraham 2005/2006, 206211; 2015, 40, 44-50; Lemos 2010, 242-244.

734 Zadok 1985, 13 . 
rural village at some distance from the bigger cities. ${ }^{735}$ The groom Nabû-ahuṣur was of Judean descent, judging by the name of his father, Hatā-Yāma. ${ }^{736}$ The bride Tallâ-Uruk, her brother Il-natan, and her father Barā-il bore West Semitic names; ${ }^{737}$ her mother Bānītu had an Akkadian name. The list of witnesses is a mixture of Akkadian and West Semitic names, which further corroborates the assumption that the agreement was concluded in a rural settlement of foreign population. Although numerous mistakes in the text betray that the scribe was not very competent, ${ }^{738}$ the text closely follows the general structure of Babylonian marriage agreements. The single deviation from the standard formulas is the splitting of the divorce clause in two, although this does not seem to alter its meaning in any significant way. ${ }^{739}$ It is noteworthy that both A1 and yos 6188 contain the 'iron dagger' clause, which was characteristic of marriage agreements outside the urban upper class. ${ }^{740}$

Although both marriage agreements discussed above were written in the countryside and involved parties of foreign origin, they generally comply with the structure of other Babylonian marriage agreements. In any case, there are some peculiarities, especially in the marriage agreement from Yāhūdu. Kathleen Abraham has been able to trace similar non-standard stipulations in other marriage agreements involving non-Babylonian parties, and she argues that this reflects the way in which the two parties negotiated the terms of the marriage. ${ }^{741}$ According to her, the parties had their say in the wording of an agreement and it was not dictated only by the Neo-Babylonian legal and scribal traditions.

Despite some links between the documents $\mathrm{A}_{1}, \mathrm{~B}_{1}, \mathrm{C} 1$, and $\mathrm{C}_{10}$ and other early texts from Yāhūdu, the isolated texts do not fit into a hypothetical private archive of Șidqī-Yāma or Rapā-Yāma. Because two of the texts feature the scribe Nabû-nāṣir/Nabû-zēr-iqīša, it is conceivable that administrative practices brought these diverse texts together. For now, it is necessary to remain open to the possibility that the texts pertaining to Șidqī-Yāma and Rapā-Yāma were also a part of the same administrative archive. The main group of texts from Yāhūdu, which I will discuss below, sheds more light on this issue.

\footnotetext{
735 Abraham 2015, 47.

736 Zadok (1979a, 20; 1988, 30, 174, 305) and Oded $(2000,102)$ analyse the name as Yahwistic, but cf. Abraham 2015, 40.

737 Zadok 1977, 78, 83-84, 86.

738 Roth $1989,69-70$.

739 Roth 1989, 12-15; Abraham 2015, 46, 53.

740 See Section 3.3.1.

741 Abraham 2015, 42-50, 56-57.
} 


\subsubsection{Texts Pertaining to Ahīqam/Rapā-Yāma and His Sons}

The bulk of the texts from Yāhūdu are related to the activities of Rapā-Yāma's son Ahīqam and grandsons Nīr-Yāma, Haggâ, and Yāhû-izrīi. ${ }^{742}$ Two early texts (C12-13) pertaining to Ahīqam originate from the fifth and seventh years of Cyrus (533-531 ВСE), but the rest of his documents are dated between the fourth and fifteenth years of Darius I (518-507 BCE) ${ }^{743}$ Ahīqam died soon after his last documented transaction, and his business assets in Babylon were divided by his sons probably in the sixteenth year of Darius I. ${ }^{74}$ His sons NīrYāma, Haggâ, and Yāhû-izrī engaged in business activities already before their father's death and continued after Ahìqam had passed away. ${ }^{745}$ The last attestation of Yāhû-izrī was recorded in $34 \operatorname{Dar}$ (B16, 488 вCE).

The activities of this Judean family were centred in Yāhūdu, but the three earliest attestations of Ahĩqam were written outside the village. The first Ahīqam document $(\mathrm{C} 12,5 \mathrm{Cyr})$ records his ilku payment ${ }^{746}$ to the substitute of a Judean dēkû official in Kēš, which suggests that Ahīqam was a landholder in the land-for-service sector, and perhaps a member of a Judean hatru-like organisation. Two years later, most likely after the death of Rapā-Yāma, Ahīqam travelled to Našar to settle a debt which was originally owed by his father $\left(\mathrm{C}_{3}\right.$, 7 Cyr). ${ }^{747}$ This transaction connects Ahìqam closely with the group of texts pertaining to Ahīqar: Našar was not only the hotspot of Ahīqar's activity, but the scribe and the first witness of $\mathrm{C}_{13}$ were known to Ahĩqar as well. The scribe Arad-Gula wrote the majority of Ahīqar's documents, and Arad-Gula's son Bēlupehhir witnessed some of his transactions.

After the two early documents from the reign of Cyrus, Ahīqam disappears from sight until he appears again in Babylon in the fourth year of Darius I (B5). If the previous documents pertaining to Rapā-Yāma and Ahīqam seem to relate to their activities as landholders, promissory note $\mathrm{B}_{5}$ for over five minas of silver and five sheep paints a completely different picture. As usual, the reason for the debt is not made explicit in the text, but several pieces of information

742 Yāhû-izrī's name is once written as Yāhû-azar $\left(\mathrm{C}_{30}\right)$, but he must be identical with the Yāhû-izrī attested in B15-16; C45 (Pearce and Wunsch 2014, 297).

743 Ahīqam is mentioned in $\mathrm{B}_{5}-6,9,12$; $\mathrm{C} 12-14,16-20,23,25,29-31,33-36,40-44$.

744 His last transaction was recorded in $24-\mathrm{V}-15$ Dar (C25), and his sons divided his assets in 5-VII-16(?) Dar (C45||A2). The year of the inheritance division is not perfectly clear: there is discrepancy between the transliteration (sixteenth year) and cuneiform copy (nineteenth year) in C45. The photograph seems to suggest ' 16 ' instead of ' 19 '.

745 Ahīqam's sons are attested in B8, 10, 13, 15-16; C24-27, 29-30, 32, 37, 39, 45-46; J8.

746 Ilku refers to a service obligation or (most often) to its compensation in silver. See van Driel 2002, 254-259; Jursa 2011a, 441.

747 See Pearce and Wunsch 2014, 115. 
may help us to understand the context of the transaction. First of all, this is the biggest transaction related to Ahīqam. Because of its sheer size, it cannot have resulted from the cultivation of his own plot of royal land. Rather, the transaction should be situated in the realm of business or in the sphere of the institutional economy. Second, over half of the silver is described as ša nadāni $u$ mahāri, '(silver) for giving and receiving. This type of silver was intended for commerce, ${ }^{748}$ which also suggests that this promissory note had a commercial background. Third, sheep may have been an additional payment by the debtor; they do not necessarily imply that the debt was related to herding. Finally, the later documents $\mathrm{C}_{44}-45$ pertain to Ahīqam's beer-brewing activities in Babylon: the former records the delivery of 15 vats of beer to Babylon, the price of which Ahīqam paid in barley in Yāhūdu. The latter is an inheritance division of Ahīqam's business assets in Babylon, including some vats and two slaves. Promissory note $\mathrm{B}_{5}$ is thus to be related to Ahìqam's commercial activities in Babylon, the importance of which I return to later.

Promissory note $\mathrm{B}_{5}$ was written in Babylon, but the repayment was to take place after a month in Yāhūdu. One or more people attested in the document lived in the environs of Yāhūdu and Našar as well. The scribe of the document, Arad-Gula/Nabû-šum-ukīn/Amēl-Ea, is attested numerous times in the village of Našar. The debt was owed to Ahīqam by a man whose broken name should probably be reconstructed as Banā-Yāma/Abdi-Yāhû. If this is correct, he is possibly attested as Ahīqam's creditor in Yāhūdu nine years later $\left(\mathrm{C}_{3} 6,13\right.$ Dar). ${ }^{749}$ In $\mathrm{C}_{3} 6$, the debt of 16;1.4 kurru of barley was royal property (makkūr šarri) managed by Banā-Yāma/Abdi-Yāhû. This implies that the creditor BanāYâma was involved in the management of state lands. The second witness of B5, Hanan/Habbuhru, is probably attested as a witness to Ahīqam's transaction in 12 Dar (B9). ${ }^{750}$ Therefore, we may conclude that some people who were present at Ahīqam's transaction had travelled from the countryside to Babylon.

There is one puzzling feature in promissory note $\mathrm{B}_{5}$, namely, the presence of the scribe Arad-Gula with Ahiqam in Babylon, outside his normal sphere of influence in Našar. The scribe was active in $3 \mathrm{Cyr}-4$ Dar, but despite the great number of documents he wrote, he is seldom attested outside Našar: except for the present document, he appears only three times in Bīt-Bāba-ēreš (B34, 39; C8o). Arad-Gula and Ahīqam had known each other for a long time, because

748 Vargyas 2001, 21-24; Jursa 2010a, 488; Pearce and Wunsch 2014, 167.

749 Because both Banā-Yāma and Abdi-Yāhû are common names in the text corpus (Pearce and Wunsch 2014, 257, 264), it cannot be confirmed that the namesakes in $\mathrm{B}_{5}$ and $\mathrm{C}_{3} 6$ were actually one and the same person.

The text was written in Adabilu, which was located close to Yāhūdu (see C9-10). 
the scribe wrote a document for Ahīqam in Našar already fourteen years earlier ( $\left.\mathrm{C}_{13}, 7 \mathrm{Cyr}\right)$. Ahìqam does not appear in a single document during these fourteen years which coincide with Ahīqar's and Arad-Gula's peak activity. ${ }^{751}$ $\mathrm{B}_{5}$ therefore marks a watershed in the composition of the corpus, as it is the last attestation of Arad-Gula and it starts the period of Ahìqam's peak activity. ${ }^{752}$ I will return to this document and its importance in Section 4.3.10 when I discuss the interrelations between the different text groups in the corpus.

Promissory note B 5 is dramatically different from Rapā-Yāma's and Ahīqam's previous transactions in $1 \mathrm{AM}-7 \mathrm{Cyr}$. These earlier documents paint a picture of a father and son who cultivated a plot or two of royal land in the land-forservice sector and who occasionally had to take out a loan to fulfil their tax or service obligations. Ahiqqam's activities and the whole economic landscape in Yāhūdu look very different in the fourth year of Darius I. From then on, Ahīqam was working as a rent farmer in the land-for-service sector, buying rights to collect payments from landholders and converting the rent in staples to silver through beer brewing and retail sales. The organisation of the land-for-service sector in Yāhūdu was also different, and Judean landholders - called šušānus worked in hatru-like administrative units.

The change must have taken place at some point during the undocumented period in the reign of Cambyses or the early years of Darius I, because all the essential components of Ahīqam's business and the new administrative structures were in place already in the fourth and fifth years of Darius: in addition to his business dealings in Babylon, Ahīqam collected imittu rental payments, and his connections to Babylonian officials were well established. C33 (4 Dar) is a promissory note for 21;1 kurru of dates, an imittu rent from the fields of šušānus, which is owed to Ahīqam by a certain Banā-Yāma/Ahu-Yāma(?). ${ }^{753}$ The debtor hardly cultivated the gardens himself, and the formulation of the promissory note indicates that he was a sublessor or business partner of Ahīqam and managed the landholdings of the unnamed šušānus. ${ }^{754}$ Furthermore, $\mathrm{B}_{12}$ and $\mathrm{C}_{14}$ from the fifth year of Darius I feature Ahĩqam as a witness to the lists of estimated imittu rents from Judean šušānus. C 15 belongs to this group as well, because it closely resembles the other lists, except for the absence of Ahīqam. The lists were written in the seventh month, just before the date harvest, when a group of officials travelled in the countryside and

$75^{1} \quad$ Figure 1.

$75^{2}$ Figure 3.

753 The reading of the patronymic is unclear. See Abraham et al. 2018.

754 Pearce and Wunsch 2014, 155. 
assessed the rental payments of landholders. ${ }^{75}$ It appears that most of the šušānus held only a fraction of a bow land. This did not necessarily result from inheritance divisions which split the plots, for the state could also grant fractional bow lands to landholders. ${ }^{756}$

Ahīqam witnessed the imittu lists in his role as a rent farmer who had bought the rights to collect payments from landholders in the surroundings of Yāhūdu. This aspect of his business operations is clarified by three documents from the last month of the ninth year of Darius I. ${ }^{757}$ Two receipts ( $\mathrm{C}_{17}$ and B6) record Ahìqam's payment of 4 minas of silver to Babylonian officials. The documents are not duplicates, as the former concerns sūtu rent of the ninth year of Darius and the latter of the tenth year. ${ }^{758}$ Ahīqam paid a lump sum in silver in order to buy the rights to collect rental payments in kind. Promissory note C18 records Ahīqam's debt of 160 kurru of barley, the equivalent of 4 minas of silver, which Ahìqam had to deliver in the second month of the tenth year of Darius. The way in which these three documents were written seems to imply that Ahīqam paid the rental fees of 9-10 Dar in silver but was required to deliver 160 kurru of barley again a couple of months later. This would not make sense, and it is reasonable to suggest that Ahīqam paid off the debt of 160 kurru barley in silver and retained a copy of the promissory note as a further proof of the transaction.

The documents discussed above show that Ahịam worked as a middleman between the state administration and the units of landholders by collecting annual rental payments from the latter. He bought the rights to collect rent in a lump sum of silver, but the rental payments were made in dates or barley, which indicates that he had the means to convert crops into cash. ${ }^{759}$ Three documents pertain to Ahīqam's beer-brewing activities, ${ }^{760}$ and we have to suppose that he had channels to sell the barley crops as well. ${ }^{761}$ It is noteworthy that the retail sales of beer took place in Babylon (C44-45); thus, Ahìqam's business was regional rather than local. ${ }^{762}$ Promissory note $\mathrm{B}_{5}$ for over 5 minas

755 Pearce and Wunsch 2014, 120.

756 van Driel 2002, 239-240, 247-249. Cf. Pearce and Wunsch 2014, 120.

757 See the discussion in Pearce and Wunsch 2014, 126-130.

758 Pearce and Wunsch $(2014,126)$ regard the texts as duplicates.

759 Imittu and other rental payments to Ahīqam include C23, 25, 33, 35. C16 is closely related to the same phenomenon.

$760 \quad \mathrm{C} 40,44,45$.

761 There is no direct evidence of retail sales of barley, but $\mathrm{C}_{44}$ shows that Ahīqam used his barley income to finance his beer brewing business in Babylon.

762 B1o, a sharing contract for a donkey, is another piece of evidence for the trading activities of the family. On donkeys and trade, see Jursa 2010a, 216, 259-261. 
of silver and five sheep from Babylon fits the context of retail sales as well, as my previous discussion of the text shows. In sum, Ahīqam's activities in Yāhūdu and Babylon were two integral parts of his business which can be compared with the dealings of some native Babylonian businessmen. ${ }^{763}$ They acquired the rights to collect rent from farmers in staples, converted the staples into silver through retail sales, and paid their fees to the crown in silver. ${ }^{764}$

Ahīqam did not run his business alone, as several people were involved in it. Most notably, three of his sons - Nīr-Yāma, Haggâ, and Yāhû-izrī - were active during his lifetime and for a long time after his death in 15 or 16 Dar. However, their business profile was different from that of their father: whereas Ahìqam was primarily involved in rent farming and retail, his sons practised agricultural management. This is the same type of management as practised by Ahīqar: the efficient cultivation of fields required plough teams of four oxen, and substantial resources were needed to form such a team. A group of people pooled the lands they owned or had rented from farmers and entered into partnerships to secure the workmen, oxen, and equipment needed to cultivate the fields. Ahĩqam also participated in agricultural management, but that primarily belonged to the business portfolio of his sons. ${ }^{765}$ As opposed to Ahĩqar, credit granting was only of minor importance to Ahĩgam and his sons, and the fields they managed were more likely rented than pledged. ${ }^{766}$

Business partners who did not belong to the family are also regularly present in the documents pertaining to Ahīqam and his sons. Most notable was Izrīqam/Šamā-Yāma. ${ }^{767}$ His career was long (11-34 Dar) and his activities changed over time. In the beginning, he worked as a rent farmer of the fields of Judean šušānus, just like Ahīqam (C19, 11 Dar), but he primarily engaged in agricultural management together with Ahĩqam's sons after the death of their father. This reflects the change from Ahīqam's rent farming activities to the

763 Compare with the Murašû family (Section 5.1) and Itti-Šamaš-balāțu from Larsa, for which see Beaulieu 2000. For further examples, see van Driel 1989; Jursa 2010a, 198-203.

764 For a somewhat different analysis of Ahīqam's business profile, see Berlejung 2017b, $110-119$.

765 Regarding Ahīqam: pooling land: $\mathrm{C}_{23}$; acquiring oxen: $\mathrm{C}_{31}$; partnership contract for cultivation: C29. Regarding Ahīqam's sons: leasing land: B8; C26; dispute over a landholding: C27; acquiring oxen: $\mathrm{C}_{30}$; J8; partnership contracts for cultivation: $\mathrm{B}_{15}-16$.

766 C41 is a clear instance of credit granting: Ahīqam loaned silver to a certain Abdi-Yāhû/ Hašdâ to help him hire a substitute to serve in Elam. The debt was to be paid back in barley. $\mathrm{C}_{43}$ relates to commercial activities (debt of 11.5 shekels of silver ša nadāni $u$ mahāri), and the debtor Bēl-zēr-ibni/Bēl-ahhē-erība was probably a business partner of Ahīqam and his sons (Bēl-zēr-ibni is attested as a witness in B1o and C25). C34 may be related to future rental payments rather than real credit granting.

767 B13-16; C19, 27-28. 
agricultural management practised by his sons. It remains unclear, however, if these changes reflect actual developments in business activities or if they just result from the accidental preservation of ancient documents. Izrīqam's relationship to the family of Ahīqam is made explicit in $\mathrm{C}_{27}$, in which he appears among the witnesses bearing the title kinattu ša Nirr-Yāma ('the colleague of Nìr-Yāma'). The three last documents of this group (B13, 15-16) are important because they show that Izrīqam and Haggâ/Ahīqam still practised agricultural management in 31 Dar, and that Izrīqam and Yāhû-izrī/Ahīqam entered into partnership contracts for the cultivation of land in 32 and 34 Dar, almost twenty years after Ahīqam's death. Even though Izrīqam is attested twice alone without any family members of Ahīqam, these documents can be connected to the Ahiqam family via other people present in the texts. ${ }^{768}$ The documents pertaining to Izrīqam thus appear to be closely related to the text group documenting the activities of Ahìqam and his sons.

Ahīqam's business partner Q̄ill-Yāma/Šikin-Yāma engaged in rent farming and agricultural management. His activities are documented only for a period of a year in 11-12 Dar (C20, 22-23). Most interesting of these three documents is promissory note C2o for imittu rent in dates, owed by Qīl-Yāma and Šalāmān/ Rapā-Yāma to Iddinâ/Šinqā. Ahīqam is among the witnesses of the document, leading to the conclusion that Šalāmān was his brother. Roughly ten years earlier (C80, 2 Dar), Šalāmān/Rapā-Yāma bought a cow in Našar in the presence of the scribe Arad-Gula, thus providing yet another connection between the descendants of Rapā-Yāma and Našar. Unfortunately, Šalāmān is not attested in any other text of the corpus.

In addition to Izrīqam and Qīl-Yāma, several other people were close to Ahīqam's family, either as clients or business partners. ${ }^{769}$ Bahi-iltā/Zakar-Yāma acted as a surety for Nīr-Yāma's debt to his father Ahīqam (C25) and witnessed another document pertaining to Haggâ (B1o). Bēl-zēr-ibni/Bēl-ahhē-erība witnessed both of these documents (B10; $\mathrm{C} 25)$, and Ahĩqam granted him an interest-free loan of silver which was intended for trading (kaspu ša nadāni $u$ mahāri; C43). Šalammu/Bahi-Esu rented a house out to Nīr-Yāma (C46), with whom he was also in litigation about the holding of a plot of land (C27). Finally, Zumbâ/Amidû operated in the same sector of agricultural management as Ahīqam's family and Izrīqam/Šamā-Yāma (C23, 27-28).

768 Yāhû-izrī/Barīk-Yāma connects B14 to B13, and Zumbâ/Amidû connects $\mathrm{C}_{2} 8$ to $\mathrm{C}_{23}$ and $\mathrm{C} 27$.

769 Bahi-iltā/Zakar-Yāma (Bı; C25), Bēl-zēr-ibni/Bēl-ahhē-erība (B1o; C25, 43), Šalammu/ Bahi-Esu $(\mathrm{C} 27,46)$, and Zumbâ/Amidû (C23, 27-28). 
Ahìqam and his colleagues probably belonged to the same social class of state-controlled landholders as the people from whom they collected rent, but they managed to obtain a position that allowed them to profit from the structures of the land-for-service sector. Judeans are prominent in the texts, but, interestingly enough, Judean witnesses are mostly absent from the documents pertaining to direct transactions with the royal administration. ${ }^{770}$ In these documents, witnesses have both Akkadian and West Semitic names, but Ahīqam or his colleagues are usually the only ones who can be safely connected with the Judean community. This is not dependent on the place of writing: Judeans did not witness Ahĩqam's transactions with Babylonian officials in Yāhūdu, but the division of Ahīqam's private business assets was witnessed by several Judeans in Babylon. ${ }^{771}$ We may suggest that Ahīqam and his colleagues were working between two worlds, while most Judeans had only limited access to the higher administrative echelons of the land-for-service sector.

None of the surviving documents directly pertain to Ahīqam and his family members' private life. This also applies to the inheritance division, which is only concerned with Ahīqam's business assets in Babylon. ${ }^{772}$ However, the numerous documents pertaining to Rapā-Yāma, Ahīqam, and his sons are generous with information about family relationships. We know that Samak-Yāma had at least three sons, of whom one of them, Rapā-Yāma, was married to a certain Yapa-Yāhû (Section 4.3.6.2). Two sons of Rapā-Yāma and Yapa-Yāhû are known to us: Šalāmān and Ahīqam, the latter of whom was the father of five sons. Two of the sons, Yāhû-azza and Yāhûšu, are attested only in the inheritance division, whereas Nīr-Yāma, Haggâ, and Yahû-izrī certainly continued their father's businesses after Ahīqam's death in 15 or 16 Dar (507-506 вСЕ). Ahīqam probably had two wives, because his sons are classified into two groups in the inheritance division: one group consists of Nīr-Yāma and Yāhûazza and the other group of Haggâ, Yahû-izrī, and Yāhûšu. ${ }^{773}$ The last attestation of Ahīqam's sons dates to $34 \operatorname{Dar}(488 \mathrm{BCE})$, when Yahû-izrī is mentioned in a contract related to joint farming (B16).

It is highly likely that Samak-Yāma or his father belonged to the first generation of Judeans settled in Yāhūdu, ${ }^{774}$ and this village remained home for his

\footnotetext{
$770 \quad \mathrm{~B} 6,12 ; \mathrm{C}_{14}-15,17-22,24-25$.

771 Compare $\mathrm{C}_{14}-15,19-22$ with $\mathrm{C} 45$ || A2.

$772 \mathrm{C}_{45} \| \mathrm{A} 2$ (16? Dar). The inherited property was related to beer brewing, and it consisted of two slaves, eighteen vats, and some unspecified equipment.

773 Abraham 2007, 210; Pearce and Wunsch 2014, 172. Pearce and Wunsch also raise the possibility that the grouping of the sons is related to the larger share of the firstborn, but this seems unlikely to me.
}

774 Pearce and Wunsch 2014, 7 . 


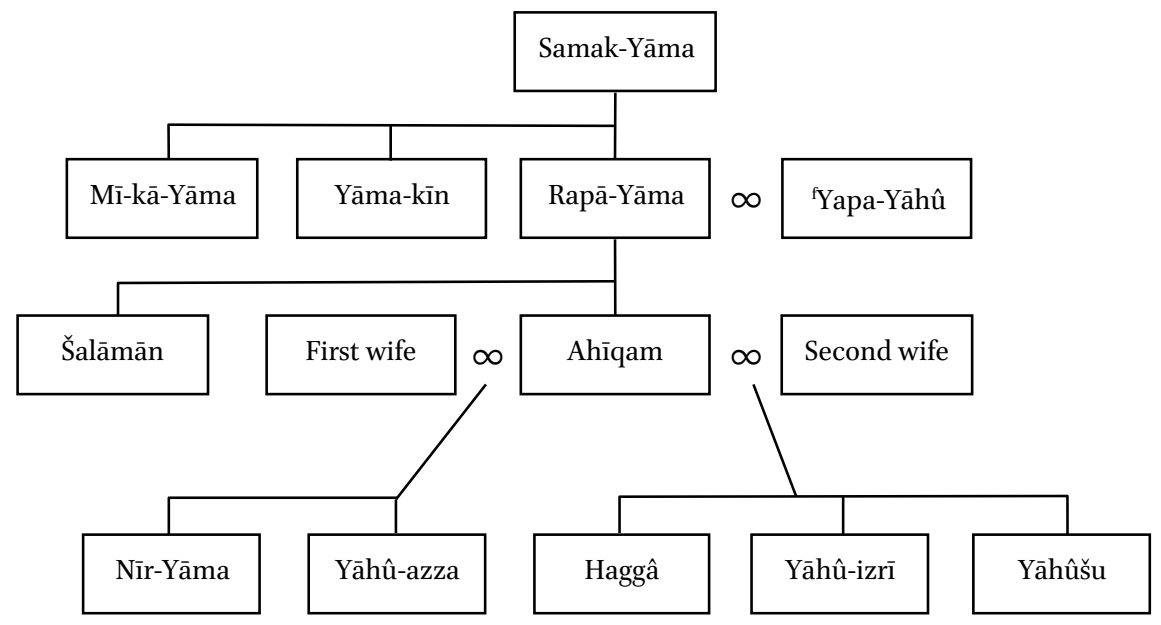

FIGURE 4 The descendants of Samak-Yāma

Cf. Pearce and Wunsch 2014, 8.

descendants as well. More than half of the documents pertaining to the family were written in the village, and most of the remaining documents in its immediate surroundings. Nīr-Yāma even rented a house in Yāhūdu for three years, but the lease was more likely connected to his business activities than to private housing. ${ }^{775}$ It is striking that most of the place names in the environs of Yāhūdu refer either to an estate or to a settlement of a professional or ethnic group. ${ }^{776}$ This is yet another sign of the prevalence of the land-for-service sector in this rural area. The evidence of beer brewing in Babylon shows that the family's activities extended beyond the countryside surrounding their home village.

775 C46. The house was leased ana aššābūti. According to CAD A/2, 462, this means 'in tenancy', but Pearce and Wunsch $(2014,175)$ translate it as 'to live in'. The former translation is to be preferred in light of the large-scale business activities run by the family. These activities probably resulted in some wealth, which was often invested in houses in other contemporary archives. It is unlikely that Nīr-Yāma's generation was still living in a rented property, but the renting of houses for business purposes fits well with the picture emerging from other texts. On owning and renting houses in Babylonia, see Baker 2004, 47-62; Jursa 2010a, 169-171.

776 Ālu ša Amurru-šar-ușur ša muhhi nār Zabinā (C16), Ālu ša ${ }^{\text {líx }{ }^{m e s ̌ ~}}$ (B16), Ālu ša ${ }^{\text {lúdam. }}$

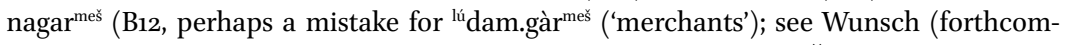
ing), 43), Ālu-ša-Ṭūb-Yāma (C8), Bīt-Bāba-ēreš (C80), and Bīt-Šinqāma (C18). Bīt$\mathrm{Na}^{2}$ innašu $\left(\mathrm{B} 6 ; \mathrm{C}_{17}\right)$ and Adabilu $(\mathrm{B} 9,15 ; \mathrm{C} 9,23)$ are perhaps to be added to this group as well. On the last two place names, see Pearce and Wunsch 2014, 72, 112. 
Ahīqam's family followed Judean naming practices, but at the same time they adapted to Babylonian culture. Yahwistic names prevailed in Ahīqam's family, and none of the family members bore a Babylonian name. Although the family was in regular contact with Babylonian officials and traded in Babylon, they did not adopt local name-giving practices like the Judean royal merchants in Sippar (Chapter 3). At the same time, Ahiqam used a stamp seal that fully conforms to the style of contemporary Babylonian seals (B9, 12 Dar). It depicts a worshipper standing before a spade and an eight-pointed star, the symbols of Marduk and Ištar. ${ }^{777} \mathrm{~A}$ small, unclear figure stands on a pedestal at the feet of the worshipper. Worshipper scenes like this were one of the standard motifs of Babylonian seal impressions in the sixth century. ${ }^{778}$ The sealed document is a promissory note for 21 shekels of silver owed by Ahìqam, whose slave woman was pledged to secure the debt. Her work for the creditor substituted for interest payments on the silver. Ahìqam acts as a private person, and his seal was therefore his personal property, not a seal related to a certain office. This is the single attestation of a Judean seal owner before the mid-fifth century; in the Murašû archive, several Judeans owned seals. ${ }^{779}$ This results from a general change in sealing practices in the Persian period, when private persons increasingly started to use seals. In the time of Ahĩqam, seals were predominantly used by obliged parties or parties who ceded rights in the stamped document. ${ }^{780}$ Ahīqam's seal use in B9 is related to the transfer of rights in the document.

Ahīqam's success in establishing business relationships with Babylonian officials and his commercial activities in Babylon bear witness to his integration into local society, but the adherence to Yahwistic and West Semitic naming practices attests to the persistence of Judean cultural traditions. The occurrence of Yahwistic names, the spade of Marduk, and the star of Ištar do not necessarily mean that all or any of these deities were worshipped by the family of Ahĩqam. However, they show that the family was exposed to the influence of Babylonian society even when they adhered to Judean naming practices. The readiness to integrate and adapt to the local customs may have been both the key to and the result of their evidently successful careers.

777 For an illustration of the seal and discussion of its imagery, see Berlejung 2017b, 114-115.

$77^{8}$ Bregstein 1993, 82-85; Ehrenberg 1999, 15-25, 43-44. The scene depicted on the seal of Ahīqam resembles the image on the seal of the official Ērišu in B27. In addition to the simple stamp seal depicting a fish in B18, these are the only seal impressions in the corpus.

779 Section $5 \cdot 7$.

780 On Babylonian sealing practices, see Section 5.1.3. 
The composition of the text group pertaining to Ahĩam and his sons resembles that of the Ahìqar texts: apart from the inheritance division, documents pertaining to family affairs or immovable property are absent. However, not every text is a simple business document, and especially the imittu rent lists from the fifth year of Darius I are undoubtedly administrative documents (B12; $\left.\mathrm{C}_{4}-15\right)$. There are also other documents which do not neatly fit into a private business archive; they will be discussed in the next section. This composition of texts, which comprises business transactions and administrative documents, must relate to Ahīqam's role as a middleman between Judean landholders and the royal administration. Although Ahīqam and his sons might be labelled businessmen, they also provided an important level in the management of the land-for-service sector. The success and failure of their business was dependent on local officials, but the same officials needed intermediaries like Ahīqam to ensure the efficient cultivation of fields and the steady flow of tax income. ${ }^{781}$

\subsubsection{Royal Administration in the Environs of Yāhūdu}

The bulk of the documents from Yāhūdu would easily fit in a hypothetical private archive of Ahīqam and his sons, but a number of texts constitute a welldefined subgroup interconnected by Iddinâ, son of Šinqāa, the deputy of the rab urâti. He is attested in eleven documents written in Yāhūdu and its surroundings in 5-12 Dar. ${ }^{782}$ The rab urâti was a royal official or military officer who was in charge of horse teams, and, according to the Murašu texts, he had an estate in the Nippur region. ${ }^{783}$ Even though such an estate is not attested in the surroundings of Yāhūdu, the example of the rab mügi's estate makes its existence quite possible. The rab urâti himself is never attested in the present corpus, and the title occurs only in connection to his deputy. In light of his father's Arabian name Šinqā, Iddinâ himself was of non-Babylonian origin. ${ }^{784}$ The estate of Bīt-Šinqāma was evidently named after Iddinâ's father; this is one of the places where Iddinâ and Ahīqam negotiated the latter's rent farming rights $(\mathrm{C} 18) \cdot{ }^{785}$

The documents pertaining to Iddinâ can be further divided into three groups. The earliest texts from 5 Dar are lists of imittu rents owed by Judean

781 Cf. Berlejung 2017a, 2017 b for a too positive view of Judean businessmen, their freedom, social climbing, and collaboration with the Babylonians.

782 B6-7, 12; $\mathrm{C}_{14}-15,17-22$.

783 On rab urâti, see CAD U-W, 258-259; Stolper 1977, 1985, 95-96. On the estate of the $r a b$ urâti in the Murašû archive, see Stolper 1985, 73 .

784 Pearce and Wunsch 2014, 85 .

785 Pearce and Wunsch 2014, 130. 
šušānus to Iddinâ, who managed their lands (B12; $\mathrm{C}_{14-15)}$. Royal property was distributed as bow lands to šušānus, who were grouped together in units of ten and represented by one of the respective farmers. ${ }^{786}$ Ahiquam witnessed two of the three lists, apparently in the role of a rent farmer of the lands in question. Another three texts from 9 Dar show how Ahīqam bought rights to collect rent from local landholders ( $\left.\mathrm{B} 6 ; \mathrm{C}_{17}-18\right)$. These documents elaborate on the role of Iddinâ and the administrative hierarchy of the local land-for-service sector: Iddinâ appears to have been a subordinate of a certain Mudammiq-Nabû, son of Nabû-aplu-iddin, whose title is not given in the documents. ${ }^{787}$ Ultimately, they were both subordinate to Uštanu, the governor of Across-the-River, who was responsible for the royal lands in the environs of Yāhūdu. ${ }^{788}$ Based on these six texts, the administrative hierarchy of the land-for-service sector in Yāhūdu and its surroundings is visualised in Figure 5.

The third group of texts pertaining to Iddinâ was written in 11-12 Dar. Four documents $\left(\mathrm{B}_{7} ; \mathrm{C}_{19-21)}\right.$ are promissory notes for dates or barley, concerning imittu rents from the fields of Judean šušānus. The creditor is always Iddinâ and the debtors bear Yahwistic names or patronymics. C22 resembles these documents, but the reason for the debt is not given in the promissory note. Three of the documents (C19-20, 22) can be directly connected to Ahĩqam: he is a witness in C19-20, the debtors Izrīqam/Šamā-Yāma (C19) and Qīl-Yāma/ Šikin-Yāma $(\mathrm{C} 20,22)$ are his business partners, and his brother Šalāmān is the second debtor in $\mathrm{C}_{20 .}{ }^{789}$ The debtor of $\mathrm{C} 21$ witnessed a document pertaining to Ahīqam (B9), which suggests that he was Ahīqam's acquaintance as well. Only the debtor of $\mathrm{B} 7$ cannot be connected to Ahĩqam.

786 Ten landholders are represented by one nominal debtor in $\mathrm{C}_{14}$ and twenty landholders by two nominal debtors in $\mathrm{C}_{5}$. Because of the damaged state of the tablets, only one of the nominal debtors, Qațib-Yāma in C15, can be identified on the list of landholders. B12 pertains to the imittu rents of only two landholders. The organisational structure in $\mathrm{C}_{14-15}$ resembles eširtus, units of ten, which are attested in Babylonian cities and temples, and which were responsible for tax payments and work or military service. See Jursa 1999, 101, 104; 2011a, 439-441; van Driel 2002, 295, 298-299, 309; MacGinnis 2010, 160-161.

787 B6; $\mathrm{C}_{17}-18$.

788 The relevant texts are $\mathrm{B}_{7} ; \mathrm{C} 18-21$. Bloch $(2017,102-111)$ argues that the designation 'Across-the-River' in the Yāhūdu documents does not refer to Uštanu but to Judean šušānus, although he does not deny that the person named Uštanu was indeed the governor of Babylon and Across-the-River. This would mean that the deported Judeans and their descendants still had responsibilities towards the region they originated from. According to Bloch, the term šušānu was still related to the care of horses in the late sixth century and Judean šušānus had to send horses to military units in Across-the-River. However, nothing in the texts suggests that the Judean šušānus in Yāhūdu bred or trained horses.

789 On these people, see the previous section. 


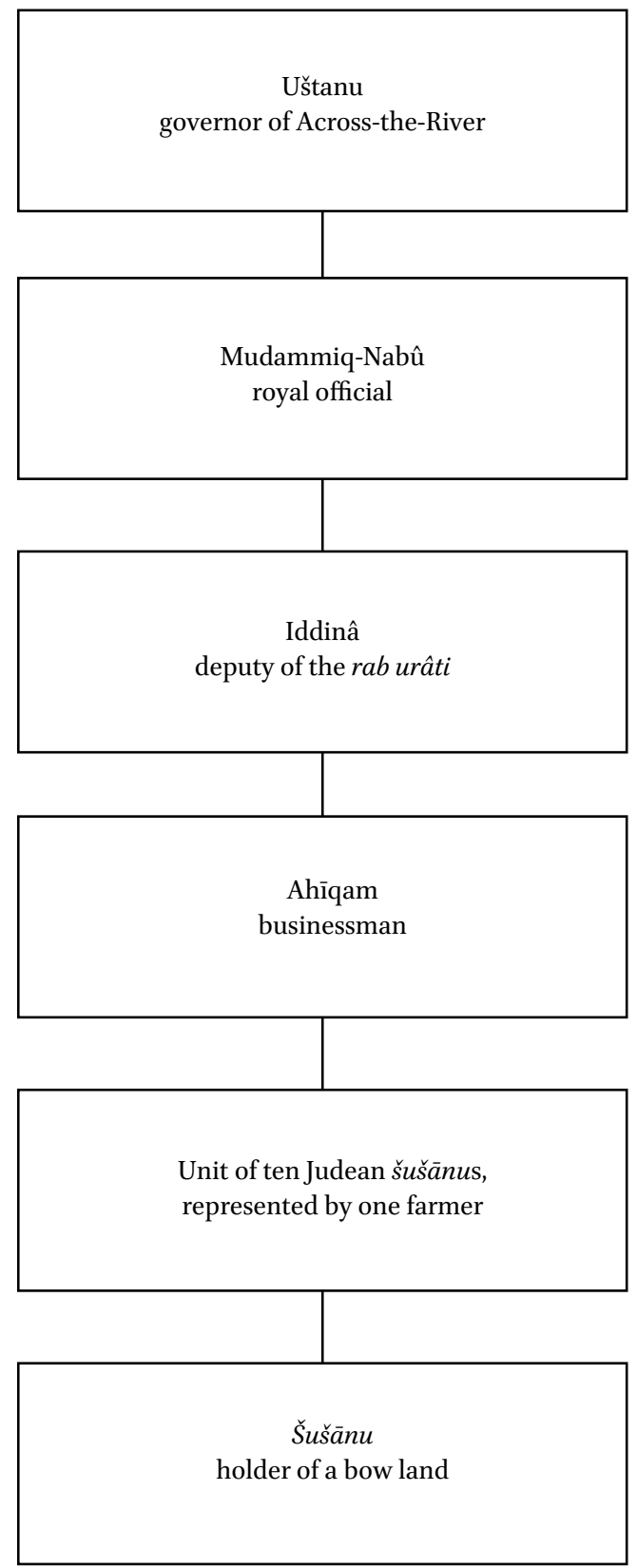

FIGURE 5 Administrative hierarchy in the environs of Yāhūdu 
The last group of texts discussed above emphasise that Ahīqam and his sons were not the only Judeans who practised rent farming in Yāhūdu. Other people also worked as middlemen in the land-for-service sector and bought rights to collect rental payments from landholders. Although Ahīqam knew most of these people, the presence of their documents in the corpus is difficult to explain if we would like to assign all tablets from Yāhūdu to a private business archive of Ahīqam's family. ${ }^{790}$ The same difficulty applies to the administrative lists of imittu rents (B12; $\left.\mathrm{C}_{14}-15\right)$. A closer look at the people attested in these documents reveals that the texts are not only interconnected by Iddinâ but by scribes and other administrative personnel as well.

The assessment of the imittu rents in $\mathrm{B}_{12}$ and $\mathrm{C}_{14-15}$ (5 Dar) was performed by a single group of administrative personnel: the witnesses are always Nabûzēr-ibni/Il-gabrī and Bēl-ēreš/Šalāmān, and the scribe is Šamaš-ēreš/Mardukmukīn-apli/Mudammiq-Adad. The assessment was performed in the countryside where the orchards were located, in Yāhūdu and in Ālu ša lídam.nagar ${ }^{\text {meš. }} .791$ Šamaš-ēreš was a frequent scribe in the environs of Yāhūdu and evidently a member of the local administration in the land-for-service sector. In addition to the imittu lists, he wrote the documents pertaining to Ahīqam's purchase of rent farming rights in $9 \mathrm{Dar}\left(\mathrm{B} 6 ; \mathrm{C}_{17}-18\right)$, two promissory notes on rental payments (C22, 24; 12 and 14 Dar), and a judicial document (B11, during the reign of Darius I).

Documents relating to Ahīqam's purchase of rent farming rights (B6; $\mathrm{Cl}_{7}-$ 18) were witnessed by several people, some of whom appear in several other documents as well. The importance of the transactions is emphasised by the presence of the courtier (ša rēš šarri) Nabû-lū-salim among the witnesses; this is the only time when a person bearing this high official title is attested in the corpus. ${ }^{792}$ Two other noteworthy persons on the witness lists are Bit-il-šarușur/Šalammu and his son Bīt-il-ab-uṣur. The name of the father betrays a connection to the royal administration. ${ }^{793}$ Bìt-il-ab-ușur is attested in numerous other documents relating to the administration of the local countryside. ${ }^{794}$ Bēl-ušallim/Šinqā (B6-7; $\left.\mathrm{C}_{17}, 19-22\right)$ was a royal official but apparently of a lower rank than his brother Iddinâ.

Something changed in the administration of the land-for-service sector around the twelfth year of Darius I. Iddinâ, his brother Bēl-ušallim, and the

790 Waerzeggers 2015, 185-186.

791 As Pearce and Wunsch $(2014,120)$ put it: 'A commission of appraisers travels the area about one month before the harvest and has the pertinent debt records issued'.

792 For ša rēššsarri officials, see Jursa 2011b.

793 On šarru names, see Section 1.5.1.

794 Bìt-il-šar-uṣur: B6; $\mathrm{C}_{17-18}$; 24. Bìt-il-ab-ușur: B6-7; C17-22, 24. 
governor Uštanu ${ }^{795}$ disappear from the documentation, and new officials are suddenly in charge of the lands managed by Ahīqam and his sons. The new functionaries include a nameless commander of the troops at the riverbank (C23: rab șābi ša kišād nāri), Kanzarā, the commander of the (reserve?) troops (C24: rab șāb kutalli?), ${ }^{796}$ and Zababa-ușur(?), the commander of the troops of Across-the-River (C26: rabșābi ša Ebir Nāri) ${ }^{797}$ Even though Iddinâ and Uštanu are not mentioned any more, there was continuity in the administration of the local land-for-service sector before and after the twelfth year of Darius. People living in the vicinity of Yāhūdu were still supervised by the officials of Acrossthe-River, and Bīt-il-šar-ușur and Bìt-il-ab-ușur are attested in 9-14 Dar and the scribe Šamaš-ēreš in 5-14 Dar. If the royal estates were redistributed among the high functionaries of the Persian Empire around 12 Dar, this did not significantly affect the local land-for-service sector.

\subsubsection{Texts from $\bar{A} l$-šarri}

Âl-šarri ('Kingstown') was a village located not far away from Yāhūdu. ${ }^{798}$ The place name itself suggests that the fields and orchards in the vicinity of Āl-šarri belonged to the land-for-service sector: $\mathrm{C}_{47}$ and $\mathrm{C}_{5} 1$ were written in $\mathrm{A} l$-šarri ša qašti eššeti ('Kingstown of the New Bow Land'). This was certainly the same place as Âl-šarri, as its name apparently fluctuated in a similar way as the name of Yāhūdu. ${ }^{799}$ Here we have yet another locality which was founded to bring new royal lands under cultivation. Ahīqam is attested there once in promissory

795 Because of the sporadic evidence, the chronology of the governors of Across-the-River cannot be reconstructed precisely. Uštanu was certainly the governor of Babylon and Across-the-River from the first until the third or the sixth year of Darius I, and a certain Tattannu was the governor of Across-the-River in the twentieth year of Darius. The documents from Yāhūdu suggest that Uštanu was the governor of Across-the-River at least until 1 Dar, but the absence of his full title in the Yāhūdu texts complicates the matter (see Bloch 2017, 102-111). The reference to the estate and slave of Uštanu in C103 (3 Xer) is so late that it cannot be taken as firm evidence for Uštanu still being governor or even alive. See Stolper 1989, 290-291; Pearce 2015, 17-18.

796 lúgal șa-ab gú.tar? The reading of the last sign is not completely clear, and as Pearce and Wunsch $(2014,138)$ note, the official title is not attested elsewhere. Kanzarā is attested without a title in $\mathrm{C} 25$.

797 See the collations of C26 in Waerzeggers 2017; Abraham et al. 2018.

798 On the Âl-šarri texts, their protagonists, and the location of Āl-šarri, see Wunsch (forthcoming), 7 .

799 Yāhūdu was also known as Ālu ša Yāhūdāya and Yāhūdu ša ina muhhi [...] (see Pearce and Wunsch 2014, 312). The name Āl-šarri ša qašti eššeti is attested in o and 2(?) Camb, and the first certain attestation of the name Āl-šarri is from 4 Camb. However, B2 (6 Cyr) is most likely written in Âl-šarri, even though the place name is damaged. The available space on the tablet does not allow us to restore the long form but only Âl-šarri, which suggests that 
note $\mathrm{C}_{41}$ (5 Dar). He granted credit to a certain Abdi-Yāhû/Hašdâ in order to help him hire a substitute to perform service obligations in Elam. Apart from $\mathrm{C}_{41}$, all the other six texts from Āl-šarri are difficult to connect to the rest of the corpus. They were written within twelve years in $6 \mathrm{Cyr}-1 \mathrm{Nbk}$ IV, which is roughly contemporary with the early period of Ahīqar's activity.

The texts from Āl-šarri centre around two persons: Iqbâ/Nabû-šum-ukīn (B2; C47, 49; 6 Cyr - 1 Nbk IV) and Bēl-lēêi/Mīnu-ana-Bēl-dannu/Ša-nāšišu $\left(\mathrm{C}_{48}-51 ; 2\right.$ ? Camb - 1 Nbk IV). They are not attested outside Âl-šarri and they had no connections to the other protagonists of the corpus. Iqbâ engaged in the workings of the land-for-service sector by leasing bow lands from their holders for cultivation $\left(\mathrm{B}_{2}\right.$; $\left.\mathrm{C} 49\right)$ and granting credit to farmers $\left(\mathrm{C}_{47}\right){ }^{800}$ Two of the documents pertaining to Iqbâ were written by a scribe named IttiŠamaš-balāțu/Bāba-ēreš (B2; C47) and the third one by Bēl-lēèi/Mīnu-ana-Bēldannu/Ša-nāšišu. The latter is attested in three other Āl-šarri texts as well, twice as a scribe $\left(\mathrm{C}_{4} 8,5^{\circ}\right)$ and once as a debtor $\left(\mathrm{C}_{51}\right)$. $\mathrm{C}_{4} 8$ is a promissory note for two shekels of silver, to be paid back at the time of the barley harvest. Both $\mathrm{C}_{50}$ and $\mathrm{C}_{51}$ pertain to sales of oxen to settle debts in silver. In $\mathrm{C}_{51}$, Bèl-lēei is one of the two debtors whose outstanding debt is settled by seizing an ox from the wife of Bēl-lēe'i's co-debtor Kinnâ. As draught animals were of high value and importance, the sale of an ox to settle a debt signals a strained economic situation. It is important to note that difficulties like this are not only found among farmers of foreign origin, since Bēl-lēêi, a scribe in Āl-šarri and a Babylonian bearing a family name, could also find himself in such a bind.

Other people in the Âl-šarri texts do not connect the text group to the rest of the corpus either. In addition to Ahīqam and his debtor, only two Judeans appear in the texts from Âl-šarri: one is a witness in $\mathrm{C}_{50}$ and the other seizes the ox in $\mathrm{C}_{51}$. However, they are not attested elsewhere in the corpus. Two other connections are possible but very unlikely. A person named Nabû-rēêušunu/ Arad-Nabû is attested as a lessor in $\mathrm{B} 2$ (Āl-šarri, $6 \mathrm{Cyr}$ ) and as a witness to the transaction of Nīr-Yāma/Ahīqam in C26 (21 Dar, the place of writing not preserved). The gap of thirty-two years makes it unlikely that the same person is referred to on both occasions. Another hypothetical link is Šamaš-erība/Nabû[...]-iddin, the debtor in $\mathrm{C}_{47}$ (Āl-šarri, o Camb). If the patronymic is amended as Nabû-zēr-iddin, a homonymous individual is attested as a witness to B21

there was no linear change from the longer to the shorter form of the place name (but see Pearce and Wunsch 2014, 176).

800 Iqbâ's patronymic is lost in C49, but restoring Nabû-šum-ukīn is well-founded on the basis of B2 and $\mathrm{C}_{47}$ (see Pearce and Wunsch 2014, 179). It must be noted, however, that two other men named Iqbâ are attested in C 50 (Āl-šarri, 1 Nbk IV). 
(Hamat, 4 Cyr), a text belonging to the Rīmūt/Abì-ul-ìde group. ${ }^{801}$ I hold both of the above suggestions to be improbable, and even if they were right, the presence of these men in $\mathrm{C}_{2} 6$ or B21 would not explain why the Âl-šarri texts ended up in the present corpus. These texts cannot belong to the hypothetical private archives of Ahīqar or Ahìqam, nor do they fit into group 1, where Pearce and Wunsch assign them. ${ }^{802}$ The existence of a group of isolated texts stresses the complicated archival structure of the corpus.

\subsubsection{Texts Pertaining to Zababa-šar-ușur and Büt-Abì-râm}

Texts pertaining to the royal official Zababa-šar-ușur and to the estate of BitAbī-râm are assigned to group 3 by Pearce and Wunsch, and the great majority of them remain unpublished. Zababa-šar-ușur is attested in seven texts published by Joannès and Lemaire $(\mathrm{J} 1-7), 803$ and Bìt-Abī-râm is the place where $\mathrm{C} 102$ (1 Cyr) was written. Moreover, C1o1 (Hazatu, 5 Cyr) should be included in this group as well, because it can be linked to the rest of the corpus only via Nabû-zēr-iddin/Balāssu, the creditor in C102. ${ }^{804}$ According to Pearce and Wunsch, text $\mathrm{C}_{103}$ (Bīt-Ṭāb-Bēl, 3 Xer) belongs to this group as well, but no person or place in this text is attested elsewhere in the corpus. ${ }^{805}$ This makes the total number of published texts nine or ten, depending on the choice to include $\mathrm{C}_{103}$ or not. The publication of a hundred or so texts from this group is forthcoming (see Section 4.1), which means that all the following conclusions are preliminary at best and need to be adjusted when more texts become available. ${ }^{806}$

The context of C101-103 and J1-7 is similar to that of the other texts in the corpus. They relate to the cultivation and management of royal lands in the Babylonian countryside, and the structures and terminology of the land-forservice sector are apparent in many of the texts. Zababa-šar-ușur/Nabû-zēriddin, the steward of the crown prince's estate (rab bitti ša bit ridûti), is the central figure in texts $\mathrm{J} 1-7$. According to the information available in Pearce

801 There appears to be an additional sign or a remnant of a sign between the ag and the mu signs, which looks like the pap sign (see Pearce and Wunsch 2014, 176). Reading 'numun' instead of 'pap' would result in the name Nabû-zêr-iddin.

802 Waerzeggers 2015, 184.

803 Joannès and Lemaire 1996.

804 Waerzeggers 2015, 184. For no obvious reason, the text is included in group 2 in Pearce and Wunsch 2014, 247.

805 Pearce and Wunsch 2014, 251. The document refers to the estate and slave of a certain Uštanu. Even if this Uštanu was the governor of Across-the-River, this information does not provide a link to the other texts mentioning the governor.

806 For preliminary discussions of the text group, see Joannès and Lemaire 1996, $55^{-} 56$; Pearce and Wunsch 2014, 6-9. 


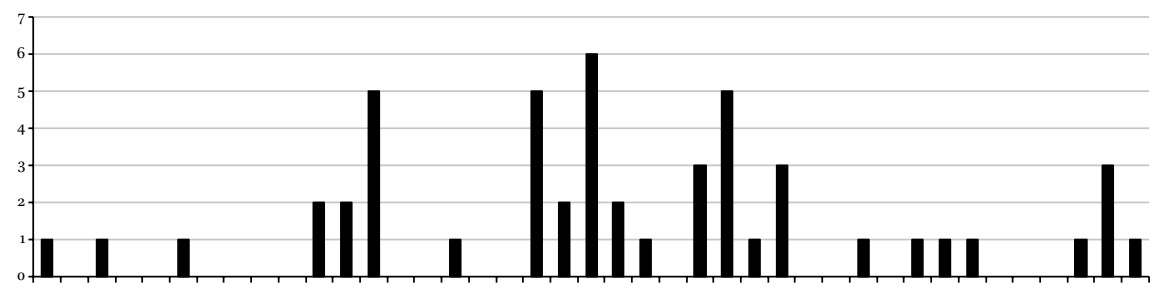

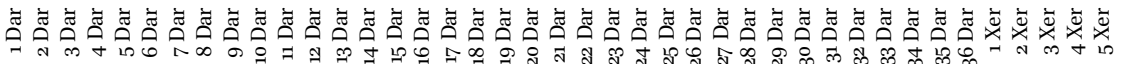
FIGURE 6 Documents pertaining to Zababa-šar-uṣur

and Wunsch 2014, he is attested in 1 Nbk IV - 5 Xer (521-481 BCE), and the peak of his activities is centred in the years 19-28 Dar (503-494 BCE). The chronological distribution of the Zababa-šar-uṣur texts in Joannès and Lemaire 1996 and Wunsch (forthcoming) is shown in Figure $6 .{ }^{807}$ In the available sources, he appears as the manager of the crown prince's lands $(\mathrm{J} 2-4)$, a creditor $(\mathrm{J} 1,5)$, a lessee (J6), and perhaps as a debtor $(\mathrm{J} 7)$. The name of this official with its šarru element is a good example of Beamtennamen in first-millennium Babylonia. 808

In J2-4, Zababa-šar-uṣur is not an active protagonist, but only referred to as the manager of royal lands in texts pertaining to a certain Barīk-Tammeš/Zēria. The latter was a rent farmer of the lands belonging to the crown prince's estate: ${ }^{809}$ in three documents $\left(\mathrm{J}_{2}-4\right)$ written in the seventh month of 21 Dar, three different persons owe him significant amounts $(18,30$, and 100 kurru $)$ of dates as an imittu rent. These dates were produced in three different localities on the lands of the crown prince's estate. According to the information available in the indices of Pearce and Wunsch 2014, Barik-Tammeš is attested in an additional two promissory notes related to rental income (B45-46), both written in the seventh month of 21 Dar, again in two different locations. Interestingly enough, all the localities attested in these five documents are hardly referred to in any other texts in the corpus. Only Kār-Adad is attested once in B 79. ${ }^{810}$ Accordingly, B 45-46 and J2-4 appear to constitute a well-defined subgroup, which allows us a glimpse of agriculture practices at the estate of a very

807 The figure shows 50 tablets which can be dated to a certain year and which refer directly to Zababa-šar-uṣur: B43-57, 59-64, 66-72, 75-76, 78-84, 86-87, 90-91, 94-95; J1-7. This does not include the Zababa-šar-ușur texts in Iraq, no information on which is available. The information on the tablets in Wunsch (forthcoming) is based on Pearce and Wunsch 2014, xxxviii-xlii, 298.

808 See Section 1.5.1.

809 Joannès and Lemaire 1996, $53^{-} 54$.

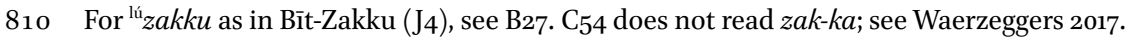


high-ranking person in the Persian Empire. As would be expected, the owner of the estate had appointed a steward to take care of his landholdings in the Babylonian countryside. In turn, the steward Zababa-šar-ușur outsourced the everyday management of the estate's lands to rent farmers, one of them being Barik-Tammeš, who collected the rental payments from the farmers or their representatives. ${ }^{811}$ The hierarchy is somewhat similar to the one at the governor Uštanu's estates near Yāhūdu. ${ }^{812}$

The rest of the published texts pertaining to Zababa-šar-ușur are more random and shed light on various sides of his activities. An important text (J6) from 26 Dar shows him visiting Babylon, where he leased a large plot of 45 kurru (circa 6o hectares) of land from a certain Bagazuštu/Marharpu. ${ }^{813}$ The lessor appears to be a high official of Egyptian origin: his first name is Iranian but patronymic Egyptian, and he is explicitly referred to as límișirāya ('Egyptian'). ${ }^{814}$ His official title, ša rēššarri ustarbaru, which can be translated roughly as 'courtier' or 'chamberlain', shows that Zababa-šar-ușur interacted both with local farmers and high officials in the Persian administration. ${ }^{815}$ It is not clear whether Zababa-šar-ușur leased the lands in an official capacity or for his own personal interests, but judging by the inclusion of Bagazuštu's bow land, the rented property included or consisted of royal lands. ${ }^{816}$

Two promissory notes from 6 Dar (J1) and 22 Dar (J5) are similar in various ways: the creditor is Zababa-šar-ușur, but he bears no official title, the debts are rather small and their origin is not explained, and the delivery of the staples is to take place in Bìt-Abì-râm after the date harvest, even though the debts are in sesame, barley, and sheep. What is important is that both tablets bear an Aramaic epigraph referring to the name of the debtor. Two other published tablets (C102; J7) from this group bear Aramaic epigraphs as well, which makes the proportion of Aramaic epigraphs on the published Zababa-šar-ușur/Bìt-Abīrâm tablets $(40 \%)$ significantly higher than in the corpus in general. ${ }^{817}$ The obverse of $\mathrm{J} 7$ ( 4 Xer) is almost completely lost, but the Aramaic epigraph on the

811 Cf. Joannès and Lemaire 1996, 53-54.

812 Figure 5 .

813 See Henkelman 2003, 122, 162-164.

814 For an analysis of the personal names, see Pearce and Wunsch 2014, 42, 65.

815 On ša rēšš šarri and ustarbaru, see Henkelman 2003, esp. 122, 162-164; Jursa 2011b; see also Hackl and Jursa 2015, 167-168.

816 As Hackl and Jursa $(2015,168)$ note, Bagazuštu leased out his own estates. This is in accordance with the general picture of complex hierarchies in the management of crown lands and the estates of high officials. See also Joannès and Lemaire 1996, 54, 56 .

817 Circa ten per cent of the texts published in Pearce and Wunsch 2014 contain Aramaic epigraphs (personal communication with Rieneke Sonnevelt; cf. Pearce and Wunsch 2014, $301)$. 
reverse refers to Zababa-šar-ușur, which may suggest that he was the debtor of this document. ${ }^{818}$ The fourth Aramaic epigraph is found on document $\mathrm{C102}$ written in Bìt-Abi-râm, and it probably also refers to the debtor of the document; see more on this text below. If the number of Aramaic epigraphs is equally high in the unpublished tablets of the Zababa-šar-ușur and Bìt-Abìrâm group, it provides us with important information on the use of Aramaic in the royal administration in Babylonia of the mid-first millennium.

Texts C101 and C102 do not pertain to Zababa-šar-uṣur, but they are connected to group 3 via Nabû-zēr-iddin/Balāssu, who is the creditor in both documents. The texts were written in Bīt-Abī-râm $\left(\mathrm{C}_{102}, 1 \mathrm{Cyr}^{819}\right)$ and Hazatu (C101, $5 \mathrm{Cyr}$ ), and they concern debts in barley which were due after the harvest in the second month. The barley fields belonged to the land-for-service sector, which is suggested by the reference in $\mathrm{C} 102$ to a pledged bow land and in C101 to a person managing the fields. Like Barīk-Tammeš/Zēria in J2-4, Nabû-zēriddin was a rent farmer on royal lands, and he is also attested in the earliest text pertaining to Zababa-šar-uṣur (B75, 1 Nbk IV) ${ }^{820}$ The place names in these two texts are noteworthy: $\mathrm{C} 102$ is the earliest attestation of Bït-Abì-râm, and Hazatu in C101 is yet another example of a twin town in Babylonia, this time referring to Gaza. ${ }^{821}$

Promissory note $\mathrm{C}_{103}$ (3 Xer) is one of the latest texts in the corpus and almost completely isolated, even though Pearce and Wunsch assign it to group $3 \cdot{ }^{822}$ The references to the estate and slave of a certain Uštanu remind the reader of the homonymous governor of Across-the-River, but any link to group 3 seems to be missing.

Due to the limited number of texts available at the time of writing this study, very little can be said about the connections between the Zababa-šar-uṣur dossier and other text groups in the corpus. The following remarks are thus preliminary and must be reviewed when more texts become available. First, it can be noted that the texts pertaining to Zababa-šar-ușur and Bìt-Abī-râm are not closely related to the Judean community in the environs of Yāhūdu, but they

818 Joannès and Lemaire $\left(1996,5^{0-51}\right)$ are not completely certain about the reading of the epigraph. However, they suggest reading it as $b^{\varsigma} l[\ldots ?]$ ? $h t y^{\top} z y z b b s^{2} r^{?} s b^{\varsigma} l p /$, with the last sign being a vertical wedge. They interpret $b^{\varsigma} l p /$ as an abbreviation of the official title $b \bar{e} l$ piqitti, and they translate the epigraph as '[...] the wheat of Zababa-šar-ușur, the super 〈intendent)'.

819 The name of the king is damaged in the date of the tablet, but Cyrus is the most plausible restoration of [...]-áš, especially given the date of C101. See Pearce and Wunsch 2014, 250.

820 The information on B75 is gathered from the indices of Pearce and Wunsch 2014.

821 Eph'al 1978, 80-82; Zadok 1985, 158; Pearce and Wunsch 2014, 247.

822 Pearce and Wunsch 2014, 251. 
originate from the same economic environment. Only one Judean (Nabû-ușur/ Dalā-Yāma in C101) is attested in the ten texts discussed above, and the same applies to the whole group as well. ${ }^{823}$ However, the texts evidently relate to the land-for-service sector, shedding light on how the estates of Persian royalty were administered and their fields were cultivated. Despite the absence of Judeans, the presence of people with non-Akkadian names and the twin town of Hazatu suggest that groups of foreign origin were living in the villages surrounding the crown prince's estate. ${ }^{824}$

Second, there are a number of important connections between the Zababašar-ușur dossier and the rest of the corpus. It is noteworthy that Ahīqar's son Nīr-Yāma is attested as a debtor in B88, a promissory note for silver written in Dibtu in 25 Dar. ${ }^{825}$ The witnesses and the scribe are not attested elsewhere, but the creditor Aplâ/Šamšăia is a central person in the dossier pertaining to Zababa-šar-ușur. He is attested in ten Zababa-šar-ușur texts, including document J6, a lease which he witnessed in Babylon. ${ }^{826}$ Nīr-Yâma's connection to Zababa-šar-ușur's entourage suggests that people in the environs of Našar came in touch with or under the influence of the crown prince's estate in the early fifth century at the latest. Another important link between the Zababašar-ușur texts and other groups in the corpus is the royal administration. The scribe Arad-Gula plays a central role in Našar, the presence of royal officials is notable in the Ahīqam texts, and Zababa-šar-ușur himself was a royal official. Finally, the Zababa-šar-ușur dossier is chronologically related to the texts pertaining to Ahīqar and Ahīqam. The corpus can be divided into three successive phases: Ahīqar's peak activity in $7 \mathrm{Cyr}-3$ Dar, Ahīqam's activity in 4-15 Dar, and Zababa-šar-ușur's activity in 19-28 Dar. These issues will be discussed in more detail in Section 4.3.10.

\subsubsection{Loosely Connected and Isolated Texts}

A number of texts cannot be easily assigned to any of the previous groups, but all of them adhere to one of the general characteristics of the corpus: they refer to Yāhūdu or Našar, or some people with Yahwistic names appear in them. Accordingly, it is probable that these documents also originate from the same find-spot as the rest of the corpus. At the same time, they emphasise the complicated structure of the corpus, as they highlight the internal heterogeneity of Pearce and Wunsch's groups 1 and 2.

823 Pearce and Wunsch 2014, 9.

824 See Joannès and Lemaire 1996, 52-53; Pearce and Wunsch 2014, 9.

825 This information is gathered from the indices of Pearce and Wunsch 2014.

826 The other documents are B48-49, 71, 76, 79-80, 84, 86; J4. 
B11 is a verdict on the ownership rights of a ram (reign of Darius I, place broken). The document was written by the well-attested scribe Šamaš-ēreš/ Marduk-mukīn-apli/Mudammiq-Adad, who wrote several documents in the environs of Yāhūdu. ${ }^{827}$ The parties of the litigation, Il-lindar/Nabû-zēr-iddin and Nadab-Yāma/Abdi-Yāhû, also appear in C16, which pertains to litigation over rental income between Ahīqam and Nadab-Yāma (9 Dar, the town of Amurru-šar-ușur on the Zabinā canal). Il-lindar is among the witnesses in $\mathrm{C} 16$, but nothing suggests that the legal cases were connected. Other witnesses or the scribe of $\mathrm{C}_{1} 6$ do not appear in other documents. It is possible that Ahīqam bought the ram at a later point in time and received Bi1 as a further proof of legal ownership. However, the administrative connection is again noteworthy and may better explain why B11 ended up in the corpus: the scribe Šamaš-ēreš was a central figure in the administration of the local land-for-service sector.

The latest documents of the corpus, $\mathrm{C}_{52}{ }^{2} 53$, were written in the seventh and ninth year of Xerxes, respectively ( 479 and $477 \mathrm{BCE}$ ). The texts come from the same region and from the same economic environment as the earlier texts of the corpus, but the people appearing in these late texts are not attested elsewhere. The texts show that the text corpus was not affected by Xerxes' reprisals against the rebelling Babylonians in his second regnal year. ${ }^{828}$ Promissory note $\mathrm{C}_{53}$ for imittu rents from Yāhūdu bears witness to the continuity of Judean settlement and the basic structures of the land-for-service sector until the fifth century BСЕ. Nevertheless, the organisation of or the terminology relating to the land-for-service sector had changed over time: the fields of šušannus or estates of royal officials are not referred to, but the fields are instead said to be located in a pardèsu, a Persian royal estate. ${ }^{829} \mathrm{C}_{52}$ is a sale of a slave woman and her child, witnessed by a Judean and written in uru é $h a-{ }^{\ulcorner} a m-m a^{\top}-[. .$.$] ,$ which may be identical to the previously attested village of Hamat. ${ }^{830}$ Apart from that, nothing connects this text to the rest of the corpus.

$\mathrm{B}_{3}$ is a peculiar text pertaining to the transfer from father to daughter of a slave woman and a share in a cow. Something had gone wrong and the original tablet was apparently lost, which prompted someone to draft the present document. Its genre is difficult to establish, but following Wunsch, it can be characterised as a 'reconstruction of lost bequest record and quest for expert

827 See Section 4.3.6.4.

828 On the events in the second year of Xerxes and the end of many Babylonian urban archives, see Waerzeggers 2003/2004.

829 See CAD P, 182.

830 Pearce and Wunsch 2014, 190. See Section 4.3.2. 
witness. ${ }^{\prime 31}$ The slave woman bears the Egyptian name Huțuatā, ${ }^{832}$ but all the other persons are Judeans. The name of the scribe and the time and place of writing are not recorded. The last witness Sidqī-Yāma/Natīn may be identical to the homonymous witness in the marriage agreement from Yāhūdu $(\mathrm{Al})$, but no one else is attested in other documents.

In $\mathrm{B} 4$, a Judean man hires a substitute to perform royal service duties in Elam. ${ }^{833}$ The document is written in Yāhūdu in 10 Dar, and it provides us with important information about the service obligations and ways to deal with them in the land-for-service sector. Even though the document is dated to the period of Ahĩqam's peak activity, only the scribe and perhaps two witnesses can be connected to him or his sons. ${ }^{834}$

$\mathrm{B} 17$ is a broken contract for cultivation, and none of its protagonists or witnesses can be identified in other documents. The text was probably written in Yāhūdu in the eleventh year of Darius I. It is possible that the contract is somehow connected to the business of Ahiqqam and his sons, but the damaged tablet does not yield such information.

$\mathrm{C}_{54}$ is a list of expenses, like a note for personal use. A date is not given. The tablet refers to a number of place names, including Yāhūdu, Hursagkalamma (Kiš), and Susa. ${ }^{835}$ The text cannot be connected to other documents in the corpus, but its wide geographic scope suggests that it was more likely related to the royal administration than Judean farmers.

\subsubsection{Administrative Practices and the Origins of the Text Corpus}

The preceding discussion of the texts from Yāhūdu, Našar, Bìt-Abī-râm, and their surroundings has revealed that the documents cannot be easily assigned to a single private or institutional archive. They certainly stem from the same geographical area and economic context of the land-for-service sector, but the texts belong to several groups. These groups seem to be interlinked by scribal and administrative practices, which emphasises the role of the state in the origins of the text corpus. In order to understand the forces which brought the text corpus into being, this section will discuss the relations between the text groups in detail. The meagre number of available texts from Bìt-Abī-râm hinders attempts to link these texts with the rest of the corpus, and the following

\footnotetext{
831 Wunsch (forthcoming), 8.

832 Pearce and Wunsch 2014, 56 .

833 The name of the Judean alternates strangely between Šalam-Yāma and Šamā-Yāma.

834 Iddin-Nabû/Marduk-êțir/Naggāru also wrote documents C21, 32, 37. Šamā-Yāma/PiliYāma or his namesake is attested in C14, and Yāhû-izrī/Barīk-Yāma or his namesake in B13 and B14.

835 See the new edition of the reverse in Waerzeggers 2017.
} 
discussion thus focuses on finding factors that interconnect the other text groups with each other.

The first impression of the texts from Yāhūdu, Našar, and their immediate surroundings is that they constitute two groups, one documenting the business activities of Ahīqam/Rapā-Yāma and his sons and the other those of Ahīqar/Rīmūt. However, a closer look reveals that there are two groups of texts which precede the activities of Ahīqam and Ahīqar. The first one not only pertains to Ahīqam's father Rapā-Yāma but also includes other early texts from Yāhūdu. The group featuring Rīmūt/Abī-ul-ìde and Rīmūt/Samak-Yāma is like a prelude for the business activities of Ahīqar/Rīmūt. One of the men could be the father of Ahīqar, but this connection would not explain the inclusion of the texts pertaining to the other Rīmūt. Further investigation reveals more subgroups, which pertain to the village of Āl-šarri and to a certain Bēl-ahhē-erība from Našar. Some isolated texts resist being connected to any other documents.

Ahīqam and Ahīqar are never mentioned in one and the same document, even though they must have known each other. They were contemporaries, men of Judean descent, who lived in close proximity to each other. They both worked in the land-for-service sector, being liable for paying taxes to the same dēkû official (C12, 83), and Ahīqam once visited Našar, the focal point of Ahīqar's activity ( $\left.\mathrm{C}_{3}\right)$. They both knew the scribe Arad-Gula and his son Bēlupehhir. Šalāmān, the brother of Ahīqam, is once attested in Bīt-Bāba-ēreš (C80) on the very same day when Ahìqar visited the village (B34). ${ }^{836}$ Moreover, promissory note B42, relating to the ownership history of Ahĩqam's slave woman Nanâ-bihī, reveals that Nanâ-bihì's previous owners were active in Našar. ${ }^{837}$

The most peculiar feature of the texts pertaining to Ahĩqam and Ahīqar is their chronological distribution. Both men are first attested in the reign of Cyrus, Ahīqam in two texts referring to a tax payment and the settlement of his father's debts in 5 and $7 \mathrm{Cyr}\left(\mathrm{C}_{12-13}\right)$. The first two Ahīqar texts were written in 1 and $3 \mathrm{Cyr}$, but the main period of his business activities extends from $7 \mathrm{Cyr}$ until 3 Dar, including a break in 6-7 Camb. Only one Ahīqar text was written after the third year of Darius I (C94 in 7 Dar), whereas Ahĩqam's business activities took place in 4-15 Dar. The chronological distribution of the documents directly pertaining to Ahīqar and Ahīqam is presented in Figure 7 .

$8_{36}$ Both B 34 and C8o are written by Arad-Gula, and Ibâ/Nabû-iddin and Mukkêa/Yāhû-azza are attested in both documents.

837 Nanâ-bihī is listed among the business assets in the inheritance division C45||A2. B42 was written by Arad-Gula in Našar, and one of the two creditors of the document, Šum-iddin/ Bēl-zēr-iddin, is attested together with Ahīqar in C98-99. 


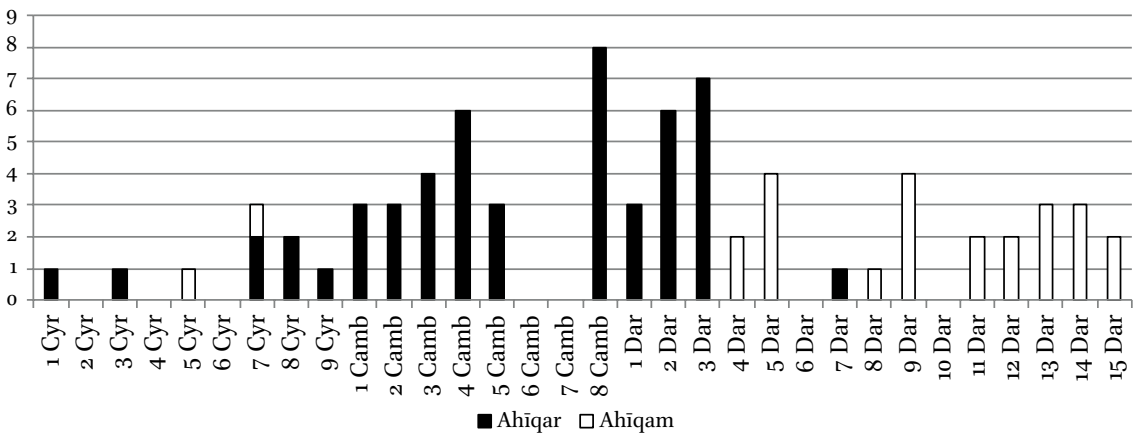

FIGURE 7 Documents pertaining to Ahīqar and Ahīqam

However, as was shown above, the nature of Ahīqar's business was very different from that of Ahìqam and the contents of the text groups do not show continuity from one file to another. In the same vein, the geographical focal point of the texts shifts from Našar to Yāhūdu when Ahīqam starts his business activities. The abrupt end of the Ahìqar file and the sudden start of Ahīqam's activities are hinged by a text written in Babylon in $15-\mathrm{V}-4 \mathrm{Dar}\left(\mathrm{B}_{5}\right)$, which is the earliest document pertaining to Ahīqam's own business activities. The promissory note for over five minas of silver and five sheep owned to Ahīqam by a certain Banā-Yāma/Abdi-Yāhû was written by the scribe Arad-Gula. The debt was to be paid back within one month in Yāhūdu, and we may encounter the debtor Banā-Yāma again in $\mathrm{C}_{3} 6$ (13 Dar), now as the creditor of Ahīqam. B5 stands out from the patterns we see in the texts pertaining to Ahīqam, Ahīqar, and Arad-Gula, and it implies that the Ahīqam and Ahīqar texts were not fully independent from each other. The text might be related to Ahīqam's beer brewing and retail sale activities in Babylon, but the presence of Arad-Gula creates the impression that the text somehow marks the transition from the Ahīqar-Našar group to the Ahīqam-Yāhūdu group.

Despite the centrality of Ahīqar, Ahīqam, and the latter's son Nīr-Yāma in the texts from Našar and Yāhūdu, two other persons played an extremely important role as well. Arad-Gula/Nabû-šum-ukīn/Amēl-Ea and his son Bēlupehhir are present in numerous documents as a scribe and witness but never as active parties in the transactions. Arad-Gula wrote the majority of documents pertaining to Ahīqar but also two documents relating to Ahīqam (B5; $\left.\mathrm{C}_{13}\right)$, and his son is attested as a witness to the transactions of Ahìqar $\left(\mathrm{C}_{75^{-}}{ }^{-6}\right.$, 92, 97), Ahīqam (C13), and Ahīqam's son Nìr-Yāma ( $\mathrm{C}_{32}$ ).

Arad-Gula seems to have been more than a mere scribe in a small village. As I argue above, Našar was not only a rural village but also an administrative estate in the land-for-service sector. It is highly unlikely that Arad-Gula just lived 
in Našar and wrote documents for Ahīqar, Ahīqam, and others who lived in or visited the village. Instead, Arad-Gula probably belonged to the administrative personnel of the estate, who not only recorded but also supervised the transactions of the local farmers (see Section 4.3.5). It is noteworthy that Arad-Gula is attested from 3 Cyr until 4 Dar $\left(53^{6}-518\right.$ вСЕ), but the only text (C86) written in Našar during the short rebellion of Nebuchadnezzar IV is not written by him but by Lâbâši-Marduk/Arad-Nabû/Sîn-imitti, who is not otherwise attested. Changes in local rule may have been reflected in the status of Arad-Gula as well. 838

Arad-Gula's role is further clarified by three documents pertaining to Bēlahhē-erība/Nūr-Šamaš (Section 4.3.4). The transactions are similar to those of Ahīqar, even though he is not mentioned in these texts. Bēl-ahhē-erība's debtor in $\mathrm{C}_{5}$, Šum-iddin/Șillâ, was also Ahīqar's debtor and a witness to his transaction (C89-9o), but the strongest link between Bēl-ahhē-erība and Ahīqar are Arad-Gula and his son Bēl-upehhir. The scribe wrote all three tablets pertaining to Bēl-ahhē-erība $\left(\mathrm{C}_{4}-65,84\right)$, and two of them were witnessed by his son $\left(\mathrm{C}_{65}, 84\right)$. If Bēl-ahhē-erība was not Ahīqar's business partner, his documents most likely found their way into the corpus via Arad-Gula and Bèl-upehhir.

Other scribes were also involved in the administration of the land-forservice sector. As discussed above, Šamaš-ēreš/Marduk-mukīn-apli/Mudammiq-Adad was attached to the administration of the royal lands in Yāhūdu and its surroundings in 5-14 Dar (see Section 4.3.6.4). Neither was Arad-Gula's and Ahīqam's journey to Babylon unique: Ah-immê/Rīmūt and the scribe Nabûêtir/Niqūdu are attested together in Babylon in 3 Cyr (C61), and the same Nabû-ētị wrote two documents pertaining to Ah-immê's father Rīmūt in BìtDibušiti in $14 \mathrm{Nbn}\left(\mathrm{C}_{57}-58\right)$.

The text groups of the present corpus did not originally belong to a single large archive, but they were created and brought together by the administration of the land-for-service sector. It seems probable that the business dossiers of Ahìqam and Ahìqar existed originally as independent units and that they were held by the Judeans themselves. Some other groups of the archive, such as the texts pertaining to Bēl-ahhē-erība, have a similar background. The word 'business' should be understood in the widest sense of the term: a distinction between private business and official administration can be misleading, because men like Ahīqar and Ahịam had a central role in the running of the land-for-service sector.

By recording their transactions, the state administration supervised the rural population in the land-for-service sector. Changes in the administrative

838 Waerzeggers 2015, 187 . 
hierarchy affected all the members of this system, and they are also reflected in the composition of the text corpus. A noticeable change took place during the first years of Darius I. The peak activity of Ahīqar ceased and that of Ahìqam started at the moment of administrative changes in the environs of Yāhūdu and Našar. It is hardly a coincidence that the term šušānu appears for the first time in the fourth year of Darius $\left(\mathrm{C}_{33}\right)$ and that evidence for hatru-like units of landholders cannot be found before the fifth year of his reign. The scribe AradGula disappeared from the scene after the fourth year of Darius, but new administrative personnel had arrived in the countryside: Zababa-šar-uṣur is attested in the first and Iddinâ/Šinqā in the fifth year of Darius.

The transition from the Ahīqar texts to those of Ahīqam marks a shift to a very different administrative landscape. In the course of this transition, the documentation relating to the previous period was no longer needed, and it was sorted and deposited in an administrative archive. It is also noteworthy that no Ahīqam texts survive from $8 \mathrm{Cyr}-3$ Dar, although his business had to have been running already before 4 Dar. This implies that the tablets documenting the early phase of Ahīqam's business activities were deposited around the fourth year of Darius, but they have not come down to us. Just like the Ahīqar tablets, these documents were not needed anymore after the reorganisation of the land-for-service system.

Other texts found their way into the corpus in a similar way: the texts from $\bar{A} l$-šarri and those pertaining to Bēl-ahhē-erība document economic activity in the land-for-service sector before the early reign of Darius. The dossiers were created independently, but they were deposited in a single administrative archive. This explains how isolated texts and administrative documents found their way into the corpus as well. All the texts clearly originate from the same geographical and economic environment of the land-for-service sector in the surroundings of Našar and Yāhūdu.

The career of Zababa-šar-uṣur, the steward of the crown prince's estate, also started at the time of administrative changes in the late reign of Cambyses or the early reign of Darius. As can be seen in Figure 8, the texts pertaining to Zababa-šar-ușur constitute the third and last phase of the corpus. According to published texts and the indices of Pearce and Wunsch 2014, Ahīqam and his sons had no contact with Zababa-šar-uṣur, but Ahīqar's son Nīr-Yāma was in touch with a person in Zababa-šar-ușur's entourage in 25 Dar (B88). This suggests that people and local administration in the environs of Yāhūdu and Našar came under the influence of the crown prince's estate in the late reign of Darius at the latest. These developments resulted in the final composition of the corpus. Zababa-šar-ușur is attested until the fifth year of Xerxes and the last document of the corpus, $\mathrm{C}_{53}$ from Yāhūdu, was written in the ninth year of 


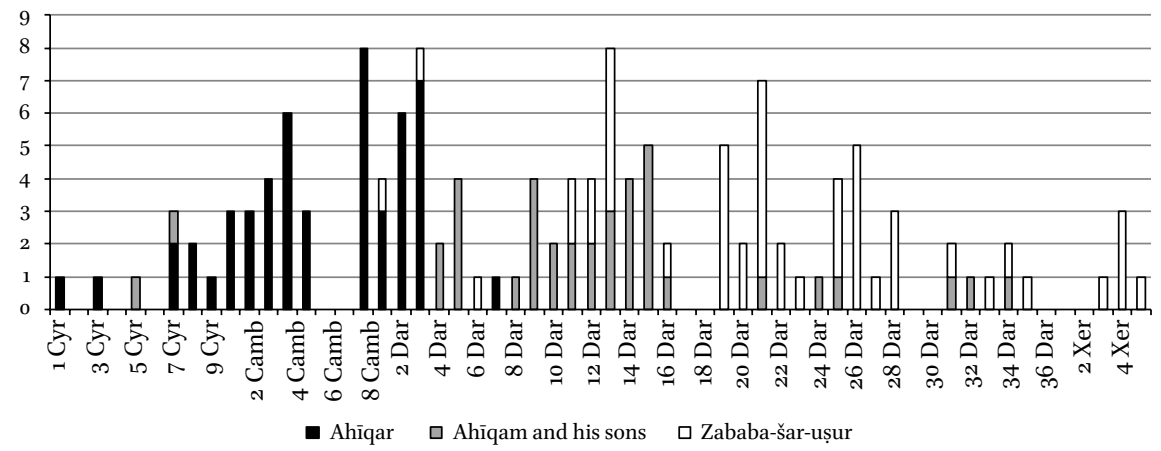

FIGURE 8 Main text groups of the Yāhūdu corpus

Xerxes. Around this time one or more administrative archives were sorted and a number of texts pertaining to the land-for-service sector in the environs of Yāhūdu were disposed of. These disposed documents comprise the corpus of texts discussed in this chapter. ${ }^{839}$

\subsection{Judeans in Yāhūdu and Its Surroundings}

It is evident that the careers of Ahīqam and Ahīqar were exceptional, such that the average Judean is to be sought among their clients. The ancestors of these people had arrived in the region of Yāhūdu and Našar in the early sixth century as a result of the Babylonian deportations, were settled in communities, and were provided with plots of land to cultivate. These plots were a part of the land-for-service sector of the Babylonian agriculture, and, aside from providing a source of income, they were burdened with taxes and service obligations. It appears that some farmers struggled to make ends meet and they had to rely on the services of men like Ahīqar. Credit was needed to pay taxes or to hire a substitute to perform service obligations, and sometimes indebtedness resulted in the pledging of landholdings. In the worst case, the landholder found himself cultivating his own field as a lessee of his creditor.

The problem of indebtedness among landholders is visible in the Murašû archive as well. In no way was it restricted to Judeans, as the predicament applied to small farmers in the land-for-service sector in general. ${ }^{840}$ However, it is impossible to estimate how common this problem was, since our sources document especially those cases when indebtedness occurred. At the same time,

839 Cf. Pearce and Wunsch 2014, 9.

840 See Chapter 5 . 
the careers of Ahīqam and Ahīqar demonstrate that Judeans could expand their economic activities beyond their plots and enter into the world of administration and business within the land-for-service sector. As I argued above, these men should not be seen as private entrepreneurs per se, as their economic activities were controlled and encouraged by the state. In addition to doing business, a man like Ahīqam could also act as a representative or foreman of the Judean community in Yāhūdu, serving the interests of his own, his community, and the local administration. A similar pattern can be observed among a group of farmers in the Murašu archive, on which see Section 5.2 below. It is noteworthy that the geographical scope of Ahĩqam's activities extended to Babylon, which shows that his local operations in Yāhūdu were connected to retail sales in the regional economic centre.

Judeans worked in the land-for-service sector as officials as well. Two Judean dēkûs, tax-summoners, appear in the texts. Judging by his name, Bēl-/Yāhû-šarușur pursued a career in the state administration as well. ${ }^{841}$ The hierarchical structure of the land-for-service sector provided opportunities for Judeans, who occupied some lower-level positions between their fellow landholders and higher state officials. The term šušānu is often used in the texts from Yāhūdu when referring to Judeans - it implied a legal status different from that of a slave or fully free person. ${ }^{842}$ The status of šušānus might be characterised as being semi-free, protected from slavery but not free to alienate their landholdings and the associated obligations.

One possibly Judean slave is attested in the corpus, but because he was owned by a Judean family, he may have received his Yahwistic name by his masters $\left(\mathrm{C}_{45} \| \mathrm{A} 2\right)$. In general, a great number of Judean slaves in the countryside is not to be expected, because the land-for-service sector was not run by slaves but by people whose social status was that of a šušānu. On the other hand, some Judeans were slave-owners: Ahīqam owned at least three slaves and Malēšu/Mī-kī-Yāma and Șidqī-Yāma/Šillimu each had one slave. ${ }^{843}$ Both Ahīqam and Malēšu had a slave woman of Egyptian origin, ${ }^{844}$ whereas the rest of the slaves bore Yahwistic and generally West Semitic names. ${ }^{845}$ The status

841 Dēkûs: C12, 83; J9; Bēl-/Yāhû-šar-uṣur: C2-4. See below.

842 See Sections 4.2.2 and 4.3.6.

843 On slavery in the text corpus, see Magdalene and Wunsch 2011.

844 The slave woman Nanâ-bihî is mentioned among the business assets divided by Ahīqam's sons in $\mathrm{C}_{45} \| \mathrm{A}$ 2. Nanâ-bihī's Egyptian origin is made explicit in B42. Malēšu's slave woman was named Huțuatā (B3); see Pearce and Wunsch 2014, $5^{6}$ on the Egyptian etymology of the name.

845 Ahīqam owned a slave called Abdi-Yāhû (C45||A2) and a slave woman called Ilā-bî (B9). Șidqī-Yāma had a slave called Puhullā $\left(\mathrm{C}_{5}\right)$. On the names, see Pearce and Wunsch 2014, $33,57,76$. 
difference between Ahīqam and his Judean clients or the Judean ownership of Egyptian slave women and a possibly Judean slave are strong evidence for diversity among the immigrants in rural Babylonia. Not everybody cultivated their small plots of state land. Some people acquired wealth, while others served their fellow immigrants as slaves.

Because of their economic nature, the texts from the surroundings of Yāhūdu and Našar do not directly touch upon the cultural traits of their Judean protagonists. However, the practice of using Yahwistic names may tell us something about group identity, religious views, and changes in these over time. ${ }^{846}$ It is noteworthy that Judean fathers bearing Yahwistic names tended to give Yahwistic names to their sons, while fathers bearing non-Yahwistic names had sons bearing Yahwistic names; it happened less frequently that a person bearing a Yahwistic name had a son with a non-Yahwistic name. ${ }^{847}$ The non-Yahwistic names borne by Judeans were more often linguistically West Semitic than Akkadian, which indicates that Aramaic and Hebrew played a major role in the Judean communities. ${ }^{848}$

An interesting feature in the non-Yahwistic names borne by Judeans is their religious neutrality: the great majority of them do not pertain to any divinity but are non-theophoric, like Rīmūt and Šillimu. There are only four examples of Babylonian theophoric names borne by people who can be identified as Judeans. ${ }^{849}$ Given the size of the sample (261 Judeans), this cannot be a pure coincidence, and we may conclude that there was a tendency to favour Yahwistic names at the expense of other theophoric names. However, this should not lead us to conclude that the Judeans of the Yāhūdu region only worshipped Yahweh. It should also be kept in mind that it is not possible to identify most of the Judeans who had a non-Yahwistic name and patronymic. Yet, one cannot escape the conclusion that traditional name-giving practices and Judean

846 On name-giving practices among Judeans in Yāhūdu and its surroundings, see Pearce and Wunsch 2014, 10-29; Pearce 2015. This section on naming practices has greatly benefitted from the discussions at the conference 'Die Religionspolitik der Achaimeniden und die Rolle der kleinasiatischen und vorderasiatischen Lokalheiligtümer', Münster, 24-26 February 2016. Especially valuable were the comments and suggestions by Reinhard Kratz.

847 There are 56 cases of Yahwistic father and Yahwistic son; 23 cases of Yahwistic father and non-Yahwistic son; 42 cases of non-Yahwistic father and Yahwistic son; and 2 cases of nonYahwistic father and non-Yahwistic son. The man known as Bēl-šar-uṣur or Yāhû-šar-uṣur, son of Nubâ $\left(\mathrm{C}_{2}-4\right)$, is excluded from these numbers.

84838 names are West Semitic, 15 Akkadian, 9 of uncertain origin, and 3 generally Semitic.

849 Bēl-šar-ușur/Nubâ (also known as Yāhû-šar-ușur) in C2-4, Nabû-ah-ușur, the brother of Aqabi-Yāma, in C77, Nabû-uṣur/Dalā-Yāma in Cıo1, and Bēl-ušallim, the father of Yāmaaqabī, in B29. One person bears the Aramaic name Bahi-iltā, referring to a goddess (B10; C25). There are some names referring to ilu ('god'), but these should be considered as neutral in the present context. 
customs persisted among the rural population, and Yahweh had a special place in the beliefs of the community. 850

A peculiar exception to the previous pattern should be noted, however. In the early Yāhūdu documentation, a man was known by two names, Bēl-šarușur ('Bēl, protect the king', C2-3) and Yāhû-šar-ușur ('Yahweh, protect the king', C4). ${ }^{851}$ It is beyond doubt that these two names refer to one individual, a son of Nubâ: he is always attested as a creditor of Șidqī-Yāma/Šillimu in promissory notes written in Yāhūdu in the reigns of Nebuchadnezzar II and Nabonidus. The use of different names in different situations does not make much sense here, because all three transactions closely resemble each other. It seems probable that the man changed his name from Bēl-šar-ușur to Yāhû-šar-uṣur around the fifth or sixth year of Nabonidus, as a consequence of Belshazzar's (Bēl-šar-ușur) coregency in Babylon. ${ }^{852}$ The decision to use the name Bēl-šarușur in the first place may have been somehow motivated by the status of Bēl/ Yāhû-šar-ușur, because the šarru element of the name betrays its bearer's connection to the royal administration. ${ }^{853}$ It appears that naming practices remained more traditional among Judean farmers than their countrymen who lived in bigger cities or were members of the royal administration. Finally, it should be noted that the theophoric element Bèl allows one to play with words and meanings. As a divine name, Bēl usually denoted Marduk in the Neo-Babylonian period, but, in general usage, the word simply meant 'lord'. It is not inconceivable that some Judeans found it tempting to equate Bēl to Yahweh, who occupied a central position in their pantheon.

A few documents pertaining to family affairs shed very little light on the everyday life of the Judean community. A marriage agreement has survived from Yāhūdu $(\mathrm{Al})$, but it is a problematic piece of evidence because there is no way of knowing whether any of the parties were Judean. ${ }^{854}$ However, as the document was witnessed by several Judeans, at least the milieu where the contract originated was distinctly Judean. Even though the document follows the structure of Neo-Babylonian marriage agreements in general, some of the stipulations differ from the standards of that time. ${ }^{855}$ By comparing this document with other marriage agreements involving non-Babylonian parties, Kathleen Abraham shows that these deviations likely reflect some non-Babylonian legal

\footnotetext{
$850 \quad$ See also Section 8.5 .

851 See Pearce 2015, 24-28.

$85^{2}$ Pearce 2015, 26-27; compare to the name change of the scribe Nabû-na'id/Nabû-zēr-iqiša (Section 4.3.6.2).

853 See Bloch 2014, 135-136; Jursa 2015b; Section 1.5.1.

854 See Section 4.3.6.2.

855 Abraham 2005/2006, 202-206.
} 
and cultural traditions. ${ }^{856}$ This implies that the people of foreign origin had some agency in the wording of the documents and they were not dictated by the scribes or the Babylonian party of the marriage. ${ }^{857}$

The inheritance division of Ahīqam's business assets in Babylon conforms to Babylonian legal practice. ${ }^{858}$ The text does not pertain to the division of Ahīqam's whole property but only to his brewing enterprise in the capital. Accordingly, no conclusions about Ahiqqam's wealth can be drawn from the document. In any case, two remarks are in order. First, Ahīqam may have had two wives, because his sons are divided into two groups in the document. ${ }^{859}$ Second, the great number of Judean witnesses in Babylon sheds some light on the Judean community in the capital. As none of these people are mentioned in other texts of the corpus, it is unlikely that they all travelled from Yāhūdu to Babylon. ${ }^{860}$

Mostly, the naming practices help us to glean some information on the traditions and beliefs of the Judean communities in Yāhūdu and its surroundings. Yahwistic names played a major role in the Judean onomasticon and it appears that non-Yahwistic theophoric names were rarely used. This does not mean that the Judeans only worshipped Yahweh, but it attests to the continuity of cultural traditions and the importance of Yahweh in the Judean pantheon. At the same time, there is no reason to suspect that Judeans aimed to isolate themselves from the surrounding society, as evidenced first and foremost by the careers of Ahīqam and Ahīqar. Both men were in regular interaction with non-Judeans, and they were not stationed in their villages but travelled around the region.

One does not find an assimilationist policy from the side of the Babylonians or Persians. This is corroborated by the policy of settling deportees in twin towns and by the survival of these communities from the reign of Nebuchadnezzar II until Xerxes. Natural integration into the surrounding society can be observed on many levels: Judeans found their place in the local economy, no tensions between Judeans and other population groups are evident, and some Judeans were able to find ways to prosper beyond the limits of their plot of royal land.

856 Abraham 2015 .

857 Abraham 2015, 57 .

858 Magdalene and Wunsch 2011, 121-125, esp. 124. See also the discussion in Abraham 2007; Pearce and Wunsch 2014, 172-173.

859 Abraham 2007, 210-211; Pearce and Wunsch 2014, 172.

86o Cf. Pearce and Wunsch 2014, 173. 


\section{Judeans in the Murašû Archive}

\subsection{Introduction}

The Murašu archive was the most important source for the study of Judeans in Babylonia until the publication of the texts from the environs of Yāhūdu. ${ }^{861}$ The archive consists of circa 730 texts $^{862}$ relating to the business activities of the descendants of Murašû in the Nippur region from the tenth year of Artaxerxes I to the first year of Artaxerxes II (454-404 BCE). ${ }^{863}$ The Babylonian family of the Murašûs were entrepreneurs in the land-for-service sector of local agriculture, and their archive is an indispensable witness to this economic sphere and the role of immigrants in it.

This chapter is divided into six sections. Sections 5.2 and 5.3 focus on Judean farmers and landholders in the Nippur countryside, and Sections 5.4 and 5.5 discuss Judean officials and witnesses. Sections 5.6 and 5.7 analyse the socioeconomic status and cultural traits of the Judeans in the Murašû archive.

\subsubsection{The Murašû Archive}

The Murašû archive was found in situ in Nippur during the American excavations led by John Henry Haynes in May and June of 1893. The clay tablets and twenty clay bullae were unearthed in a small room in the so-called Camp Hill, west of the Inanna temple and Ekur. As no excavation reports were published, only meagre information on the archaeological context can be obtained from Haynes' field notes and letters. According to them, the tablets were discovered in a single room which was part of a larger house. ${ }^{864}$ The bulk of the clay tablets were divided between Istanbul and Philadelphia, and currently they are kept at the Istanbul Archaeological Museum and the University of Pennsylvania Museum of Archaeology and Anthropology. A number of tablets found

861 This chapter has benefitted from the working notes on the Murašû texts by Govert van Driel and his students (see van Driel 1989, 227 n. 1), archived at Leiden University. Particularly helpful were the transliterations of the texts in PBS 2/1 and van Driel's geographical classification of the texts according to the respective canals and settlements. In the following discussion, these working notes are referred to as 'van Driel, working notes'.

862 Stolper 1985, 14; Jursa 2005a, 113.

863 Stolper 1985, 23.

864 Stolper 1985, 1, 157-168. On the history of early American excavations in Nippur, see Meade 1974, 47-63. 
their way to Jena, Yale, the British Museum, and other collections. ${ }^{865}$ Hermann V. Hilprecht and Albert T. Clay published a significant number of Murašû tablets in 1898-1912, and Matthew W. Stolper and Veysel Donbaz continued their work in the last quarter of the twentieth century. ${ }^{866}$ In addition to these major publications, small groups of tablets have been made available in several publications. $^{867}$

Unlike the Neo-Babylonian cuneiform documents in general, the texts from the Murašû archive hardly ever identify persons using three-tier genealogies with family names. ${ }^{868}$ Thus, the members of the Murašu family are not descendants of an eponymous ancestor from time immemorial but the sons and grandsons of Murašû, son of Hatin, who is attested in two early documents of the archive. ${ }^{869}$ The chief protagonists of the family were Enlil-šum-iddin (active in 445/444-421 ВСE) and his nephew Rīmūt-Ninurta (429-415/414 BCE), ${ }^{870}$ but the servants of the family also play a prominent role in the archive, the most important of them being Rībātu/Bēl-erība. ${ }^{871}$ Although family names cannot be used to link the Murašu family to a specific segment of society, their residence in Nippur, ${ }^{872}$ high socio-economic status, ${ }^{873}$ and personal names referring to Enlil and Ninurta, the chief deities of Nippur, indicate that they belonged to the urban Nippurean upper class.

The business activities of the Murašu family took place in a certain economic sphere. ${ }^{874}$ Persian aristocracy and high officials administered royal

865 Stolper 1985,$11 ; 2001,84-85$.

866 Hilprecht and Clay 1898 (BE 9); Clay 1904 (BE 10); Clay 1912 (PBS 2/1). Three tablets (nos. 124, 126, and 127) in Clay 1908 (BE 8) belong to the Murašû archive. Stolper's 1974 dissertation is published as Stolper 1985 (EE). The tablets in Istanbul are published in Donbaz and Stolper 1997 (Імт). On the publication history, see Cardascia 1951, ii-iii; Stolper 1985, 11-14; 2001, 83-84. Texts from BE 9 and BE 10 have been recently transliterated by Gauthier Tolini and texts from PBS $2 / 1$ by Denis Bouder (http://www.achemenet.com).

867 Lutz 1928 (UCP 9/3); nos. 124, 145-148, 180, 182-191, 203-204 in Krückmann 1933 (TuM 2-3); nos. 40-42, 63-70, 72-88 in Joannès 1987; no. 126 in Spar and von Dassow 200o; nos. 1-6 in Stolper 2001.

868 Wunsch 2014, 295 + n. 21; Zadok 2015a, 103.

869 Stolper 1985, 19.

870 Stolper $1985,18-20$.

871 Cardascia 1951, 11-17.

872 The archive was unearthed in Nippur and the majority of documents were drafted there. See Stolper 1985, 24.

873 This is suggested by the size of their transactions (Stolper 1985, 125-151), their role in the agricultural management in the Nippur region (Stolper 1985, passim), and slave ownership (Cardascia 1951, 11-17).

874 This overview is based on Cardascia 1951; Stolper 1985; van Driel 1989, 2002, 226-322; Jursa 2010a, 405-414; 2011a, 435-437. 
lands in the Nippur countryside, and smaller landholdings, attached to larger administrative units, were given to individual farmers or families to cultivate. The basic structure of this land-for-service scheme resembles the one we encountered in the texts from the surroundings of Yāhūdu: people - often of foreign origin - were settled on royal lands, given a plot to cultivate, and expected to pay taxes and perform service in exchange. Like in Yāhūdu, the farmers of the state lands are occasionally called šušānus in the documents, and they were part of a complex hierarchical structure of land tenure. The typical designation of a single plot of land remained bìt qašti ('bow land'). However, the system developed over time and some terms which are not attested in Yāhūdu figure prominently in the Murašu texts. The two most important of these are the hatru and šaknu. The former refers to the organisational units into which the holders of bow lands and other crown properties were grouped, and the latter to the official who was in charge of land tenure and the fulfilment of obligations in a given hatru.

The Murašu archive documents the business transactions of a family of entrepreneurs working in the land-for-service sector. The archive consists of promissory notes, leases, receipts, and other legal texts primarily relating to credit granting and agricultural management. ${ }^{875}$ The Murašûs served as middlemen between small landholders and the administrative apparatus, as they facilitated the payment of taxes by granting credit to landholders. The Murašus received payments from the farmers in agricultural produce but paid rent and taxes primarily in silver; retail sales of produce were an essential part of their business, as is shown by a number of texts on beer brewing in the archive. ${ }^{876}$ The Murašûs also managed the cultivation of royal lands in the Nippur region. They acquired landholdings in two ways: first, they leased land and water rights directly from the representatives of the crown. Second, they granted credit to farmers in the land-for-service sector and gained control over the plots that were pledged to secure the debts. The Murašûs then subleased lands, water rights, and draught animals to tenants, including the actual holders of the pledged lands.

In contrast to the abundance of business documents in the Murašu archive, there are no texts referring to the family's houses or other property than slaves. This implies that the present archive is a selection of tablets removed from the

875 On the business profile of the Murašûs, see Stolper 1985, 2005; van Driel 1989; Jursa 2010a, 198-199, 405-414; Pirngruber 2017, 47-66.

876 van Driel 1989, 225-226. 
main archive when not needed anymore. ${ }^{877}$ However, it remains unclear who was responsible for selecting the texts that remain to us. This uncertainty is caused by the last documents of the archive, which do not refer to the Murašûs anymore but to a certain Enlil-supê-muhur, a former servant of the family. ${ }^{878}$ After the Murašûs disappeared, Enlil-supê-muhur worked as the paqdu ('manager') of Prince Aršam, leasing out the prince's herds of sheep and goats. Here private business, the interests of the crown, and administrative mechanisms of the land-for-service sector seem to be intertwined, like in the texts from Yāhūdu and its surroundings.

\subsubsection{Judeans in the Murašû Archive}

The economic and legal aspects of the Murašu archive have been thoroughly studied, ${ }^{879}$ and the ethnic and onomastic diversity in the Nippur region has been surveyed in several studies. ${ }^{880}$ However, there has been less interest in the life of the people figuring in the archive. This applies to the Murašus themselves, as well as to their clients, many of whom were descendants of foreign deportees. The social and religious history of Judeans in the Nippur region has been briefly discussed by Daiches, Bickerman, and Zadok, ${ }^{881}$ and although the presence of Judeans in the Murašû archive is acknowledged in most studies dealing with the Babylonian exile, only a page or two is normally devoted to discussing the material.

Although the Murašu archive documents business activities from the viewpoint of the archive-holding family, it is a relatively rich source for the study of Judeans in Babylonia. Altogether 61 Judean individuals appear in 64 different documents, making the archive the most extensive source for the study of Judeans after the texts from Yāhūdu and its surroundings. ${ }^{882}$

The documents pertaining to Judeans cover the whole chronological span of the archive. A Judean is already attested in the second earliest text of the archive from the thirteenth year of Artaxerxes I (BE $93,45^{2} \mathrm{BCE}$ ), and another Judean features in the late Aršam group in the eleventh year of Darius II (PBS 2/1 148, 413 BCE). Moreover, the chronological distribution of the documents

877 van Driel 1989, 203-204, 223-226; Jursa 2005a, 113. Stolper 1985 $\left(28-29,15^{2-156)}\right.$ has different ideas about the end of the archive, but see Stolper 2001, 85 .

878 Stolper 1985, 23-24; van Driel 1989, 204; Jursa 2005a, 113 .

879 Cardascia 1951; Stolper 1985, 2005; van Driel 1989, 2002, 155-322; Jursa 2010a, esp. 405-414; Gordin and Zadok 2016.

88o Coogan 1976a; Eph'al 1978; Zadok 1979a, 2002, 2015a; Dandamayev 2004; Lämmerhirt 2014.

881 Daiches 1910; Bickerman 1978, 1984; Zadok 1979a.

882 A prosopographical database of Judeans in the Murašu archive is available online at https://doi.org/10.5281/zenodo.3351259. 


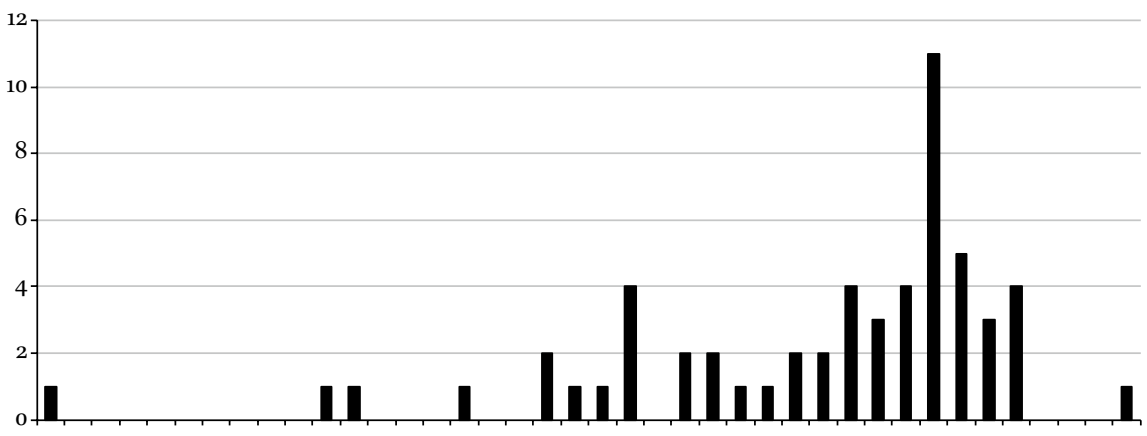

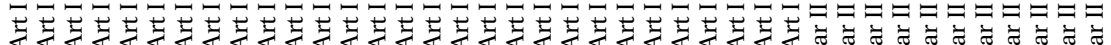

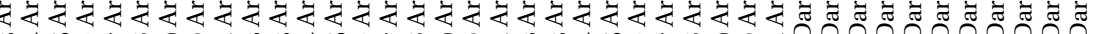

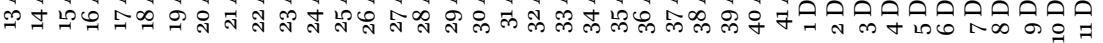

FIGURE 9 Murašû texts pertaining to Judeans

featuring Judeans also fits the distribution of the whole archive. As the graphs presented in Donbaz and Stolper 1997 clearly show, ${ }^{883}$ the fortieth year of Artaxerxes I marks a watershed in the chronological distribution of the tablets in the archive, as the majority of documents were written during a period of peak activity in 40 Art I - 7 Dar II (425-417 BCE). The same pattern can be seen in Figure 9, which records the datable transactions pertaining to Judeans in the Murašû archive.

Some features of Figure 9 require explanation. First, the peak in the thirtyfourth year of Artaxerxes I is incidental, and it results from the fact that PiliYâma/Šillimu happened to witness three documents in Nippur on the same day (BE 9 34; IMT 7, 8). Second, there is no peak in the number of documents from the last year of Artaxerxes I and the first year of Darius II. In the archive as a whole, the peak in these two years results from the large number of debts to the Murašûs by landholders whose plots were pledged to secure the debts. As Stolper suggests, these mortgages may have resulted from the financial difficulties that farmers in the Nippur region experienced because of the increased burden of tax and service obligations during the fight for the Persian throne after the death of Artaxerxes I. ${ }^{884}$ Some Judeans were also affected by the crisis (BE 1033 ; $\mathrm{PBS} 2 / 127,185$ ), and it remains unclear if the small number of Judeans involved only results from the accidental preservation of texts or if their situation was different from landholders in general. Third, there is a sharp peak in the number of documents pertaining to Judeans in the fourth year of

883 Donbaz and Stolper 1997, 6-10.

884 Stolper 1985, 104-124; Donbaz and Stolper 1997, 5-15; Jursa and Stolper 2007, 270. Cf. van Driel 1989, 223-224. 
Darius II. This year is very well documented in the archive in general, but such a steep rise in numbers is unexpected. There seems to be no common denominator between the eleven texts, and Judeans are attested as witnesses, minor officials, landholders, and creditors. Given the small sample of texts pertaining to Judeans, this anomaly may be incidental as well.

These statistics indicate that no major changes occurred among the Judean population in the Nippur region in the last half of the fifth century. Because the chronological distribution of Judean texts mirrors that of the archive as a whole, large groups of Judeans hardly migrated to or from the region. As this chapter shows, nothing in the texts suggests that the socio-economic status of Judeans was any different from other deportees in the Nippur countryside, and the statistical anomalies in 41 Art I - 1 Dar II and in 4 Dar II are probably incidental.

\subsubsection{Seal Impressions}

The sealing of cuneiform tablets has a long history in Babylonia. In addition to their legal value, seal impressions conveyed other messages: some seals were connected to a certain office or royal authority, whereas seal use and imagery can shed light on the social status and cultural values of an individual. Accordingly, seal impressions can effectively supplement the picture emerging from the texts themselves. The use of personal seals became increasingly common in the Persian period, and the Murašû archive is a rich source for the study of sealing practices in Babylonia. Judeans followed the general trend: the single Judean seal owner attested before the mid-fifth century is Ahīqam/Rapā-Yāma, who impressed his seal on a single tablet in the twelfth year of Darius I (B9). This changes in the Murašû archive, in which fourteen Judeans used seals, some of them even two different ones. ${ }^{885}$

This remarkable difference is the result of changes in sealing practices in Babylonia from the sixth to the late fifth centuries. ${ }^{886}$ In the archives from the early sixth century, only documents pertaining to the transfer of real estate were sealed, and the sealers belonged to a distinct group of scribes or notaries. The sellers of real estate impressed their nail marks on the tablets, but their seal impressions are never attested. ${ }^{887}$ Sealing practices started to change in the late Neo-Babylonian and early Persian periods: new document types were sealed or marked with nails and sealing was not practised exclusively by scribes. The sealing of a tablet still remained an exception, rather than the rule.

885 BE $925,45,69$; BE 10 65, 83, 118; EE 34, 65, 89, 107; PBS 2/1 5, 50, 60, 84, 107, 119, 218; UCP 9/3.

886 For an overview, see Oelsner 1978.

887 Oelsner 1978, 168-169; Baker and Wunsch 2001. 
The change accelerated in the reign of Darius I, and Ahīqam's use of a seal in Darius' twelfth regnal year should be seen in this context. ${ }^{888}$

Seal use became more widespread during the fifth century, and the Murašû archive is a very rich source for the practice. ${ }^{889}$ The principals who ceded rights or took an obligation rather consistently impressed their seals or nail marks on the tablet, and if judges were present at the transaction, they always used a seal. Impressing a nail mark did not necessarily imply that the person could not afford to buy a seal, as the use of nail marks was preferred in certain types of transactions. ${ }^{890}$ Witnesses occasionally impressed their seals on tablets in the early reign of Artaxerxes I, but this custom changed drastically in the late reign of Artaxerxes I and the early reign of Darius II, when the majority of witnesses sealed tablets. ${ }^{891}$

These developments are the underlying factor for the scarcity of Judean seal owners in the environs of Yāhūdu and their frequent attestation in the Murašû archive. Some Judean seal owners will be treated in the discussion below, and Judean seal use in its socio-economic and cultural context will be treated in Section 5.7.

\subsection{Yadi-Yāma and Pili-Yāma: Entrepreneurs or Representatives?}

The members of the Murašu family are an example of people who worked as middlemen between the state administration and landholders, finding business opportunities within the framework of the land-for-service sector. It is not always easy to determine, however, if people dealing with the Murašu family were landholders in their own right, representatives of a family or community, minor officials of the land-for-service sector, or entrepreneurs who further subleased the landholdings at their disposal. Such a strict classification of roles may even be misleading, as the interplay of family ties, communal and personal interests, and official capacities is common in any human society. An important example of this complexity is a dossier of twelve texts pertaining to Pili-Yāma/Šillimu, Yadi-Yāma/Banā-Yāma, and Yadi-Yāma's son Yāhû-natan. ${ }^{892}$ These Judean men dealt with the Murašûs and the farmers in the village of BìtGērāya in 24-40 Art I (441-425 вСE). A careful analysis of these men and their

888 Oelsner 1978, 168-169; Baker and Wunsch 2001, 203.

889 Bregstein 1993.

890 Bregstein 1993, 340-354.

891 Bregstein 1993, 359-360.

892 BE 9 14, 25, 29, 34, 45; EE 2, 26, 92, 94, 98; IMT 7-8. 
activities sheds light on the communal aspects of landholding in the land-forservice sector. Moreover, it emphasises that people dealing with the Murašûs could be representatives of larger communities, not mere landholders or businessmen.

\subsubsection{Business Partners of the Murašûs?}

The earliest document pertaining to Yadi-Yāma/Banā-Yāma was written in Nippur in 5-V-24 Art I (EE 2). He leased out the Bēl and Mušēzib-Bēl canals and perhaps $u z b \bar{a} r u$ land to Enlil-šum-iddin/Murašu for the annual rent of 200 kurru of produce. ${ }^{893}$ Two documents from the twenty-eighth (BE 9 16) and thirty-first (EE 30) years of Artaxerxes I show that Enlil-šum-iddin later subleased the Bēl canal to his tenants and slaves. ${ }^{894} \mathrm{EE} 2$ is not explicit about the status of Yadi-Yāma, and one might interpret him either as a royal agent or sublessor. According to Stolper, the Murašûs leased canals predominantly - if not exclusively - from the royal administration, but van Driel is open to the possibility of subleases as well. ${ }^{895} \mathrm{EE} 2$ could well be a sublease, judging by the fact that Yadi-Yāma did not bear any official title and that the royal administration is referred to only at the end of the operative part, where Yadi-Yāma guarantees that the canal manager ( $\check{s} a$ muhhi sūti ša nār $\mathrm{d}[\mathrm{x}]$ ) will not contest the lease. This assumption is further supported by the analysis of other documents in this cluster, which show that Yadi-Yāma was involved in the exploitation of canals and adjoining lands rather than their management.

Pili-Yāma/Šillimu appears for the first time in Nippur in 28-X-28 Art I (BE 914). He and Enlil-šum-iddin/Murašû pay the sūtu rent of 97 kurru of millet to the manager of the Sîn canal, the servant (mār bìti) of the mašennu official Artabara. ${ }^{896}$ The payment is due from the land of Bēl ${ }^{897}$ and (a part of) the

893 The lease of a canal probably included the adjoining lands as well, even if this is not made explicit in the contract. See van Driel 1989, 217 n. 25; Stolper 2005, 335. The text of EE 2 is broken, and it is unclear if the $u z b \bar{a} r u$ land was included in or excluded from the lease (see van Driel 2002, 201). Uzbāru was a type of royal land. See Stolper 1985, 41-42; van Driel 2002, 200-202.

894 van Driel, working notes.

895 Stolper 1985, 50; van Driel 1989, 217. But see the somewhat indecisive position taken by Stolper in $2005,335^{-} 336$.

896 On the term mär bìti, see Stolper 1985, 21. Mašennu officials were in charge of royal landholdings and taxation (Stolper 1985, 45-49; Jursa and Stolper 2007, 260), and people called $\check{s} a$ ana muhhi sūti ša nār $\mathrm{x}$ ('the one in charge of the rents of the canal $\mathrm{x}$ ') appear to have been their subordinates, either officials directly involved in transactions concerning royal lands and canals (Stolper 1985, 37-45; Stolper 2001, 117) or rent farmers (van Driel 1989, 215; see also Stolper 2005, 335-336). In both cases, the authority of canal managers derived from the crown and they were royal agents in that sense.

897 See Stolper 1985, 42-44. 
Puratti-Nippur canal. The receipt suggests that Pili-Yāma and Enlil-šum-iddin were business partners or at least shared an interest in obtaining rights to land and water from the royal administration or its representatives. The document is witnessed by a certain Šillimu/Pa-ni- $a$, who might be Pili-Yāma's father. ${ }^{898}$

These two texts alone would suggest that Yadi-Yāma and Pili-Yāma appear to be entrepreneurs like the Murašûs, leasing and subletting royal properties in the Nippur countryside. However, their transactions in the following years indicate that they may be better understood as representatives of larger communities, not merely as entrepreneurs acting for their own profit. 899

\subsubsection{Yadi-Yāma and the Village of Bït-Gērāya}

Yadi-Yāma's economic status worsened over time, which is already apparent in the thirty-first year of Artaxerxes I. In a document written in Nippur (BE 925 , 17-I-31 Art I), he leases the Urâti canal, his bit ritti, 'the land for which he is agent' (a.šà $n a-a ́ s ̌ s-p a r-t i-s ̌ u ́),{ }^{900}$ and his pledged property for three years from Enlil-šum-iddin for the annual rent of 200 kurru of barley. The rent was to be paid in a place called Gērāya. Some of his landholdings had apparently been pledged as a security for some previous debt, and they had come into the disposal of Enlil-šum-iddin. In BE 9 25, Yadi-Yāma asks his creditor to lease the pledged lands to Yadi-Yāma himself instead of leasing them to someone else. This transaction is a good example of the business model of the Murašûs: credit granting allowed the family to get hold of land properties, which could be leased back to their actual holders. ${ }^{901}$ The meaning of bit ritti is not completely understood, but it does not seem to denote a specific type of landholding in the land-for-service sector like bìt qašti. In the Murašû archive, it was perhaps more of an umbrella term which could refer to various types of landholdings, sometimes - if not usually - belonging to a temple or the crown. In Hellenistic Uruk, bit ritti properties were closely related to the temple of Anu. ${ }^{902}$ It is quite probable that the bit ritti was not Yadi-Yāma's private property.

Three details of the transaction shed light on Yadi-Yāma's economic role in the land-for-service sector. First, he was the nominal holder of some of the leased lands, not just a businessman taking them on lease. Second, the lease also involved lands (a.šà na-áš-par-ti-šú) that were not Yadi-Yāma's personal

\footnotetext{
898 On the name and person, see Zadok 1979a, 32, 59.

899 As already suggested by Zadok 1979a, 54-58 (Yadi-Yāma as a member of the Banā-Yāma clan); van Driel 2002, 215 (Yadi-Yāma as a member of a group of villagers joining forces).

900 The translation is adopted from CAD N/2, 76 .

901 Stolper 1985, 104-107.

902 On bit rittis on agricultural land, see van Driel 2002, 305-308 with further literature. On bit rittis in Hellenistic Uruk, see Baker 2005, 30-37; Corò Capitanio 2012.
} 
holdings. Našpartu means 'agency, proxy' or 'service, business' in comparable Neo-Babylonian legal and economic contexts, ${ }^{903}$ and, in the present document, Yadi-Yāma obviously held a plot of land on behalf of other people, or he represented them in the transaction. Third, his sons Yāhû-natan and PadāYāma witnessed the document, and the caption next to Yadi-Yāma's seal impression reads 'the seal of Yadi-Yāma and his brothers'. The explicit reference to a seal owned by several people is unique in the Murašû archive, ${ }^{904}$ and it seems to imply that Yadi-Yāma was not acting only on his own behalf. He represented at least his family or even a larger community, as the word $a h u$ ('brother') often refers to collegial relations in general. ${ }^{905}$ Yadi-Yāma and his sons are, however, the only Judeans attested in this document. In addition to this seal, ${ }^{906}$ YadiYāma also owned another seal, which he impressed on BE $945 \cdot{ }^{907}$ No other Judeans impressed their seals on the documents belonging to this dossier.

Yadi-Yāma's representative role in BE 925 is corroborated by BE 945 (Nippur, 20-V-36 Art I). Enlil-šum-iddin leases water rights and land to Yadi-Yāma, his three sons, a Judean man, four other people, and their anonymous colleagues (kinattu) in Bīt-Gērāya for three years. The leased property consists of the Urâti canal, tithe land (bìt ešrî̀) and Yadi-Yāma's bìt ritti on the banks of the Urâti, lands on the left bank of the Milidu canal, and three plots of land irrigated by waterlifts ${ }^{908}$ on the right bank of the same canal. The annual rent was 700 kurru of barley, two oxen, and twenty sheep, far more than a single farmer could produce in a year. ${ }^{909}$ Here the lessees quite clearly constitute a community of farmers who not only leased new lands to cultivate them, but also sought to retain their hold on Yadi-Yāma's bit ritti. As the interests of the larger group and Yadi-Yāma appear to be intertwined and as BE 925 and 45 partially pertain to the same landholdings, it seems quite certain that Yadi-Yāma's transaction in BE 925 relates to this community of farmers as well. ${ }^{910}$

\footnotetext{
903 CAD N/2, 75-76.

904 Bregstein 1993, 365-366.

$905 \mathrm{CAD} \mathrm{A} / 1,200-203$.

906 Bregstein 1993 no. 578 . The seal depicts a nude couple embracing.

907 Bregstein 1993 no. 642. The imagery is unclear.

908 3-ta dìm.me.meš on line 11 may refer to waterlifts (CAD M/1, 143) or, more likely, to plots irrigated by waterlifts (Stolper 2001, 122-123).

909 The average barley yield of a hectare was 1,728 litres in sixth-century Sippar, and the material from Uruk and Sippar show that a single plough team could not work more than 37.5 hectares of land in a ploughing season (Jursa 2010a, 49-50). This means that circa 73 hectares of land and two full plough teams were needed to produce the rent of 700 kurru of barley.

910 van Driel 2002, 215.
} 
This community of farmers should be geographically connected to (Bìt-) Gērāya, ${ }^{911}$ a settlement which was probably located by the canal system fed by the Euphrates of Nippur (Purat Nippur). ${ }^{912}$ The place name is only mentioned in BE 9 25, BE 9 45, and EE 98 (20-IX-36 Art I), which was written in the same village. The latter document (EE 98 ) is a promissory note for 70 vats of beer, owed by a certain Bēl-idrī to Yadi-Yāma. The repayment of the debt was to take place after the next date harvest. If read together only with EE 2, this promissory note would corroborate the idea that Yadi-Yāma was an entrepreneur like the Murašûs, practising agricultural management and turning his revenue of agricultural produce into silver by beer brewing and retail. EE 98 undoubtedly reflects commercial activity, and it might well be connected to the retail of date beer to urban customers. However, as the transaction took place in BìtGērāya only four months after BE 9 45, it is fully possible that Yadi-Yāma did not act only on his own behalf here either. The debtor's name Bēl-idrī cannot be found in any other Murašû document, and thus his identity and the relationship of this transaction to the Murašûs remain unknown. It is noteworthy that both EE 98 and BE 945 were witnessed by Pili-Yāma, while a certain Satturu/Šabbatāya witnessed EE 98 and was Yadi-Yāma's co-lessee in BE 945. EE 98 is the last attestation of Yadi-Yāma.

The village of Bīt-Gērāya was evidently the focal point of Yadi-Yāma's activities. He had colleagues in the village, he was supposed to deliver his rental payment there, and one of his transactions was concluded there. At the same time, the communal aspects of his transactions suggest that he was not merely a businessman working in Bït-Gērāya but more like a representative or foreman of the local community.

\subsubsection{Pili-Yäma's Transactions}

After his first appearance as Enlil-šum-iddin's co-lessee in 28 Art I (BE 9 14), Pili-Yāma is attested five times as a witness before he appears again as a debtor and lessee in 37 and 38(?) Art I (EE 94, 26). In addition to Yadi-Yāma's transactions BE 945 and EE 98, Pili-Yāma witnessed three documents (BE 9 34; IMT 7,8 ) which were written in Nippur in 7-IV-34 Art I by the same scribe before the same witnesses. ${ }^{913}$ All documents are leases of animals and/or land granted by Enlil-šum-iddin to three different lessees. None of the lessees bore a Judean name, and Pili-Yāma had no obvious connection to them. It is possible

\footnotetext{
911 Zadok 1979a, 57.

912 Zadok 1978a, 288-292 (but cf. 318); 2015a, 140.

913 Except for Mukīn-apli/Enlil-na'id, who is attested in IMT 7 and 8 but not in BE 9 34. Cf. Donbaz and Stolper 1997, 84 .
} 
that he happened to be present in Nippur when the documents were written and, being Enlil-šum-iddin's old acquaintance, he was asked to witness the transactions.

Two documents from the late years of Artaxerxes I shed more light on PiliYāma's connections with the Murašu family. The first document is a promissory note for a kur.ra textile ${ }^{914}$ worth 30 shekels of silver, written in Nippur in 26-V-37 Art I (EE 94). The debtor is Pili-Yāma and the creditor Tīrīkāma, a wellknown servant of Enlil-šum-iddin. ${ }^{915}$ The value of the textile is surprisingly high in comparison to the prices of kur.ra textiles from the late seventh to the late sixth century, when the prices fluctuated generally between two and seven shekels of silver. ${ }^{916}$ Although the price of kur.ra textiles rose in the late sixth century, ${ }^{917}$ the general trend of prices in Persian-period northern Babylonia ${ }^{918}$ does not favour the assumption that kur.ra textiles were on average worth half a mina in central Babylonia in the late fifth century. As far as I know, there are no other Murašû texts referring to kur.ra textiles. The textile in EE 94 is described as biršu ${ }^{919}$ eššu, 'coarse (fabric and) new', which does not unequivocally indicate that the high quality of the textile made it exceptionally valuable. As kur.ra was a common type of textile in Babylonia, the promissory note cannot be related to any specific type of economic activity. However, the exceptional value of the textile and the absence of other kur.ra texts in the Murašu archive make this an intriguing document.

The last document (EE 26) pertaining to Pili-Yāma ${ }^{920}$ is a lease of the Badiātu canal of Marduka (nār Badiāti ša Marduka). The transaction is badly broken, but it shows that Pili-Yāma and two other men leased the canal from a member of the Murašû family, most likely Enlil-šum-iddin, around 38 Art I. ${ }^{921}$ In order to understand the context of this transaction, it is necessary to study two earlier documents concerning this branch or part of the Badiātu canal.

In 12-V-32 Art I (BE 9 29), Marduka, the slave of Enlil-šum-iddin, rented the Badiātu canal of Yadi-Yāma (nār Badiāti ša Yadi-Yāma), adjoining lands,

914 On kur.ra textiles, see Bongenaar 1997, 39-40; Zawadzki 2010, esp. 412-414; Spar and Jursa 2014, 67 .

915 Stolper 1985, 21.

916 Jursa 2010a, 619-623.

917 There are some late cases when the price was 7, 7.25, and 13 shekels; see Jursa 2010a, 622.

918 Hackl and Pirngruber 2015.

919 CAD B, 261: 'woolen fabric with raised nap'. Villard 2010, 395: 'de texture grossière' or 'feutré'; according to Villard, the term may indicate fabrics of ordinary finish.

920 Pili-Yāma's name in this text is broken, and only the signs -ia-a-ma A-šá Iše-li-im-mu are fully preserved. However, the remnants of the sign 'li' can be seen before the sign 'ia', and the contents of the transaction make the identification very probable.

921 On the date of this document, see below. 
ploughs, oxen, ${ }^{922}$ and seed corn from his master for three years for the annual rent of 1,025 kurru of produce. ${ }^{923}$ It is likely that the canal was named after its former holder, Yadi-Yāma, although there are no texts which pertain to YadiYāma's tenancy of this canal. Three years later, Pān-Enlil-adaggal, another servant of Enlil-šum-iddin, leased the Badiātu canal of Marduka (nār Badiāti ša Marduka) under similar conditions for three years from Enlil-šum-iddin (IMT 10, 16-XIIb-35 Art I).

In light of these three transactions, 'the Badiātu canal of Marduka' and 'the Badiātu canal of Yadi-Yāma' refer to one and the same canal. The name of the current or previous tenant served as an identification marker which helped to distinguish the canal from other homonymous watercourses or to specify which part of the canal was meant. ${ }^{924}$ Because Pān-Enlil-adaggal's three-year lease was recorded in 35 Art I, Pili-Yāma and his two co-lessees leased the canal after Pān-Enlil-adaggal, probably in 38 Art I (EE 26). ${ }^{925}$

Nothing is known about Yadi-Yāma's tenancy of this branch or part of the Badiātu canal, but given the other documents referring to him, two scenarios are possible: first, Yadi-Yāma leased the canal directly from the royal administration and it came into the possession of Enlil-šum-iddin by a sublease or as a result of Yadi-Yāma's insolvency. Alternatively, Yadi-Yāma leased the canal from Enlil-šum-iddin, like Marduka and others after him. Be that as it may, the Badiātu canal of Yadi-Yāma and Marduka was at the disposal of the Murašûs for almost a decade or more, and the family repeatedly leased it out to its servants and other tenants. The document referring to Pili-Yāma's lease (EE 26) is badly broken, and the names of his two co-lessees survive only as PN/Barik-il and Minyamin/PN. Barīk-il and Minyamin are both West Semitic names, ${ }^{926}$ and the Judean background of these people remains a possibility that cannot be confirmed or excluded. ${ }^{927}$ However, Minyamin is perhaps attested together

922 Only the ploughs are mentioned in the text, but the oxen were likely included as well (Stolper 1985, 132).

923 The sum of the different types of produce is 1,025 kurru, but the tablet gives the sum as 1,015 kurru. See Augapfel 1917, 70.

924 Zadok $(1978 a, 292,314)$ favours the idea that there was more than one Badiātu canal, and the qualifiers were used to distinguish the canals. Both he (292, but cf. 314) and Stolper $(1985,40+$ n. 13) suggest that the Badiātu of Yadi-Yāma and the Badiātu of Marduka were one and the same canal, named after its current tenant.

925 The regnal year of Artaxerxes is damaged in the document, and only three vertical wedges can be read. Stolper $(1985,244)$ restores the number as ' 36 ', but given the three-year lease of Pān-Enlil-adaggal in 16-XIIb-35 Art I (IMT 10), a more probable restoration is ' 38 '.

926 On Barik-il, see Pearce and Wunsch 2014, 44; on Minyamin, see Section 1.5.2.

927 Cf. Zadok 2002, 39. 
with Pili-Yāma in BE 9 45, when a certain Minyamin/Bānia figures on the witness list right after Pili-Yāma. ${ }^{928}$

The information on the extent of the lease and the size of the rent has been mostly destroyed in EE 26 , and only the references to the $\mathrm{Na}^{\text {' }}$ ilti-il canal and 76 kurru of emmer remain. Emmer was usually only a subsidiary component of the annual rent in the leases of canals, ${ }^{929}$ and the extent of the lease in EE 26 may resemble IMT 10, which refers to the fields extending as far as the $\mathrm{Na}^{\text {' }}$ ilti-il canal. As the annual rent in the earlier leases of the Badiātu canal of Yadi-Yāma and Marduka was around 1,00o kurru of produce, it is likely that the scope of EE 26 was roughly the same.

At first glance, Pili-Yāma's transactions could well pertain to his private business. The two leases of canals and the promissory note for a kur.ra textile do not directly pertain to the community of farmers in Bīt-Gērāya. However, Pili-Yāma and Yadi-Yāma shared an interest in the tenancy of one and the same canal, and Pili-Yāma was also connected to Bīt-Gērāya. He witnessed Yadi-Yāma's transaction in the village and another document connected to Yadi-Yāma and his colleagues in Bìt-Gērāya. The leases of the Badiātu canal could have merely been private transactions, but they may also indicate that the canal was important to the community to which the two Judeans belonged.

\subsubsection{Yāhî-natan, Son of Yadi-Yäma}

After Yadi-Yāma and Pili-Yāma disappear from the scene, Yadi-Yāma's son Yāhûnatan appears in yet another lease of the Urâti canal in 29-V-40 Art I (EE 92). He had been involved in the leases of this canal already earlier: he witnessed a lease of the canal in 31 Art I (BE 9 25) and was among his father's co-lessees in 36 Art I (BE 9 45). In EE 92, he and Bānia/Amēl-Nanâ promise Enlil-šum-iddin to perform maintenance work on part of the canal during a two-week period until the twelfth day of the sixth month. This period from late August to early September coincides with the time when the water level in the Euphrates was low after the annual flood season was over. ${ }^{930}$ This was a natural moment to dig canals and repair damage caused by the flood. In compensation for their work, Yāhû-natan and Bānia were granted a lease of the canal, ${ }^{931}$ but it remains unclear how long it was for. In any case, a very short lease, such as only for the

928 Zadok 2002, 39 .

929 According to Stolper $(1985,131)$, barley was the main component of rental payments. For the relative importance of barley and emmer in some leases, see BE 9 29; EE 2; IMT 10.

930 Charles 1988, 6, 38.

931 See Zadok 2002, 37-39. Stolper seems to understand the document similarly, as he inserts $\langle$ bi in-na-na-ši $\rangle$ ('please give it') on line 4 of his transliteration $(1985,271)$. 
duration of the maintenance work, makes little sense from an agricultural perspective.

This document again stresses the fact that Yāhû-natan and Bānia could not have acted alone, but they had to have had a considerable workforce at their disposal. The workers digging the canal were most probably the inhabitants of Bìt-Gērāya, represented here by Yāhû-natan and Bānia. This link is not only suggested by the connections to Yadi-Yāma and the Urâti canal, for Bānia was also a member of the community in Bìt-Gērāya. He was Yadi-Yāma's co-lessee in BE 945 and a witness to Yadi-Yāma's promissory note for beer (EE 98), which was written in Bìt-Gērāya. Furthermore, he might have been the father of Minyamin/Bānia, the aforementioned witness of BE 945 and a possible colessee of Pili-Yāma in EE $26 .{ }^{932}$

\subsubsection{Representatives of a Community of Farmers}

The picture emerging from the documents relating to Yadi-Yāma, Pili-Yāma, and Yāhû-natan is one of men who were capable of organising the cultivation of large tracts of land and mustering a sufficient workforce to dig a canal. In the earliest documents, both Yadi-Yāma and Pili-Yāma deal with Enlil-šum-iddin like business partners, but in the later documents they only appear as tenants of the Murašû family. Yadi-Yāma's economic situation was evidently difficult after the thirtieth year of Artaxerxes I, and his dependency on the Murašus is reflected by the fact that he had to lease his own pledged lands from Enlil-šumiddin. Nothing suggests that the social or professional status of Yadi-Yāma and Pili-Yâma changed over time, and the changes in their economic status may reflect the fact that they were actually the more vulnerable party in their transactions with the Murašu family.

One way to explain Yadi-Yāma's and Pili-Yāma's transactions is to perceive them as entrepreneurs who were engaged in agricultural management, similar to the Murašûs. That would neatly explain the earliest leases: EE 2 would be a sublease of the properties which Yadi-Yāma had leased from the state administration, and in BE 9 14, Pili-Yāma and Enlil-šum-iddin would simply be business partners leasing some royal properties. The later leases would bear testimony to the tenancy of royal lands one step below the Murašu family: the Judean men leased rights to water and land from the Murašûs and then subleased those rights to their tenants. Yadi-Yāma's and Pili-Yāma's profit was generated from the difference between the rent they paid to the Murašus and the rent they charged from their tenants. The reference to date beer perfectly

932 Zadok 1979a, 56, 58. 
fits this entrepreneurial scenario, because brewing was a necessary activity for many business-oriented people in an agricultural setting. ${ }^{933}$

The weakness of the entrepreneurial scenario is the strong communal aspect of Yadi-Yāma's and Pili-Yāma's activities. This is apparent in the lease of the Urâti canal in BE 9 45, in which Yadi-Yāma does not act alone but with eight co-lessees and their unnamed colleagues in Bìt-Gērāya. ${ }^{934}$ The Urâti canal is the subject of two other leases (BE 9 25; EE 92), both of which exhibit strong connections to BE 945 . There is only one more Murašu text (IMT 24) referring to this canal, ${ }^{935}$ but the contents of this small fragment are incomprehensible. The three leases of the Urâti canal not only show that the canal was of great importance to the family of Yadi-Yāma, but all establish a firm connection to the village of Bìt-Gērāya.

Bìt-Gērāya is only attested in three documents in the Murašû archive, all of which are related to Yadi-Yāma's transactions (BE 9 25, 45; EE 98). Several other people link these documents to each other: Pili-Yāma, Satturu/Šabbatāya, and Bānia/Amēl-Nanâ appear in BE 945 and EE 98, and Yāhû-natan is attested in BE 925 and $45 .{ }^{936}$ The population of Bìt-Gērāya was at least partially of Judean origin. In EE 98, which is the only document written in Bīt-Gērāya, almost every witness bears a West Semitic name or patronymic. The only exception is Bānia/Amēl-Nanâ, but, as shown above, Bānia was not an outsider but a man with close ties to Yadi-Yāma's family. West Semitic names are also well represented among Yadi-Yāma's co-lessees in BE 9 45, who, according to the document, appear to be people from Bìt-Gērāya. ${ }^{937}$ Bānia/Amēl-Nanâ is again the only person bearing both an Akkadian name and patronymic. Yahwistic names are well represented among the West Semitic onomasticon, both in EE 98 and in BE 945 .

It thus appears that Yadi-Yāma and Pili-Yāma were connected to the settlement of Bìt-Gērāya, which was inhabited by people of Judean and generally non-Babylonian origin, and which was insignificant enough to be very rarely mentioned in the Murašû archive. It was apparently a village located near the Urâti canal, as people from Bìt-Gērāya rented the canal in BE 945 , and the rental payment of the canal was to be delivered to the village (BE 925 ). The canal was important to the village, and the leases in BE 925 and EE 92 are to be seen in the context of BE 9 45. The roles of Yadi-Yāma, Yāhû-natan, and

933 On Ahīqam's brewing activities, see Section 4.3.6.3.

934 The idea that BE 925 and 45 reflect villagers' attempts to promote their own cause is proposed by van Driel 2002, 215.

935 van Driel, working notes.

936 The Nippurean witnesses of BE 925 and 45 are not taken into account here.

937 'PN1, PN2, ... PN9, and all their colleagues who are in Bīt-Gērāya'. 
Bānia/Amēl-Nanâ were as representatives, and they acted on behalf of the village community. While the large rents could only be met by a group of farmers, it was not practical or necessary for all the villagers to travel to Nippur to close deals.

Pili-Yāma had close connections to Yadi-Yāma and Bìt-Gērāya, but he was also in regular contact with the Murašûs and often present in Nippur. The most revealing document about his status is EE 26, in which he leases the Badiātu canal of Marduka, the same canal which was held or leased by Yadi-Yāma several years earlier. His two co-lessees were of non-Babylonian descent, and one of them was perhaps attested as a witness in BE 945 . The case bears resemblance to that of the Urâti canal, and it is reasonable to suggest that this derivative or part of the Badiātu canal was also of special importance to Yadi-Yāma, Pili-Yāma, and the community in Bìt-Gērāya. The Badiātu canal of Yadi-Yāma and Marduka cannot be geographically located in relation to Bīt-Gērāya, ${ }^{938}$ but it is hardly a coincidence that Yadi-Yāma and Pili-Yāma shared an interest in this canal. Moreover, Pili-Yāma's lease of the Badiātu canal of Marduka took place in 38 Art I or later, and as Yadi-Yāma is not attested after 36 Art I, there is a good chance that Pili-Yāma took over some communal responsibilities after Yadi-Yāma's death. This scenario also fits Yāhû-natan's lease of the Urâti canal in 40 Art I.

Despite the entrepreneurial features of Yadi-Yāma's and Pili-Yāma's transactions, they cannot simply be labelled as businessmen. ${ }^{939}$ Both men were Judeans, closely linked to the village of Bìt-Gērāya where they perhaps also resided. There is no reason to suppose that the community in Bìt-Gērāya was exclusively Judean, ${ }^{940}$ but it is evident that many of its inhabitants were of Judean origin. Surprisingly, bow lands, hațrus, or minor officials of the land-forservice sector are not referred to in the documents pertaining to Yadi-Yāma and Pili-Yāma. Therefore, these men were hardly officials, such as šaknu-type foremen of a hatru in the environs of Bìt-Gērāya, but influential members of the village community. ${ }^{941}$ In this function, they travelled to Nippur to represent the community and lease canal rights from the Murašu family. This does not exclude the possibility that their private interests are present in the documents

\footnotetext{
938 Zadok 1978a, 292 claims that the Badiātu of Yadi-Yāma and Marduka flowed through BìtGērāya. However, there is no evidence to support this claim. On the different watercourses named Badiātu, see Zadok 1978a, 288, 292, 314 .

939 On Pili-Yāma, see Cardascia 1951, 77.

940 Cf. Zadok 2002, 39, who identifies all Yadi-Yāma's partners in BE 945 as Judeans. See also his concept of Judean clans in the Nippur region in Zadok 1979a, 53-58.

941 Cf. Zadok 1979a, 58-59.
} 
as well. Pili-Yāma's debt of a kur.ra textile need not concern the economic interests of the people in Bīt-Gērāya, and Yadi-Yāma's brewing activities may have been very beneficial to him personally. As will be shown in the context of similar documents below, it is difficult to say if Yadi-Yāma's bìt ritti was held by him and his family alone or if he was its nominal holder on behalf of a larger community. Yadi-Yāma's and Pili-Yāma's earliest transactions show that the two men leased water and land to Enlil-šum-iddin and together with him. This was hardly possible without the backing of the rural community, although the responsibility rested nominally on a single man alone.

The size of the transactions pertaining to Yadi-Yāma and Pili-Yāma is very different from what we see in the documents from Yāhūdu and its surroundings. Ahīqam's largest transactions of over 5 minas of silver or 160 kurru of barley $\left(\mathrm{B}_{5}, 6 ; \mathrm{C}_{17}, 18\right)$ are of comparable size, but, in general, the transactions from the environs of Yāhūdu are significantly smaller. It is noteworthy that Ahīqam's largest transactions pertain to his business with the royal administration (B6; $\left.\mathrm{C}_{7}, 18\right)$ or dealings in Babylon (B5); accordingly, they do not relate to his interaction with farmers or small landholders. Texts pertaining to Ahīqam testify that he acted as an intermediary between farmers and the royal administration. Yadi-Yāma and Pili-Yāma occupied the same functional position in the administrative hierarchy of the land-for-service system. As representatives of the villagers of Bït-Gērāya, they acted as intermediaries between the farmers and the next level of hierarchy, the Murašu family or state administration. Private, communal, and official roles should not be seen mutually exclusive, and all three of the Judeans were in a position to benefit from their status of an intermediary.

\subsection{Judean Landholders and the Land-for-Service Sector}

\subsubsection{General Features}

The Murašû archive is held as the prime example of the land-for-service sector in Babylonia, but the documents pertaining to Yadi-Yāma and Pili-Yāma hardly touch upon this issue. No hatrus or bow lands are mentioned, and although Yadi-Yāma's bit ritti may not have been his private property, the term itself is not characteristic of the land-for-service sector. The Bīt-Gērāya dossier was written in 24-40 Art I, and it belongs to a less intensively documented phase of the Murašû archive. The dossier constitutes a distinct group, and none of its Judean protagonists is attested after 40 Art I.

The absence of certain terminology does not necessarily mean that YadiYāma, Pili-Yāma, and their colleagues in Bīt-Gērāya were not integrated into 
the land-for-service sector, but the reason may lie in the distribution of different text types in the Murašu archive. As discussed above, the majority of documents in the archive were written in 40 Art I - 7 Dar II, and especially mortgages are clustered in the last year of Artaxerxes I and the first year of Darius II. Receipts of rents and taxes paid by the Murašûs are also concentrated in 40 Art I - 7 Dar II. ${ }^{942}$ These are all document types which are not attested in the Bìt-Gērāya dossier but typically pertain to bow lands and other land properties managed by the Murašuss. ${ }^{943}$ On the contrary, leases of land and canals from the Murašûs are more evenly distributed over time. ${ }^{944}$ Because Judean holders of bow lands are attested after 40 Art I, it is likely that the invisibility of the land-for-service sector in the Bìt-Gērāya dossier results from the internal composition of the archive.

Eleven Judeans in seven different documents are attested as holders of bow lands in the Murašû archive. ${ }^{945}$ It is evident that 'bow land' does not simply refer to a plot that was held or cultivated by a single farmer: in six documents, bow lands are held nominally by at least two people, and four documents refer to an undetermined group of 'brothers' (šeš.meš; BE 10 118; EE 111) or 'lords of the bow land' ('íen.meš gišban; PBS 2/1 89, 218) as co-holders of these properties. ${ }^{946}$ This applies to the Murašû archive as a whole, and, in the promissory notes with real estate securities, bow lands are normally held by more than one person. ${ }^{947}$ This is not unattested in the environs of Yāhūdu either, where six documents refer to the co-ownership of a bow land. ${ }^{948}$ Inheritance divisions are often given as the reason for the co-ownership of bow lands, ${ }^{949}$ but this is not the entire picture, as co-holders also bore different patronymics and were thus presumably unrelated. ${ }^{950}$ There is also one example of a Judean holding a share in a horse land (UCP 9/3, 18-X-2 Dar II); I will discuss this important document in more detail below.

Like the number of co-holders, the size of bow lands varied considerably. In the Murašû archive, the debts secured with landholdings range between 10 and

942 Donbaz and Stolper 1997, 8.

943 On promissory notes with real estate as security, see Stolper 1985, 104-124; van Driel 1989, 223-224; Donbaz and Stolper 1997, 9-12. On receipts, see Cardascia 1951, 69-123.

944 Donbaz and Stolper 1997, 8.

945 BE $986 a$; BE 10 118; EE 111; PBS 2/1 27, 89, 185, 218. Note BE 10 33, which pertains to the same bow land as PBS $2 / 127$ and 89 , although the Judean co-landholder is not mentioned.

946 BE 9 86a refers to the lands of Rahìm-il and his sons.

947 Cardascia 1951, 29.

948 B2, 13; C15:15-16; 66, 69, 72.

949 Stolper 1985, 26; van Driel 1999, 219-220; Pearce and Wunsch 2014, 120.

950 B13; C69, 72; PBS 2/1 27, 89, 185. 
11,270 kurru of dates, ${ }^{951}$ and the security usually consists of a single bow land. ${ }^{952}$ Furthermore, the amount of rent in silver paid by the Murašus per bow land ranges between 3 and 60 shekels. ${ }^{953}$ As these payments have to be in some relation to the size of the respective landholdings, the variation in their size suggests a variation in the size of bow lands. ${ }^{954}$ A comparison with the data from the environs of Yāhūdu also attests to variation, but, surprisingly, the transactions are generally smaller than in the Murašû archive. The payments related to bow lands range from less than 1 kurru to 28 kurru of produce, the majority being smaller than 10 kurru.

A critical question regarding the functioning of the land-for-service system is the relationship between the size of a bow land and the number of its holders. If the scenario of successive inheritance divisions is right, most bow lands should have been split into tiny fragments by the late fifth century. As Judeans were settled in the Babylonian countryside soon after the deportations from Judah in the early sixth century, the holders of the bow lands in the Murašû archive must have belonged at least to the fifth or sixth generation. If a man held a hereditary bow land which was divided in equal parts and given to two sons in successive generations, his descendants in the fifth generation would only inherit a $1 / 16$ share of the bow land, or $1 / 32$ in the sixth generation. On the contrary, the available evidence shows that an average share in a bow land was still large enough to support a family. Based on his analysis of promissory notes with real estate securities, imittu rents, and leases of date gardens, Jursa concludes that the average share in a bow land in the Murašu archive roughly corresponded to the size of a plot held by a family in other Babylonian sources. ${ }^{955}$

As shares in bow lands were hereditary, ${ }^{956}$ it is reasonable to suggest that more royal lands were taken under cultivation as the rural population grew over time. The low cost of land and the prevalence of extensive arable farming suggest that land was readily available. ${ }^{957}$ This supports the commonly held view that one of the fundamental aims of the land-for-service system was to bring new lands under cultivation and royal control, and thus increase agricultural output and tax income. ${ }^{958}$

\footnotetext{
951 Cardascia 1951, 28; Jursa 2010a, 409.

952 Cardascia 1951, 36.

953 Stolper 1985, 147.

954 See Jursa 2010a, 409.

955 Jursa 2010a, 409-412.

956 Cardascia 1951, 29 n. 5; Stolper 1985, 25.

957 Stolper 1985, 125-134; Jursa 2010a, 417-418.

958 Stolper 1985, 99; van Driel 2002, 311-313; Jursa 2011a, 435.
} 
Even if a single plot was cultivated by a single family, the communal aspect of landholding is evident. Most bow lands were cultivated by several landholders, but only some of them often acted as representatives of the whole group, in the same vein as Yadi-Yāma and Pili-Yāma above. The use of representatives makes sense from a practical perspective: if a group of people shared the responsibilities related to a certain landholding, it was not necessary to record everybody's name on the document. As the majority of documents were written in Nippur while the landholdings were located in the countryside, it was good for the agrarian community if not everybody had to make the journey to the city. A clear example of the use of representatives is found in PBS $2 / 1218$, a receipt of sūtu rent paid by Rīmūt-Ninurta/Murašû concerning the bow land of Abī-Yāma/Šabbatāya, Zabad-Yāma, and 'all the other holders of their bow land' (lúen.meš gišban-šúu-nu gab-bi). At the end of the operative part of the document, Abi-Yāma takes responsibility for the whole group and guarantees that his colleagues (kinātātišu) will not contest the transaction. This phenomenon is reminiscent of the structure of the Yāhūdu imittu lists, in which a group of ten landholders is represented by one of their peers $\left(\mathrm{C}_{14}, 15\right)$.

The communal aspects of landholding are apparent in the texts pertaining to the three bit ritti lands (co-)held by Judeans in the Murašu archive. As argued above, Yadi-Yāma's leasing operations were closely related to certain canals and the community at Bìt-Gērāya, and, accordingly, it is possible that his bit ritti may actually be a property held by a larger group of people (BE 925,45$)$. Two other bìt rittis were held by two persons. Haggâ and Mattan-Yāma hold a bit ritti together in EE 24. In BE 9 3, Arad-Gula and Hanan-Yāma's bìt ritti is leased to five persons for sharecropping. This indicates that the size of the landholding was rather large and that there may have been other landholders in addition to Arad-Gula and Hanan-Yāma.

In order to place these observations in a larger context, it is necessary to examine the size of transactions pertaining to Judeans in the Murašû archive. Table 1 presents all transactions with quantifiable data: documents in which Judeans appear as debtors or lessees, documents in which the Murašûs cultivate land on behalf of Judean landholders, and documents in which Judeans appear as creditors or lessors. The table reveals that small transactions of no more than 10 kurru or 10 shekels - those typical to the tablets from the environs of Yāhūdu - are very rare in the documents pertaining to Judeans in the Murašu archive. Only two transactions (10\%) belong to this category. When the total size of the payment is divided by the number of obliged persons, the share of a single person remains above 10 kurru or 10 shekels in all but two cases. This emphasises a key difference between the texts from the environs of Yāhūdu and those from the Murašû archive: Ahīqar and Ahīqam dealt directly with 
TABLE 1 Transactions with quantifiable data pertaining to Judeans

Document Date $\quad \begin{aligned} & \text { Number of } \\ & \text { persons }^{a}\end{aligned}$ Amount $^{b} \begin{aligned} & \text { Amount } \\ & \text { per person }\end{aligned}$ Quality Type of document

1. Judeans among debtors or lessees

\begin{tabular}{|c|c|c|c|c|c|c|}
\hline BE 914 & 28-X-28 Art I & 2 & 97.28 & 48.64 & millet & $\begin{array}{l}\text { Receipt: rent } \\
\text { (canal and land) }\end{array}$ \\
\hline BE 925 & 17-I-31 Art I & 1 & 200 & 200 & barley & $\begin{array}{l}\text { Lease: canal and } \\
\text { land }\end{array}$ \\
\hline BE 945 & 2o-V-36 Art I & $\begin{array}{l}9+ \\
\text { colleagues }\end{array}$ & 700 & $<77.78$ & barley & $\begin{array}{l}\text { Lease: canal and } \\
\text { land }\end{array}$ \\
\hline EE 94 & 26-V-37 Art I & 1 & 30 & 30 & silver & $\begin{array}{l}\text { Debt: kur.ra } \\
\text { textile, worth } 30 \\
\text { shekels of silver }\end{array}$ \\
\hline EE 26 & ?-?-38? Art I & 3 & $76+x$ & $?$ & produce & Lease: canal \\
\hline IMT 94 & 13-XII-40 Art I & 2 & 30 & 15 & silver & Debt \\
\hline BE $986 a$ & ?-III?-41 Art I & 2 & 2,761 & $1,380.5$ & produce & $\begin{array}{l}\text { Lease: land, } 72 \\
\text { oxen, } 18 \text { ploughs, } \\
\text { seed corn, barley } \\
\text { for wages }\end{array}$ \\
\hline EE 113 & ?-?-33+ Art I & 4 & $5^{0}$ & 12.5 & workers & $\begin{array}{l}\text { Contract: } \\
\text { payment of debt } \\
\text { by providing } \\
\text { labour }\end{array}$ \\
\hline $\mathrm{EE} 24$ & ?-X-? Art I & 2 & $5^{0}$ & 25 & barley & $\begin{array}{l}\text { Lease: } 2 \text { oxen for } \\
5^{\circ} \text { kurru of barley }\end{array}$ \\
\hline EE 86 & 10+-?-Art I & 1 & 10 & 10 & barley & Debt \\
\hline $\begin{array}{l}\text { PBS } 2 / 1 \\
185\end{array}$ & 2-VII-1 Dar II & 3 & 70 & $23 \cdot 33$ & dates & Debt \\
\hline BE 1077 & 9-XI-3 Dar II & 1 & 2.5 & 2.5 & barley & Debt \\
\hline $\begin{array}{l}\text { PBS } 2 / 1 \\
89\end{array}$ & 28-IX-4 Dar II & 2 & 60 & 30 & dates & $\begin{array}{l}\text { Debt: dates } \\
\text { instead of silver }\end{array}$ \\
\hline $\begin{array}{l}\text { PBS } 2 / 1 \\
208\end{array}$ & 25-VI-5 Dar II & $5(?)$ & 500 & 100 & fish & Lease: 5 nets \\
\hline $\begin{array}{l}\text { PBS } 2 / 1 \\
148\end{array}$ & $\begin{array}{l}\text { 25-VI-11 Dar } \\
\text { II }\end{array}$ & 1 & 276 & 276 & animals & $\begin{array}{l}\text { Lease: } 276 \text { sheep } \\
\text { and goats }\end{array}$ \\
\hline EE 89 & Dar II & 1 or more & 260 & $?$ & dates & Debt \\
\hline
\end{tabular}


TABLE 1 Transactions with quantifiable data pertaining to Judeans (cont.)

Document Date

$\begin{array}{ll}\begin{array}{l}\text { Number of Amount Amount Quality } \\ \text { persons }\end{array} & \begin{array}{l}\text { per person } \\ \text { per }\end{array}\end{array}$

Type of document persons per person

2. The Murašûs cultivate land on behalf of Judean landholders

\begin{tabular}{|c|c|c|c|c|c|c|}
\hline $\begin{array}{l}\mathrm{PBS} 2 / 1 \\
218\end{array}$ & $\begin{array}{l}\text { 26-VIII-6 Dar } \\
\text { II }\end{array}$ & $\begin{array}{l}2+ \\
\text { colleagues }\end{array}$ & 60 & $<30$ & silver & Receipt: rent \\
\hline EE 34 & 4-VII-7 Dar II & 1 & 20 & 20 & silver & $\begin{array}{l}\text { Receipt: rent } \\
\text { (silver instead of } \\
\text { dates) }\end{array}$ \\
\hline \multicolumn{7}{|c|}{ 3. Judeans as creditors or lessors } \\
\hline $\mathrm{EE} 2$ & $5-\mathrm{V}-[24$ Art I $]$ & 1 & 200 & 200 & produce & $\begin{array}{l}\text { Lease: canals and } \\
\text { land }\end{array}$ \\
\hline EE 98 & 20-IX-36 Art I & 1 & 70 & 70 & $\begin{array}{l}\text { vats of } \\
\text { beer }\end{array}$ & Debt \\
\hline
\end{tabular}

a 1. Number of debtors or lessees. 2. Number of landholders. 3. Number of creditors or lessors.

b The amount of dates, barley, millet, and other produce is given in kurrus and the amount of silver in shekels.

individual farmers and landholders, whereas the Murašûs more often operated with the representatives and foremen of larger communities of landholders.

\subsubsection{Hațru of the Sēpirus}

5·3.2.1 Haţrus in the Murašû Archive

As the land-for-service sector was designed to generate tax income and provide the state with a workforce and soldiers, the landholders and their holdings were attached to complex administrative structures. In Yāhūdu, the fields of Judean šušānus were eventually put under the supervision of the governor Uštanu, and several royal officials participated in their everyday administration through a long chain of command. The estates of royalty and high officials are also attested in the region. A similar picture emerges from the Murašû archive: landholdings were attached to estates of the crown, royalty, and high officials, and the governor Gübaru and his agents were also involved in the management of the land-for-service sector. ${ }^{959}$

959 On the administration of the land-for-service sector in the Murašû archive, see Stolper $1985,5^{2-103 .}$ 
In comparison to the environs of Yāhūdu, an important feature of late fifthcentury Nippur is the organisation of landholdings in administrative units called hațrus. ${ }^{960}$ More than sixty different hațus are attested in the Murašû archive, and their names generally refer to an administrative unit, such as the estate of the rab urâti ('the one in charge of horse teams'), or to professional and ethnic groups, such as the gate guards and the Carians. ${ }^{961}$ It is hard to believe that these designations were completely arbitrary, and, at least originally, they must have been related to the people attached to the hatru, to its function, or to its administrative affiliation. ${ }^{962}$ Names referring to the estates of the crown or high officials demonstrably reflect the submission of the given hatru, its landholders, and their holdings to the estate. ${ }^{963}$ In the case of ethnic designations of hatrus, the most logical reason behind these names is the assignment of deportees to hatrus according to their place of origin. ${ }^{964}$

However, the case of professional designations is more complicated. Despite the absence of a hatru of the Judeans, it is striking that all the bow and horse lands which were (co-)held by Judeans and which can be connected to a certain hațru belonged to a hatru of sēpirus (PBS 2/1 89, 218), sêpirus of the troops (uqu) (PBS 2/1 27; UCP 9/3), or sêpirus of the estate of the rab unqāti ('the one in charge of seals', PBS 2/1 185). In addition, a Judean is also attested as a co-holder of grain fields (zêru $\bar{u} \bar{\iota}$ šulpi) belonging to the hatru of the gardu ('dependent workers', BE 10 92), and another one served as the šaknu ('foreman') of the šušānus of the storehouse (nakkandu) in BE 1065 .

\subsubsection{Hatru of the Sépirus (of the Troops)}

Since Cardascia's and Stolper's studies, it has been well established that the designations hațru ša sēpirī, hațru ša sēpirī ša uqi, and hațar uqi refer to a single hatru. ${ }^{965}$ The professional designation sēpiru not only refers to scribes competent in Aramaic, but the available evidence shows that they also took care of administrative tasks. ${ }^{966}$ Accordingly, it would be tempting to argue that the evidence of hatrus of seppirus shows that a large number of Judean landholders were literate clerks in the state administration. However, although a number of

\footnotetext{
96o Stolper 1985, 70-103; van Driel 2002, 308-310.

961 Stolper $1985,72-79$.

962 See Stolper 1985,72 .

963 Stolper $1985,54-55,89-93$.

964 Eph $^{\complement}$ al 1978, 80-83; Jursa 2011a, 435.

965 Cardascia 1951, 113; Stolper 1985, 76, 93-95.

966 Stolper 1985, 22; Pearce 1999; Jursa 2012; Bloch 2018.
} 
texts in the Murašu archive pertain to hațrus of sēpirus, ${ }^{967}$ none of them suggest that the holders of bow or horse lands actually worked as seppirus. As this matter is of prime importance for the present study, it will be discussed here in detail.

Three documents from the beginning of the reign of Darius II show that the hatrus of the sêpirus and the sêpirus of the troops were identical. ${ }^{968} \mathrm{~A}$ certain Bēl-Yadā/Mannu-kì-Nanâ, a Judean man called Aqbi-Yāma/Bāba-êțir, and their anonymous colleagues held a bow land belonging to the hatru of sēpirus in 28IX-4 Dar II (PBS 2/1 89). The bow land was located in Bìt-Ṣurrāya by the HarriPiqūdu canal, and it was under the supervision of a certain Nabû-mìt-uballiț. Their bow land was pledged to secure a debt of 6o kurru of dates, the equivalent of the taxes in silver which Rīmūt-Ninurta/Murašû had paid to their šaknu. Three years earlier, Bēl-Yadā and Aqbi-Yāma held half a bow land together with Nidinti-[Enlil] (PBS 2/1 27, 14-?-1 Dar II). ${ }^{969}$ Their land was at the disposal of Enlil-šum-iddin/Murašû, who paid taxes on their behalf to Nabû-mìt-uballiț/ Balāțu, the brother $(a h u)$ of Zabīn the šaknu of [...]. Here ahu is not a mere designation of a collegial relationship, for the two men were actually brothers. ${ }^{970}$ In another document (PBS 2/1 29) written on the same day before the same witnesses, Nabû-mit-uballit collects taxes on bow lands belonging to the hatru of the sēpirus of the troops. He is again described as the brother of Zabin, whose title is now fully preserved as the šaknu of the sêpirus of the troops. It becomes clear that the hatrus of the sêpirus and the sēpirus of the troops were identical, and that Zabīn and Nabû-mìt-uballit played a key role in the administration of this hatru.

Both Zabīn and Nabû-mìt-uballiț worked as šaknus in the hațru of the seppirus (of the troops) during the first years of Darius II. The evidence relating to Zabīn was discussed above, and his brother Nabû-mìt-uballit held the position in the first year of Darius II (BE 10 7, 2-I-1 Dar II). ${ }^{971}$ This document is

967 Ša sēpirī: BE 10 33, 37, 57; EE 82; PBS 2/1 3, 11, 89, 218. Ša sēpirǐ ša uqi: BE 10 102; P BS 2/1 (27), 29, 34, 66; UCP 9/3. Hațar uqi + šaknu ša sēpirī: BE 10 7. Ša sēpirī ša büt rab unqāti: IMT 5; PBS $2 / 1$ 185. Ša sêpirī ša büt rab ummu: РвS 2/1 196. These designations will be discussed below.

968 Augapfel 1917, 43-45; Cardascia 1951, 113-114; Stolper 1985, 83, 94.

969 Bēl-Yadā, Nidinti-Enlil, and their anonymous colleagues of the hațru of the sêpirus are also attested in BE 1033 (27-IV-1 Dar II). The text pertains to the same bow land in BitȘurrāya by the Harri-Piqūdu. The land was pledged to Enlil-šum-iddin to secure the debt of $287 ; 3$ kurru of dates. This document is a good example of the legal and scribal practices in the archive: although Aqbi-Yāma must have been among the landholders, his name is this time lumped together with other anonymous colleagues.

970 BE 10102 gives Zabīn's patronymic, Balāțu. See Stolper 1985, 83.

971 See Stolper 1985, 83, 85, 93-94. 
peculiar, as it refers to the administrative unit as the hatru of the troops ( $h a-t a-$ riú-qu), but Nabû-mìt-uballit bears the title of the šaknu of the sēpirus. ${ }^{972}$ The titles held by the two brothers were apparently quite flexible, because Nabûmìt-uballit is also titled as the deputy (šanû) of Zabīn the šaknu in the same year (PBS 2/1 34, ?-?-1 Dar II ). In the following years, Nabû-mìt-uballit no longer has the title of šaknu, but he appears in a šaknu-like function in PBS 2/1 89 (28IX-4 Dar II), in which the hatru of the seppirus is said to be under his management (šá ina šu $\left.{ }^{\mathrm{II}}\right) \cdot{ }^{973}$ As Stolper has shown, there is a lot of flexibility in the tenure of a šaknu, and it is possible that two šaknus had overlapping periods of service in the same hatru. ${ }^{974}$ Judging by the available evidence, it appears that both Zabīn and Nabû-mìt-uballit were strongly involved in the management of the same hatru, although there was considerable variation in their titles.

The evidence discussed thus far confirms that the hatru managed by Zabin and Nabû-mìt-uballit was known by three names: hațru of the sēpirus, hațru of the sêpirus of the troops, and hatru of the troops. This variance is not a result of different scribes favouring different names, because a single scribe, Ninurtaab-ușur/Enlil-šum-iddin, wrote the great majority of tablets pertaining to this hatru and used all three designations. ${ }^{975}$ From now on, I use the name ' $h a t r u$ of the sēpirus of the troops' to refer to this unit. The designation 'hatru of the troops' is attested only in BE 10 7:3 and might be a scribal mistake. ${ }^{976}$

\subsubsection{Hatrus and High-Ranking Sēpirus}

In addition to the three names discussed above, there are two other hatru names that refer to sēpirus. The first, hațru ša sēpirī ša bit rab unqāti, is attested in IMT 5 (18-VI-40 Art I) and PBS 2/1 185 (2-VII-1 Dar II).977 The name refers to the estate of the rab unqa $\bar{t} i$ ('the one in charge of seals'), a high official in Babylonia who is attested in the Neo-Babylonian and Persian periods. His exact duties are unknown, but it is likely that he belonged to the king's retinue. ${ }^{978}$ Apart

972 Cardascia $(1951,113)$ and Stolper $(1985,93)$ discuss BE 107 , but they mistakenly claim that the document refers to the hatru of the sêpirus of the troops.

973 Stolper 1985,85 , argues that he was the šaknu at this time.

974 Stolper $1985,83-88$.

$975 \mathrm{BE} 10$ 7, 33, 37, 102; PBS 2/13, 27, 29, 66, 89, 218; UCP 9/3. In addition, three documents (IMT 5; PBS $2 / 1185,196)$ are special cases and they will be discussed below.

976 However, note that Nabû-mit-uballiț's title on the following line is simply 'the šaknu of the sēpirus'.

977 On the correct reading of PBS 2/1 185, see Donbaz and Stolper 1993, 1997, 82. CAD U-W, 203 should be corrected accordingly.

978 See Donbaz and Stolper 1997, 82. The rab unqäti's close connection to the king is suggested by BIN 122 ; YOS 6 10, 11. On the two latter documents, see Frame 1991, 54-61. 
from the two texts discussed below, the rab unqa $\bar{t} i$ is not attested in any other texts of the Murašû archive.

According to PBS 2/1 185, two Judean men, Abī-Yāma/Šabbatāya and Hannān/Hanan-Yāma, and a certain Bēl-ittannu/Qiš-ga-a belonged to the hațu of the sêpirus of the rab unqāti's estate and held a bow land which was located in Bīt-Erībâ by the Harri-Piqūdu canal. The bow land was pledged to Enlil-šum-iddin's son Murašû to secure a debt of 70 kurru of dates. ${ }^{979}$ Five years later, Abī-Yāma/Šabbatāya held a bow land together with a Judean named Zabad-Yāma and their colleagues in Bīt-Šalāmē by the Harri-Piqūdu canal (PBS 2/1 218, 26-VIII-6 Dar II). The bow land belonged to the hatru of the sêpirus of the troops and was at the disposal of Rīmūt-Ninurta, who paid the sūtu rent of 1 mina of silver to Abī-Yāma. It appears that the documents refer to two different bow lands, but it is surprising that a person named Abī-Yāma/Šabbatāya appears as a co-holder of both of them. There are no other attestations of the name Abì-Yâma in the Murašû archive. It is also an important observation that the names of the two hatrus resemble each other and that both bow lands were located by the Harri-Piqūdu canal, by which some other landholdings of the hatru of the seppirus of the troops lay. ${ }^{980}$ These observations suggest some connection between the two hatrus. IMT 5 adds little to this discussion, but it shows that a certain Lâbâši/Nabû-ittannu and his colleagues held land belonging to the sêpirus of the rab unqāti's estate. The plot was located in Tilhurdi, which lay at the junction of the Sîn and Enlil canals. ${ }^{981}$

Neither Iмт 5 nor Р BS $2 / 1185$ refer to the šaknu of the sêpirus of the rab unqāti's estate, but the latter document reveals that the hatru was under the management of a certain Mannukiya. The name (spelled Man-ki-ia or Man$n u-k i-i a)$ is very rare in the Murašu archive, with only one man having it. He was a servant $(a r d u)$ of Prince Manuštānu in the late reign of Artaxerxes I, 982 and, after the accession of Darius II and the defeat and death of Manuštānu, ${ }^{983}$ he served as a sêpiru of Gūbaru, the governor of Akkad. ${ }^{984}$ His father Paqiqi probably served Gūbaru as well and acted as a šaknu in the hațru of the

979 On Murašû/Enlil-šum-iddin, see Cardascia 1951, 10; Stolper 1985, 20.

$980 \quad$ BE 107,33 ; PBS 2/1 3, 89 .

981 On Til-hurdi, see Zadok 1978a, 289, 291, 306; 1985, 310-311, 370.

982 TuM 2-3 180 (40 Art I); BE 984 (41 Art I). EE 56 is a broken text which refers both to Manuštānu and to Mannukiya (20+ Art I).

983 Stolper 1985, 90-92; Briant 2002, 588-589.

984 IMT 46 (text: 5 Dar II, but emendated by Stolper 1992, $71+$ n. 10 as 6 Dar II ); PBS 2/1 100+ (6 Dar II; edited in Stolper 1992, 75-76); BE 10118 (7 Dar II). In these texts, he is always attested together with Iqǐša, another sēpiru of Gūbaru. He is probably attested with Iqiša 
sword-bearers (BE 10 84, 85, both 4 Dar II). ${ }^{985}$ Mannukiya's career is an example of administrative continuity in a period of political turbulence. Stolper has noted that some of Manuštānu's holdings and servants were transferred to a certain Artahšar after the accession of Darius II, ${ }^{986}$ and the case of Mannukiya and Gūbaru was clearly the same.

Mannukiya was a man of importance, emphasised by the fact that he visited Susa together with Rīmūt-Ninurta and other people from Babylonia at the end of Darius II's sixth year. ${ }^{987}$ The visits of Babylonian businessmen and officials to Susa were related to taxation, ${ }^{988}$ and Mannukiya's role as a seppiru of the governor, supervisor of a hatru, and witness of tax-related transactions (EE 56; TuM 2-3 180) fits this pattern perfectly. ${ }^{989}$ Moreover, his servants received a payment for transporting barley used for flour from Nippur to the Kabaru canal, which was the principal waterway connecting Babylonia to Susa. ${ }^{990}$ In addition to managing tax flows from the Nippur region, Mannukiya's local importance in Nippur is underlined by a legal case involving property worth 30 minas of silver, which he witnessed together with other officials (BE 10 118). It must be noted that not all sêpirus in the archive exercised such power, but most of them were literate clerks employed by royal officials or businessmen. ${ }^{991}$

The hatru of the sêpirus of the troops was also managed by a high-ranking sēpiru. ${ }^{992}$ A certain Abì-ul-īde, who is in charge of the hațru in PBS 2/1 3, is most likely Abì-ul-īde the sēpiru in BE 105 and PBS 2/1 173. Abī-ul-īde was not a low-ranking clerk but superior to the minor officials of the hatru (PBS 2/1 3) and the master of a number of servants (PBS 2/1 173). He also authorised tax collection in the hatru of the sword-bearers of the crown prince's estate (BE 10 5), which connects him to Mannukiya's father, who supervised the same hatru.993

in EE 111 ( 7 Dar II?) as well; the text is closely related to BE 10 118. On Gūbaru, see Stolper 1987, 396-398; 1989, 290-291.

985 TuM 2-3 180 reveals Mannukiya's patronymic, and it is plausible that the homonymous individual in BE 1084 and 85 is his father. See Zadok 2015a, 117.

986 Stolper 1985, 91-92. See Section 5.4.

987 IMT 46; PBS 2/1 100+. See Stolper 1992; Waerzeggers 2010b, 784-785.

988 Waerzeggers 2010b, esp. 797-809.

989 Cf. Bloch 2018, 302-317.

990 BE 984 (see Stolper 1990, 167; Waerzeggers 2010b, 807 n. 111). On the Kabaru canal and tax deliveries to Susa, see Waerzeggers 2010b, 790, 804-807; Tolini 2011 vol. 1, 491-498.

991 Cardascia 1951, 15; Stolper 1985, 22.

992 Stolper 1985, 93-94.

993 On the hatru of the sword-bearers (of the crown prince's estate), see Stolper 1985, 54-55, 76 . 
Abì-ul-īde appears in PBS 2/1 3 together with a man named Șihā, who is perhaps identical with Ṣihā the ahšadrapānu ('satrap') in PBS 2/1 2.994 In addition to Abì-ul-īde and Șihā, two other men, Patēšu and Ispitāma', had authority over the hatru of the sēpirus of the troops in the first year of Darius II. ${ }^{995}$ Their titles are not given in any text, but they appear to be men of high rank. Ispitāma? was perhaps the son of Patěšu, and he is attested as a member of the jury in a legal case from the accession year of Darius II (IMT 105) ${ }^{996}$ and perhaps as a landholder in the environs of Babylon or Borsippa in a text from the Kasr archive (unpublished YвC 11562). ${ }^{997}$

It is hardly a coincidence that both Mannukiya and Abì-ul-īde were sēpirus. Although the offices held by Ṣihā, Patēšu, and Ispitāma? remain uncertain, it is reasonable to suggest that the sêpirus who are referred to in the names of some hatrus were officials of high rank and beneficiaries of the landholdings, not the people who cultivated the fields, paid taxes, and performed military service. ${ }^{998}$

Mannukiya also helps to establish a link between the sêpirus of the rab unqāti's estate and Zabīn, the šaknu of the hatru of the sêpirus of the troops. The two men appear in a document of litigation in Nippur in 13-I-7 Dar II (BE 10 118): only the seal of Zabīn/Balāțu and the accompanying caption have been preserved, but he was most probably among the witnesses of the document. He bears here an exceptional title, didakku, an Iranian loanword based on *didi-ka ('supervisor'). ${ }^{999}$ This is the only attestation of didakku in Babylonian sources, and it likely renders his usual title šaknu. Mannukiya is listed among the witnesses together with Iqiša, his frequent companion and a sēpiru of Gūbaru. ${ }^{1000}$ Their official titles are not preserved in the document, but another document related to the same litigation (EE 111) features Iqī̌sa, the sēpiru of Gübaru, and thus confirms the identification. In light of these documents, it appears more and more unlikely that the hațru of the sēpirus of the troops and the hațru of the sēpirus of the rab unqāti's estate were unrelated.

994 Stolper 1985, 94. See also Jursa and Stolper 2007, 264-265, 269-270. The title ahšadrapānu does not necessarily refer to a satrap (governor) of a province (Jursa and Stolper 2007, 264).

995 Patēšu: BE 1033 (27-IV-1 Dar II ); BE 1037 (2-V-1 Dar II). Ispitāma?': PBS 2/1 27, 29 (both 14-?-1 Dar II). See Stolper 1985, 94-95.

996 On their possible consanguinity and identification with Petisas and Spitames in Ctesias' Persica, see Stolper 1985, 94 + n. 100; Dandamayev 1992b, 88, 112; Donbaz and Stolper 1997, 153 .

997 Stolper 1987, 395, 400 .

998 Stolper 2001, 106 seems to suggest this as well.

999 Tavernier 2007, 419-420. See also CAD D, 135.

1000 See above. 
There is yet another administrative designation pertaining to seepirus, namely, the šaknu of the sēpirus of the rab ummu's estate. A certain Lâbâši/MušēzibBèl, who held this title in the third year of Darius II (PBS 2/1 196, 28-VI-3 Dar II), was in charge of a bow land in the village of Bannēšu ${ }^{1001}$ by the Namgardūr-Enlil canal. The word hatru does not occur in this document, but there is no doubt that the text concerns a similar administrative unit. The rab ummu was a Babylonian official, but, as is the case of the rab unqāti, his concrete duties are mostly unknown. ${ }^{1002}$ A text from the Ebabbar archive (BM 64707) $)^{1003}$ and the rab ummu's seal impression with a military scene (Stolper 2001 no. 9) may imply that he had a military function, and Stolper proposes that the word ummu in his title may mean 'quiver'1004 However, this remains speculative in the absence of further evidence. ${ }^{1005}$ The title rab ummu is attested in several texts from the Murašû archive, and one holder of this title, Mīnu-ana-Bēl-dān/ Tahhūa, is known by name. ${ }^{1006}$

Mīnu-ana-Bēl-dān the rab ummu can also be connected to the sēpirus of the governor Gūbaru. He witnessed a large tax payment of 15 minas of silver in Nippur together with Tattannu/Aplâ the simmagir and Bēl-ab-uṣur/ Bēl-abușur, the sêpiru of the governor Gūbaru (BE 10 101, 18-VII-5 Dar II). The career of Bēl-ab-ușur was perhaps similar to that of Mannukiya, who first served Prince Manuštānu and later the governor Gūbaru. In 29-III-40 Art I, a certain Bēl-ab-uṣur/Bēl-[...] the brewer ("'ísiraš), another brewer, and a mār [bīti?] of Manuštānu received a sūtu payment of 40 kurru of kasû by the written order of Manuštānu (IMT 40). As the lower left horizontal wedge of the ad sign and the upper right Winkelhaken of the ùru sign seem to be preserved, reconstructing Bēl-ab-ușur's patronymic as Bēl-ab-ușur is likely. ${ }^{1007}$ Given the delivery of kas $\hat{u}$, a plant commonly used in brewing, ${ }^{1008}$ Bēl-ab-ușur was obviously a brewer of some sort. However, he was not necessarily involved in the actual brewing process; he could perhaps have been a foreman of a brewery held by Manuštānu. ${ }^{1009}$ In the early years of Darius II, Bēl-ab-ușur/Bēl-ab-uṣur is attested in three

\footnotetext{
1001 'The town of Caria', apparently a settlement of Carian deportees or mercenaries. See Zadok $1985,64-65$.

1002 MacGinnis 1998; Stolper 2001, 103-111; CAD U-W, 133.

1003 Published in MacGinnis 1998.

1004 Stolper 2001, 107.

1005 See Stolper 2001, 106-107; cf. MacGinnis 1998, 180.

1006 The title rab ummu is attested in the following Murašû texts: BE 9 72; BE 10 101; PBS 2/1 175, 196, 207. Mīnu-ana-Bēl-dān is attested in BE 10 101; PBS 2/1 207 (his servant witnesses); and in a non-Murašû text edited in Stolper 2001 (no. 9).

1007 Cautiously suggested by the editors of the text as well.

1008 Stol 1994, 175-179.

1009 Personal communication with Caroline Waerzeggers.
} 
documents in addition to BE $10101 .{ }^{1010}$ All four documents pertain to the same individual, which is confirmed by the identical seal impressions accompanying his name. ${ }^{1011}$ One of these documents is BE 10118 , which I already discussed above: Bēl-ab-uṣur appears as a witness together with Zabīn and Mannukiya. Moreover, Bēl-ab-uṣur also knew the brother of Zabīn. Bēl-ab-uṣur, Tattannu the simmagir, and Nabû-mìt-uballiț/Balāțu appear among the witnesses of a sūtu payment in 25?-XI-3 Dar II (PBS 2/1 72). Although Nabû-mìt-uballiț's seal is different from the one he used in other documents, ${ }^{1012}$ his rare name makes it very likely that he was the Nabû-mit-uballit of the hațru of the sêpirus of the troops. ${ }^{1013}$

\subsubsection{Conclusion}

A careful reading of the texts pertaining to the hatru of the seppirus of the troops, sêpirus of the rab unqāti's estate, and sêpirus of the rab ummu's estate reveals close connections between the officials in charge of these holdings. At the same time, it becomes clear that the administrative structures in the landfor-service sector were complex and several people of higher and lower statuses participated in the management of landholdings and their taxation. Two brothers, Zabīn and Nabû-mit-uballit, took care of the everyday affairs of the hatru of the sêpirus of the troops, but three different men - Abì-ul-ìde, Patēšu, and Ispitāma ${ }^{\text {? }}$ - figure as their superiors in the first year of Darius II. At the same time, Mannukiya managed the hațru of the sêpirus of the rab unqāti's estate. Other documents reveal that both Abì-ul-īde and Mannukiya were sēpirus, but not mere alphabetic scribes.

The career of Mannukiya is especially noteworthy: he first served Prince Manuštānu and later the governor Gūbaru, and he travelled to Susa in his role as an official in charge of tax flows from Babylonia. He also knew Zabīn and another sēpiru of Gūbaru, Bēl-ab-uṣur. In his turn, Bēl-ab-uṣur was in contact with both Zabīn and Nabû-mìt-uballit, and he witnessed an important transaction with Mīnu-ana-Bēl-dān, the rab ummu. Accordingly, the people managing the three hațrus of seepirus were closely connected. Moreover, Abī-Yāma/ Šabbatāya was obviously a landholder in the hațus of the sêpirus of the troops and the sēpirus of the rab unqāti's estate.

The case of Abì-ul-ide and Mannukiya suggests that the holders of bow lands in these three hatrus were not sēpirus themselves but subordinates of

1010 BE 10 118; PBS 2/1 72, 224.

1011 Bregstein 1993 no. 173.

1012 Compare Bregstein 1993 no. 38 to no. 27.

1013 Bregstein 1993, 430 makes the same identification. 
high-ranking sēpirus. In other words, one should not perceive the petty landholders as literate sēpirus but common farmer-soldiers. ${ }^{1014}$ This argument is corroborated by the unique text UCP 9/3 (18-X-2 Dar II ), in which Gadal-Yāma/ Rahīm-il agrees with Rīmūt-Ninurta to perform the service obligations attached to a horse land. ${ }^{1015}$ It appears that Gadal-Yāma's father had adopted Rīmūt-Ninurta's uncle Enlil-šum-iddin, which allowed the Murašûs to have a share in Rahim-il's horse land. ${ }^{1016}$ The official in charge of the call-up was Zabinn, the šaknu of the hatru of the sēpirus of the troops, which reveals that the horse land belonged to this administrative unit. Gadal-Yāma was to be equipped with a horse, weapons, clothing, and travel provisions, and then he would travel to Uruk.

It is evident that Gadal-Yāma was supposed to perform military service as a horseman, and he was not the only soldier travelling to Uruk at this time. Six other documents from the Murašu archive show that holders of bow lands in the Nippur region were obliged to send soldiers to Uruk in the tenth month of the second year of Darius II. ${ }^{1017}$ The terminology employed in the texts makes it very clear that people were fitted out as soldiers and were sent to Uruk to perform actual service. Although external sources do not shed light on the circumstances which led to the mustering of troops at this precise moment - if the call-up was not annual ${ }^{1018}$ - the documents emphasise the fact that the military and service obligations attached to bow and horse lands were not fictional. As there is no military rationale to send an educated scribe or clerk to serve as a soldier, Gadal-Yāma, a member of the family who held the horse land, was hardly a sêpiru. The document is the only piece of evidence showing that Judeans also held shares in horse lands.

The previous investigation has revealed that the sêpirus who lent their titles to the pertinent hatrus were not subordinates of these units but high officials

1014 Cf. Bloch 2018, 317-331, 380-397.

1015 This document has been discussed in several studies. See Lutz 1928; Cardascia 1951, 179182; Ebeling 1952; Zadok 1979a, 66-67; Stolper 2001, 120-127; van Driel 2002, 235-236; Manning 2016; Bloch 2018, 326-331.

1016 See Cardascia 1951, 179-182; Joannès 1995, 1481. The clause about the adoption is difficult as it refers to Barīk-il's share, which Rahīm-il had given to Enlil-šum-iddin. Some commentators have judged that Barìk-il was Rahīm-il's (step-)father (Lutz 1928, 269; Zadok 1979a, 66-67; 2002, 40), but EE 35 suggests that Barik-il was Rahīm-il's son and thus GadalYāma's brother (see my discussion in Section 5.3.3 below).

1017 BE 10 61, 62; PBS 2/1 54, 162, 194; IMT 83. EE 117 is badly broken but may belong to this group as well. The texts were written between the eighteenth and twenty-fourth day of the tenth month. See Augapfel 1917, 17-18; Cardascia 1951, 40, 99; Joannès 1982a, 17-20; Stolper 1985, 123 + n. 46; 2001, 124 n. 53; Briant 2002, 598-599.

1018 See Stolper 1985, 123; Briant 2002, 598-599. 
in the Nippur region. They were servants of the governor of Akkad, and they witnessed documents together with other high officials such as the simmagir and the rab ummu. It would probably be more accurate to speak of only a single hatru, because the different designations discussed above may all refer to the same administrative unit. ${ }^{1019}$ This suggestion is supported by the following factors: first, there was significant linkage between the officials in charge of the various hatrus of sēpirus. Second, the example of the hatru of the sēpirus of the troops demonstrates that the names of hatrus were very flexible. Third, the bow lands held by Judeans were concentrated in these hatrus. Finally, AbīYāma/Šabbatāya held plots in the hațrus of the sēpirus of the troops and the sēpirus of the rab unqäti's estate.

A number of people and institutions were supervisors and beneficiaries of the hatru, among them the sêpirus, the rab ummu, the rab unqa ti, their estates, the governor of Akkad, and, eventually, the king. Like in the environs of Yāhūdu, the highest official in this administrative hierarchy was a governor, in this case Gūbaru. His seepirus, high officials in the Nippur region, supervised the landholdings and tax flows together with the staff of the rab ummu's and rab unqāti's estates. This structure also resembles the situation in the surroundings of Yāhūdu, where the deputy of the rab urâti was in charge of the governor's lands. This picture is in line with Stolper's observations about the administration of other landholding units in the Nippur countryside. ${ }^{1020}$ Judean landholders in the hatru were not sēpirus themselves but farmers who had to perform actual military service for the state.

\subsubsection{Large-Scale Landholding: Rahìm-il and His Family}

Not all Judean landholders in the land-for-service sector farmed a modest plot of land. Some had significantly larger holdings. An important example is Rahīm-il, who together with his family held several plots, including a horse land, in the Nippur region. ${ }^{1021}$ At least some of Rahim-il's landholdings belonged to the hațru of the sēpirus: Gadal-Yāma, who was discussed above in the context of his trip to Uruk to perform military service, was Rahìm-il's son (UCP 9/3). The family is attested in eleven documents from the thirty-third year of Artaxerxes I until the fifth year of Darius II. Figure 10 presents their family tree.

1019 Stolper 1985, 76 and Bregstein 1993, 648 suggest that there was some connection between the hatru of the seppirus of the troops and the hațru of the seppirus of the rab ummu's estate.

1020 Stolper 1985, 48-49, 54-55, 88 + n. 70, 89-96, 100-103.

1021 Some aspects of this family's activities are briefly discussed by Zadok 1979a, 54, 64-67; 2002, 38-40. He accepts fewer people as members of this family than I do. 


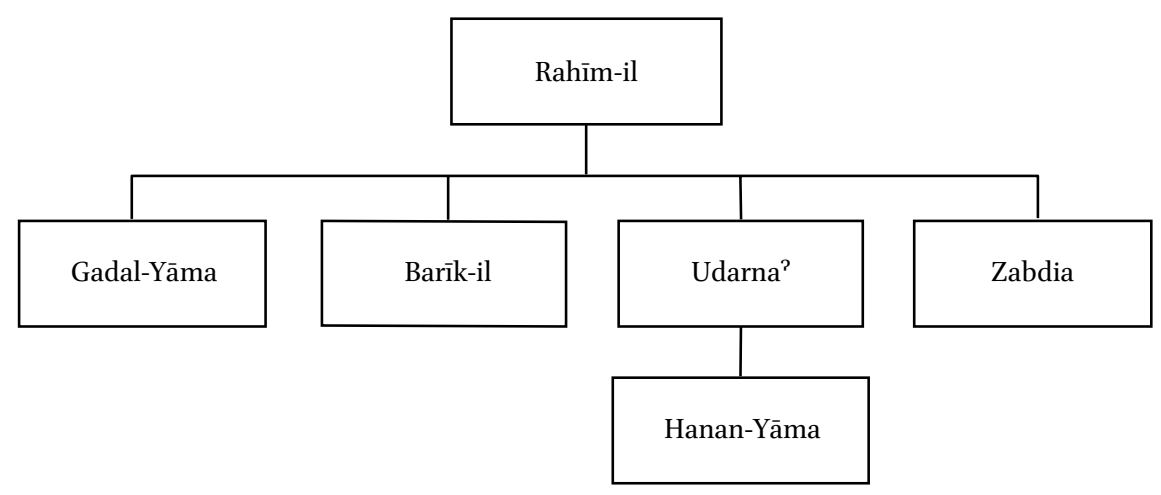

FIGURE 10 The descendants of Rahīm-il

The earliest document pertaining to the family is EE 35 (17-I-[33] Art I), a receipt of a sūtu payment in silver from Barìk-il/Rahīm-il to Munnātu/Umahparê. The amount of silver is broken and the juridical status of the pertinent landholding remains unclear. Munnātu/Umahparê, the recipient of the rental payment, was probably a royal official, judging by his Iranian name and Egyptian patronymic. ${ }^{1022}$ Udarna', a brother of Barik-il, witnessed the transaction.

Udarna"s Iranian name ${ }^{1023}$ betrays his father's familiarity with the onomasticon of the foreign elite, which most likely resulted from regular contact with the officials in the land-for-service sector. This view is supported by two documents which Udarna ${ }^{2}$ witnessed in the following years. The first one pertains to Enlil-šum-iddin's leasing of land for thirty years from Halabesu/ Paț-Esu and Halabesu/Mukēšu (IMT 3, 8-XI-34 Art I), and the second one to Enlil-šum-iddin's sūtu rent payment to Mitrēn, a servant of the mašennu official Tattannu (BE 9 59, ?-?-37 Art I). Mitrēn's name is Iranian, ${ }^{1024}$ and Halabesu's Egyptian patronymic Pat-Esu ${ }^{1025}$ suggests that he was connected to the royal administration.

The life of the family was affected by distrust and tension between the brothers. In the thirty-ninth year of Artaxerxes I, Udarna? addressed Enlil-šumiddin at the assembly (puhru) of Nippur, claiming that Enlil-šum-iddin's servants and agents together with Udarna"s brother Zabdia and a certain Bēlittannu, had come to Udarna"'s house and taken his property illegally (BE 969 ,

1022 Munnātu: Tavernier 2007, 337; Umahparê: Zadok 1989-1990, 274; Hackl and Jursa 2015, 179.

1023 Tavernier 2007, 65 .

1024 Tavernier 2007, 250.

1025 Mattila 2004; Hackl and Jursa 2015, 178. 
4-XII-39 Art I ). ${ }^{1026}$ The nature and value of the property is not specified, but the accusation was apparently well founded, as Enlil-šum-iddin had to return the property to Udarna?. The litigation was witnessed by Udarna?'s son HananYāma, and both the father and son impressed their cylinder seals on the tablet. ${ }^{1027}$ The fact that they possessed such objects implies that they needed them regularly.

The extensive size of Rahīm-il's landholdings becomes apparent in BE 9 86a (?-?-[41] Art I). This document is a lease of several plots of land from Enlil-šumiddin to his slave Ea-zittišu/Ahdatuše and a certain $[G] a-d a-a l^{-}{ }^{2}-a /$ Šabbatāya. The leased lands consist of the holdings of Enlil-šum-iddin and two bow lands of Rahīm-il and his sons ('ra-hi-im-dingir.meš $u$ dumu.meš-šú). Rahīm-il's bow lands must have been vast, as one holding was located in Til-Gabbāri, Bīt-ilšakā, Til-Rahīmu, and the environs (limìtu) of Til-Gabbāri, and the other in Titurru ša simmagir, Hușșēti ša [rēêêe],1028 Išqallūnu, Bīt-Kikī, Bīt-Akkē, and extending onto both sides of the Simmagir canal. In addition to these lands, 72 oxen, 18 ploughs, seed corn, and barley for the wages of workmen were included in the three-year lease, the annual rent of which was 2,700 kurru of produce and additional payments.

A reference to the bow lands of Rahìm-il and his sons in BE 9 86a would not alone confirm that the Rahim-il in question is identical with the Judean man discussed in this section. However, $[G] a-d a-a l^{-}{ }^{2}-a / S ̌$ sabbatayya, the lessee of the lands in BE $986 \mathrm{a}$, can be connected to the Judean family. First, there was a close relationship between a certain Gadal-Yāma/Šabbatāya and the family of Rahīm-il. Hanan-Yāma/Udarna? and Gadal-Yāma/Šabbatāya together witnessed two documents, the litigation document BE 969 and BE 107 (2-I-1 Dar II), a receipt of tax payment from horse and bow lands belonging to the hatru of the sēpirus of the troops. Second, $\mathrm{Ga}-\mathrm{da}-a \mathrm{l}^{2}-\mathrm{a}$ is a hypocoristic writing of Gadal-Yāma. A similar writing of the name Gadal-Yāma is attested in EE 65 (20?-VI-[41 Art I]), in which a seal caption naming a certain Ga-da-al-ia is preserved on a partially illegible tablet. The same cylinder seal is attested in UCP $9 / 3$, in which the seal user's name is Gadal-Yāma. ${ }^{1029}$ We may conclude that $[G] a-d a-a l-{ }^{2}-a / S ̌$ Sabbatāya in BE 9 86a was identical with Gadal-Yāma/Šabbatāya

\footnotetext{
1026 Zabdia, son of Rahīm-il, is also attested as a witness to Enlil-šum-iddin's transaction in BE $965(28-?-38$ Art I ).

1027 Udarna?: Bregstein 1993 no. 362. A lion attacks a prey, perhaps a bull or boar. Hanan-Yāma: Bregstein 1993 no. 108. The Babylonian hero subjugates a bull, and the crescent moon hovers above them.

1028 The emendation is suggested by Augapfel 1917, 66; Zadok 1985, 176 .

1029 Bregstein 1993 no. 16. The Persian hero holds two lions in his hands.
} 
in BE 969 and BE 10 7, and, furthermore, that the landholder Rahim-il in BE 9 $86 \mathrm{a}$ is the Judean man discussed in this section.

It becomes apparent that Rahìm-il was not a subsistence farmer cultivating a small plot with his family but a significant landholder in the land-for-service sector. The same picture emerges from UCP $9 / 3$, which concerns the horse land of Rahīm-il. His son Gadal-Yāma travelled to Uruk to perform the military service incumbent on the holder of the horse land. This Rahim-il is most likely identical with the Rahīm-il discussed in this section, as, according to the text, he had given Barik-il's share in the horse land to Enlil-šum-iddin by means of a fictional adoption. Our Rahīm-il had a son named Barīk-il as well, and the document fits the picture of a family that was a significant landholder in the Nippur region but suffered from financial difficulties in the late reign of Artaxerxes I. During that difficult period - perhaps related to the accession wars after Artaxerxes' death - Enlil-šum-iddin was able to interfere with the family property. The fictional adoption of Enlil-šum-iddin was obviously a way to transfer part of the horse land to the Murašûs and perhaps settle some outstanding claims (UCP 9/3). ${ }^{1030}$ Similarly, some bow lands of the family had come into the disposal of Enlil-šum-iddin, possibly via a lease or as pledged property (BE 9 86a). Finally, the tensions between Enlil-šum-iddin and Rahīm-il's family are betrayed by the litigation over Udarna"s stolen property (BE 969 ).

Despite its difficulties, the family did not disappear from the scene after the accession of Darius II, and Hanan-Yāma is attested twice as a witness in the fourth and fifth years of the king (BE 10 84; PBS 2/1 107). It is noteworthy that he impressed a different seal on the later document, compared to BE 969 seven years before. ${ }^{1031}$ Ownership of seals was very common in this family, as Udarna ${ }^{\text {? }}$ Hanan-Yāma, and Gadal-Yāmaa ${ }^{1032}$ all impressed their seals on one or more documents in the archive. This is suggestive of the high socio-economic status of the family. An interesting feature of the seals is their imagery, which always employs the motif of a bull or lion. This may tell something about the preferences of the family, because these motifs were not otherwise favoured by Judean seal owners. ${ }^{1033}$

The texts pertaining to Rahīm-il and his descendants constitute an exceptionally informative group about an important Judean family in the Nippur region. The family had several large landholdings in the land-for-service sector,

\footnotetext{
1030 See Cardascia 1951, 181-182.

1031 Bregstein 1993 no. 268. The seal depicts a bull.

1032 Bregstein 1993 no. 16. The Persian hero holds two lions in his hands. The seal is attested in EE 65 and UCP $9 / 3$.

1033 See Section 5.7 .
} 
including a horse land, which implies that the family belonged to an upper social stratum in the hierarchy of the land-for-service sector. Their use of seals, their frequent presence as witnesses, and Udarna"s Iranian name point towards the same conclusion. Their horse land belonged to the hatru of the sēpirus of the troops, and Hanan-Yāma/Udarna? and Gadal-Yāma/Šabbatāya witnessed another transaction pertaining to the same hatru. This was perhaps the general administrative context of Rahìm-il's landholdings.

The only comparable group of texts related to Judeans are the documents on the community in Bìt-Gērāya. Although the groups differ in many ways, they show a similar relationship between the Murašus and the protagonists of the text groups. The protagonists had significant resources at their disposal, but their distressed financial situation or aspiration to expand their farming activities forced them to seek help from the Murašûs. This is a common pattern in the archive, and Judean landholders are usually attested only when they needed the services provided by the Nippurean family. Those Judeans who never sought such help or support are invisible to us. This aspect of the archive's composition needs to be taken seriously, as it can greatly affect the conclusions about Judean landholding in the Nippur region.

\subsubsection{Other Judean Landholders}

Apart from the documents discussed above, one more Judean landholder can be connected to a particular hatru. BE 1092 (13?-IX-4 Dar II) is a receipt of a sūtu rent of grain fields (zērū pi šulpi) in Appāru ša Tahmiya and Gammalē, which belonged to the hatru of the gardu. Šabbatāya/Hi-il-lu-mu-tu - a man of Judean origin ${ }^{1034}$ - held these lands together with Il-gabrī and Nabû-nā, the sons of Šuzzubu, and their anonymous colleagues. The same brothers appear again in IMT 32 (?-V-? Dar II) as holders of a bow land which was leased out for date cultivation. The communal nature of landholding is apparent again, as the brothers held this date plantation with two other named colleagues from the hatru of the gardu. The appellation gardu is somewhat elusive in Babylonia, but its semantic range corresponds to its Elamite counterpart kurtaš, which is a designation for state-dependent workers in the Persepolis archives. ${ }^{1035}$

The rest of the land properties (co-)held by Judeans cannot be linked to any particular hatru or estate. In two documents related to the same litigation over land properties in Gammalē and Išqallūnu (BE 10 118, 13-I-7 Dar II; and EE 111,

1034 The identification of this person as a Judean is based on his rare patronymic, which is attested only in IMT 94 (Hi-il-mu-tu) as the patronymic of a certain Šamā-Yāma.

1035 Stolper 1985, 56-59; Briant 2002, 429-439, 456-459; Tavernier 2007, 423-424; cf. CAD G, 50. 
date broken), seven Judeans and their anonymous brothers are attested as coholders of a bow land. The landholders belonged to two families, being sons of Tuūb-Yāma and Zabīnâ. Although the Judeans were holders of a bow land, they also owned land and houses that could be sold. They accuse Rīmūt-Ninurta of taking their lands illegally, whereas Rīmūt-Ninurta claims that he has bought them for 30 minas of silver from the sons of Țūb-Yāma (BE 10 118) and for 10 minas of silver from the sons of Zabinnâ (EE 111). These are very large amounts of silver, and they emphasise the fact that people in the land-for-service sector could own and sell valuable real estate.

In addition to the documents pertaining to the bow and horse lands, four texts relate to bit rittis and one text to a date garden (co-)held by Judeans. The earliest attestation of a Judean landholder and the second earliest text in the whole Murašû archive is BE 93 (26-II-13 Art I), in which Enlil-hātin/Murašû leases the bit ritti land of Arad-Gula and Hanan-Yāma to five people for sharecropping. As customary, any institutional affiliation of the bit ritti is not given, but as pointed out above, landholdings designed like this may also have belonged to a temple or the crown. Another bit ritti, held by Haggâ/PN and Mattan-Yāma/PN, is mentioned in passing in EE 24 (?-X-? Art I). The landholders rent two oxen from Enlil-šum-iddin to plough the fields in their bit ritti. The bìt ritti lands of Yadi-Yāma (BE 925 , 45) were discussed in Section 5.2.2.

There is only one document that refers to a Judean landholder not explicitly linked to the land-for-service sector or an institutional landholding. HananYāma/Aplâ had leased his date plantation (zēru zaqpu) in Bīt-Murānu by the Harri-Piqūdu canal to Rīmūt-Ninurta, who paid the imittu rent in 20 shekels of silver instead of dates (EE 34, 4-VII-7 Dar II). It is interesting that Hanan-Yāma bore the title sêpiru (see Section 5.4) and he had given an Iranian name Bagēšu ${ }^{1036}$ to his son. Gukka ${ }^{1037}$ the slave of Bagěšu, collected the rental payment from the sêpirus of Rìmūt-Ninurta. There is no reason to suppose that Hanan-Yāma was a high-ranking official like Mannukiya; more likely he was one of the petty officials attested in the Murašû archive. His duties perhaps brought him into regular contact with the Persians, which could have encouraged him to give an Iranian name to his son.

\subsubsection{Patterns of Judean Landholding}

The results of the previous survey of Judean landholders and landholdings conform to the general patterns of the Murašû archive. Judeans are primarily attested as holders of bow lands and bit rittis, and only one Judean landholder

1036 Tavernier 2007, 135 .

1037 Another Iranian name; Tavernier 2007, 187. 
cannot be linked to any institution or institutional landholding. Moreover, the Judean landholdings were regularly at the disposal of the Murašus as a result of a lease or as a security for a debt. This picture is somewhat skewed, of course, because we can only perceive Judeans from the viewpoint of the Murašu family who ran their business in a specific sector of the Babylonian economy. The majority of Judeans in the Nippur region were hardly ever in contact with the Murašûs, although it may well be that they were all integrated into the landfor-service sector.

There seems to be no reason to doubt that most Judean deportees worked in the land-for-service sector in Babylonia. The picture emerging from the Murašû archive is consistent with that from the environs of Yāhūdu: Judeans were settled in communities and assigned to certain administrative units which were still observable 150 years after the deportations from Judah. The strong Judean presence in Bìt-Gērāya and the hațru of the sēpirus emphasises this observation, but there are also other villages in which Judeans are regularly attested. Noteworthy examples are Gammalē ${ }^{1038}$ and Išqallūnu: ${ }^{1039}$ Judeans are present in every document pertaining to the former, and a group of Judeans owned houses in the latter (BE 10 118; EE 111). ${ }^{1040}$ The landholders in Išqallūnu bore exclusively West Semitic names, and, in addition to Judeans, Philistines obviously lived in this twin town of Ashkelon. ${ }^{1041}$ There is no evidence of a hatru of Judeans, but the administrative logic behind the local communities and the hatru of the seppirus was the same. It was practical to retain the basic communal structures which allowed the local officials to deal with the representatives of the community, not directly with each family unit.

The communal aspect of landholding characterises the transactions pertaining to Judean farmers. There is no direct evidence of landholdings being split into tiny fragments by inheritance divisions; rather, judging by their patronymics, the co-holders of land properties were often unrelated. As I argued above, the idea of shrinking landholdings is contradictory to the aims of the land-for-service sector. If land was readily available and the crown strived to increase agricultural output and tax flows, there was every reason to bring new lands under cultivation when the existing fields and gardens could not support their holders anymore.

It must also be emphasised that there was a lot of flexibility in the terminology pertaining to the land-for-service sector. A bow land was not a plot of

1038 Attested in BE 10 83, 92, 118; [EE 111]; PBS 2/1 115 .

1039 Attested in BE 9 86a; BE 10 118; EE 111; IMT 17.

1040 On Gammalē and Išqallūnu, see Zadok 1978a, 311, 319; 1985, 137-138, 183 .

1041 See Eph ${ }^{\varsigma}$ al 1978, 80-83; Zadok 1978b, 61. 
standard size, designed to support one landholder and his family. Some bow lands could produce huge tax and rental payments, whereas others appear to be very tiny. In the same vein, the frequent references to anonymous coholders of bow lands attest that larger communities were involved in farming them. There were no fixed representatives of a particular landholding, as the same bow land could be represented by different people on different occasions.

Finally, it must be emphasised that farming communities and groups of colandholders were hardly homogenous. Some co-landholders of Judeans bore Babylonian names, and Philistine deportees must have composed the bulk of the original population in the village of Išqallūnu. These two phenomena - the survival of communities and their constant interaction with other deportees have important implications for the discussion of Judean culture and identity in the Nippur countryside. I will return to these questions in Section 5.7 below.

\subsection{Judean Officials}

The efficient collection of taxes and organisation of work and military service necessitated the presence of administrative personnel in Nippur and the surrounding countryside. Judeans are not attested among the higher functionaries of the hierarchy, but some minor officials were recruited from their ranks.

As I argued above, the Judeans attached to the hatru of the sêpirus were not sêpirus themselves, and there is no reason to suppose that the level of literacy was high among the Judean farmers. Hanan-Yāma/Aplâ is the single Judean sēpiru attested in the archive (EE 34). ${ }^{1042}$ The Iranian name Bagēšu, given to his son, suggests that Hanan-Yāma was in regular contact with the Persian authorities, which naturally fits his profession. Nothing is known about HananYāma's professional duties, because EE 34 pertains to the lease of his date plantation (see Section 5.3.4). However, there is no reason to suppose that he was a high-ranking official like Mannukiya; more likely he was one of the petty officials attested in the Murašû archive.

The duties of four Judean officials were directly related to the administration of the land-for-service sector. Išrib-Yāma/Pili-Yāma, the only Judean šaknu in the Murašu archive, managed the hațru of the šušannus of the storehouse (nakkandu). ${ }^{1043}$ As šaknus were not systematically recruited from among the

1042 On this text, see Bloch 2018, 344-347.

1043 See Stolper 1985, 89-93 for a discussion of this estate and its personnel. 
landholders of the pertinent $h a t+r u,{ }^{1044}$ it remains unclear if Išrib-Yāma himself held land in this organisation. He held the title of šaknu in 5-V-3 Dar II (BE 10 65), but a year later, Pamunu, a servant ( $a r d u)$ of Artahšar, is attested in the same position (PBS 2/1 205, 16-?-4 Dar II). ${ }^{1045}$ Išrib-Yāma was still involved in the management of the hatru and was perhaps in a superior position in relation to Pamunu, as the šaknu Pamunu collected the payments according to the written tablet (libbû šațāri țuppi) $)^{1046}$ of Išrib-Yāma. This does not mean that the tablet was written by Išrib-Yāma, and it is not a proof of Išrib-Yāma's literacy in cuneiform. Artahšar, the master of Pamunu - and obviously of Išrib-Yāma as well - has been identified with Artoxares, who appears in Ctesias' Persi$c a{ }^{1047}$ According to Ctesias, Artoxares was among the people on the winning side during Darius II's fight for the throne of Persia. The Murašû archive shows that like Gūbaru, Artahšar took over some of Prince Manuštānu's landholdings and personnel in Babylonia. Išrib-Yāma impressed his seal on BE 10 65. It depicts a Persian hero holding two monsters, with the god Ahura Mazda hovering above the scene. ${ }^{1048}$

A Judean called Il-yadin/Yadi-Yāma ${ }^{1049}$ was a servant ( $\left.a r d u\right)$ of Artahšar as well. He and Nidinti-Šamaš/Kartakku, another servant of Artahšar, collected a rental payment (zittu) originating from the fields of their master in PBS 2/1 84 ([Sîn-b]ēlšunu, 19-V-4 Dar II). The lands were taken on lease by the Murašûs, and, two years later, Rīmūt-Ninurta and Il-yadin are attested as co-creditors in Sîn-bēlšunu (PBS 2/1 121, 10-VI-6 Dar II). Il-yadin does not bear any title in the latter document, and Rīmūt-Ninurta appears to have been the main creditor who kept the pledged bow land at his disposal until the debt was paid back. Although Il-yadin is not attested in other documents, his colleague NidintiŠamaš is better known. He was the manager ( $p a q d u$ ) of Artahšar's estate and a frequent witness in the early reign of Darius II. ${ }^{1050}$ His co-occurrence with Ilyadin and the contents of PBS $2 / 184$ and 121 suggest that the Judean was also

\footnotetext{
1044 Stolper $1985,85^{-88 .}$

1045 On Pamunu, see Stolper 1985, 92 n. 89.

1046 On this expression, see CAD L, 173.

1047 Stolper 1985, 91-92.

1048 Bregstein 1993 no. 37.

1049 His patronymic has been preserved as $I a-a-d[a-]$ in PBS $2 / 184$ and $I a-d i-h u-i a-a$-[...] in PBS 2/1 121, and the restoration Yadi-Yāma is very likely.

1050 Stolper $1985,92+$ n. 88 (his reference to PBS $2 / 184$ is to be corrected: Nidinti-Šamaš is titled $a r d u$ instead of paqdu); Bregstein 1993, 442, 607. Note that he witnessed two documents pertaining to the hatru of the sêpirus of the troops, PBS $2 / 127,29$. On the title paqdu, see Stolper 1985, 22, 66-67; CAD P, 135-136.
} 
an official in charge of Artahšar's landholdings. Il-yadin had a seal which depicts two Persian heroes fighting against monsters (PBS 2/1 84). ${ }^{1051}$

Parysatis, the Persian queen and wife of Darius II, held lands in the Nippur region, which were managed by her paqdu Ea-bullissu. ${ }^{1052}$ A Judean called Mattan-Yāma/Amuše collected rental payments from the Murašûs on behalf of Ea-bullissu in PBS 2/1 50 (12-IX-3 Dar II $)^{1053}$ and witnessed another rental payment pertaining to Parysatis' holdings in P BS 2/1 60 (3-IV-3 Dar II). He impressed his iron ring on both documents. ${ }^{1054}$ Mattan-Yāma is also attested in EE 113 (?-?-33+ Art I), which does not refer to Parysatis or Ea-bullissu but is a contract between four Judeans and Enlil-šum-iddin. The Judeans, one of them Mattan-Yāma, owed a debt which they agreed to pay back by providing Enlilšum-iddin with forty paid workers and ten šušānus for a month. The document attests that human labour was used to pay off debts, ${ }^{1055}$ but unfortunately the text does not specify the relationship between the debtors and the workforce. However, BE 928 (18-VII-31 Art I) sheds some light on the institutional affiliation of the debtors: Šillimu/Yāhû-laqim, one of the co-debtors in EE 113, appears as a witness to rental payments pertaining to the lands of the queen's estate (é mí śá é.gal).1056

The emerging picture conforms to Stolper's hypothesis that Parysatis took over the landholdings of the former queen after the accession of her husband Darius II. ${ }^{1057}$ In the late reign of Artaxerxes I, a group of Judeans were attached to the queen's estate. The four Judeans were in a position to hire forty paid workers and order ten šušānus to work for the Murašûs, but their relationship to the workers is not made explicit. Given the fact that the Judeans were indebted to the Murašûs, the transaction should be seen in the same context as EE 92, in which Yāhû-natan and Bānia lease a canal from the Murašûs and pay the rent by assuming the maintenance work of the canal. As headmen of the village of Bìt-Gērāya, Yāhû-natan and Bānia had the resources of the community at their disposal. Likewise, the four Judeans of EE 113 were representatives of the local community, and they were important enough to be mentioned as witnesses in other documents as well. In the reign of Darius II, Parysatis gained control over the queen's estate and the landholdings attached to it, including the holding of Mattan-Yāma and his Judean colleagues. In this new situation,

\footnotetext{
1051 Bregstein 1993 no. 93 .

1052 See Stolper 1985, 63-64; Cardascia 1991. On Parysatis, see also Stolper 2006b.

1053 See Cardascia 1991, 367-368 for a helpful reconstruction of this broken document.

1054 Bregstein 1993 no. 281. The seal impression depicts a lion.

1055 Stolper $1985,81$.

1056 On this estate, see Stolper $1985,62-63$.

1057 Stolper 1985, 64.
} 
Mattan-Yāma became a servant of the paqdu of Parysatis' estate, collecting rental payments and witnessing documents relating to such payments. He was perhaps not an official in a strict sense, but rather the headman of a local community, who controlled the estate's landholdings and the flow of taxes to the coffers of the estate.

Finally, a Judean man called Barìk-Yāma, a servant ( $a r d u)$ of the mašennu official Artabara, ${ }^{1058}$ collected some oil from the subordinates of RīmūtNinurta (BE 10 6o, 25-IX-2 Dar II). He acted together with Bēl-iddin/Bēlbullissu, the sēpiru of the mašennu. Barik-Yāma did not impress a seal on the tablet and he is not attested in any other document.

Some Judeans worked as minor officials in the land-for-service sector of the Nippur region, but the number is small in comparison to the numerous attestations of Egyptian officials. Moreover, unlike Egyptians, Judeans are only attested on the lowest rungs of the administrative hierarchy. ${ }^{1059}$ Only two Judeans, one sēpiru and one šaknu, bore a formal title, but the Judean servants of high officials obviously acted in an official position as well. The Murašu archive provides examples of people who are sometimes designated as servants of high officials and royalty but bear an official title in other documents. ${ }^{1060} \mathrm{An}$ interesting feature that characterises Judean officials is the frequent use of seals, implying that they participated in transactions so often that it made sense for them to acquire one. The imagery of these seals and the hints they give of their owners' cultural identity will be discussed below in Section 5.7

\section{$5.5 \quad$ Judean Witnesses}

In almost half (45\%) of all occurrences in the Murašu archive, Judeans are attested as witnesses. Some Judean witnesses, such as Pili-Yāma and Udarna ${ }^{2}$, had a business relationship with the Murašû family, but 55 per cent of Judean witnesses are never attested as principals in the documents. It is well known that the parties of a transaction sought to have their family members, friends, and business partners as witnesses to their documents, ${ }^{1061}$ and the Murašû family also had its circle of frequent witnesses. ${ }^{1062}$ The testimony of such witnesses

\footnotetext{
1058 On Artabara and mašennu officials in general, see Stolper 1985, 45-49; Jursa and Stolper $2007,260$.

1059 Hackl and Jursa 2015, 168-172.

106o See, for example, the case of Nidinti-Šamaš/Kartakku above, and the case of Girparna? in Stolper 1985, 67, 96. See also Hackl and Jursa 2015, 161.

1061 von Dassow 1999b, 5-7; Still 2019, 169-170.

1062 Cardascia 1951, 20; Cussini 2013, 43-49.
} 
was required if the transaction was ever contested, and men close to the principal of the transaction were indispensable in the case of litigation. ${ }^{1063}$

Judeans witnessed transactions concerning their family members and other Judean acquaintances, but this was only sometimes the case. Pili-Yāma, for instance, witnessed two documents pertaining to Yadi-Yāma (BE 9 45; EE 98), as well as three others which do not pertain to any Judean principal (BE 934 ; IMT $7-8$ ). The three latter documents were written on the same day before the same witnesses, and they all concern Enlil-šum-iddin's business dealings. Mattan-Yāma/Širkā is attested three times as a witness to Rīmūt-Ninurta's transactions, but only one of the documents features Judean principals (BE 10 83; EE 34; PBS 2/1 203). Likewise, Udarna"'s son Hanan-Yāma witnessed a litigation concerning his father (BE 969 ), but he appears as a witness in three documents without Judean principals (BE 10 7, 84; PBS 2/1 107). These two men themselves are never attested as principals of a transaction, but they both owned a seal ${ }^{1064}$ and were obviously men of some importance. It is possible, of course, that Pili-Yāma, Mattan-Yāma, or Hanan-Yāma belonged to the Murašû family's circle of witnesses, but it is more likely that they acted in an official capacity or were considered neutral parties, who were occasionally asked to witness a document when they were available in Nippur. ${ }^{1065}$

\subsection{Socio-Economic Status}

\subsubsection{The Framework of the Archive: the Land-for-Service Sector}

The text groups discussed above shed light on different aspects of life in the Nippur countryside. The documents pertaining to Yadi-Yāma, Pili-Yāma, and the villagers in Bìt-Gērāya show few affinities with the texts relating to the hatru of the sêpirus. The former group lacks the keywords typical of the landfor-service sector, such as hatru, bow land, and šaknu, and it attests to the efforts of villagers and their representatives to make the best of their economic situation in the Babylonian countryside. On the other hand, Judeans attached to hatrus and Judean officials were evidently living in the framework of the land-for-service sector and under the control of high officials and royal estates. It is not immediately clear if the seeming difference between the two groups is

1063 Still 2019, 169.

1064 Mattan-Yāma: Bregstein 1993 no. 574; Hanan-Yāma: nos. 108 and 268.

1065 On neutral parties as witnesses, see Still 2019, 169-170. 
real or if it only results from the composition of the archive; as pointed out above, the Bìt-Geerayya texts predate the bulk of the texts in the archive, especially the cluster of texts pertaining to bow lands in 40 Art I -7 Dar II.

However, the structures of the land-for-service sector were not created in the beginning of Darius II's reign. Bow lands and hatru-like structures existed in the environs of Yāhūdu long before the Murašû archive. Given the importance of the land-for-service sector in the Nippur countryside, it is unlikely that the villagers in Bìt-Gērāya - many of them descendants of Judean deportees were left outside of it. Although bit ritti is an ambiguous term in this regard, it implies that Yadi-Yāma's landholdings were not exclusively his private property. At the same time, the case of Bìt-Gērāya reminds us that the landholders in the land-for-service sector were not deprived of their agency and that they could strive to improve their economic situation. This picture is corroborated by other texts as well. BE 10118 and EE 111 show that owning private lands and holding bow lands were not mutually exclusive, and Ahīqam and Ahīqar did much more than cultivate their landholdings in Yāhūdu and Našar. The texts pertaining to Bìt-Gērāya should be seen in this context.

In general, it has to be kept in mind that the Murašû archive emphasises certain social and economic aspects of life in the Nippur countryside. Because credit granting and agricultural management dominate the contents of the preserved texts, Judeans are usually attested when they needed assistance with farming their lands or fulfilling the state obligations imposed on them. Those who did not require such services had little reason to deal with the Murašû family. Alternatively, the Murašûs met some Judean minor officials when managing lands belonging to the state and royalty. This structural skew may lead to inaccurate conclusions about the economic status of agricultural communities, because their financial difficulties are more likely to be reflected in the archive than their ability to pay taxes and fulfil service obligations. Consequently, other economic activities than farming are obviously underrepresented. A couple of texts shed light on other ways of making a living in the countryside: in one case, a Judean fisherman and his colleagues lease nets from a servant of the Murašûs (PBS 2/1 208), ${ }^{1066}$ and in another a Judean herd the sheep and goats of Prince Aršam (PBS 2/1 148). In any event, half of the population is absent from the archive: not a single Judean woman is attested.

1066 The sequence of lessors' names and patronymics on lines 1-3 is unclear and it can be read in different ways. Compare, for example, the edition at CTIJ to Horowitz and Gheva 2017. In light of the fact that the fishermen lease five nets, the most probable number of lessors is five. One of them is Judean, Zabad-Yāma/Hinnī-Bēl. 


\subsubsection{Taxation and Service Obligations}

Given the fact that the Judeans in the Murašû archive were primarily attached to the land-for-service sector of the Babylonian economy, taxation and service obligations had a decisive impact on their life and economic situation. However, only two texts shed light on the taxation of Judean landholders in particular. These documents pertain to the taxation of the bow land held by Aqbi-Yāma, together with his co-landholders in the hatru of the sēpirus of the troops. Even in this case the payment was indirect, as members of the Murašu family paid taxes on behalf of landholders. In the first year of Darius II, Enlilšum-iddin paid the qēmu and bāru taxes (PBS 2/1 27), and three years later, the landholders owed 6o kurru of dates to Rīmūt-Ninurta, who had paid their taxes in silver (PBS 2/1 89). An instructive case is also BE 1065 , in which the Judean šaknu Išrib-Yāma collects the taxes incumbent on a number of bow lands. The payment of 2 minas of silver comprises the whole $i l k u$, the king's man (șa $b$ šarri), flour (qēmu), bāru, and any other presents to the house of the king (mimma nadānātu ša bìt šarri).

The terminology employed in these documents is representative of the Murašû archive as a whole. ${ }^{1067}$ The usual phrase covering the annual tax obligation is ilku gamrūtu șāb šarri qēmu ša šarri bāru u mimma nadānātu ša bìt šarri, meaning 'the whole ilku tax, the king's man, the king's flour, the bāru tax, and any other presents to the house of the king. In the Murašû archive, this tax obligation is normally paid in silver. The word ilku originally denoted a service obligation towards the state, but in the late fifth century, it had become an umbrella term which could include all other tax payments as well. In fact, it is customarily used alone, having the same general meaning as the entire long phrase. ${ }^{1068} S \grave{a} b$ šarri, the king's troops, still designated actual service in the sixth century, but the documents from the Murašû archive refer to it as a type of tax payment. ${ }^{1069}$ The flour tax (qēmu) relates to agricultural produce provided for the king. As grinding flour was considered a menial task, delivering flour to one's overlord can be seen as a symbolic act. The nature of the bāru tax an Iranian loanword meaning 'to carry' - is not well understood. ${ }^{1070}$ The litany of taxes paid in silver is completed by the reference to any other deliverables to the king (mimma nadānātu ša büt šarri), affirming that everything was included

1067 On taxation in the Murašû archive, see Cardascia 1951, 98-106; van Driel 2002, 226-273; Jursa 2011a.

1068 Cardascia 1951, 98-99; van Driel 2002, 254-259.

1069 van Driel 1989, 210-212; Stolper 2001, 123-127.

1070 van Driel 2002, 268-270. 
in the tax payment. Thus, it appears as if a whole range of obligations was neatly covered with a single payment in silver.

It has to be noted, however, that there was a real link between landholdings and service obligations in the late fifth century as well. This is emphasised by the texts from the second year of Darius II, which show how the holders of bow and horse lands in the Nippur region had to equip bowmen and horsemen and send them to Uruk. ${ }^{1071}$ The service was performed by the landholders themselves. Gadal-Yāma, the co-holder of a horse land, travelled to Uruk with a horse, arms, and other necessary gear of a horseman. This text group is exceptional in the Murašu archive, but the affair was perhaps not exceptional in itself. Ad hoc recruitment of soldiers would have been extremely impractical, especially when it came to horsemen and charioteers. As one cannot ride a horse or chariot - let alone engage in battle - without training, it would have been a waste of resources to equip unskilled farmers with very expensive animals and gear and then send them to perish in their first encounter with the enemy. Horses were not used in Babylonian agriculture, and, unlike in early modern Europe, the average farmer or landholder probably had no experience of riding or handling a horse. It therefore seems likely that Gadal-Yāma and his colleagues had received training and that they belonged to a permanent reserve of the army. Work service in the land-for-service sector was also concrete: two documents pertaining to Judean communities (EE 92, 113) show how a large group of people could be assigned to dig a canal or work for the Murašû family in order to pay back a substantial debt.

The documents from the environs of Yāhūdu corroborate the view that tax payments and concrete service obligations could exist at the same time. ${ }^{1072}$ Sūtu and imittu payments in produce and $i l k u$ payments in silver were delivered by proxies to the officials who managed the land-for-service sector, and these payments should be considered taxes. At the same time, landholders hired substitutes to perform work and military service on their behalf. Although actual work or military service is only sporadically attested in the environs of Yāhūdu and in the Murašû archive, the preserved texts show that such levies were imposed and that $i l k u$ payments in silver did not cover all service obligations. There are obvious reasons why concrete military and work service is rarely attested in the Murašû archive: the service obligations were not incumbent on the Murašûs, and they only touched upon the Nippurean family if landholders needed credit to fulfil their duties. If a šaknu ordered thirty landholders in his hatru to travel to Elam, this left no traces in the archive.

1071 Section 5.3.2.4.

1072 See Chapter 4. 
It also has to be taken into account that the average bow land in the late fifth century does not appear to have been cultivated by a single farmer and his family but a larger group of co-landholders. ${ }^{1073}$ The size of bow lands varied significantly, and the tax and service obligations had to vary respectively. In any case, a larger group of landholders was obviously better suited for fulfilling the service obligations, and the single farmer did not need to balance between the agricultural duties and his other obligations. The communal aspect of landholding and the attachment of bow lands to hatrus and larger estates imply that substitutes could easily be recruited locally.

Indebtedness among landholders and their strained economic situation in relation to the Murašû family are characteristic features of the Murašu archive. ${ }^{1074}$ They are reflected in the texts pertaining to Judeans as well: YadiYāma and his colleagues had to lease Yadi-Yāma's pledged landholdings from the Murašûs, and Rahìm-il's landholdings had come into the disposal of the Nippurean family. The documents pertaining to Ahīqar's activities show that the same difficulties also touched upon some landholders in the environs of Našar. However, it is impossible to know if this picture applies to landholders in the land-for-service sector in general. We are again dependent on the available sources, which illustrate the situation from the perspective of the credit grantor. If a landholder did not need credit, this left no traces in the archives of the businessmen in the land-for-service sector.

We may conclude that Judean landholders in the land-for-service sector were subject to tax payments in silver and to concrete work and military service. Although tax payments in silver are prevalent in the Murašu archive, the central aim of the whole tax regime was to provide the state with workers and soldiers, not to fill the Persian treasuries with tons of the precious metal. ${ }^{1075}$ However, taxes paid in silver could be used to hire troops and labour locally. It is therefore likely that many Judeans had to serve the state as workers or soldiers not only in Babylonia but also in other parts of the empire. The burden of these obligations on a single farmer remains unclear; ${ }^{1076}$ although there are symptoms of indebtedness among Judean landholders, there are reasons to suppose that such cases are overrepresented in the Murašû archive.

\subsubsection{Dependency and Freedom}

The majority of Judeans in the Murašû archive are farmers, and a small number worked as minor officials in the land-for-service sector. There are no

1073 Sections 5.2 and $5 \cdot 3$.

1074 Stolper 1985, 104-114.

1075 Jursa 2011 .

1076 See van Driel 2002, 270-272. 
Judean chattel slaves in the archive, and the Judeans called slaves (ardu) of high officials and royalty were obviously officials themselves. Rather than being somebody's slaves, the Judeans' freedom was limited by the constraints of the land-for-service sector. Landholdings and the incumbent obligations were an effective means of control: as bow lands were hardly ever sold, according to the available evidence, it is likely that they were principally inalienable. ${ }^{1077}$ Accordingly, landholders had to organise the farming of their plots one way or the other in order to pay the pertinent taxes and fulfil service obligations. Although landholders could lease out their lands and hire substitutes to perform work or military service, they were eventually tied to the land and to the obligations attached to it. As the substitutes were hired locally, the burden of work and military service rested on the rural population. ${ }^{1078}$ Moreover, at least the holders of horse and chariot lands had to be able to provide the state with trained soldiers, which implies that some members of the rural population could be designated as farmer-soldiers in reserve.

Unlike in the environs of Yāhūdu, Judeans are not explicitly called šušānus in the Murašû archive, although the term is well attested, especially in the names of hatrus. ${ }^{1079}$ As discussed in Section 4.2.2, the term refers to dependent people who were attached to the state or landed estates and who could not be sold into chattel slavery. Despite the lack of direct evidence, it is probable that the status of šušānu applied to some part of the Judean population in the environs of Nippur. An important text in this regard is EE 113, in which four Judeans provide Enlil-šum-iddin with forty paid workers and ten šušānus to pay a back a debt. This text seems to imply that there were two sorts of people in rural communities: those who had to be actually hired and those who could be sent to work without salary. In light of the evidence from Yāhūdu, it seems likely that the holders of bow lands predominantly belonged to the category of šušānus. Stolper might be right in suggesting that ' $\mathrm{t}] \mathrm{he}$ frequency of the term šušānu in characterizing hațrus and their members indicates that this status was typical and perhaps universal among Babylonian feudatories.' ${ }^{\prime 080}$

The context of the land-for-service sector proved to be a successful way to control Judean deportees and their descendants for more than 150 years after the deportations to Babylonia. Although some Judeans held large plots of land and they could work as minor officials and engage in business activities, the constraints of landholding effectively limited their freedom. There was no need to enslave the deportees. As it was not possible to sell the plots and get rid

1077 Stolper 1985, 25.

1078 See Jursa 2011a.

1079 On šušānus in the Murašû archive, see Stolper 1985, 72-82; van Driel 2002, 210-211.

108 o Stolper $1985,82$. 
of the incumbent obligations, ties to the land effectively attached Judean landholders to the Babylonian countryside.

\section{$5 \cdot 7 \quad$ Culture}

Like other legal documents from Babylonia, the Murašû archive is a difficult source for the study of culture and identity among the rural population. The texts pertain to the economic activities of a Babylonian family, and Judeans appear in the documents only sporadically. The Murašû archive has one advantage, however: seal impressions on the tablets are abundant, and nineteen seals used by Judeans are also attested. Because there are clearly distinguishable patterns of seal use in the archive, the choice of seals appears to adhere to the preferences of their users. The imagery of the seals can therefore reveal something about the Judean seal users as well.

\subsubsection{Seal Use}

The seals used by Judeans are an important source of information about the taste and preferences of their users. However, some caution needs to be exercised: the use of a certain seal does not necessarily imply that its imagery reflected its user's values or beliefs. In any case, Bregstein's analysis of sealing practices in the Murašu archive highlights some differences in the seal choice between various social and ethnic groups. ${ }^{1081}$ As the number of different seals in the Murašu archive is close to $700,{ }^{1082}$ these statistical differences cannot be taken as completely incidental. Bregstein's criteria for identifying Judeans are somewhat different from the ones used in the present study, ${ }^{1083}$ and the figures which she provides cannot be used as such. Table 2 lists the seal users whom I identify as Judeans.

Following Bregstein's typology, the seals used by Judeans can be assigned to four different categories. ${ }^{1084}$ The two largest ones are contest scenes ( 6 attestations, $38 \%)^{1085}$ and Western-style rings (5 attestations, $\left.31 \%\right) .{ }^{1086}$ Three seal

\footnotetext{
1081 Bregstein 1993, 366-373.

1082 Bregstein catalogues 657 seal impressions in her dissertation. Some twenty or so seal impressions from Istanbul need to be added to this number. Bregstein $1993,5^{1-} 5^{2}+\mathrm{n} .8$.

1083 Bregstein $(1993,226)$ does not include people who bore non-Judean personal names but whose fathers had Judean names. At the same time, she apparently considers some nonYahwistic personal names as distinctly Judean, although she only names the Yahwistic element as a criterion for identification (Bregstein 1993, 226 but cf. 577).

1084 Bregstein 1993, 71-108.

1085 Nos. 16, 31, 37, 91, 93, 108.

1086 Nos. $559,568,571,574,578$.
} 
impressions depict animals (19\%), ${ }^{1087}$ and the impression with a goatfish and crook (no. 491) is to be assigned to the category of composite and humanheaded monsters (6\%). One unclear ring impression (no. 642) cannot be assigned to any of these categories (6\%).

The first remarkable feature of Judean seal usage is the large number of Western-style rings and rings in general. By 'Western-style rings', Bregstein refers to motifs which were not traditionally Babylonian but originated in the Greek-speaking Eastern Mediterranean region. The use of metal rings in general was a novelty in Babylonia, where stone was traditionally used to produce stamp and cylinder seals. ${ }^{1088}$ Only $10 \%$ of the seals in the Murašû archive were

TABLE 2 Judean seal users in the Murašû archive

\begin{tabular}{|c|c|c|}
\hline Person & Document & Description of the seal \\
\hline $\begin{array}{l}\text { Yadi-Yāma/Banā-Yāma } \\
\text { and brothers }\end{array}$ & BE 925 & $\begin{array}{l}\text { Ring: nude couple embracing } \\
\text { (Bregstein no. } 578 \text { ) }\end{array}$ \\
\hline Yadi-Yāma/Banā-Yāma & BE 945 & $\begin{array}{l}\text { Ring: different from the one in } \\
\text { BE } 925 \text {; design is unclear (no. } \\
642 \text { ) }\end{array}$ \\
\hline Udarna'/Rahīm-il & BE 969 & $\begin{array}{l}\text { Cylinder: lion attacks a bull or } \\
\text { boar (no. } 362)\end{array}$ \\
\hline Hanan-Yāma/Udarna? & BE 969 & $\begin{array}{l}\text { Cylinder: Babylonian hero } \\
\text { holds a bull, crescent moon is } \\
\text { above the bull's head (no. 108) }\end{array}$ \\
\hline Hanan-Yāma/Udarna? & PBS 2/1 107 & Stamp: bull (no. 268) \\
\hline Gadal-Yāma/Rahīm-il & EE 65 & $\begin{array}{l}\text { Cylinder: Persian hero stands } \\
\text { on two sphinxes and holds two } \\
\text { lions (no. 16) }\end{array}$ \\
\hline Gadal-Yāma/Rahīm-il & UCP $9 / 3$ & $\begin{array}{l}\text { Cylinder: Persian hero stands } \\
\text { on two sphinxes and holds two } \\
\text { lions (no. 16) }\end{array}$ \\
\hline Išrib-Yāma/Pili-Yāma & BE 1065 & $\begin{array}{l}\text { Cylinder: Persian hero holds } \\
\text { two monsters, Ahura Mazda } \\
\text { hovers above him (no. 37) }\end{array}$ \\
\hline
\end{tabular}

1087 Nos. $268,281,362$.

1088 Bregstein 1993, 52-54, 94-97. 


\begin{tabular}{|c|c|c|}
\hline Person & Document & Description of the seal \\
\hline Mattan-Yāma/Širkā & BE 1083 & $\begin{array}{l}\text { Ring(?): seated woman wearing } \\
\text { a robe and crown holds a } \\
\text { branch or stalk (no. } 574)^{\mathrm{a}}\end{array}$ \\
\hline Mattan-Yāma/Širkā & EE 34 & Broken (see no. 574) \\
\hline $\begin{array}{l}\text { Banā-Yāma/x-na-din- } \\
\text { numun(?) }\end{array}$ & BE 10118 & $\begin{array}{l}\text { Ring(?): soldier holding a spear } \\
\text { and shield (no. } 559)^{\mathrm{b}}\end{array}$ \\
\hline Zabad-Yāma & EE 89 & $\begin{array}{l}\text { Ring: bald fat man sitting with } \\
\text { snake/s (no. } 571)\end{array}$ \\
\hline Hanan/Padā-Yāma & EE 107 & $\begin{array}{l}\text { Stamp(?): goatfish and crook } \\
\text { (no. 491) }\end{array}$ \\
\hline Rahīm/Banā-Yāma & PBS $2 / 15$ & $\begin{array}{l}\text { Stamp: Persian hero holds a } \\
\text { monster and a spear (no. 91) }\end{array}$ \\
\hline Mattan-Yāma/Amušê & PBS $2 / 15^{\circ}$ & Ring: lion (no. 281) \\
\hline Mattan-Yāma/Amušê & PBS 2/1 60 & Ring: lion (no. 281) \\
\hline Il-yadin/Yadi-Yāma & PBS $2 / 184$ & $\begin{array}{l}\text { Cylinder: two Persian heroes } \\
\text { with daggers hold monsters } \\
\text { (no. 93) }\end{array}$ \\
\hline Yāhû-natan/ & PBS 2/1 119 & Stamp: Persian hero holds two \\
\hline Mattan-Yāma & & lion-monsters (no. 31) \\
\hline Abī-Yāma/Šabbatāya & PBS $2 / 1218$ & $\begin{array}{l}\text { Ring: crouching naked man } \\
\text { (no. } 568)\end{array}$ \\
\hline
\end{tabular}

a According to Bregstein 1993, 979, the impression resembles a ring, although the caption reads na ${ }_{4} \cdot$ kišib.

b See the previous footnote; Bregstein 1993, 964.

Western-style rings, but the number is twofold among the people with a West Semitic name or patronymic (19\%) and threefold among Judeans (31\%). Rings, regardless of imagery, count for $33 \%$ of the seals in the whole corpus, $50 \%$ of the seals used by people with a West Semitic name or patronymic, and $44 \%$ of the seals used by Judeans. ${ }^{1089}$

1089 The figures in the Murašû archive in general and the people with West Semitic names are adopted from Bregstein 1993, 225. I have calculated the percentage of people with a West Semitic name or patronymic by combining the data from the fourth and sixth columns of Bregstein's table. 
Another peculiar aspect is the prominence of contest scenes on the stamp and cylinder seals used by Judeans. The scenes depict heroes who fight against monsters and animals or who hold subjugated creatures in their hands. The heroes can be divided into two categories according to their clothing, which Bregstein defines either as Babylonian or Persian. ${ }^{1090}$ The contest scenes with a Persian hero constitute $13 \%$ of the seals in the whole corpus, $15 \%$ of the seals used by people with West Semitic names or patronymics, and $31 \%$ of the seals used by Judeans. The scenes with a Babylonian hero count for $10 \%$ of the seals in the whole corpus, $10 \%$ of the seals used by people with West Semitic names or patronymics, and 6\% of the seals used by Judeans. ${ }^{1091}$

A scene that is never attested on the seals used by Judeans, and very rarely on the seals of people with West Semitic names or patronymics (3\%), is that of worship. ${ }^{1092}$ Depicting a man - namely, 'a worshipper' - standing alone or before divine symbols or creatures, it was one of the standard motifs of Babylonian seal impressions in the sixth century. ${ }^{1093}$ The scene is attested in $8 \%$ of the seal impressions in the Murašu archive. Favoured by scribes and regular witnesses of the documents, it was also used by people with Iranian names. ${ }^{1094}$

Based on the rarity of worship scenes on the seals used by Judeans and other people with West Semitic names, Bregstein argues that these people deliberately avoided scenes depicting foreign religious rituals. ${ }^{1095}$ However, when the texts from the environs of Yāhūdu have now become available, her statement needs to be adjusted. Ahīqam's seal on By depicts the Babylonian worship scene, even though Ahīqam's patronymic Rapā-Yāma and the Yahwistic names of his sons leave little doubt about his Judean origin. ${ }^{1096}$ Using a seal with the worship scene was evidently not unthinkable for someone dealing regularly with royal officials. Moreover, it has to be emphasised that the seals used by Judeans in the Murašu archive did contain other religious symbolism. The seal of Hanan-Yāma/Udarna? depicts the crescent moon above the bull held by the Babylonian hero (no. 108), and the god Ahura Mazda hovers above the Persian hero on the seal of Išrib-Yāma (no. 37). It is very unlikely that the crescent

\footnotetext{
1090 Bregstein 1993, 73-79.

1091 Bregstein 1993, 225.

1092 Bregstein 1993, 225.

1093 Bregstein 1993, 82-85; Ehrenberg 1999, 15-25, 43-44.

1094 Bregstein 1993, 189-205, 225, 233-234.

1095 Bregstein 1993, 227, 234-235.

1096 See Section 4.3.6.3.
} 
refers to something or someone else than the moon god, and it would be dangerous to suggest that the Judeans simply equalled Persian Ahura Mazda with Yahweh.

Judeans did not avoid religious imagery on their seals, and the reasons for differing preferences need to be sought in local traditions and social structures. One decisive factor seems to again be the division between the urban upper class and the rest of society. Judeans, like other people with West Semitic names, favoured rings and imagery from the Eastern Mediterranean, both of which were novelties in Babylonia. The worship scene, on the other hand, had a long history in Babylonia and it was traditionally used by scribes. ${ }^{1097}$ Thus, it is not surprising to find that the scene was very popular among the scribes and frequent witnesses of the Murašu documents: of all people attested in the archive, these men most likely belonged to the Nippurean urban upper class. At the same time, the scribes and regular witnesses used Western-style rings $(5 \%)$ and rings in general (19\%) much less frequently than all seal users in the archive $\left(10 \%\right.$ and $33 \%$, respectively). ${ }^{1098}$ This comparison suggests that traditional imagery was favoured by the urban Nippureans, whereas Judeans and other people with West Semitic names were open to international influences and did not share the same traditional values as the urban upper class. ${ }^{1099}$

A surprising feature of Judean seal usage is the exceptional frequency of Persian contest scenes. Thirteen per cent of all seal impressions in the archive belong to this category, and the figure is roughly the same among people with Babylonian, Iranian, and West Semitic names. ${ }^{1100}$ However, almost one third of the seals used by Judeans depict this scene. ${ }^{1101}$ The scene with the Persian hero was not traditionally Babylonian but created during the reign of Darius I. ${ }^{1102}$ The novelty of this imagery may again explain the Judean preference for it.

Judean seal use does not exhibit aniconic or marked religious tendencies. Different religious symbols and motifs were employed, but Judeans often used

\footnotetext{
1097 Bregstein 1993, 191-192.

1098 Bregstein 1993, 191, 200. Seventeen per cent of scribal seals were rings with Western-style compositions, but Bregstein notes (191) that they also employ Mesopotamian symbols.

1099 Bregstein (1993, 191-197, 200-202) acknowledges the cultural factors which influenced the seal choice of scribes and regular witnesses, but she fails to notice the sociocultural reasons behind the seal choice of Judeans and other people with West Semitic names (218-238).

1100 Bregstein 1993, 220-221, 225.

1101 Because Bregstein's criteria for identifying Judeans are different, the preference for Persian contest scenes does not appear so strikingly in her figures (1993, 226-227). She proposes that an avoidance of other types of images might explain this preference.

1102 Bregstein 1993, 76-79.
} 
seal types and imagery that were new in Babylonia. They were open to Eastern and Western novelties, whereas the Babylonian urban upper class preserved older traditions in their choice of seals.

\section{5·7.2 Naming Practices}

Because we can only identify Judean families on the basis of Yahwistic names, it is not possible to say what percentage of Judeans used such names in the late fifth century. It becomes clear, however, that in addition to Yahwistic names, Judeans in the Murašû archive bore West Semitic, Akkadian, and Iranian names, including names which refer to other deities than Yahweh. The use of Akkadian and non-Yahwistic West Semitic names is by no means surprising, but the adoption of Iranian names is interesting, as it shows that the Persian rule affected naming practices even in the Babylonian countryside. Table 3 summarises the data on Judean naming practices in the Murašû archive. The reader immediately notices differences in naming practices between Judean fathers and sons. This phenomenon, first observed by E.J. Bickerman, ${ }^{1103}$ will be discussed in a larger context in Section 8.5.

Two Judeans, Udarna ${ }^{2} /$ Rahīm-il and Bagēšu/Hanan-Yāma, bore Iranian names. The use of Iranian names in these families seems to result from their interaction with Persian officials. The family of Rahīm-il held several plots, including a horse land, in the Nippur region, and their large-scale landholding makes it probable that the family had closer interaction with the Persian administration than the average Judean landholder (Section 5.3.3). Bagēšu's father Hanan-Yāma (EE 34) was a sēpiru, which suggests that he was also regularly in touch with the Persians. If Iranian names were not simply trendy, they

TABLE 3 Judean naming practices in the Murašû archive

\begin{tabular}{lcrlr}
\hline \multicolumn{2}{c}{ Patronymics } & First names \\
\hline $\begin{array}{l}\text { Names borne } \\
\text { by Judeans }\end{array}$ & 41 & & 60 & \\
Yahwistic & 19 & $46 \%$ & 40 & $67 \%$ \\
West Semitic & 10 & $24 \%$ & 15 & $25 \%$ \\
non-Yahwistic & & & & \\
Akkadian & 9 & $22 \%$ & 3 & $5 \%$ \\
Iranian & 1 & $2 \%$ & 2 & $3 \%$ \\
\hline
\end{tabular}

1103 Bickerman 1978. 
were perhaps seen as a way to get closer to the administrative elite in the landfor-service sector.

There are two noteworthy examples of fluctuation in the spelling of Yahwistic names. The West Semitic name Mattan-Yāma ('Gift of Yahweh') is often spelled in the quasi-Akkadian form Mannu-danni-Yāma ('Who is stronger than Yahweh?'). ${ }^{104}$ There are two persons whose name is attested in both variants, ${ }^{1105}$ and, in one case, the same scribe employed both orthographies. ${ }^{1106}$ Two different factors may contribute to this phenomenon: on the one hand, cuneiform scribes often had difficulties in spelling non-Akkadian names, and they were perhaps tempted to use a quasi-Akkadian orthography to render the West Semitic name. On the other hand, it is possible that the Judeans themselves played with the ambiguity of their name, using a quasi-Akkadian form in the public sphere. ${ }^{1107}$

There is also ambiguity in the way in which the patronymic of Yadi-Yāma's father is spelled. Three times the patronymic is spelled $B a-n a^{-}{ }^{2}$-dingir.meš ( $\mathrm{BE}$ 925 , 45; EE 98), reflecting the name Banā-il. However, the patronymic is once spelled Ba-na-ia-a-ma (EE 2), reflecting the Yahwistic name Banā-Yāma. Because two different scribes employed the form Banā-il but there are no parallel cases of representing the Yahwistic element with dingir.meš, it is likely that Yadi-Yāma himself used the forms Banā-il and Banā-Yāma interchangeably when referring to his father. ${ }^{1108}$

Finally, full names and hypocoristics formed from Yahwistic names were sometimes used interchangeably. Hanan-Yāma/Udarna? is attested with his full name in three documents (BE 969 ; BE 10 7; PBS 2/1 107), but the hypocoristic Hananī (Ha-an-na-ni- $\left.{ }^{-}\right)$is used in BE 10 84. The name Gadal-Yāma appears twice in its hypocoristic form $[G] a-d a-a l^{2}-a$ (BE 9 86a) or Ga-da-al-ia (EE 65).

\subsubsection{Conclusion}

The texts from the Murašû archive refer to numerous ethnic minorities living in the Nippur countryside. Although deportees were originally settled in communities according to their origin, the population of the settlements had become diverse by the late fifth century. A noteworthy example of this phenomenon is Išqallūnu, a village named after the Philistine city of Ashkelon: it was

\footnotetext{
1104 The names are attested in BE 10 83; EE 24, 34, 113; PBS 2/1 50, 53, 60, 119, 148, 203. See the discussion in Stolper 1976, 26-27; Pearce and Wunsch 2014, 64, 66; Pearce 2015, $23-24$.

1105 One cluster of texts is EE 113; PBS 2/1 50, 60; another one is BE 10 83; EE 34; PBS 2/1 203.

1106 BE 10 83; EE 34.

1107 These ideas are expressed in some form already in Coogan 1974, 11; Stolper 1976, 26-27; Pearce 2015, 23-24.

1108 Cf. Zadok 1979a, 12.
} 
one of the places with significant Judean inhabitation. ${ }^{1109}$ In addition to other deportees, Judeans were also in interaction with the indigenous Babylonian population and the Persian administrators of the land-for-service sector. The culturally diverse environment in which Judeans lived is reflected in several ways in the texts.

Judean seal users chose their seals on sociocultural grounds: they used seals with diverse religious imagery but favoured Western and Persian seal types, which were not traditional in Babylonia. They rarely used Babylonian seal types, which suggests that the cultural preferences of the Babylonian urban elite were quite different from those of the multi-ethnic rural population. Nevertheless, at least some Judean landholders were in regular contact with cuneiform scribes who belonged to this Babylonian urban elite. The ambiguity of some Judean names may attest to their efforts to support their own naming traditions but, at the same time, use names that sounded familiar to a Babylonian ear.

In addition to West Semitic anthroponyms, Judeans used Babylonian and Persian names. The adoption of Persian - and perhaps also Babylonian names - was related to an effort to get closer to the governing elite of the landfor-service sector. At the same time, the persistence of Yahwistic names in late fifth-century Babylonia implies that some descendants of Judean deportees still supported their own naming traditions.

\subsection{Conclusion}

As the Murašu archive focuses on business activities related to the land-forservice sector of Babylonian agriculture, only certain population groups in the Nippur region are represented in it. The clients of the Murašû family were predominantly holders of state lands encumbered with tax and service obligations. Another important group in the archive are state officials and servants of estate owners, from whom the Murašus leased canals and lands and to whom they paid taxes and rental payments. Judeans are attested among both groups, as landholders and as minor officials.

The Judean landholdings varied in size and juridical status. Although Judeans owned some private land as well, the evidence from the Murašu archive primarily pertains to institutional landholdings such as bow lands, horse lands, and bit rittis. None of these designations referred to a plot of standard size, as the extent of bow lands and the number of pertinent landholders varied

1109 See Section 5·3.5. 
greatly. Landholding was often collective, and several people shared responsibility for a single plot of land. Landholders and their landholdings were grouped together in administrative units called hatrus, which were managed by a number of officials and royal estates. Many Judeans belonged to the hatru of the sēpirus, which was eventually supervised by the governor of the province of Babylon. The landholders themselves were not Aramaic scribes, or sēpirus; thus, the names of these hatrus refer to high officials in charge of tax revenues in the Nippur region. Accordingly, there is no evidence of widespread literacy among Judeans, and only a single Judean sēpiru is attested in the Murašû archive.

Although the holders of state lands could not apparently alienate their holdings, they could lease them out, possess private land, and strive to improve their income in other ways. A good example of this is found in the villagers of Bìt-Gērāya, whose efforts in expanding agricultural production are reflected in the documents pertaining to Pili-Yāma, Yadi-Yāma, and Yāhû-natan. These people were not mere serfs under the control of feudal lords, and it is thus dangerous to apply the terminology of European feudalism to the Babylonian land-for-service sector. ${ }^{1110}$ Annual tax payments and the fulfilment of more or less regular service obligations appear to have been the primary constraints of their freedom. The majority of Judean landholders in the land-for-service sector co-held modest bow lands with several colleagues, but some Judeans had significantly larger holdings. Rahìm-il held several bow lands and a horse land, and judging by the Iranian name of his son and the frequent seal usage among the family, their socio-economic status was rather high.

Some Judeans were involved in the management of the land-for-service sector as minor officials in the service of royalty and high officials. However, they apparently did not succeed to the middle and higher rungs of the administrative hierarchy. Judean officials are often called slaves (ardus) of high officials, but the word obviously refers to hierarchical subordination. Judean chattel slaves are not attested in the archive. Some significant sectors of the Babylonian rural economy are seriously underrepresented in the archive: two documents indicate that Judeans also worked as fishermen and herdsmen.

Analysis of Judean seal use reveals that Judeans did not avoid Persian and Babylonian religious imagery, but their preferences were very different from those of the Nippurean upper class. Judeans favoured ring seals, which were a novelty in Babylonia, and the motifs of their seals primarily originated from

1110 On this question, see Cardascia 1983; Stolper 1985, 24-25 + n. 96 . 
Persia and the Eastern Mediterranean. This implies that Judeans were culturally quite distinct from the old families of Nippur. At the same time, the multiethnic landscape of rural Babylonia is reflected in Judean naming practices: in addition to Yahwistic and other West Semitic names, Judeans used Babylonian and occasionally Iranian names.

The Murašu archive constitutes the last significant corpus of cuneiform evidence on Judeans in Babylonia. Only a single text survives from the fourth century, drafted in the eighth regnal year of Artaxerxes II or III. ${ }^{1111}$ Rabbinic writings from the early first millennium CE shed light on the life of Judean - or better put, Jewish - communities again.

1111 TuM 2-3 123. Because four people sealed the tablet, it was hardly written in the eighth year of Artaxerxes I (Zadok 2002, 45). 


\section{Judeans Outside the Main Archives}

The great majority of documents pertaining to Judeans in Babylonia belong to the text groups discussed in Chapters $2-5$. The texts predominantly originate from the land-for-service sector of Babylonian agriculture, where the majority of foreign deportees apparently worked. A modest number of miscellaneous texts diversify this picture somewhat, showing that some Judeans lived in the sphere of Babylonian temples while others worked as royal officials outside the land-for-service sector. However, these documents emphasise the connection between Judeans and Babylonian institutions, especially the royal administration. Even texts from private archives betray the close ties between Judeans and royal lands. As the texts discussed in this chapter originate from multiple archives and geographical locations, they will be discussed in thematic categories. ${ }^{112}$

\subsection{Officials}

The previous chapters have shown that although the majority of Judeans worked as farmers in the land-for-service sector, some of them served the local or state administration as officials. A Judean sēpiru and a group of Judean courtiers were stationed in Babylon, ${ }^{1113}$ and a number of Judeans worked as minor officials in the land-for-service sector in the environs of Yāhūdu and Nippur. ${ }^{1114}$ An additional five documents enrich this picture.

1112 These texts and their archival connections are briefly discussed and catalogued in Zadok 2002, 2004, 2014a; Waerzeggers 2014b. Almost all texts are transliterated at CTIJ, and the photos of some tablets are available at CDLI (http://cdli.ucla.edu/). In addition to the texts discussed below, Zadok has identified Judeans in a number of unpublished texts which I could not access when preparing this study. These include tablet no. 192 at the Institute for Antiquity and Christianity, Claremont Graduate University (Zadok 2002, 27-28 no. 8); BM 59765 (Pinches 1892b, 15; cf. Zadok 2002, 35 no. 55 with an erroneous BM number); and Pinches 1910, 63 no. 3:19 (the museum number given by Pinches is mistaken; see Zadok 2002, 45 no. 156). A prosopographical database of Judeans outside the Yāhūdu corpus and the Murašû archive is available online at https://doi.org/10.5281/ zenodo.3354074.

1113 Section 2.4.

1114 Sections 4.4 and 5.4 . 
The most notable Judean official known to us was a certain Gadal-Yāma/ Banna-Ea, who is attested in Babylon in 24-VI-36 Dar (486 в СЕ, BM $74554=$ Stolper 1989). ${ }^{1115} \mathrm{Hu}-\mathrm{ta}-\mathrm{x}-\mathrm{x}^{-2}{ }^{2} /$ Pagakanna (the governor of Babylon and Acrossthe-River), Liblut (sēpiru bēl țēmi), and Gadal-Yāma/Banna-Ea (sēpiru bēl țēmi) authorised Șihā/Ahulap, the chief of the prison of a brickworks, ${ }^{1116}$ to collect a tax payment of 14 kurru of barley. The governor of Babylon and Across-theRiver was in charge of an important province of the Persian Empire, ${ }^{1117}$ and Libluṭ and Gadal-Yāma apparently belonged to the administrative personnel at his disposal. As was discussed in Section 5.3.2, the title sêpiru could be held by ordinary scribes competent in Aramaic but also by officials of a higher rank. The latter seems to be the case here. The title bèl têmi is rare in Babylonian documents, ${ }^{1118}$ but the term $b^{\varsigma} l t^{\varsigma} m$ is also attested in contemporary Aramaic. ${ }^{1119}$ There seems to have been a close connection between the officials called bèl têmi and the provincial administration of the Persian Empire. ${ }^{1120}$ The most notable example is a document from Egypt mentioning a certain Anani (' $n n y)$, who issued an administrative order on behalf of the governor of Egypt. ${ }^{1121}$ In light of this evidence, Gadal-Yāma is a unique example of a Judean working in the provincial administration in Babylonia. Moreover, the document records a rare occasion of a Judean being in an authoritative position in relation to a member of the Babylonian urban elite. The taxpayer Iddin-Bēl/Iqī̌sa-Marduk/ Šangû-Šamaš belonged to a Sipparean prebendary family. ${ }^{1122}$

Another document from Babylon (BM 26553 = Bloch 2018 no. 79, ${ }^{1123} 3$-X-14 Dar, 507 BCE) records a similar case. Nabû-zēr-ušebši/Nabû-ēṭir-napšāti, a member of the important Borsippean prebendary family of Ilia, ${ }^{1124}$ and a certain Ṭābia/Nabû-êtị/Rēš-ummāni made a tax payment of 15 kurru of barley to

\footnotetext{
1115 On this document, see most recently Bloch 2018, 277-281.

1116 l'

1117 Stolper 1989, 288-298; Pearce 2015, 17-18.

1118 Stolper 1989, 299; CAD Ṭ, 97.

1119 Kaufman 1974, 109 + n. 390; Stolper 1989, 299-303.

1120 Porten 1968, 55-58; Stolper 1989, 299-303; Dušek 2007, 509-510; Tavernier 2008, 70-73; Fried 2012, 45-46; Kuhrt 2014, 131-132.

1121 TAD A 6.2:23 (411 BCE).

1122 Bongenaar 1997, 451, 461; Jursa 2005a, 128-129 + n. 988. The document belongs to his archive (Jursa 2005a, 129).

1123 At some points, my readings of the text are divergent from Bloch's edition. See Jursa and Waerzeggers 2009, 255-257. Caroline Waerzeggers kindly provided me with her transliteration of the text.

1124 The document belongs to the Ilia D archive (Jursa 2005a, 87-88; Waerzeggers 2005, 355356 ; 2010a, 351 n. 1183, 434-435). On the different branches of the Ilia family and their social world, see Waerzeggers 2010a, 153-195, 372-437.
} 
a Judean sēpiru. ${ }^{1125}$ The sēpiru's name is broken off, but his father bore the Yahwistic name Zakar-Yāma. If the broken text is understood correctly, this Judean was a sēpiru of the troops or workmen (ummānu) and a subordinate of the rab kașiri, a high official in charge of the royal treasury. ${ }^{1126}$ This terminology is reminiscent of the hatru of the sēpirus of the troops (uqu) in the Murašû archive, but there is hardly a real connection between the Judean sêpiru in Babylon and the Judean farmers in the Nippur countryside. The seepirus of the troops were high-ranking officials in the Murašû archive, ${ }^{1127}$ but Judeans only cultivated land properties at their disposal. On the contrary, the anonymous son of ZakarYāma was a government official of some importance, as he collected taxes from prominent Babylonian families.

Officials of Judean and West Semitic background travelled from Babylonia to Susa for the purpose of taxation. Two promissory notes (OECT $10152=$ Bloch 2014 no. 7, 18-I-28 Dar, 494 BCE; and VS 6155 = Bloch 2014 no. 8, 6-VIII-29 Dar, 493 BCE) record the presence of prominent Babylonians in the Persian capital Susa. ${ }^{1128}$ These texts relate to the wider phenomenon discussed in Section 5.3.2: in an attempt to control Babylonia and its tax flows, Persian kings made people from the province regularly visit the Persian court at Susa. The Babylonian visitors included businessmen and officials, generally people responsible for taxation or tax payments in one way or the other. ${ }^{1129}$ The texts discussed here belong to the archives of two important families of the Babylonian urban elite, the Egibis of Babylon (OECT 10 152) and the Ilias of Borsippa (VS 6155). ${ }^{1130}$

The parties, witnesses, and scribes of the documents have traditional Babylonian names, the only exceptions being Yāhû-šar-ușur/Šamaš-iddin (OECT 10 152), Nabû-ahhē-šullim/Aqbi-il, and Šabbatāya/Nabû-šar-bulliṭ (VS 6 155). Yāhû-šar-uṣur bears a name with a Babylonian predicate and the Yahwistic

1125 Pasa'du ('equipment costs') and qaštu ('bow tax') are mentioned. See Jursa and Waerzeggers 2009, 255-257; Jursa 2011a, 441-442 + n. 62.

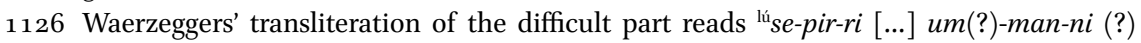
ina(?) šu ${ }^{\mathrm{II}} \mathrm{I} z a b$-[...] gal-ka-șir. See the comments and transliterations in Jursa 2010a, $249 \mathrm{n}$. 1474; Waerzeggers 2014b, $141+$ n. 68; Zadok 2014a, 116-117; Bloch 2018 no. 79. The word итmа̄nu is rare in Babylonian legal and administrative texts from the mid-first millennium; see CAD U-W, 102-108. On the rab kașirii, see Bongenaar 1997, 136-137; Stolper 2006a, 229; Jursa 2010b, 82-83.

1127 Section 5.3.2.

1128 On these texts, see Bloch 2014, 137-139, 161-167.

1129 Waerzeggers 2010b.

1130 Waerzeggers 2010b, 783. On the Egibi family and its archive, see Wunsch 1993, 1999, 2000a, 200ob, 2007; Abraham 2004; Jursa 2005a, 65-66. VS 6155 belongs to the Ilia D archive. On the Ilia family, see above in this chapter. 
theophoric element, the name Aqbi-il is West Semitic, ${ }^{1131}$ and Šabbatāya is a West Semitic name often possessed by Judeans. ${ }^{1132}$ Yāhû-šar-uṣur's name suggests that he was a Judean connected to the royal administration in Babylonia, in the same vein as Bēl-/Yāhû-šar-uṣur in Yāhūdu. ${ }^{1133}$ Šabbatāya's father Nabûšar-bullit also had a name that connects him to the royal administration, and his son's presence in Susa suggests that Šabbatāya continued in his father's footsteps. However, as Šabbatāya was not an exclusively Judean name, his Judean origin remains no more than a possibility. ${ }^{1134}$ Since the visits of Babylonian officials to Susa are a well-attested phenomenon and since Yāhû-šar-ușur's and Šabbatāya's fathers had Babylonian names, we may conclude that both men were Babylonian officials responsible for tax-related matters.

Finally, we may add a certain Malak-Yāma to the list of Judean officials in Babylonia. He appears as a messenger of a courtier (ša rēššarri) in an unpublished text from the reign of Neriglissar. ${ }^{1135}$

Like their Judean colleagues in the land-for-service sector, the officials discussed above were predominantly involved in the collection of taxes from Babylonia. None of these men were high officials with considerable power and resources at their disposal, but their positions were more important than those of the minor tax collectors in the countryside. It is noteworthy that four out of five documents were written in the reign of Darius I, but this seems to be a mere coincidence since several Judean royal officials are attested already in the Neo-Babylonian period. ${ }^{1136}$

\subsection{Temples}

Although many spheres of Babylonian society, including the administration, trade, crafts, and the military, were open to deportees, the temple cult was not. Rigid rules of access characterised Babylonian temples, and the sacrificial cult

1131 Zadok 1977, 32, 80; Pearce and Wunsch 2014, 40; but cf. Bloch 2014, 139.

1132 Coogan 1976a, 34-35, 84; Section 1.5.

$1133 \mathrm{C}_{2}-4$; see Section 4.4. On the Beamtennamen of royal officials, see Section 1.5. See the thorough discussion of Judeans with Beamtennamen in Bloch 2014, 135-141.

1134 Section 1.5; cf. Bloch 2014, 139.

1135 According to Zadok $(2002,28)$, the document in the New York Public Library (box 43, 4?) belongs to the archive of Tabnēa/Zērūtu/Dannēa from Marad. On this archive, see Jursa 2010a, $90+$ n. 479. A witness of the document is perhaps a Judean as well (Ha-na-na-a[ma?]). I could not access this tablet during the course of my research.

1136 See above in this chapter. 
was run by a relatively small number of Babylonian families in each city. ${ }^{1137}$ There was a strict hierarchy among these families as well, and only the socalled 'temple enterers' (érib bititi) were allowed to access the innermost parts of the temple. No Judeans or other deportees made their way into the closed priestly circles and participated in the temple cult. Nevertheless, temples were large institutions with multifaceted economic interests, ${ }^{1138}$ and dependent personnel, hired men, and contractors of local and foreign origin took care of their holdings. Although Babylonian kings donated deportees and other spoils of war to temples, ${ }^{1139}$ in many cases it remains unclear if a Judean person was hired by or dependent on the temple.

Three documents from the Ebabbar archive pertain to Judeans working for the temple of Šamaš in Sippar. ${ }^{1140}$ A woman named Yāhû-dimri and two sūtu (12 litres) of flour are mentioned in CT 57700 (1-II, no year). ${ }^{1141}$ The short receipt does not reveal anything else about Yāhû-dimri or the background of the transaction, but it seems quite probable that the recipient of the flour was Ebabbar and the woman belonged to the temple's dependent personnel. Moreover, two Judeans, Banā-Yāma and Natan-Yāma, are listed among 22 hired men of a certain Ile ${ }^{2}$ i-Marduk in CT ${ }_{5}^{6} 795$ (no date). Although Ile? $\mathrm{i}$-Marduk cannot be identified with any known person from the Ebabbar archive, he was most likely the foreman of the work gang in question. Finally, someone with a broken Yahwistic name (-ki-ia-a-ma) is attested in the badly preserved text CT 55 341 (several dates, no year). The text refers to sailors (malähu) and bitumen (kupru), and the Judean is to be counted among the sailors working for Ebabbar as well.

An intimate witness to the Judean presence in Sippar is a love affair documented in Cyr 307 (3-IV-8 Cyr, 531 BCE). ${ }^{1142}$ It is a judicial document ${ }^{1143}$ regulating

1137 Waerzeggers 2010a, 2011; Still 2019.

1138 Jursa 1995, 2010a, esp. 316-623; MacGinnis 1995; Bongenaar 1997; Da Riva 2002; Kleber 2008; Kozuh 2014.

1139 Section 8.2.

1140 These documents probably originate from the Ebabbar temple in Sippar, although their find-spots are unknown and the temple or city is not mentioned in the documents. The documents are receipts and lists typical of an institutional administration (Jursa 2004c, 2005a, 118-120), and they belong to the British Museum 82-7-14 collection, which is primarily comprised of material from Sippar (Reade 1986, xxxiii). See also Waerzeggers (forthcoming c).

1141 The copy in CT 57 has 'hu' as the last sign of the name, but the correct reading is 'ri', according to Zadok 2002, 35 .

1142 For a transliteration and translation, see Joannès 1994. The document is also discussed in Abraham 2005/2006, 211; Waerzeggers (forthcoming c).

1143 On the genre of the document, see Holtz 2009, 209-217. 
the relationship between a Judean girl called Ṭābat-Iššar/Yaše-Yāmaa ${ }^{1144}$ and a man named Kulû/Kalbā. It appears that the two had been meeting each other outside the framework of an officially established marriage, which was not tolerated by their families or guardians. The document states that Țābat-Ǐšar should not meet Kulû anymore or that she should ask the head of her house (bēl bìti) to write to Kulû's father Kalbā. If she did not do this and was again found with Kulû, she would be marked as a slave. ${ }^{1145}$ Ṭābat-Iššar's mother Halâ was present at the writing of the document, but no other family members of Taabat-Iššar or Kulû appear to have been involved in the process. Instead of parents or brothers, the Ebabbar temple probably played a decisive role in regulating the behaviour of the two lovers. ${ }^{1146}$ First, this is suggested by the obscure reference to the bè l biti and by the fact that the issue was not solved within and between the families. Second, although it remains unclear which legal body delivered the verdict, a rent farmer (ša muhhi sūti ša Šamaš) of Ebabbar and a priest of the temple witnessed the document. ${ }^{1147}$ This raises the possibility that the girl and perhaps the man as well were somehow attached to the temple, either as dependants or free workers. ${ }^{1148}$

A number of texts from the Ebabbar archive pertain to Judeans who were involved in the agricultural sector of the temple's economy. A certain HūlYâma delivered dates to the temple, according to the administrative list CT 57 197, and he was most probably a gardener himself. ${ }^{1149}$ Nothing in the document suggests that he was more than a small farmer who cultivated a plot of temple land and had to deliver a share of his harvest to Ebabbar.

1144 The name Țābat-Iššar is Assyrian (Zadok 2002, 30-31). Zadok (1995, 3; 2014a, 111; 2015b, 175 $+n$. 80) notes the presence of Assyrian names in sixth-century Sippar and reasonably suggests that these people had migrated from Assyria and Upper Mesopotamia to Northern Babylonia. According to Zadok, Țābat-Iššar's family was of Judean or Israelite descent, having perhaps migrated from Upper Mesopotamia to Babylonia as well. However, it is also possible that the family had people of Assyrian origin among its acquaintances and this affected its naming practices.

1145 This may also be a figurative expression; see Wunsch and Magdalene 2014, 339 n. 19.

1146 Joannès 1994; Abraham 2005/2006, 211; Waerzeggers (forthcoming c).

1147 On the rent farmer Šāpik-zēri/Šamaš-ah-iddin, see Jursa 1995, 99; on rent farmers in general, see Jursa 1995, 85-116; van Driel 1999, 216-217. The second witness Šamaš-erība/ Balīhu/Šangû-Šamaš held a brewer's prebend at Ebabbar (see Bongenaar 1997, 225, 455456). The scribe of the document, Arad-Bēl/Bēl-ušallim/Adad-šamê, was a frequent scribe of judicial documents in Sippar (Bongenaar 1997, 66, 481-482), although he was a businessman without any apparent connections to the temple (Waerzeggers 2014a, 21-22, 89; cf. Bongenaar 2000, 85-88; Jursa 2005a, 120-121).

1148 For different perspectives on this matter, see Joannès 1994; Abraham 2005/2006, 211; Berlejung 2018, 1063-1065; Waerzeggers (forthcoming c).

1149 On this text, see Zadok 2002, 36; Waerzeggers (forthcoming c). 
A better-known Judean is Minu-eššu/Yāhû-râm, who farmed Ebabbar's fields in the area of Tīl-gubbi. ${ }^{150} \mathrm{He}$ was a sharecropper who leased five kurru (6.75 hectares) of uncultivated land from the temple in order to reclaim it (Jursa 1995 no. 47; Sippar, 4-?-5 Nbn, 551-550 BCE). Six years later he still cultivated Ebabbar's fields in Till-gubbi, this time paying his share (zittu) of 1;0.5 kurru of sesame to the temple (CT 56 132; 13-VII-11 Nbn, 545 BCE). ${ }^{1151} \mathrm{He}$ was hardly a member of the temple's personnel but a (semi-)independent farmer cultivating institutional land.

It is possible that Minu-eššu's son and father are also attested in the Ebabbar archive. A certain Nabû-šar-ușur/Minu-eššu is attested in the Ebabbar document CT 5574 (Sippar, 27-IX-1 Dar, 520 BCE). ${ }^{1152} \mathrm{He}$ and two other men had to deliver a small amount of sesame and silver to a tithe farmer of Ebabbar as a remainder of the temple tithe (ešru) from Āl-Hummāya. ${ }^{1153}$ The three men appear to be farmers of temple land, and, given the reasonable time gap between CT 56132 and CT 55 74, it is very well possible that Nabû-šar-ușur's father was identical with Minu-eššu/Yāhû-râm. It is noteworthy that Nabû-šar-ușur bore a Beamtenname with the šarru element, which indicates that the family had connections to the royal administration or that it strived to create some. ${ }^{1154}$

Minu-eššu's father is possibly attested in SCT 100, an undated list of payments of unknown geographical origin. ${ }^{1155}$ A certain Yāhû-râm delivered more than 12 kurru of barley and flour, including transport costs (gimru $)^{1156}$ and income (erbu). ${ }^{1157}$ The recipient of the agricultural products and payments is not mentioned, but the text type and terminology point towards an institutional context, most likely a temple. ${ }^{1158}$ Given the rarity of the names of Minu-eššu and Yāhû-râm, it is very well possible that all four texts pertain to members of one family who cultivated Ebabbar's fields in the Sippar countryside. ${ }^{1159}$ The profile of these people resembles that of Judean farmers in the environs of Yāhūdu and Nippur, as they were obviously not temple dependants but farmers

\footnotetext{
$115^{0}$ See Jursa 1995, 141, 177, 230-233; 2010a, 338-340; Zadok 2002, 28; Waerzeggers 2014b, 140.

$115^{1}$ The text is transliterated and translated in Jursa 1995, 177.

$115^{2}$ See Zadok 2004, 111-112.

1153 On tithes and tithe farmers, see Jursa 1998a, esp. 42, 91 on the text in question. Jursa suggests that the place name Âl-Hummāya refers to a village of Cilicians, but Zadok (2005, 78-79) does not accept this on linguistic grounds.

1154 See Section 1.5.

1155 See Zadok 2014a, 119 .

1156 On gimru, see CAD G, 77-78; van Driel 2002, 171-172; Weszeli in Jursa 2010a, 140-141.

1157 On erbu, see Jursa 1995, 153, 156-157; van Driel 2002, 284; Kleber in Jursa 2010a, 541-547. Notice that erbu and ešru are sometimes interchangeable terms (Jursa 1998a, 88-89).

$115^{8}$ Zadok 2014a, 119 suggests that the text may originate from Sippar.

1159 Zadok 2004, 111; 2014a, 119 .
} 
who tilled institutional lands in somewhat marginal rural areas. ${ }^{1160}$ Nabû-šarușur's name may indicate that instead of being dependent on the Ebabbar temple, the family was somehow attached to the royal administration, perhaps via the land-for-service scheme.

Furthermore, a document from the Ebabbar archive hints at the possibility that Israelites or Judeans were present in Babylonia already in the late seventh century. A certain Gir-re-e-ma and five other people with Akkadian names had a huge flock of sheep at their disposal in the Nippur region, according to CTMMA 41 (= BE 8 141). The document was written in the last years of Assyrian rule in Babylonia, in the accession year of Sîn-šum-līšir (626 BCE). ${ }^{1161}$ The total value of the animals was no less than 30 talents of silver, and the value of a single sheep is specified as being 1 shekel. Accordingly, the total number of sheep was 108,000 animals. Gir-re-e-ma and his companions were perhaps herdsmen contracted to care for Ebabbar's flocks because a purchase of this scale seems unlikely, especially during the turbulent political situation in Babylonia. ${ }^{1162}$ In any case, the importance of the transaction is emphasised by the fact that the qīpu of Ebabbar, Bēl-īpuš, was present in Nippur where the document was written. ${ }^{1163}$ If the spelling Gir-re-e-ma represents a Yahwistic name, this document is unique in two ways. ${ }^{1164}$ First, it pertains to a man of Judean or Israelite descent who was involved in the herding of a massive flock of thousands of sheep. Second, it would be the earliest occurrence of a Yahwistic name in Babylonian cuneiform sources, and it would predate Nebuchadnezzar II's deportations from Judah. This implies that if Gir-re-e-ma is indeed a Yahwistic name, its bearer was probably a descendant of Israelite or Judean deportees who arrived in Mesopotamia in the eighth century. ${ }^{165}$

Although every document discussed above originates from the archive of the Ebabbar temple in Sippar, there is no reason to assume that Judeans did not have contact with other Babylonian temples. A piece of evidence which supports this assumption is $\mathrm{BM} 103632$, an administrative list which belongs to

\footnotetext{
116o See Jursa 2010a, 339; Waerzeggers 2014b, 140.

1161 On Sîn-šum-lǐšir's reign and Ebabbar texts from this period, see Da Riva 2001.

1162 See Spar and Jursa 2014, 4.

1163 The qipu was a high official, royal representative in the administration of a Babylonian temple. He had no cultic duties, but he took care of the king's interests in the temple (Bongenaar 1997, 34-55; Waerzeggers 2010a, 42-43).

1164 Zadok (1979a, 34; 2002, 27; 2014a, 110) identifies Gir-re-e-ma as a Yahwistic name. However, the orthography of the Yahwistic element is peculiar, and the form -e-ma is attested only in one other document (C18; see Zadok 2002, 14; Pearce and Wunsch 2014, 23-24). Moreover, there are no other attestations of Yahwistic names in Babylonia before 597 .

1165 Zadok 2014a, 110.
} 
the British Museum 1911-4-8 collection. ${ }^{1166}$ The document lists sheep which were given to a certain Nìr-Yāma, to a household (bìtu), and to a certain Inašär-Bēl-abluț. Some of the sheep were given as travel provisions for journeys to Babylon and Kiš, but the list does not indicate the reason why Nīr-Yāma was among the recipients. The text type, references to a household, and distribution of travel provisions suggest that the document originates from an institutional context. A possible candidate is the Ebabbar temple in Larsa, as some documents from its archives have found their way into the 1911-4-8 collection, together with the Itti-Šamaš-balāțu archive. ${ }^{1167}$

The documents discussed above shed light on the different roles Judeans had vis-à-vis Babylonian temples, but their small number emphasises that only few Judean deportees were donated to the temples. Although the word širku ('temple dependant') $)^{1168}$ is never used to characterise a Judean, some of the people discussed above were most likely temple dependants. At the same time, Judeans also rented temple lands for cultivation on a seemingly voluntary basis and without any formal ties to the temple. Given the huge size of the temple archives from Sippar and Uruk, very few Judeans are attested in temple-related documents. ${ }^{1169}$ This is in stark contrast to the situation in the land-for-service sector, and it strongly indicates that the state primarily integrated deportees into its own economic sphere. Temples played only a minor role in Babylonian deportation schemes.

\subsection{Royal Lands and the Land-for-Service Sector}

Throughout this study, Judeans have primarily been attested in contexts which relate to the royal administration and land-for-service sector in one way or another. A number of miscellaneous texts can be added to this group.

A Judean man called Yāhû-nūru/Zabdia cultivated land in Bīt-Nabû-lềi in the Borsippa countryside, according to VS 36 (Bìt-Nabû-lê'i, 2o-VII-22 Nbk, 583 ВСE). ${ }^{1170}$ He owed a debt of $1 ; 3$ kurru of barley to a certain Mušẽzib-Bēl//Tunāya,

1166 The tablet is unpublished, but its transliteration is available at CTIJ. My remarks are based on this transliteration and the information available in Jursa 2010a, 133-134 n. 804; Zadok 2014a, 121.

1167 Jursa 2005a, 108-109; 2010a, 133-134 n. 804; but cf. Zadok 2014a, 121.

1168 On širkus, see Kleber 2011.

1169 The Ebabbar and Eanna archives comprise tens of thousands of documents in total (Jursa 2005a, 116-120, 138-139).

1170 See Zadok 2004, 108-109; Waerzeggers 2014b, 136. The reading of the first sign of Yāhû-

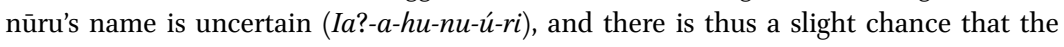
name is not Yahwistic. 
who managed farmlands in the service of Marduk-šāpik-zēri//Eppēešilī and Ṭābia//Sîn-ilī.1171 The debt bore no interest, outstanding debts or tax payments are not referred to, and the debt was to be paid back at the time of the next barley harvest. Accordingly, the promissory note most probably disguises the prepaid purchase of a future harvest. ${ }^{1172}$ As it is known that Ṭābia and MušēzibBēl leased and organised the cultivation of royal lands, ${ }^{1173}$ Yāhû-nūru was not necessarily an independent farmer but an agricultural worker in Mušēzib-Bēl's service or a farmer in the land-for-service sector. ${ }^{1174}$

YOS 1936 is a promissory note for 5;2.3 kurru of barley given as capital to a harrānu venture (Nippur, 13-I-14 Nbn, 542 BCE). ${ }^{1175}$ The document belongs to the archive of Bēl-ețēri-Šamaš/Aplā, an entrepreneur who was - among other things - involved in the management of royal lands in the Nippur region. ${ }^{1176}$ yos $193^{6}$ pertains to a harrānu venture in which Bēl-ețēri-Šamaš and another man participated as active partners and which was financed by a certain Bēlețēri-Šamaš/Zarīqu-ēreš. The latter had lent over 65 kurru of barley from royal property to Bēl-ețēri-Šamaš/Aplā already four years earlier (Yos 19 34). It is thus likely that the harrānu venture in Yos 1936 had royal backing as well, either as a direct royal investment or as a private investment of harvest cultivated on royal land. ${ }^{1177}$ A Judean named Kutāya/Ahu-Yāma was among the witnesses of the document. ${ }^{1178}$ If he was not randomly chosen to witness the deed, it is possible that he was involved in farming or managing royal properties in the Nippur countryside.

Two roughly contemporary documents from well-known private archives further strengthen the view that the great majority of Judeans were indeed settled on royal land or were otherwise connected to the royal administration in Babylonia. Documents from the archives of the Egibis ${ }^{1179}$ and

\footnotetext{
1171 The document belongs to the Sîn-ilī archive. See Wunsch 1988; Jursa 2005a, 69-71; 2010a, $210-211$.

1172 See Jursa 2010a, 211-212.

1173 Jursa 2010a, 210; Waerzeggers 2014b, 136.

1174 Cf. Jursa 2010a, 210.

1175 The text is re-edited and translated as no. 10 in Jursa 2005b.

1176 On the archive and business profile of Bēl-ețēri-Šamaš, see Jursa 2005a, 112; 2005b.

1177 See Jursa 2005b, 209.

1178 His name Kutāya ('Cuthean') is an interesting example of Judean name-giving practices in Babylonia. On the name, see Zadok 2002, 28; Vanderhooft 2017, 122. On the city of Cutha, see Jursa 2010a, 115-116, 124-126.

1179 See Section 6.1.
} 
Marduk-rēmanni ${ }^{1180}$ relate to various spheres of Babylonian society, but the few Judeans attested in the archives appear in contexts connected to the royal administration. In addition to the cases discussed above, ${ }^{1181}$ these archives refer to two Judeans named Nīr-Yāma/Bēl-zēr-ibni and Haddāya/Yāhû-qâm. Both Judeans appear in dossiers which relate to the private management of institutional land. Nīr-Yāma guaranteed a substantial payment of 16 minas of silver on behalf of two men working for Marduk-nāșir-apli//Egibi in Dar 310 (Babylon, 9-XI-11 Dar, 510 BCE). ${ }^{1182}$ The debt originated from Marduk-nāṣirapli's purchases of commodities produced on institutional - temple and royal - land in Šahrinnu in the environs of Babylon. ${ }^{1183}$ Given the large amount of silver involved, Nīr-Yāma was hardly a small farmer but perhaps one of Marduknāṣir-apli's local associates in Šahrīnu. On the contrary, Haddāya/Yāhû-qâm was hardly more than a farmer of royal land in the village of Zazannu in the Sippar countryside (MR 9o; Zazannu Ālu-ša-Bēl-iddin, 14 Dar, 508-507 BCE). ${ }^{1184}$ Marduk-rēmanni//Șāhit-ginê leased royal lands from a high official in Zazannu and organised their cultivation through subleases. ${ }^{1185} \mathrm{MR} 90$ is a receipt relating to these subleases, and it was written at the estate of the high official in charge of the leased lands. Haddāya appears among the witnesses, and his status is probably equal to those small farmers who witnessed documents in other regional centres, such as Našar.

Three Judeans are attested in a sale of oxen belonging to the Tattannu archive. ${ }^{1186}$ At least one of them was a servant of Tattannu II, a member of the rich, archive-holding family. The businesses of the family pertained to tax farming and to the management of royal properties in the land-for-service sector, and, moreover, the eldest protagonist of the archive, Tattannu I, was perhaps identical with the homonymous governor of Across-the-River. ${ }^{1187}$

1180 Also known as the Șāhit-ginê A archive. See Jursa 2005a, 125-126; Waerzeggers 2014a; Section 3.3.2.

1181 The royal official Yāhû-šar-ușur/Šamaš-iddin (OECT 10 152; see Section 6.1) and the merchant Aia-ahâ/Šani-Yāma ( $N b k$ 361; see Section 3.4) are attested in the Egibi archive. Aia-ahâ's connection to the royal administration is suggested by his participation in longdistance trade.

1182 The text is transliterated and translated in Abraham 2004 no. 106.

1183 Abraham 2004, 118-127. On the location of Šahrīnu, see Zadok 1985, 283-284.

1184 On the location of Zazannu, see Zadok 1985, 334; Waerzeggers 2014a, 157 + n. 26.

1185 Waerzeggers 2014a, 157-159.

1186 HSM 1931.1.1 (the village of $\mathrm{Hu}$-ia, 2-III-11+ Art I, 454-445 BCE). The document is unpublished but transliterated at CтIJ. The text features Gabrī-Yāma/Bēl-ittannu (if the reading of the broken name is correct) and his father and brother. See Zadok 2014a, 120-121.

1187 Jursa and Stolper 2007; Jursa 2010a, 375. On the Tattannu archive, see Jursa 2005a, 94-97. 
Although the sale of oxen does not pertain to royal concerns, the Judeans served a family with obvious connections to the royal administration.

Finally, three more documents can be added to the cases discussed above. First, a Judean named $\mathrm{d} I a-(a)-h u-u-m u-[. .$.$] witnessed two documents relating$ to the rent farming of royal lands in the environs of Isin. ${ }^{1188}$ Second, TCL 13210 is a list of debts and remaining payments in barley owed by a number of people, some of whom bore Arabian names. ${ }^{1189}$ A Judean man called Malak-Yāma was in charge of the respective promissory notes and held them at the estate (bït) of someone called Kabar-il. ${ }^{1190}$ The Judean and Arabian personal names and a reference to a rural estate are indicative of an environment typical of the land-for-service sector.

The texts analysed in this section are additional evidence of Judeans who were integrated into the sphere of the royal administration or royal landholdings in one way or another. The texts emphasise that the environs of Yāhūdu and the Nippur countryside were not special cases, as the king and his officials also held land properties in other parts of Babylonia. Deportees were resettled in these rural areas as well.

\subsection{Miscellaneous Texts}

There are a small number of documents which cannot be properly contextualised and which thus yield only little information on Judeans. These include a broken document witnessed by $I-u-h u-{ }^{2} /$ Zababa-iddin in Kišs(Hursagkalamma), ${ }^{1191}$ a receipt of a rental payment concerning a house owned by ${ }^{\mathrm{Id}} I a^{-}{ }^{2}-u^{\prime}-[\ldots]$ in Babylon, ${ }^{1192}$ a promissory note for a small amount of wheat and barley guaranteed

1188 ROMCT 225 and Stigers 1976 no. 44. Judging by the similar contents of the documents and the number of witnesses in common, they were probable drafted around the same time in Isin (14 Dar, 508-507 BCE). See Joannès 1986, 80. The tablets belong to the archive of Silim-Bēl/Arrabi, a rent farmer in Isin (Joannès 1986, 80; van Driel 1989, 214-215; Jursa 2005a, 102).

1189 The place and date of writing the document are not recorded. On the Arabian names, see Zadok 1981, 79 .

1190 Zadok's suggestion $(2002,45)$ that the broken personal name Ga-mir-[...] on line 10 should be emended as $\mathrm{Ga}$-mir-i[ $[a-a-m a]$ is hypothetical.

1191 OЕСT 10183 (Hursagkalamma, 11-XI-17 Xer, $468 \mathrm{BCE}$ ). The broken document is perhaps related to agriculture. I am not certain if the name is Yahwistic (cf. Zadok 2002, 14), because the orthography has no parallels and the tablet in question cannot be linked to other documents mentioning Judeans.

1192 Cyr 43 (Babylon, 19-IV-2 Cyr, 537 BCE). The text is transliterated at Achemenet (http:// www.achemenet.com). 
by Zakar-Yāma/Sepā-Yāma in Nippur, ${ }^{1193}$ a sale of two female slaves by BanāYāma in Nippur, ${ }^{1194}$ and a sale of slaves witnessed by two Judeans in Cutha. ${ }^{1195}$

\subsection{Seals of Exiles}

A number of seals featuring Yahwistic and other supposedly Judean or Israelite names have been used as a further witness to the presence of Judeans and Israelites in Mesopotamia. ${ }^{196}$ However, as these seals are of unprovenanced origin, ${ }^{1197}$ any information about their archaeological context is permanently lost. ${ }^{1198}$ If they are indeed ancient artefacts, there is no way of knowing if they were manufactured in Mesopotamia or in the Levant in an Assyrian or Babylonian style. It has to be noted that no seals owned by Judeans have been found during controlled excavations in Babylonia. Although some cuneiform tablets from the environs of Yāhūdu and the Murašû archive bear seal impressions which attest to Judean seal ownership in Babylonia, none of these impressions include Hebrew or Aramaic writing. ${ }^{1199}$ This raises doubts about the Babylonian origin of the 'seals of exiles' and their alphabetic epigraphs, and, all in all, there remains the possibility that some of them are modern forgeries. Given the problematic circumstances, the seals will not be treated in this study.

\subsection{Conclusion}

The documents which pertain to Judeans but originate from several different Babylonian archives are instrumental in evaluating the picture which emerges

1193 TuM 2-3 123 (the eighth year of Artaxerxes II or III, the fourth century BCE). Because four people sealed the tablet, it was hardly written in the eighth year of Artaxerxes I (Zadok 2002, 45). The place of writing is broken, but the commodities were to be delivered in Nippur. Zakar-Yāma's ring is impressed on the tablet.

$1194 \mathrm{~N} 4518$, an unpublished, broken tablet at the University of Pennsylvania Museum of Archaeology and Anthropology (Nippur, 22-XII-? Dar, 521-486 вСЕ). The text is transliterated at CTIJ. See Zadok 2014a, 120.

1195 Unpublished BM 55063+55268 (25-XI-Art I, 464-424 BCE). See Zadok 2002, 40-41; Jursa 2003, 62. Collated in June 2014. I wish to thank the Trustees of the British Museum for their kind permission to study and cite from tablets in their care.

1196 Avigad 1965; Heltzer 2005.

1197 Heltzer 2005, 173 .

1198 On the ethical problems involved, see Section 1.4.2. On unprovenanced seals in particular, see Joffe 2003 .

1199 See Sections 4.3.6.3 and 5.7. 
from the preceding chapters of this study. These documents corroborate the view that Judeans were predominantly resettled in the land-for-service sector and that, in general, the state integrated deportees into its economic sphere. Relatively few Judeans were dependants of Babylonian temples or participated in farming of temple lands. It is noteworthy that documents from private archives also support this view: although the archive-holding Babylonian families had multi-faceted interests, Judeans are attested in contexts which relate to the royal administration or the cultivation of royal land. 


\section{The Neirabian Community in Babylonia}

Until now, this study has focused on Judean communities in Babylonia. It has to be emphasised, however, that Judeans were but one of numerous population groups deported to Babylonia in the late seventh and early sixth centuries. A case study of the Neirabian community in Babylonia allows us to control the research results obtained so far and determine whether they can be applied to deported communities in Babylonia in general. The Neirabians originated from Neirab, Syria, whence they were deported to Babylonia and resettled in the village of Neirab. They were integrated into the land-for-service sector of the agrarian economy, and the documents pertaining to them closely resemble the transactions from Yāhūdu and its surroundings. However, the cuneiform tablets pertaining to the Neirabians were discovered in Neirab, Syria. This indicates that a number of Neirabians returned to their ancestral hometown in the early Persian period.

\subsection{Neirab of Syria and Neirab of Babylonia}

The town of Neirab, located some ten kilometres south-east of Aleppo, has retained its ancient name across the millennia and can still be found on maps of modern Syria. ${ }^{1200}$ This Aramean town is known from Neo-Assyrian royal correspondence and royal inscriptions, ${ }^{1201}$ and its site was partly excavated in 1926-1927 after a stone sarcophagus and two funerary stelae were discovered during construction work in the late nineteenth century. ${ }^{1202}$ The Aramaic stelae commemorate two priests of Sahr at Neirab, Sîn-zēr-ibni and Si'gabbar, the latter of whom is also mentioned in a Neo-Assyrian letter from the late eighth

1200 Röllig 1998-2001, 215; Tolini 2015, 58.

1201 The town is mentioned in SAA 1 189; SAA 6 326; RINAP 1, Tiglath-pileser III 43: ii 3. The first document, a letter probably sent by the governor of Harran to Sargon II, refers to

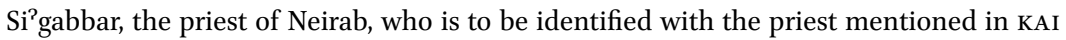
226 (see Parpola 1985; PNA 2/II, 858-859). The second document is a sale of an agricultural holding near the town of Neirab in the reign of Assurbanipal (see PNA 3/1, 10381041). The last document, a royal inscription of Tiglath-pileser III, lists Neirab among the towns which were under Assyrian rule in the territory of Bìt-Agūsi (see also Röllig 19982001, 215).

1202 Barrois 1927; Carrière and Barrois 1927; Abel and Barrois 1928. 
century. ${ }^{1203}$ Even though no temple was found during the excavations of the site, references to the priests of Sahr suggest that the West Semitic moon god had a shrine in the city. ${ }^{1204}$ The excavations revealed an ancient cemetery that was in use from the late Neo-Assyrian until Persian period; however, the tell was only partially excavated, and the living and public quarters of the city remain unstudied. ${ }^{1205}$ Due to the incomplete excavations and brief excavation reports, we know relatively little about the site.

Judging by the stelae of the two priests and stone sarcophagi discovered at the site, at least a part of the people buried in the necropolis of Neirab belonged to the higher strata of the local community. This needs to be taken into account when evaluating the find of 27 Neo-Babylonian cuneiform tablets from the cemetery: 25 of them were found next to a scarab and human remains in 1926 and two more tablets were discovered in an unspecified archaeological context a year later. In addition, a piece of pottery with some Assyrian cuneiform signs was discovered in $1927 .{ }^{1206}$ In contrast to the stelae and stone sarcophagi found at the site, the tomb next to the 25 tablets was simple; however, the connection between the tomb and the tablets remains obscure. ${ }^{1207}$ The tablets were published by Édouard Dhorme in $1928,{ }^{1208}$ but due to the advancements in the field during the past century, a new edition of the tablets is a desideratum. Gauthier Tolini has announced his plans to republish the texts held in Jerusalem, but the tablets in Aleppo would not be included in the new edition. ${ }^{1209}$

In his editio princeps, Dhorme declared that the tablets were written in the period extending from the reign of Nebuchadnezzar II to the reign of Darius I. ${ }^{1210}$ Some tablets were drafted in Neirab, others in Babylon, Ammat (which he identified as Hamath), Hīt, and Bīt-dayyān-Adad (which he located near Aleppo,

1203 The stelae, first published in Clermont-Ganneau 1897 and subsequently edited as KAI 225 and 226, are discussed in Yun 2006; Niehr 2014, 190-192, pls. XVII, XIX; both with bibliographies. For the Neo-Assyrian letter, see the footnote above.

1204 Niehr 2010, 255.

1205 On the dating and the importance of the cemetery, see Röllig 1998-2001, 215; Nunn 2000, 393, 436-439; Niehr 2010, 253-258; 2014, 192. Also see the excavation reports in Barrois 1927; Carrière and Barrois 1927; Abel and Barrois 1928.

1206 Barrois 1927, 263; Carrière and Barrois 1927, 138; Abel and Barrois 1928, 318.

1207 Oelsner $(1989,72)$ rightly describes the burial as a simple one. He also suggests that the tablets were found in the foundations of a house, but the excavation report seems to suggest a graveyard context.

1208 Dhorme 1928. Other important studies are Fales 1973; Eph'al 1978; Oelsner 1989; Cagni 1990; Timm 1995; Cussini 2000; Tolini 2014, 2015.

1209 Tolini 2015, $59+$ n. 8 .

1210 Dhorme $1928,53-55$. 
the cult centre of Hadad). Dhorme noticed that the descendants of a man called Nusku-gabbē had a prominent role in the documents, but since his primary aim was to publish the tablets, he did not devote much space to a discussion of their contents.

Dhorme's chronology was questioned by Albrecht Goetze, who proposed that the time span of the archive should be shortened from Nebuchadnezzar II Darius I to Neriglissar - Darius I. According to him, the concentration of the documents in the reign of Nabonidus makes it problematic to assign nos. 1 and $2^{1211}$ to the reign of Nebuchadnezzar II. He argues that the short reign of Nebuchadnezzar IV is more fitting. ${ }^{1212}$ The case of no. 1 (4-VI-1 Nbk) is a clear one, because dating the tablet to the reign of Nebuchadnezzar IV shortens the timespan of the archive by several decades. No. 2 does not preserve the exact regnal year, and dating it to the late reign of Nebuchadnezzar II would not expand the temporal scope of the archive too much. ${ }^{1213}$ That would also shorten the active period of a certain Nuhsāya/Nusku-gabbē from 35 years (o Nbn - 1 Nbk IV) to circa 25 years (late Nbk II to $16 \mathrm{Nbn}$ ). ${ }^{1214}$ However, the activity of a certain Nargia/Hananaia in $3 \mathrm{Nbn}-1$ Camb (nos. 6, 11, 12, and 19) and the attestation of his son Hidirāya in no. 2 supports the dating of the tablet later, because the son was hardly active before his father. ${ }^{1215}$ Accordingly, it is sensible to date no. 2 to the reign of Nebuchadnezzar IV as well: Nuhsāya's active period of 35 years is not unprecedented, Hidirāya was likely active only after his father, and the timespan of the archive is shortened by some years.

Dhorme's natural assumption was that the place name Neirab mentioned in the tablets was to be identified as the place where the tablets were excavated. This view held until 1978, when Israel Eph'al proposed that the Neirab mentioned in the cuneiform tablets should be located in Babylonia instead of Syria. ${ }^{216} \mathrm{Eph}^{\varsigma}$ al argued that various problems occur when one tries to follow Dhorme's suggestion that the toponyms mentioned in the archive should primarily be located in Syria. Julius Lewy had already earlier criticised Dhorme's identification of Ammat (Am-mat) with the Syrian city of Hamath because the place name Hamath is normally written in Assyrian and Babylonian sources as Ha-ma-(a)-tu or A-ma-tu. ${ }^{1217}$

\footnotetext{
1211 The numbering of the texts follows Dhorme 1928.

1212 Goetze 1944, 45 n. 22. He is followed by Eph'al 1978, 84; Tolini 2015, 58 + n. 2.

1213 Oelsner 1989, 68-69.

1214 His earliest certain attestation is in $24-\mathrm{VI}-\mathrm{o}$ Nbn and his last certain attestation in 1-X-16 Nbn.

1215 Tolini 2015, 71-72+ n. 54 .

1216 Eph'al 1978, 84-87.

1217 Lewy 1943-1944, 431-433; 1950-1951, 373-374 + n. 52. See also Eph`al 1978, 85.
} 
Eph'al noticed that some persons are present in several localities attested in the texts, which indicates that the places were not far away from each other. ${ }^{1218}$ In one case, a scribe and witness appear in two documents written on the second and fourth days of the seventh month in the tenth year of Nabonidus: the first document (no. 11) in Bīt-dayyān-Adad and the second (no. 12) in Ammat. If the former town was located near Aleppo and the latter is identical with Hamath, the two persons travelled a distance of 150 kilometres in a couple of days. Moreover, Hìt and Babylon are both far away from the Syrian town of Neirab. In addition, one tablet (no. 17) was written in a place called Ālu ša Nērebāya ša ina muhhi nāru ša Bēl-ab-uṣur ('the Town of the Neirabians which is located on the Bēl-ab-ușur canal'). There were not, however, any canals in the vicinity of Neirab in Syria. Finally, Eph ${ }^{\mathrm{S}}$ al argued that it is peculiar to find a dossier of Babylonian cuneiform tablets in the Aramaic-speaking region in Syria, where people would probably have used their mother tongue to write such documents. All the scribes in the archive bore Babylonian names.

These observations led $\mathrm{Eph}^{\complement}$ al to suggest that the Neirab attested in the clay tablets should be located in Babylonia instead of Syria. This would explain why the tablets are similar to Babylonian legal documents from the sixth century and why canals are mentioned in the texts. In fact, the town of Ammat ${ }^{1219}$ and the Bēl-ab-ușur canal are known to have existed in the Nippur region. ${ }^{1220}$ What is most important, the phenomenon of twin towns is widely attested in the countryside around Nippur. ${ }^{1221}$ According to Eph ${ }^{\varsigma}$ al, the Neirabians lived in Babylonia as deportees, but some of them returned to their ancestral hometown in Syria in the early Persian period and took some of their cuneiform documents along. That is the reason why the tablets were excavated from Neirab, Syria. Eph ${ }^{\Upsilon} a l ' s$ theory has aroused criticism by Stephanie M. Dalley and Luigi Cagni, ${ }^{1222}$ but most scholars accept his view. ${ }^{1223}$ As there seems to be no other way to explain the contents of the archive and its find-spot in Syria, $\mathrm{Eph}^{\varsigma}$ al's thesis is followed here.

Accordingly, the village of Neirab is to be seen as a settlement of Neirabian deportees in the Babylonian countryside. The deportation took place during the campaigns of Nabopolassar or Nebuchadnezzar II, and, following a wellknown practice, the deportees were settled in a community according to their

\footnotetext{
1218 Eph $^{\varsigma}$ al $1978,84-87$.

1219 BE 840.

1220 BE 9 65; PBS 2/1 104.

1221 Dandamayev 2004.

1222 Dalley 1984; Cagni 1990.

1223 Joannès 1982b, 35; Oelsner 1989 (with some caution); Timm 1995; Dandamayev 2004, 141142; Pearce 2006, 408; Beaulieu 2007, 201-202; and, most recently, Tolini 2015, 60-66.
} 
place of origin and their settlement was named Neirab or 'the Town of the Neirabians on the Bēl-ab-ușur canal.'.1224 The usage of these two different place names closely resembles the case of Yāhūdu and Āl-Yāhūdāya. Some of the Neirabians returned to their ancestral hometown in Syria in the early Persian period, taking a dossier of cuneiform tablets along with them. Because the tablets were unearthed in an ancient cemetery, it is likely that they were buried together with a deceased returnee from Babylonia. The deceased probably enjoyed some social standing in the community because he was buried in the same necropolis with local priests.

\subsection{The Archive and Its Socio-Economic Context}

\subsubsection{The Protagonists of the Texts}

The protagonists of the Neirab texts are descendants of a certain Nusku-gabbē. The central figures include his two sons, Nuhsāya and Nusku-killanni, and the latter's son Nusku-iddin, who was perhaps the last owner of the archive. ${ }^{1225}$ Other sons of Nusku-gabbē - Sîn-uballit, Manniya, and Sîn-ab-ușur - appear in the archive sporadically. ${ }^{1226}$ The sons and grandsons of a certain İn-Nusku are also important, because several members of the family are present in eight or nine documents of the archive (nos. $7,13(?), 14 \| 24,15,17-18,21$, and 27$).{ }^{1227} \mathrm{~A}$ longstanding business relationship or a kinship tie is the most likely reason for the strong presence of the İn-Nusku family in the archive. In the same manner, Nargia/Hananaia was probably a relative or business partner of the Nuskugabbē family; he is attested in nos. $6,11-12$, and 19, and his son Hidirāya in no. 2. ${ }^{1228}$

A peculiar feature of the archive is the abundance of personal names connected with the lunar cult, and the deities Nusku and Sahr/Sîn have a prominent role among the deities attested as theophoric elements in personal names. ${ }^{1229}$ This phenomenon is to be connected to the geographic origin of the archive holders: the lunar cult was of great importance in northern Syria in the

\footnotetext{
1224 The place name is written in two different ways. The shorter form is attested in nos. 19, 23, and 26 , and the longer form in no. 17 .

1225 Nuhsāya: nos. 2, 3(?), 4-6, 10-13, 17-18; Nusku-killanni: nos. 7, 8||9, 10, 14||24, 15-16; and Nusku-iddin: 1, 18-19, 27(?). See Fales 1973, 132-137; Tolini 2015, 67-70.

1226 Sîn-uballiț: no. 4; Manniya: nos. 7, 8||9; Sîn-ab-uṣur: no. 8\||9.

1227 For this family, see Fales 1973, 138-141; Tolini 2015, 72-73.

1228 For the identification of Nargia and Hidirāya, see Tolini 2015, 71.

1229 Tolini 2015, 67-76. See also Zadok 2003, 556-558.
} 
mid-first millennium. ${ }^{1230}$ This does not apply only to Harran, the cultic centre of Sîn, but also to Neirab, as the two stelae of the priests of Sahr demonstrate. Moreover, text no. 26 of the Neirab archive refers to Sîn of Neirab, which further stresses the importance of the lunar cult for the Neirabians. In the Neirab archive, the theophoric elements Sîn and Nusku in West Semitic names can be used as a criterion to identify people of Neirabian origin. ${ }^{1231}$ The concentration of Sîn and Nusku names in the Neirabian texts can be compared with the concentration of Yahwistic names in Yāhūdu.

\subsubsection{Promissory Notes for Barley}

The documents of the archive are mainly promissory notes for barley and silver, accompanied by some property and family documents. On average, the size of silver loans is relatively smaller than those of barley: eight out of nine promissory notes for silver range between 2.25 and 9.5 shekels, with only one broken document referring to a loan of at least one mina. On the other hand, the amounts of eight barley loans range between 6.66 and $40+k u r r u$, with the average being over 18 kurru. Only three promissory notes (nos. 4-6) hold interest.

The eight promissory notes for barley $(3-6,10,15,17,18)$ appear to fit a certain pattern. As noticed by Tolini, seven out of the eight debts were to be paid back in the second month of the year, at the time of barley harvest. ${ }^{1232}$ Moreover, except for nos. 4 and $5,{ }^{1233}$ all promissory notes were issued at the turn of the year, which leads Tolini to suggest that some of the debts were taken to support the Neirabian community during the time of food shortage before the new harvest. Since the descendants of Nusku-gabbē are debtors in all documents, but the amounts of barley are too large for the consumption of a single family, Tolini suggests that the family played a leading role in the community to which it distributed the borrowed barley. ${ }^{1234}$ However, two additional features of the documents and their socio-economic setting have to be taken into account.

First, five promissory notes can be connected to the royal administration. The names of three creditors - Šar-gabbi-lē’i/Ilqataru, Šar-bēlšunu/[...]-tarra, and Iltammeš-ili/Šar-gabbi-lēêi $(4,5,10)$ - betray such a link. One creditor,

\footnotetext{
1230 Lipiński 2000, 620-623.

1231 For a more thorough methodological discussion, see Tolini 2015, 70.

1232 Tolini 2015,81 . No. 7 is damaged and the term of the loan is illegible.

1233 No. 4 is written in 24 -VI-o Nbn. No. 5 is damaged and the month of issue is illegible.

1234 Tolini 2015, 77-83, 86. But cf. Fales (1973, 137-142), who perceives the descendants of Nusku-gabbē as businessmen. According to him, the preserved tablets constitute only a part of their archive, not including the promissory notes issued by the family.
} 
Adad-[...]/Harimma ${ }^{2}$, has the title of royal merchant. ${ }^{1235}$ The West Semitic names of Ilqataru, Iltammeš-ili, and Harimma? yet again emphasise the international character of the royal administration in the long sixth century. ${ }^{1236} \mathrm{In}$ no. 6, the leased barley originates from the royal property (níg.ga lugal). The strong involvement of the royal administration in the promissory notes is noteworthy, and it indicates that the crown had substantial interests in the agricultural activities pursued in Neirab.

Second, two promissory notes exhibit a more complicated administrative structure. In no. 6, barley from the royal property is owed to PN/Itti-Šamaš[balāțu?], at the disposal of a certain Ardiya, and owed by Nuhsāya/Nuskugabbē. In promissory note no. 18, three sons of Nusku-gabbē owe a sūtu rent of 6;3.2 kurru of barley. The rent is due from a landholding, the management of which involved three different persons; unfortunately, their names are broken. The texts suggest that the Neirabian community was part of a complex hierarchy of land tenure and their position was close to the lowest rung of the ladder. Text no. 18 could be related to lands in private ownership, ${ }^{1237}$ but text no. 6 betrays the royal ownership of the land under tenure. Moreover, royal involvement in the affairs of the Neirabians is corroborated by no. $8 \| 9$, preserved in two copies. In this text, Manniya, Sîn-ab-ușur, and Nusku-killanni, sons of Nusku-gabbē, hire their slave Šer-idri to perform royal service (palāh šarri). In the Murašu archive, this term is related to obligations in the land-for-service sector. ${ }^{1238}$ It is therefore likely that the family of Nusku-gabbe held a bow land or similar property which was burdened with tax and service obligations. ${ }^{1239}$

The strong royal involvement in the barley debts found in the archive, the royal ownership of the cultivated land, the reference to service obligations, and the very existence of the twin town of Neirab indicate that the Neirabians were integrated into the land-for-service sector of Babylonian agriculture. It is conceivable that, like many other deportees, the Neirabians were settled in a newly founded community and provided with state lands to cultivate. Because most creditors of the barley debts are connected to the royal administration, the texts seem to be related to tax payments. It is possible that the

1235 No. 17. According to Tolini's collation $(2015,84 \mathrm{n} .83)$, the text reads l' gàr lugal which Tolini interprets as a scribal mistake for lúdam.gàr lugal. This is a plausible explanation for the difficult reading. The merchant's father has a West Semitic name, which allows us to count him among the several non-Babylonian royal merchants of this period. See Chapter 3 and Tolini 2015, 84 n. 83 .

1236 On the names, see Tolini $2015,71-72,84$ n. 83 .

1237 Cf. Tolini 2015, 83-84.

1238 CAD P, 46-47; Stolper 1985, 61-62; van Driel 2002, 290.

1239 Tolini $(2015,87)$ arrives at the same conclusion. 
sons of Nusku-gabbē simply paid their own taxes or that they were either foremen of the Neirabian community or businessmen engaged in agricultural management. ${ }^{1240}$

\subsubsection{Promissory Notes for Silver}

The promissory notes for barley fit into a certain pattern, but the set of silver debts is more diverse. However, the promissory notes for barley and silver share a common feature: there was no single loan that the Nusku-gabbē family gave to outsiders - they were always debtors, or the loan was given to other members of the Nusku-gabbē or Īn-Nusku families. ${ }^{1241}$ An interesting difference between the promissory notes for barley and silver is their date of issue: all barley loans were given in the reigns of Neriglissar and Nabonidus, whereas the silver loans were given in the reigns of Nabonidus, Cambyses, Nebuchadnezzar IV, and Darius I. Accordingly, the barley loans characterise the earlier phase and silver loans (nos. 1, 7, 13, 14||24, 16, 19-21, 27) the later phase of the archive. ${ }^{1242}$ Most of the silver loans were of modest size (2.25-9.5 shekels), but the last loan (no. 27) from the reign of Darius was considerably larger, at least one mina. The geographical nature of the barley and silver loans also differed: all of the barley loans were issued in the countryside, whereas the silver loans were issued both in the countryside and in two cities, Babylon (no. 1) and Hìt (no. 19).

Four promissory notes for silver, issued in the countryside in the reign of Nabonidus, are likely to stem from the same economic context as the loans of barley. Two of these can be classified as internal loans within the circles of the Nusku-gabbē and İn-Nusku families: no. 7 is a loan of 8.5 shekels from Manniya/Nusku-gabbē to his brother Nusku-killanni, and no. 14||24, preserved in two copies, is a loan of 4 shekels from Nusku-killanni to Sîn-lēeri/Inn-Nusku. The debtor and the creditor of no. 13 are not attested in other documents, but the loan of 6 shekels, the remainder of the price of a donkey, is guaranteed by Nuhsāya/Nusku-gabbē. Text no. 16 is a promissory note for a modest sum of 2.25 shekels owed by Nusku-killanni to a certain Zabadu/Edu-ana-ummišu. Like in the promissory notes for barley, the dates of issue and repayment are clustered at the turn of the Babylonian year (except for no. 7).

\footnotetext{
1240 Compare to the community of Bīt-Gērāya in the Murašû archive (Section 5.2) and to Ahīqam in Yāhūdu (Section 4.3.6.3).

1241 Fales 1973, 140-141.

1242 For an overview of promissory notes for silver, see Tolini 2015, 78-79.
} 
Two promissory notes for silver (nos. 20 and 27) do not refer to the Nuskugabbē family at all, ${ }^{1243}$ and no. 21 is too fragmentary to allow any reliable restoration of the names of the creditor (PN/Nusku-[...]) and the debtor (PN/ Nusku-[...]). However, nos. 21 and 27 can be connected to the archive via Nusku-na'id/Sîn-lē’i of the İn-Nusku family, who appears as a witness in both documents. All three promissory notes were issued in the Persian period, but the place of writing is illegible on every one of them. On the basis of the Nusku names in nos. 21 and 27, these two transactions took place within the Neirabian community. It is noteworthy that no. 27 concerns a debt that is significantly larger than others, at least one mina. The debts were issued and to be paid back at the turn of the year.

Two debts owed by Nusku-iddin/Nusku-killanni did not originate in the countryside but in the cities of Hìt and Babylon (nos. 19 and 1, respectively). No. 19 is a promissory note for 9.5 shekels of silver, the price of a donkey (1 Camb). Nusku-iddin bought the pack animal in Hit, a city which was located to the north of Babylonia but important for Babylonia because of its bitumen industry. ${ }^{1244}$ Corvée work in Hìt could have forced Nusku-iddin to travel north, ${ }^{1245}$ but the purchase of a pack animal suggests that the journey was connected to trade; of course, labour service and trading activities could take place during the same trip. In any case, it is evident that Nusku-iddin was not the only Neirabian in Hit: the debt was to be paid back in Neirab; the first witness of the document, Nargia/Hananaia, is attested in other texts of the archive; and the name of the second witness, Ilteri-nūr/Nusku-rapē, betrays his Neirabian background.

Another promissory note that was written further away from Neirab is no. 1, issued in Babylon during the short reign of Nebuchadnezzar Iv. Nusku-iddin/ Nusku-killanni owed 6.25 shekels of silver to Šamaš-udammiq/Nusku-māttukkin, but the badly damaged document does not supply any further information. The Nusku name of the creditor suggests that this transaction also took place within the Neirabian community. The background of the debt is probably similar to no. 19, and business activities drove Nusku-iddin to travel to Babylon.

The concentration of silver debts in the later phase of the archive, transition from barley to silver loans, and the archive's wider geographical scope in the Persian period leads Tolini to perceive a greater freedom for the Neirabians at

1243 No. 20 can perhaps be connected with no. 22 via a certain Barīkia. See Fales 1973, 138.

1244 Jursa 2010a, 145-148; Zadok 2014c; Tolini 2015, 88 + n. 89 .

1245 Tolini 2015, 87-88. 
this time. ${ }^{1246}$ This may be true, but, as Tolini notes, these developments may also indicate a change in the business activities of the Nusku-gabbe family. ${ }^{1247}$ It is noteworthy that the change of generation coincides with the widening of the archive's geographical scope, and Nusku-iddin, the grandson of Nuskugabbē, is for the first time attested as a fully independent actor in the promissory notes written in Hìt and Babylon. As several Babylonian archives testify, a change of generation sometimes resulted in changes in economic activities as well. ${ }^{1248}$

The previous discussion shows that - unlike the promissory notes for barley the silver debts do not easily fit a single pattern. The promissory notes for silver from the reign of Nabonidus originate from the countryside, and most of the debtors and creditors belong to the Neirabian community. No links to the royal administration can be observed. According to Tolini, these short-term debts of silver were social loans that helped the Neirabian community to survive during the time of shortage before the new harvest. ${ }^{1249}$ While this might be the case, the documents can also be related to business: ${ }^{1250}$ no. 13, a promissory note for 6 shekels of silver, results from the purchase of a donkey, a pack animal. Three promissory notes from the Persian period do not refer to the descendants of Nusku-gabbē, but two of them pertain to people with typically Neirabian names and can be connected to the rest of the archive via the İn-Nusku family. Finally, two promissory notes indicate a change in the last phase of the archive and Nusku-iddin's presence in the cities of Hìt and Babylon. These documents seem to relate to business activities. The structural difference between the promissory notes for barley and silver apply to the archive as a whole: the earlier tablets from the Neo-Babylonian period are a more coherent group and directly connected to the Nusku-gabbēs, whereas documents from the Persian period are more diverse and sometimes cannot be connected to other documents at all.

\subsubsection{Diverse Documents}

The rest of the documents in the archive are more difficult to put in a larger context, because they are all severely mutilated, otherwise difficult to understand, or do not exhibit links to any other documents of the archive. Nos. 11 and 12 are promissory notes for some unidentified commodity (to be read as ra-su-nu

\footnotetext{
1246 Tolini 2015, 87-90.

1247 Tolini 2015, 89-90.

1248 This is clearly visible in the Egibi archive. See Wunsch 200ob, 2007. See also the texts pertaining to Ahīqam and his sons in Yāhūdu (Section 4.3.6.3).

1249 Tolini 2015, 82.

$125^{\circ}$ See Fales 1973, 137-142.
} 
or ri-sa-nu?) and they are closely linked to each other. They were both issued in the seventh month of the tenth year of Nabonidus, two days between one another, and between the same creditor and debtor, Nargia/Hananaia and Nuhsāya/Nusku-gabbē. They were both written by the scribe Mukīn-apli/ Nādin in Bìt-dayyān-Adad (no. 11) and Ammat (no. 12). The loans were issued in an agricultural context between friends, relatives, or business partners, because Nargia and his son Hidirāya are attested several times in the archive.

No. 2 is a mutilated sale of some property worth 1 mina and 10 shekels of silver. The seller was Nuhsāya/Nusku-gabbē, but the part of the tablet containing the name of the buyer and the place of issue has broken off. The tablet was probably written in the reign of Nebuchadnezzar IV. It indicates - like no. 27 that the size of silver transactions grew in the last phase of the archive.

Two miscellaneous documents do not exhibit links to the Nusku-gabbē or Īn-Nusku families or to Nargia/Hananaia. No. 22 is a sale of a slave in the reign of Cambyses. The seller Barikia may be identical with the co-debtor of no. 20, but the broken sales contract does not allow us to extract any further information. Even less can be said about no. 25: the broken personal names cannot be connected to any other document.

No. 23 (= BMA 11) is a marriage agreement between the groom Bar-ahhāya/ Kukizza and the bride Bazīti's brother Nabû-êtir/Ea-zēr-iddin. The names of the bride, her brother, and her father were all Akkadian, ${ }^{1251}$ but the groom bore a West Semitic name and patronymic. ${ }^{1252}$ As the operative part breaks after introducing the parties of the agreement, nothing can be said about the conditions of the marriage. It is noteworthy that none of the parties bore Sin or Nusku names typical of the Neirabian community, and none of the protagonists or witnesses are attested in other documents. This situation is reminiscent of the marriage agreement from Yāhūdu $(\mathrm{Al}) \cdot{ }^{1253}$ It is possible that the document found its way to the Neirab corpus via a later marriage. ${ }^{254}$

The last document to be discussed is no. 26 , a property document, perhaps a sale, referring several times to Sîn of Neirab. The subject of the transaction is connected to Sîn of Neirab, but the nature of this object will remain obscure until the tablet is collated in the Aleppo museum. However, the reference to Sîn of Neirab seems to imply that the cult of the Neirabian moon god survived among the exiles in Babylonia.

$125^{1}$ On the female name Bazīti, see Cousin and Watai 2016, 10-11.

$125^{2}$ Tolini 2015, 71.

1253 See Section 4.3.6.2.

1254 Cf. Tolini 2015, 91 n. 96. 
The village of Neirab and its inhabitants can be located in the land-for-service sector of Babylonian agriculture. The strong royal presence in the promissory notes for barley, the reference to royal service (paläh šarri), the multi-layered administrative structures, and the archive's origin in the countryside point towards this conclusion. The texts from the village are centred on the descendants of Nusku-gabbē, suggesting that they belonged to their archive. The reference to the service obligations of this family indicates that they held a plot of royal land and were obliged to pay taxes and perform work or military service. The promissory notes for barley were most likely related to tax payments, because the majority of these documents pertain to the royal administration. Except for no. 18, all promissory notes for barley are owed by the sons of Nuskugabbē, and it is possible that these documents simply relate to the tax payments by the family.

There are, however, some features which suggest that the descendants of Nusku-gabbē participated in business activities. First, two sales of a pack animal, a donkey, imply a trading context. Second, Nusku-iddin's travels to Hìt and Babylon and the promissory notes for silver issued in these cities are better explained by commercial activities than tax payments. Third, members of the In-Nusku family are present in several transactions of the archive. They appear most often as witnesses, but no. 18 is a noteworthy exception: Sîn-lēe $\mathrm{i} / \overline{\mathrm{In}}$-Nusku and two members of the Nusku-gabbē family owe a sūtu rent together. This document implies that the three men were involved in agricultural management and that the descendants of Nusku-gabbē and Īn-Nusku were business partners.

We may suggest that the Nusku-gabbē family not only cultivated their own plot of land but also engaged in some entrepreneurial activities. Texts from the reigns of Neriglissar and Nabonidus document their activities in the land-for-service sector: they organised the cultivation of royal properties in the environs of Neirab together with the In-Nusku family. The sale of a donkey, guaranteed by Nuhsāya/Nusku-gabbē, suggests that the family participated in trading activities already at that time. In the last phase of the archive, the activities of Nusku-iddin/Nusku-killanni extended beyond Neirab and the surrounding villages, and beyond agricultural management in the landfor-service sector. He traded in Hìt and Babylon, but the nature of his transactions remains elusive. The family did not work alone, for the İn-Nusku family and Nargia/Hananaia and his son Hidirāya were also involved in several transactions. 
The majority of texts from Neirab can easily be assigned to the business archive of the descendants of Nusku-gabbē. ${ }^{1255}$ However, there are a number of documents which are not related to the family or its business partners. This may result from return migration: when part of the Neirabians returned from Babylonia to their ancestral hometown, some of them brought a number of cuneiform tablets along. Some originally independent documents got mixed up with the texts of the Nusku-gabbē family, and when one of the returnees died in Neirab of Syria, the tablets were buried together with him.

The texts from Neirab pertain to the same social and economic context as the majority of the documents relating to Judeans. Texts from Neirab, Yāhūdu, and the Murašû archive show that the Babylonian state resettled deportees in communities according to their ethnic origin. This is reflected in the names of the new settlements: Neirab was also known as the town of Neirabians and Yāhūdu as the town of Judeans. The deportees were given a plot of land to cultivate, and they were obliged to pay taxes and perform work and military service in exchange. Accordingly, the deportees were a source of revenue and they were closely supervised. The royal administration is strongly present in all the three text corpora.

It is noteworthy that the texts from Neirab and from the environs of Yāhūdu were written in Babylonian cuneiform. The deportees themselves were hardly literate in Akkadian, but some of them could probably read and write Aramaic or Hebrew. The evidence from the environs of Yāhūdu suggests that the state administration played a central role in the production of the texts, apparently in order to control the activities in the land-for-service sector. The state required that documents were written in cuneiform; this is the reason why transactions between the members of the Neirabian community were written in cuneiform as well. Five documents from Neirab bear Aramaic epigraphs, and such epigraphs are common in the texts from the environs of Yāhūdu and the Murašu archive as well. The existence of the epigraphs suggests that Aramaic was widely used, but that it was necessary to record the transactions primarily in cuneiform.

The naming practices of the Neirabian community exhibit continuity. Names containing the theophoric elements Nusku and Sîn are common in the archive, as are other West Semitic names. The scribes were by far the largest group of people bearing fully Babylonian names, but the influence of Babylonian can be detected in the Neirabian onomasticon as well. Some members of the community had pure West Semitic names, while others used Babylonian

1255 Fales 1973, 137-142. 
names referring to the lunar cult. The persistence of Sîn and Nusku names is reminiscent of the continuity of Yahwistic names among Judean communities in the countryside. It appears that the Babylonian practice of settling deportees in ethnically homogenous villages in the countryside supported cultural continuity among the immigrant communities. 


\section{Conclusions}

In the previous chapters, I have discussed several text groups pertaining to Judeans and Neirabians in Babylonia in the sixth and fifth centuries BCE. They concern different geographic and social contexts: King Jehoiachin of Judah and his sons were held hostage in Babylon where some Judean professionals worked as well (Chapter 2). A family of Judean royal merchants lived in Sippar, traded with the local temple, and was well-integrated into the Sipparean community of traders (Chapter 3). Judean and Neirabian farmers cultivated fields and gardens in the land-for-service sector of the Babylonian rural economy (Chapters 4-5, 7). They were granted plots of state land to cultivate and they were required to pay taxes and do work and military service in exchange. These texts reveal notable diversity in the deportees' socio-economic status and level of integration into Babylonian society. The financial means and social networks of the royal merchants were quite different from those of the average Judean farmer, while some farmers were able to benefit from the structures of the land-for-service sector at the expense of their compatriots.

None of the texts explicitly touch upon the reasons which brought Judeans and Neirabians to Babylonia. They are never called prisoners, captives, or deportees. Nevertheless, there seems to be no doubt that the great majority of these people were deportees and their descendants. The presence of Judeans in Babylon is clearly linked to the deportations of the upper class from Jerusalem, and the rural communities of people of foreign origin could not have come into existence without state-organised forced migration and resettlement. The Judean royal merchants and some other Judeans living in cities are the only group which could have arrived in Babylonia voluntarily. Accordingly, even if voluntary migration is a well-attested phenomenon in the ancient Near East, the subjects of the present study are primarily deportees and their descendants.

Throughout this book, naming practices were the primary means of identifying people of non-Babylonian origin. As explained in detail in Section 1.5, Judeans are identified on the basis of theophoric names containing a Yahwistic element, whereas people with West Semitic Sîn and Nusku names from the village of Neirab are regarded as Neirabians. Logically following from this, the family members of these people are labelled as Judeans or Neirabians as well. The caveat of this method is its inability to identify a large part of the deportees and their descendants. People with common Babylonian or West Semitic 
names could be descendants of recently arrived immigrants or belong to families which had lived in Babylonia for centuries. Consequently, only those immigrant families which continued to use Yahwistic names, for instance, can be identified, and they come to represent the whole Judean population in Babylonia. The method used in this study can thus identify only people who stuck to certain naming traditions, and it may be that the more conservative and less integrated subset of immigrants dominates the sources which we have identified.

This concluding chapter aims to provide the reader with an overview of some larger themes concerning deportees in Babylonia. Whereas the previous chapters analysed specific text groups or archives, the present chapter draws from the whole corpus of texts pertaining to Judeans and Neirabians. Many findings related to these two groups are applicable to deportees as a whole, and, accordingly, this chapter often refers to deportees in general instead of Judeans or Neirabians in particular.

\subsection{Sources: the Perspective of Babylonian Scribes}

The availability of sources for a historical study is not only subject to the preservation of textual and material remains from the past but also to the limits of what sources were actually produced. ${ }^{1256}$ Except for clay tablets, there are no material remains which can be linked to deportees living in Babylonia in the sixth and fifth centuries BCE. ${ }^{1257}$ When it comes to written sources, it is evident that a wealth of texts was produced in Babylonia during those two hundred years. Even the tiny portion that has come to us consists of tens of thousands of cuneiform documents. However, not everybody produced texts as we do nowadays; a small literate minority was responsible for the whole enterprise. ${ }^{1258} \mathrm{It}$ is perhaps better to speak of two literate minorities, as texts were written in Akkadian and Aramaic, but literacy in one did not obviously mean literacy in the other. The social contexts in which these languages were written were different: the stronghold of Akkadian was located in the sphere of temples and the urban upper class, whereas Aramaic had an established position in the state administration. Both languages were spoken, but Aramaic was replacing Akkadian as a vernacular. Moreover, if deportees from Syria and the Levant wrote any of these two languages, it was most likely Aramaic. No deportees are

1256 For a helpful scheme of the process of disappearance and preservation, see Baker 2004, 6 .

1257 Section 1.4.

$125^{8}$ Section 1.2.4. 
attested among the cuneiform scribes who bore Babylonian names and belonged to an exclusive group of urban families. At the same time, some Aramaic scribes (sēpirus) of foreign origin are attested, and many deportees came from regions where Aramaic had been spoken and written for centuries.

For the purpose of a historical study, the most decisive difference between Akkadian and Aramaic is the medium of writing. Akkadian was written on clay tablets, while Aramaic was written on perishable materials, and all that is left of Aramaic texts from Babylonia are short captions on a relatively small number of cuneiform tablets. Accordingly, the sources of this study are not representative of all literary production in Babylonia, and, what is more important, they were written by members of one rather homogenous group in Babylonian society. This group, commonly referred to in this study as the urban upper class, consisted of families which perpetuated the Akkadian scribal traditions, dwelled in cities, and were closely attached to the temple cult. It is on the basis of the perspective of these people that we perceive immigrants and Babylonian society in general. ${ }^{1259}$

The preserved Akkadian texts primarily originate from temple archives and archives of urban families. Judeans hardly ever appear in temple archives, nor are they attested in most private archives, the protagonists of which belonged to the urban upper class. Nothing similar to the state archives of Assyria has been unearthed, and all that was found during the excavation of royal palaces in Babylon is the so-called Palace Archive of Nebuchadnezzar II (Chapter 2). This is presumably explained by the incidental preservation of clay tablets and the importance of Aramaic in the state administration.

Texts pertaining to the land-for-service sector of Babylonian agriculture are a rich source for the study of immigrants, but the agency of deportees in producing these documents should not be overestimated. The Murašû archive was the business archive of a Babylonian family from Nippur, and it is doubtful if the texts from the environs of Yāhūdu actually belonged to Judean private archives, similar to those of urban Babylonian families. As suggested by Waerzeggers, recording economic activity was an efficient means of control, and the scribes in the land-for-service sector were part of the administrative apparatus. ${ }^{1260}$

It has to be emphasised that the voice of deportees themselves can hardly ever be heard in the surviving documentation. The existence of Akkadian texts pertaining to transactions between two Judeans or two Neirabians does not necessarily mean that they decided to use cuneiform instead of Aramaic, as

1259 Section 1.2.4.

1260 Waerzeggers 2015. See Chapters 4 and 5. 
this may have been dictated by administrative or legal necessities. If Judeans or Neirabians themselves produced texts in Babylonia, no material remains of such activity have survived. The eyes through which we perceive deportees are those of Babylonian scribes and the state administration.

\subsection{Resettlement and Organisation of Deportees}

Unlike Assyrian sources, the extant Neo-Babylonian royal inscriptions and letters do not boast about the crowds of captives brought to Babylonia or inform us about the process of moving and resettling them in Babylonia. Accordingly, our knowledge of Babylonian practices of deportation is scarce. ${ }^{1261}$ There is no doubt, however, that deportations did take place, especially in the reigns of Nabopolassar and Nebuchadnezzar II when Babylonia conquered the territories of the former Assyrian Empire. Babylonian chronicles occasionally refer to kings taking prisoners during their campaigns, ${ }^{1262}$ and Nabonidus claims in one instance that he donated 2,850 prisoners of war to Babylonian temples. ${ }^{1263}$ The Hebrew Bible attests to the tribute and deportees which Nebuchadnezzar II took from the Levant, and the archaeological excavations in Judah and Ashkelon confirm the picture of destruction and population collapse. Nebuchadnezzar boasts that all the regions and peoples of his empire participated in the construction works of the ziggurat Etemenanki and his South Palace, ${ }^{1264}$ but this can imply payment of taxes and tributes instead of concrete corvée work in Babylon. ${ }^{1265}$ In any case, ration lists from Babylon attest that foreign professionals and exiled royalty lived in the capital and were maintained by the state administration. ${ }^{1266}$ Second Kings 24:14-16 also supports the view that Babylonia practised selective deportations, as Judean royalty and craftsmen are explicitly mentioned among the people transferred from Jerusalem to Babylon.

Although the process of deportation cannot be reconstructed in detail, more can be said about the practices of resettling deportees and organising them in administrative structures. The situation in the countryside is the clearest.

1261 For brief summaries, see Dandamayev 1991, 268-270; Vanderhooft 1999, 110-112; Albertz $2003,82-83$.

1262 See, for example, $A B C$ 3:5-9; 6:8-23.

1263 Nabonidus' stela from Babylon (Schaudig 2001, 521 ix:31'-41'). See Beaulieu 2005, 58. Egyptian temple dependants (širkus) are well attested at the Ebabbar temple (Hackl and Jursa $2015,15^{8-160)}$.

1264 Langdon 1912, 146-148 cols. ii-iii; Da Riva 2013, 211 v*:21'-34'.

1265 See Beaulieu 2005, 2008, 7-8; Jursa 2010a, 661-669; Da Riva 2013, 204-205, 219-220.

1266 Section 2.4 . 
The twin towns of Yāhūdu and Neirab bear witness to the custom of settling deportees in villages which were named according to the geographic origin of their inhabitants. ${ }^{1267}$ The state assigned plots of land to deportees, who were required to pay taxes and perform work or military service in exchange. The majority of sources pertaining to Judeans and Neirabians originate from this land-for-service sector of Babylonian agriculture, and it is probable that this not only results from an incidental preservation of sources but reflects actual deportation policies. Babylonia was an agricultural society, and the majority of its population lived and worked in the countryside. ${ }^{268}$ There was an abundance of fertile soil, but the limited availability of water, men, oxen, and tools constrained agricultural produce. This applied especially to central Babylonia, which trailed behind the intensification of agriculture in the north. The Murašû archive originates from this region (Chapter 5 ), and there are reasons to suppose that the villages of Yāhūdu, Našar, and Neirab were located there as well (Chapters 4 and 7 ).

Texts pertaining to Judeans also allow us to trace some chronological developments in the land-for-service sector. ${ }^{1269}$ The earliest texts from Yāhūdu, written in the reigns of Nebuchadnezzar II and Nabonidus, show that Judeans cultivated state lands, some of which were under the authority of a high officer (rab mügi). The term 'bow land' (bìt qašti) is not attested, but a text refers to a 'quiver land' (bit azanni) held by a Judean man. This term is extremely rarely attested, but given its literal meaning, it must have been roughly equivalent to a bow land. A bow land was a parcel of land of varying size, the holder of which had to pay certain taxes and fulfil service obligations. The term implies service as a bowman, but the available sources attest to remarkable difference in the size of bow lands, which must have been somehow reflected in the respective service duties as well. Larger landholdings were called 'horse land' (bït sīsê) and 'chariot land' (bit narkabti)' and their holder was obliged to provide the state with a horseman or war chariot.

No visible changes took place in the beginning of the Persian period, but texts from the reign of Darius I show clear terminological differences. Judeans now hold bow lands and their dependent status is emphasised by the title šušānu. Šušānus belonged to the class of the semi-free population in Babylonia: they were not chattel slaves, but the state and its representatives could control them and exploit their labour quite extensively. Moreover, landholders

\footnotetext{
1267 Chapters 4, 5, and 7 .

1268 On the Babylonian economy in the mid-first millennium BCE, see Stolper 1985; van Driel 1989, 2002; Jursa 2010a.

1269 Chapters 4 and 5 .
} 
are now organised in units of ten and they are represented by one of their peers. This structure resembles eširtus, or units of ten, which are attested in Babylonian cities and temples, and which were responsible for tax payments and work or military service. Finally, texts from the reign of Darius I introduce the governor of Across-the-River as the highest authority over Judean landholders, but the official called rab mügi does not feature in the texts any more.

The texts from the Murašu archive from the late fifth century pertain to Judean holders of bit rittis (a kind of institutional landholding), bow lands, and horse lands, often as partners of people with non-Yahwistic names. The most important novelty in the Murašu archive is the hațru, an administrative unit in which holders of state lands were grouped together. The names of hatrus often pertain to ethnic or professional groups. However, these names did not always designate the status of landholders but rather the status of the beneficiaries of the hatru. Judeans, for instance, were primarily organised in hatrus of seppirus, which were named after high-ranking officials in charge of the units. Thus, the names do not indicate that the Judean landholders were sêpirus themselves. Taxation terminology appears to be more standardised in the Murašû archive, and the annual tax obligation is usually represented as the whole $i l k u$, the king's man (șāb šarri), flour (qēmu), bāru, and any other presents to the house of the king (mimma nadānātu ša büt šarri). The evidence from the environs of Yāhūdu is more random, and some texts refer to ilku, some to șāb šarri, and others to rental payments (sūtu and imittu) to the crown.

Although the texts from the environs of Yāhūdu and from the Murašu archive cover a period of 150 years and contain terminological differences, it is difficult to know which changes reflect historical processes and which are just a result of the incidental nature of the documentation. As bow lands are attested in other sources already in the reign of Nebuchadnezzar II, they were not a novelty introduced by Darius I. Moreover, the existence of Yāhūdu in the mid-sixth century and the large number of twin towns in the late fifth century suggest that the deportees were organised from the very beginning in communities according to their geographic origin, and this custom did not change over time. The ten-man units of farmers and fields of Judean šušānus in Yāhūdu and the hatru system in the Murašu archive attest to the same phenomenon. Terminology and organisational structures evidently developed over time, but the land-for-service sector remained essentially the same. The basic outcomes of this system did not radically change either: texts from the environs of Yāhūdu and from the Murašû archive pertain to tax payments, concrete work or military service, and payments made to hire substitutes to perform the service obligations. Details of this system are difficult to reconstruct, because both text groups show that the preservation of pertinent evidence was often 
incidental. The evidence of șāb šarri payments in the environs of Yāhūdu is the result of the unrest surrounding the accession of Darius I, and the concrete nature of military service in the Murašu archive is confirmed only by a single text group from the second year of Darius II.

Two well-known features of the Assyrian deportation policy are the holding of royal hostages at the imperial capital and the assignment of foreign craftsmen and elite troops to building projects and the army. Babylonian evidence of these practices comes primarily from the Palace Archive of Nebuchadnezzar II which attests to the presence of foreign royalty, soldiers, and craftsmen in Babylon (Chapter 2). The presence of King Jehoiachin, his retinue, and some Judean officials in Babylon corroborate the account in 2 Kings 24 of the deportation of upper classes from Jerusalem. Apart from a Judean gardener, Judean craftsmen and soldiers are not attested in the archive.

It appears that Babylonian kings donated deportees to temples or assigned them as corvée labour to public building projects only to a small extent. There is some evidence of both practices, but deportees did not play a key role in the temple economy and hired labour was largely used in building projects. ${ }^{1270}$ Given the huge size of the preserved temple archives, this is hardly incidental, and it is likely that the state primarily kept deportees under its own control and did not donate them to temples in large numbers. The main destination for deportees was the land-for-service sector in the countryside. It met the needs of the state by increasing agricultural output and providing the state with taxes, soldiers, and labour.

The aims of Babylonian deportations were similar to their Assyrian counterparts. They primarily aimed at pacifying conquered regions and generating economic growth. Deportation could serve as a punishment for rebellion, ${ }^{1271}$ and foreign royalty were held hostage to prevent their relatives from revolting in the future. Soldiers, craftsmen, and other professionals were taken captive and employed in the army, crafts, building works, and the state apparatus. Agriculture was of huge importance to the Babylonian economy, and a great many deportees were settled in the countryside to bring new land under cultivation. There is no evidence that the Babylonians practised Assyrian-style two-way deportations, but deportees were predominantly taken to Babylonia, especially to depopulated areas in the countryside.

Voluntary migration undoubtedly took place in the sixth and fifth centuries as well, and the presence of Iranians and Arabs in Babylonia attest to this phenomenon. However, when it comes to Judeans, Neirabians, and other recent

1270 On hired labour in public projects, see Jursa 2010a, 661-681.

1271 On the case of Judah, see Section 1.2.3. 
arrivals from Syria and the Levant, it is likely that only a tiny portion of them were not deported to Babylonia. It is hard to imagine that the population of twin towns, foreign royalty and professionals in Babylon, and foreign temple dependants (širkus) had arrived in Babylonia of their free will. Merchants offer the only example of Judeans whose migration to Babylonia could well have been voluntary. Long-distance trade connected the Eastern Mediterranean to Babylonia, and it cannot be excluded that some foreign merchants travelled to Babylonia for the purpose of trade and eventually settled there. Nevertheless, it is perhaps no coincidence that many foreign traders worked as royal merchants and were thus somehow part of the state apparatus. There is no evidence to corroborate this suggestion, but one needs to remain open to the possibility that deported merchants were attached to the state in the same manner as craftsmen or professional soldiers.

\subsection{Social and Economic Aspects of Life in Babylonia}

The majority of deportees were settled in the countryside, and most - if not all of them - were attached to the land-for-service sector. Large numbers of deportees were settled in underdeveloped rural areas in central Babylonia, and they were given plots of land to cultivate. The plots could not be sold, and their holder was responsible for paying taxes and performing service obligations incumbent on the landholding.

Although the terminology concerning the land-for-service sector developed over time, there was no parallel process of standardisation. Landholdings were described as bow, horse, and chariot lands according to the type of troops they were obliged to outfit for royal service. At the same time, a bow land could refer to a small plot cultivated by a family or to a huge holding which had to be cultivated by dozens - if not hundreds - of farmers. Therefore it is likely that a bow land was not always expected to equip only a single bowman but sometimes several bowmen, according to its size. The burden of tax and service obligations also varied in relation to political circumstances. Landholdings in the land-for-service sector were only sometimes under the direct control of the king and his estates, and usually they were at the disposal of royalty and high officials of the state. These men of high status were able to use the resources for their own benefit, and the struggles for the Persian throne after the death of Cambyses and Artaxerxes I are reflected in the texts from the environs of Yāhūdu and in the Murašû archive, respectively. ${ }^{1272}$

1272 Chapters 4 and 5 . 
Judeans held bow lands in the environs of Yāhūdu and in the Nippur countryside, and a Judean family is attested as holders of a horse land in the Murašû archive. Several Judeans also held properties called bit ritti, the exact nature of which still escapes us. In any case, it is quite clear that the term describes properties which were not the private property of their holders. No Judean holders of chariot lands are attested. In the environs of Yāhūdu, Judean landholders and their landholdings were organised together as an ethnic unit: Judeans lived in the village of Judah, documents refer to the fields of Judean šušānus in a collective tone, and Judean landholders were organised in units of ten. Similarly, the village of Neirab was named after the geographic origin of its inhabitants, and references to the royal property, state officials, and royal service (palāh šarri) show that Neirabian deportees were integrated into the land-forservice sector as well. The term 'Judean' is not used in the Murašû archive, but the practice of organising landholders according to their ethnic or geographic origin is well attested in the archive. Judeans primarily belonged to the hatrus of sēpirus, and they appear as inhabitants of certain villages. At the same time, the co-holders of a bow land often bore very diverse names, and it is likely that Judeans shared their responsibilities with people of non-Judean origin as well.

The communal aspect of living and landholding in the countryside is not only reflected in the administrative organisation of farmers, as landholdings and the pertinent obligations were often shared between several families. Villagers could join their forces to secure a stronger position vis-à-vis the state and businessmen in the land-for-service sector and thus improve their economic condition. This aspect is often obscured by the extant documentation, which usually refers to a couple of landholders only, but a closer study reveals that the named people were often representatives of a larger group of local farmers. ${ }^{1273}$

Landholders in the land-for-service sector were a semi-free population. They cannot be described as slaves, but not as free peasants either. They did not own the land they held and thus could not sell it, although the plots were transferred as inheritance from one generation to the other. The landholder was responsible for paying taxes and providing the state or its representatives with work and military service. Sources from the Persian period often use the word šušānu to describe landholders in this context, but it remains unclear if the term practically covered all subjects of the land-for-service sector or if it had a more specific meaning. Despite the obligations incumbent on them, the landholders had considerable freedom to move about in Babylonia, lease out their plots, or hire substitutes to perform service obligations. This allowed

1273 See Section 5.2. 
landholders to outsource to others the responsibilities related to their plots and to find alternative ways of earning income in the countryside. Some of them had careers as businessmen and they could profit from the structures of the land-for-service sector. Some of these people bought rights to collect rental payments on behalf of the state, while others provided credit to less fortunate landholders. These operations were often accompanied by beer brewing and trade in staples, which brought rural businessmen to cities to sell their produce. Successful businessmen could benefit from the financial difficulties of their fellow landholders, which created inequality within the rural communities. In the same vein, there was disparity between the holders of small plots and families with more extensive landholdings.

Some landholders in the land-for-service sector also owned private land, but there is, for instance, no evidence of free Judean peasants who only cultivated their own lands. Chattel slaves did not play any important role in agriculture, but some landholders and agricultural businessmen had slaves who served the family at home or ran a brewery or tavern in the city. Some Judeans had slaves of presumably Egyptian origin, and there is one example of a Judean family who owned a slave with a Yahwistic name. If the slaves were not renamed by their current or former masters and if they actually originated from Egypt and Judah, these cases attest to significant social stratification within rural deportee communities. ${ }^{1274}$ The deportees called slaves of high officials or royalty are better seen as minor officials. Deportees also fished and herded animals, but the sources are scarce and it is unknown how common this was.

The available sources from cities are fewer but more diverse than those from the countryside. If the state archives of Babylonia had been preserved to the same extent as their Assyrian counterparts, the number of attested foreign soldiers, craftsmen, and workers would probably be significantly larger, at least in Babylon. This is suggested by the fact that the only extant part of the administrative archives from Babylon attest to the presence of numerous professionals of foreign origin in the capital. As noted above, private archives from cities are generally a fruitless source for the study of immigrants, as the archive-holding families primarily interacted with a closed circle of friends and colleagues.

The presence of King Jehoiachin of Judah, his five sons, two Ashkelonite princes, and perhaps some members of Lydian royalty in Babylon in the 590 s testify to deportations of upper classes from the Eastern Mediterranean (Chapter 2). The Judeans were held hostage in order to prevent rebellions in Judah, but this did not stop Zedekiah from rising against his Babylonian overlords. As the preserved tablets were written already before Zedekiah's rebellion, it

1274 On Judean slaves and slave ownership in Babylonia, see Magdalene and Wunsch 2011. 
remains unclear if his actions had any consequences for his relatives in Babylon. In any case, the conditions of royal hostages were closer to house arrest than imprisonment, and the large oil rations to Jehoiachin suggest that his royal status was reflected in the way he was treated. If his five sons were not already born in Jerusalem, he was apparently able to live with his family and even produce heirs in captivity. The account of 2 Kgs 25:27-30 on the amnesty of Jehoiachin hardly fits this evidence, such that it is better seen as a literary creation and hopeful ending to the biblical book. ${ }^{1275}$

Foreign soldiers and craftsmen from the border regions of the empire were also deported to Babylon and maintained by the royal administration. The troops guarded important locations in the capital, and craftsmen, such as boatbuilders, practised their profession for the benefit of the empire. Given their value for the state, it appears that foreign professionals were treated well, although they were dependent on the palace and obviously could not leave the city freely. If they were allowed to marry and reproduce, it is unknown if their children were still regarded as dependants of the palace. The communities in the countryside lived under the same conditions for generations, but not all children of a soldier were fit for their father's profession.

Because literacy in Akkadian was by no means a prerequisite for working in the royal administration, some educated deportees were assigned to offices of lower and higher rank. Judeans are primarily attested as minor officials in the land-for-service sector, and as such they were responsible for collecting taxes, organising work and military service, and ensuring the efficient cultivation of royal lands. Judeans found their way into more important positions in exceptional cases only, and the Judean sēpiru and Judean courtiers (ša rēšs šarri) in Babylon in the 59os were probably former members of the court in Jerusalem. A Judean sêpiru served the governor of Across-the-River in the early Persian period, but the background of this rare case cannot be reconstructed from the single reference to his name in a single document. ${ }^{1276}$ Egyptians and people with West Semitic names are frequently attested in high offices, but their nonBabylonian names do not suggest that they were deportees. West Semitic names in Babylonia are not indicative of foreign origin in the mid-first millennium, and it is uncertain that all Egyptians had arrived in Babylonia as deportees.

Very few Judeans were integrated into urban communities to the extent that their social networks also included people from Babylonian families. The royal

1275 Section 2.5.

1276 See Section 6.1. 
merchants in Sippar examined in this study were a rare example of such people, as they were members of the local mercantile community and even gave their daughter in marriage to a Babylonian man with a family name (Chapter 3). The community of traders in Sippar was multicultural, and Judeans and other people of foreign origin worked there together with indigenous Babylonians. Nevertheless, this community was distinct from the priestly community of Sippar, and although the Judeans met temple personnel when they traded with the temple, their personal networks did not reach the priestly circles. The relatively small dowry paid to the family of the Babylonian groom indicates that it was attractive to marry into the Judean family: this can be explained by their rather high status as royal merchants and perhaps by their business networks as well. The case of this single Judean family is representative of the situation in cities as a whole. Deportees and other foreigners are found in the spheres of trade, crafts, and the administration, but not in the circles of Babylonian families who held priestly offices and ran the temples.

The presence of deportees in cities does not necessarily mean that they all lived there. People from the countryside are regularly attested as witnesses in the Murašû documents drafted in Nippur. Some of these people are also attested as principals in other documents, which shows that they were usually landholders in the land-for-service sector. They had to come to Nippur to deal with officials or the Murašu family, and once they had come there, they were occasionally asked to witness some documents. Brewing, keeping a tavern, and the retail of agricultural produce also brought deportees from rural communities to cities.

Deportees were not controlled by means of enslavement, but their dependence on the state was secured by other means. Integration of deportees into the land-for-service sector and the centralised maintenance of foreign professionals in Babylon brought them under close supervision by the state. Some non-professional corvée labour in large projects was probably controlled in the same way, but the available sources suggest that this was not a major occupation of deportees. Babylonian kings donated some deportees to temples, which gave a newcomer the status of širku ('temple dependant'), but this was the fate of a relatively small number of deportees.

The protagonists of the available sources primarily belong to the better-offs among the deportees in Babylonia. People like Ahīqam and Ahīqar from the environs of Yāhūdu, King Jehoiachin in Babylon, and Judean royal merchants in Sippar are not typical examples of deportees. A small farmer in the landfor-service sector was the average deportee in Babylonia in the mid-first millennium. The majority of the population in Babylonia lived on or below the 
subsistence level, ${ }^{1277}$ and the income of these landholders was not any higher. In addition to providing for their family, landholders had to take care of tax payments and service obligations or substitute payments in silver. These obligations occasionally exceeded the income of their plot, and landholders were forced to assume a loan to make ends meet. This often led to serious financial problems if the debtor had to pledge his landholding to secure the debt, and, consequently, he could become a lessee of his own plot. The life of a farmer was probably not any harder in Babylonia than in Judah or Neirab, but given the elevated social background of many deportees, their new socio-economic status in Babylonia may have felt miserable.

\subsection{Women}

Men dominate the Neo-Babylonian textual records, and this also applies to the documents pertaining to deportees and their descendants. Although women could engage in the same types of legal contracts and economic transactions as men did, ${ }^{1278}$ they remain in the margins of the documentary sources of the patriarchal society. This section surveys the role and status of women in Judean and Neirabian deportee communities in Babylonia.

The Assyrian Empire deported women and children in addition to men, and the Babylonians continued this practice. Second Kings 24:15 refers to the deportation of the king's mother and wives from Jerusalem, and the evidence from Nebuchadnezzar II's Palace Archive suggests that King Jehoiachin was able to live with his family in Babylon. More importantly, the creation of permanent twin towns in the Babylonian countryside was only possible if both men and women were settled there. Quite surprisingly, no Judean women are attested in the Murašu archive, but several women - some of them of Judean origin - feature in the texts from Yāhūdu and its surroundings. In the texts from Neirab, only a single document - a marriage agreement - pertains to women (Chapter 7 ).

In the documents from Yāhūdu and its surroundings, women are usually attested together or in relation to their husbands, brothers, or sons (Chapter 4). Women guaranteed their husbands' debts and concluded transactions on their behalf. Moreover, wives and mothers are attested as debtors together with their husbands and sons, and some married couples participated in harrānu

1277 Jursa 2010a, $762-764$.

1278 Wunsch $2003 \mathrm{~b}$. 
business ventures together. Despite the usual co-occurrence of women and their male relatives in the extant documentation, women occasionally concluded transactions completely on their own. They could grant credit and own, buy, and sell movable property, such as animals and slaves. This evidence implies that women not only participated in economic activities at home but could also assume an active role outside. However, this becomes explicit only in exceptional cases, such as when their male relative was not available or the other party of the transaction required an additional guarantee for the fulfilment of the obligation. The two extant marriage agreements from Judean communities support this view: brides of foreign origin were given in marriage by their brothers and mothers in the absence of their fathers.

Not all deported women shared the semi-free social status of the people in the land-for-service sector, as some of them were enslaved and others attached to temple households. Judean slave women are not attested, but some wealthier Judeans owned slave women of foreign origin. This seems to indicate that certain less fortunate deportees ended up serving other deportees in Babylonia. Although temples were not among the main destinations of deportees, a couple of Judean women were dependants of the Ebabbar temple in Sippar.

Deportees not only married within their own community.1279 A Judean woman from a family of royal merchants even married into a Babylonian family from the urban upper class. This was exceptional, however, and most deportees found spouses among other deportees and local lower classes. Marriages involving deportees were at least occasionally recorded on clay tablets, according to the Babylonian practice, but it remains unclear if such documents were also written in Aramaic on perishable materials. ${ }^{1280}$ Nothing suggests that there was a legal obligation to write a document in Akkadian before the marriage was valid, ${ }^{1281}$ nor was there a specific social context to which the marriage agreements belong. They are attested in urban and rural contexts, and, in the most peculiar example, two families with Egyptian names concluded a Babylonian-style marriage agreement in Susa. ${ }^{1282}$

When it comes to the wife's status in marriage, some differences can be observed despite the general homogeneity of Babylonian marriage agreements in

1279 Marriage agreements from Judean and Neirabian communities are discussed in Sections 3.3, 4.3.6.2, and 7.2.4.

1280 Such Aramaic documents are attested in the Elephantine and Babatha archives. See Lemos 2010, 62-80. On Babylonian marriage agreements, see Roth 1989; on marriage agreements pertaining to people of foreign origin, see Abraham 2005/2006, 2015.

1281 Roth 1989, 28.

1282 BMA 34. See also marriage agreements BMA 35 and Joannès 1990 no. 1, as well as the discussion in Abraham 2015, 41-44. 
the sixth century. First, all marriage agreements pertaining to brides without a family name include the so-called 'iron dagger' clause: if the wife was caught with another man, she would die by the (iron) dagger. This applied to all marriages involving deportees as well. On the contrary, the clause is absent from marriages which involved a bride from the urban upper class. Adulterous wives were undoubtedly punished in upper-class families as well, but the social norms which guided behaviour in the upper social stratum were apparently different from those prevailing in the lower strata. ${ }^{2283}$ Second, families of nonBabylonian origin could influence the wording and stipulations of marriage agreements, even though they were written by Babylonian scribes. ${ }^{1284}$ An interesting example is a marriage agreement between two Egyptian families, which explicitly allows the bride to get a divorce from her husband. Normally only the husband was able to do this, and such a stipulation is not attested in any other extant marriage agreement from Babylonia. ${ }^{1285}$

The small number of documents pertaining to Judean and Neirabian women conforms to the picture emerging from the contemporary Babylonian sources. Men dominated the public space, and they are typically attested as the protagonists, witnesses, and scribes of the documents. However, women are attested in various contexts and text types, and they could assume an active role especially when their husband was absent or deceased. When the male head of the family was not present, his wife could give their daughter in marriage or pay taxes and debts on behalf of her husband. Women could also own and manage valuable property, such as slaves and cattle. However, because women did not have a share in their fathers' inheritance and the dowry was not at their disposal, their economic independence was severely restricted and most of them were ultimately dependent on their father or husband. ${ }^{1286}$

\subsection{Religion}

Ancient religion is often perceived through the lens of temple worship and state-sponsored cults. This results from the fact that private worship and household religion are far less often touched upon in the available sources. This applies both to the Levant and Mesopotamia: monumental temples are among the most notable archaeological discoveries, and a wealth of written

1283 Waerzeggers 2016.

1284 Abraham 2015.

1285 BMA 34. See Roth 1989, 14-15.

1286 Wunsch 2003b. 
sources describe different aspects of state-sponsored cults. When it comes to deportees' religion in Babylonia, textual sources are few, and no material evidence exists. This section is an attempt to sketch some rough outlines about this aspect.

The destruction of Jerusalem and its temple and the deportations to Babylonia have rightfully been seen as transformative events in ancient Judean religion. ${ }^{1287}$ It has been suggested that many religious practices, such as Sabbath observance, developed, gained new importance, or were reshaped among the Judeans in Babylonia as response to these changed circumstances. ${ }^{1288}$ However, one should not be guided by the idea (Deut 12) that the Yahwistic sacrificial cult was only possible in the temple of Jerusalem ${ }^{1289}$ and that altars or temples dedicated to Yahweh could not exist in Babylonia. The evidence of Yahwistic temples in Elephantine and Leontopolis, for instance, attests to the existence of other cultic centres which were contemporaneous with the second temple in Jerusalem. ${ }^{1290}$ In light of this evidence, there seems to be no internal religious reasons which would have prevented Judeans from constructing a temple or a small shrine in Babylonia as well. ${ }^{1291}$ Indeed, the mention of 'Casiphia the place' in Ezra 8:15-20 has been interpreted as a reference to a Yahwistic temple in Babylonia. ${ }^{1292}$

Cuneiform texts or archaeological sources do not attest to a temple of Isis, Baal, or Yahweh in Babylonia, but the absence of a monumental building does not mean that such sacrificial cults did not exist. A small altar in the midst of a village or in the courtyard of an urban dwelling would have sufficed, ${ }^{1293}$ but material remains of such cultic places may never be identified in an archaeological survey or excavation. If there had been resources to build a temple for a West Semitic, Egyptian, or Judean deity, the local population hardly had any ideological or political reasons to oppose the undertaking. The absence of any traces of Egyptian shrines is especially noteworthy, because many Egyptians had a high social status in Babylonia and presumably the economic means to build places of worship in Babylonian cities. An interesting - although somewhat different - point of comparison is the temple of Assur in Uruk in the sixth

1287 Albertz 1994, 369-436; 2003, 132-138; Becking and Korpel (eds.) 1999; Middlemas 2005, 2007.

1288 Grünwaldt 1992, 1, 222-228 (with references to older literature); Albertz 1994, 407-411.

1289 On Deuteronomy and cultic centralisation in Judah, see Reuter 1993; Knowles 2006; Kratz et al. (eds.) 2010.

1290 See Runesson et al. 2008, 274-294.

1291 See Chong 1996.

1292 See Runesson et al. 2008, 274-275; Blenkinsopp 2009, 60 + n. 34 .

1293 As proposed by Martti Nissinen (personal communication). 
century. ${ }^{1294}$ A community of Assyrian origin ran the temple, and it is possible that they had arrived and established the shrine in Uruk only after the fall of the Neo-Assyrian Empire. ${ }^{295}$ If this was the case, the temple of Assur is an important example of a cultic centre of an immigrant community in Babylonia. Continuation of the worship of Sîn among the Neirabian community in Babylonia is suggested by a clay tablet (Dhorme 1928 no. 26) referring to some property of Sîn of Neirab in a severely damaged context. ${ }^{1296}$

Observance of the Sabbath or religious festivals described in the Hebrew Bible is not mentioned in any surviving documents from Babylonia. This is quite contrary to the Elephantine texts, which refer both to the Sabbath and Passover. ${ }^{1297}$ Some Judeans in Babylonia bore the name Šabbatāya, which may imply the importance of the seventh day of the week, but it cannot be confirmed that the name was exclusively Judean or referred to observance of the Sabbath in particular. ${ }^{1298}$ Ran Zadok has proposed that Judeans rarely - if at all concluded or witnessed transactions on the Sabbath or during Judean religious festivals, ${ }^{1299}$ but this suggestion is impossible to evaluate. The congruence of Babylonian and Judean calendars remains unclear, and there is no way of knowing how weeks and their seventh days should be counted. It is even uncertain what religious festivals Judeans observed and when, as the evidence from Elephantine emphasises the diversity of Judean religious practices in the late fifth century.1300 The same difficulties apply to the nature and timing of the Sabbath in the sixth and fifth centuries.

Judeans did not refuse to use seals which included non-Yahwistic divine imagery: the divine symbols or images of Marduk, Ištar, Sîn, and Ahura Mazda are attested on seals owned by Judeans. ${ }^{1301}$ Moreover, marriage agreements pertaining to Judeans and other people of foreign origin summon the Babylonian deities Marduk, Zarpanìtu, and Nabû to punish the violator of the agreement, but no foreign deities are ever attested among them. These examples show that the worship of Yahweh was compatible with the worship of Babylonian deities,

1294 Beaulieu 1997.

1295 Radner 2017; but cf. Beaulieu 1997, 61-62, who argues that the community and its temple originated already in the seventh century.

1296 See Dhorme 1928, 67; Tolini 2015, 70 n. 49, 91 n. 96.

1297 On Judean religious practices at Elephantine, see, most recently, Kratz 2015, 137-147; Granerød 2016, 128-208.

1298 See Section 1.5.2.

1299 Zadok 1979a, 81-82; 2014a, 117.

1300 Kratz 2015; Granerød 2016, 128-208 with further literature.

1301 See Section 5.7. Cf. Zadok 2014a, 117, who argues that Judeans did not use 'pagan' imagery on their seals. 
and any claims about exclusive reverence of Yahweh are unfounded. At the same time, one has to emphasise that Yahweh was of special importance to a notable group of Judean deportees and their descendants. As the following discussion shows, both Yahwistic and non-Yahwistic theophoric names were rarely used in a single Judean family.

In addition to being the primary means of identification, naming practices remain the most important source for the study of deportees' religious practices in Babylonia. A theophoric name does not naturally mean that its bearer was a devoted worshipper of the deity in question, but it suggests that the bearer's parents had a reason to choose this specific name from among all the other available options. Family traditions, the socio-economic status of the parents, and even trends undoubtedly influenced the choice, but theophoric names were hardly devoid of religious significance. As the literal meaning of a Hebrew theophoric name was presumably understandable for a native speaker of Hebrew, its devotional aspects were much more apparent than those of its modern counterparts, such as John or Michael. Accordingly, we may surmise that families which used theophoric names with Baal, Nusku, or Yahweh revered the respective deities.

As a logical result of the methodology employed, the majority of identified Judeans bear Yahwistic names. A more nuanced picture emerges from the analysis of the two large text corpora from the countryside, namely, the documents from the environs of Yāhūdu and the Murašû archive. Yahwistic names are generally dominant, but there are striking generational differences. First, there are always less Yahwistic names among Judean patronymics than Judean first names. In the documents from Yāhūdu and its surroundings (572-477 BCE ), $66 \%$ of Judean fathers and $82 \%$ of their children have Yahwistic names. The figures for the Murašû archive $\left(45^{2-413)}\right.$ are $46 \%$ and $67 \%$, respectively. Even if the documents from the environs of Yāhūdu are assigned to three subsets (33 Nbk - 17 Nbn; 1 Cyr - 16 Dar; 17 Dar - 9 Xer), children always have Yahwistic names more often than their fathers. ${ }^{1302}$ Second, Judeans from the environs of Yāhūdu rarely used Akkadian names (fathers $7 \%$, children $5 \%$ ) or non-Yahwistic theophoric names (fathers $5 \%$, children $2 \%$ ). However, a generational difference is obvious in the Murašû archive: $22 \%$ of Judean fathers have Akkadian names and $17 \%$ non-Yahwistic theophoric names. For their children, the frequency in both categories is only $5 \%$. Table 4 summarises the data from the environs of Yāhūdu in 572-477, from the environs of Yāhūdu during the

$130233 \mathrm{Nbk}-17 \mathrm{Nbn}$ (34 years): $53 \%$ of fathers and $86 \%$ of their children had Yahwistic names; 1 Cyr - 16 Dar (33 years): $70 \%$ of fathers and $81 \%$ of their children had Yahwistic names; 17 Dar -9 Xer (29 years): $69 \%$ of fathers and $81 \%$ of their children had Yahwistic names. 


\section{Environs of Yāhūdu \\ Environs of Yāhūdu \\ 1 Cyr-16 Dar Murašû archive}

Patronymics First names Patronymics First names Patronymics First names

\begin{tabular}{|c|c|c|c|c|c|c|c|c|c|c|c|c|}
\hline \multicolumn{13}{|l|}{ Names borne } \\
\hline Yahwistic & 73 & $66 \%$ & 124 & $82 \%$ & 54 & $70 \%$ & 89 & $81 \%$ & 19 & $46 \%$ & 40 & $67 \%$ \\
\hline West Semitic & & & & & & & & & & & & \\
\hline non-Yahwistic & 21 & $19 \%$ & 17 & $11 \%$ & 13 & $17 \%$ & 12 & $11 \%$ & 10 & $24 \%$ & 15 & $25 \%$ \\
\hline Akkadian & 8 & $7 \%$ & 7 & $5 \%$ & 5 & $6 \%$ & 7 & $6 \%$ & 9 & $22 \%$ & 3 & $5 \%$ \\
\hline $\begin{array}{l}\text { Non-Yahwistic } \\
\text { theophoric }\end{array}$ & 5 & $5 \%$ & 3 & $2 \%$ & 3 & $4 \%$ & 3 & $3 \%$ & 7 & $17 \%$ & 3 & $5 \%$ \\
\hline
\end{tabular}

a The category of non-Yahwistic theophoric names overlaps the categories of Akkadian and West Semitic non-Yahwistic names. The first category comprises all non-Yahwistic theophoric names, including the theophoric names attested in the second and third categories.

peak activity of Ahīqar and Ahīqam in 538-506 (1 Cyr - 16 Dar), and from the Murašû archive in 452-413.

The interpretation of these figures causes serious difficulties. In his study of Judean naming practices in the Murašû archive, E.J. Bickerman suggests that the dramatic change in Judean naming practices during the fifth century was a consequence of the 'YHWH-alone' movement in Babylonia, which also sparked the missions of Ezra and Nehemiah. ${ }^{1303}$ A religious revival among the Judeans in exile would explain the dramatic decrease in the use of Akkadian and non-Yahwistic theophoric names and the simultaneous increase in the use of Yahwistic names. However, such a religious revival seems to have taken place in every generation in the environs of Yāhūdu as well, because Judean fathers consistently bore Yahwistic names less often than their children. This problem is emphasised by the comparison of the three chronological subgroups of texts from Yāhūdu and its surroundings. If the figures reflect the naming practices as they were, one would suppose that the children of the previous subgroup would have roughly the same percentage of Yahwistic names as the fathers of the following subgroup. This is not the case, and the

1303 Bickerman 1978. 
difference between the early and middle groups is 16 percentage points, and between the middle and late groups it is 12 percentage points.

It must be concluded that the available data on naming practices is somehow skewed, as it constantly inflates the number of Yahwistic names as first names and/or undervalues the number of Yahwistic names as patronymics. The reason for this corruption remains unclear, and, for now, one must refrain from drawing any conclusions from this generational pattern. When it comes to the differences between the surroundings of Yāhūdu and the Murašû archive, we may carefully suggest that there was some decrease in the use of Yahwistic names from the sixth to the fifth century. Alternatively, this may also be indicative of different naming practices in Judean communities, and the situation in the environs of Yāhūdu may not be representative of the situation in the countryside of Nippur in the same period.

It is noteworthy that a very small percentage of attested Judeans in the environs of Yāhūdu bore non-Yahwistic theophoric names. This can lead to two different conclusions. First, Judean families did not generally use non-Yahwistic theophoric names in the region. Second, families strongly stuck to certain naming traditions, and some Judean families did not use Yahwistic names at all, while others favoured Yahwistic names and almost never gave non-Yahwistic theophoric names to their children. The second option presupposes that Yahwistic names did not dominate Judean naming traditions in Judah either, and people also favoured theophoric names referring to El, Baal, Bìt-il, or other deities. This idea finds some support in the onomasticon of Yāhūdu and its surroundings, which includes some names with Bìt-il or Il/El as their theophoric element. ${ }^{1304}$ The co-occurrence of Yahweh and Bit-il in theophoric names is reminiscent of the situation at Elephantine, ${ }^{1305}$ but it must be emphasised that the Bìt-il and Il/El names are relatively rare in the environs of Yāhūdu. Yahweh is the most often attested deity in the West Semitic names of the corpus, which suggests that most Judean families favoured Yahwistic names.

It seems that despite contacts with Babylonians and visits to bigger cities, the Judean community in Yāhūdu and its surroundings stuck to traditional Yahwistic names and adopted only a few Akkadian and non-Yahwistic theophoric names. This practice can be contrasted to the contemporary naming practices of Judean royal merchants in Sippar. The older generation of the mercantile family had both Judean and Babylonian names, but their children bore only Akkadian, mostly theophoric names. This was probably due to their everyday interaction with the local population, manifested in their social

1304 See Pearce and Wunsch 2014, 13.

1305 See, most recently, Porten 2014; van der Toorn 2016b. 
networks and in the marriage of their daughter into an established Babylonian family. A relatively high social status and intimate ties to the local population distinguished them from their compatriots in Yāhūdu, and this also explains the observable differences in naming practices. ${ }^{1306}$

As I argued above, theophoric names were hardly devoid of religious significance and they must have somehow reflected the wishes of parents who chose to give a certain name to their child. The theophoric sentence names had a meaning, and giving thanks to a certain deity or asking a certain god to protect the baby could not have been completely arbitrary. Although exact figures cannot be given and the data appears to be somewhat skewed, some Judeans definitely continued to use Yahwistic names in Babylonia from the sixth until the late fifth century. As it seems improbable that the use of Yahwistic names was only a tradition, we may conclude that the worship of Yahweh continued in some form among the exiled Judean community. A similar pattern emerges from the village of Neirab where Sîn and Nusku names were exceptionally prominent. This indicates that the moon god and his son remained important for the Neirabians who were deported to Babylonia from a region where the lunar deities were widely worshipped.

Even if a Yahwistic name probably indicates that a person's parents felt some affinity for Yahweh, it remains uncertain which other deities the parents worshipped or which deities the person worshipped himself. Several different deities in addition to Yahweh were worshipped in the kingdom of Judah, and the religious plurality of Babylonian society was nothing new to Judean deportees. It is thus expected that deportees from Judah had no reason to refrain from worshipping deities other than Yahweh. The use of both Babylonian and Yahwistic theophoric names in some families supports this view, although it has to be noted that the number of such cases is relatively small. An exceptional case is the use of the names Bēl-šar-uṣur and Yāhû-šar-uṣur by one and the same person in Yāhūdu. ${ }^{1307} \mathrm{~A}$ name change is more likely than the use of a double name in this case, and it was probably motivated by Belshazzar's coregency in Babylon, as common people avoided using the names of the ruling king and the crown prince. The šarru element of the name indicates that its bearer had connections to the royal administration, and this may explain the use of the Babylonian name Bēl-šar-ușur in the first place. These two names may indicate that its bearer worshipped both Bēl (Marduk) and Yahweh or

1306 This discussion has benefitted from the conversations with Reinhard Kratz and other participants in the conference 'Die Religionspolitik der Achaimeniden und die Rolle der Lokalheiligtümer', held in Münster in February 2016.

1307 C2-4. See Section 4.4. 
equated the two deities, but the ambiguity of the name Bēl ('lord') could also allow some play with the meaning of the name.

\subsection{Identity and Integration}

The continued use of Yahwistic names - and presumably the continued worship of Yahweh - in Babylonia from the sixth until the late fifth century indicates that some descendants of Judean deportees shared an identity which was somewhat different from that of the surrounding culture. At the same time, these Judeans did not live in isolation; they were in regular interaction with Babylonian and Persian officials and entrepreneurs in the land-forservice sector. These observations apply to Neirabians in the sixth century as well. This section is aimed at discussing different aspects of identity and questions about integration into Babylonian society.

The Babylonian practice of settling deportees in rural communities according to their geographic origin undoubtedly had consequences for integration and the preservation of identity. The sources from Yāhūdu emphasise the Judean character of this village, and they confirm that the names of twin towns really had a descriptive function. The West Semitic names featuring the deities Sîn and Nusku in Neirab point towards the same conclusion. There is some evidence that ethnic enclaves existed in cities as well. The Palace Archive of Nebuchadnezzar II refers to ethnically homogenous groups of foreign soldiers and craftsmen who received rations from the royal administration.

The very existence of cuneiform documents from the Babylonian twin towns confirms that the population of Yāhūdu or Neirab was not isolated from the rest of society. The aims of the land-for-service sector necessitated control and the supervision of landholders. Officials were in charge of collecting taxes and channelling men to work projects and military service, but even everyday business transactions in the villages appear to have been controlled by Babylonian scribes. The seeming omnipresence of the scribe Arad-Gula in the village of Našar and his peculiar role as the hinge between the dossiers of Ahīqar and Ahīqam is the clearest example of this phenomenon. Moreover, it has to be emphasised that even if the majority of original inhabitants in a twin town shared a common geographic origin, the population was not - and did not remain - homogenous. The early documents from Yāhūdu do not conform to the idea of an exclusively Judean population, and there appears to have been significant Judean habitation in the village of Ashkelon near Nippur in the late fifth century. 
The movement of people between different villages and between the countryside and cities does not support the idea of isolated rural communities either. The protagonists of the texts from the environs of Yāhüdu are attested in several villages and in Babylon, the inhabitants of Neirab appear in Hìt and Babylon, and landholders from rural villages frequently visited the city of Nippur. Nothing suggests that the local and regional movement of deportees was restricted, and this allowed them to be in touch with people outside their immediate surroundings.

Although there was movement and interaction, not all deportees had the same level of contact with other population groups. Socio-economic diversity among the deportees also affected their possibilities to interact and integrate. Accordingly, royal merchants, rural businessmen, and small indebted farmers did not share the same means and interests to integrate into the surrounding society. Royal merchants worked for the state one way or the other, they traded with Babylonian temples, and their social circles consisted of merchants of both Babylonian and foreign origin. My study of the social networks of the Judean royal merchants in Chapter 3 revealed that they were deeply integrated into the mercantile community of Sippar, as reflected by the marriage of their daughter into an urban, upper-class Babylonian family. The transition from a mixture of Judean and Babylonian names in the second generation to the exclusively Babylonian names of the third generation reveals that the family deliberately sought to blend into their social world. Given the international character of the Sipparean mercantile community and the evidence of other royal merchants of non-Babylonian origin, it appears that the family of Judean royal merchants is an example of a wider phenomenon.

A Babylonian - or later Persian - background or name was not a prerequisite for serving in the state administration. Even the Babylonian kingship in the sixth century was in the hands of Aramean and Chaldean tribes which did not belong to the exclusive upper class of Babylonian cities. Examples of foreign officials are numerous, and especially Egyptians were held in high esteem. People with West Semitic names are also attested in high offices, but most Judean officials worked in minor positions in the land-for-service sector. These people were often middlemen between farmers and higher echelons of administration, and they presumably originated from and lived in the same rural communities as the farmers they administered. A Judean is attested in a higher position as a subordinate of the governor of Across-the-River and a number of his compatriots as officials at the court of Nebuchadnezzar II. ${ }^{1308}$

1308 Sections 2.4 and 6.1. 
The strong presence of non-Babylonians in the state administration is apparently intertwined with the growing importance of Aramaic as an administrative language, and some Judeans belonging to this group were obviously literate. Four Judean sēpirus - Aramaic scribes or clerks - are attested. This is not surprising and some literacy among the Judean deportees is expected, as the deportations targeted the upper classes of Jerusalem. However, nothing written on parchment has survived in the Mesopotamian climate and short Aramaic inscriptions on clay tablets and bricks are the only material evidence of the use of alphabetic scripts. Unfortunately, it is difficult to assign these inscriptions to any particular people, and more research is needed to judge if the inscriptions on tablets were written by cuneiform scribes, the parties involved in the transaction, or someone else. ${ }^{1309}$ It has to be emphasised that no Hebrew writings from Babylonia survive, despite the claims that an early tablet from Yāhūdu (C10) bears a short Paleo-Hebrew inscription. ${ }^{1310}$ Some of the letter forms in this inscription are indisputably old, but a certain qualification of the script as Paleo-Hebrew is not sustainable on the basis of palaeographic features, clues from the cuneiform text, and conventions regarding the writing of alphabetic epigraphs in Babylonia. ${ }^{1311}$ In any case, there were some literate Judeans in Babylonia, and it is possible that some literary production took place among the deportees.

Although the world of the administration and Aramaic was open to deportees, the spheres of the temple cult and cuneiform writing were not. They were dominated by the Babylonian urban upper class, which resided in old cities and traced its ancestry to eponymous forefathers who gave their name to the families. Cuneiform scribes came predominantly from these families, and even the tablets written in remote locations in the countryside were written by Babylonians with family names. There is no evidence that Judeans or other deportees worked as cuneiform scribes, and Babylonian sources do not corroborate the idea that people of foreign origin had access to scribal training. ${ }^{1312}$ The same applies to the priesthood of Babylonian temples: only certain people were fit for temple service, and priests came from a certain stratum in Babylonian society. Some deportees were attached to temples as free workers or dependants, but they did not make their way into the priesthood which was responsible for the daily offerings and temple service.

1309 Aramaic epigraphs on Neo-Babylonian cuneiform tablets will be studied in Rieneke Sonnevelt's forthcoming dissertation (Leiden University).

1310 Lemaire 2006, 188; Pearce and Wunsch 2014, 112; Pearce 2016b, 231.

1311 Personal communication with Rieneke Sonnevelt.

1312 On the situation in Yāhūdu, see Hackl 2017. 
Analysis of Judean social networks reveals that deportees were in regular interaction with people from the urban upper class, because even the rural cuneiform scribes belonged to this group. At the same time, deportees and Babylonian scribes and priests did not belong to the same social circles, and they did not come together as friends or business partners or through marriage. A somewhat different group is made up of Babylonian entrepreneurs, some of whom bore family names. These people lived and worked in the same circles as traders of foreign origin, but they did not usually belong to the social networks of Babylonian scribes and priests.

The majority of the deportees lived in the countryside, and the Babylonian practice of settling deportees in communities according to their origin offered a favourable environment for preserving culture, identity, and traditions. The state closely supervised these villages and their inhabitants, and the scribe Arad-Gula's permanent residence in the village and the administrative estate of Našar is probably representative of the situation in the land-for-service sector in general. However, supervision does not necessarily entail much cultural interaction between the supervisors and the supervised, and Judean farmers probably knew little about the Babylonian culture which Arad-Gula and his educated colleagues belonged to. A more important factor is the settlement of people in neighbouring villages from different parts of the empire. This is manifested by the analysis of naming practices in the villages of Yāhūdu and Našar, which were undoubtedly located close to each other. Whereas the majority of people attested in Yāhūdu bore Yahwistic names, hardly anybody in Našar bore such names; other West Semitic names prevailed there. Thus, farmers in the land-for-service sector were not surrounded by the Babylonian culture embraced by the urban upper class, but instead they lived in a multicultural environment which mixed influences from Babylonia and abroad. Finally, it must be emphasised that the available sources do not attest to any significant adoption of cultural traits from this multicultural milieu. Very few Judeans bore non-Yahwistic West Semitic names, and the village of Neirab had onomastic characteristics of its own.

In addition to officials, merchants, craftsmen, and other city-dwellers, entrepreneurs and foremen of rural communities such as Ahīqam and Yadi-Yāma were in closer interaction with Babylonians than the average farmer. Because of the nature of the business he was involved in, Ahìqam regularly met small farmers, Babylonian officials, and people living in cities. He supported Judean cultural traditions by giving Yahwistic names to his sons, but he had no problem using a seal which depicted a worshipper in front of the divine symbols of Ištar and Marduk. Although Ahīqam lived in Yāhūdu, which was also the focal point of his business activities, he had business partners with Akkadian names 
and patronymics, and he ran a beer-brewing business in Babylon. Ahìqam's career was probably exceptional rather than typical of Judeans in the land-forservice sector, but it confirms that some deportees could act as important bridges between the city and the countryside, as well as between deportees and native Babylonians.

The previous discussion has shown that deportees were by no means isolated from the rest of society, and people from rural communities visited cities close to them but also farther away. They were in contact with Babylonians and other deportees, and the example of Judean royal merchants shows that some became deeply integrated into urban communities. At the same time, living conditions in rural settlements such as Yāhūdu and Neirab facilitated the cohesion of deportee communities and the preservation of their indigenous culture. Relatively homogenous communities of deportees allowed nurturing of their identity, and nothing brought them into constant interaction with other groups in society. Life in rural communities could stay pretty much the same for centuries and the more dynamic cultural interaction characteristic of urban life was foreign to most rural communities.

The Murašû archive attests to the presence of a lively Judean community in the Nippur region almost two centuries after the deportations from Judah. After a substantial break of any textual evidence, Jewish communities appear again in Babylonia in the first century $\mathrm{CE}$, and they flourished there until the mid-twentieth century. 


\section{Research Data}

The following sets of research data are freely available online:

A data set of the chronological distribution of the documents from the village of Yāhūdu and its surroundings: https://doi.org/10.5281/zenodo.2661373.

A prosopographical database of people attested in Yāhūdu and its surroundings: https://doi.org/10.5281/zenodo.2654300.

A prosopographical database of Judeans in the Murašû archive: https://doi. org/10.5281/zenodo.3351259.

A prosopographical database of Judeans outside the Yāhūdu corpus and the Murašû archive: https://doi.org/10.5281/zenodo.3354074. 


\section{Bibliographical Abbreviations}

$\begin{array}{ll}\text { A1 } & \text { Text edited in Abraham 2005/2006 } \\ \text { A2 } & \text { Text edited in Abraham 2007 } \\ \text { ABC } & \text { Grayson 1975a } \\ \text { ABS } & \text { Archaeology and Biblical Studies } \\ \text { AfO } & \text { Archiv fü Orientforschung } \\ \text { AIL } & \text { Ancient Israel and Its Literature } \\ \text { ANEM } & \text { Ancient Near East Monographs } \\ \text { AOAT } & \text { Alter Orient und Altes Testament } \\ \text { AoF } & \text { Altorientalische Forschungen } \\ \text { B } & \text { Texts edited in Wunsch (forthcoming) } \\ \text { BaAr } & \text { Babylonische Archive } \\ \text { BASOR } & \text { Bulletin of the American Schools of Oriental Research } \\ \text { BE } 8 & \text { Clay 1908 } \\ \text { BE 9 } & \text { Hilprecht and Clay 1898 } \\ \text { BE 10 } & \text { Clay 1904 } \\ \text { BIN 1 } & \text { Keiser, Clarence Elwood. Letters and Contracts from Erech Written } \\ & \text { in the Neo-Babylonian Period. Babylonian Inscriptions in the Col- } \\ \text { BiOr } & \text { lection of James B. Nies 1. New Haven: Yale University Press, 1918. } \\ \text { BM } & \text { Bibliotheca Orientalis } \\ \text { BMA } & \text { Tablets in the collections of the British Museum } \\ \text { BN } & \text { Texts edited in Roth 1989 } \\ \text { BSA } & \text { Biblische Notizen } \\ \text { BZAw } & \text { Bulletin on Sumerian Agriculture } \\ \text { C } & \text { Beihefte zur Zeitschrift für die alttestamentliche Wissenschaft } \\ \text { CAD } & \text { Texts edited in Pearce and Wunsch 2014 } \\ & \text { The Assyrian Dictionary of the Oriental Institute of the University of } \\ \text { Chicago. Chicago: The Oriental Institute of the University of Chi- } \\ \text { cago, 1956-2011. } \\ \text { Strassmaier, JN. Inschiften von Cambyses, Konig von Babylon. }\end{array}$

Camb Strassmaier, J.N. Inschriften von Cambyses, König von Babylon. Babylonische Texte Ix. Leipzig: Eduard Pfeiffer, 1890.

CatBM Catalogue of the Babylonian Tablets in the British Museum

CHANE Culture and History of the Ancient Near East

CLeO Classica et Orientalia

CM Cuneiform Monographs

CT 4 Pinches, T.G. Cuneiform Texts from Babylonian Tablets in the British Museum 4. London: The British Museum, 1898.

CT 55-57 Pinches, T.G. Cuneiform Texts from Babylonian Tablets in the British Museum, vols. 55-57. London: The British Museum, 1982. 
CTIJ Cuneiform Texts Mentioning Israelites, Judeans, and Related Population Groups (http://oracc.museum.upenn.edu/ctij/corpus)

CTMMA 4 Texts edited in Spar and Jursa 2014

Cyr Strassmaier, J.N. Inschriften von Cyrus, König von Babylon. Babylonische Texte VII. Leipzig: Eduard Pfeiffer, 1890.

Dar Strassmaier, J.N. Inschriften von Darius, König von Babylon. Babylonische Texte X-XII. Leipzig: Eduard Pfeiffer, 1892-1897.

EE $\quad$ Texts edited in Stolper 1985

GAG von Soden, Wolfram. Grundriss der akkadischen Grammatik samt Ergänzungsheft zum Grundriss der akkadischen Grammatik. Analecta Orientalia 33/47. Rome: Pontificium Institutum Biblicum, 1969 .

GMTR Guides to the Mesopotamian Textual Record

HdO Handbook of Oriental Studies, Section 1: The Near and Middle East

HSM Tablets in the collections of the Harvard Semitic Museum

IMT Texts edited in Donbaz and Stolper 1997

ISCANEE International Scholars Conference on Ancient Near Eastern Economies

J1-7 Texts edited in Joannès and Lemaire 1996

J8-9 Texts edited in Joannès and Lemaire 1999

JANEH Journal of Ancient Near Eastern History

JAOS Journal of the American Oriental Society

$J B L \quad$ Journal of Biblical Literature

JCs Journal of Cuneiform Studies

JESHO Journal of the Economic and Social History of the Orient

JNES Journal of Near Eastern Studies

JSJ Journal for the Study of Judaism

Jsots Journal for the Study of the Old Testament Supplement Series

KAI Texts edited in Donner and Röllig 2002

KTU Dietrich, Manfred et al. The Cuneiform Alphabetic Texts from Ugarit, Ras Ibn Hani and Other Places. Second, enlarged edition. Abhandlungen zur Literatur Alt-Syrien-Palästinas und Mesopotamiens 8. Münster: Ugarit-Verlag, 1995.

LAOS Leipziger Altorientalistische Studien

MR Texts edited in Waerzeggers 2014a

NABU Nouvelles Assyriologiques Bréves et Utilitaires

Nbk Strassmaier, J.N. Inschriften von Nabuchodonosor, König von Babylon. Babylonische Texte V-VI. Leipzig: Eduard Pfeiffer, 1889.

Nbn Strassmaier, J.N.Inschriften von Nabonidus, Königvon Babylon. Babylonische Texte I-IV. Leipzig: Eduard Pfeiffer, 1889.

ND Field numbers of tablets excavated at Nimrud 
oect 10 McEwan, G.J.P. Late Babylonian Texts in the Ashmolean Museum. Oxford Editions of Cuneiform Texts 10. Oxford: Clarendon, 1984.

OIP 122 Weisberg, David B. Neo-Babylonian Texts in the Oriental Institute Collection. Oriental Institute Publications 122. Chicago: The Oriental Institute of the University of Chicago, 2003.

OIs Oriental Institute Seminars

OLA Orientalia Lovaniensia Analecta

PIHANS Uitgaven van het Nederlands Historisch-Archaeologisch Instituut te Istanbul = Uitgaven van het Nederlands Instituut voor het Nabije Oosten te Leiden

PBS 2/1 Clay 1912

PNA The Prosopography of the Neo-Assyrian Empire. Helsinki: The NeoAssyrian Text Corpus Project, 1998-.

$R A \quad$ Revue d'assyriologie et d'archéologie orientale

RINAP 1 Tadmor, Hayim and Yamada, Shigeo. The Royal Inscriptions of Tiglath-pileser III (744-727 BC), and Shalmaneser $V(726-722$ BC), Kings of Assyria. The Royal Inscriptions of the Neo-Assyrian Period 1. Winona Lake: Eisenbrauns, 2011.

RINAP 3 Grayson, A. Kirk and Novotny, Jamie. The Royal Inscriptions of Sennacherib, King of Assyria (704-681 BC), vols. 1-2. The Royal Inscriptions of the Neo-Assyrian Period 3. Winona Lake: Eisenbrauns, 2012-2014.

RINAP 4 Leichty, Erle. The Royal Inscriptions of Esarhaddon, King of Assyria $(680-669$ B $)$. The Royal Inscriptions of the Neo-Assyrian Period 4. Winona Lake: Eisenbrauns, 2011.

RlA Reallexikon der Assyriologie und Vorderasiatischen Archäologie. Berlin: De Gruyter, 1928-2018.

Rомст 2 McEwan, G.J.P. The Late Babylonian Tablets in the Royal Ontario Museum. Royal Ontario Museum Cuneiform Texts 2. Toronto: Royal Ontario Museum, 1982.

SAA 1 Parpola, Simo. The Correspondence of Sargon II, Part I: Letters from Assyria and the West. State Archives of Assyria 1. Helsinki: Helsinki University Press, 1987.

SAA 6 Kwasman, Theodore and Parpola, Simo. Legal Transactions of the Royal Court of Nineveh, Part I: Tiglath-pileser III through Esarhaddon. State Archives of Assyria 6. Helsinki: Helsinki University Press, 1991.

SAA 7 Fales, F.M. and Postgate, J.N. Imperial Administative Records, Part I: Palace and Temple Administration. State Archives of Assyria 7. Helsinki: Helsinki University Press, 1992. 
$S A A B \quad$ State Archives of Assyria Bulletin

SAOC Studies in Ancient Oriental Civilization

SCT Gordon, Cyrus H. Smith College Tablets: 110 Cuneiform Texts Selected from the College Collection. Smith College Studies in History 38. Northampton: Department of History of Smith College, $195^{2}$.

TA Tel Aviv

TAD A Porten, Bezalel and Yardeni, Ada. Textbook of Aramaic Documents from Ancient Egypt, vol. 1: Letters. Jerusalem: Hebrew University, 1986.

TCL 13 Contenau, G. Contrats néo-babyloniens, vol. 2: Achéménides et Séleucides. Textes cunéiformes, Musée du Louvre 13. Paris: Geuthner, 1929 .

TSAJ Texts and Studies in Ancient Judaism

TuM 2-3 Texts edited in Krückmann 1933

UCP 9/3 Text edited in Lutz 1928

UF Ugarit-Forschungen

van Driel, Working notes and transliterations of the Murašû texts by Govert working van Driel and his students, archived at Leiden University notes

VS 3-6 Ungnad, Arthur. Vorderasiatische Schriftdenkmäler der königlichen Museen zu Berlin, vols. 3-6. Leipzig: Hinrichs, 1907-1908.

VT Vetus Testamentum

VTSup Supplements to Vetus Testamentum

WdO Die Welt des Orients

WZKM Wiener Zeitschrift für die Kunde des Morgenlandes

Yos 6 Dougherty, Raymond Philip. Records from Erech, Time of Nabonidus (555-538 B.c.). Yale Oriental Series, Babylonian Texts 6. New Haven: Yale University Press, 1920.

yos 19 Beaulieu, Paul-Alain. Legal and Administrative Texts from the Reign of Nabonidus. Yale Oriental Series, Babylonian Texts 19. New Haven: Yale University Press, 2000.

ZA Zeitschrift für Assyriologie und Vorderasiatische Archäologie

ZAW Zeitschrift für die alttestamentliche Wissenschaft

ZDMG Zeitschrift der Deutschen Morgenländischen Gesellschaft 


\section{Bibliography}

Abel, M. and Barrois, A.
1928 'Fouilles de l'École Archéologique Française de Jérusalem, effectuées à Neirab
du 12 septembre au 6 novembre 1927'. Syria 9, 187-206, 303-319.

\section{Abraham, Kathleen}

2004 Business and Politics Under the Persian Empire: The Financial Dealings of Marduk-nāṣir-apli of the House of Egibi (521-487 B.C.E.). Bethesda: CDL.

2005/2006 'West Semitic and Judean Brides in Cuneiform Sources from the Sixth Century BCE: New Evidence from a Marriage Contract from Āl-Yahudu'. AfO 51, 198-219.

2007 'An Inheritance Division among Judeans in Babylonia from the Early Persian Period'. Meir Lubetski (ed.), New Seals and Inscriptions, Hebrew, Idumean, and Cuneiform. Hebrew Bible Monographs 8. Sheffield: Sheffield Phoenix, 206-221.

2015 'Negotiating Marriage in Multicultural Babylonia: An Example from the Judean Community in Āl-Yāhūdu'. Jonathan Stökl and Caroline Waerzeggers (eds.), $E x$ ile and Return: The Babylonian Context. BZAW 478. Berlin: De Gruyter, $33-57$.

\section{Abraham, Kathleen et al.}

2018 'Further Collations to CUSAS 28'. NABU 2018/53.

\section{Adams, Robert McC.}

1981 Heartland of Cities: Surveys of Ancient Settlement and Land Use on the Central Floodplain of the Euphrates. Chicago: University of Chicago Press.

\section{Adams, Robert McC. and Nissen, Hans J.}

1972 The Uruk Countryside: The Natural Setting of Urban Societies. Chicago: University of Chicago Press.

\section{Ahituv, Shmuel}

2008 Echoes from the Past: Hebrew and Cognate Inscriptions from the Biblical Period. Jerusalem: Carta.

\section{Ahn, John J.}

2011 Exile as Forced Migrations: A Sociological, Literary, and Theological Approach on the Displacement and Resettlement of the Southern Kingdom of Judah. BZAW 417. Berlin: De Gruyter. 


\section{Ahn, John J. and Middlemas, Jill (eds.)}

2012 By the Irrigation Canals of Babylon: Approaches to the Study of the Exile. Library of Hebrew Bible / Old Testament Studies 526. New York: T\&T Clark.

\section{AIA}

2016 'Code of Ethics'. Available online at https://www.archaeological.org/about/ governance/policies/.

\section{Albertz, Rainer}

1994 A History of Israelite Religion in the Old Testament Period 2: From the Exile to the Maccabees. Old Testament Library. Louisville: Westminster John Knox.

2003 Israel in Exile: The History and Literature of the Sixth Century B.C.E. Studies in Biblical Literature 3. Atlanta: Society of Biblical Literature.

\section{Albright, William F.}

1942 'King Joiachin in Exile'. Biblical Archaeologist 5, 49-55.

\section{Allard, Sébastien}

2008 'Der Mythos Babylon vom 16. bis zum 19. Jahrhundert'. Moritz Wullen et al. (eds.), Babylon: Mythos und Wahrheit 1: Mythos. Munich: Hirmer, 145-167.

\section{Alstola, Tero}

2016 Review of Documents of Judean Exiles and West Semites in Babylonia in the Collection of David Sofer by Laurie E. Pearce and Cornelia Wunsch. Orientalistische Literaturzeitung 111, 326-329.

2017 'Judean Merchants in Babylonia and Their Participation in Long-Distance Trade'. $\mathrm{WdO} 47,25-51$.

\section{Altaweel, Mark}

2013 'Simulating the Effects of Salinization on Irrigation Agriculture in Southern Mesopotamia'. T.J. Wilkinson et al. (eds.), Models of Mesopotamian Landscapes: How Small-Scale Processes Contributed to the Growth of Early Civilizations. British Archaeological Reports, International Series 2552. Oxford: Archaeopress, 219-238.

\section{Aperghis, Gerassimos G.}

2000 'War Captives and Economic Exploitation: Evidence from the Persepolis Fortification Tablets'. Jean Andreau et al. (eds.), Économie antique: La guerre dans les économies antiques. Entretiens d'archéologie et d'histoire 5. Saint-Bertrand-deComminges: Musée archéologique départemental de Saint-Bertrand-de-Comminges, $127-144$. 


\section{ASOR}

2015 'Policy on Professional Conduct'. Available online at http://www.asor.org/ about-asor/policies/policy-on-professional-conduct/.

\section{Aubet, María Eugenia}

2001 The Phoenicians and the West: Politics, Colonies and Trade. Second edition. Cambridge: Cambridge University Press.

\section{Augapfel, Julius}

1917 Babylonische Rechtsurkunden aus der Regierungszeit Artaxerxes I. und Darius ii. Kaiserliche Akademie der Wissenschaften in Wien, philosophisch-historische Klasse, Denkschriften 59, 3. Vienna: Alfred Hölder.

\section{Avigad, Nahman}

1965 'Seals of Exiles'. Israel Exploration Journal 15, 222-232.

\section{Avishur, Yitzhak and Heltzer, Michael}

2007 Jehoiachin, King of Judah in Light of Biblical and Extra-Biblical Sources: His Exile and Release according to Events in the Neo-Babylonian Kingdom and the Babylonian Diaspora'. Transeuphratène 34, 17-36.

\section{Baker, Heather D.}

2001 'Degrees of Freedom: Slavery in Mid-First Millennium bc Babylonia'. World Archaeology 33, 18-26.

2002 'Approaches to Akkadian Name-Giving in First-Millennium bc Mesopotamia'. Cornelia Wunsch (ed.), Mining the Archives: Festschrift for Christopher Walker on the Occasion of His 6oth Birthday, 4 October 2002. BaAr 1. Dresden: ISLET, 1-24.

2004 The Archive of the Nappāhnu Family. AfO Beiheft 30. Vienna: Institut für Orientalistik der Universität Wien.

2005 'The Property Portfolio of a Family of Builders from Hellenistic Uruk'. Heather D. Baker and Michael Jursa (eds.), Approaching the Babylonian Economy: Proceedings of the START Project Symposium Held in Vienna, 1-3 July 2004. AOAT 330. Münster: Ugarit-Verlag, 7-43.

2007 'Urban Form in the First Millennium BC'. Gwendolyn Leick (ed.), The Babylonian World. New York: Routledge, 66-77.

2012 'The Neo-Babylonian Empire'. D.T. Potts (ed.), A Companion to the Archaeology of the Ancient Near East 2. Blackwell Companions to the Ancient World. Oxford: Wiley-Blackwell, 914-930.

2014 'The Babylonian Cities: Investigating Urban Morphology Using Texts and Archaeology'. Natalie N. May and Ulrike Steinert (eds.), The Fabric of Cities: Aspects 
of Urbanism, Urban Topography and Society in Mesopotamia, Greece and Rome. CHANE 68. Leiden: Brill, 171-188.

2015 'Family Structure, Household Cycle, and the Social Use of Domestic Space in Urban Babylonia'. Miriam Müller (ed.), Household Studies in Complex Societies: (Micro) Archaeological and Textual Approaches. OIS 10. Chicago: The Oriental Institute of the University of Chicago, 371-407.

\section{Baker, Heather D. and Wunsch, Cornelia}

2001 'Neo-Babylonian Notaries and Their Use of Seals'. William W. Hallo and Irene J. Winter (eds.), Seals and Seal Impressions. Proceedings of the XLV ${ }^{\mathrm{e}}$ Rencontre AssyriologiqueInternationale, PartII:YaleUniversity. Bethesda:CDL,197-213.

\section{Barjamovic, Gojko}

2004 'Civic Institutions and Self-Government in Southern Mesopotamia in the MidFirst Millennium BC.' Jan Gerrit Dercksen (ed.), Assyria and Beyond: Studies Presented to Mogens Trolle Larsen. PIHANS 100. Leiden: Nederlands Instituut voor het Nabije Oosten, 47-98.

\section{Barrois, A.}

1927 'Fouilles à Neirab: Septembre-Novembre 1926'. Revue Biblique 36, 257-265, pls. iv-ix.

\section{Barstad, Hans M.}

1996 The Myth of the Empty Land: A Study in the History and Archaeology of Judah During the 'Exilic' Period. Symbolae Osloenses Fasc. Suppl. 28. Oslo: Scandinavian University Press.

\section{Beaulieu, Paul-Alain}

1997 'The Cult of AN.ŠÁR/Aššur in Babylonia After the Fall of the Assyrian Empire'. $S A A B$ 11, 55-73.

2000 'A Finger in Every Pie: The Institutional Connections of a Family of Entrepreneurs in Neo-Babylonian Larsa'. A.C.V.M. Bongenaar (ed.), Interdependency of Institutions and Private Entrepreneurs: Proceedings of the Second MOS Symposium (Leiden 1998). PIHANS 87. MOS Studies 2. Istanbul: Nederlands HistorischArchaeologisch Instituut, $43-72$.

2005 'Eanna's Contribution to the Construction of the North Palace at Babylon'. Heather D. Baker and Michael Jursa (eds.), Approaching the Babylonian Economy: Proceedings of the START Project Symposium Held in Vienna, 1-3 July 2004. AOAT 330. Münster: Ugarit-Verlag, 45-74.

2007 'Official and Vernacular Languages: The Shifting Sands of Imperial and Cultural Identities in First-Millennium B.C. Mesopotamia'. Seth L. Sanders (ed.), 
Margins of Writing, Origins of Cultures. OIS 2. Chicago: The Oriental Institute, 191-220.

2008 'Nebuchadnezzar's Babylon as World Capital'. Journal of the Canadian Society for Mesopotamian Studies 3, 5-12.

2011 'Yahwistic Names in Light of Late Babylonian Onomastics'. Oded Lipschits et al. (eds.), Judah and the Judeans in the Achaemenid Period: Negotiating Identity in an International Context. Winona Lake: Eisenbrauns, 245-266.

2013a 'Arameans, Chaldeans, and Arabs in Cuneiform Sources from the Late Babylonian Period'. Angelika Berlejung and Michael P. Streck (eds.), Arameans, Chaldeans, and Arabs in Babylonia and Palestine in the First Millennium B.C. LAOS 3. Wiesbaden: Harrassowitz, 31-55.

2013b 'Aspects of Aramaic and Babylonian Linguistic Interaction in First Millennium BC Iraq'. Journal of Language Contact 6, 358-378.

2014 'An Episode in the Reign of the Babylonian Pretender Nebuchadnezzar IV'. Michael Kozuh et al. (eds.), Extraction \& Control: Studies in Honor of Matthew W. Stolper. SAOC 68. Chicago: The Oriental Institute of the University of Chicago, $17-26$.

\section{Becking, Bob}

1992 The Fall of Samaria: An Historical and Archaeological Study. Studies in the History of the Ancient Near East 2. Leiden: Brill.

1998 'Ezra's Re-enactment of the Exile'. Lester L. Grabbe (ed.), Leading Captivity Captive: The 'Exile' as History and Ideology. JSOTS 278. Sheffield: Sheffield Academic Press, 40-61.

2006 "'We All Returned as One!": Critical Notes on the Myth of the Mass Return'. Oded Lipschits and Manfred Oeming (eds.), Judah and the Judeans in the Persian Period. Winona Lake: Eisenbrauns, 3-18.

2007 From David to Gedaliah: The Book of Kings as Story and History. Orbis Biblicus et Orientalis 228. Fribourg: Academic Press; Göttingen: Vandenhoeck \& Ruprecht.

2009a 'Does Exile Equal Suffering? A Fresh Look at Psalm 137'. Bob Becking and Dirk Human (eds.), Exile and Suffering: A Selection of Papers Read at the 5oth Anniversary Meeting of the Old Testament Society of South Africa OTWSA/OTSSA, Pretoria August 2007. Oudtestamentische Studiën 5o. Leiden: Brill, 183-202.

2009b 'The Identity of Nabu-sharrussu-ukin, the Chamberlain: An Epigraphic Note on Jeremiah 39, 3'. BN 140, 35-46.

2011 Ezra, Nehemiah, and the Construction of Early Jewish Identity. Forschungen zum Alten Testament 8o. Tübingen: Mohr Siebeck.

2011 b 'Yehudite Identity in Elephantine'. Oded Lipschits et al. (eds.), Judah and the Judeans in the Achaemenid Period: Negotiating Identity in an International Context. Winona Lake: Eisenbrauns, 403-419. 


\section{Becking, Bob et al.}

2009 From Babylon to Eternity: The Exile Remembered and Constructed in Text and Tradition. Bible World. London: Equinox.

\section{Becking, Bob and Human, Dirk (eds.)}

2009 Exile and Suffering: A Selection of Papers Read at the 5oth Anniversary Meeting of the Old Testament Society of South Africa OTWSA/OTSSA, Pretoria August 2007. Oudtestamentische Studiën 5o. Leiden: Brill.

\section{Becking, Bob and Korpel, Marjo C.A. (eds.)}

1999 The Crisis of Israelite Religion:Transformation of Religious Tradition in Exilic and Post-Exilic Times. Oudtestamentische Studiën 42. Leiden: Brill.

\section{Bedford, Peter R.}

2009 'The Neo-Assyrian Empire'. Ian Morris and Walter Scheidel (eds.), The Dynamics of Ancient Empires: State Power from Assyria to Byzantium. Oxford Studies in Early Empires. Oxford: Oxford University Press, 30-65.

\section{Bellwood, Peter}

2013 First Migrants: Ancient Migration in Global Perspective. Chichester: Wiley-Blackwell.

\section{Ben-Dov, Jonathan}

2008 Head of All Years: Astronomy and Calendars at Qumran in their Ancient Context. Studies on the Texts of the Desert of Judah 78. Leiden: Brill.

\section{Ben-Shlomo, David}

2003 'The Iron Age Sequence of Tel Ashdod: A Rejoinder to "Ashdod Revisited" by I. Finkelstein and L. Singer-Avitz'. TA 30, 83-107.

2005 'Introduction'. Moshe Dothan and David Ben-Shlomo (eds.), Ashdod VI: The Excavations of Areas H and K(1968-1969). IAA Reports 24. Jerusalem: Israel Antiquities Authority, 1-9.

\section{Berlejung, Angelika}

2012 'The Assyrians in the West: Assyrianization, Colonialism, Indifference, or Development Policy?'. Martti Nissinen (ed.), Congress Volume Helsinki 2010. VTSup 148. Leiden: Brill, 21-6o.

2017a 'New Life, New Skills and New Friends in Exile: The Loss and Rise of Capitals of the Judeans in Babylonia'. Israel Finkelstein et al. (eds.), Alphabets, Texts and Artifacts in the Ancient Near East: Studies Presented to Benjamin Sass. Paris: Van Dieren, 12-46. 
2017b 'Social Climbing in the Babylonian Exile'. Angelika Berlejung et al. (eds.), Wandering Arameans: Arameans Outside Syria: Textual and Archaeological Perspectives. LAOS 5. Wiesbaden: Harrassowitz, 101-124.

2018 'Social Demarcation Lines and Marriage Rules in Urban Babylonia and Their Impact on the Golah'. Itzhaq Shai et al. (eds.), Tell It in Gath: Studies in the History and Archaeology of Israel: Essays in Honor of Aren M. Maeir on the Occasion of His Sixtieth Birthday. Ägypten und Altes Testament 9o. Münster: Zaphon, $1051-1077$.

\section{Berlin, Adele}

2001 'The Book of Esther and Ancient Storytelling'.JBL 120, 3-14.

\section{Bickerman, Elias J.}

1978 'The Generation of Ezra and Nehemiah'. Proceedings of the American Academy for Jewish Research 45, 1-28.

1984 'The Babylonian Captivity'. W.D. Davies and Louis Finkelstein (eds.), The Cambridge History of Judaism, Volume 1:Introduction: The Persian Period. Cambridge: Cambridge University Press, $342-35^{8}$.

\section{Blenkinsopp, Joseph}

2009 Judaism: The First Phase: The Place of Ezra and Nehemiah in the Origins of Judaism. Grand Rapids: Eerdmans.

\section{Bloch, Yigal}

2014 'Judeans in Sippar and Susa during the First Century of the Babylonian Exile: Assimilation and Perseverance under Neo-Babylonian and Achaemenid Rule'. JANEH 1, 119-172.

2015 'The Contribution of Babylonian Tablets in the Collection of David Sofer to the Chronology of the Revolts against Darius I'. AoF 42, 1-14.

2017 'From Horse Trainers to Dependent Workers: The šušānu Class in the Late Babylonian Period, with a Special Focus on Āl-Yāhūùdu Tablets'. KASKAL 14, 91-118.

2018 Alphabet Scribes in the Land of Cuneiform: Sēpiru Professionals in Mesopotamia in the Neo-Babylonian and Achaemenid Periods. Gorgias Studies in the Ancient Near East 11. Piscataway: Gorgias.

\section{Boda, Mark J. et al. (eds.)}

2015 The Prophets Speak on Forced Migration. AIL 21. Atlanta: Society of Biblical Literature. 


\section{Bodner, Keith}

2016 'The Rule of Death and Signs of Life in the Book of Kings'. Danna Nolan Fewell (ed.), The Oxford Handbook of Biblical Narrative. New York: Oxford University Press, 204-214.

\section{Boiy, Tom}

2005 'Akkadian-Greek Double Names in Hellenistic Babylonia'. W.H. van Soldt et al. (eds.), Ethnicity in Ancient Mesopotamia: Papers Read at the 48th Rencontre Assyriologique Internationale, Leiden, 1-4 July 2002. PIHANS 102. Leiden: Nederlands Instituut voor het Nabije Oosten, 47-6o.

\section{Bongenaar, A.C.V.M.}

1997 The Neo-Babylonian Ebabbar Temple at Sippar: Its Administration and Its Prosopography. PIHANS 80. Istanbul: Nederlands Historisch-Archaeologisch Instituut.

2000 'Private Archives in Neo-Babylonian Sippar and their Institutional Connections'. A.C.V.M. Bongenaar (ed.), Interdependency of Institutions and Private Entrepreneurs: Proceedings of the Second MOS Symposium (Leiden 1998). PIHANS 87. Istanbul: Nederlands Historisch-Archaeologisch Instituut, 73-94.

\section{Bongenaar, A.C.V.M. and Haring, B.J.J.}

1994 'Egyptians in Neo-Babylonian Sippar'.JCS 46, 59-72.

\section{Bregstein, Linda B.}

1993 Seal Use in Fifth Century B.C. Nippur, Iraq: A Study of Seal Selection and Sealing Practices in the Murašû Archive. PhD diss., University of Pennsylvania.

\section{Briant, Pierre}

2002 From Cyrus to Alexander: A History of the Persian Empire. Winona Lake: Eisenbrauns.

\section{Brinkman, J.A.}

1968 A Political History of Post-Kassite Babylonia, ${ }_{15} 8-722$ B.C. Analecta Orientalia 43. Rome: Pontificium Institutum Biblicum.

1976-1980 'Karduniaš'. RlA 5, 423.

1984a Prelude to Empire: Babylonian Society and Politics, 747-626 B.C. Occasional Publications of the Babylonian Fund 7. Philadelphia: Babylonian Fund, University Museum. 
1984b 'Settlement Surveys and Documentary Evidence: Regional Variation and Secular Trend in Mesopotamian Demography'.JNES 43, 169-180.

\section{Brodie, Neil}

2011 'The Market in Iraqi Antiquities 1980-2009 and Academic Involvement in the Marketing Process'. Stefano Manacorda and Duncan Chappell (eds.), Crime in the Art and Antiquities World: Illegal Trafficking in Cultural Property. New York: Springer, 117-133.

\section{Brodie, Neil et al.}

2013 'Trafficking in Cultural Objects: An Empirical Overview'. Stefano Manacorda and Arianna Visconti (eds.), Beni culturali e sistema penale: Atti del Convegno Prevenzione e contrasto dei reati contro il patrimonio culturale: La dimensione nazionale ed internazionale. Milan: Vita e Pensiero, 19-30.

\section{Brodie, Neil et al. (eds.)}

2006 Archaeology, Cultural Heritage, and the Antiquities Trade. Cultural Heritage Studies. Gainesville: University Press of Florida.

\section{Brodie, Neil and Renfrew, Colin}

2005 'Looting and the World's Archaeological Heritage: The Inadequate Response'. Annual Review of Anthropology 34, 343-361.

\section{Broshi, Magen and Finkelstein, Israel}

\section{Brown, Mark}

2015 'The 21st-Century Tower of Babel Made of Bone-China Mini Shops'. The Guardian, 8 September 2015. Available online at https://www.theguardian.com/ artanddesign/2015/sep/o8/london-wallpaper-ceramic-exhibit-shop-fronts-museumtower-of-babel.

\section{van der Brugge, Caroline and Kleber, Kristin}

2016 'The Empire of Trade and the Empires of Force: Tyre in the Neo-Assyrian and Neo-Babylonian Periods'. Juan Carlos Moreno García (ed.), Dynamics of Production in the Ancient Near East 1300-50o BC. Oxford: Oxbow, 187-222.

\section{Cagni, Luigi}

1990 'Considérations sur les textes babyloniens de Neirab près d'Alep'. Transeuphratène $2,169-185$. 


\section{Cameron, George G.}

1948 Persepolis Treasury Tablets. Oriental Institute Publications 65. Chicago: The University of Chicago Press.

\section{Cardascia, Guillaume}

1951 Les archives des Murašû: Une famille d'hommes d'affaires babyloniens a l'époque perse (455-403 av.J.-C.). Paris: Imprimerie Nationale.

1983 'Le fief dans la Babylonie achéménide'. Les liens de vassalité et les immunités Vassalage and Immunities. Second edition. Recueils de la Société Jean Bodin pour l'histoire comparitive des institutions 1. Paris: Dessain et Tolra, $55^{-88 .}$

1991 'La ceinture de Parysatis: Une Morgengabe chez les Achéménides?'. Dominique Charpin and Francis Joannès (eds.), Marchands, diplomates et empereurs: Études sur la civilisation mésopotamienne offertes à Paul Garelli. Paris: Éditions Recherche sur les Civilisations, 363-369.

\section{Carr, David M.}

2005 Writing on the Tablet of the Heart: Origins of Scripture and Literature. Oxford: Oxford University Press.

2014 Holy Resilience: The Bible's Traumatic Origins. New Haven: Yale University Press.

\section{Carrière, B. and Barrois, A.}

1927 'Fouilles de l'École Archéologique Française de Jérusalem effectuées à Neirab du 24 septembre au 5 novembre 1926'. Syria 8, 126-142, 201-212.

\section{Carroll, Robert P.}

1986 The Book ofJeremiah: A Commentary. Old Testament Library. London: SCM.

1992 'The Myth of the Empty Land'. Semeia 59, 79-93.

1998 'Exile! What Exile? Deportation and the Discourses of Diaspora'. Lester L. Grabbe (ed.), Leading Captivity Captive: The 'Exile' as History and Ideology. JSOTS 278. Sheffield: Sheffield Academic Press, 62-79.

\section{Carter, Charles E.}

1999 The Emergence of Yehud in the Persian Period: A Social and Demographic Study. Sheffield: Sheffield Academic Press.

\section{Casana, Jesse}

2015 'Satellite Imagery-Based Analysis of Archaeological Looting in Syria'. Near Eastern Archaeology 78, 142-152. 


\section{Chan, Michael J.}

2013 'Joseph and Jehoiachin: On the Edge of Exodus'. ZAW 125, 566-577.

\section{Charles, M.P.}

1988 'Irrigation in Lowland Mesopotamia'. BSA 4, 1-39.

\section{Charpin, Dominique}

2012 Hammurabi of Babylon. London: I.B. Tauris.

\section{Chavalas, Mark W.}

2002 'Assyriology and Biblical Studies: A Century and a Half of Tension'. Mark W. Chavalas and K. Lawson Younger, Jr. (eds.), Mesopotamia and the Bible: Comparative Explorations. Grand Rapids: Baker Academic, 21-67.

\section{Cherry, John F.}

2014 'Publishing Undocumented Texts: Editorial Perspectives'. Matthew T. Rutz and Morag M. Kersel (eds.), Archaeologies of Text: Archaeology, Technology, and Ethics. Joukowsky Institute Publications 6. Oxford: Oxbow, 227-244.

\section{Chevannes, Barry}

1994 Rastafari: Roots and Ideology. Utopianism and Communitarianism. Syracuse: Syracuse University Press.

\section{Chong, Joong Ho}

1996 'Were There Yahwistic Sanctuaries in Babylonia?'. Asia Journal of Theology 10, 198-217.

\section{Clancier, Philippe}

2011 'Cuneiform Culture's Last Guardians: The Old Urban Notability of Hellenistic Uruk'. Karen Radner and Eleanor Robson (eds.), The Oxford Handbook of Cuneiform Culture. Oxford: Oxford University Press, $75^{2-773 .}$

\section{Clay, Albert T.}

1904 Business Documents of Murashû Sons of Nippur: Dated in the Reign of Darius II. (424-404 B.C.). The Babylonian Expedition of the University of Pennsylvania Series A, volume 10. Philadelphia: The Department of Archaeology and Paleontology of the University of Pennsylvania.

1907 Light on the Old Testament from Babel. Second edition. Philadelphia: The Sunday School Times. 
1908 Legal and Commercial Transactions Dated in the Assyrian, Neo-Babylonian and Persian Periods Chiefly from Nippur. The Babylonian Expedition of the University of Pennsylvania Series A, volume 8/1. Philadelphia: The Department of Archaeology, University of Pennsylvania.

1912 Business Documents of Murashu Sons of Nippur:Dated in the Reign of Darius II. University of Pennsylvania, The Museum Publications of the Babylonian Section 2/1. Philadelphia: The University Museum.

\section{Clermont-Ganneau, Charles}

1897 'Les Stèles araméennes de Neîrab'. Études d'archéologie orientale 2. Paris: Émile Bouillon, 182-223.

\section{Cogan, Mordechai}

2008 The Raging Torrent: Historical Inscriptions from Assyria and Babylonia Relating to Ancient Israel. Jerusalem: Carta.

2013 Bound for Exile: Israelites and Judeans Under Imperial Yoke: Documents from Assyria and Babylonia. Jerusalem: Carta.

\section{Cogan, Mordechai and Tadmor, Hayim}

1988 II Kings: A New Translation with Introduction and Commentary. The Anchor Bible 11. Garden City: Doubleday.

\section{Cole, Steven W.}

1996 Nippur in Late Assyrian Times c. 755-612 BC. State Archives of Assyria Studies 4. Helsinki: The Neo-Assyrian Text Corpus Project.

\section{Cole, Steven W. and Gasche, Hermann}

1998 'Second- and First-Millennium BC Rivers in Northern Babylonia'. Hermann Gasche and Michel Tanret (eds.), Changing Watercourses in Babylonia: Towards a Reconstruction of the Ancient Environment in Lower Mesopotamia 1. Mesopotamian History and Environment Series 2, Memoirs 5. Ghent: The University of Ghent; Chicago: The Oriental Institute of the University of Chicago, 1-64.

\section{Collins, John J.}

1993 Daniel: A Commentary on the Book of Daniel. Hermeneia. Minneapolis: Fortress Press.

\section{Collins, John J. et al. (eds.)}

2001 The Book of Daniel: Composition and Reception. 2 volumes. VTSup 83. Leiden: Brill. 


\section{Coogan, Michael David}

1973 'Patterns in Jewish Personal Names in the Babylonian Diaspora'. JSJ 4, 183-191.

1974 'Life in the Diaspora: Jews at Nippur in the Fifth Century B.C... The Biblical Archaeologist 37, 6-12.

1976a West Semitic Personal Names in the Murašû Documents. Harvard Semitic Monographs 7. Missoula: Scholars Press.

1976b 'More Yahwistic Names in the Murashu Documents'. JSJ 7, 199-200.

\section{Cooper, J.S.}

2012 'Sumer, Sumerisch'. RlA 13, 290-297.

\section{Corò Capitanio, Paola}

2012 'By the Written Order of the rab ša rēš āli ša Uruk: Towards an Understanding of the bit ritti System in Hellenistic Uruk'. Giovanni B. Lanfranchi et al. (eds.), Leggo! Studies Presented to Frederick Mario Fales on the Occasion of His 65th Birthday. LAOS 2. Wiesbaden: Harrassowitz, 149-160.

\section{Cousin, Laura and Watai, Yoko}

2016 'Onomastics of Women in Babylonia in the First Millennium BC'. Orient 51, $3^{-27}$.

\section{Cross, Frank Moore, Jr.}

2005 'Statement on Inscribed Artifacts without Provenience'. Biblical Archaeology Review 31 (5), 58-6o.

\section{Crouch, Carly L.}

2009 War and Ethics in the Ancient Near East: Military Violence in Light of Cosmology and History. BZAW 407. Berlin: De Gruyter.

\section{Curtin, Philip D.}

1984 Cross-Cultural Trade in World History. Studies in Comparative World History. Cambridge: Cambridge University Press.

\section{Cussini, Eleonora}

2000 'Palaeography of the Aramaic Epigraphs from Tell Neirab'. Simonetta Graziani (ed.), Studi sul Vicino Oriente antico dedicati alla memoria di Luigi Cagni 3. Istituto Universitario Orientale, Dipartimento di Studi Asiatici, Series Minor 61. Naples: Istituto Universitario Orientale, 1459-1479.

2013 'The Career of Some Elephantine and Murašû Scribes and Witnesses'. Alejandro F. Botta (ed.), In the Shadow of Bezalel: Aramaic, Biblical, and Ancient Near Eastern Studies in Honor of Bezalel Porten. CHANE 6o. Leiden: Brill, 39-52. 


\section{Da Riva, Rocío}

2001 'Sippar in the Reign of Sîn-šum-līšir'. AoF 28, 40-64.

2002 Der Ebabbar-Tempel von Sippar in frühneubabylonischer Zeit (640-580 v. Chr.). AOAT 291. Münster: Ugarit-Verlag.

2008 The Neo-Babylonian Royal Inscriptions: An Introduction. GMTR 4. Münster: Ugarit-Verlag.

2013 'Nebuchadnezzar II's Prism (ES 7834): A New Edition'. ZA 103, 196-229.

\section{Daiches, Samuel}

1910 The Jews in Babylonia in the Time of Ezra and Nehemiah according to Babylonian Inscriptions. Jews' College Publications 2. London: Jews' College.

\section{Dalley, Stephanie M.}

1984 'The Cuneiform Tablet from Tell Tawilan'. Levant 16, 19-22.

1985 'Foreign Chariotry and Cavalry in the Armies of Tiglath-pileser III and Sargon II'. Iraq 47, 31-48.

1990 'Yahweh in Hamath in the 8th Century BC: Cuneiform Material and Historical Deductions'. VT 40, 21-32.

1998 'Yabâ, Atalyā and the Foreign Policy of Late Assyrian Kings'. SAAB 12, 83-98.

2013 'Gods from North-Eastern and North-Western Arabia in Cuneiform Texts from the First Sealand Dynasty, and a Cuneiform Inscription from Tell en-Nașbeh, $c$. 1500 BC'. Arabian Archaeology and Epigraphy 24, 177-185.

\section{Dalley, Stephanie M. and Postgate, J.N.}

1984 The Tablets from Fort Shalmaneser. Cuneiform Texts from Nimrud 3. London: British School of Archaeology in Iraq.

\section{Dandamayev, Muhammad A.}

1971 'Die Rolle des tamkārum in Babylonien im 2. und 1. Jahrtausend v.u.Z.. Horst Klengel (ed.), Beiträge zur sozialen Structur des alten Vorderasien. Schriften zur Geschichte und Kultur des Alten Orients 1. Berlin: Akademie-Verlag, $69-78$.

1983 'Aliens and the Community in Babylonia in the 6th-5th Centuries B.C.. Les communautés rurales $=$ Rural Communities 2: Antiquité $=$ Antiquity. Recueils de la Société Jean Bodin pour l'histoire comparative des institutions 41. Paris: Dessain et Tolra, 133-145.

1984 Slavery in Babylonia: From Nabopolassar to Alexander the Great (626-331 BC). Revised edition. DeKalb: Northern Illinois University Press.

1987 'Free Hired Labor in Babylonia During the Sixth through Fourth Centuries BC'. Marvin A. Powell (ed.), Labor in the Ancient Near East. New Haven: American Oriental Society, 271-279. 
1991 'Neo-Babylonian Society and Economy'. John Boardman et al. (eds.), The Cambridge Ancient History Volume 3, Part 2: The Assyrian and Babylonian Empires and Other States of the Near East, from the Eighth to the Sixth Centuries B.C. Second Edition. Cambridge: Cambridge University Press, 252-275.

1992a 'Egyptians in Babylonia in the 6th-5th Centuries B.C... Dominique Charpin and Francis Joannès (eds.), La circulation des biens, des personnes et des idées dans le Proche-Orient ancien: Actes de la XXXVIIIe Rencontre Assyriologique Internationale (Paris, 8-1ojuillet 1991). Paris: Éditions Recherche sur les Civilisations, 321-325.

1992b Iranians in Achaemenid Babylonia. Columbia Lectures on Iranian Studies 6. Costa Mesa: Mazda.

1995 'The Neo-Babylonian tamkārū'. Ziony Zevit et al. (eds.), Solving Riddles and Untying Knots: Biblical, Epigraphic, and Semitic Studies in Honor of Jonas C. Greenfield. Winona Lake: Eisenbrauns, 523-530.

2004 'Twin Towns and Ethnic Minorities in First-Millennium Babylonia'. Robert Rollinger and Christopf Ulf (eds.), Commerce and Monetary Systems in the Ancient World: Means of Transmission and Cultural Interaction: Proceedings of the Fifth Annual Symposium of the Assyrian and Babylonian Intellectual Heritage Project, Held in Innsbruck, Austria, October 3rd-8th, 2002. Melammu Symposia 5. Stuttgart: Franz Steiner, 137-151.

\section{von Dassow, Eva}

1999a 'On Writing the History of Southern Mesopotamia'. ZA 89, 227-246.

1999b 'Introducing the Witnesses in Neo-Babylonian Documents'. Robert Chazan et al. (eds.), Ki Baruch Hu: Ancient Near Eastern, Biblical, and Judaic Studies in Honor of Baruch A. Levine. Winona Lake: Eisenbrauns, 3-22.

\section{David, Yonah}

2007 'Jerahmeel ben Solomon'. Michael Berenbaum and Fred Skolnik (eds.), Encyclopaedia Judaica (Second edition) 11, 124.

\section{Deller, Karlheinz and Finkel, Irving}

1984 'A Neo-Assyrian Inventory Tablet of Unknown Provenance'. ZA 74, 76-91.

\section{Dhorme, Édouard}

1928 'Les tablettes babyloniennes de Neirab'. $R A$ 25, 53-82.

\section{Dietrich, Manfred}

1970 Die Aramäer Südbabyloniens in der Sargonidenzeit (7oo-648). AOAT 7. Kevelaer: Butzon \& Bercker; Neukirchen-Vluyn: Neukirchener Verlag. 


\section{Dignas, Beate and Winter, Engelbert}

2007 Rome and Persia in Late Antiquity: Neighbours and Rivals. Cambrigde: Cambridge University Press.

\section{Diodorus Siculus}

- $\quad$ The Library of History. Loeb Classical Library. Cambridge, MA: Harvard University Press.

\section{Donbaz, Veysel and Stolper, Matthew W.}

1993 'Gleanings from Murašû Texts in the Collections of the Istanbul Archaeological Museums. NABU 1993/102.

1997 Istanbul Murašû Texts. PIHANS 79. Leiden: Nederlands Instituut voor het Nabije Oosten.

\section{Donner, Herbert and Röllig, Wolfgang}

2002 Kanaanäische und aramäische Inschriften 1. Fifth edition. Wiesbaden: Harrassowitz.

\section{van Driel, Govert}

1985-1986 'The Rise of the House of Egibi: Nabû-ahḩ̄ē-iddina'. Jaarbericht van het Vooraziatisch-Egyptisch Genootschap Ex Oriente Lux 29, 50-67.

1986 'Neo-Babylonian Texts from the Louvre'. BiOr 43, 5-20.

1988 'Neo-Babylonian Agriculture'. BSA 4, 121-159.

1989 'The Murašûs in Context'. JESHO 32, 203-229.

1990 'Neo-Babylonian Agriculture III: Cultivation'. BSA 5, 219-266.

1992 'Neo-Babylonian Texts from Borsippa'. BiOr 49, 28-50.

1993 'Neo-Babylonian Sheep and Goats'. BSA 7, 219-258.

1995 'Cattle in the Neo-Babylonian Period'. BSA 8, 215-240.

1999 'Agricultural Entrepreneurs in Mesopotamia'. Horst Klengel and Johannes Renger (eds.), Landwirtschaft im Alten Orient: Ausgewählte Vorträge der XLI. Rencontre Assyriologique Internationale: Berlin, 4.-8.7.1994. Berliner Beiträge zum Vorderen Orient 18. Berlin: Dietrich Reimer, 213-223.

2001 'On Villages'. W.H. van Soldt et al. (eds.), Veenhof Anniversary Volume: Studies Presented to Klaas R. Veenhof on the Occasion of His Sixty-Fifth Birthday. PIHANS 89. Leiden: Nederlands Instituut voor het Nabije Oosten, $103^{-118 .}$

2002 Elusive Silver: In Search of a Role for a Market in an Agrarian Environment: Aspects of Mesopotamia's Society. PIHANS 95. Leiden: Nederlands Instituut voor het Nabije Oosten. 


\section{Dušek, Jan}

2007 Les manuscrits araméens du Wadi Daliyeh et la Samarie vers 450-332 av. J.-C. CHANE 3o. Leiden: Brill.

\section{Ebeling, Erich}

1952 'Die Rüstung eines babylonischen Panzerreiters nach einem Vertrage aus der Zeit Darius II'. ZA 50, 203-213.

\section{Edelman, Diana}

2005 The Origins of the 'Second' Temple: Persian Imperial Policy and the Rebuilding of Jerusalem. BibleWorld. London: Equinox.

\section{Ehrenberg, Erica}

1999 Uruk: Late Babylonian Seal Impressions on Eanna-Tablets. Ausgrabungen in Uruk-Warka 18. Mainz am Rhein: Philipp von Zabern.

\section{Eilers, Wilhelm}

1940 'Kleinasiatisches'. ZDMG 94, 189-233.

\section{Elat, Moshe}

1987 'Der tamkāru im neuassyrischen Reich'.JESHO 30, 233-254.

\section{Emberling, Geoff and Hanson, Katharyn (eds.)}

2008 Catastrophe! The Looting and Destruction of Iraq's Past. Oriental Institute Museum Publications 28. Chicago: The Oriental Institute.

\section{Eph`al, Israel}

1978 'The Western Minorities in Babylonia in the 6th-5th Centuries B.C.: Maintenance and Cohesion'. Orientalia 47, 74-90.

1982 The Ancient Arabs: Nomads on the Borders of the Fertile Crescent, 9th-5th Centuries B.C. Jerusalem: Magnes; Leiden: Brill.

1983 'On the Political and Social Organization of the Jews in Babylonian Exile'. Fritz Steppat (ed.), XXI. Deutscher Orientalistentag vom 24. bis 29. März 1980 in Berlin: Vorträge. ZDMG Supplement 5. Wiesbaden: Franz Steiner, 106-112.

\section{Estrin, Daniel}

2015 'Ancient Tablets Displayed in Jerusalem Part of Debate over Looting of Antiquities in Mideast'. U.S. News \& World Report, 12 February 2015. Available online at https://www.usnews.com/news/world/articles/2015/02/12/ancient-tablets -displayed-in-jerusalem-fuel-looting-debate. 


\section{Fales, Frederick Mario}

1973 'Remarks on the Neirab Texts'. Oriens Antiquus 12, 131-142.

2007a 'Arameans and Chaldeans: Environment and Society'. Gwendolyn Leick (ed.), The Babylonian World. The Routledge Worlds. New York: Routledge, 288-298.

2007b 'Multilingualism on Multiple Media in the Neo-Assyrian Period: A Review of the Evidence'. $S A A B$ 16, 95-122.

2011 'Moving around Babylon: On the Aramean and Chaldean Presence in Southern Mesopotamia'. Eva Cancik-Kirschbaum et al. (eds.), Babylon: Wissenskultur in Orient und Okzident. Topoi 1. Berlin: De Gruyter, 91-111.

2012 'After Ta'yinat: The New Status of Esarhaddon's adê for Assyrian Political History'. $R A$ 106, 133-158.

\section{Falkner, Margarete}

1971 'Gaza'. RlA 3, 152-153.

\section{Fantalkin, Alexander}

2001 'Meẓad Ḥashavyahu: Its Material Culture and Historical Background'. TA 28, $3^{-165}$.

2011 'Why Did Nebuchadnezzar II Destroy Ashkelon in Kislev 6o4 B.C.E.?'. Israel Finkelstein and Nadav Na'aman (eds.), The Fire Signals of Lachish: Studies in the Archaeology and History of Israel in the Late Bronze Age, Iron Age, and Persian Period in Honor of David Ussishkin. Winona Lake: Eisenbrauns, 87-111.

2014 'Ashdod-Yam on the Israeli Mediterranean Coast: A First Season of Excavations'. Skyllis 14, 45-57.

2015 'Coarse Kitchen and Household Pottery as an Indicator for Egyptian Presence in the Southern Levant: A Diachronic Perspective'. Michela Spataro and Alexandra Villing (eds.), Ceramics, Cuisine and Culture: The Archaeology and Science of Kitchen Pottery in the Ancient Mediterranean World. Oxford: Oxbow, 233-241.

\section{Fantalkin, Alexander and Lytle, Ephraim}

2016 'Alcaeus and Antimenidas: Reassessing the Evidence for Greek Mercenaries in the Neo-Babylonian Army'. Klio 98, 90-117.

\section{Faust, Avraham}

2011 'Deportation and Demography in Sixth-Century B.C.E. Judah'. Brad E. Kelle et al. (eds.), Interpreting Exile: Interdisciplinary Studies of Displacement and Deportation in Biblical and Modern Contexts. AIL 10. Atlanta: Society of Biblical Literature, 91-103.

2012 Judah in the Neo-Babylonian Period: The Archaeology of Desolation. ABS 18. Atlanta: Society of Biblical Literature. 
Fiddian-Qasmiyeh, Elena et al. (eds.)

2014 The Oxford Handbook of Refugee and Forced Migration Studies. Oxford: Oxford University Press.

\section{Finkel, Irving}

1999 'The Lament of Nabû-šuma-ukîn'. Johannes Renger (ed.), Babylon: Focus mesopotamischer Geschichte, Wiege früher Gelehrsamkeit, Mythos in der Moderne. Colloquien der Deutschen Orient-Gesellschaft 2. Saarbrücken: SDV, 323-342.

\section{Finkel, Irving and Seymour, Michael (eds.)}

2008 Babylon: Myth and Reality. London: The British Museum.

\section{Finkelstein, Israel}

2008a 'Archaeology and the List of Returnees in the Books of Ezra and Nehemiah'. Palestine Exploration Quarterly 140, 7-16.

2008b 'Jerusalem in the Persian (and Early Hellenistic) Period and the Wall of Nehemiah'. Journal for the Study of the Old Testament 32, 501-520.

2010 'The Territorial Extent and Demography of Yehud/Judea in the Persian and Early Hellenistic Periods'. Revue Biblique 117, 39-54.

2013 The Forgotten Kingdom: The Archaeology and History of Northern Israel. ANEM 5. Atlanta: Society of Biblical Literature.

\section{Finkelstein, Israel and Singer-Avitz, Lily}

2001 'Ashdod Revisited'. TA 28, 231-259.

2004 “Ashdod Revisited” - Maintained'. TA 31, 122-135.

\section{Fischer, Georg}

2005 Jeremia 26-52. Herders Theologischer Kommentar zum Alten Testament. Freiburg: Herder.

\section{Fleming, Daniel E.}

2014 'Chasing Down the Mundane: The Near East with Social Historical Interest'. JANEH $1,5^{-20}$.

\section{Foster, Benjamin R.}

2005 Before the Muses: An Anthology of Akkadian Literature. Third edition. Bethesda: CDL.

2007 Akkadian Literature of the Late Period. GMTR 2. Münster: Ugarit-Verlag. 


\section{Fowler, Jeaneane D.}

1988 Theophoric Personal Names in Ancient Hebrew: A Comparative Study. JSOTS 49. Sheffield: JSOT Press.

\section{Fox, Michael V.}

2010 Character and Ideology in the Book of Esther: Second Edition with a New Postscript on a Decade of Esther Scholarship. Eugene: Wipf and Stock.

\section{Frahm, Eckart (ed.)}

2017 A Companion to Assyria. Blackwell Companions to the Ancient World. Hoboken: Wiley.

\section{Frame, Grant}

1991 'Nabonidus, Nabû-šarra-uṣur, and the Eanna Temple'. ZA 81, 37-86.

1992 Babylonia 689-627 B.C.: A Political History. PIHANS 69. Istanbul: Nederlands Historisch-Archaeologisch Instituut te Istanbul.

2013 'The Political History and Historical Geography of the Aramean, Chaldean, and Arab Tribes in Babylonia in the Neo-Assyrian Period'. Angelika Berlejung and Michael P. Streck (eds.), Aramaeans, Chaldeans and Arabs in Babylonia and Palestine in the First Millennium B.C. LAOS 3 . Wiesbaden: Harrassowitz, 87-121.

\section{Fried, Lisbeth S.}

2012 'The Artaxerxes Correspondence of Ezra 4, Nehemiah's Wall, and Persian Provincial Administration'. Aren M. Maeir et al. (eds.), 'Go Out and Study the Land' (Judges 18:2): Archaeological, Historical and Textual Studies in Honor of Hanan Eshel. JSJ Supplements 148. Leiden: Brill, 35-57.

\section{Fried, Lisbeth S. (ed.)}

2011 Was 1 Esdras First? An Investigation into the Priority and Nature of 1 Esdras. AIL 7. Atlanta: Society of Biblical Literature.

\section{Fuchs, Andreas}

1994 Die Inschriften Sargons II. aus Khorsabad. Göttingen: Cuvillier.

2014 'Die unglaubliche Geburt des neubabylonischen Reiches oder: Die Vernichtung einer Weltmacht durch den Sohn eines Niemand'. Manfred Krebernik and Hans Neumann (eds.), Babylonien und seine Nachbarn in neu- und spätbabylonischer Zeit: Wissenschaftliches Kolloquium aus Anlass des 75. Geburtstags von Joachim Oelsner, Jena, 2. und 3. März 2007. AOAT 369. Münster: Ugarit-Verlag, 25-71. 


\section{Gabbay, Uri and Secunda, Shai (eds.)}

2014 Encounters by the Rivers of Babylon: Scholarly Conversations between Jews, Iranians and Babylonians in Antiquity. TSAJ 160. Tübingen: Mohr Siebeck.

\section{Galil, Gershon}

2009 'Israelite Exiles in Media: A New Look at ND 2443+'. VT 59, 71-79.

\section{Gaster, Moses}

1899 The Chronicles ofJerahmeel. Oriental Translation Fund NS 4. London: Royal Asiatic Society.

\section{Geller, Markham J.}

1997 'The Last Wedge'. ZA 87, 43-95.

2010 Ancient Babylonian Medicine: Theory and Practice. Ancient Cultures. Chichester: Wiley-Blackwell.

\section{Gerhards, Meik}

1998 'Die Begnadigung Jojachins - Überlegungen zu 2.Kön.25, 27-30 (mit einem Anhang zu den Nennungen Jojachins auf Zuteilungslisten aus Babylon)'. BN 94, $5^{2-67}$

\section{Gerstenblith, Patty}

2014 'Do Restrictions on Publication of Undocumented Texts Promote Legitimacy?'. Matthew T. Rutz and Morag M. Kersel (eds.), Archaeologies of Text: Archaeology, Technology, and Ethics. Joukowsky Institute Publications 6. Oxford: Oxbow, 214-226.

\section{Gesche, Petra D.}

2000 Schulunterricht in Babylonien im ersten Jahrtausend v. Chr. AOAT 275. Münster: Ugarit-Verlag.

\section{Glassner, Jean-Jacques}

2004 Mesopotamian Chronicles. Writings from the Ancient World 19. Atlanta: Society of Biblical Literature.

\section{Goetze, Albrecht}

1944 'Additions to Parker and Dubberstein's Babylonian Chronology'. JNES 3, $43-46$.

\section{Gordin, Shai and Zadok, Ran}

2016 'The Illil-mukīn-apli Dossier: A Case Study from the Murašû Archive in the Context of Taxation'. Aula Orientalis 34, 37-56. 


\section{Gould, David M.}

1994 'Immigrant Links to the Home Country: Empirical Implications for U.S. Bilateral Trade Flows'. The Review of Economics \& Statistics 76, 302-316.

\section{Grabbe, Lester L.}

1998a “The Exile” under the Theodolite: Historiography as Triangulation'. Lester L. Grabbe (ed.), Leading Captivity Captive: The 'Exile' as History and Ideology. JSOTS 278. Sheffield: Sheffield Academic Press, 80-100.

1998b Ezra-Nehemiah. Old Testament Readings. London: Routledge.

2006 'The "Persian Documents" in the Book of Ezra: Are They Authentic?'. Oded Lipschits and Manfred Oeming (eds.), Judah and the Judeans in the Persian Period. Winona Lake: Eisenbrauns, 531-570.

2015 'The Reality of the Return: The Biblical Picture Versus Historical Reconstruction'. Jonathan Stökl and Caroline Waerzeggers (eds.), Exile and Return: The Babylonian Context. BZAW 478. Berlin: De Gruyter, 292-307.

\section{Grabbe, Lester L. (ed.)}

1998 Leading Captivity Captive: The 'Exile' as History and Ideology. JSOTS 278. Sheffield: Sheffield Academic Press.

2003 'Like a Bird in a Cage': The Invasion of Sennacherib in 701 BCE. JSOTS 363 . European Seminar in Historical Methodology 4. London: Sheffield Academic Press.

\section{Granerød, Gard}

2015 'Siste skrik fra elvene i Babel: Nye kilder til det judeiske eksilet i Babylon'. Teologisk Tidsskrift 4, 357-372.

2016 Dimensions of Yahwism in the Persian Period: Studies in the Religion and Society of the Judaean Community at Elephantine. BZAW 488. Berlin: De Gruyter.

\section{Granovetter, Mark S.}

1973 'The Strength of Weak Ties'. American Journal of Sociology 78, 1360-1380.

\section{Graslin-Thomé, Laetitia}

2009 Les échanges à longue distance en Mésopotamie au Ier millénaire: Une approche économique. Orient \& Méditerranée 5. Paris: De Boccard.

2014 'Les marchands mésopotamiens et la théorie des jeux'. Zoltán Csabai (ed.), Studies in Economic and Social History of the Ancient Near East in Memory of Péter Vargyas. Ancient Near Eastern and Mediterranean Studies 2. Budapest: L'Harmattan, 603-628.

\section{Grayson, A. Kirk}

1975a Assyrian and Babylonian Chronicles. Texts from Cuneiform Sources 5. Locust Valley: J.J. Augustin. 
1975b Babylonian Historical-Literary Texts. Toronto Semitic Texts and Studies 3. Toronto: University of Toronto Press.

\section{Grünwaldt, Klaus}

1992 Exil und Identität: Beschneidung, Passa und Sabbat in der Priesterschrift. Bonner Biblische Beiträge 85. Frankfurt am Main: Hain.

\section{Gry, Léon}

1922 'Israélites en Assyrie, Juifs en Babylonie 1'. Le Muséon 35, 153-185.

1923 'Israélites en Assyrie, Juifs en Babylonie 2'. Le Muséon 36, 1-26.

\section{Hackl, Johannes}

2017 'Babylonian Scribal Practices in Rural Contexts: A Linguistic Survey of the Documents of Judean Exiles and West Semites in Babylonia (CUSAS 28 and BaAr 6)'. Angelika Berlejung et al. (eds.), Wandering Arameans: Arameans Outside Syria: Textual and Archaeological Perspectives. LAOS 5. Wiesbaden: Harrassowitz, 125-140.

(forthcoming) 'Language Death and Dying Reconsidered: The Rôle of Late Babylonian as a Vernacular Language'. Cornelia Wunsch (ed.), The Neo-Babylonian Workshop of the 53rd RAI: City Administration in Neo-Babylonian Times. Babel und Bibel. Winona Lake: Eisenbrauns.

\section{Hackl, Johannes and Jursa, Michael}

2015 'Egyptians in Babylonia in the Neo-Babylonian and Achaemenid Periods'. Jonathan Stökl and Caroline Waerzeggers (eds.), Exile and Return: The Babylonian Context. BZAW 478. Berlin: De Gruyter, 157-180.

\section{Hackl, Johannes and Pirngruber, Reinhard}

2015 'Prices and Related Data from Northern Babylonia in the Late Achaemenid and Early Hellenistic Periods, c. 480-30o BC. R.J. van der Spek et al. (eds.), A History of Market Performance: From Ancient Babylonia to the Modern World. Routledge Explorations in Economic History 68. London: Routledge, 107-127.

\section{Haider, Peter W.}

1988 Griechenland - Nordafrika: Ihre Beziehungen zwischen 1500 und 600 v. Chr. Impulse der Forschung 53. Darmstadt: Wissenschaftliche Buchgesellschaft.

\section{Hartman, Louis F. and Di Lella, Alexander A.}

1978 The Book of Daniel. The Anchor Bible 23. Garden City: Doubleday. 


\section{Haubold, Johannes et al. (eds.)}

2013 The World of Berossos. CLeO 5. Wiesbaden: Harrassowitz.

\section{Hawkins, J.D.}

2007 'Que. A. Geschichte'. RlA 11, 191-195.

\section{Heinemann, Joseph}

2007 'Leviticus Rabbah'. Michael Berenbaum and Fred Skolnik (eds.), Encyclopaedia Judaica (Second edition) 12, 740-742.

\section{Heltzer, Michael}

2005 'Again on Seals of Exiles (from Israel to Judah and Mesopotamia)'. W.H. van Soldt et al. (eds.), Ethnicity in Ancient Mesopotamia. Papers Read at the 48th Rencontre Assyriologique Internationale, Leiden, 1-4 July 2002. PIHANS 102. Leiden: Nederlands Instituut voor het Nabije Oosten, 173-179.

2006 'The "Royal Merchants" ( $\operatorname{tamkāru}(\check{s} a)$ šarri) in Neo-Babylonian and Achaemenid Times and the West Semites among them'. UF 38, 347-351.

\section{Henkelman, Wouter}

2003 'An Elamite Memorial: The Šumar of Cambyses and Hystaspes'. Wouter Henkelman and Amélie Kuhrt (eds.), A Persian Perspective: Essays in Memory of Heleen Sancisi-Weerdenburg. Achaemenid History 13. Leiden: Nederlands Instituut voor het Nabije Oosten, 101-172.

2008 The Other Gods Who Are: Studies in Elamite-Iranian Acculturation Based on the Persepolis Fortification Texts. Achaemenid History 14. Leiden: Nederlands Instituut voor het Nabije Oosten.

\section{Henkelman, Wouter and Stolper, Matthew W.}

2009 'Ethnic Identity and Ethnic Labelling at Persepolis: The Case of the Skudrians'. Pierre Briant and Michel Chauveau (eds.), Organisation des pouvoirs et contacts culturels dans les pays de l'empire achéménide. Persika 14. Paris: De Boccard, $271-329$.

\section{Herodotus}

- $\quad$ The Persian Wars. Loeb Classical Library. Cambridge, MA: Harvard University Press.

\section{Hezser, Catherine}

2011 Jewish Travel in Antiquity. TSAJ 144. Tübingen: Mohr Siebeck. 


\section{Hilprecht, Hermann V. and Clay, Albert T.}

1898 Business Documents of Murashû Sons of Nippur:Dated in the Reign of Artaxerxes I. (464-424 B.C.). The Babylonian Expedition of the University of Pennsylvania Series A, volume 9. Philadelphia: The Department of Archaeology and Paleontology of the University of Pennsylvania.

\section{Holladay, William L.}

1989 Jeremiah 2: A Commentary on the Book of the Prophet Jeremiah, Chapters 26-52. Hermeneia. Minneapolis: Fortress Press.

\section{Holloway, Steven W.}

2002 Aššur Is King! Aššur Is King!: Religion in the Exercise of Power in the Neo-Assyrian Empire. CHANE 10. Leiden: Brill.

\section{Holtz, Shalom E.}

2009 Neo-Babylonian Court Procedure. CM 38. Leiden: Brill.

\section{Horowitz, Wayne and Gheva, David}

2017 'Fish for the Jewish High Holidays in Fifth Century BCE Babylonia and Some Further Thoughts on Al-Yahudu'. Bible Lands e-Review 2017/S2. Available online at https://biblelandsreview.wordpress.com/complete-articles/.

\section{Huber, Irene}

2006 'Von Affenwärtern, Schlangenbeschwörern und Palastmanagern: Ägypter im Mesopotamien des ersten vorchristlichen Jahrtausends'. Robert Rollinger and Brigitte Truschnegg (eds.), Altertum und Mittelmeerraum: Die antike Welt diesseits und jenseits der Levante: Festschrift für Peter W. Haider zum 6o. Geburtstag. Oriens et Occidens 12. Stuttgart: Franz Steiner, 303-329.

\section{Jacobson, Howard}

1997 'Thoughts on the Chronicles of Jerahmeel, Ps-Philo's Liber Antiquitatum Biblicarum, and Their Relationship'. David T. Runia and Gregory E. Sterling (eds.), Wisdom and Logos: Studies in Jewish Thought in Honor of David Winston. The Studia Philonica Annual 9. Brown Judaic Studies 312. Atlanta: Scholars, $239-263$.

\section{Jakob-Rost, Liane}

1970 'Urkunden des 7. Jahrhunderts v. u. Z. aus Babylon'. Forschungen und Berichte $12,49-60$. 


\section{Joannès, Francis}

1982a Textes économiques de la Babylonie récente. Étude des textes de TBER 6. Paris: Éditions Recherche sur les civilisations.

1982b 'La localisation de Șurru à l'époque néo-babylonienne'. Semitica 32, 35-43.

1986 Review of The Late Babylonian Tablets in the Royal Ontario Museum by G.J.P. McEwan. $R A$ 80, 79-81.

1987 'Fragments de Nippur d'époque néo-babylonienne'. Anatolica 14, 107-130.

1989 Archives de Borsippa, la famille Ea-ilûta-bâni: Étude d'un lot d'archives familiales en Babylonie du VIIIe au Ve siècle av.J.-C. École pratique des hautes études, IV e section: Sciences historiques et philologiques 2: Hautes études orientales 25. Geneva: Droz.

1990 'Textes babyloniens de Suse d'époque achéménide'. François Vallat (ed.), Contribution à l'histoire de l'Iran: Mélanges offerts à Jean Perrot. Paris: Éditions Recherche sur les Civilisations, $173^{-180 .}$

1992 'Inventaire d'un cabaret'. $N A B U$ 1992/64.

1994 'Amours Contrariées'. NABU 1994/72.

1995 'Private Commerce and Banking in Achaemenid Babylon'. Jack M. Sasson (ed.), Civilizations of the Ancient Near East 3. New York: Charles Scribner's Sons, $1475^{-1485}$.

1999 'Structures et opérations commerciales en Babylonie à l'époque néo-babylonienne'. Jan Gerrit Dercksen (ed.), Trade and Finance in Ancient Mesopotamia: Proceedings of the First MOS Symposium (Leiden 1997). PIHANS 84. Istanbul: Nederlands Historisch-Archaeologisch Instituut, 175-194.

2002 'Les droits sur l'eau en Babylonie récente'. Annales 57, 577-6o9.

\section{Joannès, Francis and Lemaire, André}

1996 'Contrats babyloniens d'époque achéménide du Bît-Abî râm avec une épigraphe araméenne'. $R A$ 90, 41-6o.

1999 'Trois tablettes cunéiformes à onomastique ouest-sémitique (collection Sh. Moussaïeff)'. Transeuphratène 17, 17-34.

\section{Joffe, Alexander $\mathrm{H}$.}

2003 Review of Messages from the Past: Hebrew Bullae from the Time of Isaiah through the Destruction of the First Temple by Robert Deutsch and Biblical Period Personal Seals in the Shlomo Moussaieff Collection by Robert Deutsch and André Lemaire. JNES 62, 119-124.

\section{Josephus}

- $\quad$ Against Apion. Loeb Classical Library. Cambridge, MA: Harvard University Press. 


\section{Jursa, Michael}

1995 Die Landwirtschaft in Sippar in neubabylonischer Zeit. AfO Beiheft 25. Vienna: Universität Wien.

1998a Der Tempelzehnt in Babylonien vom siebenten bis zum dritten Jahrhundert v. Chr. AOAT 254. Münster: Ugarit-Verlag.

1998b 'Bogenland schon unter Nebukadnezar II... NABU 1998/124.

1999 Das Archiv des Bēl-rēmanni. PIHANS 86. Istanbul: Nederlands Historisch-Archaeologisch Instituut.

2000 'Ṭerdu: Von Entführung in Babylon und Majestätsbeleidigung in Larsa'. Simonetta Graziani (ed.), Studi sul Vicino Oriente antico dedicati alla memoria di Luigi Cagni 1. Istituto Universitario Orientale, Dipartimento di Studi Asiatici, Series Minor 61. Naples: Istituto Universitario Orientale, 497-514.

2001 'Kollationen'. NABU 2001/102.

2003 'Spätachämenidische Texte aus Kutha'. $R A$ 97, 43-140.

2004a 'Grundzüge der Wirtschaftsformen Babyloniens im ersten Jahrtausend v.Chr.'. Robert Rollinger and Christopf Ulf (eds.), Commerce and Monetary Systems in the Ancient World: Means of Transmission and Cultural Interaction. Melammu Symposia 5. Stuttgart: Franz Steiner, $115^{-136 .}$

2004b 'Neubabylonische Texte'. Bernd Janowski and Gernot Wilhelm (eds.), Texte zum Rechts- und Wirtschaftsleben. Texte aus der Umwelt des Alten Testaments, Neue Folge 1. Gütersloh: Gütersloher Verlagshaus, 89-110.

2004c 'Accounting in Neo-Babylonian Institutional Archives: Structure, Usage, Implications'. Michael Hudson and Cornelia Wunsch (eds.), Creating Economic Order. Record-Keeping, Standardization, and The Development of Accounting In The Ancient Near East. ISCANEE 4. Bethesda: CDL, 145-198.

2005a Neo-Babylonian Legal and Administrative Documents: Typology, Contents and Archives. GMTR 1. Münster: Ugarit-Verlag.

2005b 'Das Archiv von Bēl-ețēri-Šamaš. Heather D. Baker and Michael Jursa (eds.), Approaching the Babylonian Economy: Proceedings of the START Project Symposium Held in Vienna, 1-3 July 2004. AOAT 330. Münster: Ugarit-Verlag, 197-268.

2006 Review of Neo-Babylonian Texts in the Oriental Institute by David B. Weisberg. JAOS 126, 452-458.

2007a 'Eine Familie von Königskaufleuten judäischer Herkunft'. NABU 2007/22.

$2007 \mathrm{~b}$ 'The Transition of Babylonia from the Neo-Babylonian Empire to Achaemenid Rule'. Harriet Crawford (ed.), Regime Change in the Ancient Near East and Egypt: From Sargon of Agade to Saddam Hussein. Proceedings of the British Academy 136. Oxford: Oxford University Press, 73-94.

2007c 'Texte aus dem "Palastarchiv" Nebukadnezars, außerhalb von Berlin'. NABU $2007 / 54$. 
2007d 'The Babylonian Economy in the First Millennium BC'. Gwendolyn Leick (ed.), The Babylonian World. The Routledge Worlds. New York: Routledge, 224-235.

2008 'Nabû-šarrūssu-ukīn, rab ša-rēši, und "Nebusarsekim" (Jer. 39:3)'. NABU $2008 / 5$.

2009 'Business Companies in Babylonia in the First Millennium BC: Structure, Economic Strategies, Social Setting. Myriam Wissa (ed.), The Knowledge Economy and Technological Capabilities: Egypt, the Near East and the Mediterranean, 2nd Millennium B.C. - 1st Millennium A.D. Aula Orientalis Supplementa 26. Sabadell: AUSA, $53^{-68 .}$

$2010 \mathrm{a}$ Aspects of the Economic History of Babylonia in the First Millennium BC: Economic Geography, Economic Mentalities, Agriculture, the Use of Money and the Problem of Economic Growth. M. Jursa with contributions by J. Hackl, B. Janković, K. Kleber, E.E. Payne, C. Waerzeggers and M. Weszeli. AOAT 377. Münster: Ugarit-Verlag.

2010b 'Der neubabylonische Hof'. Bruno Jacobs and Robert Rollinger (eds.), Der Achämenidenhof, The Achaemenid Court: Akten des 2. Internationalen Kolloquiums zum Thema 'Vorderasien im Spannungsfeld klassischer und altorientalischer Überlieferungen', Landgut Castelen bei Basel, 23.-25. Mai 2007. CLeO 2. Wiesbaden: Harrassowitz, 67-106.

2011 'Taxation and Service Obligations in Babylonia from Nebuchadnezzar to Darius and the Evidence for Darius' Tax Reform'. Robert Rollinger et al. (eds.), Herodot und das Persische Weltreich - Herodotus and the Persian Empire: Akten des 3. Internationalen Kolloquiums zum Thema 'Vorderasien im Spannungsfeld klassischer und altorientalischer Überlieferungen, Innsbruck, 24.-28. November 2008. CLeO 3. Wiesbaden: Harrassowitz, 431-448.

$2011 b$ “Höflinge” (ša rēši, ša rēš šarri, ustarbaru) in babylonischen Quellen des ersten Jahrtausends'. Josef Wiesehöfer et al. (eds.), Ktesias'Welt - Ctesias'World. CLeO 1. Wiesbaden: Harrassowitz, 159-173.

2012 'Ein Beamter flucht auf Aramäisch: Alphabetschreiber in der spätbabylonischen Epistolographie und die Rolle des Aramäischen in der babylonischen Verwaltung des sechsten Jahrhunderts v. Chr.' Giovanni B. Lanfranchi et al. (eds.), Leggo! Studies Presented to Frederick Mario Fales on the Occasion of His 65th Birthday. Wiesbaden: Harrassowitz, 379-397.

2014a 'The Neo-Babylonian Empire'. Michael Gehler et al. (eds.), Imperien und Reiche in der Weltgeschichte: Epochenübergreifende und globalhistorische Vergleiche 1: Imperien des Altertums, Mittelalterliche und frühneuzeitliche Imperien. Wiesbaden: Harrassowitz, 121-148.

2014b 'The Lost State Correspondence of the Babylonian Empire as Reflected in Contemporary Administrative Letters'. Karen Radner (ed.), State Correspondence in 
the Ancient World: From New Kingdom Egypt to the Roman Empire. Oxford Studies in Early Empires. Oxford: Oxford University Press, 94-111.

2014c 'Babylonia in the First Millennium BCE - Economic Growth in Times of Empire'. Larry Neal and Jeffrey G. Williamson (eds.), The Cambridge History of Capitalism 1: The Rise of Capitalism: From Ancient Origins to 1848. Cambridge: Cambridge University Press, 24-42.

2015a 'Labor in Babylonia in the First Millennium BC'. Piotr Steinkeller and Michael Hudson (eds.), Labor in the Ancient World. ISCANEE 5. Dresden: ISLET.

2015b 'Families, Officialdom, and Families of Royal Officials in Chaldean and Achaemenid Babylonia'. Alfonso Archi (ed.), Tradition and Innovation in the Ancient Near East: Proceedings of the 57th Rencontre Assyriologique Internationale at Rome, 4-8 July 2011. Winona Lake: Eisenbrauns, 597-6o6.

\section{Jursa, Michael and Baker, Heather D.}

2011 'Sippar. A. II. Im 1. Jahrtausend'. RlA 12, 533-537.

\section{Jursa, Michael and Stolper, Matthew W.}

2007 'From the Tattannu Archive Fragment'. WZKM 97, 243-281.

\section{Jursa, Michael and Waerzeggers, Caroline}

2009 'On Aspects of Taxation in Achaemenid Babylonia: New Evidence from Borsippa'. Pierre Briant and Michel Chauveau (eds.), Organisation des pouvoirs et contacts culturels dans les pays de l'empire achéménide. Persika 14. Paris: De Boccard, 237-269.

\section{Jursa, Michael and Weszeli, Michaela}

2000 'Der "Zahn" des Schreibers: Ein aramäischer Buchstabenname in akkadischer Transkription'. ZA 90, 78-84.

\section{Kahn, Dan'el}

2008 'Some Remarks on the Foreign Policy of Psammetichus II in the Levant (595589 B.C.)'. Journal of Egyptian History 1, 139-157.

2015 'Why Did Necho II Kill Josiah?'. Jana Mynářová et al. (eds.), There and Back Again - the Crossroads II: Proceedings of an International Conference Held in Prague, September 15-18, 2014. Prague: Charles University in Prague, Faculty of Arts, $511-528$.

\section{Kalimi, Isaac and Richardson, Seth (eds.)}

2014 Sennacherib at the Gates of Jerusalem: Story, History and Historiography. CHANE 71. Leiden: Brill. 


\section{Kanchan, Chaitanya and Radner, Karen}

2012 'Babylon and the Cities and Tribes of Southern Mesopotamia'. Assyrian Empire Builders. London: University College London. Available online at http://www. ucl.ac.uk/sargon/essentials/countries/babylonia/.

\section{Katzenstein, H.J.}

1994 'Gaza in the Neo-Babylonian Period (626-539 B.C.E.)'. Transeuphratène 7, $35-49$.

\section{Kaufman, Stephen A.}

1974 The Akkadian Influences on Aramaic. Assyriological Studies 19. Chicago: University of Chicago Press.

\section{Keetman, Jan}

2017 'Notes on the God $J a^{2} u$ and Bitt-ja'-kin'. NABU 2017/18.

\section{Kelle, Brad E. et al. (eds.)}

2011 Interpreting Exile: Interdisciplinary Studies of Displacement and Deportation in Biblical and Modern Contexts. AIL 10. Atlanta: Society of Biblical Literature.

\section{Kessler, Karlheinz}

2004 'Urukäische Familien versus babylonische Familien'. $A o F$ 31, 237-262.

\section{Kinnier Wilson, J.V.}

1972 The Nimrud Wine Lists: A Study of Men and Administration at the Assyrian Capital in the Eight Century, B.C. Cuneiform Texts from Nimrud 1. London: British School of Archaeology in Iraq.

\section{Kleber, Kristin}

2005 'Von Bierproduzenten und Gefängnisaufsehern: dezentrale Güterverteilung und Buchhaltung in Eanna'. Heather D. Baker and Michael Jursa (eds.), Approaching the Babylonian Economy. Proceedings of the START Project Symposium Held in Vienna, 1-3 July 2004. AOAT 330. Münster: Ugarit-Verlag, 289-321.

2008 Tempel und Palast: Die Beziehungen zwischen dem König und dem Eanna-Tempel im spätbabylonischen Uruk. Veröffentlichungen zur Wirtschaftsgeschichte Babyloniens im 1. Jahrtausend v. Chr. 3. AOAT 358. Münster: Ugarit-Verlag.

2011 'Neither Slave nor Truly Free: The Status of the Dependents of Babylonian Temple Households'. Laura Culbertson (ed.), Slaves and Households in the Near East. OIS 7. Chicago: The Oriental Institute of the University of Chicago, 101-111. 
2015 'Taxation in the Achaemenid Empire'. Oxford Handbooks Online. Oxford: Oxford University Press. Available online at http://dx.doi.org/10.1093/oxfordhb/ 9780199935390.013.34.

2017 Spätbabylonische Texte zum lokalen und regionalen Handel sowie zum Fernhandel aus dem Eanna-Archiv. BaAr 7. Dresden: ISLET.

\section{Knauf, Ernst Axel}

1984 'Eine nabatäische Parallele zum hebräischen Gottesnamen'. BN 23, 21-28.

\section{Knoppers, Gary N.}

2004 'In Search of Post-exilic Israel: Samaria after the Fall of the Northern Kingdom'. John Day (ed.), In Search of Pre-exilic Israel: Proceedings of the Oxford Old Testament Seminar. JSOTS 406. London: T\&T Clark, 150-180.

\section{Knowles, Melody D.}

2006 Centrality Practiced:Jerusalem in the Religious Practice of Yehud and the Diaspora in the Persian Period. ABS 16. Atlanta: Society of Biblical Literature.

\section{Koldewey, Robert}

1969 Die Königsburgen von Babylon 1: Die Südburg. Ausgrabungen der Deutschen Orient-Gesellschaft in Babylon 5. Wissenschaftliche Veröffentlichungen der Deutschen Orient-Gesellschaft 54. Osnabrück: Otto Zeller.

\section{Kozuh, Michael}

2014 The Sacrificial Economy: Assessors, Contractors, and Thieves in the Management of Sacrificial Sheep at the Eanna Temple of Uruk (ca. 625-52o B.C.). Explorations in Ancient Near Eastern Civilizations 2. Winona Lake: Eisenbrauns.

\section{Kratz, Reinhard G.}

2011 Judean Ambassadors and the Making of Jewish Identity: The Case of Hananiah, Ezra, and Nehemiah'. Oded Lipschits et al. (eds.), Judah and the Judeans in the Achaemenid Period: Negotiating Identity in an International Context. Winona Lake: Eisenbrauns.

2015 Historical and Biblical Israel: The History, Tradition, and Archives of Israel and Judah. Oxford: Oxford University Press.

\section{Kratz, Reinhard G. et al. (eds.)}

2010 One God - One Cult - One Nation: Archaeological and Biblical Perspectives. BZAW 405. Berlin: De Gruyter. 


\section{Krückmann, Oluf}

1933 Neubabylonische Rechts-und Verwaltungstexte. Texte und Materialien der Frau Professor Hilprecht Collection of Babylonian Antiquities im Eigentum der Universität Jena 2-3. Leipzig: Hinrichs.

\section{Kuhrt, Amélie}

1995 The Ancient Near East c. 30oo-33o BC, volume 2. Routledge History of the Ancient World. London: Routledge.

2014 'State Communications in the Persian Empire'. Karen Radner (ed.), State Correspondence in the Ancient World: From New Kingdom Egypt to the Roman Empire. Oxford Studies in Early Empires. Oxford: Oxford University Press, 112-140.

\section{Lämmerhirt, Kai}

2014 'Die Bevölkerung der Region Nippur in neu- und spätbabylonischer Zeit'. Manfred Krebernik and Hans Neumann (eds.), Babylonien und seine Nachbarn in neu- und spätbabylonischer Zeit: Wissenschaftliches Kolloquium aus Anlass des 75. Geburtstags von Joachim Oelsner, Jena, 2. und 3. März 2007. AOAT 369. Münster: Ugarit-Verlag, 113-133.

\section{Langdon, Stephen}

1912 Die neubabylonischen Königsinschriften. Vorderasiatische Bibliothek 4. Leipzig: Hinrichs.

\section{Law, David et al.}

2013 'Trade, Diaspora and Migration to New Zealand'. The World Economy 36, $582-606$.

\section{Law, Timothy Michael and Halton, Charles (eds.)}

2014 Jew and Judean: A Marginalia Forum on Politics and Historiography in the Translation of Ancient Texts. Marginalia Review of Books. Available online at http:// marginalia.lareviewofbooks.org/jew-judean-forum/.

\section{Lecoq, Pierre}

1997 Les inscriptions de la Perse achéménide: Traduit du vieux perse, de l'élamite, du babylonien et de l'araméen, présenté et annoté par Pierre Lecog. L'aube des peuples. Paris: Gallimard.

\section{Leichty, Erle et al.}

1988 Tablets from Sippar 3. CatBM 8. London: The British Museum. 


\section{Leichty, Erle and Grayson, A. Kirk}

1987 Tablets from Sippar 2. CatBM 7. London: The British Museum.

\section{Lemaire, André}

2004 'Ostraca and Incised Inscriptions'. David Ussishkin (ed.), The Renewed Archaeological Excavations at Lachish (1973-1994), volume IV. Sonia and Marco Nadler Institute of Archaeology, Monograph Series 22. Tel Aviv: Emery and Claire Yass Publications in Archaeology, 2099-2132.

2006 'Hebrew and Aramaic in the First Millennium B.C.E. in the Light of Epigraphic Evidence (Socio-Historical Aspects)'. Steven E. Fassberg and Avi Hurvitz (eds.), Biblical Hebrew in Its Northwest Semitic Setting: Typological and Historical Perspectives. Publication of the Institute for Advanced Studies 1. Jerusalem: The Hebrew University Magnes Press; Winona Lake: Eisenbrauns, 177-196.

\section{Lemche, Niels Peter}

2000 'Ideology and the History of Ancient Israel'. Scandinavian Journal of the Old Testament 14, 165-193.

\section{Lemos, Tracy $\mathrm{M}$.}

2010 Marriage Gifts and Social Change in Ancient Palestine: 1200 BCE to 200 CE. Cambridge: Cambridge University Press.

2011 'The Emasculation of Exile: Hypermasculinity and Feminization in the Book of Ezekiel'. Brad E. Kelle et al. (eds.), Interpreting Exile: Interdisciplinary Studies of Displacement and Deportation in Biblical and Modern Contexts. AIL 10. Atlanta: Society of Biblical Literature, 377-393.

2012 “They Have Become Women": Judean Diaspora and Postcolonial Theories of Gender and Migration'. Saul M. OIyan (ed.), Social Theory and the Study of Israelite Religion: Essays in Retrospect and Prospect. Resources for Biblical Study 71. Atlanta: Society of Biblical Literature, 81-109.

\section{Lenski, Gerhard E.}

1966 Power and Privilege: A Theory of Social Stratification. McGraw-Hill Series in Sociology. New York: McGraw-Hill.

\section{Lenski, Gerhard E. et al.}

1991 Human Societies: An Introduction to Macrosociology. Sixth edition. New York: McGraw-Hill.

\section{Lewy, Julius}

1943-1944 'The Old West Semitic Sun-God hammu'. Hebrew Union College Annual 18, 429-488.

1950-1951 'Tabor, Tibar, Atabyros'. Hebrew Union College Annual 23, 357-386. 


\section{Lipiński, Edward}

1971 'An Israelite King of Hamat?'. VT 21, 371-373.

2000 The Aramaeans: Their Ancient History, Culture, Religion. OLA 100. Leuven: Peeters.

2001 Semitic Languages: Outline of a Comparative Grammar. Second edition. OLA 8o. Leuven: Peeters.

\section{Lipschits, Oded}

2005 The Fall and Rise of Jerusalem: Judah under Babylonian Rule. Winona Lake: Eisenbrauns.

2011 'Shedding New Light on the Dark Years of the "Exilic Period": New Studies, Further Elucidation, and Some Questions Regarding the Archaeology of Judah as an "Empty Land"'. Brad E. Kelle et al. (eds.), Interpreting Exile: Interdisciplinary Studies of Displacement and Deportation in Biblical and Modern Contexts. AIL 10. Atlanta: Society of Biblical Literature, 57-90.

\section{Lipschits, Oded and Oeming, Manfred (eds.)}

2006 Judah and the Judeans in the Persian Period. Winona Lake: Eisenbrauns.

\section{Liverani, Mario}

2005 Israel's History and the History of Israel. BibleWorld. London: Equinox.

\section{Lorenz, Jürgen}

2005/2006 '20, 30, 40 Schekel'. AfO 51, 248-251.

2008 Nebukadnezar III/IV: Die politischen Wirren nach dem Tod des Kambyses im Spiegel der Keilschrifttexte. Dresden: ISLET.

\section{Luckenbill, Daniel David}

1924 The Annals of Sennacherib. Oriental Institute Publications 2. Chicago: The University of Chicago Press.

\section{Lundbom, Jack R.}

2004 Jeremiah 21-36: A New Translation with Introduction and Commentary. The Anchor Bible 21B. New York: Doubleday.

\section{Lutz, Henry Frederick}

1928 'An Agreement between a Babylonian Feudal Lord and his Retainer in the Reign of Darius Ir'. University of California Publications in Semitic Philology 9/3, $269-277$.

\section{MacGinnis, John}

1994 'The Royal Establishment at Sippar in the 6th Century BC'. ZA 84, 198-219. 
1995 Letter Orders from Sippar and the Administration of the Ebabbara in the LateBabylonian Period. Poznań: Bonami.

1998 'BM 64707 and rikis qabli in the Ebabbara'. WZKM 88, 177-183.

2010 'Mobilisation and Militarisation in the Neo-Babylonian Empire'. Jordi Vidal (ed.), Studies on War in the Ancient Near East: Collected Essays on Military History. AOAT 372. Münster: Ugarit-Verlag, 153-163.

2012 The Arrows of the Sun:Armed Forces in Sippar in the First Millennium BC. BaAr 4. Dresden: ISLET.

\section{Magdalene, F. Rachel and Wunsch, Cornelia}

2011 'Slavery between Judah and Babylon: the Exilic Experience'. Laura Culbertson (ed.), Slaves and Households in the Near East. OIS 7. Chicago: The Oriental Institute of the University of Chicago, 113-134.

\section{Manning, Patrick}

2013 Migration in World History. Second edition. With contributions by Tiffany Trimmer. Themes in World History. London: Routledge.

\section{Manning, Sean}

2016 'A Closer Look at the Gadal-Yama Contract (UCP 9/3 pp. 269 ff.)'. Paper presented at Melammu Symposia 10: 'Societies at War', Kassel, 26-28 September 2016. Available online at https://bookandsword.files.wordpress.com/2016/og/ gadal_yama_poster_v5_corrected.pdf.

\section{Marzahn, Joachim et al. (eds.)}

2008 Babylon: Mythos und Wahrheit 2: Wahrheit. Munich: Hirmer.

\section{Mason, Steve}

2007 'Jews, Judaeans, Judaizing, Judaism: Problems of Categorization in Ancient History'. JSJ 38, 457-512.

\section{Mattila, Raija}

2004 'Isis in Babylonia?'. Hannu Juusola et al. (eds.), Verbum et Calamus: Semitic and Related Studies in Honour of the Sixtieth Birthday of Professor Tapani Harviainen. Studia Orientalia 99. Helsinki: The Finnish Oriental Society, 161-163.

\section{Matty, Nazek Khalid}

2016 Sennacherib's Campaign Against Judah and Jerusalem in 701 B.C.: A Historical Reconstruction. BZAW 487. Berlin: De Gruyter. 


\section{McKane, William}

1996 A Critical and Exegetical Commentary on Jeremiah II: Commentary on Jeremiah $X X V I-L I I$. The International Critical Commentary on the Holy Scriptures of the Old and New Testaments. Edinburgh: T\&T Clark.

\section{Meade, C. Wade}

Road to Babylon: Development of U.S. Assyriology. Leiden: Brill.

\section{Middlemas, Jill}

2005 The Troubles of Templeless Judah. Oxford Theological Monographs. Oxford: Oxford University Press.

2007 The Templeless Age: An Introduction to the History, Literature, and Theology of the 'Exile'. Louisville: Westminster John Knox.

2012 'The Future of the "Exile". John J. Ahn and Jill Middlemas (eds.), By the Irrigation Canals of Babylon: Approaches to the Study of the Exile. The Library of Hebrew Bible/Old Testament Studies 526. New York: T\&T Clark, $63-81$.

\section{Miglus, Peter A.}

1999 Städtische Wohnarchitektur in Babylonien und Assyrien. Baghdader Forschungen 22. Mainz am Rhein: Philipp von Zabern.

2004 'Palast. B. Archäologisch. § 8.1.9. Spätbabylonische Zeit'. RlA 10, 254-255.

\section{Millard, Alan R.}

2009 'Assyria, Aramaeans and Aramaic'. Gershon Galil et al. (eds.), Homeland and Exile: Biblical and Ancient Near Eastern Studies in Honour of Bustenay Oded. VTSup 130. Leiden: Brill, 203-214.

2013 'Transcriptions into Cuneiform'. Geoffrey Khan (ed.), Encyclopedia of Hebrew Language and Linguistics 3. Leiden: Brill, 838-847.

\section{Miller, J. Maxwell and Hayes, John H.}

2006 A History of Ancient Israel and Judah. Second edition. London: SCM.

\section{Mitchell, T.C.}

1991 'The Babylonian Exile and the Restoration of the Jews in Palestine (586-c. $5^{00}$ B.C.)'.John Boardman et al. (eds.), The Cambridge Ancient History Volume 3, Part 2: The Assyrian and Babylonian Empires and Other States of the Near East, from the Eighth to the Sixth Centuries B.C. Second edition. Cambridge: Cambridge University Press, 410-46o. 


\section{Müller, Hans-Peter}

1980 'Gab es in Ebla einen Gottesnamen Ja?'. ZA 70, 70-92.

\section{Müller, Reinhard et al.}

2014 Evidence of Editing: Growth and Change of Texts in the Hebrew Bible. Resources for Biblical Study 75. Atlanta: Society of Biblical Literature.

\section{Murray, Donald F.}

2001 'Of All the Years the Hopes - or Fears? Jehoiachin in Babylon (2 Kings 25:2730)'.JBL 120, 245-265.

\section{$\mathrm{Na}^{\text {?aman, Nadav }}$}

1974 'Sennacherib's "Letter to God" on His Campaign to Judah'. BASOR 214, 25-39.

1978 'Looking for $K T K$ '. WdO 9, 220-239.

1991 'The Kingdom of Judah under Josiah'. TA 18, 3-71.

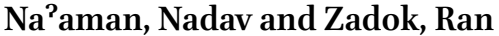

1988 'Sargon II's Deportations to Israel and Philistia (716-708 B.C.)'. JCS 40, $36-46$.

\section{Neusner, Jacob}

1986 Judaism and Scripture: The Evidence of Leviticus Rabbah. Chicago Studies in the History of Judaism. Chicago: The University of Chicago Press.

\section{Niehr, Herbert}

2010 'Religion in den Königreichen der Aramäer Syriens'. Corinne Bonnet and Herbert Niehr (eds.), Religionen in der Umwelt des Alten Testaments II: Phönizier, Punier, Aramäer. Kohlhammer Studienbücher Theologie 4, 2. Stuttgart: Kohlhammer, $187-324$.

2014 'Religion'. Herbert Niehr (ed.), The Aramaeans in Ancient Syria. HdO 106. Leiden: Brill, 127-203.

\section{Nielsen, John P.}

2011 Sons and Descendants: A Social History of Kin Groups and Family Names in the Early Neo-Babylonian Period, 747-626 BC. CHANE 43. Leiden: Brill.

2012 'Marduk's Return: Assyrian Imperial Propaganda, Babylonian Cultural Memory, and the akitu Festival of 667 BC'. Martin Bommas et al. (eds.), Memory and Urban Religion in the Ancient World. Cultural Memory and History in Antiquity. London: Bloomsbury, 3-32.

2015 Personal Names in Early Neo-Babylonian Legal and Administrative Tablets, 747626 B.C.E. Nisaba 29. Winona Lake: Eisenbrauns. 


\section{Nissinen, Martti}

2010 'The Exiled Gods of Babylon in Neo-Assyrian Prophecy'. Ehud Ben Zvi and Christoph Levin (eds.), The Concept of Exile in Ancient Israel and its Historical Contexts. BZAW 404. Berlin: De Gruyter, 27-38.

2014 'Assyria'. Herbert Niehr (ed.), The Aramaeans in Ancient Syria. HdO 106. Leiden: Brill, 273-296.

2015 '(How) Does the Book of Ezekiel Reveal Its Babylonian Context?'. WdO 45, $85^{-98 .}$

\section{Norman, Naomi J.}

2005 'Editorial Policy on the Publication of Recently Acquired Antiquities'. American Journal of Archaeology 109, 135-136.

\section{Noth, Martin}

1981 The Deuteronomistic History. JSOTS 15. Sheffield: Department of Biblical Studies, the University of Sheffield.

\section{Nunn, Astrid}

2000 'Nekropolen und Gräber in Phönizien, Syrien und Jordanien zur Achämenidenzeit'. $U F$ 32, 389-463.

\section{Oded, Bustenay}

1979 Mass Deportations and Deportees in the Neo-Assyrian Empire. Wiesbaden: Reichert.

1995 'Observations on the Israelite/Judaean Exiles in Mesopotamia during the Eighth-Sixth Centuries BCE'. Karel van Lerberghe and Anton Schoors (eds.), Immigration and Emigration within the Ancient Near East: Festschrift E. Lipiński. OLA 65. Leuven: Peeters, 205-212.

2000 'The Settlements of the Israelite and the Judean Exiles in Mesopotamia in the 8th-6th Centuries BCE'. Gershon Galil and Moshe Weinfeld (eds.), Studies in Historical Geography and Biblical Historiography Presented to Zecharia Kallai. VTSup 81. Leiden: Brill, 91-103.

\section{Oelsner, Joachim}

1978 'Zur neu- und spätbabylonischen Siegelpraxis'. B. Hruška and G. Komoróczy (eds.), Festschrift Lubor Matouš 2. Assyriologia 5. Budapest: Eötvös Loránd Tudományegyetem, Ókori Történeti tanszék, 167-186.

1989 'Weitere Bemerkungen zu den Neirab-Urkunden'. AoF 16, 68-77.

\section{Oelsner, Joachim et al.}

2003 'Neo-Babylonian Period'. Raymond Westbrook (ed.), A History of Ancient Near Eastern Law 2. HdO 72/2. Leiden: Brill, 911-974. 


\section{Oppenheim, A. Leo}

1967 'Essay on Overland Trade in the First Millennium B.C... JCS 21, 236-254.

\section{Oppenheimer, Aharon}

2005 Between Rome and Babylon: Studies in Jewish Leadership and Society. TSAJ 108. Tübingen: Mohr Siebeck.

\section{Oshima, Takayoshi}

2011 Babylonian Prayers to Marduk. Orientalische Religionen in der Antike 7. Tübingen: Mohr Siebeck.

\section{Ossendrijver, Mathieu}

2008 'Astronomie und Astrologie in Babylonien'. Joachim Marzahn et al. (eds.), Babylon: Mythos und Wahrheit 2: Wahrheit. Munich: Hirmer, 373-386.

\section{Owen, David I.}

2009 'Censoring Knowledge: The Case for the Publication of Unprovenanced $\mathrm{Cu}$ neiform Tablets'. James Cuno (ed.), Whose Culture? The Promise of Museums and the Debate over Antiquities. Princeton: Princeton University Press, $125^{-142 .}$

\section{Pakkala, Juha}

2004 Ezra the Scribe: The Development of Ezra 7-10 and Nehemiah 8. BZAW 347. Berlin: De Gruyter.

2006 'Zedekiah's Fate and the Dynastic Succession'. JBL 125, 443-452.

2010 'The Exile and the Exiles in the Ezra Tradition'. Ehud Ben Zvi and Christoph Levin (eds.), The Concept of Exile in Ancient Israel and its Historical Contexts. BZAW 404. Berlin: De Gruyter, 91-101.

\section{Pardee, Dennis}

1982 Handbook of Ancient Hebrew Letters. Sources for Biblical Study 15. Chico: Scholars Press.

\section{Parker, Barbara}

1961 'Administrative Tablets from the North-West Palace, Nimrud'. Iraq 23, 15-67, pls. IX-XXX.

\section{Parker, Richard A. and Dubberstein, Waldo $\mathrm{H}$.}

1942 Babylonian Chronology 626 B.C. - A.D. 45. SAOC 24. Chicago: University of Chicago Press. 


\section{Parpola, Simo}

1985 'Si'gabbar of Nerab Resurrected'. Orientalia Lovaniensia Periodica 16, 273-275.

1986 'The Royal Archives of Nineveh'. Klaas R. Veenhof (ed.), Cuneiform Archives and Libraries: Papers Read at the $30^{e}$ Rencontre Assyriologique Internationale, Leiden, 4-8 July 1983. PIHANS 57. Istanbul: Nederlands Historisch-Archaeologisch Instituut, $223-236$.

\section{Pearce, Laurie E.}

1999 'Sepīru and 'úA.BA: Scribes of the Late First Millennium'. K. Van Lerberghe and G. Voet (eds.), Languages and Cultures in Contact: At the Crossroads of Civilizations in the Syro-Mesopotamian Realm: Proceedings of the 42th RAI. Leuven: Peeters, 355-368.

2006 'New Evidence for Judeans in Babylonia'. Oded Lipschits and Manfred Oeming (eds.), Judah and the Judeans in the Persian Period. Winona Lake: Eisenbrauns, 399-411.

2011 “Judean": A Special Status in Neo-Babylonian and Achemenid Babylonia?'. Oded Lipschits et al. (eds.), Judah and the Judeans in the Achaemenid Period: Negotiating Identity in an International Context. Winona Lake: Eisenbrauns, 267-277.

2014 'Continuity and Normality in Sources Relating to the Judean Exile'. Hebrew Bible and Ancient Israel 3, 163-184.

2015 'Identifying Judeans and Judean Identity in the Babylonian Evidence'. Jonathan Stökl and Caroline Waerzeggers (eds.), Exile and Return: The Babylonian Context. BZAW 478. Berlin: De Gruyter, 7-32.

2016a 'Looking for Judeans in Babylonia's Core and Periphery'. Ehud Ben Zvi and Christoph Levin (eds.), Centres and Peripheries in the Early Second Temple Period. Forschungen zum Alten Testament 108. Tübingen: Mohr Siebeck.

2016b 'Cuneiform Sources for Judeans in Babylonia in the Neo-Babylonian and Achaemenid Periods: An Overview'. Religion Compass 10, 230-243.

\section{Pearce, Laurie E. and Wunsch, Cornelia}

2014 Documents of Judean Exiles and West Semites in Babylonia in the Collection of David Sofer. Cornell University Studies in Assyriology and Sumerology 28. Bethesda: CDL.

\section{Pedersén, Olof}

1998 Archives and Libraries in the Ancient Near East 1500-30o B.C. Bethesda: CDL.

2005a Archive und Bibliotheken in Babylon: Die Tontafeln der Grabung Robert Koldeweys 1899-1917. Abhandlungen der Deutschen Orient-Gesellschaft 25. Saarbrücken: Saarländische Druckerei und Verlag. 
2005b 'Foreign Professionals in Babylon: Evidence from the Archive in the Palace of Nebuchadnezzar II'. W.H. van Soldt et al. (eds.), Ethnicity in Ancient Mesopotamia: Papers Read at the 48th Rencontre Assyriologique Internationale, Leiden, 1-4 July 2002. PIHANS 102. Leiden: Nederlands Instituut voor het Nabije Oosten, 267-272.

2009 'Neo-Assyrian Texts from Nebuchadnezzar's Babylon: A preliminary Report'. Mikko Luukko et al. (eds.), Of God(s), Trees, Kings, and Scholars: Neo-Assyrian and Related Studies in Honour of Simo Parpola. Studia Orientalia 106. Helsinki: The Finnish Oriental Society, 193-199.

\section{Person, Raymond F., Jr.}

1997 The Kings - Isaiah and Kings - Jeremiah Recensions. BZAW 252. Berlin: De Gruyter.

\section{Pettinato, Giovanni}

$1980 \quad$ 'Ebla and the Bible'. The Biblical Archaeologist 43, 203-216.

\section{Pinches, T.G.}

1892a 'Old Persian Names in Babylonian Contracts'. Hebraica 8, 134-135.

1892b 'Yâ and Yâwa (Jah and Jahweh) in Assyro-Babylonian Inscriptions'. Proceedings of the Society of Biblical Archoeology 15, 13-15.

1910 An Outline of Assyrian Grammar. London: Henry J. Glaisher.

\section{Pirngruber, Reinhard}

2017 The Economy of Late Achaemenid and Seleucid Babylonia. Cambridge: Cambridge University Press.

\section{Popović, Mladen}

2014 'Networks of Scholars: The Transmission of Astronomical and Astrological Learning between Babylonians, Greeks and Jews'. Jonathan Ben-Dov and Seth L. Sanders (eds.), Ancient Jewish Sciences and the History of Knowledge in Second Temple Literature. New York: Institute for the Study of the Ancient World. Available online at http://dlib.nyu.edu/awdl/isaw/ancient-jewish-sciences/ chapter7.xhtml.

\section{Popović, Mladen et al. (eds.)}

2017 Jewish Cultural Encounters in the Ancient Mediterranean and Near Eastern World. JSJ Supplements 178. Leiden: Brill. 


\section{Porten, Bezalel}

1968 Archives from Elephantine: The Life of an Ancient Jewish Military Colony. Berkeley: University of California Press.

2014 'A Comprehensive Table of Bethel Names in Ancient Inscriptions'. Maarav 21, 223-234.

\section{Porter, Barbara Nevling}

1993 Images, Power, and Politics: Figurative Aspects of Esarhaddon's Babylonian Policy. Memoirs of the American Philosophical Society Held at Philadelphia for Promoting Useful Knowledge 208. Philadelphia: American Philosophical Society.

\section{Potts, D.T.}

2013 'Mesopotamian and Persian Migrations'. Immanuel Ness (ed.), The Encyclopedia of Global Human Migration. Chichester: Wiley-Blackwell.

\section{Powell, Marvin A.}

1980 'Karkar, Dabrum, and Tall Ǧidr: An Unresolved Geographical Problem'.JNES 39, $47-52$.

\section{Raaflaub, Kurt A.}

2004 'Archaic Greek Aristocrats as Carriers of Cultural Interaction'. Robert Rollinger and Christopf Ulf (eds.), Commerce and Monetary Systems in the Ancient World: Means of Transmission and Cultural Interaction. Melammu Symposia 5. Stuttgart: Franz Steiner, 197-217.

\section{Radner, Karen}

1999 'Traders in the Neo-Assyrian Period'. Jan Gerrit Dercksen (ed.), Trade and Finance in Ancient Mesopotamia: Proceedings of the First MOS Symposium (Leiden 1997). PIHANS 84. Istanbul: Nederlands Historisch-Archaeologisch Instituut, 101-126.

2012 'After Eltekeh: Royal Hostages from Egypt at the Assyrian Court'. Heather D. Baker et al. (eds.), Stories of Long Ago: Festschrift für Michael D. Roaf. AOAT 397. Münster: Ugarit-Verlag, 471-479.

2014a 'The Neo-Assyrian Empire'. Michael Gehler et al. (eds.), Imperien und Reiche in der Weltgeschichte: Epochenübergreifende und globalhistorische Vergleiche 1: Imperien des Altertums, Mittelalterliche und frühneuzeitliche Imperien. Wiesbaden: Harrassowitz, 101-119. 
2014b 'An Imperial Communication Network: The State Correspondence of the NeoAssyrian Empire'. Karen Radner (ed.), State Correspondence in the Ancient World: From New Kingdom Egypt to the Roman Empire. Oxford Studies in Early Empires. Oxford: Oxford University Press, 64-93.

2017 'Assur's "Second Temple Period": The Restoration of the Cult of Aššur, c. 538 BCE. Christoph Levin and Reinhard Müller (eds.), Herrschaftslegitimation in Vorderorientalischen Reichen der Eisenzeit. Orientalische Religionen in der Antike 21. Tübingen: Mohr Siebeck, 77-96.

\section{Rauch, James E. and Trindade, Vitor}

2002 'Ethnic Chinese Networks in International Trade'. The Review of Economics \& Statistics $84,116-130$.

\section{Reade, Julian E.}

1986 'Introduction: Rassam's Babylonian Collection: The Excavations and the Archives'. Erle Leichty (ed.), Tablets from Sippar 1. CatBM 6. London: The British Museum, xiii-xxxvi.

2000 'Ninive (Nineveh). § 17. Cuneiform Records'. RLA, 421-427.

\section{Reuter, Eleonore}

1993 Kultzentralisation: Entstehung und Theologie von Dtn 12. Bonner Biblische Beiträge 87. Frankfurt am Main: Hain.

\section{Richardson, Seth}

2007 'The World of Babylonian Countrysides'. Gwendolyn Leick (ed.), The Babylonian World. The Routledge Worlds. New York: Routledge, 13-38.

2014 'Mesopotamian Political History: The Perversities'. JANEH 1, 61-93.

\section{Rochberg, Francesca}

2004 The Heavenly Writing: Divination, Horoscopy, and Astronomy in Mesopotamian Culture. Cambridge: Cambridge University Press.

\section{Röllig, Wolfgang}

1998-2001 'Nērebu, Nirabi/u'. RlA 9, 214-215.

\section{Rollinger, Robert}

1998 'Überlegungen zu Herodot, Xerxes und dessen angeblicher Zerstörung Babylons'. AoF 25, 339-373.

1999 'Xerxes und Babylon'. NABU 1999/8. 


\section{Rollinger, Robert et al. (eds.)}

2011 Herodot und das Persische Weltreich - Herodotus and the Persian Empire: Akten des 3. Internationalen Kolloquiums zum Thema 'Vorderasien im Spannungsfeld klassischer und altorientalischer Überlieferungen', Innsbruck, 24.-28. November 2008. CLeO 3. Wiesbaden: Harrassowitz.

\section{Rom-Shiloni, Dalit}

2013 Exclusive Inclusivity: Identity Conflicts between the Exiles and the People Who Remained (6th-5th Centuries BCE). The Library of Hebrew Bible/Old Testament Studies 543. New York: Bloomsbury T\&T Clark.

\section{Römer, Thomas}

2015 'The Invention of History in Ancient Judah and the Formation of the Hebrew Bible'. $W d O$ 45, 255-272.

\section{Roth, Martha T.}

1988 “She Will Die By the Iron Dagger": Adultery and Neo-Babylonian Marriage'. JESHO 31, 186-206.

1989 Babylonian Marriage Agreements: 7 th-3rd Centuries B.C. AOAT 222. Kevelaer: Butzon \& Bercker; Neukirchen-Vluyn: Neukirchener Verlag.

1989/1990 'The Material Composition of the Neo-Babylonian Dowry'. AfO 36-37, 1-55.

1991 'The Dowries of the Women of the Itti-Marduk-balātu Family'. JAOS 111, 19-37.

\section{Runesson, Anders et al.}

2008 The Ancient Synagogue from Its Origins to 200 C.E.: A Source Book. Ancient Judaism and Early Christianity 72. Leiden: Brill.

\section{Rutz, Matthew T. and Kersel, Morag M. (eds.)}

2014 Archaeologies of Text: Archaeology, Technology, and Ethics. Joukowsky Institute Publications 6. Oxford: Oxbow.

\section{Sader, Hélène}

2014 'History'. Herbert Niehr (ed.), The Aramaeans in Ancient Syria. HdO 106. Leiden: Brill, 11-36.

\section{SBL}

2016 'SBL Policy on Scholarly Presentation and Publication of Ancient Artifacts'. Society of Biblical Literature. Available online at https://www.sbl-site.org/assets/ pdfs/SBL-Artifacts-Policy_2016ogo3.pdf. 


\section{Schaudig, Hanspeter}

2001 Die Inschriften Nabonids von Babylon und Kyros' des Großen samt den in ihrem Umfeld entstandenen Tendenzschriften: Textausgabe und Grammatik. AOAT 256. Münster: Ugarit-Verlag.

\section{Schipper, Bernd U.}

2010 'Egypt and the Kingdom of Judah under Josiah and Jehoiakim'. TA 37, 200-226.

2011 'Egyptian Imperialism after the New Kingdom: The 26th Dynasty and the Southern Levant'. Shay Bar et al. (eds.), Egypt, Canaan and Israel: History, Imperialism, Ideology and Literature: Proceedings of a Conference at the University of Haifa, 3-7 May 20og. CHANE 52. Leiden: Brill, 268-290.

\section{Schneider, Jens and Crul, Maurice}

2010 'New Insights into Assimilation and Integration Theory: Introduction to the Special Issue'. Ethnic and Racial Studies 33, 1143-1148.

\section{Scholz, Dieter}

2008 'Das Babylon-System: Gefangenschaft, Klage und Rebellion von den Nazarenern bis zu den Rastafari: Zur Rezeption von Psalm 137'. Moritz Wullen et al. (eds.), Babylon: Mythos und Wahrheit 1: Mythos. Munich: Hirmer, 181-190.

\section{Seux, M.-J.}

1967 Épithètes royales akkadiennes et sumériennes. Paris: Letouzey et Ané.

\section{Seymour, Michael}

2008a 'The Tower of Babel in Art'. Irving Finkel and Michael Seymour (eds.), Babylon: Myth and Reality. London: The British Museum, 132-141.

2008b 'Babylon in the Book of Revelation'. Irving Finkel and Michael Seymour (eds.), Babylon: Myth and Reality. London: The British Museum, 179-180.

\section{Shahbazi, A. Shapur}

1994-2011 'Deportations. I. In the Achaemenid Period'. Encyclopcedia Iranica. Available online at http://www.iranicaonline.org/articles/deportations.

\section{Sidersky, D.}

1929 'L’Onomastique hébraïque des Tablettes de Nippur'. Revue des Études Juives 87, 177-199.

\section{Silverman, Jason M.}

2015a 'Judaeans under Persian Forced Labor and Migration Policies'. Anabasis 6, 14-34. 
2015b 'Sheshbazzar, a Judean or a Babylonian? A Note on His Identity'. Jonathan Stökl and Caroline Waerzeggers (eds.), Exile and Return: The Babylonian Context. BZAW 478. Berlin: De Gruyter, 308-321.

\section{Smith, Mark S.}

1994 The Ugaritic Baal Cycle I: Introduction with Text, Translation and Commentary of KTU 1.1-1.2. VTSup 55. Leiden: Brill.

\section{Smith-Christopher, Daniel L.}

1989 The Religion of the Landless: The Social Context of the Babylonian Exile. Bloomington: Meyer-Stone.

2002 A Biblical Theology of Exile. Overtures to Biblical Theology. Minneapolis: Fortress.

\section{von Soden, Wolfram}

1975 Review of Babylonian Historical-Literary Texts by A. Kirk Grayson. ZA 65, $282-285$.

\section{Southwood, Katherine}

2012 Ethnicity and the Mixed Marriage Crisis in Ezra 9-10: An Anthropological Approach. Oxford Theological Monographs. Oxford: Oxford University Press.

2015 'The Impact of the Second and Third-Generation Returnees as a Model for Understanding the Post-Exilic Context'. Jonathan Stökl and Caroline Waerzeggers (eds.), Exile and Return: The Babylonian Context. BZAW 478. Berlin: De Gruyter, 322-335.

\section{Spar, Ira and von Dassow, Eva}

2000 Private Archive Texts from the First Millennium B.C. Cuneiform Texts in the Metropolitan Museum of Art 3. New York: The Metropolitan Museum of Art; Turnhout: Brepols.

\section{Spar, Ira and Jursa, Michael}

2014 The Ebabbar Temple Archive and Other Texts from the Fourth to the First Millennium B.C. Cuneiform Texts in the Metropolitan Museum of Art 4. New York: The Metropolitan Museum of Art; Winona Lake: Eisenbrauns.

\section{van der Spek, R.J.}

2014 'Cyrus the Great, Exiles, and Foreign Gods: A Comparison of Assyrian and Persian Policies on Subject Nations'. Michael Kozuh et al. (eds.), Extraction \& Control: Studies in Honor of Matthew W. Stolper. SAOC 68. Chicago: The Oriental Institute of the University of Chicago, 233-264. 


\section{Stager, Lawrence E.}

2011 'Ashkelon on the Eve of Destruction in 604 B.C... Lawrence E. Stager et al. (eds.), Ashkelon 3: The Seventh Century B.C. Final Reports of the Leon Levy Expedition to Ashkelon 3. Winona Lake: Eisenbrauns, 3-11.

\section{Stager, Lawrence E. et al. (eds.)}

2008 Ashkelon 1: Introduction and Overview (1985-2006). Final Reports of the Leon Levy Expedition to Ashkelon 1. Winona Lake: Eisenbrauns.

2011 Ashkelon 3: The Seventh Century B.C. Final Reports of the Leon Levy Expedition to Ashkelon 3. Winona Lake: Eisenbrauns.

\section{Stamm, Johann Jakob}

1939 Die akkadische Namengebung. Mitteilungen der Vorderasiatisch-Aegyptischen Gesellschaft 44. Leipzig: Hinrichs.

\section{Stern, Elsie R.}

2010 'Esther and the Politics of Diaspora'. The Jewish Quarterly Review 100, $25-53$.

\section{Stern, Ephraim}

2001 Archaeology of the Land of the Bible II: The Assyrian, Babylonian, and Persian Periods, $73^{2-} 332$ B.C.E. The Anchor Bible Reference Library. New York: Doubleday.

\section{Stigers, Harold G.}

1976 'Neo- and Late Babylonian Business Documents from the John Frederick Lewis Collection'. JCS 28, 3-59.

\section{Still, Bastian}

2019 The Social World of the Babylonian Priest. CHANE 103. Leiden: Brill.

\section{Stökl, Jonathan and Waerzeggers, Caroline (eds.)}

2015 Exile and Return: The Babylonian Context. BZAW 478. Berlin: De Gruyter.

\section{Stol, Marten}

1994 'Beer in Neo-Babylonian Times'. Lucio Milano (ed.), Drinking in Ancient Societies: History and Culture of Drinks in the Ancient Near East: Papers of a Symposium Held in Rome, May 17-19, 199o. History of the Ancient Near East / Studies 6. Padova: Sargon, $155^{-183}$. 


\section{Stolper, Matthew W.}

1974 Management and Politics in Later Achaemenid Babylonia: New Texts from the Murašû Archive. PhD diss., the University of Michigan.

1976 'A Note on Yahwistic Personal Names in the Murašû Texts'. BASOR 222, 25-28.

1977 'Yet Another Iranian Loanword in Late Babylonian: Babyl. mašăka < Ir. *važăka-'. JAOS 97, 547-549.

1985 Entrepreneurs and Empire: The Murašû Archive, the Murašû Firm, and the Persian Rule in Babylonia. PIHANS 54. Istanbul: Nederlands Historisch-Archaeologisch Instituut.

1987 'Bēlšunu the Satrap'. Francesca Rochberg (ed.), Language, Literature, and History: Philological and Historical Studies Presented to Erica Reiner. American Oriental Series 67. New Haven: American Oriental Society, 389-402.

1989 'The Governor of Babylon and Across-the-River in 486 B.C.. JNES 48, 283-305.

1990 'Tobits in Reverse: More Babylonians in Ecbatana'. Archaeologische Mitteilungen aus Iran $23,161-176$.

1992 'The Murašû Texts from Susa'. $R A$ 86, 69-77.

2001 'Fifth Century Nippur: Texts of the Murašûs and from Their Surroundings'.JCS $53,83^{-132 .}$

2005 'Farming with the Murašûs and Others: Costs and Returns of Cereal Agriculture in Fifth-Century Babylonian Texts'. Heather D. Baker and Michael Jursa (eds.), Approaching the Babylonian Economy: Proceedings of the START Project Symposium Held in Vienna, 1-3 July 2004. AOAT 330. Münster: Ugarit-Verlag, 323-342.

2006a 'Iranica in Post-Achaemenid Babylonian Texts'. Pierre Briant and Francis Joannès (eds.), La transition entre l'empire achéménide et les royaumes hellénistiques (vers 350-30o av.J.-C.). Persika 9. Paris: De Boccard, 223-26o.

2006b 'Parysatis in Babylon'. Ann K. Guinan et al. (eds.), If a Man Builds a Joyful House: Assyriological Studies in Honor of Erle Verdun Leichty. CM 31. Leiden: Brill, $463-472$.

\section{Stone, Elizabeth C.}

2008 'Patterns of Looting in Southern Iraq'. Antiquity 82, 125-138.

\section{Streck, Michael P.}

1999 'Der Gottesname "Jahwe" und das amurritische Onomastikon'. WdO 30, $35^{-46 .}$

2001 'Das Onomastikon der Beamten am neubabylonischen Ebabbar-Tempel in Sippar'. ZA 91, 110-119.

2005 'Pirindu'. RlA 10, 572-573. 
2011 'Babylonian and Assyrian'. Stefan Weninger et al. (eds.), The Semitic Languages: An International Handbook. Handbücher zur Sprach- und Kommunikationswissenschaft 36. Berlin: De Gruyter Mouton, 359-396.

2014 'Babylonia'. Herbert Niehr (ed.), The Aramaeans in Ancient Syria. HdO 106. Leiden: Brill, 297-318.

\section{Sweeney, Marvin A.}

2005 The Prophetic Literature. Interpreting Biblical Texts. Nashville: Abingdon.

2007 I \& II Kings: A Commentary. Old Testament Library. Louisville: Westminster John Knox.

2013 'Israelite and Judean Religions'. Michele Renee Salzman and Marvin A. Sweeney (eds.), The Cambridge History of Religions in the Ancient World 1: From the Bronze Age to the Hellenistic Age. Cambridge: Cambridge University Press, 151-173.

\section{Szuchman, Jeffrey (ed.)}

2009 Nomads, Tribes, and the State in the Ancient Near East: Cross-Disciplinary Perspectives. OIS 5 . Chicago: The Oriental Institute of the University of Chicago.

\section{Tallqvist, Knut}

1905 Neubabylonisches Namenbuch zu den Geschäftsurkunden aus der Zeit des Šamaššumukîn bis Xerxes. Acta Societatis Scientiarum Fennicae 32/2. Helsinki: Societas Scientiarum Fennica.

\section{Tavernier, Jan}

2007 Iranica in the Achaemenid Period (ca.550-330 B.C.): Lexicon of Old Iranian Proper Names and Loanwords, Attested in Non-Iranian Texts. OLA 158. Leuven: Peeters.

2008 'Multilingualism in the Fortification and Treasury Archives'. Pierre Briant et al. (eds.), L'archive des Fortifications de Persépolis: État des questions et perspectives de recherches. Persika 12. Paris: de Boccard, 59-86.

\section{Thareani, Yifat}

2016 'The Empire and the "Upper Sea": Assyrian Control Strategies along the Southern Levantine Coast'. BASOR 375, 77-102.

\section{Timm, Stefan}

1995 'Die Bedeutung der spätbabylonischen Texte aus Nērab für die Rückkehr der Judäer aus dem Exil'. Manfred Weippert and Stefan Timm (eds.), Meilenstein: Festgabe für Herbert Donner zum 16. Februar 1995. Ägypten und Altes Testament 30. Wiesbaden: Harrassowitz, 276-288. 


\section{Tolini, Gauthier}

2009 'Les repas du Grand Roi en Babylonie: Cambyse et le palais d'Abanu'. Xavier Faivre et al. (eds.), Et il y eut un esprit dans l'Homme: Jean Bottéro et la Mésopotamie. Travaux de la Maison René-Ginouvès 6. Paris: De Boccard, 237-254.

2011 La Babylonie et l'Iran: Les relations d'une province avec le coeur de l'empire achéménide (539-331 avant notre ère). 2 volumes. PhD diss., Université Paris I.

2013 'The Economic Activities of Ishunnatu, a Slave Woman of the Egibi Family'. REFEMA. Available online at http://refema.hypotheses.org/766.

2014 'Le rôle de la famille de Nusku-gabbē au sein de la communauté de Neirab'. Lionel Marti (ed.), La famille dans le Proche-Orient ancien: réalités, symbolismes, et images: Proceedings of the 55th Rencontre Assyriologique Internationale at Paris 6-9July 20og. Winona Lake: Eisenbrauns, 591-598.

2015 'From Syria to Babylon and Back: The Neirab Archive'. Jonathan Stökl and Caroline Waerzeggers (eds.), Exile and Return: The Babylonian Context. BZAW 478. Berlin: De Gruyter, ${ }^{8}{ }^{-}-93$.

\section{van der Toorn, Karel}

1992 'Anat-Yahu, Some Other Deities, and the Jews of Elephantine'. Numen 39, 80-101.

1995 'Yahweh'. Karel van der Toorn et al. (eds.), Dictionary of Deities and Demons in the Bible. Leiden: Brill, 1711-1730.

2007 Scribal Culture and the Making of the Hebrew Bible. Cambridge: Harvard University Press.

2016a 'Ethnicity at Elephantine: Jews, Arameans, Caspians'. TA 43, 147-164.

2016b 'Eshem-Bethel and Herem-Bethel: New Evidence from Amherst Papyrus 63'. $Z A W 128,668-68$ o.

\section{Torczyner, Harry et al.}

1938 Lachish (Tell ed Duweir) I: The Lachish Letters. The Wellcome Archaeological Research Expedition to the Near East Publications 1. Oxford: Oxford University Press.

\section{Tropper, Josef}

2001

'Der Gottesname *Yahwa'. VT 51, 81-106.

\section{UNESCO}

1970 'Convention on the Means of Prohibiting and Preventing the Illicit Import, Export and Transfer of Ownership of Cultural Property'. Available online at http:// portal.unesco.org/en/ev.php-URL_ID=13039\&URL_DO=DO_TOPIC\&URL_ SECTION=201.html. 


\section{Ussishkin, David}

2004 'A Synopsis of the Stratigraphical, Chronological and Historical Issues'. David Ussishkin (ed.), The Renewed Archaeological Excavations at Lachish (1973-1994) 1. Sonia and Marco Nadler Institute of Archaeology, Monograph Series 22. Tel Aviv: Emery and Claire Yass Publications in Archaeology, 50-119.

\section{Utas, Bo}

1993 'Byzantium Seen from Sasanian Iran'. Lennart Rydén and Jan Olof Rosenqvist (eds.), Aspects of Late Antiquity and Early Byzantium: Papers Read at a Colloquium Held at the Swedish Research Institute in Istanbul 31 May - 5 June 1992. Swedish Research Institute in Istanbul Transactions 4. Stockholm: Swedish Research Institute in Istanbul, 21-30.

\section{Valkama, Kirsi}

2010 'What Do Archaeological Remains Reveal of the Settlements in Judah during the Mid-Sixth Century BCE?'. Ehud Ben Zvi and Christoph Levin (eds.), The Concept of Exile in Ancient Israel and its Historical Contexts. BZAW 404. Berlin: De Gruyter, 39-59.

2012 Judah in the Mid-Sixth Century BCE: Archaeological Evidence for a Post-Collapse Society. PhD diss., University of Helsinki.

\section{Van De Mieroop, Marc}

1997a The Ancient Mesopotamian City. Oxford: Clarendon Press.

1997 b 'On Writing a History of the Ancient Near East'. BiOr 54, 285-305.

2003 'Reading Babylon'. American Journal of Archaeology 107, 257-275.

2013 'Recent Trends in the Study of Ancient Near Eastern History: Some Reflections'. Journal of Ancient History 1, 83-97.

2016 Philosophy before the Greeks: The Pursuit of Truth in Ancient Babylonia. Princeton: Princeton University Press.

\section{Van De Mieroop, Marc and Garfinkle, Steven}

'Editorial Introduction to JANEH'. JANEH 1, 1-3.

\section{Vanderhooft, David}

1999 The Neo-Babylonian Empire and Babylon in the Latter Prophets. Harvard Semitic Monographs 59. Atlanta: Scholars Press.

2012 'Chebar'. Encyclopedia of the Bible and Its Reception Online. Available online at http://www.degruyter.com/view/EBR/MainLemma_1696.

2017 'The Name of the Prophet hăbaqqûq'. Baruch Halpern et al. (eds.), Cultural Contact and Appropriation in the Axial-Age Mediterranean World: A Periplos. CHANE 86. Leiden: Brill, 116-124. 


\section{Vargyas, Péter}

2001 A History of Babylonian Prices in the First Millennium BC, vol. 1: Prices of the Basic Commodities. Heidelberger Studien zum Alten Orient 10. Heidelberg: Heidelberger Orientverlag.

\section{Vera Chamaza, Galo W.}

2002 Die Omnipotenz Aššurs: Entwicklungen in der Aššur-Theologie unter den Sargoniden Sargon II., Sanherib und Asarhaddon. AOAT 295. Münster: Ugarit -Verlag.

\section{Versluys, Miguel John}

2014 'Understanding Objects in Motion: An Archaeological Dialogue on Romanization'. Archaeological Dialogues 21, 1-20.

\section{Villard, Pierre}

2010 'Les textiles néo-assyriens et leurs couleurs'. Cécile Michel and Marie-Louise Nosch (eds.), Textile Terminologies in the Ancient Near East and Mediterranean from the Third to the First Millennia BC. Ancient Textiles 8. Oxford: Oxbow, 388-399.

\section{de Vries, Jan}

1984 European Urbanization 1500-180o. London: Methuen and Co.

\section{Vukosavović, Filip}

2015 By the Rivers of Babylon: The Story of the Babylonian Exile. Jerusalem: Bible Lands Museum Jerusalem.

\section{Waerzeggers, Caroline}

1999/2000 'The Records of Inșabtu from the Naggāru Family'. AfO 46-47, 183-200.

2001 'A Note on the Marriage Gift biblu in the Neo-Babylonian Period'. Akkadica 122, $65^{-70}$.

2003/2004 'The Babylonian Revolts Against Xerxes and the "End of Archives"'. AfO 50, 150-173.

2005 'The Dispersal History of the Borsippa Archives'. Heather D. Baker and Michael Jursa (eds.), Approaching the Babylonian Economy: Proceedings of the START Project Symposium Held in Vienna, 1-3July 2004. Studies in the Economic History of First Millennium Babylonia 2. AOAT 330. Münster: Ugarit-Verlag, 343-363.

2006 'The Carians of Borsippa'. Iraq 68, 1-22.

2010a The Ezida temple of Borsippa: Priesthood, Cult, Archives. Achaemenid History 15. Leiden: Nederlands Instituut voor het Nabije Oosten. 
2010b 'Babylonians in Susa: The Travels of Babylonian Businessmen to Susa Reconsidered'. Bruno Jacobs and Robert Rollinger (eds.), Der Achämenidenhof, The Achaemenid Court: Akten des 2. Internationalen Kolloquiums zum Thema 'Vorderasien im Spannungsfeld klassischer und altorientalischer Überlieferungen,' Landgut Castelen bei Basel, 23.-25. Mai 2007. CLeO 2. Wiesbaden: Harrassowitz, 777-813.

2011 'The Babylonian Priesthood in the Long Sixth Century BC'. Bulletin of the Institute of Classical Studies 54 (2), 59-70.

2014a Marduk-rēmanni: Local Networks and Imperial Politics in Achaemenid Babylonia. OLA 233. Leuven: Peeters.

2014b 'Locating Contact in the Babylonian Exile: Some Reflections on Tracing JudeanBabylonian Encounters in Cuneiform Texts'. Uri Gabbay and Shai Secunda (eds.), Encounters by the Rivers of Babylon: Scholarly Conversations between Jews, Iranians and Babylonians in Antiquity. TSAJ 16o. Tübingen: Mohr Siebeck, 131-146.

2014c 'Social Network Analysis of Cuneiform Archives - a New Approach'. Heather D. Baker and Michael Jursa (eds.), Documentary Sources in Ancient Near Eastern and Greco-Roman Economic History: Methodology and Practice. Oxford: Oxbow, 207-233.

2015 Review of Documents of Judean Exiles and West Semites in Babylonia in the Collection of David Sofer by Laurie E. Pearce and Cornelia Wunsch. Strata 33, 179-194.

2016 'What Do Names Not Tell Us about Social Realities? The Issue of the "FamilyName-Bearing Elites" versus the "Non-Family-Name-Bearing Others"'. Paper presented at the Babylonian Name and Name-Giving conference, Leuven, 8-9 February 2016.

2017 'Collations of CUSAS 28'. NABU 2017/86.

(forthcoming a) 'Weidner Texts'. Tero Alstola et al. (eds.), Handbook of the Exile: New Perspectives from Judean and Babylonian Evidence. ANEM. Atlanta: SBL Press.

(forthcoming b) 'The Lament of Nabû-šuma-ukīn'. Tero Alstola et al. (eds.), Handbook of the Exile: New Perspectives from Judean and Babylonian Evidence. ANEM. Atlanta: SBL Press.

(forthcoming c) 'Judeans in the Sippar Archives'. Tero Alstola et al. (eds.), Handbook of the Exile: New Perspectives from Judean and Babylonian Evidence. ANEM. Atlanta: SBL Press.

\section{Wagner, Allon et al.}

2013 'Quantitative Social Network Analysis (SNA) and the Study of Cuneiform Archives: A Test-case based on the Murašû Archive'. Akkadica 134, 117-134. 


\section{Walker, C.B.F.}

1988 'Introduction'. Erle Leichty et al. (eds.), Tablets from Sippar 3. CatBM 8. London: The British Museum, xi-xxv.

\section{Wallis, Gerhard}

1953 Die soziale Situation der Juden in Babylonien zur Achämenidenzeit auf Grund von fünfzig ausgewählten babylonischen Urkunden. $\mathrm{PhD}$ diss., HumboldtUniversität.

1980 'Jüdische Bürger in Babylonien während der Achämeniden-Zeit'. Persica 9, 129-188.

\section{Wasmuth, Melanie}

2011 'Tracing Egyptians outside Egypt: Assessing the Sources'. Kim Duistermaat and Ilona Regulski (eds.), Intercultural Contacts in the Ancient Mediterranean: Proceedings of the International Conference at the Netherlands-Flemish Institute in Cairo, 25th to 29th October 2008. OLA 202. Leuven: Peeters, 115-124.

2016 'Introduction: The Eastern Mediterranean Area of Connectivity in the 8th-6th Century BCE - Setting an Agenda'. Journal of Ancient Egyptian Interconnections 12 , vi-Xvi.

\section{Weidner, Ernst F.}

1939 'Jojachin, König von Juda, in Babylonischen Keilschrifttexten'. Mélanges syriens offerts à Monsieur René Dussaud par ses amis et ses élèves 2. Bibliothèque archéologique et historique 30. Paris: Geuthner, 923-935.

\section{Weippert, Manfred}

2007 'Azriyau und Azaryau: Zur Unterscheidung israelitischer und judäischer theophorer Personennamen in keilschriftlicher Wiedergabe'. Jürg Luchsinger et al. (eds.), '... der seine Lust hat am Wort des Herrn!' Festschrift für Ernst Jenni zum 80. Geburtstag. AOAT 336. Münster: Ugarit-Verlag, 379-392.

\section{Westenholz, Aage}

2010 'Illicit Cuneiform Tablets: Heirlooms or Stolen Goods?'. Alexandra Kleinerman and Jack M. Sasson (eds.), Why Should Someone Who Knows Something Conceal It? Cuneiform Studies in Honor of David I. Owen on his 7oth Birthday. Bethesda: CDL, 257-272.

\section{Weszeli, Michaela}

1996 'Eseleien'. WZKM 86, 461-478. 


\section{Widell, Magnus et al.}

2013 'Staple Production, Cultivation and Sedentary Life: Model Input Data'. T.J. Wilkinson et al. (eds.), Models of Mesopotamian Landscapes: How SmallScale Processes Contributed to the Growth of Early Civilizations. British Archaeological Reports, International Series 2552. Oxford: Archaeopress, 81-101.

\section{Wiesehöfer, Josef et al. (eds.)}

2011 Ktesias' Welt -Ctesias'World. CLeO 1. Wiesbaden: Harrassowitz.

\section{Wiseman, Donald J.}

1985 Nebuchadnezzar and Babylon. The Schweich Lectures of the British Academy 1983. Oxford: Oxford University Press.

\section{Woods, Christopher}

2005 'On the Euphrates'. ZA 95, 7-45.

\section{Wright, Jacob L.}

2011 'The Deportation of Jerusalem's Wealth and the Demise of Native Sovereignty in the Book of Kings'. Brad E. Kelle et al. (eds.), Interpreting Exile: Interdisciplinary Studies of Displacement and Deportation in Biblical and Modern Contexts. AIL 10. Atlanta: Society of Biblical Literature, $105^{-133 .}$

\section{Wullen, Moritz et al. (eds.)}

2008 Babylon: Mythos und Wahrheit 1: Mythos. Munich: Hirmer.

\section{Wunsch, Cornelia}

1988 'Zur Entwicklung und Nutzung privaten Großgrundbesitzes in Babylonien während des 6. Jh. v. u. Z. nach dem Archiv des Țābija'. Petr Vavroušek and Vladimir Souček (eds.), Šulmu: Papers on the Ancient Near East Presented at International Conference of Socialist Countries (Prague, Sept. 30 - Oct. 3, 1986). Prague: Charles University, 361-378.

1993 Die Urkunden des babylonischen Geschäftsmannes Iddin-Marduk: Zum Handel mit Naturalien im 6. Jahrhundert v. Chr. 2 volumes. CM 3a-b. Groningen: Styx.

1999 'Neubabylonische Urkunden: Die Geschäftsurkunden der Familie Egibi'. Johannes Renger (ed.), Babylon: Focus Mesopotamischer Geschichte, Wiege früher Gelehrsamkeit, Mythos in der Moderne: 2. Internationales Colloquium der Deutschen Orient-Gesellschaft 24.-26. März 1998 in Berlin. Colloquien der Deutschen Orient-Gesellschaft 2. Saarbrücken: SDV, 343-364. 
2000a Das Egibi-Archiv 1: Die Felder und Gärten. 2 volumes. CM 20a-b. Groningen: Styx.

200ob 'Neubabylonische Geschäftsleute und ihre Beziehungen zu Palast- und Tempelverwaltungen: Das Beispiel der Familie Egibi'. A.C.V.M. Bongenaar (ed.), Interdependency of Institutions and Private Entrepreneurs: Proceedings of the Second MOS Symposium (Leiden 1998). PIHANS 87. Istanbul: Nederlands Historisch-Archaeologisch Instituut, 95-118.

2002 'Debt, Interest, Pledge and Forfeiture in the Neo-Babylonian and Early Achaemenid Period: The Evidence from Private Archives'. Michael Hudson and Marc Van De Mieroop (eds.), Debt and Economic Renewal in the Ancient Near East. ISCANEE 3. Bethesda: CDL, 221-255.

2003a Urkunden zum Ehe-, Vermögens- und Erbrecht aus verschiedenen neubabylonischen Archiven. BaAr 2. Dresden: ISLET.

2003b 'Women's Property and the Law of Inheritance in the Neo-Babylonian Period'. Deborah Lyons and Raymond Westbrook (eds.), Women and Property in Ancient Near Eastern and Mediterranean Societies. Available online at http://chs. harvard.edu/CHS/article/display/1219.

2007 'The Egibi Family'. Gwendolyn Leick (ed.), The Babylonian World. New York: Routledge, 236-247.

2010 'Neo-Babylonian Entrepreneurs'. David S. Landes et al. (eds.), The Invention of Enterprise: Entrepreneurship from Ancient Mesopotamia to Modern Times. Kauffman Foundation Series on Innovation and Entrepreneurship. Princeton: Princeton University Press, 40-61.

2013 'Glimpses on the Lives of Deportees in Rural Babylonia'. Angelika Berlejung and Michael P. Streck (eds.), Arameans, Chaldeans, and Arabs in Babylonia and Palestine in the First Millennium B.C. LAOS 3. Wiesbaden: Harrassowitz, 247-26o.

2014 'Babylonische Familiennamen'. Manfred Krebernik and Hans Neumann (eds.), Babylonien und seine Nachbarn in neu- und spätbabylonischer Zeit: Wissenschaftliches Kolloquium aus Anlass des 75. Geburtstags von Joachim Oelsner, Jena, 2. und 3. März 2007. AOAT 369. Münster: Ugarit-Verlag, 289-314.

(forthcoming) Judeans by the Waters of Babylon: New Historical Evidence in Cuneiform Sources from Rural Babylonia in the Schøyen Collection. With Contributions by L.E. Pearce. BaAr 6. Dresden: ISLET.

\section{Wunsch, Cornelia and Magdalene, F. Rachel}

2014 'Freedom and Dependency: Neo-Babylonian Manumission Documents with Oblation and Service Obligation'. Michael Kozuh et al. (eds.), Extraction \& Control: Studies in Honor of Matthew W. Stolper. SAOC 68. Chicago: The Oriental Institute of the University of Chicago, 337-346. 


\section{Younger, K. Lawson, Jr.}

1998 'The Deportations of the Israelites'. JBL 117, 201-227.

2002 'Yahweh at Ashkelon and Calah? Yahwistic Names in Neo-Assyrian'. VT 52, 207-218.

2016 A Political History of the Arameans: From Their Origins to the End of Their Polities. ABS 13. Atlanta: Society of Biblical Literature.

\section{Yun, Ilsung Andrew}

2006 'A Case of Linguistic Transition: The Nerab Inscriptions'. Journal of Semitic Studies 51, 19-43.

\section{Zadok, Ran}

1976 'On the Connections between Iran and Babylonia in the Sixth Century B.C... Iran 14, 61-78.

1977 On West Semites in Babylonia during the Chaldean and Achaemenian Periods: An Onomastic Study. Jerusalem: Wanaarta.

1978a 'The Nippur Region during the Late Assyrian, Chaldean and Achaemenian Periods Chiefly according to Written Sources'. Israel Oriental Studies 8, 266-332.

1978b 'Phoenicians, Philistines, and Moabites in Mesopotamia'. BASOR 230, 57-65.

1979a The Jews in Babylonia during the Chaldean and Achaemenian Periods according to the Babylonian Sources. Studies in the History of the Jewish People and the Land of Israel Monograph Series 3. Haifa: The University of Haifa.

1979b 'On Some Foreign Population Groups in First-Millennium Babylonia'. TA 6, 164-181.

1981 'Arabians in Mesopotamia during the Late-Assyrian, Chaldean, Achaemenian and Hellenistic Periods Chiefly according to the Cuneiform Sources'. ZDMG 131, 42-84.

1985 Geographical Names According to New-and Late-Babylonian Texts. Répertoire Géographique des Textes Cunéiformes virı. Beihefte zum Tübinger Atlas des Vorderen Orients, Reihe B Nr. $7 / 8$. Wiesbaden: Reichert.

1988 The Pre-Hellenistic Israelite Anthroponymy and Prosopography. OLA 28. Leuven: Peeters.

1989-1990 Review of Entrepreneurs and Empire: The Murašû Archive, the Murašû Firm, and the Persian Rule in Babylonia by Matthew W. Stolper. WdO 20-21, 273-276.

1990 'On Early Arabians in the Fertile Crescent'. TA 17, 223-231.

1992 'Egyptians in Babylonia and Elam during the 1st Millennium B.C.. Lingua Aegyptia $2,139-146$.

1995 'On the Late-Assyrian Texts from Dūr-Katlimmu and the Significance of the NA Documentation for Ethno-Linguistic Classification'. NABU 1995/3. 
1996 'Notes on Syro-Palestinian History, Toponymy and Anthroponymy'. UF 28, 721-749.

2002 The Earliest Diaspora: Israelites and Judeans in Pre-Hellenistic Mesopotamia. Publications of the Diaspora Research Institute 151. Tel Aviv: Tel Aviv University.

2003 'The Representation of Foreigners in Neo- and Late-Babylonian Legal Documents (Eighth through Second Centuries B.C.E.)'. Oded Lipschits and Joseph Blenkinsopp (eds.), Judah and the Judeans in the Neo-Babylonian Period. Winona Lake: Eisenbrauns, 471-589.

2004 'Israelites, Judeans and Iranians in Mesopotamia and Adjacent Regions'. J. Harold Ellens et al. (eds.), God's Word for Our World: Theological and Cultural Studies in Honor of Simon John De Vries 2. JSOTS 389. London: T\&T Clark, 98-127.

2005 'On Anatolians, Greeks and Egyptians in "Chaldean" and Achaemenid Babylonia'. TA 32, 76-106.

2009 Iranisches Personennamenbuch VII: Iranische Namen in semitischen Nebenüberlieferungen 1 B: Iranische Personennamen in der neu- und spätbabylonischen Nebenüberlieferung. Sitzungsberichte der philosophisch-historischen Klasse 777. Iranische Onomastik 4. Vienna: Verlag der Österreichischen Akademie der Wissenschaften.

2013 'The Onomastics of the Chaldean, Aramean, and Arabian Tribes in Babylonia during the First Millennium'. Angelika Berlejung and Michael P. Streck (eds.), Arameans, Chaldeans, and Arabs in Babylonia and Palestine in the First Millennium B.C. LAOS 3. Wiesbaden: Harrassowitz, 261-336.

2014a 'Judeans in Babylonia - Updating the Dossier'. Uri Gabbay and Shai Secunda (eds.), Encounters by the Rivers of Babylon: Scholarly Conversations between Jews, Iranians and Babylonians in Antiquity. TSAJ 16o. Tübingen: Mohr Siebeck, 109-129.

2014b 'On Population Groups in the Documents from the Time of the First Sealand Dynasty'. TA 41, 222-237.

$2014 \mathrm{c}$ 'Hìt in Sūhu'. KASKAL 11, 1-22.

2015a 'West Semitic Groups in the Nippur Region between c. 750 and 330 B.C.E.. Jonathan Stökl and Caroline Waerzeggers (eds.), Exile and Return: The Babylonian Context. BZAW 478. Berlin: De Gruyter, 94-156.

2015b 'Israelites and Judaeans in the Neo-Assyrian Documentation (732-602 B.C.E.): An Overview of the Sources and a Socio-Historical Assessment'. BASOR 374, 159-189.

2015c 'Notes on the onomastics from Yahūdu'. NABU 2015/85.

2015d 'Yamu-iziri the Summoner of Yahūdu and Aramaic Linguistic Interference'. $N A B U 2015 / 86$. 


\section{Zadok, Ran and Zadok, Tikva}

2003 'Neo/Late-Babylonian Geography and Documentation'. NABU 2003/35.

\section{Zawadzki, Stefan}

1990 'Great Families of Sippar during the Chaldean and Early Persian Periods (626$482 \mathrm{BC})^{\prime} \cdot R A$ 84, 17-25.

1995 'Hostages in Assyrian Royal Inscriptions'. Karel Van Lerberghe and Antoon Schoors (eds.), Immigration and Emigration within the Ancient Near East: Festschrift E. Lipinski. OLA 65. Leuven: Peeters, 449-458.

2010 'Garments in Non-Cultic Context (Neo-Babylonian Period)'. Cécile Michel and Marie-Louise Nosch (eds.), Textile Terminologies in the Ancient Near East and Mediterranean from the Third to the First Millennia BC. Ancient Textiles 8. Oxford: Oxbow, 409-429.

2015 'The Chronology of Tyrian History in the Neo-Babylonian Period'. AoF 42, $276-287$.

\section{Zehnder, Markus}

2005 Umgang mit Fremden in Israel und Assyrien: Ein Beitrag zur Anthropologie des 'Fremden' im Licht antiker Quellen. Beiträge zur Wissenschaft vom Alten und Neuen Testament 168. Stuttgart: Kohlhammer. 


\section{General Index}

Abī-ul-īde the sēpiru 191-192, 194

Across-the-River 110, 143-146, 151, 224, 233

Administration $\quad 61-63,70-71,121-125$, 135-137, 142-146, 149-159, 186-196, 231-234, 242-243, 248-250, 253-256, 273-274

Aga' ${ }^{2}$, King of Ashkelon $\quad 66-67$

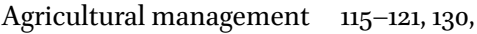
137-138, 147, 166, 178-179, 208, 244, 248

Ahīqam/Rapā-Yāma 121-123, 125-126, 133-147, 154-161

Ahīqar/Rīmūt $\quad 112-125,133,135,137,142$, $155^{-159}$

Ahura Mazda 204, 214, 216-217, 267

Akkadian 16, 22-23, 218-219, 249, 252-254, 264

Alphabetic inscriptions $100,128,130$, 150-151, 235, 249, 274

Āl-šarri $\quad 146-148,155,158$

Amēl-Marduk 34, 72-77

Amušê/Arih $\quad 84,86-87$

Antiquities trade $\quad 39-43,102-103,235$

Arabs, Arabian $\quad 8,18-19,32,142,234,257$

Arad-Gula/Nabû-šum-ukīn/Amēl-Ea 106, 120-125, 133-135, 138, 155-158

Aramaic 4, 16, 52, 100, 128, 150-151, 161, 240, 249, 252-254, 264, 274

Arameans $3-4,8,18-20,237$

Ararru family $\quad 92-94$

Archaeology

Ethics $\quad 40-41$

of Babylonia $\quad 46-47,58-61,164$

of Judah $\quad 12,14,29$

of Neirab $\quad 237-238$

Archival structures $\quad 38-39,88,110-112$, $124-127,134-135,154-159,166-167$

Arih $83 \mathrm{n} 498,87$

Artahšar 191, 204-205

Artaxerxes I 168, 190, 199, 205, 258

Ashkelon $\quad 63-67,71-72,202,219-220,260$, 272

Babylon $\quad 5^{8-59}, 92-94,112,133^{-139}, 150,163$, 224, 231, 233-234, 244-246, 260-261
Babylonia

Political geography $\quad 16-20$

Political history $\quad 5-7,11-15$

Society $15^{-24}$

Badiātu canal $\quad 175^{-177,180}$

Bardiya 117

Barīk-il/Rahīm-il $\quad$ 195nı16, 197, 199

Basia/Arih $\quad 83,86$

Beer 90, 117, 134-136, 174, 178-179, 260

Bēl see Marduk

Bēl-ahhē-erība/Nūr-Šamaš $\quad 120-125,155$, 157-158

Bēl-iddin/Amušê 90, 94-95

Bēl-šar-uṣur/Nubâ 129, 160, 162, 271-272

Bēl-uballiț/Amušê 87

Bēl-upehhir/Arad-Gula/Amēl-Ea $\quad$ 122, 124, 133, 155-157

Bethel (Bìt-il) 270

Bìt-Abī-râm 102-103, 107, 148-152

Bīt-Gērāya $\quad$ 170-182, 207-208

Borsippa $\quad 107-108,225,231$

Bow land 109, 115, 118, 136, 143, 146-147, 151, 166, 182-186, 198-203, 207-209-212, 243, $255^{-259}$

Brewing see Beer

Cambyses $117,135,158,258$

Canals 21-22, 171-173, 175-180, 240

Chaldeans $\quad 3,5,8,18-24,273$

Chariot land 109, 212, 255, 259

Chebar see Kabaru

Cities see Babylon; Borsippa; Nippur; Sippar

Cows see Oxen

Craftsmen $\quad 64-65,77-78,257,261$

Credit granting $116-121,137,147,166,208,211$, 260

Culture 161-163, 199, 213-220

Cutha 232n1178, 235

Darius I $3,7-8,110,117,135,145^{-146}, 158$,

$$
255^{-257}
$$

Darius II 168, 190-191, 195, 199, 204-206, 208

Deportation, deportees $\quad 4-6,9-15,23,63-71$, $77-78,127,159,187,202-203,212-213$, 219-220, 226-227, 230-231, 240-244, $249,254-258$ 
Donkeys $\quad 99-100,136 n 762,244-245,248$

Dowry $\quad 88-90,97-98,131,262,265$

Ebabbar temple $\quad 83-88,91-95,227-230$, $254 n 1263$

Economy $\quad 6-7,21-22,108-110$

Egibi family $\quad 92-93,98 \mathrm{n} 585,225,23^{2-233}$

Egypt, Egyptians $\quad 5-6,11-13,23,47 n 273,49$, $55,64-65,72,97,150,154,160-161,197$, 206, 224, 254n1263, 26o-261, 264-266

Elam 64, 137n766, 147, 154, 210 See also Susa

Elephantine $\quad 52,131,266-267,270$

Elite, Babylonian see Urban upper class

Enlil-šum-iddin/Murašû $\quad 165,171-178,188$, 195, 197-199, 201, 205, 207, 209, 212

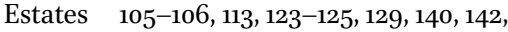
$146,148-153,156-157,186-196,204-206$, 233-234

Evil-merodach see Amēl-Marduk

Family $\quad 68-72,76-77,87-90,119-120$, 130-132, 139-141, 162-163, 263-265

Farmers 116-161, 172-213, 228-234, 242-244, $255^{-260}$

Fishing, fish trade $\quad 112-115,208,260$

Freedom $\quad 70-71,211-213,259-260$

Gadal-Yāma/Banna-Ea 224

Gadal-Yāma/Rahīm-il 195-197, 199, 210,214

Gold 81, 83-84

Governor 110, 143-146, 186, 190-194, 196, 221, 224, 233,256

Gūbaru 186, 190-194, 196, 204

Gudadadītu 87

Guzānu/Kiribtu/Ararru $\quad 87,89,92-94$

Haggâ/Ahīqam 133, 137-140

Hanan-Yāma/Udarna? 197-200, 207, 214, 216, 219

Harri-Piqūdu canal $\quad$ 188, 190, 201

Hebrew 52, 13on725, 161, 235, 274

Herding see Sheep

Hìt 238, 240, 244-246, 248

Horse land $109,182,195^{-196,198-200, ~ 210, ~}$ 212, 255-256, 259

Hostages $\quad 6,64,71-78,257,260-261$
Houses $83-84,92,107,121-124,126 n 707,138$, 140, 201, 234

Humadēšu 99-100

Hursagkalamma see Kiš

Iddinâ/Šinqā $\quad 142-146,158$

Identity $18,95^{-9} 98,161-163,213^{-220}$, $249-250,272-276$

Ilia family $\quad 224-225$

Inheritance division $\quad 134,139,163$

In-Nusku family $\quad 241,244-245,247-248$

Integration 2 n4, 97-98, 141, 161-163, 199-200, 272-276

Iranian see Persian, Persians

Iron dagger clause $\quad 89-90,132,265$

Irrigation see Canals

Isin 234

Israel, Israelites $\quad 4,49-51,53-55,228$ n1144, 230, 235

Iššar-tarībi/Bunene-ibni $\quad 81,88,99-100$

Ištar 141, 267, 275

Izrīqam/Šamā-Yāma 137-138, 143

Jehoiachin $\quad 6,12,34,65,68-77,257,260-261$

Jerusalem $6,11-15,29,58,65,68,72,251,254$, $257,261,263,266,274$

Kabaru canal $\quad 35,107,191$

Karkara 107-108, $111 n 666$

Kaššāya/Amušê $\quad 87-90,97-98$

Kēš 107-108, 133

Kiš $107,154,231,234$

Land-for-service $\quad$ 108-161, 165-166, 181-213, 219-222, 230-234, 242-250, 255-26o

Landholders see Farmers

Larsa $\quad 231$

Literacy $\quad 187-188,194-196,203-204,25^{2-254}$, 261,274

Lydia $\quad 66,71-72$

Mannukiya/Paqiqi 190-194

Manuštānu 190-194, 204

Marad 226n1135

Marduk 96, 131, 141, 162, 267, 271, 275

Marduka/Arih 84, 86

Marduk-rēmanni/Bēl-uballiț/Ṣāhit-ginê 88, 94, 233 
Marriage $\quad 87-90,97-98,130-132,162-163$, 227-228, 247, 264-265

Merchants $80-84,91,94-95,98-100,258$ See also Royal merchants

\section{Migration}

Forced see Deportation, deportees

Voluntary $8,70,77,251,257-258$

Moon god 57, 198n1027, 214, 216-217, 237-238, 241-242, 247, 249-251, 267, $271-272$

Murašû

archive $27,31,45,107-110,142,164-170$, 208, 211, 256, 268-269

family 119, 137n763, 165-167 See also Enlil-šum-iddin/Murašû; RīmūtNinurta/Murašû

Nabonidus $\quad 20,74-76,127,162,254$

Nabopolassar $\quad 3,5,20,78,240-241,254$

Nabû 96, 131, 267

Nabû-mìt-uballiṭ/Balāṭu 188-189, 194

Nail marks $\quad$ 169-170

Names

Beamtennamen $47-48,113,129,145,162$, 226, 229, 242

Family names $\quad 20,47,89-90,165$

Hypocoristics $51,115 \mathrm{n} 680,121 n 695,198$, 219

Sîn and Nusku names $\quad 57,241-242,247$, 271

Theophoric $\quad 48,161-163,268$

Yahwistic $\quad 27-28,49-57,96,105,120,141$, 161-163, 218-219, 230, 268-272

Naming practices $\quad 96-97,120,141,149$, 161-163, 179, 197, 201, 218-219, 241-242, 249-250, 26o, 268-272, 275

Nargia/Hananaia $\quad 239,241,245,247-248$

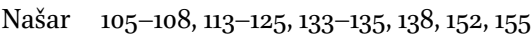

Nebuchadnezzar II $5-6,11-13,60-61,66$, $74-75,127,240,254,256$

Nebuchadnezzar III 117

Nebuchadnezzar IV 117,157

Neirab, Neirabians $\quad 3,6,45^{-46}, 57,237-250$, $255,259,263,267,271-273$

Nippur 106-108, 142, 164-222, 230, 232, 235, 240, 262

Niqūdu/Ṣillâ/Aškāpu 121-124

Nīr-Yāma/Ahīqam 122, 133, 137-140, 147, $15^{6}$
Nīr-Yāma/Ahīqar $\quad$ 115, 119-120, 125, 152, $15^{8}$ Nuhsāya/Nusku-gabbē 239, 241, 243-244, 247-248

Nusku $57,241-242,247,249-251,268$, 271-272

Nusku-iddin/Nusku-killanni $\quad 241,245^{-246}$, 248

Nusku-killanni/Nusku-gabbē $\quad$ 241, 243-244

Officials

Babylonian, Persian $\quad 61,80-82,110,116$, $127,129,135^{-136}, 139,142-150,189-197$, 221, 242-244, 255-259, 272

Deportees $\quad 64-66,82,110,119,129,133$, 16o, 203-206, 223-226, 257, 261, 273-274

Opis $\quad 98-99$

Oxen 118-119, 121, 137-138, 147, 153, 173, 198, 201, 233-234

Palace Archive of Nebuchadnezzar II $44,60-63,257$

Parysatis 205-206

Persian Empire $\quad 3,9-10,18,146,150,152$, 224-225

Persian, Persians $\quad 49,55,65,99-100,150,197$, 200-201, 203, 209, 216-218, 257

Persian royalty $\quad 165^{-167}, 190-191,193^{-194}$, 204-206, 208, 258

Pili-Yāma/Šillimu 168, 170-172, 174-181, 207

Pledge, security for a debt $117-119,121$, 128-129, 141, 159, 166, 168, 172, 188, 190, 199, 211

Ploughing, plough teams $116,118-119,121$, $137,176,198,201$

Rahīm-il 195-200

Rapā-Yāma/Samak-Yāma $\quad$ 125-133, 135, 139-140, 155

Rations $\quad 62-63,68-73,261$

Religion 96, 131, 141, 161-163, 216-219, 247, 265-272

Rent $\quad 108-110,135-138,142-143,153,171-172$

Rent farming $135^{-13} 8,143,145,149^{-151,234}$, 260

Retail 112-114, 117, 134-137, 166, 174, 260

Retroacta 39, 121

Return migration $\quad 24,29,37,169,240-241$, 249 
Rīmūt/Abī-ul-īde 112-115, 120-121, 124-125, $148,155,157$

Rīmūt-Ninurta/Murašû $\quad 165,188,190-191$, 195, 201, 204, 206-207, 209

Rīmūt/Samak-Yāma $\quad 112-115,120,124-125$, 155

Royal merchants $\quad 80-84,87,243,258,262$, 271-273 See also Merchants

Sabbath 266-267

Sailors see malāhu

Scribes

Alphabetic see sēpiru

Cuneiform 16, 19-21, 106, 121-125, 130, $132,145^{-147}, 153,15^{6-157}, 217,240$, $252-254,274$

Seals 141, 169-170, 173, 198-200, 204-207, 213-218, 235, 249

Service obligations $\quad 108-109,116,118-120,147$, 154, 159, 195-196, 209-212, 243, 245, 248, $255^{-259}$

Sheep $133^{-134}, 150,153,173,208,230-231$, 260

Sîn see Moon god

Sîn canal 107-108

Sippar 82-84, 91-95, 100, 227-230, 233, 262, 271

Slaves $89,100,122,139 n 772,141,148 \mathrm{n} 805,151$, 153-154, 16o-161, 201, 212, 228, 235, 243, $247,260,262,264$

Socio-economic status $\quad 70-72,91-98,139$, 159-163, 169, 178-181, 199-200, 207-213, 241, 248-250, 258-263

Soldiers $\quad 64,77-78,257,261$

Susa 10, 36-37, 107, 154, 191, 225-226, 264 See also Elam

Șidqī-Yāma/Šillimu 126-132, 16o

Šalāmān/Rapā-Yāma 122, 138-140, 143, 155 Šamaš 84, 91, 96 See also Ebabbar temple

Tagabi-Yāma 99-100

Taxes 108-110, 115-120, 128, 133, 142, 159, 191, 209-212, 224-226, 243-244, 248, $255^{-259}$

Temples 226-231, 247, 253-254, 257-258, 262, 266-267, 274 See also Ebabbar temple
Trade 79-82, 91-92, 94-95, 98-101, 245-246, 248, 258 See also Retail

Traders see Merchants; Royal merchants

Twin towns $6,105,108,110,113,127,140$, 151-152, 202-203, 240-241, 243, $255^{-256,272}$

Udarna 'Rahīm-il 197-200, 214, 218 Unprovenanced artefacts see Antiquities trade

Urâti canal $172-173,177-180$

Urban upper class $7,16,20-21,47,92-95$, 165-167, 217-218, 224-225, 252-253, $264-265,274-275$

Uruk 107-108, 195, 199, 210, 266-267

Uštanu 143-146, 148n8o5, 151

Villages 104-154, 170-203, 237-250, 259 See also Bīt-Gērāya

Women $\quad 87-90,97-98,119-120,122,129-132$, 139-141, 153-154, 160-161, 163, 208, $227-228,235,247,263-265$

Xerxes $3,7,21,153,158-159$

Yadi-Yāma/Banā-Yāma 170-181, 207, 214, 219 Yāhūdu

Tablets $30,41-45,102-104,110-112$, 154-159

Village of $105^{-108,113}, 115,125^{-146,151}$, 154, 182-184, 210, 255-256, 259, 263, 268-272, 275

Yāhû-izrī/Ahīqam 133, 137-140

Yāhû-natan/Yadi-Yāma 173, 177-180

Yāhû-šar-uṣur/Nubâ see Bēl-šar-uṣur/Nubâ

Yahweh 4, 49-54, 96, 161-163, 217-218, 266-272

Zababa-šar-ușur/Nabû-zēr-iddin $\quad$ 119, 125, $148-152,158-159$

Zabīn/Balāṭu 188-189, 192, 194-195

Zarpanìtu 96, 131, 267

Zedekiah $\quad 6,12-13,68-69,72-73,76,260-261$ 


\section{Terms}

\author{
'rht tmyd 73 \\ ahšadrapānu 192 \\ ahu 173 \\ akītu 73 \\ akkadû 18 \\ ana aššābūti $1400_{775}$ \\ aramu, aramāya $\quad$ 18-19 \\ arbāya see urbu
}

bābilāya $\quad 18$

bāru 209, 256

bēl piqitti $151 \mathrm{n} 818$

bèl țēmi 224

bgdy $k l^{2} w \quad 72$

bìt azanni $108 \mathrm{n} 647,109 n 650,127-128,255$

bìt ešrî 173

büt kīlāni 71

bit narkabti see Chariot land

bìt qašti see Bow land

bìt qīpūti 64

bit ritti $172-173,181,184,201,208,256,259$

bìt sapināti 64

bìt sīsê see Horse land

byt $k l^{2} \quad 7^{2}$

dēkû 105, 110, 113, 115, 119, 133, 155, 160

didakku 192

erbu 229

eršu akkadītu $\quad 97-98$

eširtu 143n786, 256

ešru 229

gardu 187,200

gimru 229

harrānu 95, 99, 112, 117, 232, 263

hașbattu 90

hațru $47,108-110,133,135,158,166,186-196$, 200, 202-204, 207-208, 210-212, 256,

259

hubtu 65

ilku 119-121, 128, 133, 209-210, 256

imittu 109, 116, 135-136, 138, 142-143, 145, 149, 153, 201, 210, 256

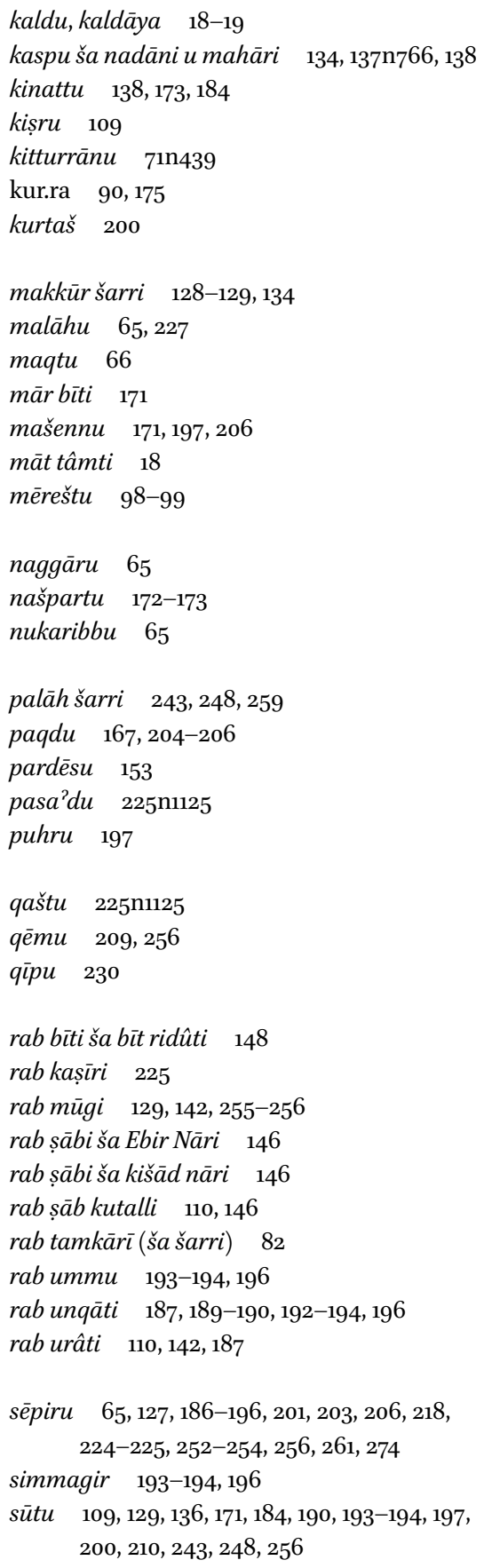


șāb šarri $\quad 117,209,256-257$

šaknu 109, 166, 187-190, 192, 195, 203-204, 206, 209-210

ša muhhi ešrî 83

ša muhhi sūti ša nār $x \quad 171$

šanû $\quad 189$

šar Bābili $\quad$ 17-18

ša rēši nāru 65

ša rēš šarri $\quad 61,64,66,145,150,226,261$

šar māt Šumeri u Akkadi $\quad$ 17-18

širku 23, 231, 254n1263, 258, 262

šušānu 109-110, 135-137, 143-144, 153, 158,

16o, 166, 187, 205, 212, 255-256, 259

šušānu ša uqūpē 65 tamkār šarri $\quad$ 80-84 See also Royal merchants

tamkāru $\quad 80-82,84$

ummānu 225

uqu 187-189

urbu 18-19

ustarbaru 150

uṣertu 710438

uzbāru 171

zèrū pišsulpi 187,200

zēruzaqpu 201

zittu 204, 229 


\section{Sources}

\section{Mesopotamian Texts}

A1 130-132, 154, 162, 247

A2 see $\mathrm{C} 45$

ABC $3 \quad 254 \mathrm{n} 1262$

ABC 5 11-12, 63n374, 66n411, 113n674

$A B C 6 \quad 66 \mathrm{n} 406,254 \mathrm{n} 1262$

$A B C$ 10n55, 10n 59

B1 $105,127-128,132$

B2 146 n $799,147,182 n 948$

B3 130, 153, 16on 844

B4 154

B5 122, 133-137, 156, 181

B6 133n $743,136,139 n 770,140 n 776,142 n 782$, $143,145,181$

B7 142n782, 143, 145

B8 133n $745,137 \mathrm{n} 765$

B9 133n $743,134,140 n 776,141,143,160 n 845$, 169,216

B10 133n $745,137 n 766,138,161 n 849$

B11 145, 153

B12 133n743, 135, 139n770, 140n776, 142-143, 145

B13 133n745, 137n767, 138, 154n834, 182ng48, $182 n 950$

B14 137n $767,138 \mathrm{n} 768,154 \mathrm{n} 834$

B15 133n742, 133n $745,137 n_{765}, 137 n_{767}, 138$, $140 n 776$

B16 133, 137n $765,137 n_{7} 67,138-139,140 n_{776}$

B17 154

B18 121, $141 \mathrm{n} 778$

B19 113n675, 114

B20 112-113

B21 108n645, 112-114, 147-148

B22 112-114, 121

B23 113-114, 115n678, 116n682, 119n691, 122

B24 115n678, 118

B25 107n642, 115n678, 118n689

B26 118n689, 121

B27 115, 118n689, 119, 125, 141n778, 149n810

B28 115n678, 118n689
B29 115n678, 115n68o, 118n689, 122-124, $161 n 849$

B3o 107n642, 115n678, 116n682, 119n691

B31 107n642, 115n678, 116n682, 119n691

B32 115n678, 116n681, 116n682, 117n685

B33 115n678, 116n682, 117n685

B34 115n678, 115n68o, 116n682, 122, 134, 155

B35 106n628, 115n678, 116n682, 117n685, 119n691, 124n705

B36 106n631, 115n678, 116n682

B37 106n628, 115n678, 116n682

B38 106n631, 115n678, 116n682, $117 n 685$

B39 115n678, 116n682, 117n685, 122, 134

B40 115n678, 124n 705

B41 121-123

B42 121-122, 155, 16on844

B43 149n8o7

B44 149n807

B45 149

B46 149

B47 108, 149n8o7

B48 149n8o7, 152n826

B49 149n8o7, 152n826

B50 149n807

B51 149n807

$\mathrm{B}_{52}$ 149n8o7

B53 149n8o7

B54 149n807

B55 149n807

B56 149n807

B57 149n807

B59 107n640, 149n8o7

B6o 149n8o7

B61 149n807

B62 149n807

B63 149n8o7

B64 149n807

B66 149n8o7

B67 149n8o7

B68 149n8o7

B69 149n8o7

B70 149n807 


$\begin{array}{ll}\text { B71 } & 149 n 807,15^{2 n 826} \\ \text { B72 } & 149 n 807 \\ \text { B75 } & 149 n 807,15^{1} \\ \text { B76 } & 149 n 807,15^{2 n 826} \\ \text { B78 } & 149 n 807 \\ \text { B79 } & 149,152 n 826 \\ \text { B8o } & 149 n 807,15^{2 n 826} \\ \text { B81 } & 149 n 807 \\ \text { B82 } & 149 n 807 \\ \text { B83 } & 149 n 807 \\ \text { B84 } & 149 n 807,15^{2 n} 826 \\ \text { B85 } & 107 n 640 \\ \text { B86 } & 149 n 807,15^{2 n 826} \\ \text { B87 } & 149 n 807 \\ \text { B88 } & 115,119,125,152,158 \\ \text { B89 } & 107 n 640 \\ \text { B9o } & 149 n 807 \\ \text { B91 } & 149 n 807 \\ \text { B94 } & 149 n 807 \\ \text { B95 } & 149 n 807 \\ \text { B97 } & 107 n 640 \\ \text { Bab } 28122 & 140 \text { Weidner }\end{array}$

Bab 28122 see Weidner 1939 A

Bab 28178 + 28299a see Weidner 1939 B

Bab 28186 see Weidner 1939 C

Bab 28232 see Weidner $1939 \mathrm{D}$

Bab 28252 see Weidner 1939 D

BE $840 \quad 240$ 1219

BE 8141 see CTMMA 41

BE $93167,184,201$

BE 914 170n892, 171, 174, 178, 185

BE $916 \quad 171$

BE 925 169n885, 170n892, 172-174, 177, 179,

$$
\text { 184-185, 201, 214, } 219
$$

BE $928 \quad 205$

BE 929 17on892, 175, 177n929

BE 934 168, 170n892, 174, 207

BE 945 169n885, 17on892, 173-174, 177-18o, 184-185, 201, 207, 214, 219

BE 965 198n1026, 240n1220

BE 969 169n885, 197-199, 207, 214, 219

BE $972 \quad 193$ n1006

BE 984 19ong82, 191n990

BE 9 86a 182n945-946, 185, 198-199, 202n1039, 219

BE 105191

BE 107 188-189, 19ong8o, 198-199, 207, 219

BE $109 \quad 108 n 645$

BE $1016 \quad$ 108n645
BE $1033 \quad 168,182 n 945$, 188n967, 188ng69, 189n975, 19ong8o, 192n995

BE 1037 188n967, 189n975, 192n995

BE $1057 \quad 188 \mathrm{n} 967$

BE $1060 \quad 206$

BE $1061 \quad 195$ n1017

BE $1062 \quad 195$ n1017

BE 1065 169n885, 187, 204, 209, 214

BE $1077 \quad 185$

BE 1083 169n885, 202n1038, 207, 215, 219n1104-1106

BE 1084 191, 199, 207, 219

BE 1085191

BE $1092 \quad 187,200,202 \mathrm{n}_{1038}$

BE $10101 \quad 193^{-194}$

BE $10102 \quad$ 188ng67, 188n970, 189n975

BE 10118 169n885, 182, 19ong84, 191, 194, 200-202, 208, 215

BIN $122 \quad 189 n 978$

Bloch 2014

no. $1 \quad 87-90,94,97-98$

no. $2 \quad 87-90,94,97-98$

no. $3 \quad 83$

no. $4 \quad 84-86$

no. $583-84,86$

no. 6 90, 94-95

no. 7 37n223, 225-226

no. $8 \quad 225^{-226}$

Bloch 2018 no. $79 \quad 224$

BM 26553 see Bloch 2018 no. 79

BM $34113 \quad 74^{-76}$

BM 40474 see Lament of Nabû-šum-ukin

BM 55063+55268 235n1195

BM $59765 \quad 223 n 1112$

BM $64707 \quad 193$

BM 65149 see Bloch 2014 no. 1

BM 68420 see Bloch 2014 no. 4

BM 68921 see Bloch 2014 no. 2

BM 74411 see Bloch 2014 no. 5

BM 7446o 99n591

BM $74469 \quad 95$

BM 74554 see Stolper 1989

BM 75434 see Bloch 2014 no. 3

BM $77945 \quad 93$

BM $103632 \quad 230$

BMA 11 see Dhorme 1928 no. 23

вмA 17 see YOS 6188

BMA $23 \quad 97$ 


\section{BMA 26 see Bloch 2014 no. 1 \\ BMA 34 264n1282, 265n1285 \\ BMA $35 \quad 264 \mathrm{n} 1282$}

\section{C1 54n327, 105, 127-128, 130, 132}

C2 105, 108n647, 109n65o, 127-128, 16on841, 161n849, 162, 271n1307

C3 127-128, 130, 16on841, 161n849, 162, 27101307

C4 127-128, 130, 16on841, 161n849, 162, 27101307

$\mathrm{C}_{5} \quad 128,160 n 845$

C6 128-129

$\mathrm{C}_{7} \quad 128-129$

C8 105, 106n632, 128-129, 140n 776

C9 128-130, 134n $750,140 n 776$

C10 127, 130, 132, 134n 750, 274

C11 128-129

C12 107n640, 110, 128, 13on723, 133, 155, 16on841

C13 105n624, 121-122, 133, 135, 155-156

C14 97, 109, 133n743, 135, 139n770-771, 142-143, 145, 154n834, 184

C15 109, 110n659, 135, 139n770-771, 142-143, 145, 182ng48, 184

C16 133n743, 136n759, 140n776, 153

C17 97, 133n $743,136,139 n 770,140 n 776$, $142 \mathrm{n} 782,143,145,181$

C18 97, 105, 110, 133n 743,136, 139n 770 , 140n $776,142-143,145,181,230 n 1164$

C19 110, 133n743, 137, 139n770-771, 142n782, 143,145

C20 110n659, 133n743, 138, 139n770-771, 142n $782,143,145$

C21 139n770-771, 142n782, 143, 145, 154n834

C22 138, 139n770-771, 142n782, 143, 145

C23 109, 133n743, 136n759, 137n765, 138, 140n 776,146

C24 110, 133n745, 139n770, 145-146

C25 110, 127n707, 133n $743-745,136$ n 759 , 137n $766,138,139 n 770,146$ n796, 161n849

C26 133n $745,137 n 765,146-148$

C27 133n 745, 137n765, 137n767, 138

C28 137n 767,138

C29 127n707, 133n 743, 133n 745, 137n765

C30 127n707, 133n742-743, 133n745, 137n765

$\mathrm{C}_{31}$ 133n743, 137n765

C32 105n624, 122, 133n $745,154 \mathrm{n} 834,156$
C33 133n743, 135, 136n $759,15^{8}$

C34 133n743, 137n766

C 35 133n743, 136n759

C 6 133n $743,134,156$

C37 133n745, 154n834

C39 127n707, 133n745

C40 133n $743,136 n 760$

C41 133n743, 137n766, 147

C42 133n743

C43 133n 743, 137n766, 138

C44 97, 133n $743,134,136$

C45||A2 97, 122n701, 133n742, 133n744-745, 134, 136, 139n771-772, 155n837, 16 o

C46 127n707, 133n745, 138, 140n775

C47 146-147

$\mathrm{C} 48 \quad 147$

$\mathrm{C} 49 \quad 147$

$\mathrm{C}_{50} 147$

$\mathrm{C}_{51} \quad 146-147$

$\mathrm{C}_{52} \quad 153$

$\mathrm{C}_{53} 105,128,153,158$

C54 107n640, 149n810, 154

C55 108n645, 112-114

$\mathrm{C}_{5} 6$ 108n645, 113

C57 112, 113n673, 124, 131n727, 157

$\mathrm{C}_{5} 8$ 112, 113n673, 124, 131n727, 157

C59 112-113

C6o 113-114, 115n678, 116n682

C61 112-113, 124, 131n 727,157

C62 115n678, 115n68o, 119n691

C63 115n678, 115n68o, 116n682, 117n685, 119n691, 124n705

C64 106, 120, 122, 157

C65 106n631, 120-122, 157

C66 115n678, 116n682, 117n685, 118, 182n948

C67 115n678, 118

C68 115n678, 116

C69 115n678, 182n948, 182n950

$\mathrm{C}_{70}$ 106n631, 115n678, 116n682, 117n685, 119

$\mathrm{C}_{71} \quad 115 \mathrm{n} 678,116 \mathrm{n} 682,117 \mathrm{n} 685$

$\mathrm{C}_{72} \quad 115 \mathrm{n} 678,116$ n682, 117n685, 182n948, $182 n 95^{\circ}$

$\mathrm{C}_{73}$ 115n678, 116n682, 117n683, 117n685

$\mathrm{C}_{74}$ 106n631, 115n678, 116n682, 117n685, 119

C75 115n678, 118n689, 119, 122, 156

$\mathrm{C}_{76} 115 \mathrm{n} 678,115 \mathrm{n} 68 \mathrm{o}, 118 \mathrm{n} 689,122,156$

C77 115n678, 115n68o, 118n689, 119n691, $161 n 849$ 


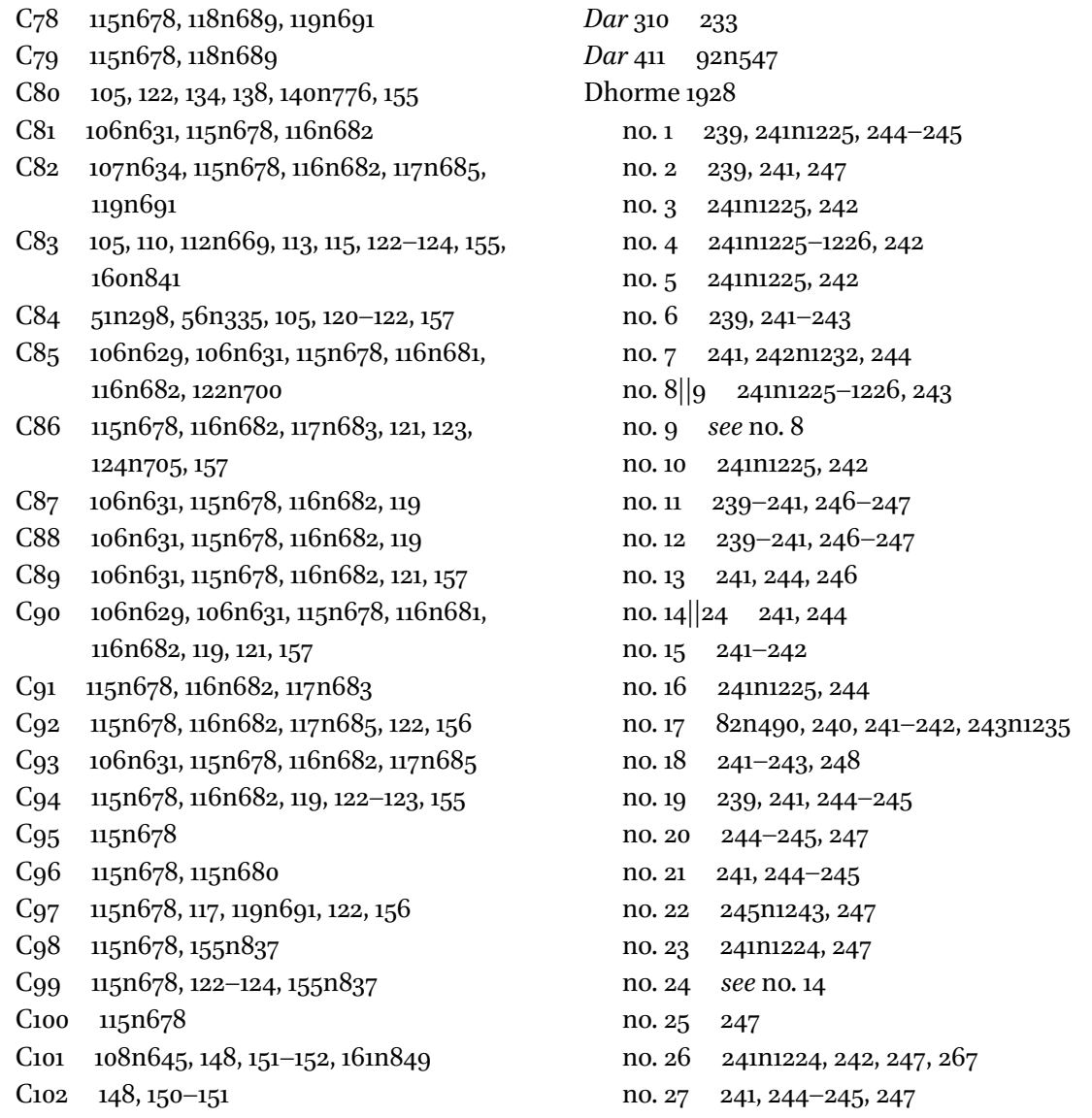

C103 146n795, 148, 151

Camb $384 \quad 82 n 492$

Cameron 1948, no. $85 \quad 82 n 492$

CT $421 \mathrm{a}$ see Bloch 2014 no. 6

CT $5574 \quad 229$

CT $55341 \quad 227$

CT $55823 \quad 82 \mathrm{n} 492$

CT $56132 \quad 229$

CT $56795 \quad 227$

CT $57197 \quad 228$

CT $57700 \quad 227$

СтMMA 41 54n327, 230

Cyr 43 234n1192

Cyr $307 \quad 227-228$

EE 2 170n892, 171, 174, 177ng29, 178, 186, 219

EE 24 184-185, 201, 219n1104

EE 26 17on892, 174-178, 180, 185

$\mathrm{EE}_{30} \quad 171$

EE 34 169n885, 186, 201, 203, 207, 215, 218, 219n1104-1106

EE 35 195n1016, 197

EE $56 \quad 190 n 982,191$

EE 65 169n885, 198, 199n1o32, 214, 219

EE 82 188ng67

EE $86 \quad 185$

EE $89169 n 885,185,215$

EE 92 170n892, 177, 179, 205, 210

EE 94 170n892, 174-175, 185

Dalley and Postgate 198499 ii:16-23 55n330

EE 98 17on892, 174, 178-179, 186, 207, 219

Dar $149 \quad 99 n 589$

EE $107 \quad 169 n 885,215$

Dar 301 see BMA 23

EE 111 182, 19ong84, 200-202, 208 
EE 113 56n334, 185, 205, 210, 212, 219n1104-1105

EE $117 \quad 195 n 1017$

Hofkalender $\quad 20,67-68,82,254 n 1264$ HSM 1931.1.1 233n1186

$\begin{array}{ll}\text { IMT } 5 & 188 \mathrm{ng} 67,189-190 \\ \text { IMT } 7 & 168,170 n 892,174,207 \\ \text { IMT } 8 & 168,170 n 892,174,207 \\ \text { IMT 10 } & 176-177 \\ \text { IMT 17 } & 202 \text { n1039 } \\ \text { IMT 24 } & 179 \\ \text { IMT 32 } & 200 \\ \text { IMT 40 } & 193 \\ \text { IMT 46 } & 190 \text { n984, 191n987 } \\ \text { IMT } 83 & 195 \text { n1017 } \\ \text { IMT 94 } & 185,200 n 1034 \\ \text { IMT 105 } & 192\end{array}$

Institute for Antiquity and Christianity, Claremont Graduate University, tablet no. $192 \quad 223 n 1112$

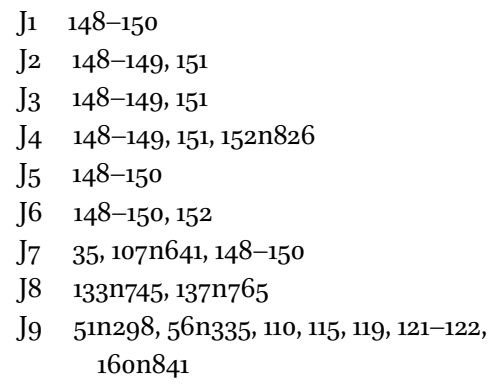

Jakob-Rost 1970 no. $4 \quad 92 n 548$

Joannès 1990 no. $1 \quad 264$ n1282

Jursa 1995 no. $47 \quad 229$

Jursa 1998b $\quad 108 \mathrm{n} 647$

Jursa and Weszeli 2000, 82-84 99n592, 100

King of Justice inscription $\quad 66 \mathrm{n} 406,74-75$

Lament of Nabû-šum-ukin $\quad 74-76$

Langdon 1912, 146-148 254n1264

MacGinnis 1995 no. $118 \quad 82 n 492$

MR $8 \quad 94 n 559$

MR 23-24 94n561

MR $25 \quad 94 n 559$
MR $39 \quad 94 n 562$

MR $69 \quad 94 n 561$

MR 85-86 94n561

MR $90 \quad 233$

MR $171 \quad 94 n 561$

N $4518 \quad 235 n 1194$

Nabonidus' stela from Babylon $\quad 254 \mathrm{n} 1263$

Nbk $137 \quad 92$

Nbk $361 \quad 98-99$

Nbk $441 \quad 97 n 581$

Nbn 1 56n334, 90-91

Nbn $258 \quad 97$

Nbn $464 \quad 82 n 492$

Nbn 6 oo $\quad 92$

ND 2443+2621 5on291

ND $2684 \quad 82 n 492$

New York Public Library, box 43, 4(?) 226n1135

Nimrud Wine Lists $\quad 62 n 364,64$

OECT $10152 \quad$ see Bloch 2014 no. 7

OECT 10183 234n1191

OECT $10295 \quad 92 n 547$

OIP $12215 \quad 83 n 498$

PBS $2 / 12 \quad 192$

PBS 2/1 3 188ng67, 189n975, 19ong8o, 191-192

PBS $2 / 15$ 169n885, 215

PBS 2/1 $11 \quad 188 \mathrm{n} 967$

PBS 2/1 $27 \quad$ 168, 182n945, 182n950, 187-188,

189n975, 192n995, 204n105o, 209

PBS 2/1 29 188, 189n975, 192n995, 204n1050

PBS 2/134 188ng67

PBS 2/1 50 169n885, 205, 215, 219n1104-1105

PBS 2/1 53 219n1104

PBS 2/1 54 195n1017

PBS 2/16o 56n334, 86n518, 169n885, 205,

215, 219n1104-1105

PBS 2/1 66 188n967, 189n975

PBS 2/1 $72 \quad 194$

PBS $2 / 184 \quad 169 n 885,204-205,215$

PBS 2/1 $89 \quad 182,185,187,188-189$, 19ong8o, 209

PBS 2/1 100+ 19ong84, 191ng87

PBS 2/1 $104 \quad 2401220$

PBS 2/1 107 169n885, 199, 207, 214, 219

PBS 2/1 $115 \quad 202 n 1038$ 


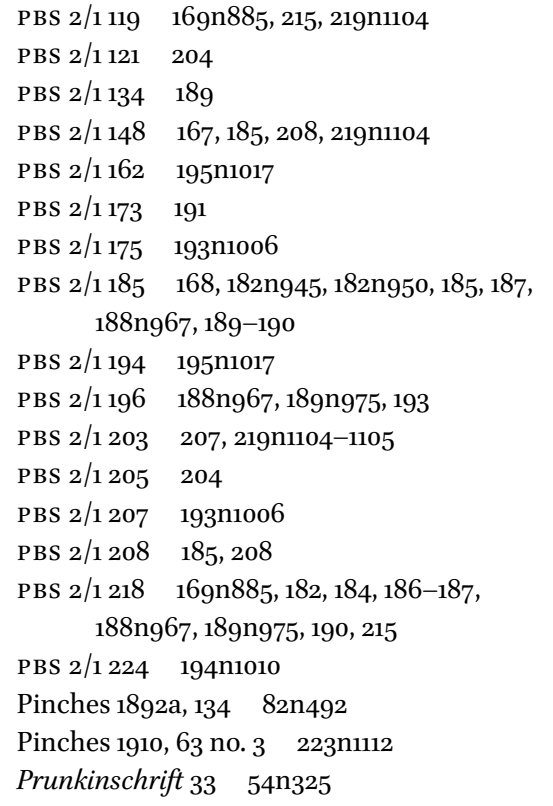

RINAP 1

Tiglath-pileser III 13:2, 31:7 53n314

Tiglath-pileser II I 43 ii:3 237n1201 RINAP 3/1

22 i:31-35 $64 n 379$

RINAP $3 / 2$

$$
\begin{aligned}
& 44 \quad 5 \text { on291 } \\
& 46: 57-62 \quad 65 \text { n } 392 \\
& \text { RINAP } 4 \\
& 33 \text { iii:14'-22' 64n379 } \\
& 126 \quad 92 \text { n } 547 \\
& \text { ROMCT } 225 \quad 234 \text { n1188 }
\end{aligned}
$$

SAA $1171 \quad 53$ n320

SAA $1189 \quad 237 \mathrm{n} 1201$

SAA $6326 \quad 237$ n1201

SAA $79 \quad 82 n 492$

SCT $100 \quad 229$

Stigers 1976 no. $44 \quad 234 n 1188$

Stolper $1989 \quad 224$

Stolper 2001 no. $9 \quad 193$

TCL $13210 \quad 234$

TuM 2-3 123 222n1111, 235n1193

TuM 2-3 $180 \quad$ 19ong82, 191
UCP 9/3 109n652, 169n885, 182, 187, 188ng67, 189n975, 195-196, 198-199, 214

$\mathrm{VS}_{3} 6 \quad 231$

VS $353 \quad 92$

VS 6155 see Bloch 2014 no. 8

Weidner 1939

A $62 n 366,62 n 367,64 n 383,65 n 389$, 65n393, 65n399-402, 66, 68

B $62 n 367,65 n 391,66 n 403,66 n 409,68$

C $62 n_{3} 67,64 n_{3} 83,65 n 390,65 n 394$, 65n396, 68, 69n423, 71

D 62n367, 65n39o, 65n394, 65n396, 68, 71n 437,710439

Weszeli 1996 no. 2 99-10o

$\begin{array}{ll}\text { YBC } 11562 & 192 \\ \text { YOS } 610 & 189 n 978 \\ \text { YOS 611 } & 189 n 978 \\ \text { YOS 6 188 } & 131-13^{2} \\ \text { YOS 19 34 } & 23^{2} \\ \text { YOS 19 36 } & 23^{2}\end{array}$

\section{Biblical Texts}

\author{
Genesis \\ 11:1-9 $\quad 26$ \\ Deuteronomy \\ $12 \quad 266$ \\ 28:47-68 25 \\ Joshua \\ 23:15-16 $\quad 25$ \\ 1 Samuel \\ 12:24-25 25 \\ 2 Samuel \\ 8:9-11 54 \\ 1 Kings \\ $8: 46-53 \quad 25$
}




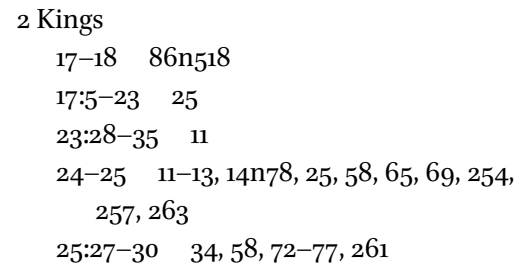

Jeremiah

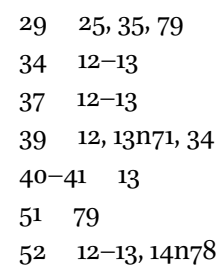

Ezekiel

1:1, 3:15, 8:1, 14:1 35

33:21-22 79

Hosea

$1 \quad 86 n_{518}$

Psalms

$137 \quad 25^{-26}, 35^{-36}$

Esther

in general $\quad 36-37$

Daniel

$$
\begin{array}{ll}
1: 1-2 & 12 n 65 \\
1-6 & 36 \\
4 & 75
\end{array}
$$

Ezra

in general $\quad 25,28-29,37,269$

8:15-20 $\quad 266$

Nehemiah in general $\quad 25,28-29,37,269$

1 Chronicles

$$
\text { 18:9-11 } 54
$$

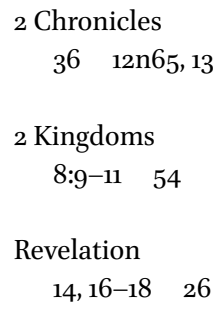

\section{Other Texts}

Chronicle of Jerahmeel $\quad 75^{-76}$

Ctesias, Persica $\quad$ 192n996, 204

Diodorus Siculus, Library of History

$$
\begin{aligned}
& \text { 17.110.3-5 10n } 56 \\
& \text { 1.46.4 10n } 57
\end{aligned}
$$

DSf $10 n_{54}$

Eusebius, Preparation for the Gospel 1.9.21 $5^{2}$

Herodotus, Persian Wars 4.200, 4.204, 6.18-20, 6.119 10n56

Josephus, Against Apion

$1.21 \quad 72 \mathrm{n} 441$

KAI $225 \quad 238 n 1203$

KAI 226 237n1201, 238n1203

KTU 1.1 iv:14 51

Leviticus Rabbah $\quad 75^{-76}$

Persepolis Fortification tablets $10 n_{54}$, $62 n_{3} 64$

TAD A $6.2 \quad 224 n 1121$ 